LAURA DE TOLEDO PONZONI MARCONDES

\title{
DANO MORAL NAS RELAÇÕES FAMILIARES
}

TESE DE DOUTORADO

ORIENTAdORA: Professora TITULAR TERESA ANCONA LOPEZ

UNIVERSIDADE DE SÃo PAULO

FACULDADE DE DIREITO

SÃo PAULO

2013 


\section{LAURA DE TOLEDO PONZONI MARCONDES}

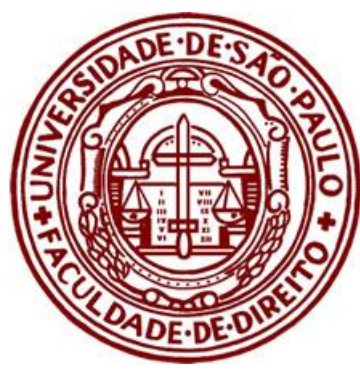

\section{DANO MORAL NAS RELAÇÕES FAMILIARES}

TESE DE DOUTORADO

Tese apresentada à Faculdade de Direito da Universidade de São Paulo, como exigência parcial para a obtenção do título de Doutora em Direito Civil, sob orientação da Professora Titular Teresa Ancona Lopez.

UNIVERSIDADE DE SÃO PAULO

FACULDADE DE DIREITO

SÃo PAULO

2013 
Aos meus pais, avós e irmã, fonte elementar de carinho e afeição. Ao meu marido, fonte inesgotável de amor e compreensão. E a Deus, fonte derradeira da justiça e da razão! 
"Due cose al mondo non ti abbandonano mai, l'occhio di Dio che sempre ti vede e il cuore della mamma che sempre ti segue”. (St. Pe. Pio DA PIETRElcina). 


\section{AgradeCimentos}

À querida Professora TERESA ANCONA LOPEZ, pela inestimável orientação e confiança em mim depositada para o desenvolvimento desta tese, diante da jovialidade e parca experiência que me acompanhavam.

Ao estimado Dr. Cláudio Ferraz de Alvarenga, pela oportunidade de, trabalhando, conciliar meus estudos, sempre com tranquilidade.

Ao meu amado JoÃo GuILHERME PONZONI MARCONDES, companheiro e primeiro leitor. Muito obrigado, sem você, restaria o impossível! 


\section{RESUMO}

Se na família ocorreram grandes mudanças sociais, é de se esperar que o ordenamento jurídico encontre dificuldades para acompanhá-las, num processo de adaptação e integração complexo e problemático. Nesse movimento, a dignidade humana assumiu papel central, como fonte normativa e valorativa de uma nova feição jurídica, resultando no desenvolvimento cada vez maior dos direitos da personalidade.

Em meio a essas alterações, a polêmica sobre a proteção dos membros da família contra violações praticadas por seus parentes ganha força, desafiando os juristas a encontrar uma solução.

O afeto foi elevado a componente essencial dos relacionamentos familiares, ao mesmo tempo em que se busca um fundamento legítimo para a responsabilização daqueles que ofendem a dignidade dos demais membros da família.

O problema da culpa no término dos relacionamentos conjugais, a incerteza sobre as implicações da Emenda Constitucional n. 66/10, a ausência de efeitos para o descumprimento de deveres matrimoniais, as consequências do rompimento do noivado, a ideia de abandono afetivo, tudo isso se soma para tornar insegura a análise da doutrina.

Neste trabalho, exploramos exemplos paradigmáticos com o intuito de demonstrar que as controvérsias a respeito dos danos morais travadas no âmbito familiar são, no fundo, questões de responsabilidade civil. Buscamos, desta forma, deixar explícita esta relação e esclarecer que, por detrás das múltiplas idiossincrasias arroladas pela doutrina civil-familiar, escondem-se os elementos essenciais da responsabilidade civil.

É preciso ter em mente que o problema dos danos morais na família deve ser solucionado na perspectiva da responsabilidade civil, não havendo efeitos jurídicos do Direito de família, e sim nas relações familiares. 


\begin{abstract}
If great social changes happened within the family, it is expected that the legal system finds it difficult to follow them in a complex and problematic process of adaptation and integration. In this movement, human dignity assumed a central role as a source of normative and evaluative feature of a new legal entity, resulting in the increasing development of personality rights.
\end{abstract}

Amid these changes, the controversy over the protection of family members against violations committed by their relatives, gains strength, challenging the lawyers to find a solution.

The affection was elevated to an essential component of family relationships, while it seeks a legitimate basis for accountability of those who offend the dignity of other family members.

The problem of guilt in the dissolution of marital relationships, uncertainty about the implications of the Constitutional Amendment 66/10, the absence of effects for the breach of marital duties, the consequences of breaking the engagement, the idea of emotional abandonment, it all adds up to make the analysis of the doctrine insecure.

In this paper, we explore paradigmatic examples in order to demonstrate that the controversies regarding the moral injuries within the family environment are, ultimately, civil liability matters. We pursue, therefore, to leave this relationship explicit and to clarify that the essential elements of liability are hidden behind the multiple idiosyncrasies enrolled by a civil-family doctrine.

It must be kept in mind that the problem of moral damages in the family must be solved from the perspective of civil liability, with no legal effects of family law, but in family relationships. 


\section{RIASSUNTO}

Se nella famiglia avvengono grandi mutamenti sociali c'è da aspettarsi che l'ordinamento giuridico incontri difficoltà nel seguirle, in un processo di adattamento e integrazione complesso e problematico. In questo movimento, la dignità umana ha assunto il ruolo centrale, come fonte normativa e di valori di un nuovo aspetto giuridico, dando come risultato uno sviluppo ogni volta maggiore dei diritti della personalità.

In mezzo a queste alterazioni, la polemica sulla protezione dei membri della famiglia contro le violazioni praticate dai parenti guadagna forza, sfidando i giuristi a trovare una soluzione.

L'affetto è stato elevato a componente essenziale delle rapporti familiari, allo stesso tempo in cui si cerca un fondamento legittimo per la responsabilizzazione di coloro che offendono la dignità degli altri membri della famiglia.

Il problema della colpa in termine di relazioni coniugali, l'incertezza sulle implicazioni della Riforma Costituzionale $n^{\circ}$ 66/10, l'assenza di effetti per l'inadempienza dei doveri coniugali, le conseguenze della rottura del fidanzamento, l'idea di abbandono affettivo, tutto ciò si somma per rendere insicura l'analisi della dottrina.

In questo lavoro, esploriamo esempi paradigmatici con l'intenzione di dimostrare che le controversie a riguardo dei danni morali stabiliti nell'ambito familiare sono, in fondo, questioni di responsabilità civile. Cerchiamo, in questo modo, di rendere esplicita questa relazione e chiarire che, dietro alle molteplici idiosincrasie elencate dalla dottrina civile familiare, si nascondono elementi essenziali della responsabilità civile.

È necessario tenere in mente che il problema dei danni morali nella famiglia deve essere risolto in prospettiva della responsabilità civile, non essendoci effetti giuridici del diritto della famiglia, ma essendoci nelle relazioni familiari. 


\section{SUMÁRIO}

I. INTRODUÇÃ $O$................................................................................................................................... 11

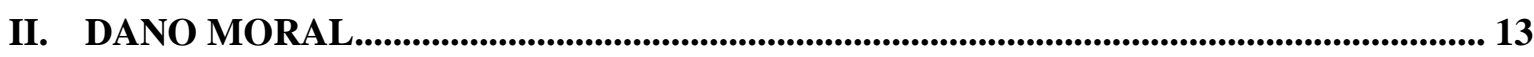

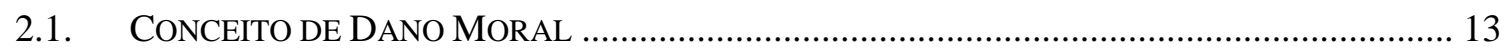

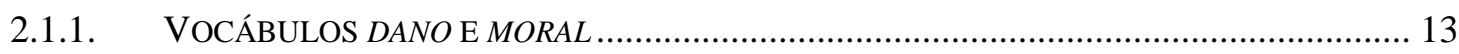

2.1.2. TEORIAS QUE VISAM À DEFINIÇÃO DO DANO MORAL ……........................................ 19

2.1.2.1. Dano extrapatrimonial - contraposição ao dano material ...................................... 19

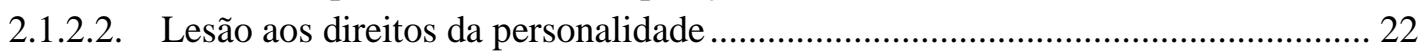

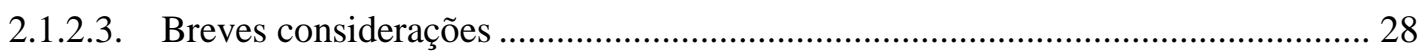

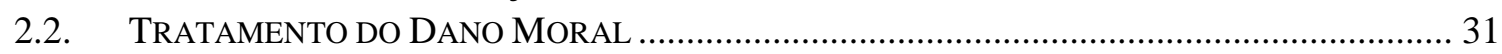

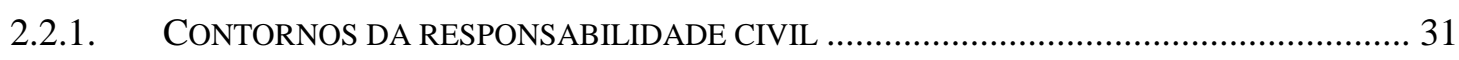

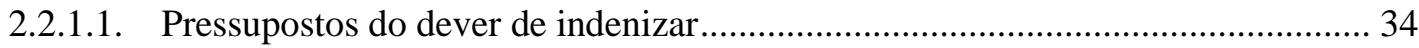

2.2.2. DANO MORAL NO DIREITO BRASILEIRO_.................................................................. 35

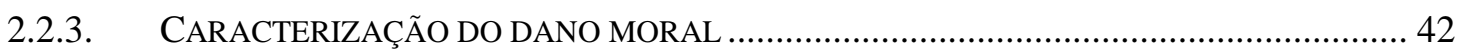

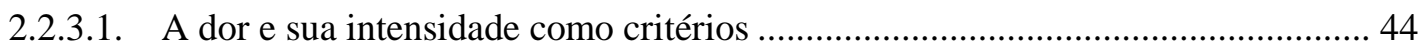

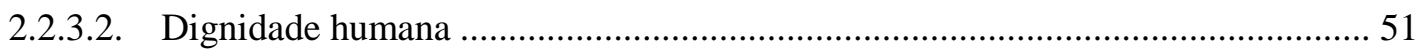

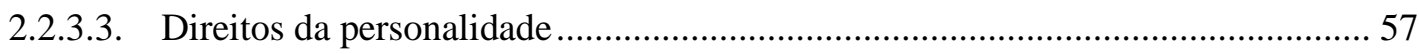

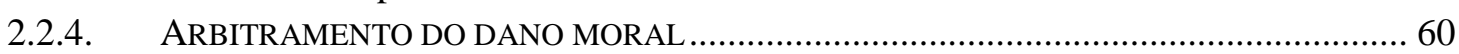

2.2.5. FUNÇÃO DO DANO MORAL (RECTIUS, DE SUA INDENIZAÇÃO) .................................. 72

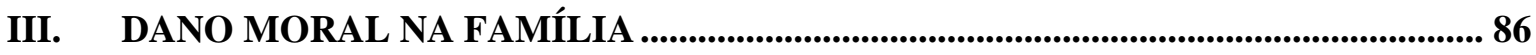

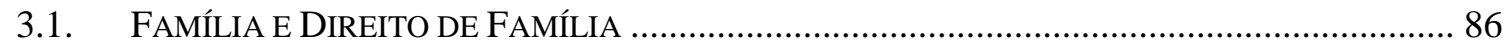

3.1.1. TRANSFORMAÇÕES NO DIREITO DE FAMÍLIA.......................................................... 90

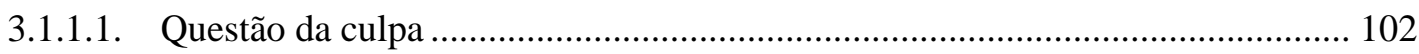

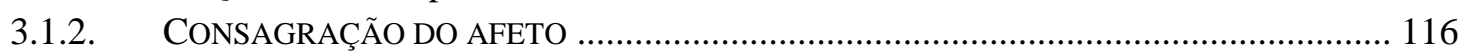

3.1.3. CRISE DA FAMÍLIA? ............................................................................................. 120

3.2. ATUAL TRATAMENTO do Dano Moral no Direito de FAmília ................................... 123

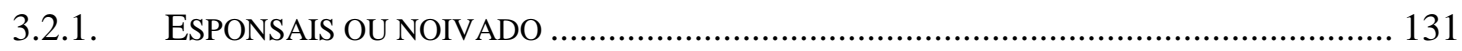

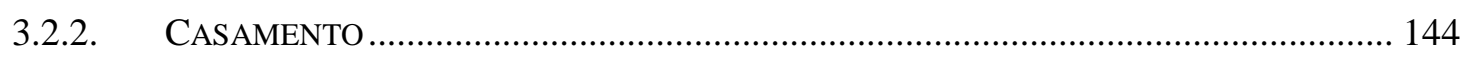

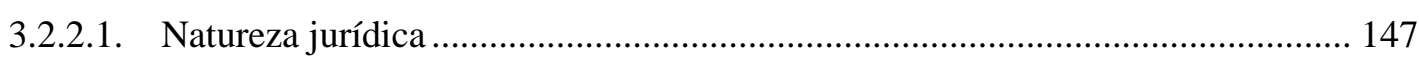

3.2.2.2. Deveres matrimoniais e consequências do descumprimento ............................. 151

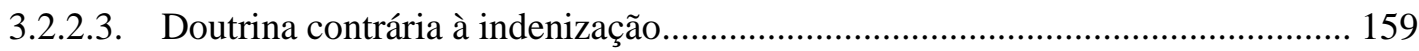

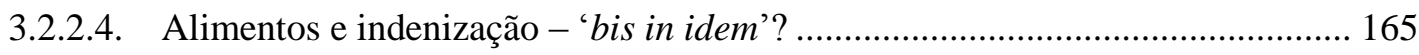

3.2.2.5. Correntes doutrinárias favoráveis à indenização............................................. 170

3.2.2.6. Hipóteses de danos em razão da infração aos deveres conjugais........................ 189

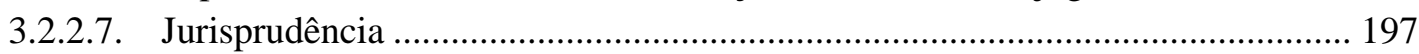

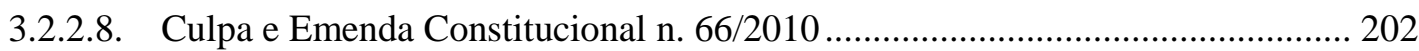

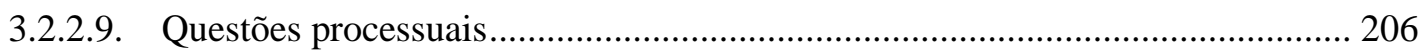

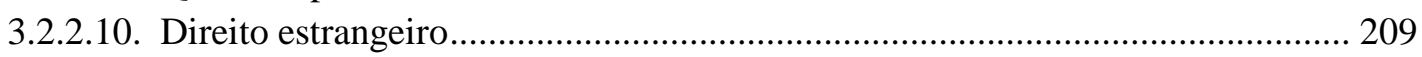

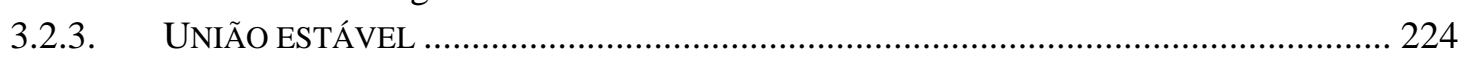

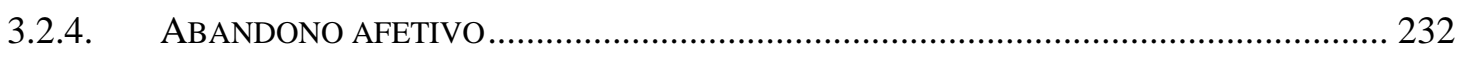

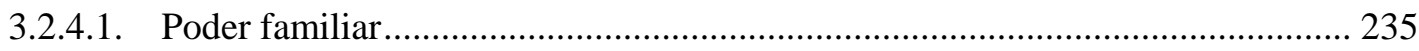

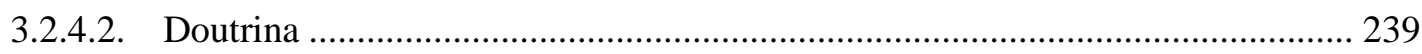

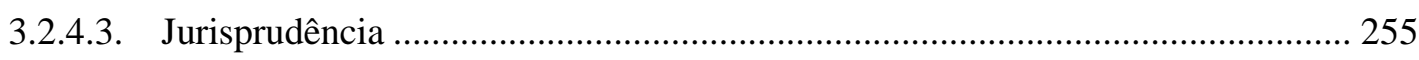


3.2.5. DEMAIS SITUAÇÕES.

3.2.5.1. Casamento anulado por erro quanto à pessoa do cônjuge e casamento putativo 264

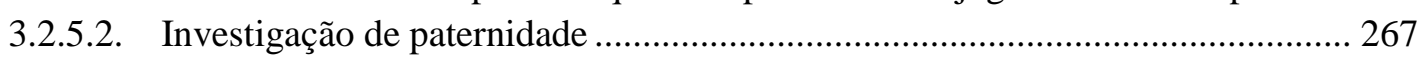

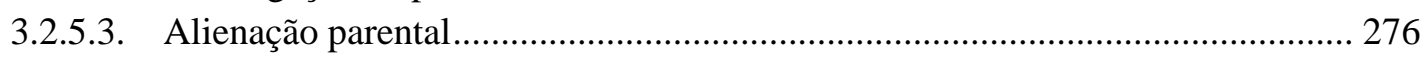

3.3. PROPOSTA DE AFERIÇÃO do DANO MORAL NAS RELAÇÕES FAMILIARES ..................... 280

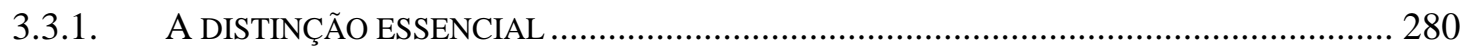

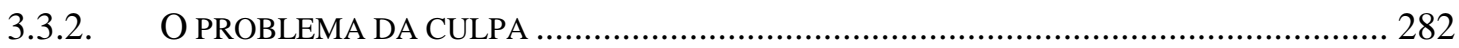

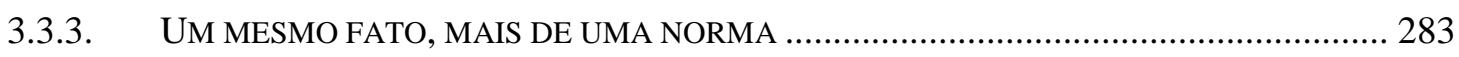

3.3.4. CASUÍSTICA E PRESSUPOSTOS DA RESPONSABILIDADE CIVIL ................................ 285

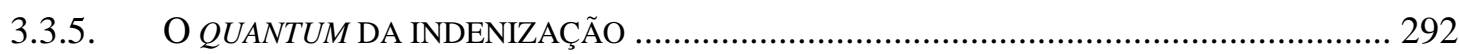

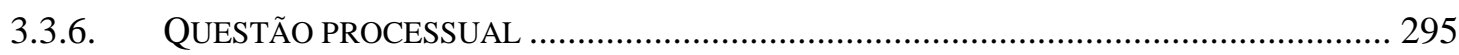

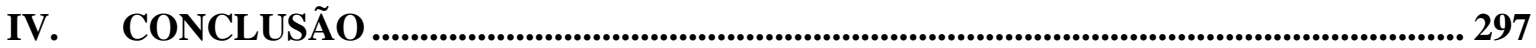

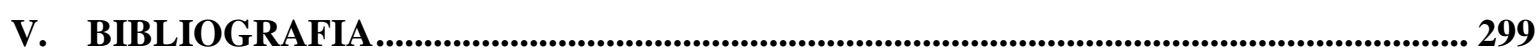




\section{INTRODUÇÃo}

Direito e família vêm mudando. E as mudanças de um e de outro acabam gerando efeitos recíprocos, fazendo nascer problemas instigantes para os juristas.

O dano moral, outrora tema polêmico, de consequências incertas, hoje conta com uma dogmática desenvolvida, ainda em transformação, mas que já apresenta um perfil suficiente para a ciência jurídica.

Já os modelos de família estão em plena mutação, suscitando discursos por vezes inflamados, opondo os juristas no tratamento das chamadas novas entidades familiares, das formas de constituição e dissolução dos vínculos. O afeto, antes assunto periférico, ganhou destaque, assumindo feições jurídicas, suscitando o retorno da dicotomia entre o Direito e a moral.

Unindo as duas tendências, a dignidade humana desponta como argumento onipresente nas construções teóricas, assumindo o cerne de muitos posicionamentos, um apoio para questões difíceis de lidar.

Por um lado, a consagração da dignidade do ser humano no mundo jurídico significou o recrudescimento da proteção ao indivíduo, redundando no florescimento dos direitos da personalidade. Por outro, o egocentrismo exacerbado vem causando conflitos sérios dentro da família, exigindo um esforço dos operadores do Direito para justificar a entrada da regulação estatal em campos íntimos, até então preservados de interferência.

É justamente na confluência dessas tensões jurídico-sociais que aparece a questão deste trabalho: o dano moral nas relações familiares.

Observar e aplicar os conceitos mais gerais desenvolvidos pela doutrina sobre o dano moral, seus fundamentos, funções, modo de aferição e quantificação, são atividades essenciais para não cairmos no equívoco, tão recorrente quando se deixa a ciência para abraçar a emoção e a opinião irrefletida.

O exame dos casos paradigmáticos, amplamente debatidos pelos estudiosos e que ainda têm tratamento incerto pela jurisprudência, é outra tarefa de extrema importância para conhecermos as peculiaridades do tema. Contudo, é possível notar algumas 
imprecisões que prejudicam o exame do dano moral nesta forma de relacionamento, de maneira que somos chamados a recuperar aquelas noções comuns, para tentar emprestar um pouco mais de clareza ao assunto.

É por isso que procuraremos esclarecer os aspectos gerais do dano moral e das alterações no Direito civil-familiar, investigando, em seguida, as espécies mais debatidas da violação jurídica nesta seara, para depois reconectar essas duas partes principais, culminando em nossa proposta para a aferição do dano moral nas relações familiares. 


\section{DANO MORAL}

\subsection{CONCEITO DE Dano Moral}

Há grande dificuldade em se aquiescer quanto ao conceito de dano moral. Para alguns, se traduz na lesão que atinge bens insusceptíveis de avaliação econômica; outros apreendem que se manifesta na afronta ao próprio âmago do indivíduo, aos seus direitos da personalidade. Assim, este conceito é composto de diversas nuances que procuraremos aclarar, fazendo antes uma digressão dos vocábulos que compõem a expressão.

\subsubsection{VOCÁBULOS DANO E MORAL}

O emprego da expressão dano moral exige explanação sobre o seu sentido.

De acordo com o léxico De Plácido e Silva, a palavra dano deriva do latim damnum, que genericamente significa "todo mal ou ofensa que tenha uma pessoa causado a outrem, da qual possa resultar uma deterioração ou destruição a coisa dele ou um prejuízo a seu patrimônio",

No dicionário HoUAISS encontramos a seguinte definição: “qualquer prejuízo, financeiro e patrimonial, sofrido por alguém, em que houve ação, influência ou omissão de outrem",

Por sua vez, o dicionário AURÉlio, conceitua a palavra dano como "mal ou ofensa pessoal, prejuizo moral" ou "prejuizo material causado a alguém pela deterioração ou inutilização de bens seus" ${ }^{\text {"3. }}$.

Também nos léxicos de LAUdELINo FreIRE e CALDAS AULETE encontramos os seguintes conceitos: "qualquer mal ou ofensa pessoal" e "deterioração, prejuízo ou deterioramento de bens pertencentes a uma pessoa", ou ainda "prejuízo causado por alguém nas coisas pertencentes a outrem ", 4

\footnotetext{
${ }^{1}$ De Plácido e Silva. Vocabulário Jurídico. Rio de Janeiro: Forense, 1975.

${ }^{2}$ HouAISS, Antônio. Dicionário Houaiss da Língua Portuguesa. Rio de Janeiro: Objetiva, 2009.

${ }^{3}$ Ferreira, Aurélio Buarque de Holanda. Novo Dicionário Aurélio da Língua Portuguesa. $4{ }^{\mathrm{a}}$ ed. Curitiba: Positivo, 2009.

${ }^{4}$ LaUdelino FreIRE. Grande e Novíssimo Dicionário da Língua Portuguesa. v. 2. $3^{\mathrm{a}}$ ed. Rio de Janeiro: José Olympio, 1957. Caldas Aulete. Dicionário Contemporâneo da Língua Portuguesa. $3^{\mathrm{a}}$ ed. Rio de Janeiro: Delta, 1979.
} 
Na língua italiana, o termo danno significa: "ogni fatto, circostanza, azione, che nuoce a persone o cose, sia materialmente sia immaterialmente", "perdita di beni materiali o morali, o perdita di integrità, di funzionalità arrecata a qleu"6. A palavra damage, em inglês, está relacionada à "loss or detriment caused by hurt or injury affecting estate, condition, or circumstances ${ }^{, 7}$.

Por conseguinte, a noção de dano envolve a ideia de mal, prejuízo, ruína, perda de alguma coisa ou da qualidade de algo. Interessante observar os sinônimos do termo: deterioração, estrago, mal ou prejuízo ${ }^{8}$.

No âmbito jurídico, conceitua-se dano como o "prejuizo sofrido pelo patrimônio econômico ou moral de alguém ",

Conforme TERESA ANCONA LOPEZ: “etimologicamente, dano vem de 'demere', que significa tirar, apoucar, diminuir. Portanto, a idéia de dano surge das modificações do estado de bem-estar da pessoa, que vem em seguida à diminuição ou perda de qualquer dos seus bens originários ou derivados extrapatrimoniais ou patrimoniais ${ }^{, 10}$.

CARlos Alberto BitTar aponta que o dano é a lesão, o prejuízo experimentado por alguém em função da ação de outrem. Essa lesão deve ser injusta, e assim se caracteriza se atingir aspectos do complexo valorativo do homem, tais como os componentes físicos, psíquicos e morais da sua personalidade. Além destes, o autor informa que os danos podem atingir o patrimônio do lesado, abrindo-se a perspectiva para as espécies de dano possíveis: morais e patrimoniais ${ }^{11}$.

Também Sergio CAVALIERI FILHo conceitua o dano como a lesão, subtração ou diminuição de um bem jurídico, quer se trate de um bem patrimonial ou moral ${ }^{12}$.

ANTONIO JEOVÁ SANTOS aprofunda essa definição:

\footnotetext{
${ }^{5}$ ZINGARELLI, Nicola. Il Nuovo Zingarelli. $10^{\mathrm{a}}$ ed. Zanichelli.

${ }^{6}$ ColetTI, Sabatini. Il Sabatini Coletti Dizionario della Lingua Italiana. Milano: RCS Libri, 2007.

${ }^{7}$ OXFORD. The Oxford English Dicitionary. v. III. Oxford, 1933.

${ }^{8}$ HouAISS, Antônio. Dicionário Houaiss: Sinônimos e Antônimos. $2^{\text {a }}$ ed. São Paulo: Publifolha, 2008.

${ }^{9}$ ACQuaviva, Marcus Cláudio. Dicionário Acadêmico de Direito. São Paulo: Jurídica Brasileira, 1999.

${ }^{10}$ LOPEZ, Teresa Ancona. $O$ dano estético: responsabilidade civil. $2^{\mathrm{a}}$ ed. São Paulo: Revista dos Tribunais, 1999, p. 20.

${ }^{11}$ Cf. BITTAR, Carlos Alberto. Danos morais e materiais decorrentes da ruptura do casamento. Revista da Faculdade de Direito da Fundação Armando Alvares Penteado, n. 1, São Paulo, 2002, p. 278.

${ }^{12}$ Cf. CAVAlieri FilHo, Sergio. Programa de responsabilidade civil. 9a ed. São Paulo: Atlas, 2010, p. 73.
} 
“dano é prejuizo. É diminuição de patrimônio ou detrimento a afeições legítimas. Todo ato que diminua ou cause menoscabo aos bens materiais ou imateriais, pode ser considerado dano. $O$ dano é um mal, um desvalor ou contravalor, algo que se padece com dor, posto que nos diminui e reduz; tira de nós algo que era nosso, do qual gozávamos ou nos aproveitávamos (...) ’13.

Dessas assertivas se infere os atributos do dano. Ele é conceituado a partir das consequências advindas de um evento que tenha causado a perda ou a diminuição de um bem que, segundo o objeto tutelado, poderá ser corpóreo ou incorpóreo.

Segundo CARlos Alberto BitTAR, a gama de fatos geradores de danos nos entrelaçamentos pessoais e patrimoniais em que se envolvem os entes personalizados é multifacetária, surgindo de diferentes estímulos externos e internos, em razão da complexidade da vida social, da extensão dos relacionamentos possíveis e das infinitas potencialidades da inteligência humana. No entanto, ele adverte que nem todo dano é reparável, sendo necessário que se mostre injusto pela configuração da invasão, contra ius, da esfera jurídica alheia ${ }^{14}$.

Nestes termos, para RUY RoSAdo DE AGUIAR JÚNIOR, no âmbito jurídico o conceito de dano não é dado, mas construído, modificando-se no mesmo passo em que a comunidade altera a sua ideia do que deva ser juridicamente protegido ${ }^{15}$.

Passando ao exame da palavra moral, notamos que designa conceitos diversos, mas conexos. Assim também é a palavra direito, que pode indicar: a norma jurídica, a autorização dada por meio da norma jurídica, o justo, o conforme, o certo, etc.

O vocábulo moral pode ser tomado como adjetivo e como substantivo.

Como adjetivo, designa qualidade do espírito ou de algo relativo ao espírito e não à matéria (assim, por exemplo, dizemos dores morais, ciências morais); ou qualidade

\footnotetext{
${ }^{13}$ SAntos, Antonio Jeová. Dano moral indenizável. $4^{\text {a }}$ ed. São Paulo: Revista dos Tribunais, 2003, p. 74.

${ }^{14}$ Cf. BitTAR, Carlos Alberto. Reparação civil por danos morais. $3^{\mathrm{a}}$ ed. São Paulo: Revista dos Tribunais, 1999, pp. 29-30.

15 Cf. Aguiar Júnior, Ruy Rosado de. Responsabilidade civil no direito de família. ADV Advocacia Dinâmica: seleções jurídicas, n. 2, 2005, p. 3.
} 
de ser conforme ao que é correto, que denota bons costumes, segundo os preceitos estabelecidos por determinado grupo social (comportamento moral) ${ }^{16}$.

Como substantivo, moral é termo masculino ou feminino, com sentidos diferentes. Sendo substantivo masculino, designa estado de espírito, ou seja, disposição para agir com maior ou menor vigor diante de circunstâncias difíceis (assim, por exemplo, dizemos pessoa de moral deprimido, alto moral das tropas). Já enquanto substantivo feminino, moral possui dois significados: é o nome de uma das ciências que compõe a filosofia e é a designação da ordenação normativa do comportamento humano ${ }^{17}$.

No dicionário AuRÉLIO, encontramos a seguinte definição para o vocábulo: “conjunto de regras de conduta consideradas como válidas, quer de modo absoluto para qualquer tempo ou lugar, quer para grupo ou pessoa determinada,"18.

Também nos léxicos de LAUdelino Freire e CALDAS Aulete a expressão significa: "corpo de preceitos e regras para dirigir as ações dos homens segundo a justiça e a equidade natural ${ }^{\prime 19}$.

No dicionário HouAISs, por sua vez, a palavra é definida como: “conjunto de valores, individuais ou coletivos, considerados universalmente como norteadores das relações sociais e da conduta dos homens ${ }^{, 20}$.

Em dicionários estrangeiros encontramos as seguintes conceituações: "che riguarda la vita pratica considerata nel suo atto fondamentale di scelta tra bene e male, giusto e ingiusto" $21 \mathrm{e}$ "of or pertaining to character or disposition, considered as good or bad, virtuous or vicious, or for pertaining to the distinction between right and wrong, or

\footnotetext{
${ }^{16}$ Cf. Telles JunIOR, Goffredo. Palavras do amigo aos estudantes de direito. $2^{\mathrm{a}}$ ed. São Paulo: Juarez de Oliveira, 2005, pp. 42-43.

${ }^{17}$ Cf. Ibidem.

${ }^{18}$ FERreIRA, Aurélio Buarque de Holanda. Novo Dicionário Aurélio da Língua Portuguesa. $4^{\mathrm{a}}$ ed. Curitiba: Positivo, 2009.

${ }^{19}$ LAUDELINo FreIRE. Grande e Novíssimo Dicionário da Língua Portuguesa. v. 2. $3^{\mathrm{a}}$ ed. Rio de Janeiro: José Olympio, 1957. Caldas Aulete. Dicionário Contemporâneo da Língua Portuguesa. $3^{\mathrm{a}}$ ed. Rio de Janeiro: Delta, 1979.

${ }^{20}$ HoUAISS, Antônio. Dicionário Houaiss da Língua Portuguesa. Rio de Janeiro: Objetiva, 2009.

${ }^{21}$ ColetTI, Sabatini. Il Sabatini Coletti Dizionario della Lingua Italiana. Milano: RCS Libri, 2007.
} 
good and evil, in relation to the actions, volitions, or character of responsible beings; ethical ${ }^{, 22}$.

No dicionário de filosofia, verificamos importante observação a respeito deste termo: "em algumas línguas, o moral opõe-se ao físico, o que explica o fato de as ciências morais compreenderem, em oposição às ciências naturais, tudo aquilo que não é puramente físico ao homem (...), isto é, tudo aquilo que corresponde às produções do espírito subjetivo e mesmo o próprio espírito subjetivo, ${ }^{, 23}$.

Ademais, os conhecidos sinônimos da palavra moral são: correto (certo, decente, digno, honesto, íntegro, probo, verdadeiro), edificante (bom, construtivo, educativo, exemplar, positivo, proveitoso, salutar, útil), doutrina (costume, norma, padrão, princípio, regra), ética (brio, caráter, deontologia, escrúpulo, moralidade, princípios), integridade (dignidade, distinção, escrúpulo, honestidade, honradez, nobreza) etc ${ }^{24}$.

Quando relacionada com o termo direito, a palavra moral é substantivo feminino e designa ordenação do comportamento. No entanto, quando relacionada à palavra dano, o termo moral aponta a qualidade, o atributo ou a característica do dano, assim, trata-se de um adjetivo, no primeiro sentido que expusemos.

Segundo Antonio JeOvá SANTOS, "é necessária a compreensão de que o adjetivo moral aponta e define o dano causado a alguém, nada tendo que ver com a conduta de quem praticou o mal" 25 . Portanto, o jurista informa que o dano moral revestese de consequências jurídicas e nem sempre vem acompanhado de algum conteúdo ético. A infração às normas da ética não tem similitude nem se aproxima do dano moral. Logo, a conduta do ofensor pode não ser reprovável do ponto de vista moral, mas ser lesiva ao patrimônio imaterial do ofendido ${ }^{26}$. Nestes termos, na opinião do autor, o intento de conceituar o dano moral esbarra em um óbice, pois a ideia de moral está vinculada à ética, aos costumes:

“a dissecação da expressão 'dano moral' guarda, em si, a dificuldade de retirar do cérebro conceituação que se faz, 'a priori', sobre o adjetivo 'moral'. Enquanto dano é

\footnotetext{
${ }^{22}$ OXFORD. The Oxford English Dicitionary. v. III. Oxford, 1933.

${ }^{23}$ Ferrater Mora, José. Dicionário de Filosofia. Tomo III. São Paulo: Loyola, 2001.

${ }^{24}$ HouAISS, Antônio. Dicionário Houaiss: Sinônimos e Antônimos. $2^{\mathrm{a}}$ ed. São Paulo: Publifolha, 2008.

${ }^{25}$ SANTOS, Antonio Jeová. Op. cit. (nota 13), p. 87.

${ }^{26}$ Cf. ibidem.
} 
o prejuízo, é o detrimento padecido por alguém em virtude de ato de outrem, como definir moral no contexto 'dano moral'? Em nossa memória permeia a moral como bom procedimento, bons costumes; proceder segundo a justiça e à honestidade. Nenhum desses caracteres faz-se presente no momento em que é indispensável a apreensão do conceito para a sua imediata aplicação,"27.

Ele assegura que no Brasil essa dificuldade tem colaborado para o mau desempenho do assunto e entende que "não é possível buscar nos dicionários a conceituação de moral para encontrar o real sentido do dano extrapatrimonial. Muito menos imaginar que a existência de noção preconcebida, e que subjaz no cérebro como algo ligado à ética, servirá para dar a exata noção do 'dano moral",28.

Assim, porque a palavra moral se presta a diversas interpretações, gerando a dificuldade em se conceituar o dano moral, alguns juristas propõem que o Direito brasileiro passe a utilizar a expressão dano à pessoa ${ }^{29}$. Todavia, o próprio ANTONIO JEOVÁ SANTOS faz veemente crítica a respeito:

"no atual quadrante do viver jurídico nacional, a expressão 'dano moral' está tão arraigada no dia-a-dia dos profissionais e do profano, que qualquer mudança somente serviria para atrapalhar a real compreensão da lesão moral. Se, de um lado, prevalece a equivocidade do vocábulo, de outro, dita expressão já se encontra de tal forma incorporada em legislações e na linguagem do foro, que é preferível continuar com o sentido equívoco da palavra até a sedimentação do autêntico significado do 'dano moral', 30 .

Dessa maneira, para o jurista, muito embora a expressão dano moral possa traduzir certa ambiguidade, deve permanecer, competindo à doutrina e à jurisprudência 'decantar os vocábulos', 'escoimá-los de impurezas' e encontrar o seu sentido 'mais puro e verdadeiro'. Ele assegura que o tempo se incumbirá de superar essa dificuldade semântica $^{31}$.

\footnotetext{
${ }^{27}$ Idem, pp. 86-87.

${ }^{28}$ Idem, p. 87.

29 ANTONIO JEOVÁ SANTOS afirma que esta modificação não seria voltada apenas às questões semânticas, pois a lesão à pessoa denotaria algo mais abrangente, tocando à essência do dano extrapatrimonial, enquanto a expressão dano moral é restritiva. Cf. idem, p. 88 .

${ }^{30}$ Idem, p. 87.

${ }^{31}$ Cf. idem, pp. 91-92.
} 


\subsubsection{TEORIAS QUE VISAM À DEFINIÇÃO DO DANO MORAL}

Sem minúcias, procuraremos expor as duas principais teorias que se propõem a encontrar o sentido do dano moral.

São elas: a) a que considera o dano moral como dano extrapatrimonial, em contraposição ao dano material; e $b$ ) a que considera dano moral aquele que lesiona um direito da personalidade.

Ambas buscam determinar a natureza do bem jurídico ofendido. Para a primeira, o bem jurídico é todo aquele que não é patrimonial. Para a segunda, são os direitos da personalidade.

ANTONIO JEOVÁ SANTOS acrescenta ainda uma terceira teoria, partindo do princípio de que o dano moral é o resultado da violação do direito, ligado ao bem jurídico $\operatorname{protegido}^{32}$.

\subsubsection{Dano extrapatrimonial - contraposição ao dano material}

Muitos juristas conceituam o dano moral de forma simples, como o dano extrapatrimonial ${ }^{33}$, a partir de sua contraposição ao dano patrimonial.

PONTES DE MiRAnda já fazia esta distinção: “dano patrimonial é o dano que atinge o patrimônio do ofendido; dano não patrimonial é o que, 'só' atingindo o devedor como ser humano, não lhe atinge o patrimônio ${ }^{\text {,34. }}$.

Também HumberTO THEODORO JÚNIOR delimita essas duas espécies de dano da seguinte forma: “'materiais', em suma, são os prejuízos de natureza econômica, e, 'morais', os danos de natureza não-econômica (...),35.

\footnotetext{
${ }^{32}$ Cf. idem, p. 92.

${ }^{33} \mathrm{O}$ prefixo extra significa fora, além, de fora, para fora. Sua junção com a palavra patrimônio nos coloca diante de uma expressão que significa: fora do patrimônio ou além do patrimônio. Indica uma dissociação do que seja patrimônio ou, gramaticalmente, algo fora da universalidade do conjunto de bens ou direitos com conteúdo econômico pertencente a um indivíduo. Cf. FENSTERSEIFER, Nelson Dirceu. Dano extrapatrimonial e direitos fundamentais. Porto Alegre: Sergio Antonio Fabris, 2008, p. 92.

${ }^{34}$ MIRANDA, Pontes de. Tratado de direito privado: parte geral. Tomo XXVI: direito das obrigações. São Paulo: Revista dos Tribunais, 2012, pp. 104-105.

${ }^{35}$ TheOdoro JúnIOR, Humberto. Dano moral. $7^{\mathrm{a}}$ ed. Belo Horizonte: Del Rey, 2010, p. 2.
} 
Nas palavras de TERESA ANCONA LOPEZ: “(...) a definição de dano moral deveria ser dada em contraposição a dano material, sendo este o que lesa bens apreciáveis pecuniariamente e aquele, ao contrário, o prejuízo a bens ou valores que não têm conteúdo econômico ${ }^{, 36}$.

Nestes termos, CARlos Alberto BitTAR conclui que a existência, ou não, de conteúdo econômico separa as duas categorias de danos: os patrimoniais (materiais) e extrapatrimoniais (imateriais ou morais) ${ }^{37}$.

Note-se que as expressões dano moral e dano extrapatrimonial são comumente utilizadas como sinônimas, pois alusivas à mesma espécie de dano. Alguns juristas ainda empregam as expressões dano imaterial ou não patrimonial $^{38}$, porém, na opinião de YUSSEF SAID CAHALI, a nomenclatura dano moral se impõe, pela força de sua expressividade, à tradição do nosso Direito ${ }^{39}$.

Assim sendo, a caracterização do dano moral é deduzida por parte da doutrina sob a forma negativa, na sua contraposição ao dano patrimonial.

Não obstante, ANTONIO JEOVÁ SANTOS faz veemente crítica a esta definição: "afirmar que 'dano moral' é lesão não patrimonial é nada definir. Princípio decorrente da boa lógica, indica que não se define, introduzindo um conceito negativo ao objeto definido. A utilização de vocábulos em sentido contrário não ajuda na formação da concepção do que se pretende conceituar ou definir. Por isso, a insuficiência dessa doutrina, tão agregada no direito brasileiro ${ }^{340}$.

Portanto, o autor não aceita a proposição de que dano moral é a lesão nãopatrimonial, pois entende que não se define por negação; a definição pressupõe afirmação $^{41}$.

\footnotetext{
${ }^{36}$ LOPEZ, Teresa Ancona. Op. cit. (nota 10), p. 21.

${ }^{37}$ Cf. BitTAR, Carlos Alberto. Op. cit. (nota 14), pp. 32-33.

${ }^{38}$ SERGIO CAVALIERI FILHO, ao definir o alcance do dano moral, entende mais apropriado utilizar essas duas expressões, como ocorre no Direito Português, pois assevera que não mais se restringe à dor, tristeza e sofrimento, estendendo a sua tutela a todos os bens personalíssimos - os complexos de ordem ética. Cf. CAVAliERi FilHO, Sergio. Op. cit. (nota 12), p. 84.

${ }^{39}$ Cf. CAHALI, Yussef Said. Dano moral. $4^{\text {a }}$ ed. São Paulo: Revista dos Tribunais, 2011, pp. 20-21.

${ }^{40}$ SANTOS, Antonio Jeová. Op. cit. (nota 13), p. 92.

${ }^{41}$ Cf. idem, p. 95.
} 
Na visão de YUSSEF SAID CAHALI, o critério distintivo à base da exclusão se revela insatisfatório quando abstraímos o caráter estritamente econômico do patrimônio para dilargar o seu conteúdo de modo a compreender valores imateriais. Assim, o jurista considera mais razoável caracterizar o dano pelos seus próprios atributos ${ }^{42}$.

Por sua vez, ANDERSON SCHREIBER assevera que definir o dano moral por via negativa, como todo prejuízo economicamente incalculável, acaba por convertê-lo em figura receptora de todos os anseios, dotada de uma vastidão tecnicamente insustentável ${ }^{43}$.

José De Aguiar Dias nota que, "quando ao dano não correspondem as características do dano patrimonial, dizemos que estamos na presença do dano moral",44. No entanto, segundo entende, ainda que a inestimabilidade do bem lesado constitua a essência do dano moral, não é critério definitivo para a sua distinção, convindo compreendê-lo em relação ao seu conteúdo ${ }^{45}$. Nestes termos, afiança que não se discrimina em patrimonial e extrapatrimonial em atenção à origem, mas aos efeitos, e conclui que o dano moral é a reação psicológica à injúria, são as dores físicas e morais que o homem experimenta em face da lesão ${ }^{46}$.

Também ANTONiO JeOvÁ SANTOS preleciona que: "buscando estremar os conceitos de 'dano moral' e dano patrimonial, é de bom alvitre admitir de plano que a diferença está na gênese do direito violado ${ }^{~} 47$. Ou seja, o dano patrimonial 'afeta o bolso', enquanto o moral 'perturba o espírito'; a lesão patrimonial atinge a pessoa naquilo que ela tem, ao passo que o dano moral repercute naquilo que a vítima $e^{48}$.

\footnotetext{
${ }^{42}$ Cf. CAHALI, Yussef Said. Op. cit. (nota 39), p. 19.

43 Cf. SCHREIBER, Anderson. Novos paradigmas da responsabilidade civil: da erosão dos filtros da reparação à diluição dos danos. $2^{\mathrm{a}}$ ed. São Paulo: Atlas, 2009, pp. 126-127.

${ }_{44}^{4}$ DiAS, José de Aguiar. Da responsabilidade civil. $11^{a}$ ed. Rio de Janeiro: Renovar, 2006, p. 992.

${ }^{45}$ Cf. idem, pp. 992-993. "A distinção, ao contrário do que parece, não decorre da natureza do direito, bem ou interesse lesado, mas do efeito da lesão, do caráter de sua repercussão sobre o lesado. De forma que tanto é possível ocorrer dano patrimonial em consequência de lesão a um bem não patrimonial como dano moral em resultado de ofensa a bem material”. Idem, p. 992.

${ }^{46}$ Cf. idem, p. 1006.

${ }^{47}$ SANTOS, Antonio Jeová. Op. cit. (nota 13), p. 116.

${ }^{48}$ Cf. idem, pp. 117-118.
} 
Neste compasso, ROLF MADALENO acredita que melhor clarifica a compreensão dos danos se considerarmos que os bens extrapatrimoniais constituem o que a pessoa representa socialmente, e os bens patrimoniais, o que ela possui ${ }^{49}$.

Já para CARLOS AlBerto BitTAR “a separação pela patrimonialidade, ou não, do reflexo produzido na esfera jurídica põe em evidência, de imediato, a bipartição do contexto valorativo que interessa ao Direito: o da pecuniaridade e o da moralidade "50, assim, de modo geral, considera essa divisão a de mais fácil circulação, pois se vale do método da exclusão. Todavia, admite que este método acaba não enunciando, de modo explícito, os danos morais, deixando ao intérprete a sua formulação concreta ${ }^{51}$.

\subsubsection{Lesão aos direitos da personalidade}

A segunda teoria considera dano moral a afetação aos direitos da personalidade. Atualmente, muitos juristas aprofundam este conceito do dano moral, vendo ambas as figuras como correlatas ${ }^{52}$.

\section{Conforme leciona ANDERSON SCHREIBER, a expressão direitos da} personalidade foi cunhada por jusnaturalistas franceses e alemães para designar certos direitos inerentes ao homem, preexistentes ao reconhecimento estatal ${ }^{53}$. Ele traça a relação entre a dignidade humana e os direitos da personalidade, de maneira que estes seriam fruto

\footnotetext{
${ }^{49}$ Cf. MADALENO, Rolf. O dano moral na investigação de paternidade. Revista da Ajuris, n. 71, 1997, p. 271.

${ }^{50}$ BITTAR, Carlos Alberto. Op. cit. (nota 14), p. 36.

${ }^{51}$ Cf. idem, p. 40.

52 Vale ressaltar que a noção de dano moral como afetação dos direitos da personalidade também é compartilhada pela doutrina estrangeira. Assim, por exemplo: na Espanha, PÉREZ MAYOR, Adrián. Crisis matrimoniales e indemnización por daño moral. Revista Jurídica de Catalunya, n. 1. Barcelona, 2004, p. 164; em Portugal, DiAs, Cristina Manuela Araújo. Responsabilidade civil e direitos familiares conjugais (pessoais e patrimoniais): possibilidade de indemnização ou fragilidade da garantia? Scientia Ivridica - Revista de Direito Comparado Português e Brasileiro, n. 286/288, 2000, p. 359. Porém, vale mencionar que na doutrina argentina há quem faça distinção entre o dano aos direitos personalíssimos e o dano moral. Os direitos personalíssimos seriam derivados das premissas básicas do sistema jurídico: o direito à vida, à dignidade e à sociabilidade. Tudo aquilo que advenha diretamente destes três marcos fundamentais se enquadraria no rol de direitos personalíssimos. Assim, o direito à saúde, o direito à imagem e o direito de não ser segregado do meio social seriam exemplos de corolários daquelas três figuras, respectivamente. A lesão a tais direitos encontraria proteção no art. 1071 do Código Civil argentino. Cf. GHERSI, Carlos Alberto, WEINGARTEN, Celia et GHERSI, Sebastián R. Daños y delitos en las relaciones de familia. $1^{\mathrm{a}}$ ed. Rosario: Nova Tesis Editorial Juridica, 2010, p. 50. Já os danos morais dizem respeito às lesões aos sentimentos, e teriam outro fundamento legal: o art. 1078 do Código Civil. Cf. idem, 145, passim.

${ }^{53}$ Cf. SCHREIBER, Anderson. Direitos da personalidade. São Paulo: Atlas, 2011, p. 5.
} 
do desenvolvimento teórico-jurídico para explicitar o conteúdo da dignidade, dando concretude à sua fluidez conceptual ${ }^{54}$.

Também Maria Helena DinIZ concarda que "o dano moral é, na verdade, lesão ao direito da personalidade ${ }^{, 55}$.

Na visão de YUSSEF SAID CAHALI, tudo aquilo que molesta gravemente a alma humana, ferindo os valores fundamentais inerentes à sua personalidade, qualifica-se como dano moral; no entanto, não há como enumerá-lo exaustivamente, apenas podendo ser evidenciando na dor, na angústia, no sofrimento, na tristeza, no desprestígio, no descrédito à reputação, na humilhação pública, nas situações de constrangimento, no devassamento da privacidade, no desequilíbrio da normalidade psíquica, nos traumatismos emocionais, na depressão e no desgaste psicológico ${ }^{56}$.

Nestes termos, CARlos Alberto BitTAR procura deixar claro que o que diferencia a natureza do dano é o reflexo experimentado pelo lesado: "será moral se o reflexo alcançar os componentes valorativos da personalidade ${ }^{, 57}$. Assim, o autor propõe identificar os danos morais da seguinte forma:

“(...) são aqueles suportados na esfera dos valores da moralidade pessoal ou social, e, como tais, reparáveis, em sua integralidade, no âmbito jurídico. Perceptíveis pelo senso comum - porque ligados à natureza humana - podem se identificados, em concreto, pelo juiz, à luz das circunstâncias fáticas e das peculiaridades da hipótese 'sub litem', respeitado o critério básico da repercussão do dano na esfera do lesado, ${ }^{, 58}$.

Portanto, infere que esta espécie de dano relaciona-se ao complexo valorativo intrínseco da pessoa e às suas projeções na sociedade, vale dizer, aos elementos que a individualizam enquanto ser, tais como a honra, a reputação e as manifestações do intelecto ${ }^{59}$; e se traduz em turbações de ânimo, em reações desagradáveis, desconfortáveis

\footnotetext{
${ }^{54}$ Cf. idem, pp. 8-10. Conforme salienta: "os direitos da personalidade consistem em atributos essenciais da pessoa humana, cujo reconhecimento jurídico resulta de uma contínua marcha de conquistas históricas". Idem, p. 12.

${ }^{55}$ DINIZ, Maria Helena. Curso de direito civil brasileiro: responsabilidade civil. v. 7. $26^{\mathrm{a}}$ ed. São Paulo: Saraiva, 2012, p. 109.

${ }_{56}^{56}$ Cf. CAHALI, Yussef Said. Op. cit. (nota 39), p. 20.

${ }^{57}$ BITTAR, Carlos Alberto. Op. cit. (nota 11), p. 279.

${ }^{58}$ BITTAR, Carlos Alberto. Op. cit. (nota 14), pp. 43-44.

${ }^{59}$ Cf. idem, pp. 33-34.
} 
ou constrangedoras ${ }^{60}$. Ele ultima: “ora, é exatamente quando se ferem os componentes da subjetividade e da consideração pessoal e social do titular de direitos, que os danos apresentam-se como morais, 61 .

Portanto, segundo esta corrente, o dano moral constitui as repercussões na esfera personalíssima da pessoa, uma lesão a um interesse jurídico relacionado aos direitos da personalidade, como a vida, a integridade corporal, a liberdade, a honra, o decoro, a intimidade, os sentimentos afetivos e a própria imagem. Ou seja, a expressão estaria relacionada às agressões injustas acometidas aos bens imateriais, que atingem o âmago do indivíduo.

Por outro lado, CARlos Alberto BitTAR postula que não se pode simplesmente extrair que da lesão a direito da personalidade provenha dano moral, diante da multiplicidade de fatores que, em concreto, podem interferir: as condições da pessoa, suas reações, seu estado de espírito, a gravidade do fato, a intenção do agente etc ${ }^{62}$.

Na opinião de Maria Celina Bodin de Moraes, o mecanismo de identificação do conceito do dano moral funciona de maneira pouco clara no Brasil, pois é utilizado um procedimento de 'dedução lógica'. Ela afirma que a maior parte dos juristas filia-se à chamada 'lição de René Savatier' o qual definiu o dano moral como "todo sofrimento humano que não é causado por uma perda pecuniária "63.

Todavia, tal conceituação negativa não permite que se colha a noção específica, pois leva a uma ideia ampla e genérica do dano moral, a ponto de admitir praticamente 'todo sofrimento humano' na sua configuração. Ou seja, o dano moral passa a ser explicitado enquanto os efeitos da ação, que originam angústia, dor, sofrimento, tristeza ou humilhação à vítima, trazendo-lhe sensações e emoções negativas ${ }^{64}$.

Para a jurista a reparação dos danos morais não pode mais operar, como vem ocorrendo, no 'nível do senso comum', pois sua importância no mundo atual exige que se busque alcançar um determinado grau de tecnicidade jurídica, edificando-se uma categoria

${ }^{60}$ Cf. idem, p. 36.

${ }^{61}$ Idem, p. 62.

${ }_{63}^{62}$ Cf. idem, p. 39.

${ }^{63}$ Moraes, Maria Celina Bodin de. Danos morais em família? Conjugalidade, parentalidade e responsabilidade civil. Revista Forense, v. 386, 2006, pp. 186-187.

${ }^{64}$ Cf. ibidem. 
teórica que seja elaborada o suficiente para demarcar as numerosas especificidades do instituto ${ }^{65}$.

Ela destaca que atualmente o dano moral vem sendo definido como aquele que fere direitos personalíssimos, isto é, todo e qualquer atributo que individualiza a pessoa ${ }^{66}$.

Mister aqui fazer uma pequena digressão. É que para a autora existem duas correntes sobre a noção do dano ressarcível: o dano como antijuridicidade, violação culposa de direito ou norma; e a teoria do interesse, que o vincula à lesão de um interesse (ou bem) juridicamente protegido ${ }^{67}$. E, em sua opinião: “o critério mais consistente, como se verá, sustenta que indenizável será o evento danoso relevante segundo uma ponderação dos interesses em jogo à luz dos princípios constitucionais" 68 .

Segundo a jurista, a conceituação de dano moral como violação a direito da personalidade poderia ser alvo das críticas à teoria do dano ressarcível como violação a um direito subjetivo. Daí que, em nome da teoria do interesse seria preciso lançar mão de uma noção que prescinda de modelos típicos de direitos subjetivos. Neste sentido, os interesses tutelados devem ser referidos a uma cláusula geral. Assim, "sob esta perspectiva constitucionalizada, conceitua-se o dano moral como a lesão à dignidade da pessoa humana" 69 .

O dano moral será somente a violação a algum dos aspectos ou substratos que compõem a dignidade humana, tais como a ofensa à liberdade, à igualdade, à solidariedade (familiar ou social) e à integridade psicofísica de uma pessoa. Porém, adverte que na

\footnotetext{
${ }^{65}$ Assim, entende que "a ausência de rigor científico e de objetividade na conceituação do dano moral tem gerado obstáculos ao adequado desenvolvimento da responsabilidade civil, além de perpetrar, quotidianamente, graves injustiças e incertezas aos jurisdicionados. Portanto, o ressarcimento do dano moral deve ser tratado com maior seriedade, tanto científica quanto metodológica, visto que séria também é a exigência de proteger eficazmente a pessoa humana e seus direitos fundamentais". MORAES, Maria Celina Bodin de. Deveres parentais e responsabilidade civil. Revista Brasileira de Direito de Família, n. 31, 2005, p. 51.

${ }^{66}$ Cf. MoRAes, Maria Celina Bodin de. Danos à pessoa humana: uma leitura civil-constitucional dos danos morais. Rio de Janeiro: Renovar, 2009, pp. 157-158.

${ }^{67}$ Cf. Moraes, Maria Celina Bodin de. A constitucionalização do direito civil e seus efeitos sobre a responsabilidade civil. In: Na medida da pessoa humana: estudos de direito civil-constitucional. Rio de Janeiro: Renovar, 2010, p. 325.

${ }^{68}$ Idem, p. 326

${ }^{69}$ Idem, p. 332
} 
situação concreta esses princípios podem entrar em colisão e, neste caso, propõe a ponderação dos interesses em conflito ${ }^{70}$.

Sem embargo dessa contribuição à ciência jurídica, acreditamos que não existe uma verdadeira contradição entre reconhecer o dano moral como violação de direito da personalidade, por um lado, e lesão à dignidade humana, por outro. A aproximação de ambas as figuras acaba superando as diferenças entre elas ${ }^{71}$. Desta forma, a violação de direitos da personalidade, que apresentam rol exemplificativo, significaria afetação de um interesse juridicamente tutelado, adstrito à dignidade humana ${ }^{72}$. Assim, a ponderação pode ser feita de acordo com o interesse inerente ao direito da personalidade em questão ${ }^{73}$.

ANTONIO JeOVÁ SANTOS também critica esta teoria, que conceitua o dano moral como lesão aos direitos da personalidade.

Em primeiro lugar, ele acredita que o intérprete poderia ser levado a concluir ter sido esta a doutrina adotada pelo Direito brasileiro, pelo fato de que o art. $5^{\circ}$, inciso X, da Constituição Federal menciona o dano moral ao fazer referência expressa a alguns dos direitos da personalidade ${ }^{74}$.

Esta teoria, em sua visão, traria um grande problema, pois, ao definir o dano como a própria lesão ao direito da personalidade, implicaria indenização idêntica para casos diversos, impedindo a consideração dos aspectos particulares de cada situação. Isto

\footnotetext{
${ }^{70}$ Cf. MorAEs, Maria Celina Bodin de. Op. cit. (nota 65), pp. 52-53. Segundo afirma, “vincular o dano moral unicamente à ofensa de valores ou interesses constitucionalmente protegidos, contidos no conceito de dignidade humana, impede que se fomente a chamada 'indústria do dano moral' na medida em que se constitui uma salvaguarda invencível contra os riscos de expansão desmensurada dos danos ressarcíveis. Além disso, vai ao encontro da tendência contemporânea de atribuir à responsabilidade civil o papel de proteção mínima e constante de direitos e interesses fundamentais (...)”. Idem, p. 53.

${ }^{71}$ De maneira geral, isto se denota de afirmações do tipo: “(...) o melhor entendimento para conceituar o dano moral está na sua vinculação com a ofensa à dignidade da pessoa humana que se perfaz diante de agressões a direitos da personalidade”. RESEDÁ, Salomão. A função social do dano moral. Florianópolis: Conceito Editorial, 2009, p. 143.

72 Neste sentido: "a definição do dano moral como lesão a atributo da personalidade tem a extrema vantagem de se concentrar sobre o objeto atingido (o interesse lesado), e não sobre as consequências emocionais, subjetivas e eventuais da lesão”. SCHREIBER, Anderson. Op. cit. (nota 53), p. 17.

${ }^{73}$ A própria autora abre esta possibilidade, ao explicar: "nos casos de colisão - como entre os direitos à informação, de um lado, e à imagem, honra ou privacidade, de outro - o melhor caminho é reconhecer nos chamados direitos da personalidade expressões da irrestrita proteção jurídica à pessoa humana e, portanto, atribuir-lhes a natureza de princípios de inspiração constitucional. Assim, tais litígios deverão ser examinados através do já amplamente aceito mecanismo da ponderação, com o objetivo de verificar, no caso concreto, onde se realiza mais plenamente a dignidade da pessoa humana, conforme a determinação constitucional". MoraEs, Maria Celina Bodin de. Ampliando os direitos da personalidade. In: Na medida da pessoa humana: estudos de direito civil-constitucional. Rio de Janeiro: Renovar, 2010, p. 128.

${ }^{74}$ Cf. SANTOS, Antonio Jeová. Op. cit. (nota 13), pp. 92-93.
} 
seria inadmissível, pois “(...) a mão de um pianista ou a perna de um jogador de futebol, evidentemente, devem merecer maior proteção do que as daqueles que não vivem dessas atividades, 75 .

Em sua visão, o dano enquanto lesão a direito é algo abstrato, de sorte que é insuficiente para originar ressarcimento. Pelo contrário, é necessário que o resultado afete a vítima em seu bem-estar psicofísico. Logo, o juiz não terá como avaliar em que constituiu o dano moral sem que antes a vítima descreva como o ato ilícito repercutiu em seu ânimo $^{76}$.

Conforme seu ponto de vista, a lesão de um interesse juridicamente protegido é sempre axiologicamente desvaliosa para o Direito. Porém, a configuração do dano ressarcível requer, ainda, a confrontação com outra perspectiva axiológica, na qual se examina o resultado da lesão, para averiguar sua conformidade e a magnitude que reveste ${ }^{77}$.

Desta forma, entende que o dano moral é a alteração no bem-estar psicofísico do indivíduo, a dor profunda que causa modificações no seu estado anímico ${ }^{78}$, de maneira que “(...) se o ilícito não repercute de forma detrimentosa na 'psique', não existe 'dano moral $^{, 79}$.

Além disto, o jurista alega que o conceito utilizado pela doutrina limita as hipóteses de dano, pois existem outros direitos, no âmbito extrapatrimonial, que não são da personalidade, mas que uma vez atingidos ocasionam ruptura na tranquilidade espiritual, como os direitos políticos, sociais e os decorrentes de laços familiares ${ }^{80}$.

\footnotetext{
75 Ibidem.

${ }^{76}$ Cf. idem, pp. 94-95. "O que determina o 'dano moral indenizável' é a consequência, o resultado que do ato dimana. Não é o dano em si que dirá se ele é ressarcível, mas os efeitos que o dano provoca. Reduzindo o dano ressarcível à lesão mesma, o fato em si é que seria indenizado. No sistema processual brasileiro, em que o autor tem de narrar os fatos e fundamentos jurídicos do pedido, mais avulta a necessidade de compreender 'dano moral' como a consequência que tem origem no mal inferido a alguém'. Idem, p. 93.

${ }^{77}$ Cf. idem, p. 94.

${ }^{78}$ Cf. idem, p. 95

${ }^{79}$ Idem, p. 94. No mesmo sentido: "é a partir da turbação anímica, com alteração do bem-estar psicofísico, que se identifica a agressão imaterial. (...) Não há que se falar em dano moral sem que haja alterações negativas no estado anímico". RESEDÁ, Salomão. Op. cit. (nota 71), p. 131.

${ }^{80}$ Cf. SANTOS, Antonio Jeová. Op. cit. (nota 13), p. 93.
} 
Por fim, o jurista acaba por afirmar que se o prejuízo afeta bem material, o dano é patrimonial; já quando a lesão afeta sentimentos, afeições legítimas e rompe o equilíbrio espiritual, o dano é moral $^{81}$.

\subsubsection{Breves considerações}

Como já havíamos adiantado, as formas de conceituar o dano estão baseadas na ideia de bem jurídico.

Fez-se a seguinte distinção: a) dano moral como afetação do bem jurídico não patrimonial; b) dano moral como afetação dos bens jurídicos (direitos) da personalidade; $\mathrm{e}$ c) dano moral como a afetação dos bens jurídicos de ordem anímica (da alma), em virtude da lesão (crítica de ANTONIO JEOVÁ SANTOS).

Há realmente uma distinção, mas essas definições não são excludentes.

Aquilo que não é patrimonial pode ser direito da personalidade ou bem de ordem anímica. É uma forma de conceituação por meio negativo, a qual, se por um lado tem a desvantagem de não dizer $o$ que é, mas apenas o que não é, por outro é mais abrangente, pois diz respeito a tudo que não seja patrimonial.

Já os bens jurídicos da personalidade não são patrimoniais e muitos deles são de ordem anímica. É uma forma de conceituação propriamente jurídica, pois diz respeito a outra categoria jurídica (direitos da personalidade). Tem a vantagem de ser positiva, e de poder se utilizar de toda a teoria desenvolvida a respeito dos direitos da personalidade, os quais, se não são infinitos (pois têm um fim), são indefinidos (não sabemos qual é o fim). Ou seja, os direitos da personalidade não encontram um rol taxativo. A doutrina pode 'descobrir' novos direitos da personalidade ${ }^{82}$.

\footnotetext{
${ }^{81}$ Cf. idem, p. 78.

${ }^{82}$ Neste sentido: "Na falta de explícito reconhecimento legal, é preciso definir se tais manifestações integram ou não a dignidade humana. Cumpre verificar se consistem em esferas essenciais da personalidade humana, que escaparam à atenção do legislador, ou se configuram, ao contrário, aspectos menores da existência individual que não podem ser elevados a direitos da personalidade". SCHREIBER, Anderson. Op. cit. (nota 53), p. 15. E complementa: “(...) o dano moral consiste justamente na lesão a um atributo da personalidade humana. Assim, a lesão a qualquer dos direitos da personalidade, sejam expressamente reconhecidos ou não pelo Código Civil, configura dano moral". Idem, p. 16. Igualmente é a colocação de MARIA CELINA BODIN DE MORAES: "a propósito dos direitos da personalidade, um de seus aspectos mais interessantes - $e$ problemáticos - consiste no fato de que se evidenciam sempre novas instâncias concernentes à personalidade do sujeito, não previstas nem previsíveis pelo legislador, de modo que estes interessem
} 
Por sua vez, os bens jurídicos de ordem anímica trazem em si um problema, pois a definição utiliza um conceito filosófico (anímico), e não jurídico. Ou seja, a utilização deste termo leva uma indefinição para dentro da definição. É claro que se pode definir o que é anímico, mas o seu significado será menos conceitual, menos trabalhado e menos adaptado ao Direito do que, por exemplo, o conceito de direitos da personalidade.

Além disto, esta terceira teoria parece enxergar uma diferença que os adeptos da segunda corrente não aceitariam. Ela separa o conceito de dano moral dos danos efetivamente sofridos, como se o primeiro estivesse circunscrito ao plano abstrato, sem alcançar as repercussões de ordem psicofísica na pessoa. Todavia, dizer que um conceito é geral e abstrato não significa afirmar que o objeto ao qual se refere não é concreto. $\mathrm{O}$ conceito de dano moral é abstrato, mas o objeto ao qual se aplica é concreto, e seus contornos serão demonstrados na análise das circunstâncias que envolvem o caso (englobando os efeitos negativos de ordem anímica).

Não obstante essas colocações, a preocupação maior é que, na situação de indefinição em que se encontra o conceito de dano moral, nele se possa incluir qualquer coisa, isto é, todo dano não patrimonial, conforme a primeira corrente; a simples violação a direito da personalidade, na acepção da segunda corrente; ou todo sofrimento humano causado pela lesão, de acordo com a terceira.

Portanto, desta análise inferimos que o dano é toda modificação negativa. A questão é saber a natureza desta modificação no dano moral. Ora, ela pode ter infinitas naturezas, a depender de qual aspecto que vamos enfatizar. Por isso é importante analisar quais são os aspectos relevantes para o Direito, o que estas três teorias tentaram fazer.

Aqui se coloca a observação de CARlos Alberto BitTAR, para quem a construção da teoria dos danos morais tem encontrado dificuldades, principalmente em razão dos embates oriundos da diversidade de perspectiva em que se têm posto os intérpretes ${ }^{83}$.

Daí porque a doutrina muitas vezes utiliza o aspecto patrimonial, pois o conceito de patrimônio é bem elaborado em Direito, e dificilmente se faz confusão entre o

precisam ser encarados como uma categoria aberta". MORAES, Maria Celina Bodin de. Op. cit. (nota 73), p. 127.

${ }^{83}$ Cf. BITTAR, Carlos Alberto. Op. cit. (nota 14), pp. 41-42. 
que é patrimônio e o que não é. De sua parte, a teoria dos direitos da personalidade também vai neste mesmo sentido, procurando abarcar tudo aquilo que não seja patrimônio $^{84}$.

Logo, o que vemos é a confluência entre as duas teorias. A teoria dos direitos da personalidade caminha para se tornar a teoria dos direitos não patrimoniais ${ }^{85}$.

Demais disto, surge um ponto que torna o assunto ainda mais complexo: a dignidade humana. Conforme analisaremos, a doutrina passou a utilizar a dignidade humana como ponto de partida, e dela nós podemos inferir simplesmente todo e qualquer direito (inclusive os patrimoniais, vale dizer), os direitos da personalidade passaram a ser os direitos essenciais para uma vida digna, o que os torna bastante abrangentes.

\footnotetext{
${ }^{84}$ Muitos acabam, deste modo, jungindo as concepções: "por isso, o dano moral possui natureza imaterial e extrapatrimonial (...) O prejuízo moral advém da agressão a um direito da personalidade, subjetivamente inerente ao indivíduo, bastando, para o dever de indenizar o 'fato da violação"'. SILVA, Michel Mascarenhas. A responsabilidade civil no rompimento do casamento e da união estável. Florianópolis: Conceito Editorial, 2009, p. 59; "O dano moral, de forma ampla, é a agressão à dignidade humana, que pode decorrer de lesão à honra, à dor sentimental ou física e de tudo o que afete a paz interior do indivíduo e cause abalos a sua personalidade" e "os danos extrapatrimoniais são, em última análise, os danos aos direitos da personalidade, e a tutela ressarcitória desses direitos se dá por meio da indenização por danos morais". AMARO, Elisabete Aloia. Responsabilidade civil por ofensa aos direitos da personalidade. In: NERY, Rosa Maria de Andrade et DonNINI, Rogério (Coords.). Responsabilidade civil: estudos em homenagem ao professor Rui Geraldo Camargo Viana. São Paulo: Revista dos Tribunais: 2009, pp. 166 e 167.

${ }^{85}$ De forma similar, J.J. GOMES CANOTILHO também leciona a confluência entre a teoria dos direitos da personalidade e os direitos fundamentais: "Muitos dos direitos fundamentais são direitos da personalidade, mas nem todos os direitos fundamentais são direitos de personalidade. (...) Contudo, hoje em dia, dada a interdependência entre o estatuto positivo e o estatuto negativo do cidadão, e em face de um direito geral de personalidade como 'direito à pessoa ser e à pessoa devir', cada vez mais os direitos fundamentais tendem a ser direitos de personalidade e vice-versa". CANOTILHO, J.J. Gomes. Direito constitucional e teoria da constituição. $7^{\mathrm{a}}$ ed. Coimbra: Almedina, 2000, p. 396. Na esteira deste pensamento, ANDERSON SCHREIBER cria um paralelo entre os direitos humanos, os direitos fundamentais e os direitos da personalidade, termos que contemplam os atributos da pessoa humana merecedores de proteção jurídica. Em sua construção, a diferença reside apenas no plano de manifestação da personalidade humana. Os direitos humanos estão no plano internacional, independentemente da regulação de cada Estado; direitos fundamentais é expressão para a positivação na Constituição; e, finalmente, direitos da personalidade aludem a atributos humanos que exigem proteção diferenciada nas relações privadas, sem embargo de encontrar fundamento constitucional e da ressonância nacional e internacional. Cf. SCHREIBER, Anderson. Op. cit. (nota 53), pp. 12-13.
} 


\subsection{TRATAMENTO DO DANO MORAL}

Até aqui, vimos o conceito do dano moral, esmiuçado nas palavras que compõem a expressão e nas principais teorias que buscam defini-lo.

Neste compasso, aprofundaremos o estudo desta espécie de dano no que toca ao seu desenvolvimento no Direito brasileiro, sua caracterização, função e natureza jurídica da reparação, bem como às inescapáveis dificuldades relacionadas ao arbitramento do quantum indenizatório. Antes, porém, realizaremos uma concisa digressão a respeito do instituto da responsabilidade civil e seus pressupostos.

\subsubsection{CONTORNOS DA RESPONSABILIDADE CIVIL}

Responsabilizar significa, em breves palavras, imputar consequências danosas a uma pessoa, que será obrigada a reparar o prejuízo causado a outra ${ }^{86}$.

Segundo CARlos Alberto BitTAR, a responsabilização do agente é a resposta do Direito a ações lesivas ${ }^{87}$, é a reação da sociedade em defesa da harmonia e da paz que devem reinar nas relações humanas ${ }^{88}$.

Para aquele que sofreu o dano, o fim da responsabilidade civil não é apagar os efeitos da lesão, mas repará-los ${ }^{89}$.

Por conseguinte, na base do dano encontra-se a ideia de reação da ordem jurídica a fatos lesivos, com a qual se objetiva, fundamentalmente, devolver ao lesado o valor representativo do interesse atingido ou voltá-lo ao estado anterior, quando possível ${ }^{90}$.

Nestes termos, o autor conclui que, repugnando à consciência humana o dano injusto e sendo necessária a proteção da individualidade para a própria coexistência

\footnotetext{
${ }^{86}$ INACIO DE CARVALHO NETO explica o sentido etimológico do termo responsabilidade: “(...) deriva do vocábulo latino 'respondere' (responder), e deste sentido surge seu significado técnico-jurídico, ou seja, responsabilizar-se, tornar-se responsável, ser obrigado a responder". CARVALHO NETO, Inacio de. Responsabilidade civil no direito de família. $4^{\mathrm{a}}$ ed. Curitiba: Juruá, 2011, p. 25.

${ }^{87}$ Cf. BitTAR, Carlos Alberto. Op. cit. (nota 14), p. 65

${ }^{88}$ Cf. idem, p. 70.

${ }^{89}$ Cf. idem, p. 72-74. "O direito à reparação é o direito que o lesado tem de obter uma resposta do ordenamento jurídico pela lesão sofrida. Significa, portanto que ele pode se valer dos mecanismos que o direito lhe põe à disposição para obter, então, uma resposta que venha a satisfazer os seus interesses. Via de regra, essa resposta se consubstancia na teoria da Responsabilidade Civil”. BITTAR, Carlos Alberto. Op. cit. (nota 11), p. 279.

${ }^{90}$ Cf. BITTAR, Carlos Alberto. Op. cit. (nota 14), p. 38
} 
pacífica da sociedade, a teoria da responsabilidade civil encontra na natureza do homem a sua própria explicação ${ }^{91}$, e com a restauração do equilíbrio rompido nas relações sociais, alcança o seu objetivo $^{92}$.

PONTES DE MIRANDA já afirmava que aquele que causa dano a outrem não prejudica somente a este, mas à ordem social; a reparação para o ofendido não adapta o culpado à vida social, nem lhe corrige o defeito de adaptação. O que faz é consolar o prejudicado, com a prestação do equivalente ${ }^{93}$.

Para Bernardo Castelo Branco, "é justamente nos pilares do conceito de justiça que encontramos a pedra fundamental de toda a construção da teoria da responsabilidade civil, uma vez que o não causar dano a outrem ('alterum non laedere') constitui um dos limites essenciais para a subsistência do equilíbrio sempre tênue, que caracteriza a vida em sociedade, ${ }^{, 94}$.

Também Regina BeAtriz Tavares da Silva afiança que, como o Direito existe em função do homem, ocorrendo ação lesiva aos seus interesses surge a necessidade de reparação dos danos, a fim de se reestabelecer o equilíbrio pessoal e social ${ }^{95}$. De forma análoga, MARIA HELENA DINIZ aponta que o restabelecimento do equilíbrio violado pelo dano é a fonte geradora da responsabilidade civil ${ }^{96}$.

Assim, para ANTONIO JeOvÁ SANTOS, quando violado o dever genérico de não lesar o próximo nasce para o ofensor outro dever, que o obriga a indenizar, como se fosse o 'reverso da medalha'. Se essa violação atinge a vítima causando menoscabo no espírito ou detrimento no patrimônio, estar-se-á diante do dano moral e da lesão patrimonial, respectivamente ${ }^{97}$.

\footnotetext{
${ }^{91}$ Cf. idem, p. 60.

${ }^{92}$ Cf. idem, p. 75.

93 Cf. Miranda, Pontes de. Manual do código civil. v. 16. Rio de Janeiro: Jacinto Ribeiro dos Santos, 1927, pp. 42-43.

94 BRAnCO, Bernardo Castelo. Dano moral no direito de família. São Paulo: Método, 2006, p. 43.

95 Cf. SANTOS, Regina Beatriz Tavares da Silva Papa dos. Responsabilidade civil dos conviventes. Revista Brasileira de Direito de Família, n. 3, 1999, p. 34.

${ }^{96}$ Cf. DINIZ, Maria Helena. Op. cit. (nota 55), p. 21.

${ }^{97}$ Cf. Santos, Antonio Jeová. Op. cit. (nota 13), pp. 32-33. "Porque o homem deve viver honestamente, a consequência direta é que não prejudique seus semelhantes. Quando ocorre o contrário, existe conduta imprópria, ilícita. O não causar dano a outrem surge do dever de fazer justiça, pois quem lesiona algo ou alguém, priva este último de alguma coisa, tira-lhe o que antes lhe aproveitava, seja porque estava em seu próprio ser (honra, intimidade, vida privada), seja em seu patrimônio material”. Idem, p. 32.
} 
Como anunciamos anteriormente, o problema maior é estabelecer a relevância jurídica do dano. A teoria da responsabilidade civil assume, deste modo, a incumbência de circunscrever a área dos danos ressarcíveis. Ou seja, na seara do direito civil, a responsabilização é, em última análise, uma forma de qualificar eventos danosos.

Note-se que a definição do que seja dano ressarcível será diferente conforme o modelo adotado por cada ordenamento jurídico. Assim, se alguns especificam taxativamente os interesses cuja violação provoca a reparação do dano, outros preveem apenas cláusulas gerais, deixando ao Judiciário ampla margem de atuação na definição dos interesses merecedores de tutela. Os primeiros são chamados típicos ou fechados; porém entre os segundos - atípicos ou abertos - encontra-se o ordenamento brasileiro, que estabeleceu nos artigos 186 e 927 do Código Civil cláusulas gerais de ressarcimento dos danos materiais e morais ${ }^{98}$.

Logo, não se reduzem a hipóteses previstas explicitamente no Direito legislado, o que se coaduna com a própria a essência da teoria da responsabilidade civil, que é dada pelo princípio do neminem laedere, devendo essa noção ser entendida em toda a sua extensão, a fim de que se possa fazer justiça ao lesado no caso concreto ${ }^{99}$.

Assim, conforme afirmamos, o "dano é toda ofensa a um bem jurídico"100, é a lesão a interesse juridicamente tutelado. Toda privação de um bem, quer de origem espiritual ou patrimonial, constitui um menoscabo porque retira a possibilidade da pessoa usufruí-lo, e por isso recebe ampla proteção do ordenamento ${ }^{101}$.

Note-se que, já no início da década de 80, ORLANDO GOMES mencionava a grande transformação por que passava a responsabilidade civil, que deixava em segundo plano a avaliação do ato ilícito para se voltar primordialmente à análise conceitual do dano injusto $^{102}$.

\footnotetext{
${ }^{98}$ Cf. SCHREIBER, Anderson. Op. cit. (nota 43), p. 95.

${ }^{99}$ Cf. BITTAR, Carlos Alberto. Op. cit. (nota 14), p. 43.

${ }^{100}$ CARVAlHo Neto, Inacio de. Op. cit. (nota 86), p. 495.

${ }^{101}$ Cf. SANTOS, Antonio Jeová. Op. cit. (nota 13), p. 39.

102 Cf. GOMES, Orlando. Tendências modernas na teoria da responsabilidade civil. In: FRANCESCO, José Roberto Pacheco di. Estudos em homenagem ao professor Silvio Rodrigues. São Paulo: Saraiva,1989, p. 293. "Com isso, a ideia de dano vinculada à de azar, de infortúnio, cede lugar, na atualidade, à de responsabilidade civil, principalmente no que se refere aos direitos da personalidade pela sua subjetividade”. Oltramari, Fernanda et Oltramari, Vitor Hugo. As tutelas da personalidade e a
} 
A tônica da responsabilidade civil passa a ser: aquele que sofreu um agravo não pode ficar sem ressarcimento. Neste contexto, desenvolve-se e avança o dano moral, ao imperar a necessidade de respeito mútuo, fundamento da convivência e exigência iniludível das relações humanas ${ }^{103}$.

BERnARDo CASTElo BRANCO assevera que a reparação dos danos essencialmente morais é um dos aspectos mais importantes desta mudança, porquanto denota a preocupação cada vez maior com a tutela dos direitos da personalidade ${ }^{104}$.

\subsubsection{Pressupostos do dever de indenizar}

São pressupostos do dever de indenizar na responsabilidade civil subjetiva: ação ou omissão do agente, dano experimentado pela vítima e relação de causalidade entre um e outro. Faz-se mister, ainda, provar a culpa (lato sensu) do agente.

Na análise de CARlos Alberto BitTAR: em primeiro lugar é necessário que exista ação ou omissão de alguém que se reflita na esfera jurídica do lesado. Essa ação tem que ser antijurídica, ou seja, contrária aos princípios e às normas do ordenamento. $\mathrm{O}$ segundo elemento é o dano, assim considerado o prejuízo suportado na esfera jurídica do lesado, que pode ser moral ou patrimonial. O terceiro é o nexo causal, ou seja, a existência de um vínculo entre o evento final e a ação desencadeada pelo lesante ${ }^{105}$. TERESA ANCONA LOPEZ aponta, ainda, entre esses pressupostos a culpa do agente ${ }^{106}$.

Portanto, o ponto de partida para que se possa falar em responsabilidade civil é a ação ou omissão. É preciso identificar a conduta que deu causa ao evento danoso. Pelo art. 186 do Código Civil, todo aquele que, por ação ou omissão voluntária, negligência ou imprudência, violar direito ou causar prejuízo a outrem, fica obrigado a reparar o dano. Trata-se da regra geral, de que a obrigação de reparar depende de dolo ou culpa do agente.

responsabilidade civil na jurisprudência do direito de família. Revista Brasileira de Direito de Família, n. 13, 2002, p. 56.

${ }^{103}$ Cf. SANTOS, Antonio Jeová. Op. cit. (nota 13), p. 73.

${ }^{104}$ Cf. BRANCO, Bernardo Castelo. Op. cit. (nota 94), pp. 41-42.

105 Cf. BITTAR, Carlos Alberto. Op. cit. (nota 11), p. 279. "Com a superveniência do resultado danoso e presente o nexo causal - preenchidos, assim, os três pressupostos da responsabilidade civil: ação, dano e vínculo - surge para o lesante a obrigação de indenizar”. BITTAR, Carlos Alberto. Op. cit. (nota 14), p. 65.

${ }^{106}$ Cf. LoPEZ, Teresa Ancona. Op. cit. (nota 10), pp. 19-20, nota 1. 
A figura do dano já foi explorada no item antecedente ${ }^{107}$, ao passo que o nexo causal, como visto, é o liame entre a ação e o dano ${ }^{108}$.

\subsubsection{DANO MORAL NO DIREITO BRASILEIRO}

A história do dano moral no Brasil pode ser dividida em dois períodos bastante distintos: antes e após a promulgação da Constituição de 1988, um marco na regulamentação do dano moral, culminando no seu pleno reconhecimento pela doutrina e jurisprudência pátrias.

Inicialmente, não havia previsão expressa em nossa legislação a respeito do dano moral e, por longos anos, houve forte resistência por parte da jurisprudência brasileira em admitir esses danos e cominar ao ofendido qualquer indenização.

Alguns autores remetem a questão dos danos morais ao período que antecede o próprio Código Civil de 1916. Nesta linha, a Consolidação de Teixeira de Freitas trazia dispositivo que supostamente sufragava a tese da reparabilidade do dano moral, ao prever que 'a indenização será sempre a mais completa possível' 109 .

No entanto, a discussão iniciou-se efetivamente com o advento do Código Civil de 1916, onde havia dispositivos que, dizia-se, contemplavam o dano moral.

Na opinião de CLÓVIS BEVILÁQUA, autor do projeto, a regra insculpida no art. 76 permitia buscar a reparação daquele dano e servia de inspiração, levando a afirmar que nossa antiga lei substantiva já encampava essa possibilidade ${ }^{110}$. Todavia, o artigo trazia preceito de cunho eminentemente processual, ao prever que para propor ou contestar uma

107 Vale aqui mencionar a observação de TERESA ANCONA LOPEZ, que enfatiza que no campo civil a responsabilidade é medida pela extensão do dano e não pelo grau de culpa, portanto, não havendo dano não há indenização, e assevera que tampouco se pode falar em ilícito civil sem a existência de um prejuízo, pois é este elemento que dá conteúdo ao ato ilícito. Cf. idem, p. 20. Esses problemas acabam ressurgindo na discussão sobre o dano moral nas relações familiares, como veremos.

${ }^{108}$ Neste ponto, cabe indicar a ressalva de ANDERSON SCHREIBER, para quem é clara a tendência de abandono - ou ao menos mitigação - desses pressupostos tradicionais da responsabilidade civil, especialmente da culpa e do nexo de causalidade, voltando-se as atenções à avaliação dos interesses jurídicos merecedores de tutela. Cf. SCHREIBER, Anderson. Op. cit. (nota 43), p. 5.

${ }^{109}$ BITTAR, Carlos Alberto. Op. cit. (nota 14), pp. 97-98.

${ }^{110}$ Em suas palavras: "se o interêsse moral justifica a ação para defendê-lo e restaurá-lo, é claro que tal interêsse é indenizável, ainda que o bem moral se não exprima em dinheiro. É por uma necessidade dos nossos meios humanos, sempre insuficientes, e, não raro, grosseiros, que o direito se vê forçado a aceitar que se computem em dinheiro o interêsse de afeição e os outros interêsses morais. Êste artigo, portanto, solveu a controvérsia existente na doutrina, e que, mais uma vez, repercutiu em nossos julgados". Beviláqua, Clóvis. Código Civil dos Estados Unidos do Brasil comentado. Rio de Janeiro: Paulo de Azevedo, 1953, p. 256. 
ação era necessário ter legítimo interesse econômico ou moral. E o parágrafo único do mesmo dispositivo estabelecia que o interesse moral somente autorizaria a ação quando diretamente relacionado ao autor ou à sua família. Portanto, muitos divergiam dessa interpretação, afirmando que a regra encontrava-se deslocada dentro do Código Civil, pois se tratava de norma de Direito processual.

Para a maioria dos doutrinadores, entretanto, a indenização por dano moral era autorizada por outro preceito do Código de 1916: o art. 159, porquanto, ao referir-se à violação de um direito, abrangeria todas as lesões, inclusive as puramente morais ${ }^{111}$.

Igualmente se mencionavam outros dispositivos daquele diploma legal, que disciplinavam a forma de liquidação do dano, onde haveria vestígios do dano moral ${ }^{112}$.

Porém, repise-se, em nenhum momento o referido Código contemplou a possibilidade de indenização do dano moral de forma expressa.

Na visão de YUSSEF SAID CAHALI 'uma coisa é admitir a 'tese' da reparabilidade do dano moral; outra coisa é reconhecer que o nosso direito civil, em suas fases anteriores, a tivesse perfilhado ${ }^{\prime 113}$. Nestes termos, o autor esclarece que a doutrina nacional, já de longa data, orientava-se no sentido de admitir a reparação destes danos. A única divergência que persistia era que alguns autores, embora aceitassem a reparabilidade do dano moral como tese, negavam tivesse a mesma sido acolhia pelo legislador como princípio geral, ressalvadas certas disposições excepcionais específicas ${ }^{114}$.

Em algumas leis esparsas, anteriores à Constituição de 1988, é possível encontrar menções ao dano moral. Merece destaque o Decreto-lei n. 2.681/12 regulamentava a responsabilidade civil das estradas de ferro no Brasil - que acolheu, ainda

\footnotetext{
${ }^{111}$ HUMBERTO THEODORO JÚNIOR afirma que "entre nós, embora sem maior explicitude acerca dos direitos da personalidade, a doutrina majoritária defendia a tese de que o art. 159 do Código Civil (de 1916), ao disciplinar a responsabilidade civil aquiliana e ao mencionar a reparabilidade de qualquer dano, estaria incluindo, em sua sanção, tanto o dano material como o moral". THEODORO JÚNIOR, Humberto. Op. cit. (nota 35), p. 5 .

${ }^{112}$ São os artigos 1.537, 1.538, 1.543, 1.547, 1.548, 1.549 e 1.550. Para YUSSEF SAID CAHALI, se é certo que o antigo Código Civil se omitira quanto a inserir uma regra geral de reparação do dano moral, não era menos certo que se referia a diversas hipóteses em que o dano moral seria reparável. Logo, ao disciplinar a forma de liquidação do dano, tais regras prestavam-se a confirmar que a ideia de reparabilidade do dano moral estava ínsita na lei civil. Cf. CAHALI, Yussef Said. Op. cit. (nota 39), p. 41.

${ }^{113}$ Idem, p. 39.

${ }^{114}$ Cf. ibidem.
} 
que por via transversa, a reparação desses danos ${ }^{115}$, e o Código Brasileiro de Telecomunicações (Lei n. 4.117/62), o primeiro diploma legal a admitir expressamente, e de maneira indiscutível, a indenização por danos morais. Em seguida, também a chamada Lei de Imprensa (Lei n. 5.250/67) enfrentou diretamente a questão. Vale notar que estas duas leis cumpriram importante papel na jurisprudência brasileira, uma vez que fixaram alguns parâmetros e criaram uma espécie de tarifação para a fixação do quantum indenizatório, questões discutidas ainda hoje em nosso país ${ }^{116}$.

Conforme anunciamos, a jurisprudência brasileira, antes de 1988, era majoritariamente contrária ao reconhecimento do dano moral puro. Argumentava-se não haver como compensar a dor com pecúnia, o que seria até mesmo imoral ${ }^{117}$.

A evolução deste entendimento passou por três estágios: em um primeiro momento, a negativa era total; em seguida, começou-se a acolher a indenização do dano moral, porém, atrelado e condicionado ao dano material; por fim, veio sua aceitação plena $^{118}$

De sua parte, a doutrina era dividida em duas correntes principais: a corrente negativa, que não reconhecia a reparação do dano moral, e a corrente afirmativa, que propugnava por sua reparação. Havia, ainda, uma terceira corrente, chamada escola eclética ou mista, que só admitia a reparabilidade dos reflexos patrimoniais dos danos morais $^{119}$.

\footnotetext{
${ }^{115}$ Registre-se que esta lei é considerada por muitos um marco histórico do reconhecimento do dano moral no Direito brasileiro, e acabou sendo estendida a todas as questões relacionadas com as atividades de transporte. ${ }^{116}$ Diversas outras leis versaram sobre o assunto: a antiga Lei de Falências (Decreto-lei n. 7.661/45), o Código Eleitoral (Lei n. 4.737/65), a Lei dos Direitos Autorais (Lei n. 5.988/73), e até mesmo a Consolidação das Leis Trabalhistas - CLT (Decreto-lei n. 5.452/43).

${ }^{117}$ Nas palavras de HUMBERTO THEODORO JÚNIOR, "a mais séria e insistente resistência era a daqueles que negavam a legitimidade moral da atribuição de um preço à dor". THEODORO JÚNIOR, Humberto. Op. cit. (nota 35), p. 5. NEHEMIAS DOMINGOS DE MELO nota que, ainda que o dano fosse efetivamente moral, dava-se o nome de dano patrimonial pela indenização, ao argumento de que seria imoral indenizar a dor. Cf. MELo, Nehemias Domingos de. Dano moral - problemática: do cabimento à fixação do quantum. $2^{\mathrm{a}}$ ed. São Paulo: Atlas, 2011, p. 17.

118 NEHEMIAS DOMINGOS DE MELo informa que "apesar de a evolução jurisprudencial ter sido lenta, no sentido do reconhecimento da tese da reparabilidade do dano moral, encontramos decisões esparsas, que de longa data, até de maneira visionária, reconheciam o dano moral puro e a necessidade de sua indenização". Ele menciona uma decisão de 1911, do magistrado Raul de Souza Martins, e outra de 1925, de Affonso José de Carvalho, que falam expressamente na reparação do dano moral. Cf. idem, p. 18.

${ }^{119}$ Cf. LOPEZ, Teresa Ancona. Op. cit. (nota 10), pp. 27-28.
} 
Os adeptos da corrente negativa ${ }^{120}$ alegavam que não se poderia atribuir um preço à dor. JOSÉ DE AGUIAR DIAS metodicamente resumiu os argumentos contrários ao ressarcimento do dano moral: “a) falta de efeito penoso durável; b) incerteza do direito violado; c) dificuldade em descobrir a existência do dano moral; d) indeterminação do número de pessoas lesadas; e) impossibilidade de rigorosa avaliação em dinheiro; $f$ ) imoralidade da compensação da dor com o dinheiro; g) extensão do arbítrio concedido ao juiz ${ }^{\prime 121}$.

Os partidários da teoria eclética ${ }^{122}$ posicionavam-se no meio termo quanto à questão, aceitando a tese do ressarcimento dos danos morais quando fossem reflexo de dano material, se originassem de delito criminal ou quando houvesse expressa determinação legal.

Já o rol de defensores da teoria afirmativa ${ }^{123}$ - que eram a favor sem qualquer subterfúgio - era maior, acabou prevalecendo em nossa doutrina e vencendo as resistências dos tribunais pátrios.

Assim, "na doutrina pátria, a tese da reparabilidade do dano moral foi francamente a vencedora" ${ }^{\prime 24}$, sendo que os adeptos desta corrente combateram os principais argumentos contrários: $a$ ) refutaram a primeira objeção com a alegação de que a sensação dolorosa só pode ter influência na avaliação e nunca no reconhecimento da existência do dano; $b$ ) informaram que o conceito de dano é único e corresponde a uma lesão de direito, ou seja, a causa do dano é uma só, a sua repercussão é que pode revestir-se de caráter patrimonial ou não-patrimonial; e c) para afastar o argumento de que é

${ }^{120}$ Nessa corrente doutrinária se filiavam: Lafaiete Rodrigues Pereira, Nelson Hungria, Tito FULGÊNCIO, JoÃo ARRUdA, SÁ PEREIRA, entre outros.

${ }^{121}$ DiAS, José de Aguiar. Op. cit. (nota 44), p. 1001. Consoante assevera ANTONIO JEOVÁ SANTOS: " $a$ doutrina que teimava em repudiar o ressarcimento de dano puramente moral, considerava que seria escandaloso discutir ante os Tribunais o valor da honra, ou das afeições mais sagradas, ou das mais íntimas e respeitáveis dores, discussão que haveria, necessariamente, de realizar-se, desde que fosse admitida a reparação, em dinheiro, do agravo moral. A apreciação pecuniária de tais danos seria sempre arbitrária, pois não tem seu equivalente em dinheiro. Repugna ao espirito o recebimento de dinheiro por um agravo à honra ou contra a probidade de alguém. O reconhecimento da indenização do 'dano moral', fomenta especulações maldosas e apetites desordenados por riquezas". SANTOS, Antonio Jeová. Op. cit. (nota 13), p. 60 .

${ }^{122}$ Dentre os que perfilavam a favor dessa teoria, merecem destaque: LUIS FREDERICO CARPENTER, JAIME LANDIM, ARNALDO MEDEIRO DA FONSECA e JORGE AMERICANO.

${ }^{123}$ Os precursores desta tese foram: Clóvis Beviláqua, Pontes de Miranda, Orozimbo nonato, Eduardo Espínola, Spencer Vampré, Bento de Faria, José de Aguiar dias, Carvalho de Mendonça, Teixeira de Freitas, Philadelpho Azevedo, Moura Bittencourt, Limongi França e Ávio BRASIL.

${ }^{124}$ LOPEZ, Teresa Ancona. Op. cit. (nota 10), p. 30. 
impossível estabelecer a existência do dano moral, afirmaram que ele é consequência irrecusável do fato danoso, e este se prova per $s e^{125}$.

JosÉ DE AGUIAR DiAS observa que “entre todas as objeções ao dano moral, a que experimentou maior fortuna foi a da impossibilidade de estabelecer equivalência entre o dano e o ressarcimento" "126. Não obstante, o jurista assevera que a equivalência, em matéria de reparação do dano moral, não significa perfeita igualdade entre a indenização e o prejuízo $^{127}$.

Quanto à imoralidade de se compensar a dor com pecúnia, segundo TERESA ANCONA LOPEZ, para os que têm 'sentimento de justiça' a reparação do dano moral é necessária, fazendo com que se aceite a fórmula pecuniária, ao menos até que se estabeleça outra mais idônea para reparar o dano moral ${ }^{128}$.

A jurista também assegura que a objeção fundada na concessão de demasiado arbítrio ao juiz 'peca pela base', pois esta faculdade é concedida ao magistrado mesmo em casos de danos patrimoniais ${ }^{129}$.

Nestes termos, Bernardo Castelo Branco, conclui ser infundado o temor daqueles que a consideravam um caminho aberto ao patrimonialismo dos valores espirituais da pessoa, que por sua natureza deveriam permanecer à margem do sentido utilitarista que a economia confere à indenização pecuniária ${ }^{130}$.

\footnotetext{
${ }^{125}$ Cf. idem, p. $28-29$.

${ }^{126}$ DiAs, José de Aguiar. Op. cit. (nota 44), p. 1003.

${ }^{127}$ Cf. ibidem. Logo, informa que tal argumento não pode ser "razão suficiente para não indenizar, e assim beneficiar o responsável, (...) porque, em matéria de dano moral, o arbitrário é até da essência das coisas”. E ainda acrescenta que "a condição da impossibilidade matematicamente exata da avaliação só pode ser tomada em benefício da vítima e não em seu prejuizo”. Idem, p. 1004.

${ }^{128}$ Cf. LopeZ, Teresa Ancona. Op. cit. (nota 10), p. 30.

${ }^{129}$ Cf. ibidem.

${ }^{130}$ Cf. BRANCO, Bernardo Castelo. Op. cit. (nota 94), p. 48. MARIA CElinA Bodin DE MORAES ilustra as transformações ocorridas: “(...) o que mudou neste caso foi exatamente a consciência coletiva acerca do conceito de justiça: o que antes era tido como inconcebível passou a ser aceitável, e, de aceitável, passou a evidente. Se era difícil dimensionar o dano, em questão de poucos anos tornou-se impossível ignorá-lo. Se era imoral receber alguma remuneração pela dor sofrida, não era a dor que estava sendo paga, mas sim a vítima, lesada em sua esfera extrapatrimonial, quem merecia ser (re)compensada pecuniariamente, para assim desfrutar de alegrias e outros estados de bem-estar psicofísico, contrabalançando ('rectius', abrandando) os efeitos que o dano causara em seu espírito". MORAES, Maria Celina Bodin de. Op. cit. (nota 66), p. 147.
} 
Quanto à jurisprudência, nossos tribunais acabaram acolhendo a possibilidade de reparação do dano moral puro ${ }^{131}$.

Consolidando a opinião majoritária, a Constituição Federal de 1988 tornou indiscutível a reparabilidade do dano moral. Disposta em seu artigo $5^{\circ}$, incisos $\mathrm{V}$ e X, a reparação do dano moral no Direito brasileiro foi elevada ao patamar de direito fundamental, encerrando de vez a contenda doutrinária e jurisprudencial ${ }^{132}$.

E, para remate de dissensos remanescentes, o Superior Tribunal de Justiça consolidou em 1992, com a edição da Súmula n. $37^{133}$, a possibilidade de cumulação dos danos moral e material, quando advindos do mesmo fato ${ }^{134}$, o que vem sendo interativamente afirmado por todos os juristas e tribunais ${ }^{135}$.

${ }^{131}$ YUSSEF SAID CAHALI informa que “(...) os insistentes reclamos doutrinários acabaram despertando esses julgadores de sua letargia, compelindo-os a encarar com maior sensibilidade a nova realidade social que se apresentava; propondo-se então os nossos tribunais de todas as instâncias a um processo revisionista de 'mea culpa', inspirado na necessidade de uma proteção mais ampla dos interesses morais, tão contundentemente feridos pelas contingências da vida moderna”. CAHALI, Yussef Said. Op. cit. (nota 39), pp. 43-44. Nestes termos, LUIZ MuRILlo FÁBREGAS observa que "a jurisprudência, até então tímida e vacilante, parecendo receosa em acolher aquilo que seria uma novidade em nosso direito, hoje se faz tranquila e remansosa, autorizando a reparação pelo dano moral (...)”. FÁBREGAS, Luiz Murillo. O dano moral resultante do divórcio ou da separação injusta e o seu ressarcimento. Revista da EMERJ, n. 6, 1999, p. 100 .

132 “Com a Constituição de 1988 veio, finalmente, o enunciado do princípio geral que pôs fim às vacilações e resistências dos tribunais (art. $5^{\circ}, V$ e X)”. THEODORO JÚNIOR, Humberto. Op. cit. (nota 35), p. 6. “Ao tratar especificamente no inc. $X$ do art. $5^{\circ}$, sobre alguns dos direitos personalíssimos, tais como a vida privada, intimidade, imagem e honra, afirmando sobre a inviolabilidade desses direitos e clamando por indenização contra quem os vulnere, explicitou a Constituição sobre o 'dano moral', de sorte que lançou uma pá de cal sobre qualquer tendência que vise a apequenar o ressarcimento dessa lesão”. SANTOS, Antonio Jeová. Op. cit. (nota 13), p. 38. “A Constituição Federal de 1988 veio a colocar uma pá de cal sobre a celeuma travada pela doutrina e a jurisprudência no tocante à indenizabilidade do dano moral no Brasil. O legislador constituinte, ao inserir no art. $5^{\circ}$ os incisos $V$ e X, a expressa previsão de indenização por dano material, dano moral e dano à imagem, pôs fim à discussão sobre o cabimento, ou não, da indenização por dano moral”. MElo, Nehemias Domingos de. Op. cit. (nota 117), p. 21. Não obstante, impende considerar que a Carta Magna apenas elevou à condição de garantia dos direitos individuais a reparabilidade dos danos morais, pois esta já estava latente na sistemática legal anterior. Assim, não é aceitável pretender-se que a reparação dos danos dessa natureza somente passou a ser devida quando verificada posteriormente àquele marco regulamentar. Cf. CAHALI, Yussef Said. Op. cit. (nota 39), p. 45. Vale salientar a crítica de ÊNIO SANTARELLI ZULIANI: "perdemos setenta e dois anos (entre 1916, data do CC, e 1988, da CF) discutindo se cabia ou não o dano moral, e a sociedade foi a única prejudicada, forçada a desenvolver-se sem o subsídio da coisa julgada que, como tônico diário indispensável para o crescimento, salva a liberdade com responsabilidade". ZULIANI, Ênio Santarelli. Dano moral: a era da jurisprudência. Revista síntese de direito civil e processual civil. Ano III, n. 13, pp. 20-37, set./out., 2001, p. 26.

${ }^{133}$ In verbis: "são cumuláveis as indenizações por dano material e dano moral oriundos do mesmo fato".

134 “Antes da Constituição de 1988, mesmo quando se admitia a reparação do dano moral, a jurisprudência predominante negava sua cumulatividade com o dano material, ao pretexto de que havendo o ressarcimento de todos os efeitos patrimoniais nocivos do ato ilícito já estaria, a vítima, suficientemente reparada”. THEODORO JúNIOR, Humberto. Op. cit. (nota 35), p. 6.

135 “Hoje, toda essa controvérsia parece superada, pois os danos à pessoa têm tratamento 'autônomo' e o dano moral é sempre 'puro'. Os prejuizos materiais e os danos morais se somam. Essa posição se vê 
Após sua consagração pela Constituição, as legislações passaram a inserir normas próprias alusivas à reparação civil pelo dano moral, culminando na edição do Código Civil de 2002, que expressamente regulamentou o instituto em seus arts. 186 e 927.

De fundamental importância, porém, apontar o relevante papel despenhado pelo Código de Defesa do Consumidor editado em 1990, que, além de prever a efetiva reparação dos danos morais, o fez sem limitações, de forma ampla e irrestrita, não estando sujeito a nenhuma espécie de tarifação. Na opinião de alguns autores, a reparação dos danos morais neste Código, ainda hoje, é mais abrangente do que a própria previsão do Código Civil ${ }^{136}$.

A admissão inconteste do dano moral, contudo, trouxe consigo outro problema. Conforme pondera YUSSEF SAID CAHALI: “(...) o desabrochar tardio da reparabilidade do dano moral em nosso direito fez desenfrear uma 'demanda reprimida', que por vezes tem degenerado em excessos inaceitáveis, com exageros que podem comprometer a própria dignidade do instituto" ${ }^{, 137}$.

A sobrevinda de exageros no requerimento desse dano ficou conhecida como 'indústria do dano moral'. ANDERSON SCHREIBER, ao comentar o termo, afirma que: "mais que a preocupação com o crescimento exponencial do número de ações de indenização por dano moral, o que o uso do termo 'indústria' anuncia é uma frontal rejeição à sua produção mecânica, algo artificial, com vistas à obtenção de lucro, em uma espécie de abordagem capitalizada de um instituto ontologicamente existencial "138

Também Maria CelinA Bodin DE MoRAes manifesta preocupação neste sentido. Para a jurista, "não foi apenas o volume dos pedidos a inflacionar; o número de concessões e o seu valor sem qualquer critério têm gerado, como consequências

definitivamente assentada a partir da Constituição de 1988 e a consequente edição da Súmula 37 do STJ, que dispõe serem cumuláveis as indenizações por dano material e moral oriundas do mesmo fato". LOPEZ, Teresa Ancona. Op. cit. (nota 10), p. 22. Para HUMBERTO THEODORO JÚNIOR, "hoje, então, está solidamente assentada a ampla e unitária teoria da reparação de todo e qualquer dano civil, ocorra ele no plano do patrimônio ou na esfera da personalidade da vítima. Há de indenizar o ofendido todo aquele que cause um mal injusto a outrem, pouco importando a natureza da lesão". THEODORO JÚNIOR, Humberto. Op. cit. (nota 35), p. 6.

${ }^{136}$ Cf. LISBOA, Roberto Senise. Responsabilidade civil nas relações de consumo. São Paulo: Revista dos Tribunais, 2001, p. 111.

${ }^{137}$ CAHALI, Yussef Said. Op. cit. (nota 39), p. 18.

${ }^{138}$ SCHREIBER, Anderson. Op. cit. (nota 43), p. 190. 
previsíveis, a banalização do dano moral e a mercantilização das relações extrapatrimoniais $" 139$.

Já YUSSEF SAID CAHALI entende que esses 'exageros da primeira hora' estão sendo paulatinamente recompostos, o que tem o mérito de restaurar a dignidade deste instituto, tão penosamente consagrado em nosso Direito ${ }^{140}$.

\subsubsection{CARACTERIZAÇÃO DO DANO MORAL}

Como vimos, a admissão plena do dano moral redundou em uma 'enxurrada' de demandas em que os litigantes buscam a reparação de agravos, muitas vezes sem que exista o substrato necessário para ensejar o ressarcimento ${ }^{141}$.

Na visão de SÉRgIO GiSCHKOW PEREIRA, do erro inicial de não se indenizar o dano moral, está se partindo para o erro oposto, constituído pelo exagero de se exigir dano moral por qualquer motivo. Para o autor já não se trata mais da 'louvável e salutar' busca dos direitos em juízo, pois a pretexto do dano moral, passa-se a almejar obter vantagens materiais a qualquer título ${ }^{142}$.

Assim, ressalta-se a dificuldade de se estremar as hipóteses de incidência do dano moral. Por isso, é necessário delimitar os interesses merecedores de tutela, na tentativa de subsidiar os operadores do direito com elementos que possam contribuir para o aperfeiçoamento do assunto.

MARia Celina Bodin DE Moraes problematiza a questão:

"seriam os danos morais decorrentes da violação a direitos subjetivos da personalidade; dos efeitos consequentes à lesão perpetrada, significando dizer que

\footnotetext{
${ }^{139}$ MoraES, Maria Celina Bodin de. Op. cit. (nota 65), p. 48.

${ }^{140}$ Cf. CAHALI, Yussef Said. Op. cit. (nota 39), p. 52.

141 "Está-se vivendo uma experiência em que todo e qualquer abespinhamento dá ensanchas a pedidos de indenização”. SANTOS, Antonio Jeová. Op. cit. (nota 13), p. 111. "Hoje há um desvirtuamento nas pretensões reparatórias. Qualquer questiúncula, por mais ridícula que seja, é motivo para aventureiros ajuizarem demandas embasados em uma pretensiosa ofensa à sua moral”. ALMEIDA JÚNIOR, Jesualdo Eduardo de. Os danos morais pelo descumprimento dos deveres pessoais do casamento. Revista IOB de Direito de Família, n. 59, 2010, p. 122.

142 "Começa-se, propositalmente ou por desconhecimento, a confundir qualquer incômodo da vida com fato gerador de dano moral. Como se a vida não fosse uma sucessão de múltiplos incômodos e como se não fosse um dos sentidos da vida exatamente enfrentar e resolver os problemas que ela nos cria. Terminar-se-á paralisando os seres humanos, que nada mais farão com receio de incidirem em dano moral a alguém”. PEREIRA, Sérgio Gischkow. Dano moral e direito de família: o perigo de monetarizar as relações familiares. Revista da Ajuris, n. 85, 2002, p. 352.
} 
podem surgir também por violação a direito patrimonial que tenha efeito no 'patrimônio' moral do sujeito; compreenderiam qualquer situação jurídica subjetiva não-patrimonial; ou, ainda e de modo mais amplo, decorreriam da violação a direitos fundamentais? ${ }^{, 143}$.

Relembre-se que em nosso país os danos morais não foram exaustivamente previstos na legislação, não sendo aceitável o argumento da tipicidade. A apreciação do dano será feita diante do caso concreto, considerando a índole do fato lesivo e sua repercussão na vítima.

Neste contexto, muitos juristas preocupam-se com a 'banalização do dano moral', em que qualquer aborrecimento trivial ou uma excessiva exposição da sensibilidade subjetiva sejam fontes de indenizações ${ }^{144}$.

Nas palavras de ANTONIO JeOvÁ SANTOS: "a moda do 'dano moral' é tão rútila que não raro, em qualquer petição inicial, embute-se o pedido de indenização por 'dano moral', sem que exista a causa de pedir, ou fundamentos jurídicos do pedido. $O$ requerimento é feito apenas para seduzir e impressionar a parte contrária "145.

Segundo o autor, essa 'vitimização do dano moral' pode ser divisada em três grupos: a) o daqueles que colaboram e tudo fazem para sofrer o dano moral, na ânsia de pretender 'engordar seu patrimônio' com lucro fácil $\left.{ }^{146} ; b\right)$ o grupo que enxerga dano moral em qualquer situação, mesmo diante de um simples aborrecimento; e $c$ ) os requerentes de ações judiciais que cumulam pedidos de ressarcimento do dano extrapatrimonial, sem nenhuma justificativa, motivação ou fundamento do pedido ${ }^{147}$.

Obtempera Jesualdo EduARdo de Almeida JÚNIOR, por outro lado, que 'o abuso não pode impedir o uso, ${ }^{, 148}$.

Existe para todos uma obrigação genérica de não prejudicar, de forma correlata, como se fosse o 'outro lado da moeda', existe o direito, também genérico, de ser ressarcido. Todavia, segundo ANTONIO JEOVÁ SANTOS, este princípio sofre mitigação

\footnotetext{
${ }^{143}$ Moraes, Maria Celina Bodin de. Op. cit. (nota 65), pp. 38-39.

${ }^{144}$ Cf. MADALENO, Rolf. Op. cit. (nota 49), p. 272.

145 SANTOS, Antonio Jeová. Op. cit. (nota 13), p. 120.

${ }^{146}$ Cf. idem, p. 119.

${ }^{147}$ Cf. idem, p. 123.

${ }^{148}$ Cf. AlmeIdA JúnIOR, Jesualdo Eduardo de. Op. cit. (nota 141), p. 123.
} 
quando se trata de ressarcimento de dano moral, pois o simples desconforto não justifica indenização ${ }^{149}$.

A fim de colocar a questão de forma mais clara, procuraremos analisá-la em três itens distintos, que se entrelaçam para formar um complexo de problemas, consistente na busca pela caracterização do dano moral. Já passamos por alguns deles ao conceituar esta figura, mas agora o intuito é aprofundar o exame, destacando aspectos que posteriormente serão trazidos à baila quando tratado o dano moral nas relações familiares.

\subsubsection{A dor e sua intensidade como critérios}

A vida em sociedade submete o indivíduo a inevitáveis atritos de interesses e aborrecimentos, como ônus natural da própria convivência, que podem, em alguns casos, resultar em danos morais.

Já advertia JosÉ DE AGUIAR DiAS, com apoio na doutrina francesa: “à medida que a civilização se desenvolve, dizem Mazeaud et Mazeaud, tornam-se mais e mais complexas as relações sociais, com interpenetração cada vez mais profunda dos círculos de atividade jurídica de cada um. É inevitável, em tais condições, o atrito de interesses, cada vez mais intenso, desdobrando-se em problemas de responsabilidade civil ${ }^{, 150}$.

No entanto, alguns contratempos e transtornos são inerentes ao atual estágio de desenvolvimento de nossa sociedade, pressupondo-se a necessidade de coexistência do ser humano com os dissabores que fazem parte do dia-a-dia.

Na prática, têm-se deduzido pedidos de danos morais embasados nas alegações de alteração no bem-estar psicofísico do indivíduo, na dor que causa modificações no estado anímico, no espanto, na emoção, na vergonha, em geral nas sensações dolorosas experimentadas pela pessoa, tornando-se comum a afirmação de que os danos morais se referem às incomodidades, agitações, vexames, constrangimentos, angústia, depressão, insegurança etc.

Maria Celina Bodin De Moraes nos coloca o problema:

\footnotetext{
${ }^{149}$ Cf. SANTOS, Antonio Jeová. Op. cit. (nota 13), p. 111.

${ }^{150}$ DiAs, José de Aguiar. Op. cit. (nota 44), p. 15.
} 
“(...) afirmar que o dano moral é 'dor, vexame, humilhação, ou constrangimento' é semelhante a dar-lhe o epiteto de 'mal evidente'. Através destes vocábulos, não se conceitua juridicamente, apenas se descrevem sensações e emoções desagradáveis, que podem ser justificáveis, compreensíveis, razoáveis, moralmente legítimas até, mas que, se não forem decorrentes de 'danos injustos', ou melhor, de danos a situações merecedoras de tutela por parte do ordenamento, não são reparáveis ${ }^{\prime 151}$.

Na opinião de ANDERSON SCHREIBER: “a toda evidência, a dor não representa elemento ontológico do dano moral, mas puro reflexo consequencialístico, que pode se manifestar ou não, sem que isto elimine o fato da lesão a um interesse extrapatrimonial ${ }^{, 152}$.

Ele informa que é justamente da confusão com a dor que deriva o engano de se tomar o dano moral não como a lesão a um interesse extrapatrimonial, mas como a consequência extrapatrimonial da lesão a um interesse qualquer. Ou seja, passa-se a aceitar a ideia de que a lesão a um bem patrimonial possa resultar em danos morais, representados pelo constrangimento ou dissabores aturados pela vítima ${ }^{153}$.

No entanto, uma acepção tão ampla de dano moral, adverte o autor, jamais poderia corresponder ao seu sentido jurídico. Essa vinculação ao sofrimento humano abre espaço a um imenso subjetivismo, daí a necessidade de se recuperar o conceito de dano como a lesão a um interesse juridicamente tutelado, retirando-se o foco das consequências emocionais $^{154}$.

Segundo Antonio Jeová SAntos, a dimensão espiritual de uma pessoa é muito mais abrangente, não está restrita a sentimentos ou a sensibilidade. A aptidão de entender, de querer e de sentir, também são integrantes desse patrimônio espiritual, que não pode ser rompido, por isso a afetação dessas capacidades também configura o dano

\footnotetext{
${ }^{151}$ Moraes, Maria Celina Bodin de. Op. cit. (nota 66), p. 130.

152 Para ele "o masoquista, o insensível e o que padece de hipoalgesia também fazem jus à reparação do dano moral. Embora pitoresca, a constatação revela que reconhecer validade ao critério da dor implica em desnecessárias discussões acerca, por exemplo, da reparabilidade do dano moral decorrente da lesão extrapatrimonial (física, à honra etc) causada a paciente em coma”. SCHREIBER, Anderson. Op. cit. (nota 43), p. 129.

${ }^{153}$ Cf. ibidem.

${ }^{154}$ Cf. idem, p. 101. Para ANDERSON SCHREIBER: "pode-se concluir que a experiência jurídica brasileira, embora partindo de uma noção abertíssima de dano - pela própria ausência de definição ou limite legislativo, vem sendo, sobretudo diante do reconhecimento dos danos extrapatrimoniais, compelida a fechar-se gradativamente, em busca de uma noção menos abrangente de dano ressarcível, que permita a seleção dos interesses merecedores de tutela indenizatória”. Idem, p. 105.
} 
moral ressarcível ${ }^{155}$. Nestes termos, ele propõe a superação do molde estreito do pretium doloris, expandindo a possibilidade da existência do dano moral a todos os casos em que a pessoa seja o centro da violação ${ }^{156}$.

Poderíamos questionar: por que a pessoa sofre, por que fica triste? Não é a tristeza que leva ao dano moral, mas o dano moral que leva à tristeza. Se disséssemos que o dano moral é a tristeza, no caso de alguém realizar uma ação legítima, correta, mas que leve outra pessoa a ficar triste, haveria dano moral. Ademais, também há dano moral sem qualquer implicação de dor ou sofrimento. Uma pessoa que possui alta estima pode não sofrer quando alguém a ofende, por exemplo. No entanto, sua honra objetiva foi afetada ${ }^{157}$.

Por outro lado, existem pessoas de suscetibilidade extremada, que sob qualquer pretexto ficam vermelhas, raivosas, enfurecidas. Para estas, pode parecer que qualquer abespinhamento origina o dano moral, qualquer modificação no espírito, ainda que fugaz, 'aquele momento passageiro de ira', pode causar indenização. Não se pode dizer que não houve lesão a algum sentimento, porém, seria reduzir o dano moral a mera sugestibilidade, ou proteger alguém que não suporta nenhum aborrecimento trivial ${ }^{158}$.

Assim, tristeza, sofrimento e dor não se confundem com o dano moral. Esses sentimentos são consequências possíveis, mas não necessárias, do dano. Ocorre que, frequentemente, afirmamos a presença do dano moral pela descoberta destes indícios, os quais, boa parte das vezes decorrem do dano moral, mas nem sempre.

A busca por uma referência visível - dor, sofrimento, tristeza - para algo que escapa ao mero aspecto material da realidade decorre da dificuldade, hoje presente, em perceber que a realidade não é composta somente por aspectos materiais. Em algumas

\footnotetext{
${ }^{155}$ Cf. SANTOS, Antonio Jeová. Op. cit. (nota 13), p. 69.

156 "Os limites à existência do 'dano moral' não podem ficar aprisionados ao preço da dor, porque é necessário que o dano extrapatrimonial seja estendido a todas as possibilidades individuais que sejam frustradas, em decorrência da lesão. Impedir que o sujeito realize seu projeto de vida ou que ele continue com a sua vida normal de relação, também é 'dano moral','. Idem, p. 70.

157 JosÉ AFONSO DA SILVA afirma que a honra é direito da personalidade, e que consiste no “(...) conjunto de qualidades que caracterizam a dignidade da pessoa, o respeito dos concidadãos, o bom nome, a reputação". SIlva, José Afonso. Curso de direito constitucional positivo. 32a ed. São Paulo: Malheiros, 2009, p. 209.

158 ANTONIO JEOVÁ SANTOS assevera que, conquanto existam pessoas cuja 'suscetibilidade aflore na epiderme', não se pode considerar que qualquer mal-estar seja apto para enfrentar o âmago. Portanto, quando alguém diz ter sofrido um prejuízo espiritual, mas este é consequência de uma sensibilidade exagerada ou de uma suscetibilidade extrema, não existe reparação. Para que exista dano moral é necessário que a ofensa tenha alguma grandeza e esteja revestida de certa importância e gravidade. Cf. SANTOS, Antonio Jeová. $O p$. cit. (nota 13), pp. 110- 111.
} 
situações, estamos acostumados e sem dificuldade aceitamos a parcela não material da realidade. Por exemplo, ninguém duvidaria que a soma de 1 mais 1 é igual a 2 , e a veracidade do resultado não depende de escrevermos esta fórmula, a pensarmos, a falarmos, ou de termos dois objetos concretos - duas maças, duas bananas, ou quaisquer outras coisas. Da mesma forma, as emoções humanas geralmente implicam efeitos corporais, como aumento de substâncias orgânicas e processos biológicos. A tristeza, a alegria, a dor ou o prazer podem levar a alterações na pressão arterial, nos batimentos cardíacos, na cor da pele, na temperatura do corpo etc, mas estes não são senão reflexos orgânicos de algo imaterial. É até mesmo possível cogitarmos a hipótese de alguém sentir aquelas emoções, mas não padecer das alterações físicas correspondentes, em virtude de alguma anomalia em seu organismo. Opostamente, também poderíamos considerar que alguém apresente os sintomas corporais relativos àqueles sentimentos sem que os esteja realmente vivenciando.

Nestes termos, assevera ANTONIO JEOVÁ SANTOS:

“as lágrimas, muitas vezes, acompanham o 'dano moral', porém, ele também pode existir onde estiver ausente sofrimento psíquico algum. O 'dano moral' é afetação espiritual do sujeito. O que não quer dizer que todo estado espiritual desvalioso seja um 'dano moral'. Devem concorrer os demais pressupostos da responsabilidade civil como o ato ilícito, o nexo causal e o dano, que é o elemento mais importante da obrigação de indenizar ${ }^{, 159}$.

Consequentemente, mostra-se irrelevante a configuração da dor para a definição ontológica do dano moral, uma vez que se trata de mera consequência eventual da lesão e, conforme expusemos, os problemas que derivam desta confusão conceitual são múltiplos, a começar pela dificuldade de aferição do dano moral diante da configuração absolutamente subjetiva do sofrimento.

Ademais, a falta de compreensão da própria dor e de sua origem também não exclui a existência do dano moral. Ou seja, a existência deste dano prescinde do que a vítima efetivamente pense, queira ou padeça. Logo, não existe razão para se deixar de indenizar uma criança, por achar que ela não entendeu o caráter do ato insidioso, causador

${ }^{159}$ Idem, p. 109. 
do dano ${ }^{160}$, pois a indenização não está condicionada a que a pessoa alvo do agravo seja capaz de sentir e de compreender o mal que lhe está sendo feito ${ }^{161}$.

Assim sendo, a lesão a um interesse juridicamente tutelado repercute de forma diversa sobre cada pessoa, e fazer depender a configuração do dano moral de um momento consequencial (dor, sofrimento) equivale a “(...) lançá-lo em um limbo inacessível de sensações pessoais, íntimas e eventuais ${ }^{\prime \prime 162}$.

\section{MARIA CELINA Bodin De MoRAES conclui que:}

"se a violação à situação jurídica subjetiva extrapatrimonial acarreta, ou não, um sentimento ruim, não é coisa que o Direito possa ou deva averiguar. O que o ordenamento jurídico pode (e deve) fazer é concretizar, ou densificar, a cláusula de proteção humana, não admitindo que violações à igualdade, à integridade psicofísica, à liberdade e à solidariedade (social e familiar) permaneçam irressarcidas ${ }^{\text {,163. }}$.

Em resumo, é preciso aceitar o inegável aspecto imaterial da realidade. Tal fato não resolve o problema da delimitação ou identificação dos danos morais, mas pelo menos afasta uma falsa ideia e abre caminho para uma resposta mais condizente com a experiência humana.

De outra parte, alguns juristas têm exigido a excepcionalidade, uma intensidade de sofrimento diversa daquela própria dos aborrecimentos corriqueiros para a caracterização do dano moral. Nas palavras de ANTÔNIO CHAVES:

"propugnar pela mais ampla ressarcibilidade do dano moral não implica no reconhecimento que todo e qualquer melindre, toda suscetibilidade exacerbada, toda exaltação do amor-próprio, pretensamente ferido, a mais suave sombra, o mais ligeiro roçar de asas de uma borboleta, mimos, escrúpulos, delicadezas excessivas,

\footnotetext{
${ }^{160}$ Cf. idem, p. 129.

${ }^{161}$ Cf. idem, p. 125.

${ }^{162}$ SCHREIBER, Anderson. Op. cit. (nota 43), pp. 104-105.

${ }^{163}$ MoRAES, Maria Celina Bodin de. Op. cit. (nota 66), p. 131. A autora persiste: “de fato, não será toda e qualquer situação de sofrimento, tristeza, transtorno ou aborrecimento que ensejará a reparação, mas apenas aquelas situações graves o suficiente para afetar a dignidade humana em seus diversos substratos materiais, já identificados, (...)”. Idem, pp. 188-189.
} 
ilusões insignificantes desfeitas, possibilitem sejam extraídas da caixa de Pandora do direito, centenas de milhares de cruzeiros ${ }^{\text {"164 }}$.

No mesmo sentido, é a lição de Sergio CAVAlieri FilHo, para quem:

“(...) só deve ser reputado como dano moral a dor, vexame, sofrimento ou humilhação que, fugindo à normalidade, interfira intensamente no comportamento psicológico do indivíduo, causado-lhe aflição, angústia e desequilíbrio em seu bem-estar. Mero dissabor, aborrecimento, mágoa, irritação ou sensibilidade exacerbada estão fora da órbita do dano moral, porquanto, além de fazerem parte da normalidade do nosso dia a dia, no trabalho, no trânsito, entre os amigos e até no ambiente familiar, tais situações não são tão intensas e duradouras, a ponto de romper o equilíbrio psicológico do indivíduo ${ }^{\text {"165. }}$

Também Maria Celina Bodin de Moraes diz que parcela da doutrina entende necessário que os sentimentos sejam intensos a ponto de se distinguirem dos dissabores do dia-a-dia ${ }^{166}$. Ou seja, para tal pensamento, salvo situações excepcionais e bem demarcadas, uma simples frustação não se indeniza ${ }^{167}$.

Por isso, na visão de HUMBERTo THEODORO JÚNIOR o dano moral não pode derivar do simples sentimento individual de insatisfação ou indisposição diante de pequenas decepções e frustrações do quotidiano ${ }^{168}$.

O jurista argentino RICARDO J. DUTTO, após definir dano moral como a lesão aos sentimentos ou afeições legítimas de uma pessoa, o sofrimento físico e a perturbação da tranquilidade ou do ritmo normal da vida, com alteração desvaliosa do bem-estar psicofísico, por meio de ação ou omissão imputável a outrem, ressalva que esta lesão deve ultrapassar um patamar mínimo, isto é, deve ser de tal envergadura que transtorne o equilíbrio espiritual $^{169}$.

\footnotetext{
${ }^{164}$ Chaves, Antônio. Tratado de Direito Civil. v. 3. São Paulo: Revista dos Tribunais, 1985, p. 637.

${ }^{165}$ CAVAliERI FilHo, Sergio. Op. cit. (nota 12), p. 87.

${ }^{166}$ Cf. MORAES, Maria Celina Bodin de. Op. cit. (nota 66), pp. 157-158.

${ }^{167}$ A autora menciona diversos julgamentos a este respeito. Cf. idem, p. 158.

${ }^{168}$ Cf. THEODORO JÚNIOR, Humberto. Op. cit. (nota 35), p. 134.

${ }^{169}$ Cf. DutTo, Ricardo J. Daños ocasionados en las relaciones de familia. $1^{\mathrm{a}}$ ed. Buenos Aires: Hammurabi, 2006, pp. 49-50.
} 
Na visão de Antonio Jeová SANTOS, o dano moral somente ingressa no mundo jurídico se houver alguma grandeza no ato ofensivo ${ }^{170}$. O autor propõe que se busque a figura do 'homem médio', para comparar aquele que tem uma suscetibilidade exacerbada com o que não se agasta facilmente ${ }^{171}$.

\section{Entretanto, na opinião de ANDERSON SCHREIBER:}

“(...) o critério da gravidade padece de forte inconsistência. Em primeiro lugar, confunde-se freqüentemente a gravidade do dano com a gravidade da conduta do ofensor. Todavia, a mera observação da vida real demonstra que condutas graves podem não dar margem a dano moral, e que, ao contrário, condutas levemente reprováveis, ou mesmo não reprováveis de tudo, podem produzi-lo",172.

Após a análise dos conceitos doutrinários de dano moral, iniciamos aqui o enfrentamento de problemas que surgem na prática jurídica e que nos demandam estreitar as distinções (entre o dano e a dor, por exemplo).

Neste sentido, uma vez diferenciado o dano moral e a dor a ele correspondente, e considerada a sugestão de utilizar a intensidade do abalo como critério para seleção do interesse legítimo, a qual também acabou por receber críticas, devemos volver àqueles conceitos gerais, que definiam o dano moral como lesão a um bem jurídico tutelado.

Daí ser imprescindível o exame dos dois pontos que, em nossa opinião, configuram a questão de fundo do dano moral: a dignidade humana e os direitos da personalidade. Embora já assinaladas neste trabalho, é preciso voltar a essas duas figuras, para contrastá-las com a 'teoria da dor', criando uma base segura para a análise posterior.

\footnotetext{
${ }^{170}$ Cf. SANTOS, Antonio Jeová. Op. cit. (nota 13), p. 113.

${ }^{171}$ Cf. idem, p. 112. "o mero incômodo, o desconforto, o enfado decorrentes de alguma circunstância, como exemplificados aqui, e que o homem médio tem de suportar em razão mesmo do viver em sociedade, não servem para que sejam concedidas indenizações”. Idem, p. 113. No mesmo sentido: “(...) para que haja a configuração concreta da agressão é necessário que o resultado seja capaz de possibilitar a diferenciação clara em relação aos simples dissabores ou, até mesmo, às pequenas frustrações cotidianas". RESEDÁ, Salomão. Op. cit. (nota 71), p. 146. E também: "é bem verdade que o dano moral deve ser observado de acordo com o padrão do homem-médio. Não se está analisando pessoas hipersensíveis ou aquelas mais duras de coração. A questão que se põe à mesa é saber a qual a gravidade inerente à agressão que atingiu este homem-padrão". Idem, p. 192.

${ }^{172}$ SCHREIBER, Anderson. Op. cit. (nota 43), pp. 126-127.
} 


\subsubsection{Dignidade humana}

A dignidade é um valor intrínseco do ser humano, ela o difere e o faz superior às coisas, tornando-o destinatário da tutela conferida pelo direito ${ }^{173}$. Sob este prisma, buscaremos investigar a hipótese de caracterizar o dano moral como a lesão à dignidade humana.

INGO WOLFGANG SARLET conceitua a dignidade humana como:

“(...) a qualidade intrínseca e distintiva de cada ser humano que o faz merecedor do mesmo respeito e consideração por parte do Estado e da comunidade, implicando, neste sentido, um complexo de direitos e deveres fundamentais que assegurem a pessoa tanto contra todo e qualquer ato de cunho degradante e desumano, como venham a lhe garantir as condições existenciais mínimas para uma vida saudável, além de propiciar e promover sua participação ativa e corresponsável nos destinos da própria existência e da vida em comunhão com os demais seres humanos",174.

Na concepção de ANDERSON SCHREIBER, "a dignidade humana é o valorsintese que reúne as esferas essenciais de desenvolvimento e realização da pessoa humana. Seu conteúdo não pode ser descrito de modo rígido; deve ser apreendido por cada sociedade em cada momento histórico, a partir de seu próprio substrato cultural" ${ }^{175}$.

Consoante anota ANTONIO JeOvÁ SAnTOS, da dignidade, da autonomia e da inviolabilidade da pessoa extrai-se a ideia de que o homem é portador em si mesmo de um valor moral intransferível e inalienável, que lhe foi atribuído pelo puro fato de ser um homem ${ }^{176}$. Segundo o autor, a dignidade guarda incomensurável e necessário conteúdo ético e pressupõe a existência de outros direitos ${ }^{177}$.

\footnotetext{
173 "No reino dos fins tudo tem ou um preço ou uma dignidade, como equivalente; mas quando uma coisa está acima de todo o preço, e portanto não permite equivalente, então tem ela dignidade”. KANT, Immanuel. Fundamentação da metafísica dos costumes. Lisboa: Ed. 70, 1986, p. 77 apud CASABONA, Marcial Barreto. Responsabilidade civil no direito de família. In: NERY, Rosa Maria de Andrade e DONNINI, Rogério (Coords.). Responsabilidade civil: estudos em homenagem ao professor Rui Geraldo Camargo Viana. São Paulo: Revista dos Tribunais: 2009, p. 355, nota 14.

${ }^{174}$ SARLET, Ingo Wolfgang. Dignidade da pessoa humana e direitos fundamentais na Constituição Federal de 1988. Porto Alegre: Livraria do Advogado, 2001, p. 60.

${ }^{175}$ SCHREIBER, Anderson. Op. cit. (nota 53), p. 8.

${ }^{176}$ Cf. SANTOS, Antonio Jeová. Op. cit. (nota 13), p. 43.

${ }^{177}$ Cf. idem, p. 41.
} 
Nestes termos, afirma-se que o efeito pretendido da dignidade da pessoa humana consiste em que as pessoas tenham uma vida digna ${ }^{178}$.

Maria Celina Bodin de Moraes aponta o cristianismo como origem da ideia da dignidade atribuída a cada indivíduo ${ }^{179}$. Nas palavras de ANTONIO JEOVÁ SANTOS: “(...) o pensamento do cristianismo toma a dignidade do fato de que o homem foi criado à imagem e semelhança de Deus ${ }^{, 180}$.

Trata-se de um conceito que foi sendo dilapidado ao longo dos anos ${ }^{181}$.

A Constituição Federal de 1988 dispôs em seu art. $1^{\circ}$, inciso III, que nosso Estado Democrático de Direito tem como fundamento a dignidade da pessoa humana ${ }^{182}$. Consagrando tal princípio e considerando sua eminência, proclamou-o entre os princípios fundamentais, atribuindo-lhe o valor de alicerce da ordem jurídica democrática, núcleo básico e informador de todo o ordenamento ${ }^{183}$.

O princípio da dignidade humana, portanto, é protegido pela ordem jurídica, que o reconhece e garante. Trata-se do valor cardeal do sistema, que por ser norma de

\footnotetext{
${ }^{178}$ Cf. BARCEllos, Ana Paula. A eficácia jurídica dos princípios constitucionais. Rio de Janeiro: Renovar, 2006, p. 304, apud PEREIRA, Caio Mário da Silva. Instituições de direito civil: direito de família. vol. V. $18^{\mathrm{a}}$ ed. Rio de Janeiro: Forense, 2010, p. 52.

179 "O desenvolvimento do pensamento cristão sobre a dignidade humana deu-se sob um duplo fundamento: o homem é um ser originado por Deus para ser o centro da criação; como ser amado por Deus, foi salvo de sua natureza, a do desejo pessoal, através da noção de liberdade de escolha, que o torna capaz de tomar decisões contra o seu desejo natural”. MorAES, Maria Celina Bodin de. Op. cit. (nota 66), p. 77.

180 SANTOS, Antonio Jeová. Op. cit. (nota 13), p. 40. Na observação de MANUEL GonÇALVES FERREIRA FILHO, a doutrina social da Igreja, iniciada com a encíclica Rerum novarum do Papa Leão XIII, de 1891, foi responsável por retomar a tese do bem comum, da essência da 'vida humana digna' de São Tomás de Aquino, levando à afirmação da necessidade de “(...) direitos que exprimem as necessidades mínimas de uma vida consentânea com a dignidade do ser humano, criado à imagem e semelhança de Deus”. FERREIRA FILHO, Manuel Gonçalves. Direitos humanos fundamentais. $5^{\text {a }}$ ed. São Paulo: Saraiva, 2002, p. 45.

${ }^{181}$ Para NeHEMIAS DOMINGOS DE MELO, "foi, claramente, a experiência nazista que gerou a consciência universal de que se devia preservar, a qualquer custo, a dignidade da pessoa humana, como uma conquista de valor ético-jurídico intangível”. MELO, Nehemias Domingos de. Op. cit. (nota 117), p. 23.

182 Para MARIA CElina BODIN DE MORAES "o advento da Constituição Federal de 1988 e a opção preferencial pela dignidade humana, inserida entre seus princípios fundamentais, fizeram com que a perspectiva jurídica tomasse a si o papel de garantidor da transição em direção ao 'personalismo', ausente em outros momentos históricos (...)”. MORAES, Maria Celina Bodin de. Op. cit. (nota 66), p. 19.

${ }^{183}$ No ensinamento de J.J. Gomes CANOTILHo, “(...) a dignidade da pessoa humana como base da República significa, sem transcendências ou metafísicas, o reconhecimento do 'homo noumenon', ou seja, do indivíduo como limite e fundamento do domínio político da República. Neste sentido, a República é uma organização política que serve o homem, não é o homem que serve os aparelhos político-organizatórios". CANOTILHO, J.J. Gomes. Op. cit. (nota 85), p. 225.
} 
Direito constitucional, encontra-se no ápice do ordenamento - alcança todos os setores da ordem jurídica infraconstitucional, devendo sempre ser observado ${ }^{184}$.

Segundo CAIO MARIO DA Silva PEREIRA, na contemporaneidade a dignidade da pessoa humana assumiu o posto de macroprincípio constitucional, de sorte que todos os princípios que nele se concretizam constituem direitos fundamentais. Assim, é considerado um dos esteios de sustentação do ordenamento jurídico, no qual se consolidam direitos fundamentais e do qual se desdobram subprincípios ou princípios implícitos ${ }^{185}$.

Para ANDERSON SCHREIBER, "embora se negue à dignidade humana, no mais das vezes, uma supremacia formal em relação às demais normas constitucionais, a ela se atribui uma espécie de superioridade material ou axiológica ${ }^{\text {"186. }}$.

Na visão de FLÁVIA PIOVESAN, a dignidade da pessoa humana confere suporte axiológico a todo o ordenamento jurídico brasileiro, servindo de parâmetro de valoração a guiar a interpretação e compreensão de todo o sistema constitucional. Ela afiança ser o princípio constitucional que mais atende às exigências de justiça social ${ }^{187}$.

Também Gustavo TEPEDINO assevera que a dignidade da pessoa humana é verdadeira cláusula geral de tutela e promoção da pessoa, tomada como valor máximo pelo ordenamento $^{188}$.

Logo, este princípio constitucional deve ser entendido como o valor central do sistema, servindo como fonte para os demais direitos fundamentais, como o direito à vida, à liberdade, à honra, à imagem, ao nome, à intimidade, à privacidade, ao decoro, enfim,

\footnotetext{
${ }^{184}$ No mesmo sentido é a lição de JOSÉ AFONSO DA SILVA, “"dignidade da pessoa humana'é um valor supremo que atrai o conteúdo de todos os direitos fundamentais do homem, desde o direito à vida". SILVA, José Afonso. Op. cit. (nota 157), p. 105.

${ }^{185}$ Cf. PEREIRA, Caio Mário da Silva. Instituições de direito civil: direito de família. vol. V. $18^{\text {a }}$ ed. Rio de Janeiro: Forense, 2010, pp. 51-52.

${ }^{186}$ SCHREIBER, Anderson. Op. cit. (nota 43), pp. 173-174.

187 Cf. PIOVESAn, Flávia. Direitos humanos e o direito constitucional internacional. São Paulo: Max Limonad, 2000, p. 53.

188 Cf. TEPEDINO, Gustavo. A tutela da personalidade no ordenamento civil-constitucional brasileiro. In: Temas de direito civil. Tomo 1. $4^{\mathrm{a}}$ ed. Rio de Janeiro: Renovar, 2008, p. 54.
} 
todos os direitos da personalidade. Ou seja, funciona como 'elemento e medida dos direitos fundamentais', e agregados a ele estão os chamados direitos da personalidade ${ }^{189}$.

A dignidade humana tem se revelado aos juristas como o grande parâmetro para a seleção dos interesses merecedores de tutela do dano moral, pois, ao eleger este princípio como fundamento do próprio Estado, nossa ordem constitucional colocou o homem no vértice do ordenamento jurídico e estabeleceu a base sobre a qual se assenta a ideia de reparação daquele dano.

Maria Celina Bodin de Moraes informa que a reparação do dano moral corresponde à contrapartida do princípio da dignidade humana: quando a dignidade é ofendida, há que se reparar o dano injusto sofrido ${ }^{190}$.

No entanto, a jurista adverte sobre a dificuldade que se enfrenta ao buscar delinear, do ponto de vista hermenêutico, os contornos e os limites deste princípio constitucional, em razão da sua elevada abstração e por trata-se de um valor que alcança todos os setores da ordem jurídica. Em suas palavras: "uma vez que a noção é ampliada pelas numerosíssimas conotações que enseja, corre-se o risco da generalização, indicando-a como 'ratio' jurídica de todo e qualquer direito fundamental. Levada ao extremo, essa postura hermenêutica acaba por atribuir ao princípio um grau de abstração tão intenso que torna impossível a sua aplicação" ${ }^{\text {191 }}$. Portanto, ela preocupa-se que a textura aberta do princípio, sem o preenchimento de seu conteúdo, possa dar origem a invocações que conduzam à sua banalização, em lugar de sua proteção ${ }^{192}$.

Daí o grande problema, apontado por muitos doutrinadores, na identificação do dano moral como a ofensa ao princípio constitucional da dignidade da pessoa humana:

\footnotetext{
${ }^{189}$ Cf. CASABOna, Marcial Barreto. Responsabilidade civil no direito de família. In: NeRY, Rosa Maria de Andrade e DonNINI, Rogério (Coords.). Responsabilidade civil: estudos em homenagem ao professor Rui Geraldo Camargo Viana. São Paulo: Revista dos Tribunais: 2009, pp. 355-356.

190 Cf. Moraes, Maria Celina Bodin de. Op. cit. (nota 66), p. 326. “a Constituição Federal de 1988 fortaleceu, de maneira decisiva, a posição da pessoa humana, e de sua dignidade, no ordenamento jurídico. Colocou-a no ápice da pirâmide que, plasticamente, dá forma ao sistema normativo. Em consequência -e este é apenas o reverso da medalha -, logrou implicitamente determinar a cabal reparação de 'todos' os prejuízos causados injustamente à pessoa humana. A base legal encontra-se na cláusula geral de tutela da pessoa, que contém, nela implícito, o milenar preceito do 'neminem laedere'”. MORAES, Maria Celina Bodin de. Op. cit. (nota 66), p. 286.

${ }^{191}$ MORAES, Maria Celina Bodin de. Op. cit. (nota 65), p. 52.

192 Cf. MAria Celina Bodin De MORAes, prefácio do livro de SchreIBER, Anderson. Op. cit. (nota 43), p. $\mathrm{xv}$.
} 
trata-se de um princípio de amplos contornos, cujo conceito precisa ser delimitado para que se torne possível sua invocação.

Ademais, CAio Mário da Silva Pereira observa que os princípios exigem um esforço muito maior do que a mera aplicação das regras, visto que, por serem abstratos, aplicam-se a uma gama de hipóteses concretas ${ }^{193}$. Assim, para o jurista, essa conceituação, de tão extensa, deve ser evitada, sob pena de se limitar o seu campo de incidência. Contudo, informa que, como macroprincípio, nunca poderá sofrer qualquer tipo de relativização, mas apenas a dos subprincípios que compõem o seu conteúdo ${ }^{194}$.

Nesse compasso, ANDERSON SCHREIBER faz um alerta: "a constante transformação do conceito de dignidade humana, com o seu crescente desdobramento em novos interesses existenciais, amplia, de forma tendencialmente ilimitada, o espectro de lesões que pode ser conduzido ao Poder Judiciário, dando margem à efetiva ocorrência de demandas algo fantasiosas de ressarcimento ${ }^{\prime 195}$.

MARIA Celina Bodin DE MoRAes oferece uma solução, ao desdobrar o substrato material da dignidade humana em quatro postulados: “(...) i) o sujeito moral (ético) reconhece a existência dos outros como sujeitos iguais a ele, ii) merecedores do mesmo respeito à integridade psicofísica de que é titular, iii) é dotado de vontade livre, de autodeterminação; iv) é parte do grupo social, em relação ao qual tem a garantia de não vir a ser marginalizado ${ }^{\prime 196}$.

Assim, segundo a autora, constitui dano moral a lesão a qualquer dos aspectos ou substratos que compõem a dignidade humana, isto é, a violação à liberdade, à igualdade, à solidariedade ou à integridade psicofísica de uma pessoa; embora também a composição das dimensões de cada um desses princípios seja de difícil demarcação. No

\footnotetext{
${ }^{193}$ Cf. PEREIRA, Caio Mário da Silva. Op. cit. (nota 185), p. 51.

${ }^{194}$ Cf. idem, p. 53.

195 SCHREIBER, Anderson. Op. cit. (nota 43), p. 243. Segundo o autor, “o risco reside exatamente em que a força ética e jurídica de que é portadora a idéia de dignidade humana, identificada com a própria condição de pessoa, impeça uma seleção criteriosa dos interesses merecedores de tutela, declarando-se ressarcível qualquer prejuízo ou desfavor que, na falta de possibilidade de aferição precisa, afete alegadamente a personalidade do ofendido". Idem, p. 122. E complementa: "Nesta tormentosa valoração, deve-se admitir, talvez com simplificação útil, que a dignidade humana atribui, a princípio, prevalência aos interesses existenciais em relação aos interesses patrimoniais. Ainda assim, somente as circunstâncias concretas permitirão verificar o modo pelo qual tal prevalência se manifesta, especialmente diante da verificação de que, na espécie, os interesses patrimoniais em jogo vinculam-se, com alta imediatez ou em alto grau, ao atendimento de outros interesses existenciais, igualmente tutelados ". Idem, p. 176.

${ }^{196}$ MorAES, Maria Celina Bodin de. Op. cit. (nota 66), p. 85.
} 
entanto, ela própria adverte que estes princípios podem entrar em colisão e, neste caso, deverão ser ponderados, através do exame dos interesses em conflito, em relação a seu fundamento, isto é, a própria dignidade humana ${ }^{197}$.

Regina BeAtriz TAVARES DA Silva, por sua vez, preleciona que a preservação da dignidade opera-se especialmente por meio da proteção aos direitos fundamentais, que, no âmbito privado, são chamados de direitos da personalidade. Esses direitos têm como objeto os atributos físicos e morais da pessoa, compondo-se de valores inatos, como a vida, a integridade física e psíquica, a liberdade e a honra, que são tutelados pela Constituição Federal ${ }^{198}$.

Destarte, muitos juristas asseguram que entre os valores que compõem a dignidade humana estão os direitos da personalidade e inferem que há que se atentar para esses direitos como uma forma de concretizar aquele princípio e melhor tutelá-lo. Ou seja, os direitos da pessoa são garantidos pelo princípio constitucional da dignidade humana e concretamente protegidos pela tutela dos direitos da personalidade ${ }^{199}$.

Neste ponto, vale salientar que a preocupação com o crescimento desmedido de demandas, que já apontamos, se repete aqui. Se antes a questão era separar a mera dor ou meros aborrecimentos do dano moral legítimo, aqui o problema surge em razão do desenvolvimento da teoria da dignidade humana.

Como adverte RuY ROSADO DE AGUIAR JÚNIOR, à medida que se alcança a exata compreensão do conceito de dignidade da pessoa humana e se lhe dá o devido desdobramento na definição dos correspondentes direitos da personalidade, se percebe o aumento das hipóteses de ofensa a tais direitos, ampliando-se as oportunidades para a existência do dano ${ }^{200}$.

\footnotetext{
${ }^{197}$ Cf. MorAES, Maria Celina Bodin de. Op. cit. (nota 63), p. 189.

198 Cf. Silva, Regina Beatriz Tavares da. A emenda constitucional do divórcio. São Paulo: Saraiva, 2011, pp. 69-70.

${ }^{199}$ Neste sentido, MORAES, Maria Celina Bodin de. Op. cit. (nota 66), p. 127.

${ }^{200}$ Cf. Aguiar Júnior, Ruy Rosado de. Op. cit. (nota 15), p. 4. Na visão de MARIA CElinA Bodin DE MORAES: "na verdade, ampliando-se desmensuradamente o rol dos direitos da personalidade ou adotandose a tese que vê na personalidade um 'valor' e reconhecendo, em conseqüencia, tutela às suas manifestações, independentemente de serem ou não consideradas direitos subjetivos, todas as vezes que se tentar enumerar as novas espécies de danos, a empreitada não pode senão falhar: sempre haverá uma nova hipótese sendo criada”. MoRAES, Maria Celina Bodin de. Op. cit. (nota 66), p. 166.
} 


\subsubsection{Direitos da personalidade}

A pessoa é o valor-fonte de todos os valores, sendo o principal fundamento do ordenamento jurídico; os direitos da personalidade correspondem à pessoa humana em cada sistema básico de sua situação e atividades sociais ${ }^{201}$.

Para Miguel ReALE, “o importante é saber que cada direito da personalidade corresponde a um 'valor fundamental', a começar pelo do próprio corpo, que é a condição essencial do que somos, do que sentimos, percebemos, pensamos e agimos ${ }^{\text {,202 }}$.

Nestes termos, observa-se que a personalidade não é um direito, mas um valor, o valor fundamental do ordenamento, que está na base de uma série aberta de situações existenciais, nas quais se traduz a incessantemente mutável exigência de tutela ${ }^{203}$.

Segundo CARlos Alberto BitTAR, a personalidade humana desdobra-se em diferentes atributos, de ordem física, psíquica e moral ${ }^{204}$. Através dos direitos da personalidade é que as pessoas se apresentam, se movimentam, e se afirmam no convívio social, perseguindo os objetivos eleitos na realização de sua missão ${ }^{205}$.

No Brasil, o ordenamento, capitaneado pela Constituição Federal, busca proteger os indivíduos de qualquer ofensa ou ameaça a seus direitos da personalidade. Não há uma enumeração desses direitos, que se espraiam por todo sistema jurídico, a começar pela própria Constituição, e também no Código Civil.

Assim, a tutela da personalidade humana deve ser colocada em supremacia a todo interesse subjetivo, e esta proteção extrapola qualquer previsão legal.

Alude CARlos Alberto BitTAR: "nesse sentido é que o Direito tutela a personalidade humana, para que cada qual possa realizar as metas correspondentes, a

\footnotetext{
${ }^{201}$ Cf. REALE, Miguel. Política e direito: ensaios. São Paulo: Saraiva, 2006, p. 89.

${ }^{202}$ Ibidem.

${ }^{203}$ Cf. Moraes, Maria Celina Bodin de. Op. cit. (nota 66), p. 121.

${ }^{204}$ Cf. BITTAR, Carlos Alberto. Op. cit. (nota 14), p. 47.

${ }^{205}$ Cf. idem, p. 58.
} 
nível individual e social”206. Daí a necessidade de pronta e cabal resposta da ordem jurídica, que se dá através da teoria da responsabilidade civil ${ }^{207}$.

Conforme anunciamos, a doutrina apreende que os direitos da personalidade integram e concretizam a dignidade humana. A afronta a esses direitos tem como efeito o dano, que atinge, em última instância, a própria dignidade humana, dando ensejo à responsabilidade ${ }^{208}$.

Concatenando o assunto, MARIA CELINA BODIN DE MORAES assevera que o dano moral tem como causa a injusta violação de uma situação jurídica subjetiva extrapatrimonial, protegida pelo ordenamento jurídico através da cláusula geral de tutela da personalidade, instituída na Constituição Federal, e decorrente diretamente do princípio fundante da dignidade humana ${ }^{209}$. Em sua opinião, esta é a razão pela qual as hipóteses de dano moral são tão frequentes, porque sendo tutelado o valor da personalidade humana, a sua reparação está posta para a pessoa como um todo ${ }^{210}$.

Dessa forma, o dano moral passou a ser vinculado às violações aos direitos da personalidade, às lesões sofridas pela pessoa em seu patrimônio ideal, que não é suscetível de valoração econômica. Ou seja, os danos aos direitos personalíssimos são os morais ou extrapatrimoniais, pois atingem atributos valorativos que integram a personalidade.

Também CARlos AlBerto BitTAR localiza a temática dos danos morais na ‘exata medida da consideração da pessoa em si' ou em suas 'projeções sociais'. São, no

\footnotetext{
${ }^{206}$ Idem, p. 48, nota 47.

${ }^{207}$ Cf. idem, p. 54.

${ }^{208}$ Esta a opinião de MARIA CELINA BODIN DE MORAES: "a ofensa tem como efeito o dano propriamente dito, que pode ser das mais variadas espécies, todas elas ensejadoras de repercussão sem qualquer conteúdo econômico imediato, recondutíveis sempre a aspectos personalíssimos da pessoa humana - mas que não precisam classificar-se como direitos subjetivos - e que configuram, em 'ultima ratio', a sua dignidade”. MORAES, Maria Celina Bodin de. Op. cit. (nota 66), p. 133.

${ }^{209}$ Cf. idem, pp. 132-133. "Circunstâncias que atinjam a pessoa em sua condição humana, que neguem esta sua qualidade, serão automaticamente consideradas violadoras de sua personalidade e, se concretizadas, causadoras de dano moral a ser reparado”. Idem, p. 327.

${ }^{210}$ Cf. idem, p. 127. Vale ressaltar sua observação: "A polêmica acerca dos direitos humanos, ou dos direitos da personalidade, refere-se à necessidade de normatização dos direitos das pessoas em prol da concretude do princípio da dignidade humana e ao modo de melhor tutelar essa necessidade, onde quer que se faça presente. Toma-se aqui, e desde logo, posição acerca da questão da tipicidade ou atipicidade dos direitos da personalidade. Não há mais que se discutir sobre uma enumeração taxativa ou exemplificativa dos direitos da personalidade, já que se está em presença, a partir do princípio constitucional da dignidade, de uma cláusula geral da tutela da pessoa humana”. MORAES, Maria Celina Bodin de. Op. cit. (nota 179), p. 112.
} 
fundo, reações na personalidade do lesado a agressões ou a estímulos negativos recebidos da ação de terceiros, que atinjam seus bens vitais ${ }^{211}$.

Daí as manifestações doutrinárias que rejeitam a enumeração taxativa do rol dos direitos da personalidade. ANDERSON SCHREIBER nega a hipótese de selecionar os interesses merecedores de tutela com base em uma prévia especificação legislativa, seja sob a forma de direito subjetivo absoluto, seja por meio de qualquer outra categoria inflexível $^{212}$. E YUSSEF SAID CAHALI observa que qualquer tentativa de classificação ou enumeração exaustiva dos danos morais se mostra inviável ${ }^{213}$.

Se os valores íntimos da personalidade são tutelados pela ordem jurídica, ela deverá prestar-lhes proteção contra agressões injustas, punindo seu desrespeito ${ }^{214}$. Mas, diante da textura aberta dos direitos da personalidade, segue o risco de banalização e de abuso no pleito de danos morais ${ }^{215}$.

$\mathrm{O}$ recurso à chamada cláusula geral de tutela da dignidade humana e aos direitos da personalidade tem servido de critério para a seleção dos interesses merecedores de tutela. No entanto, esta alusão pode resultar no aniquilamento daquilo que mais se pretende proteger.

O exame detalhado das hipóteses de danos morais nas relações familiares pode lançar uma luz sobre o problema, permitindo que, dentre a gama de situações debatidas pela doutrina, possamos encontrar um norte mais seguro para identificar, neste campo específico, quando estamos perante um dano moral que mereça reparação.

\footnotetext{
${ }^{211}$ Cf. BITTAR, Carlos Alberto. Op. cit. (nota 14), pp. 45-46. Na visão do autor: "observa-se, na análise da categoria dos danos morais, que, no respectivo âmago, se encontra a antinomia a atributos personalíssimos reconhecidos aos titulares de direitos. Reveste-se, pois, de caráter atentatório à personalidade, de vez que se configura através de lesões a elementos essenciais da individualidade. Ora, por essa razão é que recebe a repulsa do Direito, que, como já anotado, procura realizar a defesa dos valores básicos da pessoa e do relacionamento social". Idem, pp. 57-58.

${ }^{212}$ Cf. SCHREIBER, Anderson. Op. cit. (nota 43), p. 121.

${ }^{213}$ Cf. CAHALI, Yussef Said. Op. cit. (nota 39), p. 48.

${ }^{214}$ Cf. TheOdORO JÚNIOR, Humberto. Op. cit. (nota 35), p. 3 e Oltramari, Fernanda et Oltramari, Vitor Hugo. Op. cit. (nota 102), p. 56.

215 Neste ponto, anota ANDERSON SCHREIBER que "as demandas absurdas ou bagatelares, que tanto preocupam a doutrina, quando acolhidas, não o são por mero capricho ou criatividade dos juízes, mas, quase sempre, por uma eloqüente argumentação em favor da defesa da dignidade humana e dos interesses da pessoa". SCHREIBER, Anderson. Op. cit. (nota 43), p. 122-123.
} 


\subsubsection{ARBITRAMENTO DO DANO MORAL}

À discussão sobre a reparação do dano moral, seguiu-se outra, a respeito do quantum desta indenização ${ }^{216}$. Os dois problemas estão intimamente relacionados. Isto porque, para se calcular o valor, é preciso saber o que indenizar.

PONTES DE MIRANDA já lecionava que a "impatrimonialidade não quer dizer inavaliabilidade. Há bens não patrimoniais avaliáveis; e danos não patrimoniais que são avaliáveis. $O$ que se exige para a indenizabilidade do dano moral é que seja avaliável, e não que sejam 'também' patrimonial, 217 .

HUMBERTO THEODORO JÚNIOR destaca a complexidade do tema:

"quando se trata de dano material, calcula-se exatamente o desfalque sofrido no patrimônio da vítima, e a indenização consistirá no seu exato montante. Mas quando o caso é de dano moral, a apuração do 'quantum' indenizatório se complica porque o bem lesado (a honra, o sentimento, o nome, etc.) não se mede monetariamente, ou seja, não tem dimensão econômica ou patrimonial ${ }^{, 218}$.

Segundo o jurista, cabe ao prudente arbítrio dos juízes e à força criativa da doutrina a instituição de critérios e parâmetros que haverão de presidir as indenizações por dano moral, a fim de evitar que o ressarcimento se torne expressão de 'puro arbítrio', quebrando os princípios básicos do Estado Democrático de Direito ${ }^{219}$.

CARlos Roberto GonçAlves assevera que o problema da quantificação do dano moral, sem que existam parâmetros seguros para sua estimação, tem sido preocupante

\footnotetext{
${ }^{216}$ Nas palavras de NeHEMIAS DOMINGOS DE MELO, "estabelecer um valor para o dano moral é uma tarefa das mais árduas não só para quem pede (autor), como também para quem contesta (réu) e, principalmente, para quem concede (juiz)". Melo, Nehemias Domingos de. Op. cit. (nota 117), p. 97. Na opinião de ANTONIO JEOVÁ SANTOS, essa dificuldade em fixar o quantum do dano moral conspirou para o seu atraso dogmático e doutrinário, pois um dos argumentos para que não fosse reparado era a impossibilidade de encontrar-se o real valor da indenização. Cf. SANTOS, Antonio Jeová. Op. cit. (nota 13), p. 150.

${ }^{217}$ MIRANDA, Pontes de. Op. cit. (nota 34), pp. 106-107.

${ }^{218}$ THEODORO JÚNIOR, Humberto. Op. cit. (nota 35), p. 41. "Acostumados com a certeza da avaliação do dano patrimonial, em que basta a verificação do valor necessário para a reposição do bem danificado ao estado anterior, todos querem solução similar. Isso não é possivvel, pois diferentes e antinômicos o procedimento para verificar quanto vale a 'restitutio in integrum', quando algum bem é deteriorado, $e$ averiguar como uma lesão extrapatrimonial exacerbou o espírito, o íntimo, a subjetividade de uma pessoa". SANTOS, Antonio Jeová. Op. cit. (nota 13), pp. 149-150.

${ }^{219}$ Cf. THEODORO JÚNIOR, Humberto. Op. cit. (nota 35), p. 41. "Se a vítima pudesse exigir a indenização que bem quisesse e se o juiz pudesse impor a condenação que lhe aprouvesse, sem condicionamento algum, cada caso que fosse ter à Justiça se transformaria num jogo lotérico, com soluções imprevisíveis e as mais disparatadas". Ibidem.
} 
em virtude da proliferação de demandas ${ }^{220}$. Na Argentina, há quem diga haver uma verdadeira anarquia indenizatória, pela falta de um padrão de indenização e de critérios para a fixação do quantum ${ }^{221}$.

Ademais, esta dificuldade conspira para a ausência de acordos, ao fazer com que nenhuma das partes fique satisfeita com o valor da indenização, tanto que muitas vezes autor e réu recorrem simultaneamente ${ }^{222}$.

Já se entendeu que o problema em torno da quantificação da indenização por dano moral revela a insuficiência do valor monetário como meio de pacificação dos conflitos decorrentes de lesões a interesses extrapatrimoniais, devendo-se desenvolver meios não pecuniários de reparação, que não necessariamente vêm substituir ou eliminar a compensação em dinheiro, mas se associam a ela no sentido de efetivamente aplacar o prejuízo moral $^{223}$.

Nesta linha, ANDERSON SCHREIBER critica a manutenção de um remédio exclusivamente pecuniário aos danos extrapatrimoniais, sustentando a possibilidade de reparação in natura em alguns casos. Para ele "a redução última da lesão a interesse extrapatrimonial a uma quantia monetária corrobora a tese daqueles autores para os quais a responsabilidade civil atua como paradoxal instrumento de mercantilização, quantificando o inquantificável,"224.

Além disto, para ele as formas não patrimoniais de compensação satisfazem os anseios da vítima de maneira mais completa ${ }^{225}$.

ANTONIO JEOVÁ SANTOS somente admite esta hipótese de reparação in natura do dano moral nos agravos contra a honra ou erros cometidos por órgãos de comunicação, em que o ofendido pode se satisfazer com a publicação da retratação, a retificação da

\footnotetext{
${ }^{220}$ Cf. GonÇAlves, Carlos Roberto. Responsabilidade civil. $11^{\text {a }}$ ed. São Paulo: Saraiva, 2009, p. 637.

${ }^{221}$ Cf. DuTTO, Ricardo J. Op. cit. (nota 169), p. 65.

${ }^{222}$ Cf. SANTOS, Antonio Jeová. Op. cit. (nota 13), p. 151. “A incerteza que grassa nesse campo, impede acordos. É quase nula a transação em pedidos de indenizações por danos morais. Como nada existe de certo, as partes ficam sem saber qual o valor justo para minorar a dor espiritual padecida pela vítima. Ora o autor pede quantia fora dos padrões normais, ora é o réu que se recusa a pagar a quantia pedida por entender que o valor é muito superior ao que vale o menoscabo espiritual do ofendido. Tudo isso, porque não existem critérios em que as partes possam se basear para saber quanto o juiz vai fixar a título de ressarcimento". Idem, p. 150.

${ }^{223}$ Cf. SCHREIBER, Anderson. Op. cit. (nota 43), p. 192.

${ }^{224}$ Ibidem.

${ }^{225}$ Cf. Idem, pp. 193-194.
} 
notícia inexata ou agravante ${ }^{226}$. Não obstante, entende possível, também nestes casos, que a vítima pleiteie a indenização pelo dano moral que sofreu ${ }^{227}$.

Já NeHEMIAs Domingos DE MELo considera inviável a reparação in natura do dano moral, mesmo nos casos de calúnia, difamação ou injúria, em razão das peculiaridades que envolvem esse tipo de ilícito, pois as notícias negativas ganham mais destaque perante a opinião pública do que aquelas que procuram corrigir as distorções ${ }^{228}$.

Parcela da doutrina acaba por considerar inadequada a reparação in natura do dano moral. Dentre os motivos, destacam que não se pode recompor o bem ao status quo ante, em razão da impossibilidade de voltar-se ao passado e abolir os efeitos lesivos acometidos ao ofendido. Assim, resta apenas perseguir o intento da reparação com a equivalência pecuniária ${ }^{229}$.

Diante da dificuldade em se mensurar o dano moral, muitos têm propugnado pelo tarifamento, imaginando que a quantificação desta espécie de dano se resolveria se o legislador regulasse o quantum a ser indenizado. Esta proposta tem sido frequentemente levantada em razão da disparidade de julgados que fixam importâncias diferentes em casos semelhantes ${ }^{230}$.

\footnotetext{
${ }^{226}$ CARLOS ALBERTO BITTAR também menciona a retratação, na hipótese de desrespeito ou injúria pessoal, como um possível mecanismo de reparação, ao lado da fixação de soma em dinheiro. Cf. BITTAR, Carlos Alberto. Op. cit. (nota 14), pp. 68-69. Assim também: AMARO, Elisabete Aloia. Op. cit. (nota 84), p. 168. Na opinião de TERESA ANCONA LOPEZ, a satisfação dos danos não patrimoniais, às vezes, é mais perfeita se consistir num fato exigível do autor da ofensa, como no caso de retratação pública daquele que cometeu injúria. Cf. LOPEZ, Teresa Ancona. Op. cit. (nota 10), p. 112.

${ }^{227}$ Cf. SANTOS, Antonio Jeová. Op. cit. (nota 13), pp. 154-155. Em sentido contrário: "Nessa linha de raciocínio, não se afigura razoável a condenação cumulada do valor pecuniário com o direito de resposta, por ser este a representação da satisfação completa, especialmente se realizado na mesma proporção da ofensa, ou seja a tempo e por meio do mesmo veículo e com a mesma dimensão". CIANCI, Mirna. O valor da reparação moral. $3^{\mathrm{a}}$ ed. São Paulo: Saraiva, 2009, p. 123.

${ }^{228}$ Cf. Melo, Nehemias Domingos de. Op. cit. (nota 117), p. 98. Ele insiste: "além do mais, com a presença da Internet na vida das pessoas, notícias veiculadas nesse meio digital ficam para sempre acessível a quem por ela procurar e muitas vezes sem o devido 'link' de acesso ao desmentido". Idem, pp. 105-106.

229 'Esta equivalência, aliás, não existe na maioria das vezes; o que existe é um 'sucedâneo' do prejuizo sofrido, pois em alguns casos é impossível o restabelecimento absoluto do estado anterior". LOPEZ, Teresa Ancona. Op. cit. (nota 10), p. 100.

${ }^{230}$ Cf. SANTOS, Antonio Jeová. Op. cit. (nota 13), p. 165.
} 
Tarifar vem a ser a fixação rígida, em lei, de um piso mínimo e um teto máximo para a indenização, de sorte que o juiz fica adstrito àqueles valores sempre que tiver que estabelecer o montante do ressarcimento ${ }^{231}$.

Assim se manifesta GENEVIÈVE VINEY:

"enquanto a lei não se dispuser a criar tarifas para a indenização dos danos morais, a tarefa do Judiciário será muito árdua e, para os jurisdicionados, haverá sempre o risco de surpresas e incertezas. O subjetivismo dos juizes e tribunais continuará gerando um clima de insegurança e desigualdade entre os diversos litigantes, e o arbitramento, à falta de parâmetros objetivos, manterá a feição de 'loteria judiciária, ${ }^{, 232}$.

Segundo RUI STOCO, o sistema tarifado é o que se mostra mais consentâneo e justo, evitando-se os excessos das indenizações despropositadas ${ }^{233}$.

Para Antonio JeOvá SAntos, esta não é a melhor solução. Na prática, isto significaria transferir a tarefa de arbitramento do juiz para o legislador. O magistrado, pondera o jurista, ao menos está diante do caso concreto, reunindo maiores condições de aferir quanto vale o desgaste emocional causado pelo dano, ao passo que o legislador, ao disciplinar algo para o futuro, acaba igualando todos os que vierem a sofrer menoscabo espiritual $^{234}$.

CARLOS ROBERTO GONÇALVES, também contrário à tarifação, alerta para a possibilidade de 'lucro para o inescrupuloso': “o inconveniente desse critério é que, conhecendo antecipadamente o valor a ser pago, as pessoas podem avaliar as conseqüências da prática do ato ilícito e as confrontar com as vantagens que, em

${ }^{231}$ De forma análoga, alguns chegam a defender a criação de uma tabela, um rol, no qual seriam especificadas todas as espécies de danos morais, ao lado das quantias a serem pagas. Este modelo é criticado pela doutrina. NEHEMIAS DOMINGOS DE Melo é veemente a respeito: "as coisas têm preço, estas se pode tabelar; as pessoas têm dignidade, logo insuscetível de qualquer tabelamento frio e apriorístico por lei". MELO, Nehemias Domingos de. Op. cit. (nota 117), p. 104.

${ }^{232}$ VINEY, Geneviève. Les obligations. La responsabilité: effets. In: GHESTIN, Jacques. Traité de Droit Civil. Paris: LGDJ, 1988, p. 207, apud THEODORO JÚNIOR, Humberto. Op. cit. (nota 35), p. 85.

${ }^{233}$ Cf. Stоco, Rui. Tratado de responsabilidade civil: doutrina e jurisprudência. $7^{\mathrm{a}}$ ed. São Paulo: Revista dos Tribunais, 2007, p. 1739.

${ }^{234}$ Cf. SANTOS, Antonio Jeová. Op. cit. (nota 13), pp. 165-166. Para RodRIGo Mendes Delgado, a impertinência de tal sistema se verifica por dois argumentos decisivos. Primeiro, é impossível, pela própria falibilidade do sistema normativo, prever todos os casos possíveis de ocorrência de danos morais. Um segundo ponto é que possibilita pretensos ofensores assumirem o ônus de produzir o evento lesivo, após procederem a uma análise do parâmetro custo-benefício. Cf. DELGADO, Rodrigo Mendes. $O$ valor do dano moral: como chegar até ele. $3^{\mathrm{a}}$ ed. Leme: J. H. Mizuno, 2011, pp. 405-406. 
contrapartida, poderão obter, como no caso do dano à imagem, e concluir que vale a pena, no caso, infringir a lei, ${ }^{235}$.

Outra razão para se refutar a tarifação é a restrição à satisfação dos interesses da vítima, pois ao se tarifar a indenização fica diminuída a reparação integral, seja qual for a dimensão do ato lesivo, o montante em dinheiro já estará previamente escolhido ${ }^{236}$. Assim, segundo ANTONio Jeová SAnTOS, a tarifação pode ser vista como uma instância legal redutora da responsabilidade civil, porque aniquila toda a função satisfativa e dissuasória que constitui o cerne da indenização ao se autorizar a redução do valor pecuniário da reparação ${ }^{237}$.

Outra solução engendrada pela doutrina foi a elaboração de equações matemáticas para servir como ponto de partida à uniformização dos critérios de arbitramento do dano moral.

Neste sentido, Clayton ReIS sugere parâmetros mínimos e máximos de gradação das lesões, computados conforme o salário mínimo vigente, dividindo os danos morais em dois grupos: os decorrentes da ação física - homicídio, acidentes, ferimentos, imperícias médicas e danos estéticos -, e os decorrentes da ação psíquica - ofensa à honra, à privacidade, à liberdade. Assim, elabora uma equação utilizando tabelas de valores (considerando a situação econômica do réu e da vítima, a magnitude do dano, bem como o quociente de entendimento do lesionado) chegando aos parâmetros pré-estabelecidos para efetivação do cálculo ${ }^{238}$.

Segundo InACio de CARVALHo NeTo, é altamente louvável esta iniciativa, vez que propõe a adoção de critérios objetivos para quantificar o dano moral ${ }^{239}$.

NELSON DiRCEU FENSTERSEIFER também é entusiasta da proposta. Explica que, além da fórmula, a utilização de tabelas variáveis asseguraria ao magistrado a discricionariedade necessária para avaliar as vicissitudes de cada caso, a exemplo das

\footnotetext{
${ }^{235}$ GONÇALVES, Carlos Roberto. Op. cit. (nota 220), pp. 637-638.

${ }^{236}$ Cf. SANTOS, Antonio Jeová. Op. cit. (nota 13), p. 169.

${ }^{237}$ Cf. idem, p. 171.

${ }^{238}$ Cf. REIS, Clayton. A avaliação do dano moral. Rio de Janeiro: Forense, 1998, p. 98.

${ }^{239}$ Cf. Carvalho Neto, Inacio de. Op. cit. (nota 86), p. 84.
} 
penas criminais. A fundamentação da decisão permitiria ao juiz demonstrar a razoabilidade de seu raciocínio na fixação do valor a ser pago ${ }^{240}$.

No entanto, entende-se que a elaboração de equações se mostra inconveniente em razão da quebra do princípio da equidade, na medida em que limita os poderes de juiz para aplicação da justiça ao caso concreto ${ }^{241}$.

Também na jurisprudência já se afirmou que não se avalia o dano moral mediante cálculo matemático-econômico: "trata-se de uma estimação prudencial, que não dispensa sensibilidade para as coisas da dor e da alegria, para os estados d'alma humana, e que destarte deve ser feita pelo mesmo juiz, ou quando muito, por outro jurista, inútil sempre pôr em ação a calculadora do economista ou de técnico em contas ${ }^{\text {,242. }}$.

Ante o exposto, surgem os seguintes questionamentos: como atribuir a cada um o que efetivamente seja de seu direito, se esse mesmo direito está previamente tarifado? Como harmonizar o preconizado na Constituição, que estabelece a reparação proporcional ao agravo de forma integral e sem limitações, com este sistema? Como considerar as peculiaridades de cada caso se o julgador está limitado por equações?

Note-se que, durante muito tempo, os Tribunais brasileiros utilizaram-se dos tarifamentos estabelecidos pela Lei de Imprensa ${ }^{243}$ e pelo Código Brasileiro de Telecomunicações para avaliar, por analogia, o dano moral.

No entanto, foi assentado na jurisprudência que as limitações constantes das leis infraconstitucionais não foram recepcionadas pela atual Carta Magna, tendo o Superior Tribunal de Justiça se posicionado contrariamente a qualquer espécie de limite às indenizações por danos morais ${ }^{244}$.

De uma maneira ou de outra, percebe-se que tem sido especialmente importante o papel do magistrado para o arbitramento do quantum indenizatório, pois

\footnotetext{
${ }^{240}$ Cf. FENSTERSEIFER, Nelson Dirceu. Op. cit. (nota 33), p. 155.

${ }^{241}$ Cf. Santos, Antonio Jeová. Op. cit. (nota 13), p. 151.

242 Trecho do voto do Des. WALTER MORAES em Acórdão publicado na RT, vol. 650, p. 63, apud LOPEZ, Teresa Ancona. Op. cit. (nota 10), pp. 107-108.

${ }^{243}$ ElisABETE AlOIA AMARO aduz que os parâmetros da Lei de Imprensa ainda são úteis para a orientação. AMARO, Elisabete Aloia. Op. cit. (nota 84), p. 169.

${ }^{244}$ STJ, REsp n. 541682/SP, Rel. Min. BARROS MONTEIRO, j. em 23-08-05, pub. em 10-10-05.
} 
somente através da avaliação casuística será possível detectar a extensão do evento $\operatorname{danoso}^{245}$.

Neste sentido, concede-se ao juiz a mais ampla liberdade para arbitrar o valor da reparação dos danos extrapatrimoniais. Este sistema, segundo MARIA CELINA BODIN DE MORAES, tem sido considerado o que menos problemas traz e o que mais justiça e segurança oferece, atento que está para todas as peculiaridades do caso concreto. Para a autora, a fixação do quantum indenizatório atribuída ao juiz, o único a ter os meios necessários para analisar a sopesar a matéria de fato, permite que ele se utilize da equidade e aja com prudência e equilíbrio ${ }^{246}$.

Igualmente, na opinião de TERESA ANCONA LOPEZ: “aqui, muito mais do que na formação da extensão do dano, o arbítrio do juiz se manifesta e o uso deste poder discricionário talvez seja ainda a melhor maneira de chegar-se a uma reparação equitativa dos danos não patrimoniais, apesar de outras hipóteses já terem sido aventadas, 247 .

Dessa forma, a maioria da doutrina entende que a melhor forma para a fixação do quantum indenizatório por danos morais ainda é o do prudente arbítrio do juiz ${ }^{248}$. Por se tratar de arbitramento fundado exclusivamente no bom senso e na equidade, ninguém, além do próprio magistrado, está autorizado a realizar tal operação ${ }^{249}$.

\footnotetext{
${ }^{245}$ Cf. CARDIN, Valéria Silva Galdino. Dano moral no direito de família. São Paulo: Saraiva, 2012, p. 57. Neste ponto, mister recordar a opinião de TERESA ANCONA LOPEZ, para quem o ideal seria deixar à jurisprudência, auxiliada pela doutrina, a tarefa de elaborar um 'standard jurídico' que concentrasse os elementos da lesão, tendo a vantagem do dinamismo, sem a limitação e o caráter estático dos critérios legislativos. Cf. LOPEZ, Teresa Ancona. Op. cit. (nota 10), p. 101.

${ }^{246}$ Cf. MoraEs, Maria Celina Bodin de. Op. cit. (nota 66), pp. 269-270. Nas palavras de WILSON MELO DA SILVA: "é preponderante, na reparação dos danos morais, o papel do juiz. A ele, a seu prudente arbitrio, compete mediar as circunstâncias, ponderar os elementos probatórios, inclinar-se sobre as almas e perscrutar as coincidências na busca da verdade, separando sempre o joio do trigo, o lícito do ilícito, o moral do imoral, as aspirações justas das 'miragens do lucro' (...)". SILVA, Wilson Mello da. O dano moral e sua reparação. $3^{\mathrm{a}}$ ed. Rio de Janeiro: Forense, 1999, pp. 630-631.

${ }^{247}$ LOPEZ, Teresa Ancona. Op. cit. (nota 10), p. 103. "E é preciso lembrar que, mais do que em outras matérias, terá o juiz de usar da 'equidade', aqui como fonte do direito, muito mais que como método de interpretação". Idem, p. 108

${ }^{248}$ Nas palavras de NEHEMIAS DOMINGOS DE MELO, "de fato, não há outro meio mais eficiente para se fixar o valor da indenização por dano moral a não ser pelo arbitramento judicial". MELo, Nehemias Domingos de. Op. cit. (nota 117), p. 115.

${ }^{249}$ Assevera HUMBERTO THEODORO JÚNIOR que "não havendo pauta ou tarifação na lei para a grande maioria dos casos de ofensa à honra e aos direitos da personalidade, compete ao juiz arbitrar, com prudência e equidade, o valor da indenização por dano moral". Em suas palavras: "o bom senso é a regra máxima a observar por parte dos juizes”. THEODORO JÚNIOR, Humberto. Op. cit. (nota 35), pp. 69-70.
} 
Não obstante as eventuais censuras ao sistema de livre arbitramento judicial ${ }^{250}$, segundo JOSÉ DE AGUIAR DIAS, a objeção 'peca pela base', pois a faculdade é concedida ao juiz em muitos casos e até na avaliação dos danos patrimoniais ${ }^{251}$.

Todavia, não se deve confundir o livre-arbitramento, prudente e moderado, com a arbitrariedade. Ao magistrado cumpre fixar o valor da reparação moral adotando os critérios da prudência e do bom senso, levando sempre em consideração que o quantum representa um valor simbólico, pois não é possível a exata equivalência entre o dano moral e a indenização.

Assim, a quantificação da reparação por dano moral permanece uma tarefa árdua e complexa. É importante que os critérios de avaliação utilizados no caso concreto sejam sempre explicitados, fundamentando-se adequadamente a decisão e, assim, garantindo-se o controle da racionalidade da sentença. Esta é a linha que separa o arbitramento da arbitrariedade ${ }^{252}$.

Logo, o juiz deverá agir com responsabilidade e prudência, de acordo com sua experiência, examinando as circunstâncias particulares do caso concreto e realizando um juízo ético de valoração da gravidade do dano, dentro do quadro circunstancial do fato.

Quanto a isto, ANTONIO CHAVEs conclui que o arbitramento do dano moral resta entregue ao prudente arbítrio do magistrado, sendo imprescindível, apenas, que leve

\footnotetext{
250 "A sentença, além daqueles critérios técnicos que the são peculiares, contém dados da personalidade, da formação cultural, religião e moral do juiz". SANTOS, Antonio Jeová. Op. cit. (nota 13), p. 153. O juiz não pode ser indiferente, pois está vivendo uma preferência. Ele tem uma causa que é sua vida, que não pode trair. Cf. Ibidem. "Filtrando ainda mais, encontrar-se-ão os milhares de juízes de determinado Estado da Federação. Cada um com seu arbítrio prudencial a julgar pedidos de indenização sob a sua óptica particular e pessoal. Agora, pense-se no Brasil inteiro, em que o sistema federativo permite que cada Estado-membro organize sua Justiça”. Idem, p. 152.

${ }^{251}$ Cf. DiAS, José de Aguiar. Op. cit. (nota 44), pp. 1005-1006. Também YuSSEF SAID CAHALI contesta esta crítica: "quanto ao desmensurado arbitrio concedido aos tribunais na fixação do dano a ser reparado diante da impossibilidade de uma rigorosa estimação pecuniária dos danos apatrimoniais, tal arbítrio (que é inegável) também aparece, por vezes, inevitavelmente, no ressarcimento do dano patrimonial, sendo certo que os juízes, no seu prudente arbítrio, sempre saberão dosá-lo para impedir enriquecimento sem causa". CAHALI, Yussef Said. Op. cit. (nota 39), pp. 24-25.

${ }^{252}$ Cf. MoRAES, Maria Celina Bodin de. Op. cit. (nota 66), p. 270. "Deve ser possivel reconstruir os fundamentos nos quais o juiz se embasou para estabelecer uma determinada quantia ressarcitória. Por isso, na motivação da sentença, deve especificar claramente quais foram as pautas tomadas em conta para chegar a montante determinado, as provas que se ponderaram e os precedentes jurisprudenciais, sobre os quais o juiz adaptou a solução do caso concreto". CASTILLA, Gustavo Ordoqui. Daño a la persona. Montevideo: Editorial del Foro, 1996, p. 96, apud SANTOS, Antonio Jeová. Op. cit. (nota 13), p. 154.
} 
em conta a repercussão social do dano e seja compatível com a situação econômica das $\operatorname{partes}^{253}$.

ANTONIO JEOVÁ SANTOS propugna pelo aditamento de outros fatores, de outras pautas para minorar e não deixar somente ao juiz o critério prudencial para a tarefa de encontrar o montante ressarcitório ${ }^{254}$.

Da mesma maneira, TERESA ANCONA LOPEZ apregoa que, apesar de a matéria ser deixada ao prudente arbítrio do juiz, este deverá seguir certas diretrizes ${ }^{255}$.

Para MARIA Helena DINIZ, "um dos grandes desafios da ciência jurídica é o da determinação dos critérios de quantificação do dano moral, que sirvam de parâmetros para o órgão judicante na fixação do 'quantum debeatur ', 256.

Neste ponto, são parâmetros frequentemente apontados para o arbitramento do quantum indenizatório do dano moral: a natureza específica da ofensa sofrida; a intensidade real, concreta e efetiva do sofrimento; a repercussão da ofensa no meio social em que vive o ofendido; a existência de dolo, por parte do ofensor, na prática do ato danosos e o seu grau de culpa; a situação econômica do ofensor; a posição social do ofendido; a capacidade e a possibilidade real e efetiva de o ofensor reincidir no mesmo fato; a prática anterior da violação; as existências de atenuantes realizadas pelo lesante visando diminuir a dor do ofendido; a proporção entre o valor da indenização e a extensão do dano e a impossibilidade do enriquecimento sem causa ${ }^{257}$.

No que diz respeito a este último parâmetro, a vedação de que a satisfação pecuniária promova o enriquecimento à custa do empobrecimento alheio protege uma das

${ }^{253}$ Cf. CHAVES, Antonio. Responsabilidade civil - atualização em matéria de responsabilidade por danos morais. Revista Jurídica. Ano XLV, n. 231, pp. 11-30, jan. de 1997, p. 30.

${ }^{254}$ Cf. SANTOS, Antonio Jeová. Op. cit. (nota 13), p. 154.

${ }^{255}$ Cf. Lopez, Teresa Ancona. Op. cit. (nota 10), p. 100. Segundo a jurista: "no Brasil, a avaliação do dano moral opera-se 'in concreto', mas a própria lei e a jurisprudência fornecem alguns critérios gerais de avaliação: grau de culpa do ofensor; tamanho do dano, objetivamente considerado; circunstâncias particulares do ofendido (sexo, idade, condições sociais, beleza, situação familiar); perda das chances de vida e dos prazeres da vida social ou da vida intima; igualdade de tratamento dos sexos (CF, art. $\left.5^{\circ}, I\right)$; condições do ofensor, sempre lembrando que a responsabilidade civil não foi criada para enriquecimento da vítima, mas para justa reparação do mal. A justiça tem os dois lados: se o ofensor tem dinheiro para pagar melhor, isso não significa que, em sendo ele rico, deve-se determinar uma indenização muito além daquela que parece justa”. Idem, pp. 109-110.

${ }_{256}$ DINIZ, Maria Helena. Op. cit. (nota 55), p. 118.

${ }^{257}$ Há quem acrescente também: condições das partes, nível social, a personalidade da vítima e do autor do ilícito, escolaridade. Cf. FIGUEIREDo, Isabela Ribeiro de. A valoração do dano moral. Revista Síntese de Direito Civil e Processual Civil, n. 10, 2001, pp. 52 e 56. 
funções da reparação civil pelos danos morais: devolver o equilíbrio às relações. Evidentemente, não se deve impor uma indenização que ultrapasse a capacidade econômica do responsável, levando-o à ruína (o que, de resto, feriria a própria dignidade humana, que é o fundamento mesmo da reparação). De outra ponta, o valor da condenação não deve ser tão pequeno que se torne inexpressivo ${ }^{258}$.

Se a condição econômica do ofendido deverá ser considerada, para que não seja reduzido à miséria, por outro lado, a utilização do status da vítima para determinar o quantum indenizatório é questão controversa.

JESUALDO EDUARDO DE ALMEIDA JÚNIOR se mostra contrário a este critério, e afirma que a condição social da vítima não pode ser valorizada para reduzir o montante da indenização pelo dano moral, já que a dor das pessoas humildes não é menor do que aquela sofrida por pessoas abonadas ${ }^{259}$.

No mesmo sentido, a manifestação de MIRNA CIANCI, para quem "uma pessoa idônea, ainda que desprovida de fortuna ou de importantes laços, certamente padece do mesmo sofrimento, não se justificando, senão por conta de odiosa discriminação, a diminuição ou majoração do arbitramento sob tais indicadores" 260.

Ponderando a situação, TERESA ANCONA LOPEZ adverte que o juiz, ao lançar mão deste critério, não deve colocá-lo acima da gravidade do próprio dano, pois é a extensão deste que dará a medida da indenização. Caso contrário, a jurista alerta que serão cometidas injustiças, como a de negar-se ressarcimento a 'pessoa de condição humilde' ${ }^{261}$.

\footnotetext{
258 Conforme afiança HUMBERTO THEODORO JÚNIOR: “o valor da reparação terá de ser 'equilibrado', por meio da prudência do juiz. Não se deve arbitrar uma indenização pífia nem exorbitante, diante da expressão ética do interesse em jogo, nem tampouco se pode ignorar a situação econômico social de quem vai receber a reparação, pois jamais se deverá transformar a sanção civil em fonte pura e simples de enriquecimento sem causa". THEODORO JúNIOR, Humberto. Op. cit. (nota 35), p. 56. Para ele: "tem-se, é claro, que levar em conta na estimativa da reparação do dano moral, as condições sócio-econômicas da vítima e do ofensor. Nunca, porém, para isolar a situação do agente e, por causa de seu mais avantajado patrimônio, transformar a indenização num prêmio lotérico capaz de mudar a sorte econômica do ofendido. Não é possível imaginar que, pela dor moral, alguém tenha condição de transformar-se de pessoa humilde em potentado, somente porque o agente da ofensa foi uma pessoa de recurso”. Idem, pp. 89-90.

${ }^{259}$ Cf. AlMEIDA JúNIOR, Jesualdo Eduardo de. Op. cit. (nota 141), p. 139.

${ }^{260}$ CIANCI, Mirna. Op. cit. (nota 227), p. 108.

${ }^{261}$ Cf. LoPEZ, Teresa Ancona. Op. cit. (nota 10), p. 103.
} 
De seu turno, ANTONIO JEOVÁ SANTOS propõe a utilização do modelo abstrato do homem médio para a quantificação do dano, considerando uma situação econômica abstrata e genérica ${ }^{262}$.

Analogamente, MARIA CELINA BODIN DE MORAES lembra que, na quantificação da indenização, deve-se levar em conta a sensibilidade média das pessoas, a instrução da vítima e sua posição social, os princípios éticos e a influência do meio ${ }^{263}$.

Dentre os aspectos a serem considerados, merece destaque a hipótese de utilização da culpa concorrente do ofendido para diminuir o montante final.

A princípio, INACIO DE CARVALHO NETO entende que esta diminuição parece contrariar o art. 944 do Código Civil, pois se a culpa concorrente da vítima não exclui a relação de causalidade, permanece a obrigação de reparar integralmente o dano. Entretanto, segundo afirma, como cabe ao agente indenizar o dano por ele causado, haveria uma justificativa, já que o ato culposo da vítima causou parte deste dano ${ }^{264}$.

Logo, para o jurista, a culpa concorrente da vítima influirá no cálculo da indenização, que será proporcional à culpa de ambos. A responsabilidade ressarcitória é exclusiva de quem deu causa ao prejuízo, no entanto, na culpa concausal, por lógica e para evitar locupletamento sem causa da vítima, a responsabilidade pelo dano deve ser assumida por ambos, o que resulta na necessidade de redução do montante indenizatório, de modo que cada um fique responsável pelo que causou ${ }^{265}$.

Diante deste quadro complexo, vale lembrar a ponderação de NEHEMIAS Domingos DE MELO: a existência de decisões 'estapafúrdias' com relação ao valor fixado a título de dano moral, que fogem ao bom-senso e à lógica, tanto para mais quanto para menos, servem somente para justificar a preocupação daqueles que, na atualidade, se

\footnotetext{
${ }^{262}$ Cf. SANTOS, Antonio Jeová. Op. cit. (nota 13), pp. 179-180. Por outro lado, o mesmo jurista assevera: “o julgador deve estar situado e sintonizado com o contexto econômico do País. Deve ter em conta os males do custo social brasileiro. (...) A situação média de nossa população. Ter em conta a expressiva pobreza dos habitantes do País, além de levar em consideração o impacto que o valor da indenização venha a ter sobre o dinamismo econômico”. Idem, p. 182.

${ }^{263}$ Cf. MoRAES, Maria Celina Bodin de. Op. cit. (nota 66), p. 278. “Ainda a respeito da situação da vítima, o seu geral 'standard' de vida há de ser observado, como a idade, estado civil, sexo, a atividade social, o local em que vive, os vínculos familiares e outras circunstâncias tanto de natureza objetiva, como subjetiva que o caso ofereça. As circunstâncias do caso concreto, em conjunto com outros fatores, poderão definir a maneira como se encontrará o total da indenização”. SANTOS, Antonio Jeová. Op. cit. (nota 13), p. 189.

${ }^{264}$ Cf. CARvalho NeTO, Inacio de. Op. cit. (nota 86), p. 71.

${ }^{265}$ Cf. idem, p. 70.
} 
escudam na falta de parâmetros para defender o sistema tarifado ou tabelado. Assim, ressalva que essas decisões díspares são exceções, enquanto que as decisões lastreadas no bom-senso e na lógica preponderam, por isso não se deve pautar o posicionamento a partir dos desvios, que sempre irão existir, conquanto não possam inviabilizar o instituto ${ }^{266}$.

Ademais, está assente na jurisprudência do Superior Tribunal de Justiça que o arbitramento judicial da indenização por dano moral é questão relevante de direito, que comporta reexame no âmbito do Recurso Especial. O propósito da Corte Superior é corrigir as 'distorções intoleráveis'. Ela desempenha o papel de dar justas e adequadas dimensões ao problema, quer para impedir que se alastrem quantificações inexpressivas, quer para evitar condenações exageradas ${ }^{267}$.

Deste modo, tornou-se tranquilo o entendimento de que o valor da indenização do dano moral se sujeita ao controle do Superior Tribunal de Justiça, desde que o quantum estipulado nas instâncias ordinárias contraste com o bom-senso. Esta revisão somente é admitida nas hipóteses em que tenha sido fixado valor irrisório ou abusivo. Ao exercer o controle dos valores, também acaba por estabelecer certos parâmetros, que têm servido para orientar os magistrados ${ }^{268}$.

Por fim, alguns procuram o auxílio do legislador na estipulação de critérios legais a serem utilizados no arbitramento. A este respeito, observamos a existência de projetos de lei que, de uma forma ou de outra, procuram estabelecer parâmetros para as indenizações por danos morais ${ }^{269}$.

Na opinião de Nehemias Domingos DE Melo, independentemente dos aspectos atinentes à constitucionalidade das propostas, elas em nada contribuem para a resolução do problema da fixação do quantum indenizatório. $\mathrm{O}$ autor entende que o único

\footnotetext{
${ }^{266}$ Cf. Melo, Nehemias Domingos de. Op. cit. (nota 117), pp. 116-117.

${ }^{267}$ Fazendo esta indicação: GouvÊA, José Roberto Ferreira et SILVA, Vanderlei Arcanjo da. Dano moral: quantificação pelo STJ. Revista Síntese de Direito Civil e Processual Civil, n. 37, 2005, p. 150. Neste sentido, o recente julgado: STJ, AgRg no AREsp n. 227.636/SP, Rel. Min. Raul Araújo, j. em 16-10-12, pub. em 13-11-12.

${ }^{268}$ Dentre os aspectos a serem considerados na quantificação da indenização do dano moral, com base na jurisprudência do Superior Tribunal de Justiça, destaca a doutrina: a intensidade da culpa e do dano, a conduta e a capacidade econômica do ofensor, a repercussão da ofensa, a posição social ocupada pelo ofendido e as consequências suportadas. Cf. GouvÊA, José Roberto Ferreira et SILVA, Vanderlei Arcanjo da. Op. cit. (nota 267), p. 151.

269 À guisa de exemplo, os Projetos de Lei n. 150/99, n. 114/08 e n. 334/08. Todos eles, contudo, foram arquivados.
} 
escopo que moveu seus proponentes foi limitar os valores máximos passíveis de serem concedidos pelo judiciário a título de danos morais ${ }^{270}$.

Ao fim e ao cabo, mostra-se decisivo o papel do magistrado, a quem é confiada a mensuração do dano moral. Este deve fixá-lo levando em consideração os fatos pertinentes de cada caso concreto e de acordo com a ampla gama de parâmetros que podem orientá-1o ${ }^{271}$.

Diversos são os critérios que se somaram na evolução teórica e jurisprudencial para o arbitramento do dano moral. Ao lado disto, foram aventadas algumas alternativas, não sem críticas. De uma forma ou de outra, é preciso ter em mente que o cálculo da indenização depende da função que se atribui a este tipo de repercussão jurídica. Se a função de reparação do dano é unânime, outras são polêmicas e sua aceitação ou rejeição inevitavelmente altera o modo de erigir o quantum no caso concreto.

\subsubsection{FUNÇÃO DO DANO MORAL (RECTIUS, DE SUA INDENIZAÇÃO)}

Avaliar quais são as funções do dano moral ou, mais propriamente, de sua indenização, é essencial para sabemos como proceder em seu cálculo. Mais do que isto, a depender destas funções, é possível vislumbrar quais os aspectos relevantes do fato concreto, para perquirirmos tanto a existência do dano quanto a magnitude da reparação.

Conforme dissemos, o dano moral é incapaz de restaurar o lesado ao status quo ante. E, além disto, a equivalência exata entre o dinheiro e a dor é impossível ${ }^{272}$.

270 Cf. Melo, Nehemias Domingos de. Op. cit. (nota 117), p. 100. ANTONIO JeOvÁ SANTOS tem entendimento semelhante: "nada mais parece ser importante em leis desse jaez a não ser a luta denodada para não deixar ao puro critério do Poder Judiciário a quantia indenizatória”. Para este jurista, em verdade, o discurso favorável ao tarifamento da indenização esconde o que realmente se pretende: pagar pífias indenizações. Cf. SANTOS, Antonio Jeová. Op. cit. (nota 13), p. 169.

$271 \mathrm{Na}$ opinião de MARIA CELINA BODIN DE MORAES: "se assim se fizer, os valores continuarão, evidentemente, díspares, mas agora em bases racionais, e certamente não se poderá comparar os tribunais a cassinos e loterias, onde apenas a sorte e o azar prevalecem”. MORAES, Maria Celina Bodin de. Op. cit. (nota 66), p. 295.

${ }^{272}$ A doutrina é prenhe em manifestações a este respeito. Para JOSÉ DE AGUIAR DiAS, “não há dúvida, porém, que a maior dificuldade do dano moral é precisamente o fato de não encontrar correspondência no critério valorativo patrimonial". DIAS, José de Aguiar. Op. cit. (nota 44), p. 993. Nas palavras de TERESA ANCONA LOPEZ, "ora, em matéria de dano moral existe uma dificuldade enorme, de ordem prática: exatamente esta impossibilidade de achar-se um equivalente da dor para estabelecer-se o montante exato da indenização”. LOPEZ, Teresa Ancona. Op. cit. (nota 10), p. 100. Também JosÉ DE CASTRO BIGI afirmava que "não se desconhece as dificuldades de encontrar-se uma correspondência entre o dano moral e a reparação patrimonial”. BIGI, José de Castro. Dano moral em separação e divórcio. Revista dos Tribunais, v. 679, 1992 , p. 49. 
A fim de possibilitar a reparação, foi admitida a indenização por equivalência, e, para isso, o dinheiro é servível ${ }^{273}$. A reparação é incompleta e aproximada, porém outorga à vítima bens que compensem o dano produzido ${ }^{274}$.

Na opinião de JosÉ DE AgUiAR DiAS, "não é possível a sua avaliação em dinheiro, pois não há equivalência entre o prejuízo e o ressarcimento. Quando se condena o responsável a reparar o dano moral, usa-se de um processo imperfeito, mas o único realizável, para que o ofendido não fique sem uma satisfação,"275.

De fato, a condenação do responsável visa apenas resguardar, decerto imperfeitamente, mas pela única forma possível, o direito lesado. Assim, na opinião de YUSSEF SAID CAHALI, no dano moral não se reclama a equivalência em termos absolutos, na medida em que a reparação tem caráter meramente satisfativo ${ }^{276}$. Para ele, o dano moral não se resolve numa indenização propriamente dita, já que esta significa eliminação do prejuízo e das suas consequências, o que não é possível para o dano extrapatrimonial; a sua reparação se faz através de uma compensação, impondo ao ofensor a obrigação de pagar certa quantia de dinheiro em favor do ofendido, ao mesmo tempo em que agrava o patrimônio daquele, proporciona a este uma reparação satisfativa ${ }^{277}$.

Na visão de ANTONIO JEOVÁ SANTOS, a compensação em dinheiro exerce a função de "contrapeso" ${ }^{278}$, pois o dinheiro obtido como indenização, se não faz com que a vítima recupere o bem objeto do agravo, permite-lhe refazer, na medida do possível, sua situação espiritual anterior à lesão que a perturbou ${ }^{279}$.

\footnotetext{
${ }^{273}$ Indenizar traduz a ideia de tornar indene, ou seja, restaurar a vítima à situação anterior ao dano. Todavia, afirma SILVIO RoDRIGUES que nos casos em que isso não é possível há que se recorrer a uma situação postiça, representada pelo pagamento de uma indenização em dinheiro: "é um remédio nem sempre ideal, mas o único de que se pode lançar mão”. RODRIGUES, Silvio. Direito civil: responsabilidade civil. vol. 4. 20ª ed. São Paulo: Saraiva, 2003, p. 186.

${ }^{274}$ Cf. SANTOS, Antonio Jeová. Op. cit. (nota 13), p. 39.

275 DiAs, José de Aguiar. Op. cit. (nota 44), p. 1008.

${ }^{276}$ Cf. CAHALI, Yussef Said. Op. cit. (nota 39), p. 24.

277 Cf. idem, p. 38. Também INACIO DE CARVALHO NETO assevera que o dano moral não pode ser propriamente indenizado, mas apenas compensado. Cf. CARVALHO NETO, Inacio de. Op. cit. (nota 86), p. 58. ${ }^{278}$ Cf. SANTOS, Antonio Jeová. Op. cit. (nota 13), p. 156.

${ }^{279}$ Cf. idem, p. 62. Ele exemplifica: "uma música bonita satisfaz o sentido da audição, um belo ato produz em quem o realiza uma satisfação moral, o bom êxito científico é origem para o sábio de gozos intelectuais. Tudo isso pode ser conseguido ou ajudado a conseguir com o dinheiro. A função deste, de par ao motivo dos danos morais produzidos e da reparação devida, cujo objeto seria o restabelecimento da situação moral anterior, pela colocação em paz das penas, das inquietações, das aflições, das feridas causadas às afeições legítimas, das dores morais produzidas pelo agravo físico ou moral, não seria a de substituir o dano por seu equivalente em dinheiro por ser este e aquele de distinta natureza, senão a de dar à vítima um meio
} 
Também ClAytON REIS entende que o dinheiro seria apenas uma forma de a vítima alcançar uma compensação da dor vivenciada em face da ação antijurídica ${ }^{280}$.

Nas palavras de TERESA ANCONA LOPEZ, "na verdade, portanto, não há equivalente da dor em dinheiro. Não há o que se chama de 'pecunia doloris' ou 'pretium doloris', e, sim, a compensação ou benefício de ordem material, que permita ao lesado obter prazeres e distrações que, de algum modo, atenuem sua dor,"281.

No mesmo sentido, é opinião de Nehemias Domingos De Melo: “para a vítima, esse caráter compensatório nada mais seria do que lhe ofertar uma quantia capaz. de lhe proporcionar satisfações que pudessem compensar a dor sofrida, além de significar o sentimento de justiça atendido ${ }^{, 282}$.

Segundo MARIA HELENA DinIZ, a reparação viria neutralizar os sentimentos negativos da mágoa, dor, tristeza, angústia, pela superveniência de sensações positivas, possibilitando ao ofendido algum prazer. Assim, ter-se-ia uma reparação do dano moral pela compensação da dor com a alegria ${ }^{283}$.

adequado para fazer desaparecer ou, pelo menos, para neutralizar ou, sequer seja, para atenuar os efeitos". Idem, pp. 61-62. "Diante da pergunta sobre quais os remédios para a tristeza e a dor, São Tomás de Aquino respondeu que entre outros prazeres de ordem corporal o passear, o ouvir boa música, beber vinho generoso, comer um bom bocado, pois todas estas coisas, de certa forma, restabelecem a normalidade corporal, e por outra, proporcionam deleite, ou ao menos distração com que suavizar as asperezas da dor". Idem, p. 201.

${ }^{280}$ Cf. ReIs, Clayton. Dano moral. Rio de Janeiro: Forense, 2010, p. 184.

${ }^{281}$ LOPEZ, Teresa Ancona. Op. cit. (nota 10), p. 106. "Não é o preço da dor, embora essa expressão seja usada como inexata antonomásia do dano moral - é o instrumento de alguns confortos e algumas distrações, de lenitivos ao desgosto, de um possivel prazer que amorteça a dor... Não é remédio que produza a cura do mal, mas sim um calmante. Não se trata de suprimir o passado, mas sim de melhorar o futuro. $O$ dinheiro tudo isso pode". GONÇALVES, Cunha. Tratado de direito civil. vol. 12, tomo II, p. 543, apud LOPEZ, Teresa Ancona. Op. cit. (nota 10), p. 106. CARLOS AlberTo BITTAR acrescenta: "é que os diferentes bens, inclusive a moeda, exercem funções várias na vida social, proporcionando às pessoas o alcance de inúmeros objetivos, econômico, ou mesmo ideais, na satisfação de interesses os mais diversos, inclusive na própria atenuação de agruras, desgostos, desilusões e outras vicissitudes, ou sensações negativas". BITTAR, Carlos Alberto. Op. cit. (nota 14), p. 68. No mesmo sentido: “com a reparação do dano moral não se está pretendendo vender um bem moral, mas simplesmente sustentando que esse bem, como todos os outros, deve ser respeitado". FigUEIREDO, Isabela Ribeiro de. Op. cit. (nota 257), p. 51.

${ }^{282}$ Melo, Nehemias Domingos de. Op. cit. (nota 117), p. 119.

${ }^{283}$ Cf. DiNIZ, Maria Helena. Op. cit. (nota 55), p. 128. 
Portanto, o pretium consolationis se aproxima do critério a ser observado pelo juiz no momento da quantificação do dano moral, tendo em vista os prazeres compensatórios que a vítima pode usufruir $^{284}$.

Logo, há unanimidade em aceitar o caráter compensatório que a indenização proporciona àquele que suportou o dano moral. Na doutrina, contudo, outras funções foram atreladas a esta indenização ${ }^{285}$. E aqui se iniciam as diferenças e divergências entre os estudiosos.

Assim, vislumbra-se uma função punitiva da indenização, acrescentando-se a esta, por alguns, a função preventiva ou pedagógica ${ }^{286}$.

CAio MÁRIo DA Silva Pereira preceitua que "o fulcro do conceito ressarcitório acha-se deslocado para a convergência de duas forças: 'caráter punitivo' para que o causador do dano, pelo fato da condenação, se veja castigado pela ofensa que praticou; e o 'caráter ressarcitório' para a vitima, que receberá uma soma que lhe proporcione prazer como contrapartida do mal sofrido ${ }^{, 287}$.

TERESA ANCONA LOPEZ é veemente a respeito: "na reparação dos danos morais há uma dupla função: a de pena ou expiação, em relação ao culpado, e a de satisfação, em relação à vítima ${ }^{288}$. Para a jurista, é fortíssima a tendência atual de considerar este duplo aspecto da indenização por dano moral ${ }^{289}$. Assim, a soma em dinheiro paga a título de satisfação ocupa um lugar intermediário entre a indenização e a pena $^{290}$.

\footnotetext{
${ }^{284}$ Cf. SANTOS, Antonio Jeová. Op. cit. (nota 13), p. 201. Nestes termos, conclui que: "quem se predispuser a enveredar por essa verdadeira 'tópica da consolação', chega mais próximo da questão angustiante que é a quantificação do dano moral, perguntando quais e quantos bens (não materiais, apenas), podem ser adquiridos ou proporcionados à vítima, para mitigar a vulneração a seu direito”. Idem, pp. 201-202.

${ }^{285} \mathrm{Na}$ doutrina italiana, igualmente percebemos uma enumeração de diversas funções da responsabilidade civil: a) reintegradora (da situação anterior), b) sancionatória, c) organizadora (fazendo valer a igualdade dentro da família); d) macro sistemática (relativa às interações entre os ramos jurídicos); e) preventiva; $f$ ) simbólica-enfática (como lenitivo para o orgulho ferido da vítima); e $g$ ) estimuladora da realização pessoal. Cf. CENDON, Paolo et SEBASTIO, Giovanna. La responsabilità civile fra marito e moglie. In: CENDON, Paolo (Coord.). Persona e danno III: le persone deboli, i minori, i danni in famiglia. Milano: Giuffrè, 2004, pp. 2844-2847.

${ }^{286} \mathrm{~A}$ dupla função - ressarcitória e exemplar - do dano moral é também compartilhada pela jurisprudência argentina. Cf. DuTTO, Ricardo J. Op. cit. (nota 169), p. 57.

${ }^{287}$ PereIRA, Caio Mário da Silva. Responsabilidade civil. $6^{a}$ ed. Rio de Janeiro: Forense, 1995, p. 55.

${ }^{288}$ LOPEZ, Teresa Ancona. Op. cit. (nota 10), p. 106.

${ }^{289}$ Cf. idem, p. 33.

${ }^{290}$ Cf. idem, p. 106.
} 
A autora ainda menciona a função preventiva:

“a responsabilidade civil, que tem como primeira função a reparação dos danos, também deve exercer seu papel preventivo. Cada vez que é determinada uma indenização ao réu, essa sanção deveria servir não só para ressarcir os prejuízos da vítima mas também para ameaçar com a aplicação dessas penas o culpado e o resto da sociedade. Essa é uma função automática da responsabilidade civil”, ${ }^{291}$.

Também para MARIA HelENA DinIZ, a reparação pecuniária do dano moral é um misto de pena e de satisfação compensatória ${ }^{292}$.

Já para YUSSEF SAID CAHALI: “a indenizabilidade do dano moral desempenha uma função tríplice: reparar, punir, admoestar ou prevenir ${ }^{, 293}$.

Também VALÉRIA SiLva GALDINO CARDin informa que além da natureza compensatória ou ressarcitória, quanto ao ofensor a indenização busca puni-lo e inibir-lhe a prática de novos atos ilícitos que ensejem danos ${ }^{294}$.

Filia-se a este entendimento JeSUALDo EdUARDo DE ALMEIDA JÚNIOR, o qual defende que os danos morais têm natureza compensatória, punitiva e sancionadora indireta (preventiva para desestimular novas práticas). Assim, ele afiança que a indenização deve atender a uma relação de proporcionalidade, não podendo ser insignificante a ponto de não cumprir com sua função penalizante, nem ser excessiva a ponto de desbordar da razão compensatória ${ }^{295}$.

Sílvio DE SAlvo Venosa, igualmente, assevera: “(...) em sede de indenização por danos imateriais há que se apreciar sempre a conjugação dos três fatores ora

\footnotetext{
${ }^{291}$ LOPEZ, Teresa Ancona. Princípio da precaução e evolução da responsabilidade civil. São Paulo: Quartier Latin, 2010, p. 78.

${ }^{292}$ DINIZ, Maria Helena. Op. cit. (nota 55), p. 126.

${ }^{293}$ CAHALI, Yussef Said. Op. cit. (nota 39), p. 175.

${ }^{294}$ Cf. CARDIN, Valéria Silva Galdino. Op. cit. (nota 245), p. 61. Para a jurista, “a indenização a ser paga em dinheiro pelo ofensor tem como propósito fazê-lo sentir de alguma forma o dano que praticou embora o valor fixado jamais seja suficiente para compensar integralmente o lesado”. Idem, p. 60.

295 "Como é sabido, a indenização por dano moral é arbitrável judicialmente mediante estimativa prudencial que leve em conta a necessidade de, com a quantia, satisfazer a dor da vítima e dissuadir, de igual e novo atentado, o autor da ofensa. O valor da indenização deve levar em conta seu propósito pedagógico e atender aos reclamos compensatórios do ofendido”. ALMEIDA JÚNIOR, Jesualdo Eduardo de. Op. cit. (nota 141), p. 139.
} 
mencionados: compensação, dissuasão e punição. Dependendo do caso concreto, ora preponderará um, ora outro, mas os três devem ser levados em consideração, ${ }^{\text {,296. }}$.

Este tríplice papel também é reconhecido por NeHEMIAs Domingos DE Melo, que discrimina tais aspectos:

“(...) compensar a vitima pelos infortúnios sofridos, ofertando-lhe uma soma em dinheiro que possa lhe trazer satisfações; punir o ofensor de sorte que a condenação possa cumprir o papel pedagógico do desestímulo; e, de exemplaridade para a sociedade, demonstrando que aquele tipo de comportamento não é aceito impunemente pelo judiciário, agindo no sentido do desestímulo coletivo ${ }^{, 297}$.

Do mesmo modo, CARlos Alberto BitTAR percebe que a indenização tem cunho eminentemente compensatório para o prejudicado ${ }^{298}$, e representa uma sanção para o lesante $^{299}$. Assim, o juiz, ao fixar a indenização, deve estabelecer um valor que sirva como sanção, sensível ao patrimônio do lesante, de sorte a desestimular novas práticas ${ }^{300}$. Tal sancionamento também serve como alerta à sociedade, de que o Direito não compactua com os reflexos do fato lesivo ${ }^{301}$.

Na visão de Antonio JeOvÁ SAntos, ao lado do caráter ressarcitório, a indenização deve desempenhar um papel exemplar, de maneira que o montante fixado possa evitar outras infrações por parte do ofensor" ${ }^{302}$, pois "quem foi condenado a desembolsar certa quantia em dinheiro pela prática de um ato que abalou o bem-estar psicofísico de alguém, por certo não será recalcitrante na mesma prática, com receio de que sofra no bolso a consequência do ato que atingiu um seu semelhante, ${ }^{, 303}$.

Conforme se depreende dessas manifestações, as funções punitiva e preventiva (pedagógica) estão intimamente relacionadas. A sanção serve não apenas para prevenir que

\footnotetext{
${ }^{296}$ VenosA, Sílvio de Salvo. Direito civil: responsabilidade civil. vol. 4. $7^{\text {a }}$ ed. São Paulo: Atlas, 2007, p. 292.

${ }^{297}$ Melo, Nehemias Domingos de. Op. cit. (nota 117), p. 106.

${ }^{298}$ Cf. BITTAR, Carlos Alberto. Op. cit. (nota 14), p. 64.

${ }^{299}$ Cf. BitTAR, Carlos Alberto. Op. cit. (nota 11), p. 283.

${ }^{300}$ Cf. Ibidem.

${ }^{301}$ Cf. BITTAR, Carlos Alberto. Op. cit. (nota 14), p. 43.

${ }^{302}$ Cf. SANTOS, Antonio Jeová. Op. cit. (nota 13), p. 162.

${ }^{303}$ Idem, p. 44.
} 
o próprio agente volte a repetir o ato, mas também como exemplo para terceiros, a fim de que não incidam na mesma conduta ${ }^{304}$.

A adoção dos argumentos punitivo e preventivo cresce em nosso país. De acordo com Flavia PORTElla PÜSChel, alguns dos fatores que levam a isto são a inexistência de critérios legais expressos e a dificuldade de avaliação do dano moral. Em virtude da liberdade de que desfruta o juiz no momento da quantificação do prejuízo, o objetivo punitivo acaba sendo introduzido no cálculo, a despeito de modificação legislativa ou grande elaboração interpretativa ${ }^{305}$.

MARTiNHO GARCEZ NETO defende que a função penal da condenação por dano moral deve ser encarada como algo altamente moralizador, na medida em que, ao atingir o patrimônio do agressor com a sua consequente diminuição, cumpre a mais elementar noção de justiça: pune o ofensor para que o bem moral seja respeitado e, mais importante, 'faz calar' o sentimento de vingança do ofendido ${ }^{306}$.

Já ANDRÉ GuSTAVo CORRÊA DE ANDRADE avaliza que a indenização punitiva surge como instrumento jurídico constituído a partir do princípio da dignidade humana, com a finalidade de protegê-la em suas variadas representações ${ }^{307}$.

Bernardo CASTElo Branco entende que ao ofensor aplica-se, sem dúvida, uma sanção, ou seja, uma resposta da ordem jurídica, no plano privado, à ofensa por ele praticada, inibindo-o da prática de novo ilícito. Nestes termos, conclui que a difusão da noção de que um determinado comportamento ilícito, ofensivo aos direitos da

\footnotetext{
${ }^{304}$ Há quem chame, ainda, a atenção para o aspecto social da indenização ao dano moral, salientando que a agressão ilegítima ao patrimônio imaterial de um indivíduo fere o a coletividade, de sorte a emprestar à indenização um sentido restaurador da mácula à sociedade. Daí a tese elaborada por ANTONIO JUNQUEIRA DE AZEVEDO, postulando uma indenização punitiva e dissuasória, para responsabilizar o agente pelos danos sociais, que seriam “(...) lesões à sociedade, no seu nível de vida, tanto por rebaixamento de seu patrimônio moral - principalmente a respeito da segurança - quanto por diminuição de sua qualidade de vida". AzEVEDo, Antonio Junqueira de. Por uma nova categoria de dano na responsabilidade civil: o dano social. Revista Trimestral de Direito Civil, vol. 19, 2004, p. 216.

${ }^{305}$ Cf. PüsCHEL, Flavia Portella. A função punitiva da responsabilidade civil no direito brasileiro: uma proposta de investigação empírica. Revista Direito GV, n. 2, 2007, pp. 20-21.

${ }_{306}$ Cf. Garcez NeTO, Martinho. Prática de responsabilidade civil. $4^{\mathrm{a}}$ ed. São Paulo: Saraiva, 1989, p. 51.

307 “ A idéia de conferir o caráter de pena à indenização do dano moral pode ser justificada pela necessidade de proteção da dignidade da pessoa e dos direitos da personalidade, pelo menos em situações especiais, nas quais não haja outro instrumento que atenda adequadamente a essa finalidade. Além disso, responderia a um imperativo ético que deve permear todo o ordenamento jurídico”. ANDRADE, André Gustavo Corrêa de. Indenização Punitiva. Revista da EMERJ, n. 36, 2006, p. 137.
} 
personalidade, corresponderá a uma resposta do Direito, sob a forma de sanção pecuniária, acaba tendo um sentido também educativo e preventivo que se reflete na sociedade ${ }^{308}$.

Para Nehemias Domingos De Melo, a punição desempenha uma função preventiva eficaz. Ele acredita que se a sociedade tomar ciência de que determinadas condutas são reprimidas com vigor pelo Poder Judiciário, a dignidade das pessoas sofrerá menos agressões, pois a condenação será sentida 'no bolso' do infrator como fator primordial de desestímulo ${ }^{309}$.

Por sua vez, encabeçando a corrente doutrinária contrária, PONTES DE MIRANDA já afiançava que:

"a teoria da responsabilidade pela reparação dos danos não há que se basear no propósito de sancionar, de punir, as culpas, a despeito de se não atribuir direito à indenização por parte da vítima culpada. O fundamento, no direito contemporâneo, está no princípio de que o dano sofrido tem que ser reparado, se possível. A restituição é que se tem por fito, afastando qualquer antigo elemento de vingança (...). Ora, o pagamento indenizatório a título punitivo seria claramente uma afronta ao princípio do enriquecimento ilícito ${ }^{, 310 .}$

HUMBERTO THEODORO JUNIOR compartilha deste entendimento, negando a legitimidade da função punitiva ou preventiva da reparação: "a maior ou menor repercussão social, a maior ou menor intensidade do dolo ou da culpa, são dados completamente irrelevantes no plano da responsabilidade civil. O valor da indenização a ser proporcionado à vítima deve ser absolutamente desvinculado da gravidade do ato cometido, porque sua função não é punir, mas apenas ressarcir, 311.

\footnotetext{
${ }^{308}$ Cf. BRANCO, Bernardo Castelo. Op. cit. (nota 94), p. 50.

${ }^{309}$ Melo, Nehemias Domingos de. Op. cit. (nota 117), p. 120. "Por isso defendemos uma nova teoria para reparação dos danos morais, pela qual o caráter da pena pecuniária seja preponderante, cumprindo ao juiz o papel de bem sopesar a gravidade do fato, a reincidência do infrator, os efeitos danosos do evento, a potencialidade econômica do ofensor, a posição social e política das partes, dentre outros critérios, para assim chegar-se a um valor que cumpra a um só tempo o caráter compensatório para a vítima, de punição para o ofensor e de exemplaridade para a sociedade. Assim, a partir de sentenças que priorizem a vítima e punam o ofensor, acredita-se que poderão cumprir o papel de estimular condutas, corrigir desvios $e$ incentivar o respeito à dignidade da pessoa humana”. Idem, p. 115.

${ }^{310}$ Miranda, Pontes de. Tratado de Direito Civil. t. 22. São Paulo: Borsoi, 1968, p. 183, apud MoRAES, Maria Celina Bodin de. Op. cit. (nota 66), pp. 261-262.

${ }^{311}$ THEODORO JÚNIOR, Humberto. Op. cit. (nota 35), pp. 80-81.
} 
É o que defende MIRNA CIANCI: "não é também razoável a gradação do valor de acordo com a culpa ou dolo do ofensor, já que a aferição, como antes demonstrado, tem em conta a compensação da dor e não o grau de culpa do causador do dano, a não ser por conta do caráter punitivo, firmemente rejeitado nesta obra" ${ }^{\$ 12}$.

Para Eduardo Henrique de Oliveira Yoshikawa, o problema do caráter punitivo da indenização por dano moral está em que agrava a dificuldade de mensuração inerente a este tipo de lesão, por introduzir no cálculo elementos estranhos ao próprio conceito de dano, tais como grau de culpa e o patrimônio do ofensor ${ }^{313}$.

Da mesma forma, segundo o autor, esta finalidade contrariaria a Constituição, quando enuncia o princípio da reserva legal, proibindo pena sem cominação pelo ordenamento (art. $5^{\circ}$, XXXIX), bem como o Código Civil, ao dispor que a indenização é medida pela extensão do dano (art. 944) ${ }^{314}$.

Nosso sistema jurídico, diz ele, tem como objeto de tutela “(...) o resultado $(=$ evento danoso) e não o ato que lhe deu origem ou o seu autor (e as circunstâncias

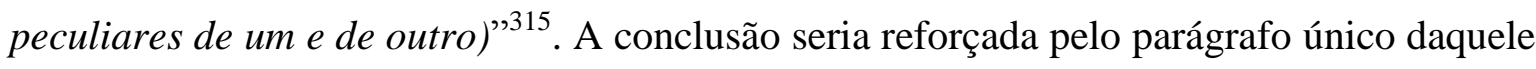
dispositivo, estabelecendo a culpa como possível elemento redutor do montante, frisando: "reduzir, não aumentar"316.

ANDERSON SCHREIBER alerta que a cominação da função punitiva aos danos morais é contrária ao próprio Código Civil, que prescreve a extensão do dano como critério para aferir a indenização (art. 944) ${ }^{317}$.

Por outro lado, HUMBERTO THEODORO JÚNIOR igualmente adverte que a aplicação da função punitiva sem prévia estipulação em lei contraria não apenas a

\footnotetext{
312 CIANCI, Mirna. Op. cit. (nota 227), p. 108.

${ }^{313}$ Cf. YoshIKAWA, Eduardo Henrique de Oliveira. A incompatibilidade do caráter punitivo da indenização do dano moral com o direito positivo brasileiro (à luz do art. 5. ${ }^{\circ}, \mathrm{XXXIX}$, da CF/88 e do art. 944, caput, do CC/02). Revista de Direito Privado, n. 35, 2008, p. 90.

${ }^{314}$ Cf. Idem, pp. 88-91.

${ }^{315}$ Cf. Idem, p. 92.

${ }^{316}$ Idem, p. 93.

317 "Pior: ao combinar critérios punitivos e critérios compensatórios, chegando-se a um resultado único, a prática brasileira distancia-se do modelo norte-americano, que distingue claramente compensatory damages e punitive damages. Com isso, cria-se, no Brasil, uma espécie bizarra de indenização, em que ao responsável não é dado conhecer em que medida está sendo apenado, e em que medida está simplesmente compensando $o$ dano, atenuando, exatamente, o efeito dissuasivo que consiste na principal vantagem do instituto". SCHREIBER, Anderson. Op. cit. (nota 43), p. 205.
} 
legalidade, mas o devido processo legal ${ }^{318}$. E MARIA CELINA Bodin DE MoRAES complementa que isto coloca em risco princípios fundamentais de sistemas jurídicos que têm na lei a sua fonte normativa ${ }^{319}$.

Na jurisprudência, é possível encontrar algumas alusões expressas e outras veladas ao caráter punitivo das indenizações por danos morais ${ }^{320}$. Na realidade, vem se operando uma modificação na orientação dos magistrados, em busca de uma justificativa mais enérgica para indenização desta espécie de danos. Vale notar que também o Superior Tribunal de Justiça, há algum tempo, aderiu à tese do caráter punitivo, em sua faceta de desestímulo ao ofensor ${ }^{321}$.

Na visão de MARIA Celina Bodin DE Moraes, a inexistência de critérios seguros para a estipulação do quantum indenizatório nos casos de dano moral tem feito com que a jurisprudência majoritária afirme, sem maiores justificativas, a existência de um caráter punitivo como forma de dissuadir condutas ilícitas e, mesmo que em pequena medida, a fim de aumentar o valor das indenizações pagas sob aquele título ${ }^{322}$.

Ademais, a disparidade de tratamento entre acontecimentos análogos e as graves distorções na fixação de uma parcela punitiva no quantum debeatur da indenização pelo dano moral, segundo a jurista, têm representado um importante obstáculo à certeza do Direito $^{323}$.

\footnotetext{
${ }^{318}$ Cf. THEODORO JÚNIOR, Humberto. Op. cit. (nota 35), p. 77. ANTONIO JeOVÁ SANTOS também chama a atenção para isto: "o maior aporte doutrinário que é contra o entendimento de que a indenização deve possuir algo de sancionatório, está no fato de que a ausência de lei que assim disciplina, vulnera o princípio da legalidade”. SANTOS, Antonio Jeová. Op. cit. (nota 13), p. 157.

319 Cf. Moraes, Maria Celina Bodin de. Op. cit. (nota 66), p. 258. Na visão de Carlos Roberto GONÇALVES, a adoção deste critério no Brasil somente se justificaria se estivesse regulamentado em lei, com a fixação de sanção mínima e máxima, revertendo ao Estado o quantum da pena. Cf. GONÇALVES, Carlos Roberto. Op. cit. (nota 220), p. 644.

320 "No Brasil, quando em diversos acórdãos e sentenças judiciais, é recomendado que na fixação do 'dano moral', o juiz se atenha à situação particular da vítima e à condição pessoal do ofensor, está-se diante do caráter punitivo do dano". SANTOS, Antonio Jeová. Op. cit. (nota 13), p. 161.

${ }^{321}$ Como exemplo: STJ, REsp. n. 839.923/MG, Rel. Min. Raul Araújo, j. em 15-05-12, pub. em 21-05-12.

${ }^{322}$ Cf. MoRAES, Maria Celina Bodin de. Op. cit. (nota 66), p. 28. A autora, vale ressaltar, mostra-se contrária à assunção da função punitiva: "o princípio da proteção da pessoa humana, determinado constitucionalmente, gerou no sistema particular da responsabilidade civil a sistemática extensão da tutela da pessoa da vítima, em detrimento do objetivo anterior de punição do responsável". MORAES, Maria Celina Bodin de. Op. cit. (nota 67), p. 323.

${ }^{323}$ Cf. MoRAes, Maria Celina Bodin de. Op. cit. (nota 66), pp. 29-30. "De nada adianta clamar por moderação e equilíbrio na fixação do quantum indenizatório quando o sistema que se veio delineando aceita a coexistência de duas regras, antagônicas por princípio, no âmbito da reparação de danos morais: a punição, de um lado, e o arbitrio do juiz, de outro. Nesses casos, em geral a função punitiva 'corre solta', não tendo qualquer significação no que tange a um suposto caráter pedagógico ou preventivo. Por outro
} 
A maioria dos juízes, portanto, não fundamenta este entendimento e não distingue a parcela da indenização que carrega o suposto caráter punitivo, o que, para alguns juristas, acaba produzindo deficiências em nosso sistema de responsabilidade civil.

Quanto a este ponto, argumenta-se que se a intenção é acolher a função punitiva, torna-se imperioso distinguir as parcelas da indenização atribuídas a título punitivo e a título compensatório. De acordo com ANDRÉ GUSTAVo CORRÊA DE ANDRADE, esta separação é importante para garantir transparência e controle sobre a adequação dos critérios utilizados e sobre a justeza da valoração efetuada pelo julgador ${ }^{324}$.

Tal quadro, para ANDERSON SCHREIBER, denota que o Brasil vive uma situação claramente anômala no que se refere aos danos morais punitivos, pois não vêm admitidos como parcela adicional de indenização, mas aparecem embutidos na própria compensação do dano moral ${ }^{325}$.

Não obstante, é preciso considerar que muitos não buscam a indenização apenas como forma de compensação, mas desejam realmente impor uma pena ao ofensor, que no âmbito civil se traduz por uma condenação pecuniária ${ }^{326}$. A condenação representaria o sentimento de justiça, aplacando no íntimo do ofendido sua sede de vingança ${ }^{327}$.

Portanto, no mais das vezes, os próprios ofendidos acabam vislumbrando o dano moral como uma penalidade ao seu ofensor, suplantando a sua função de compensação pela dor sofrida (rectius, pelo dano que originou a dor).

lado, representa, não há como negar, um forte incentivo à malícia, além de gerar a mercantilização das relações existenciais". Idem, p. 261.

${ }^{324}$ ANDRADE, André Gustavo Corrêa de. Op. cit. (nota 307), pp. 167-168. O autor apregoa que o magistrado deve agir com racionalidade e transparência no arbitramento da indenização do dano moral, deixando evidente que motivos o levaram a empreender o aspecto punitivo no caso. Cf. idem, p. 168.

${ }^{325}$ Cf. SCHREIBER, Anderson. Op. cit. (nota 43), p. 203.

${ }^{326}$ Nestes termos, assevera ANTÔNIO CHAVES que "quem exige uma reparação do dano moral sofrido não visa tanto a recomposição do seu equilíbrio de afeição ou sentimento, impossivel de conseguir, como infligir, por um sentimento de represália inato, ao seu ofensor, uma punição, por precária que seja, que, na maior das vezes não encontra outro parâmetro senão em termos pecuniários". CHAVES, Antônio. Op. cit. (nota 164), p. 634.

${ }^{327}$ Segundo NeHEMIAS Domingos DE MeLo, "conquanto o brio, o amor próprio, a honradez e a dignidade não tenham preço para o homem de bem, a condenação do ofensor em valores significativos poderá representar, para o ofendido, o sentimento de justiça realizada". MELO, Nehemias Domingos de. Op. cit. (nota 117), p. 121. 
No entanto, segundo JOSÉ DE AGUIAR DIAS, "para o sistema de responsabilidade civil que esposamos, a prevenção e repressão do ato ilícito resulta da indenização em si, sendo-lhe indiferente a graduação do montante da indenização" 328 .

Para o jurista, essa associação com a pena se dá devido ao caráter de satisfação da reparação, que é o traço comum aos institutos da pena e da indenização ${ }^{329}$. Ele sugere que se dê maior atenção às relações entre essas figuras, através de uma delimitação rigorosa, dada a sua frequente confusão ${ }^{330}$, para superar a ideia de pena em favor da noção de ressarcimento ${ }^{331}$.

$\mathrm{O}$ autor conclui que a confusão entre a vingança e a justiça deixou marcas tão profundas na ordem social que até hoje a associação não desapareceu da consciência do homem civilizado ${ }^{332}$.

Nestes termos, o objetivo de prevenção e repressão resulta não da sanção como tal, mas, como em qualquer caso de reparação de dano, do encargo que a indenização acarreta para o patrimônio do ofensor ${ }^{333}$.

Na opinião de JOSÉ DE CASTRO BIGI, a própria responsabilidade civil reveste-se em muitas hipóteses de uma força intimidatória ${ }^{334}$.

Neste compasso, CARLOS ROBERTO GONÇALVES leciona que o caráter punitivo é meramente reflexo ou indireto, em razão do próprio desfalque patrimonial que sofrerá o autor do dano, o que poderá desestimular a reiteração da conduta lesiva ${ }^{335}$.

\footnotetext{
${ }^{328}$ DiAS, José de Aguiar. Op. cit. (nota 44), p. 999.

${ }^{329}$ Cf. idem, p. 1005 (nota 1222).

${ }^{330}$ Cf. idem, p. 993 . O jurista aponta as seguintes distinções: a) a pena tem em vista a culpa do delinquente, enquanto a indenização atende à preocupação de reparar o dano, a primeira não se preocupa com a existência do prejuízo, a segunda não se compreende sem o dano, porque se mede em função dele; $b$ ) a pena é sempre consequência de delito, ao passo que a indenização tem no ato ilícito apenas uma das diversas causas de que pode surgir; $c$ ) a pena é inseparável da pessoa do delinquente, mas a indenização não; $d$ ) se tivesse caráter penal, a indenização não seria transmissível aos herdeiros do lesado; $e$ ) o irresponsável não está sujeito a pena, mas está sujeito a indenização; $f$ ) a pena pode ser convertida em outro castigo se o delinquente não a pode satisfazer, a obrigação de indenizar subsiste, embora inexequível. Cf. idem, p. 1000.

${ }^{331}$ Cf. idem, pp. 996-997.

${ }^{332}$ Cf. idem, p. 995.

${ }^{333}$ Cf. idem, p. 999. Em sua explicação, “(...), se a reparação se tem de fazer em dinheiro, avultam os pontos de contato entre a indenização e a pena, porque também esta pode empregar-se na satisfação do prejudicado, proporcionando-lhe o 'solatium', apaziguamento, e conseguindo alteração do sentimento e da vontade. Essa função oferece satisfação à consciência de justiça e à personalidade do lesado, e a indenização pode desempenhar um papel múltiplo, de pena, de satisfação e de equivalência”. Idem, p. 1001. ${ }^{334}$ Cf. BIGI, José de Castro. Op. cit. (nota 272), p. 49.
} 
Segundo Carlos Alberto BitTAR, a partir desta constatação, tem-se na responsabilidade civil uma imposição do sistema jurídico ao lesante, que o sacrifica a agir para a reparação do mal causado ${ }^{336}$. Em suas palavras: “observa-se, pois, que, sob o prisma do lesante, reveste-se a responsabilidade por danos de caráter sancionatório, e não obstante diferentes posições detectadas na doutrina, a convergência em torno desse fator tem sido a tônica, de sorte a alçá-lo à condição de elemento nuclear em seu contexto $^{, 337}$.

Depois de perscrutar a doutrina, percebemos que as três funções atreladas à reparação do dano moral trazem consigo alguns problemas, tanto de ordem teórica, como prática $^{338}$. A prevenção, podemos afirmar, está atrelada à função punitiva, a qual acaba sendo alvo de críticas.

$\mathrm{Na}$ teoria, os doutrinadores censuram a ausência de substrato legal, a contradição com o princípio da reparação pela extensão do dano e a falta de distinção técnica adequada. Na prática, a fundamentação deficiente, a ausência de clareza no cálculo e a utilização de um modo transverso de majorar a indenização por parte da jurisprudência também são recriminadas.

Este complexo de questões se repete na análise do dano moral nos diversos campos do Direito. No âmbito das relações familiares não é diferente.

Antes de adentrar, portanto, no exame das múltiplas situações onde se cogita dos danos morais na família, é importante esboçarmos algumas conclusões, ainda que sem pretensão definitiva, sobre o problema.

\footnotetext{
${ }^{335}$ Cf. GONÇALVES, Carlos Roberto. Op. cit. (nota 220), p. 636.

${ }^{336}$ Cf. BITTAR, Carlos Alberto. Op. cit. (nota 14), p. 66.

337 Ibidem. "O sancionamento ao lesante é, assim, a tônica da obrigação de reparar danos, quando questionada sob o aspecto ativo, vale dizer, de quem provocou o dano”. Idem, p. 69.

${ }^{338}$ Vale salientar uma quarta função apontada por alguns, qual seja, o reequilíbrio social. Assevera-se que o dano causado a outrem igualmente prejudica a ordem social, de maneira que o ressarcimento não deveria ficar restrito à satisfação do indivíduo, devendo ainda “(...) alcançar o verdadeiro reequilíbrio social, a prevenção e a punição de comportamentos anti-sociais, propiciando, de alguma forma, benefícios para a própria sociedade". MELO, Diogo Leonardo Machado de. Ainda sobre a função punitiva da reparação dos danos morais (e a destinação de parte da indenização para entidades de fins sociais - art. 883, parágrafo único, do Código Civil). Revista de Direito Privado, n. 26, 2006, p. 114.
} 
Parece-nos que a criação de uma nova distinção tornaria a matéria mais clara, permitindo um posicionamento mais consciente perante as chamadas funções do dano moral.

Propomos que seja feita a separação entre a função da indenização do dano moral, sua finalidade legítima, decorrente de sua natureza e do ordenamento, e o efeito dela, composto pelas consequências de sua aplicação.

Neste sentido, do modo como vem disciplinado na legislação, a função da indenização do dano moral é reparatória ou compensatória. As chamadas 'funções' punitiva e preventiva são apenas efeitos desta indenização.

A quantia convertida em favor da vítima tem a finalidade de lhe compensar o dano moral sofrido. Sucede que, como o agente causador é o responsável pelo pagamento, isto pode causar dois efeitos: sua intimidação, para que não volte a praticar o ato, e a intimidação de terceiros que conheçam esta consequência (quer concretamente - esta ou aquela indenização paga, quer abstratamente - a norma de que quem lesa outrem, deve pagar).

Portanto, os efeitos punitivos, dissuasórios, exemplares, pedagógicos etc que se inferem do pagamento da indenização são apenas fruto deste ato, mas não seu fundamento, não sua missão jurídica, não sua função, que remanesce sendo a reparação ou compensação do dano moral. 


\section{Dano Moral na Família}

\subsection{FAMília E Direito de FAMÍlia}

Por decorrência lógica, a compreensão do Direito de família demanda antes entender o sentido da palavra família $^{339}$. No entanto, Sílvio DE SALVo VENOSA observa que este conceito oferece um paradoxo ${ }^{340}$.

Isto porque a família não é definida pelo ordenamento ${ }^{341}$; não existe um conceito utilizado comumente pelas diversas áreas do conhecimento humano ou mesmo pelos diferentes ramos do Direito. Não bastasse isso, como todo fenômeno social, a acepção da família percebe uma flutuação no tempo e no espaço ${ }^{342}$.

CAio Mário da Silva Pereira também destaca a diversificação do conceito de família, concluindo que a plurivalência semântica é fenômeno normal do vocabulário jurídico e se manifesta neste âmbito ${ }^{343}$.

De fato, a ausência de um conceito jurídico geral de família no ordenamento impede a delimitação de sua aplicação, o que leva a discussões a este respeito. Não obstante, a falta de um delineamento normativo claro não é obstáculo a que, na vida diária e mesmo na técnica jurídica, saibamos nos orientar com algum sucesso, reservando a necessidade de especulação conceitual para casos-limite, onde a existência de uma família é controversa.

Em sentido biológico, a família é o conjunto de pessoas que descendem de um tronco ancestral comum; já em sentido estrito, ela se restringe ao grupo formado pelos pais e filhos ${ }^{344}$.

\footnotetext{
${ }^{339}$ Cf. Rodrigues, Silvio. Direito civil: direito de família. vol. 6. $28^{\text {a }}$ ed. São Paulo: Saraiva, 2004, p. 4.

${ }^{340}$ Cf. Venosa, Sílvio de Salvo. Direito civil: direito de família. vol. 6. $7^{\text {a }}$ ed. São Paulo: Atlas, 2007, p. 1.

341 "O legislador de 2002, mantendo a trilha do Código Civil de 1916, não apresenta a definição de família, destinando suas regras à sua constituição e efeitos, agora na abrangência da Constituição de 1988". RODRIGUES, Silvio. Op. cit. (nota 339), p. 4.

${ }^{342}$ Para Ś́ĺvio DE SALVo VENOSA, entre os vários organismos sociais e jurídicos, o conceito, a compreensão e a extensão da família são os que mais se alteraram no curso dos tempos. E, nesse alvorecer de mais de um século, a sociedade de mentalidade urbanizada, cada vez mais globalizada pelos meios de comunicação, pressupõe e define uma modalidade conceitual de família bastante distante das civilizações do passado. Cf. Venosa, Sílvio de Salvo. Op. cit. (nota 340), pp. 2-3.

${ }^{343}$ Cf. Pereira, Caio Mário da Silva. Op. cit. (nota 185), p. 23.

${ }^{344}$ Cf. ibidem. Na lição mais antiga de VIRGílIO DE SÁ PEREIRA: "em tôda parte onde puderdes reunir as cousas, as pessoas ou as idéias, e ligá-las entre si pelo nexo de parentesco, da procedência dum tronco
} 
Em rigor, no entanto, a família é apreendida pelo legislador como instituição, cuja existência é inegável ${ }^{345}$. Assim entende a doutrina majoritária, sendo esta conclusão repetida por inúmeros juristas. Sílvio DE SALVo VENOSA considera tal afirmação vaga e imprecisa, mas afirma que, como, sem dúvida alguma, a família é sociologicamente uma instituição, o Direito, como ciência social, assim a reconhece e a regulamenta. Para ele, a instituição jurídica é um universo de normas de Direito organizadas sistematicamente para regular direitos e deveres de determinado fenômeno ou esfera social, sendo este o sentido da família enquanto instituição jurídica ${ }^{346}$.

O Direito de família, destarte, tem por objeto a exposição dos princípios de direito que regem as relações de família ${ }^{347}$.

WASHINGTON DE BARRos MonTEIRO observa que é difícil definir o Direito de família sem incidir em um vício de lógica: "realmente, esse ramo do direito civil, de modo geral, disciplina a organização da família; todavia, quem assim se expresse está a conceituá-lo com o próprio objeto a definir-se, ${ }^{\text {348 }}$. Entretanto, segundo SILVIO RODRIGUES, "partindo desse conceito, decerto defeituoso por incluir na definição a palavra a ser definida, verificamos que as regras de direito de família afetam o indivíduo dentro daquele núcleo social, relativamente pequeno, em que ele nasce, cresce e se desenvolve, disciplinando suas relações de ordem pessoal e patrimonial ${ }^{, 349}$.

Nas palavras de CAIO MÁRIO DA SILVA PEREIRA, o Direito de família constitui o complexo de normas disciplinares das relações de família, isto é, das relações entre pessoas ligadas pelo parentesco e pelo casamento, sendo que este ramo do Direito atua nas questões pessoais, patrimoniais e assistenciais ${ }^{350}$.

Assim também conclui WASHINGTON DE BARROS MONTEIRO, ao afirmar que o objeto do Direito de família é formado pelo entrelaçamento das múltiplas relações

comum, podereis corretamente chamá-las 'familias '”. PEREIRA, Virgílio de Sá. Direito de família. $3^{\mathrm{a}}$ ed. Rio de Janeiro: Forense, 2008, p. 6.

${ }^{345}$ Cf. RoDrigues, Silvio. Op. cit. (nota 339), p. 7.

${ }^{346}$ Cf. Venosa, Sílvio de Salvo. Op. cit. (nota 340), p. 8.

${ }^{347}$ Cf. RODRIGUES, Silvio. Op. cit. (nota 339), p. 3.

${ }^{348}$ MonteIRo, Washington de Barros. Curso de direito civil. v. 2. $39^{\text {a }}$ ed. São Paulo: Saraiva, 2009, p. 3.

${ }^{349}$ RODRIGUES, Silvio. Op. cit. (nota 339), p. 3.

${ }^{350}$ Cf. Pereira, Caio Mário da Silva. Op. cit. (nota 185), pp. 34-36. 
estabelecidas entre os componentes da entidade familiar, originando um complexo de disposições pessoais e patrimoniais ${ }^{351}$.

Sílvio de Salvo Venosa, por sua vez, entende que “o direito de família, ramo do direito civil com características peculiares, é integrado pelo conjunto de normas que regulam as relações jurídicas familiares, orientado por elevados interesses morais $e$ bem-estar social",352.

Importante mencionarmos a definição do Direito de família apregoada por Clóvis Beviláqua, mentor do Código Civil de 1916: “direito de família é o complexo das normas, que regulamentam a celebração do casamento, sua validade e os efeitos, que dele resultam, as relações pessoais e econômicas da sociedade conjugal, a dissolução desta, as relações entre pais e filhos, o vínculo do parentesco $e$ os institutos complementares da tutela e da curatela ${ }^{, 353}$. Assim o jurista delimitava o âmbito jurídico enumerando individualmente as figuras que comportava, sendo importante observar que, na época, o centro desta seara do Direito era o casamento. Esta definição, atualmente, não exaure todas as relações jurídicas enquadráveis no direito de família, bem como, conforme veremos, o casamento já não perdura como requisito essencial.

A maioria dos autores inicia seus estudos afirmando que a família constitui a célula básica da sociedade e representa o alicerce de toda a organização social.

Nas palavras de WASHINGTON DE BARRos MonTEIRO, “desde logo, evidenciase a importância desse estudo, tão de perto ligado à própria vida. Dentre todas as instituições, públicas ou privadas, a da família reveste-se da maior significação. Ela representa, sem contestação, o núcleo fundamental, a base mais sólida em que repousa toda a organização social ${ }^{, 354}$. Por isso, nota o autor que é sensível e manifesta a atuação do Estado no campo do Direito de família, no sentido de tutelar e resguardar, em qualquer de suas manifestações, o grupo por ela composto, elemento da própria vida e base fundamental da sociedade ${ }^{355}$.

\footnotetext{
${ }^{351}$ Cf. MONTEIRO, Washington de Barros. Op. cit. (nota 348), p. 1.

${ }^{352}$ VenOSA, Sílvio de Salvo. Op. cit. (nota 340), p. 10.

${ }^{353}$ Bevilúqua, Clóvis. Código Civil dos Estados Unidos do Brasil comentado. $5^{\text {a }}$ ed. São Paulo: Francisco Alves, 1937, p. 6, apud VenosA, Sílvio de Salvo. Op. cit. (nota 340), p. 8.

${ }^{354}$ MonTEIRO, Washington de Barros. Op. cit. (nota 348), p. 1.

${ }^{355}$ Cf. idem, p. 6.
} 
Também Silvio Rodrigues e Silvio de SALVo Venosa afiançam que, devido à importância desta instituição, o Estado deve agir para preservá-la, cumprindo sua função social protetora, com moderação ${ }^{356}$.

Daí ter o legislador constitucional proclamado que a família vive sob a especial proteção do Estado. Dentro do direito de família, segundo alguns autores, o interesse coletivo é maior do que o próprio interesse individual, ou seja, o interesse da sociedade sobreleva ao dos indivíduos ${ }^{357}$.

No entanto, em razão dos exageros, vem surgindo, nos últimos anos, corrente doutrinária que contesta a intervenção estatal e afirma que deve haver maior autonomia dos membros familiares, como uma forma de preservar a sua individualidade, intimidade e, em última instância, a sua dignidade. Nestes termos, assevera MARIA CELINA BODIN DE MORAES: "ao direito de família atual não cabe ser intrusivo, cumprindo-lhe respeitar as individualidades, buscando conservar, sempre que possível, a solidariedade familiar "358.

De qualquer forma, é essencial termos em mente que todo este ramo jurídico se desenvolve e repousa na ideia de que as faculdades conferidas neste campo existem não tanto para atribuir direitos quanto para impor deveres ${ }^{359}$. Ou seja, os direitos, embora assim reconhecidos e regulados na lei, assumem na maior parte dos casos o caráter de deveres nas relações familiares, e isto é incontestável.

\footnotetext{
356 "Dentro dos quadros de nossa civilização, a família constitui a base de toda a estrutura da sociedade. Nela se assentam não só as colunas econômicas, como se esteiam as raízes morais da organização social. De sorte que o Estado, na preservação de sua própria sobrevivência, tem interesse primário em proteger a família, por meio de leis que lhe assegurem o desenvolvimento estável e a intangibilidade de seus elementos institucionais. Daí a interferência, por vezes até exagerada, do Estado nas relações familiares”. RODRIGUES, Silvio. Op. cit. (nota 339), p. 5. "Não pode também o Estado deixar de cumprir sua permanente função social de proteção à família, como sua célula 'mater', sob pena de o próprio Estado desaparecer, cedendo lugar ao caos. Daí por que a intervenção do Estado na família é fundamental, embora deva preservar os direitos básicos de autonomia. Essa intervenção deve ser sempre protetora, nunca invasiva da vida privada”. Venosa, Sílvio de Salvo. Op. cit. (nota 340), p. 10.

${ }^{357}$ Cf. Rodrigues, Silvio. Op. cit. (nota 339), pp. 7-8.

${ }^{358}$ MorAes, Maria Celina Bodin de. Op. cit. (nota 63), p. 192.

${ }^{359}$ Cf. Rodrigues, Silvio. Op. cit. (nota 339), p. 8. Nas palavras de Sílvio DE SAlvo Venosa, “o direito de família está centrado nos deveres, enquanto nos demais campos do direito de índole patrimonial o centro orientador reside nos direitos, ainda que também orientados pelo cunho social, como a propriedade”. VenOSA, Sílvio de Salvo. Op. cit. (nota 340), p. 13.
} 
Também não podemos nos esquecer de que o Direito de família possui forte conteúdo ético, e mesmo as relações patrimoniais nele contidas são secundárias, pois absolutamente dependentes da compreensão axiológica da família ${ }^{360}$.

Segundo Maria Celina Bodin de Moraes, o Direito de família existe para minorar conflitos intersubjetivos e apaziguar relações caracterizadas pela intimidade e povoadas de fortes sentimentos ${ }^{361}$.

Este ramo peculiar do Direito sofreu transformações, recebendo o influxo do desenvolvimento social, chegando a repercutir no tema central deste trabalho: o dano moral nas relações familiares. Neste sentido, o estudo destas mudanças é necessário por dois motivos: em primeiro lugar, para nos situarmos a respeito das regras que atualmente compõem o Direito de família; segundo, porque as alterações pelas quais passou este ramo do Direito foram essenciais para o próprio assentimento da possibilidade de aplicação do instituto da responsabilidade civil nas relações familiares.

\subsubsection{TRANSFORMAÇÕES NO DIREITO DE FAMÍLIA}

Já se disse que, entre os vários organismos sociais e jurídicos, o conceito, a compreensão e a extensão da família são os que mais se alteram no curso dos tempos ${ }^{362}$.

Se na família ocorreram grandes mudanças sociais, é de se esperar que o ordenamento jurídico encontre dificuldades para acompanhá-las, num processo de adaptação e integração complexo e problemático.

De qualquer maneira, pensar nas mudanças operadas na família - enquanto instituição - é diferente de ponderar as transformações por que passou o Direito de família - as normas que regulamentam aquela instituição. Há grande confusão neste aspecto, o que nos leva a esclarecer que nosso objetivo é pontuar as alterações ocorridas no regramento

\footnotetext{
${ }^{360}$ Cf. Venosa, Sílvio de Salvo. Op. cit. (nota 340), p. 2.

${ }^{361}$ Cf. MorAES, Maria Celina Bodin de. Op. cit. (nota 63), p. 192.

362 "As relações familiares, no âmbito das quais se desenvolvem os valores que fundamentam a estrutura social, vêm experimentando constantes e profundas mudanças, a partir das transformações ocorridas especialmente após o final do século XIX, sobretudo nos campos econômico, político e tecnológico. A família, como qualquer outro núcleo social, tende a refletir essa nova sociedade e, ao mesmo tempo, acaba de certo modo por influir no destino da comunidade social da qual é parte integrante”. BRANCO, Bernardo Castelo. Op. cit. (nota 94), p. 16.
} 
jurídico, na legislação, e não fazer suposições a respeito das mudanças de valores sobrevindas na instituição familiar.

É claro que as regras se modificam na medida em que a sociedade se desenvolve, e neste específico aspecto podemos falar em uma mudança de paradigmas ${ }^{363}$. Todavia, não é possível fazer generalizações, como a suposta liberação dos costumes e perda dos valores que teriam se operado no núcleo familiar, a que muitos autores aludem. $\mathrm{Na}$ realidade, tem ocorrido uma readequação deste núcleo, de acordo com mudanças sociais, quer naturais, quer decorrentes de ações deliberadas. E, neste quadro, não podemos mais divisar na família relações de discriminação e dominação, mas sim valores como a igualdade e a solidariedade, que, de resto, são valores próprios da sociedade.

Dentre as diversas transformações, faremos menção àquelas ocorridas, sobretudo, após a promulgação da Constituição Federal de 1988, e que procuraram harmonizar o Direito de família à nova ordem constitucional vigente.

O Código Civil de 1916 apresentava como princípios fundamentais a autonomia privada e a afirmação do individualismo jurídico, característicos do pensamento liberal predominante no século XIX e primórdios do século XX. A preocupação marcante de nossa codificação civil residia nas questões patrimoniais, tendo como princípio basilar a autonomia da vontade.

Como reflexo desta axiologia, a legislação civil-familiar norteava-se pela realização da pessoa na sua propriedade, em torno da qual gravitavam os demais interesses privados, juridicamente tutelados.

Atualmente, outras referências se somaram ao direito civil. A Constituição Federal de 1988, ao eleger a dignidade da pessoa humana como fundamento da República contribuiu para que institutos do Direito civil sofressem alterações, como o condicionamento à função social, cujo conteúdo é definido fora da órbita patrimonial.

\footnotetext{
363 Segundo Sílvio de SAlvo VenosA, em poucas décadas, os paradigmas do Direito de família foram diametralmente modificados, por exemplo, o princípio da indissolubilidade do vínculo do casamento e a ausência de proteção jurídica dos filhos naturais, positivados em nosso ordenamento até muito recentemente, pertencem à história do Direito do nosso país. Cf. VenosA, Sílvio de Salvo. Op. cit. (nota 340), p. 6.
} 
Daí autores afirmarem que as relações de família vivem, na atualidade, um processo de repersonalização; e o Direito civil, um processo de publicização, despatrimonialização e constitucionalização ${ }^{364}$.

Segundo CAIo Mário da Silva Pereira, a despatrimonialização do Direito civil como uma tendência 'normativa-cultural' atinge também o direito de família, não mais orientado pelo conteúdo patrimonial, mas na tutela qualificativa das relações familiares. Sob esta perspectiva, destaca a orientação no sentido de identificar a família centrada na 'dignidade da pessoa humana e na solidariedade social' ${ }^{365}$.

WASHINGTON DE BARROS MONTEIRO aponta que a 'repersonalização' significou uma grande modificação nos princípios e fundamentos do direito civil e do direito de família ${ }^{366}$. Neste compasso, CARLOS AlBERTo BITTAR observa que ao lado da proteção do núcleo em si, o legislador voltou-se para a tutela de cada um dos componentes da família ${ }^{367}$.

Nesse movimento, a família passou a ser vista como centro de preservação do ser humano, com a tutela à dignidade nas relações familiares, e esta foi a maior transformação operada neste âmbito ${ }^{368}$.

Global e genericamente, são esses os traços que conformam a mudança aludida, uma síntese inicial para nossa investigação. Doravante, ao analisarmos concretamente o antes e o depois do direito de família, teremos um cenário bem demarcado (por força do contraste) do status normativo contemporâneo.

Examinando-se o Código já revogado, verifica-se que ele continha três grandes temas de Direito de família. O primeiro dizia respeito ao casamento, isto é, o instituto básico de onde resultava a família legítima. O segundo destinava-se às relações de

\footnotetext{
${ }^{364}$ Cf. OltRAMARI, Fernanda et Oltramari, Vitor Hugo. Op. cit. (nota 102), p. 73.

${ }^{365}$ Cf. PereIRA, Caio Mário da Silva. Op. cit. (nota 185), p. 25.

${ }^{366}$ Cf. MonTEIRO, Washington de Barros. Op. cit. (nota 348), p. 11.

367 Cf. BITTAR, Carlos Alberto. O direito civil na Constituição de 1988. $2^{\mathrm{a}}$ ed. São Paulo: Revista dos Tribunais, 1991, p. 61.

${ }^{368}$ Cf. MonTEIRO, Washington de Barros. Op. cit. (nota 348), p. 5. Há quem defenda que "a base da família deve ser, acima de tudo, centrada na dignidade da pessoa humana e na solidariedade social, uma família 'repersonalizada' e 'despatrimonializada', conforme proposto pela Constituição Federal de 1988, assentada numa ordem jurídica sob diversos princípios fundamentais que, alçados à órbita constitucional, emanam valores para todo o sistema”. SILVA, Cláudia Maria da. Descumprimento do dever de convivência familiar e indenização por danos à personalidade do filho. Revista Brasileira de Direito de Família, v. 25, 2004, p. 123.
} 
parentesco. Finalmente, em uma terceira parte, encontravam-se o que muitos chamavam de institutos de Direito protetivo: a tutela, a curatela e a ausência.

Por muito tempo se considerou que o casamento constituía a parte central do Direito de família. E, assim, as regras que permeavam o Código Civil de 1916 tinham por paradigma a defesa daquela instituição. Essa orientação protetiva da família matrimonializada se confirmava na autoridade do marido - a quem era conferida a chefia da sociedade conjugal - e se consagrava na diferença entre filiação legítima e ilegítima. No sistema patriarcal havia uma divisão de tarefas dentro do lar, cabendo ao marido sustentar a família e à mulher velar pela direção da casa, realizar os serviços domésticos, cuidar da educação dos filhos e assistir moralmente a família ${ }^{369}$.

Também com o intuito de preservar o matrimônio, o Código Civil de 1916 impunha a sua indissolubilidade e negava o reconhecimento de uniões que não fossem de origem matrimonial.

Na observação de SILvio RodRIGUES: "pelas contingências sociais de sua época, o Código de 1916 não dava maior relevo à família então qualificada como ilegítima. (...) Tem-se mesmo a impressão de que, por amor à ordem e com certa pudicícia, o legislador antes preferia ignorar o concubinato a discipliná-lo como realidade inescondivel ${ }^{, 370}$.

A união fora do casamento existia como uma realidade social, sendo deixada à margem do Direito por temor de que o seu reconhecimento pudesse eventualmente infirmar a posição privilegiada da chamada família legítima.

Nos arts. 226 a 230, a Constituição dispôs as normas atinentes à proteção da família pelo Estado. Em linhas gerais, estabelece que a família é a base da sociedade (art. 226, caput), e consagra a ideia de que a entidade familiar merecedora da proteção do

\footnotetext{
${ }^{369} \mathrm{Na}$ opinião de JoÃo RiCARDO BRANDÃo AGUIRRE, "resta claro, portanto, que, para o Código Civil de 1916, a família merecedora da proteção do Estado se encontra fundada em uma estrutura jurídica estratificada, em que se consagra a superioridade do homem sobre a mulher, concedendo-se ao marido a chefia da sociedade conjugal, a administração dos bens do casal e o poder de fixar o domicílio conjugal". AGUIRRE, João Ricardo Brandão. O regime patrimonial da união estável à luz do código civil de 2002. Dissertação de mestrado apresentada à Pontifícia Universidade Católica de São Paulo - PUC, São Paulo, 2004.

${ }^{370}$ RODRIGUES, Silvio. Op. cit. (nota 339), p. 12.
} 
Estado não decorre exclusivamente do casamento (art. 226, §1º), mas também da união

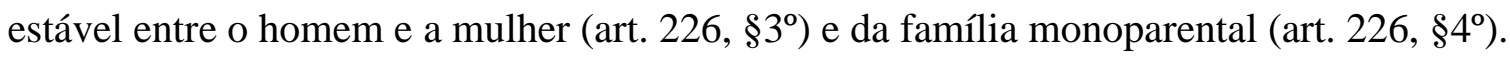

Do mesmo modo, a Carta Magna de 1988 introduziu regras a respeito da igualdade de direitos entre os cônjuges, e destes com relação aos filhos; facilitou o acesso ao divórcio; igualou os filhos nascidos de uniões extramatrimoniais e modificou as regras pertinentes à adoção. Por essa razão, para CAIO MÁrIo DA SIlva PEREIRA, a "Constituição de 1988 abriu horizontes ao instituto jurídico da família ${ }^{\text {,371. }}$

Importante observar que, contrariamente ao que apregoam alguns autores, não se pretendeu igualar o casamento à união estável, afirmando-se que seriam sinônimos, mas consolidar a ideia de que um homem e uma mulher que partilhassem dos mesmos ideais e interesses, e que convivessem durante certo período, poderiam constituir um núcleo afetivo, o qual, por essa razão, seria merecedor da proteção estatal ${ }^{372}$. O mesmo raciocínio aplica-se à família monoparental, formada por um dos pais e seus filhos.

A consagração constitucional do princípio da igualdade entre os cônjuges (art. 226, $\S 5^{\circ}$ ) levou ao desaparecimento da posição de superioridade de que desfrutava o homem, suprimindo a figura jurídica do chefe de família. Para CAIO MÁRIO DA SILVA PEREIRA, a isonomia operou a maior transformação no Direito de família ${ }^{373}$.

Neste ponto, é importante notar que, com o advento do Estatuto da Mulher Casada (Lei n. 4.121/62) e da Lei do Divórcio (Lei n. 6.515/77), o sistema jurídico já começava a mostrar sinais de preocupação com a condição de inferioridade conferida à mulher na sociedade conjugal. Foram instituídos direitos e deveres efetivos à mulher, que, com as núpcias, passou a ter a condição de companheira, consorte e colaboradora do esposo nos encargos da família, devendo velar pela sua condição moral e material.

Contudo, nestas leis, a ideia de subordinação foi substituída pela de colaboração, com o intuito de ajudar na chefia da sociedade conjugal, que ainda era desempenhada pelo cônjuge varão. Portanto, não se tratava efetivamente de uma igualdade

\footnotetext{
${ }^{371}$ Cf. Pereira, Caio Mário da Silva. Op. cit. (nota 185), p. 39.

${ }^{372}$ Neste sentido, MÁRIO LUIZ DELGADO afirma que a Constituição Federal, ao reconhecer a união estável como entidade familiar, o fez apenas para fins de proteção do Estado, não significando com isto a equiparação com o casamento. Cf. DELGADO, Mário Luiz. Direitos da personalidade nas relações de família. In: PEREIRA, Rodrigo da Cunha (Coord.). Família e dignidade humana - anais do V Congresso Brasileiro de Direito de Família. Belo Horizonte: IBDFAM, 2006, p. 718.

${ }^{373}$ Cf. PEREIRA, Caio Mário da Silva. Op. cit. (nota 185), p. 13.
} 
de direitos, que somente foi alcançada com a Constituição Federal de 1988, mas de um importante entreato, que mediou a alteração seguinte.

A nossa Carta Magna também consubstanciou o claro objetivo de proteção à pessoa dos filhos (art. 227). Foi expressamente proibida qualquer forma de discriminação da prole em razão da origem - com o término da distinção entre filiação legítima e ilegítima - fazendo-se referência aos mesmos direitos e qualificações dos filhos havidos dentro e fora do casamento, e também os adotados ${ }^{374}$.

A ausência de distinção entre os filhos, juntamente com a isonomia conferida aos homens e mulheres na sociedade conjugal, consubstanciam as duas nuances do princípio da igualdade no âmbito do direito de família.

Ao lado disto, como corolário dessas mudanças, consagrou-se o princípio da paternidade responsável e a tutela incondicionada da formação da personalidade do menor. Logo, a função do poder parental passou a ser assegurar aos filhos os cuidados necessários para o desenvolvimento da sua personalidade, através da observação do melhor interesse da criança e do adolescente.

Podemos dizer, desta maneira, que a família hoje se ancora nos seguintes princípios constitucionais: proteção da dignidade da pessoa humana (art. $1^{\circ}$, III); solidariedade familiar (art. $3^{\circ}$, I); igualdade entre filhos (art. 227, $\S 6^{\circ}$ ); igualdade entre cônjuges e companheiros (art. 226, $\S 5^{\circ}$ ); igualdade na chefia familiar (arts. 226, $\S 5^{\circ}$ e 227, $\S 7^{\circ}$ ); e melhor interesse da criança e do adolescente (art. 227, caput).

Destarte, observa Sílvio de SAlvo Venosa que em nosso país, a Constituição de 1988 representou o grande 'divisor de águas' do direito privado, especialmente das normas de direito de família. Segundo o autor, o Código Civil de 2002 complementou e estendeu esses princípios, mas, sem dúvida, a verdadeira 'revolução legislativa' já ocorrera

\footnotetext{
374 SILVIO RODRIGUES assevera que a nova ordem constitucional modificou por completo a questão da filiação, equiparando, de forma absoluta, em todos os direitos e qualificações, os filhos havidos da relação de casamento ou não, e ainda os adotados, proibindo qualquer designação discriminatória. Cf. RODRIGUES, Silvio. Op. cit. (nota 339), 2004, p. 11. Segundo CAIO MÁrIO DA SILVA PereIRA, "o princípio da 'equiparação dos filhos' constitui uma das grandes contribuições da Constituição de 1988 ao Direito de Família, resultado de efetiva conquista da Doutrina e Jurisprudência, influenciadas, inclusive, pela substituição dos modelos tradicionais de família e pelo reconhecimento jurídico de uma pluralidade de entidades familiares”. PEREIRA, Caio Mário da Silva. Op. cit. (nota 185), p. 53.
} 
antes, com a Constituição ${ }^{375}$. GUILHERME CALMON NOGUEIRA DA GAMA também enaltece o texto de nossa Carta Magna ao afirmar que ela constitui "um marco na evolução do Direito de Família no Brasil" ${ }^{376}$.

Em razão das mudanças introduzidas pela Constituição Federal e da longa tramitação do Código Civil de 2002, iniciou-se um movimento conhecido como constitucionalização do Direito civil, ou Direito civil-constitucional, no qual os muitos adeptos postulam que a base do Direito civil, e especificamente do Direito de família, estaria calcada na própria Constituição.

É fato que o Código Civil de 1916 há tempos não retratava o panorama da família, por ele disciplinada à luz de princípios que já não apresentavam a validade social de outrora. Ademais, as diversas alterações introduzidas por leis especiais, que explícita ou implicitamente revogavam o texto do Código, faziam com que o jurista se deparasse com um emaranhado de regras imprecisas e desprovidas de um princípio inspirador único, de modo a tornar praticamente impossível um tratamento sistemático da matéria ${ }^{377}$.

Concomitantemente a estas mutações do Direito civil, as sucessivas Constituições brasileiras foram albergando fatias relevantes do Direito privado, culminando na Constituição de $1988^{378}$.

Nas palavras de LUIZ EDSON FACHIN: "assim se apreende esse fenômeno, a “constitucionalização” do Direito de Família, através do qual a Constituição Federal ocupa o lugar classicamente deferido ao Código Civil e, hoje, é a lei fundamental, ali está a base do Direito de Família, regras e princípios fundamentais "379.

Flávio Tartuce e José Fernando Simão explicam que o Direito civilconstitucional procura analisar os institutos do direito privado tendo como 'ponto de origem' a Constituição Federal ${ }^{380}$. Já LOURIVAL SEREJo considera que o Direito de família está hoje condicionado pelo Direito constitucional, não sendo possível negar que a

\footnotetext{
${ }^{375}$ Cf. VenOSA, Sílvio de Salvo. Op. cit. (nota 340), p. 7.

${ }^{376}$ GAMA, Guilherme Calmon Nogueira da. O companheirismo: uma espécie de família. $2^{\mathrm{a}}$ ed. São Paulo: Revista dos Tribunais, 2001, p. 54.

${ }^{377}$ Cf. MonTEIRO, Washington de Barros. Op. cit. (nota 348), p. 10.

${ }^{378}$ Cf. idem, p. 11 .

${ }^{379}$ FACHIN, Luiz Edson. Elementos críticos do direito de família. Rio de Janeiro: Renovar, 1999, pp. 56-57.

380 TARTUCE, Flávio et SiMÃo, José Fernando. Direito civil: direito de família. Vol. 5. $3^{\text {a }}$ ed. São Paulo: Método, 2008, p. 25.
} 
elevação dos seus institutos ao status constitucional representou uma maior garantia dos princípios que os norteiam $^{381}$.

Os adeptos desta tendência afirmam que a família é um instrumento de afirmação da realização pessoal do ser humano, um lugar privilegiado para o desenvolvimento da personalidade de seus membros ${ }^{382}$.

De sua parte, WAShington de BARRos Monteiro faz uma ponderação. Diz que a ingerência da Constituição nas relações privadas realmente existe, pois devem sempre ser havidas como Leis Maiores no ordenamento jurídico. Todavia, defende que essa regulamentação constitucional de matérias civis não tinha o condão de eliminar a necessidade de uma nova codificação de Direito civil ${ }^{383}$, como não o fez. Para ele, "essa ausência de adequação constitucional do diploma civil e a proliferação de leis de conteúdo civil acarretavam uma grande crise, que não foi e não poderia ser evitada pela chamada constitucionalização do direito civil ${ }^{, 384}$.

De fato, havia grande insegurança jurídica - mesmo após a promulgação da Constituição de 1988 - e a necessidade premente de que um novo Código Civil regulamentasse o direito de família. Assim, parece acertada a conclusão de que " $a$ Constituição da República deu as linhas mestras de alguns dos principais institutos de direito privado, principalmente do direito de família, mas não a ponto de dispensar uma regulamentação mais ampla dos institutos do direito civil por um novo Código ${ }^{, 385}$.

O novo Código Civil veio quatorze anos depois, absorvendo as inovações trazidas pela Constituição de 1988 em seu texto.

Perante esta tensão de normas e da questão de como nos portarmos diante da relação estabelecida entre a Constituição e o Código, é bem-vinda alguma obtemperação,

\footnotetext{
${ }^{381}$ Cf. SEREJO, Lourival. Direito constitucional de família. Belo Horizonte: Del Rey, 1999, p.18.

${ }^{382}$ Neste sentido: FARIAS, Cristiano Chaves de. A proclamação da liberdade de permanecer casado (ou um réquiem para a culpa na dissolução das relações afetivas). Revista brasileira de direito de família, n. 18, 2003, p. 67. O autor, juntamente com NELSON ROSENVALD, postula uma mudança paradigmática da família, para se tornar o 'núcleo privilegiado para o desenvolvimento da personalidade humana'. Cf. FARIAS, Cristiano Chaves de et Rosenvald, Nelson. Direito das famílias. $2^{a}$ ed. Rio de Janeiro: Lumen Juris, 2010, p. 6.

${ }^{383}$ Cf. MonTEIRO, Washington de Barros. Op. cit. (nota 348), pp. 11-12.

${ }^{384}$ Idem, p. 12.

${ }^{385}$ Idem, p. 13.
} 
que não procura romper totalmente com o passado ou ignorar as mudanças advindas, mas absorver o novo na tradição jurídica.

Conforme este espírito ponderado, a melhor interpretação é aquela que estabelece a aplicação das regras do Direito civil e do Direito de família, previstas no próprio Código ou em leis esparsas, sempre com base nos princípios constitucionais. Ou seja, a aplicação desses princípios não prescinde das regras específicas que embasam o direito tutelado. Nestes termos, podemos dizer que, hodiernamente, há uma tendência metodológica de se interpretar as regras do Direito de família a partir de princípios constitucionais.

Voltando à opinião de WASHINGTON DE BARROS MonTEIRO, este postula que não há uma constitucionalização do Direito civil; o que ocorre é o tratamento pela Constituição Federal de institutos deste ramo jurídico, sendo que a unidade hermenêutica, com a interpretação das regras de Direito civil de acordo com os princípios constitucionais, não tem o condão de retirar sua autonomia ${ }^{386}$. Neste compasso, ZENO VELOSO firma a seguinte posição: "a meu ver, e tenho repetido isso há bastante tempo, o fenômeno notabilíssimo de nosso tempo não é, como alguns querem, o da constitucionalização do Direito Civil, mas o da civilização da Constituição ${ }^{\text {387 }}$.

Independentemente da filiação a estas correntes doutrinárias, o certo é que em nossa Lei Maior encontram-se vários dispositivos que visam à proteção da família, sendo que, conforme expusemos, a Carta Magna foi a primeira a sistematizar as diversas mudanças que vinham sendo timidamente intentadas, atendendo ao anseio de mudanças que permeava este âmbito jurídico ${ }^{388}$.

É inegável, portanto, a importância da Constituição Federal de 1988 para o Direito de família, eis que representa um marco inovador no tratamento dado às relações familiares. De seu turno, igualmente devemos notar as alterações encampadas pelo Código

\footnotetext{
${ }^{386}$ Cf. ibidem.

${ }^{387}$ Veloso, Zeno. Deveres dos cônjuges - responsabilidade civil. In: ChInEllato, Silmara Juny de Abreu, Simão, José Fernando, FujITA, Jorge Shiguemitsu e ZuCCHI, Maria Cristina (Orgs.). Direito de família no novo milênio: estudos em homenagem ao professor Álvaro Villaça Azevedo. São Paulo: Atlas, 2010, p. 174.

${ }^{388}$ Como bem observa EDUARDO OLIVEIRA LEITE, "o texto constitucional, reconhecendo a necessidade de acompanhar a evolução social e inexorável, rompeu com as amarras que atrelavam o Direito de Família a uma ordem jurídica desejada, mas nem sempre vivida no cotidiano (...)”. LEITE, Eduardo de Oliveira. A família monoparental como entidade familiar. In: WAMBIERT, Teresa Arruda Alvim et LEITE, Eduardo de Oliveia (coords.). Repertório de doutrina sobre direito de família - aspectos constitucionais, civis e processuais. v. 2. São Paulo: Revista dos Tribunais, 1995, p.45.
} 
Civil de 2002. Segundo SiLvio RodrigueS, o atual Código apresenta-se na parte destinada ao Direito de família como aglutinador das significativas inovações legislativas e conceituais a respeito deste ramo do Direito que, a partir da Constituição Federal, tem-se mostrado extremamente dinâmico ${ }^{389}$.

Todavia, por manter as diretrizes constitucionais vigentes, o Código sofreu críticas por parcela da doutrina, que o considerou pouco arrojado ${ }^{390}$. A preocupação maior do legislador de 2002 foi solidificar as transformações do Direito de família, estabelecendo um regramento infraconstitucional adequado para os princípios já anunciados ${ }^{391}$.

Assim, em consonância com o texto constitucional vigente, o Código reconheceu as diversas espécies de entidade familiar e conferiu proteção igualitária aos membros que as integram. Não fez distinção entre família legítima e ilegítima. E destinou um título específico à união estável, que já havia recebido tratamento diferenciado do legislador infraconstitucional ${ }^{392}$.

Portanto, a incorporação definitiva da igualdade jurídica entre o homem e a mulher alcançou os efeitos pessoais e patrimoniais do matrimônio, inclusive no que se refere à guarda de filhos e à chefia conjunta da sociedade conjugal. Assim, o regime passou a ser o de companheirismo, não de hierarquia, desaparecendo a figura do chefe de família ${ }^{393}$.

Por fim, observa-se o afastamento do tratamento discriminatório entre filhos, com a regulamentação dos princípios estabelecidos em nossa Constituição e os preceitos instituídos pelo Estatuto da Criança e do Adolescente.

\footnotetext{
${ }^{389}$ Cf. RoDRIGUES, Silvio. Op. cit. (nota 339), p. 15.

390 SILVIO RODRIGUES observa que "ressalvada a adaptação do texto codificado com a legislação então vigente, poucas foram as inovações significativas no Direito de Família, frustrando a comunidade jurídica e a própria sociedade, que esperava um sistema normativo mais avançado para acomodar melhor os interesses da família na sua atual dimensão”. Ibidem. Para Sílvio DE SAlvo VenosA, o Código Civil de 2002 procurou fornecer uma nova compreensão de família, adaptada ao novo século, embora ainda tenha dado passos tímidos neste sentido. Cf. VenOSA, Sílvio de Salvo. Op. cit. (nota 340), p. 10.

${ }^{391}$ Nas palavras de CAIO MÁRIO DA SILVA PEREIRA, “o Direito de Família no Código de 2002 consolidou os princípios constitucionais introduzidos pela Constituição de 1988, reconhecendo outros direitos cujas bases se fixam em nossa realidade social”. PEREIRA, Caio Mário da Silva. Op. cit. (nota 185), p. 38.

${ }^{392}$ Segundo JOÃo RICARDO BRANDÃo AGUIRRE, essa inserção de dispositivos para regulamentar a união estável no Código Civil representou um inegável avanço em nosso ordenamento jurídico e reforçou o princípio fundamental de respeito à dignidade da pessoa humana e à igualdade. Cf. AGUIRRE, João Ricardo Brandão. Op. cit. (nota 369).

${ }^{393}$ Há quem utilize a expressão 'despatriarcalização do Direito de família', já que a figura paterna deixou de exercer o poder de dominação do passado. Cf. TARTUCE, Flávio et SiMÃO, José Fernando. Op. cit. (nota 380), p. 36.
} 
Nesta trilha de modificações alcançadas pelo direito de família, as mais recentes inovações constituem-se na aprovação da separação e do divórcio extrajudiciais; na instituição da guarda compartilhada; na criação dos alimentos gravídicos; e nas mudanças introduzidas pela Emenda Constitucional n. 66/2010, a que faremos breves referências.

A Lei n. 11.441/07 possibilitou a realização da separação e do divórcio consensuais extrajudicialmente - pela via administrativa - por meio de escritura pública perante o tabelião. O primeiro e principal objetivo desta Lei foi facilitar a separação e o divórcio, e, consequentemente, desafogar o Judiciário ${ }^{394}$. Para alguns doutrinadores, ela também inovou ao primar pela menor intervenção do Estado na vida privada das pessoas, já que não há qualquer discussão a respeito dos motivos do término da relação, bastando a mera disposição das partes. No entanto, critica-se a singeleza da disposição legal que tratou o assunto, com a simples inclusão de um novo artigo no Código de Processo Civil, deixando em aberto diversas questões importantes ${ }^{395}$.

Com a entrada em vigor da Lei n. 11.698/08, alteraram-se os arts. 1.583 e 1.684 do Código Civil, integrando ao sistema jurídico a guarda compartilhada, que já compunha debates doutrinários e algumas decisões judiciais. Esta inovação se deu para que, através do poder familiar, se priorizasse a proteção dos filhos e uma sadia convivência. A guarda compartilhada tem como escopo a garantia da convivência familiar preconizada pelo art. 227 da Constituição. Este sistema consiste na responsabilização conjunta, mantendo para ambos os pais o exercício do poder familiar sobre os filhos, podendo tomar as decisões sobre os interesses da criança de forma compartilhada. Não obstante, surgem censuras quanto à aplicação prática do instituto, vez que, em alguns casos, pode acabar prejudicando os próprios objetivos para os quais foi estabelecido, acirrando os problemas familiares.

Quanto aos alimentos gravídicos, introduzidos pela Lei n. 11.804/08, são devidos ao nascituro e percebidos pela gestante durante a gravidez, devendo ser fixados

\footnotetext{
${ }^{394}$ Segundo CRISTIANo CHAVES DE FARIAS, essa foi uma grande alteração do ordenamento que teve como objetivos a racionalização das atividades processuais e a simplificação da vida jurídica dos cidadãos brasileiros. FARIAS, Cristiano Chaves de. O novo procedimento para a separação e o divórcio consensuais e a sistemática da Lei n. 11.441/2007: o bem vencendo o mal. Revista Brasileira de Direito de Família. Belo Horizonte, n. 40, 2007, pp. 49-71.

${ }^{395}$ Cf. TARTUCE, Flávio et SiMÃo, José Fernando. Op. cit. (nota 380), p. 190 e seguintes.
} 
com base nos indícios de paternidade. Procurou-se garantir a assistência e subsistência do nascituro e da mãe durante o período de gestação ${ }^{396}$. Assim, concedeu-se à gestante o direito de pleitear alimentos durante a gravidez, assegurando a responsabilidade parental desde a concepção.

Já a Emenda Constitucional n. 66/2010, estabelece, sem realizar maiores apontamentos, a possibilidade de obtenção do divórcio, o que levou a postulações de que a ruptura do vínculo matrimonial poderia doravante ser feita sem prévia separação judicial e sem a necessidade de observar o prazo legal.

As mudanças confluem no Projeto n. 2.285/2007 - Estatuto das famílias, que pretende incorporar no ordenamento de forma sistemática uma série de modificações sobre o tratamento jurídico desta seara. Na avaliação de ROSA MARIA DE ANDRADE NERY, tratase de um microssistema jurídico que almeja albergar todas as situações jurídicas (e não apenas direitos e deveres) relacionados à família. Para tanto, até mesmo este termo família - seria substituído por outro - entidades familiares - que não apenas representaria os novos arranjos deste tipo de relação, mas igualmente significaria um novo marco, o início de uma nova concepção, baseada em valores diferentes daqueles tradicionais, que levaram à concepção da família ${ }^{397}$.

Derradeiramente, não poderíamos deixar de mencionar a grande discussão, atualmente em voga, a respeito das uniões homoafetivas. Apesar de não haver mudanças concretas na legislação sobre o reconhecimento de tais uniões como núcleos familiares, há grande pressão por parcela da doutrina, que acabou sendo acompanhada pelo Judiciário ${ }^{398}$, no sentido de admiti-las e cominar-lhes efeitos. Em alguns casos, chega-se a aceitar a possibilidade do casamento entre homossexuais, sem que haja qualquer previsão expressa neste sentido.

\footnotetext{
${ }^{396}$ Os alimentos de que trata a Lei compreenderão os valores suficientes para cobrir as despesas decorrentes da gravidez, do parto, de alimentação especial, assistência médica e psicológica, exames, internações, medicamentos e demais prescrições preventivas, terapêuticas ou indispensáveis para a manutenção sadia da gestação.

${ }^{397}$ NERY, Rosa Maria de Andrade. Entidades familiares - comunidades emocionais - responsabilidade da dutrina. In: NERY, Rosa Maria de Andrade et DONNINI, Rogério (Coords.). Responsabilidade civil: estudos em homenagem ao professor Rui Geraldo Camargo Viana. São Paulo: Revista dos Tribunais, 2009, pp. 534536.

${ }^{398}$ Em maio de 2011, o Supremo Tribunal Federal pronunciou-se sobre o assunto através da decisão proferida na Arguição de Descumprimento de Preceito Fundamental n. 132 e na Ação Direta de Inconstitucionalidade n. 4.277, equiparando a união homoafetiva à união estável.
} 
O que muitos esquecem, todavia, é que as diversas mudanças que se operaram no Direito de família são resultado de um processo lento e gradual de internalização pela própria sociedade. Talvez, ao contrário do que alguns juristas propagam, nossa sociedade ainda não esteja em consonância com mais esta grande transformação. Portanto, é controversa a ideia de que essa mudança representa uma realidade social que necessita ser acolhida de imediato pelo Direito. Do contrário, parece ser resultado da imposição de alguns grupos, de forma avessa ao Estado democrático. Esta visão doutrinária redunda na concepção de que a interpretação de hoje é evidente e inarredável, e que, a da semana passada é obsoleta, ultrapassada, intolerante, e sem fundamento.

Nestes termos, não pode ser descartada a hipótese de que, de maneira diametralmente oposta, o que está sucedendo é a tentativa de mudança da sociedade por meio do Direito e, em última instância, através de uma jurisprudência dita de vanguarda. $\mathrm{O}$ que está em jogo não é a visão moral do problema, mas sim a visão jurídica, cunhada na própria democracia, que é a estrutura fundamental do nosso Direito. Destarte, qualquer mudança neste sentido deve antes passar pelo crivo democrático.

Neste quadro, superficialmente traçado, há inexoravelmente conceitos desafiadores a incitar o legislador e o jurista, com premissas absolutamente diversas daquelas encontradas no início do século passado em nosso país ${ }^{399}$. É importante ter em mente que, a seu tempo, conforme a sociedade absorve os reclamos de mudanças de paradigmas, há a resposta legislativa adequada. O Direito imposto pelo Estado não pode abstrair o fenômeno natural da família, que é preexistente. Em contrapartida, não deve o Poder Judiciário acelerar essas mudanças, agindo contrariamente ao Direito posto, no conhecido movimento de ativismo judicial.

\subsubsection{Questão da culpa}

Neste contexto de mudanças que se operaram em nosso ordenamento civilfamiliar, destacamos a discussão a respeito da culpa, que permanece instigando os juristas.

${ }^{399}$ Cf. Venosa, Sílvio de Salvo. Op. cit. (nota 340), p. 6. 
Conforme assevera Regina Beatriz TAVARES DA Silva, no Direito “a culpa é definida como a inexecução consciente de uma norma de conduta. Trata-se de um fundamento da responsabilidade civil ${ }^{\text {,400. }}$.

No Direito de família, apreende-se que a culpa se expressa no momento patológico do casamento: no término da sociedade conjugal, quando ocorre o descumprimento de um dever preexistente. Ou seja, ela é compreendida como a quebra dos deveres matrimoniais bilateralmente impostos, e atribui àquele que descumpre tais obrigações consequências consistentes na perda de direitos e imposição de sanções.

Dentre as modalidades de separação judicial, a chamada separação-sanção na qual um dos cônjuges imputa ao outro a culpa pelo fim do relacionamento, em razão de conduta desonrosa ou qualquer ato que represente grave violação de dever matrimonial sempre recebeu maior atenção dos operadores do Direito. Para esta hipótese, o ordenamento jurídico consagra um sistema de punições aplicáveis ao cônjuge considerado culpado.

Quando não se apresentam as condições favoráveis à solução consensual do conflito conjugal, este deve ser resolvido pelo juiz, por meio da separação judicial litigiosa, prevista no art. 1.572 do Código Civil. $\mathrm{O}$ art. 1.573 do mesmo diploma enumera algumas das condutas que traduzem grave violação dos deveres conjugais, que serão examinadas à frente.

É importante destacar, por outro lado, no que diz respeito ao processo estrito do divórcio, seja ele direto ou por conversão, nunca se perquiriu culpa. Discutia-se a culpa antes, no procedimento de separação, e quando já se tratasse de divórcio, a inculpação era irrelevante. Logo, não há culpado ou responsável pela ruptura do vínculo matrimonial (conquanto houvesse esta hipótese para a sociedade conjugal); não se admite que os cônjuges imputem um ao outro qualquer causa de natureza subjetiva ou responsabilidade culposa pelo fim do casamento. Basta o cumprimento dos prazos estabelecidos em lei: um ano da separação judicial ou dois anos da separação de fato.

Com estes contornos se delineia o modelo dual de separação e divórcio ${ }^{401}$, que permaneceu após a Constituição Federal de 1988 e no Código Civil de 2002.

${ }^{400}$ SILVA, Regina Beatriz Tavares da. Op. cit. (nota 198), p. 26. 
Vale observar que a separação determina o fim da sociedade conjugal, mas há possibilidade de reconciliação. As pessoas separadas não podem se casar, apenas constituir união estável com terceiros. O divórcio, por sua vez, determina o fím do vínculo matrimonial, do casamento válido, o que inclui a sociedade conjugal, não sendo possível a reconciliação. As pessoas divorciadas podem livremente se casar ou viver em união estável com terceiros. Percebe-se que a separação judicial confere uma situação transitória aos cônjuges, também considerada uma medida preparatória para o divórcio.

Este panorama tem sido criticado nos últimos anos, em razão das transformações que vem se operando na concepção da culpa no direito de família.

Muitos juristas entendem que a separação-sanção sempre gerou grande desgaste para o casal, além de perniciosa contenda no Judiciário. Afirmam que a intervenção do Estado no momento da separação, ao perquirir a culpa dos cônjuges pelo término do casamento, é inoportuna e sem utilidade ${ }^{402}$.

Ademais, alegam que quando o juiz investiga a ocorrência da culpa, ingressa na intimidade e na vida privada da sociedade conjugal e da entidade familiar, em desrespeito ao direito fundamental previsto no art. $5^{\circ}$, inciso X, da Constituição Federal ${ }^{403}$. Por este motivo, a questão da prova nas ações de separação judicial sempre foi conflituosa, vez que provar a infração dos deveres matrimoniais pelo outro cônjuge - como o cometimento de adultério - era extremamente difícil e acabava culminando na violação de direitos fundamentais ${ }^{404}$.

\footnotetext{
${ }^{401}$ No regime do Código Civil de 1916 apenas era admitido o desquite, consensual ou litigioso, que dissolvia a sociedade conjugal, mas não o casamento ou vínculo conjugal. O modelo dual surgiu com a aprovação da Lei n. 6.515/77, quando o divórcio foi admitido em nosso ordenamento, mantendo-se o desquite, sob a denominação de separação judicial.

${ }^{402} \mathrm{Na}$ literatura jurídica inglesa, notamos a reflexão sobre os aspectos negativos do processo de divórcio, sobressaindo o problema de que o procedimento provoca hostilidades e amarguras desnecessárias: "the legal process, it is said, requires the parties to look to the past and at the bad aspects of their marriage. This might destroy any last hope of reconciliation". HERRRING, Jonathan. Family law. $5^{\text {a }}$ ed. Essex: Logman Law Series, Pearson Education Limited, 2011, p. 118.

${ }^{403}$ Afirma PAULO LôBO que: “(...) nada é mais íntimo e privado que as relações entretecidas na convivência familiar. Sob esse importante ângulo, não pode a lei ordinária excepcionar, de modo tão amplo, a garantia constitucional da inviolabilidade, justamente no espaço privado e existencial onde ela mais se realiza". LÔBO, Paulo Luiz Netto. Direito civil: famílias. São Paulo: Saraiva, 2008, p. 140.

${ }^{404}$ De seu turno, para VALÉRIA SILVA GALDINO CARDIN, quando o juiz se depara com uma prova que, mesmo sendo ilícita, ilegítima ou imoral, demonstre a culpa de um dos consortes na separação judicial litigiosa, não pode deixar de conhecê-la sob a alegação de que estariam sendo violados direitos e garantias constitucionais, como o direito à privacidade, à intimidade ou à liberdade, pois, neste caso, estaria proferindo
} 
Assim, muitos juristas passaram a preconizar que todas as causas subjetivas da separação judicial litigiosa deveriam ser substituídas pela mera situação de impossibilidade da vida em comum, pois eram fatores que a esta conduziam. Os próprios julgadores começaram a optar por analisar a deterioração factual do relacionamento, e indagar a insuportabilidade da vida em comum, que restavam patentes nos autos, evitando-se a dilação probatória a respeito da culpa ${ }^{405}$.

Nesta linha de pensamento, afirma LUIZ EDSON FACHIN: "não tem sentido averiguar culpa com motivação de ordem íntima, psíquica, pois eventual conduta inadequada de um dos cônjuges provavelmente será sintoma do fim ",406.

Para RodRIGo DA CUNHA PEREIRA, estabelecer quem é o culpado não é tarefa fácil, e muitas vezes nem os próprios cônjuges sabem o verdadeiro motivo do fim do casamento, pois, frequentemente, a intolerância que se apresenta é apenas um indício da dificuldade de se conviver com as diferenças ${ }^{407}$.

Assim, Antônio Carlos Mathias Coltro afiança que melhor seria para o legislador e para os cidadãos, destinatários da lei, que não houvesse a preocupação com a culpa como motivo do fim do casamento ${ }^{408}$.

MARCIAL BARRETO CASABONA afiança que a perquirição de quais foram exatamente os deveres conjugais violados representa um verdadeiro retrocesso no Direito de família, em razão da violação do princípio da dignidade humana, da invasão da intimidade dos cônjuges pelo Poder Judiciário ${ }^{409}$. Ele assinala que quando se fala em

uma sentença injusta e imoral, conduzindo à negação do ideal de justiça, ao permitir a inimputabilidade civil do cônjuge culpado. Cf. CARDIN, Valéria Silva Galdino. Op. cit. (nota 245), pp. 136-137.

405 A doutrina argumentava que a consagração do chamado princípio da ruptura reforça a ideia do afeto como norteador das relações familiares, consagrando o princípio da dignidade da pessoa humana, livrando o indivíduo de ditames estatais, "não sendo lícito ao aparato judicial adentrar em sua intimidade na busca das razões definidas pela legislação para poder ter sucesso no seu intento de separação judicial”. ZANELLATO, Ezequiel Paulo. O afeto como fator preponderante para a manutenção da sociedade conjugal. Revista Brasileira de Direito de Família, n. 28, 2005, p. 58.

${ }^{406}$ FACHIN, Luiz Edson. Op. cit. (nota 379), p. 179.

${ }^{407}$ Cf. Pereira, Rodrigo da Cunha. Código civil anotado. Porto Alegre: Síntese, 2004. p. 1.110. Já em 1998, RODRIGO DA CUNHA PEREIRA assinalava que havia uma tendência de substituição do princípio da culpa pelo princípio da ruptura. Cf. PEREIRA, Rodrigo da Cunha. A culpa no desenlace conjugal. In: MotTA, Maria Antonieta Pisano (coord.). Caderno de estudos n. 3: direito de família e ciências humanas. São Paulo: Jurídica Brasileira, 2000, p. 144.

${ }^{408}$ Cf. Coltro, Antônio Carlos Mathias. Dissolução da sociedade conjugal: separação extrajudicial. In: Chinellato, Silmara Juny de Abreu, SiMÃo, José Fernando, FuJiTA, Jorge Shiguemitsu et ZuCCHI, Maria Cristina (Orgs.). Direito de família no novo milênio. São Paulo: Atlas, 2010, p. 303.

${ }^{409}$ Cf. CASABONA, Marcial Barreto. Op. cit. (nota 189), p. 363. 
resguardar a família com fulcro no afeto, faz-se necessário ponderar o fim da discussão da culpa para a ruptura conjugal, pois não se respeita a dignidade humana quando o Judiciário invade a privacidade das pessoas para indagar os motivos da separação, ainda que seja para estabelecer eventual reparação civil, respeitadas situações excepcionais ${ }^{410}$.

Na visão de SIDNEY SHINE, sob a perspectiva da psicologia, "a busca por provas e o recurso a testemunhas são formas de convencer a todos da 'ruindade' do excônjuge (ou da própria 'bondade'). A busca de uma platéia vem ao encontro com a necessidade de externalizar todo o ressentimento e a mágoa que não encontram reconhecimento" ${ }^{411}$.

No mesmo sentido, é a opinião de Flávio TARTUCE E JosÉ FERnANDo SimÃo: "a ação de separação-sanção, em várias situações, é utilizada com o intuito de vingança, o que não mais pode prevalecer. Esse processo de vingança em nada interessa à valorização da dignidade humana, servindo apenas para degradá-la, pois motivado por sentimentos egoísticos e de péssima índole ${ }^{\text {"412. }}$

Nestes termos, Rolf MADALENO assegura ser tendência irreversível no Direito de família a completa abolição das razões causais nas demandas de separação judicial, deixando-se de pesquisar o descumprimento dos deveres do casamento para prevalecer o 'direito fundamental à felicidade' com o princípio da ruptura, que toma o lugar processual do superado princípio da culpa. No entanto, o autor ressalva que o fato de os cônjuges solicitarem a dissolução de seu casamento sem alegarem nenhuma causa, mas tão só a mera vontade de romper a relação, não significa ignorar os casos patológicos de ruptura dos laços conjugais, quando um dos consortes não tem 'nenhum escrúpulo em maltratar e humilhar o outro, ${ }^{413}$.

Deste modo, a impossibilidade da vida em comum - cláusula aberta ao convencimento judicial, pelo fato puro e simples do desaparecimento do affectio societatis - possibilitaria ao juiz decretar a dissolução judicial sem atribuir culpa a nenhum dos

\footnotetext{
${ }^{410}$ Cf. idem, p. 356.

${ }^{411}$ SHINE, Sidney. O conflito familiar tranformado em litigio processual. In: AGOSTINHO, Marcelo Lábaki et SANCHEZ, Tatiana Maria (orgs.). Família, conflitos, reflexões e intervenções. São Paulo: Casa do Psicólogo, 2002, p. 69, apud LÔBO, Paulo Luiz Netto. Op. cit. (nota 403), p. 140.

412 TARTUCE, Flávio et SIMÃo, José Fernando. Op. cit. (nota 380). p. 201.

413 Cf. MadAleno, Rolf. Responsabilidade civil na conjugalidade e alimentos compensatórios. Revista brasileira de direito de família e sucessões, v. 13, 2010, p. 15.
} 
cônjuges $^{414}$, e tem sido premissa recorrentemente utilizada pela doutrina e jurisprudência pátria $^{415}$.

Também não se descure que as consequências punitivas arrogadas ao cônjuge culpado foram mitigadas ou extintas do ordenamento ${ }^{416}$, o que para alguns autores reforça a tendência do legislador em aplacar a culpa do Direito de família ${ }^{417}$, como veremos em item próprio.

Neste cenário, com a recente aprovação da Emenda Constitucional n. 66/2010, muitos juristas passaram a advogar o fim da culpa, e a extinção da própria figura de separação judicial.

$\mathrm{O}$ art. 226, $\S 6^{\circ}$, da Constituição Federal teve sua redação simplificada pela Emenda: "o casamento civil pode ser dissolvido pelo divórcio".

${ }^{414}$ Este entendimento foi firmado no Enunciado n. 254, da III Jornada de Direito Civil CJF/STJ, que complementou o Enunciado n. 100, aprovado na I Jornada de Direito Civil. Enunciado n. 254: “Art. 1.573: Formulado o pedido de separação judicial com fundamento na culpa (art. 1.572 elou art. 1.573 e incisos), o juiz poderá decretar a separação do casal diante da constatação da insubsistência da comunhão plena de vida (art. 1.511) - que caracteriza hipótese de 'outros fatos que tornem evidente a impossibilidade da vida em comum' - sem atribuir culpa a nenhum dos cônjuges”. Enunciado n. 100: “Art. 1.572: na separação, recomenda-se apreciação objetiva de fatos que tornem evidente a impossibilidade da vida em comum".

415 "Separação. Ação e reconvenção. Improcedência de ambos os pedidos. Possibilidade da decretação da separação. Evidenciada a insuportabilidade da vida em comum, e manifestado por ambos os cônjuges, pela ação e reconvenção, o propósito de se separarem, o mais conveniente é reconhecer esse fato e decretar a separação, sem imputação da causa a qualquer das partes. Recurso conhecido e provido em parte”. STJ, REsp. n. 467.184/SP, rel. Min. RUY ROSADO DE AGUIAR JÚNIOR, j. em 05-12-02, pub. 17-02-03. "Direito civil. Direito de família. Separação por conduta desonrosa do marido. Prova não realizada. Irrelevância. Insuportabilidade da vida em comum manifestada por ambos os cônjuges. Possibilidade da decretação da separação. Nova orientação. Código civil de 2002 (art. 1.573). Recurso desacolhido. Na linha de entendimento mais recente e em atenção às diretrizes do novo Código Civil, evidenciado o desejo de ambos os cônjuges em extinguir a sociedade conjugal, a separação deve ser decretada, mesmo que a pretensão posta em juízo tenha como causa de pedir a existência de conduta desonrosa". STJ, REsp. n. 433.206/DF, rel. Min. SÁlvio de FigueIredo TeIXEIRA, j. em 06-03-03, pub. em 07-04-03. "Separação judicial. Pedido intentado com base na culpa exclusiva do cônjuge mulher. Decisão que acolhe a pretensão em face da insuportabilidade da vida em comum, independentemente da verificação da culpa em relação a ambos os litigantes. Admissibilidade. A despeito de o pedido inicial atribuir culpa exclusiva à ré e de inexistir reconvenção, ainda que não comprovada tal culpabilidade, é possível ao Julgador levar em consideração outros fatos que tornem evidente a insustentabilidade da vida em comum e, diante disso, decretar a separação judicial do casal. Hipótese em que da decretação da separação judicial não surtem conseqüências jurídicas relevantes. Embargos de divergência conhecidos, mas rejeitados". STJ, Embargos de Divergência em REsp. n. 466.329/RS, rel. Min. BARROS MONTEIRO, j. em 14-09-05, pub. em 01-02-06.

416 Com relação à guarda dos filhos menores, o ECA disciplina em favor do interesse da criança. Os alimentos dependem da prova do binômio possibilidade/necessidade, muito mais que da culpa. A manutenção do nome do cônjuge é garantida, desde que demonstrado o prejuízo para a sua identificação. E a partilha dos bens sempre foi realizada com a adoção de critérios objetivos definidos por lei, de acordo com o regime de bens adotado no casamento. Nesses termos, LEONARDO BARRETO MOREIRA ALVES afirma que houve uma atenuação dos 'castigos' reservados ao responsável. Cf. ALVES, Leonardo Barreto Moreira. O fim da culpa na separação judicial: uma perspectiva histórico-jurídica. Belo Horizonte: Del Rey, 2007, p. 13.

${ }^{417}$ Neste sentido, postulando a falta de utilidade prática na declaração judicial da culpa: FARIAS, Cristiano Chaves de. Op. cit. (nota 382), p. 73. 
A intenção do constituinte derivado foi eliminar o prazo de dois anos de separação de fato para se requerer o divórcio direto e de um ano para a conversão da separação judicial em divórcio, bem como suprimir o requisito da prévia separação judicial, seja na forma litigiosa ou consensual, para o divórcio.

Este fito do legislador foi aceito majoritariamente pelos operadores do Direito como plenamente realizado. Entretanto, vale aqui uma breve reflexão sobre o processo de modificação do ordenamento.

O fenômeno da constitucionalização do Direito civil ou da civilização do Direito constitucional parece conter em si problemas ainda não vislumbrados pela doutrina, e que inevitavelmente eclodirão, aqui e acolá, ao longo do desenvolvimento do Direito.

Neste sentido, a presença das condições para o divórcio na redação original da Constituição de 1988 poderia ser vista como desnecessária, considerando-se a matéria como de natureza estritamente legal. Esta posição, contudo, não permite ignorarmos o fato de que a norma foi alçada ao status constitucional, de maneira que não poderia ser contrariada pela legislação inferior, e somente sofreria alteração pelo quórum diferenciado, em virtude da natureza rígida de nossa Carta Magna.

Mas, se a legislação infraconstitucional igualmente repete os requisitos para o divórcio, em que medida a simples supressão da previsão constitucional acarreta a revogação daquelas condições? Na hipótese de que o constituinte originário não tivesse disposto sobre os requisitos do divórcio, também teria a doutrina, em 1988, concluído pela impossibilidade de condicionamentos legais?

O que se percebe é a presunção de que há uma clara contradição entre a norma constitucional e a norma legal, que, em razão da hierarquia de normas, deve ser resolvida pela revogação tácita dos dispositivos inferiores.

Com a devida vênia, não nos parece que a ilação é tão evidente assim, que aponte para uma única possibilidade. Pelo contrário, a hipótese de que as exigências legais foram mantidas denota maior vigor técnico, em virtude do princípio da legalidade, previsto no art. $5^{\circ}$, inciso II, da própria Constituição - ninguém será obrigado a fazer ou deixar de 
fazer alguma coisa senão em virtude de lei -, o qual empresta ao Código Civil o poder de fazer aquelas exigências aos cônjuges.

A correta lógica jurídica nos ensina o seguinte: a modificação de uma lei, para retirar requisitos previstos na Constituição, é inconstitucional; a modificação da Constituição, para retirar requisitos igualmente previstos na lei, pode ou não gerar a inconstitucionalidade da referida lei. Tudo depende da contrariedade ou não entre a lei e a Constituição, pois a primeira pode fazer exigências a mais, desde que não sejam contrárias à norma superior.

Sucede que a modificação em análise não proibiu a exigência de requisitos para o divórcio, mas apenas retirou os requisitos previstos constitucionalmente, nada dispondo sobre as exigências previstas na lei.

Não obstante a intenção do legislador, a interpretação teleológica não basta para ignorarmos o correto procedimento legislativo e democrático, o qual demanda a alteração da legislação infraconstitucional para que sejam plenamente afastados os requisitos para o divórcio. O chamado silêncio eloquente não é suficiente neste caso, vez que outro dispositivo constitucional (o princípio da legalidade) empresta à lei a força necessária para manter suas exigências.

Em outras palavras, o Código Civil não precisa se amparar no art. $226, \S 6^{\circ}$, da Constituição, pois pode se fundamentar no art. $5^{\circ}$, inciso II. O legislador deve conhecer a técnica jurídica e respeitar as relações entre normas e o processo democrático. Para tanto, ao lado da Emenda Constitucional, deveria ter realizado a revogação dos dispositivos legais por meio de lei. Desta forma, preservaríamos tanto a intenção quanto a estrutura do ordenamento.

Há quem diga que entender a manutenção legal dos dispositivos, após a Emenda Constitucional n. 66/2010, é utilizar-se de interpretação anacrônica, que retira da força normativa da Constituição ${ }^{418}$.

Ao que nos parece, há uma tendência em enxergar em qualquer posicionamento contrário vícios de técnica jurídica por descompasso com a teoria jurídica

${ }^{418}$ Cf. RIBEIRO, Paulo Hermano Soares et FONSECA, Edson Pires da. Casamento e divórcio na perspectiva civil constitucional. Leme: J. H. Mizuno, 2012, pp. 198-199. 
contemporânea. Mas, de nossa parte, seja qual for a mudança que se pretenda fazer, não se pode sepultar o correto procedimento legislativo e democrático. A nova norma constitucional não veda condicionamentos ao divórcio, tampouco a existência da separação. Sim, esta foi a intenção do legislador, mas não foi isto que se fez.

A força normativa da Constituição significa uma qualidade dos efeitos de suas previsões, e não a vênia para que a partir de qualquer conteúdo dos dispositivos constitucionais impregnemos os efeitos jurídicos que desejamos, ao arrepio da teoria jurídica. Se o texto emendado trouxesse uma vedação a requisitos legais e à figura da separação, não haveria discussão, em virtude da hierarquia constitucional. Todavia, sem isto, nem mesmo o maior defensor da interpretação teleológica seria capaz de afastar a incidência do princípio constitucional da legalidade, que dá sustentação igualmente superior às previsões remanescentes no Código Civil.

De qualquer maneira, é razoável admitir que esta controvérsia técnica será relegada ao esquecimento, pois a prática jurídica já aceitou a revogação como certa. De nossa parte, não poderíamos deixar de demonstrar o problema que foi encoberto, ainda que o coro dos juristas sopre em sentido contrário.

Por outro lado, a mudança na Constituição reavivou a discussão sobre a culpa no Direito de família. Se a revogação das exigências para o divórcio foi aceita sem reservas, o mesmo não sucedeu com as figuras da separação e da culpa.

Assim, alguns juristas refletem se a alteração do dispositivo constitucional deve ser estendida ao Código Civil, para considerar tacitamente revogados os artigos que se referem à separação judicial litigiosa ${ }^{419}$.

Segundo PaUlo LuIZ NetTo LÔBo, esta nova redação do dispositivo constitucional teve por escopo pôr fim à exigência de comprovação da culpa de um dos cônjuges. Ademais, para o autor, Segundo o autor, a superação do dualismo legal repercute os valores da sociedade brasileira atual, pois evita que a intimidade e a vida privada dos

${ }^{419}$ Não se descure do Projeto de Lei n. 4.945/05, que pretendia expressamente revogar os dispositivos do Código Civil relativos à separação judicial. 
cônjuges e de suas famílias sejam reveladas e trazidas ao espaço público dos tribunais ${ }^{420}$. Desse modo, entende que a submissão a dois processos judiciais (separação judicial e divórcio por conversão) resultava em acréscimos de despesas para o casal, além de prolongar sofrimentos evitáveis ${ }^{421}$.

Também para Rolf MADAlENo a Emenda Constitucional n. 66/10 afastou a discussão sobre a culpa e diluiu o modelo dual, reconhecendo como suficiente o divórcio direto como forma de dissolução matrimonial ${ }^{422}$.

MARIA BERENICE DiAs sustenta que a nova redação do art. 226 , §6 ${ }^{\circ}$, da Constituição Federal extinguiu a separação judicial e eliminou a perquirição da culpa quando da dissolução da sociedade conjugal, podendo os cônjuges pleitear a ruptura do vínculo sem declinar os motivos ${ }^{423}$.

De outra parte, temos a visão que concorda com a extinção da separação judicial, mas defende a manutenção do elemento culpa. Entende-se que as mesmas causas da separação litigiosa culposa podem ser discutidas no âmbito do divórcio.

Neste sentido, para VALÉRIA Silva Galdino CARdin remanesce em nosso ordenamento jurídico uma única forma de dissolução do casamento: o divórcio. Todavia, há a possibilidade de discutir a culpa pela infração dos deveres conjugais previstos no art. 1.566 do Código Civil. Ela apreende que os dispositivos previstos no Código Civil para tratar da separação judicial litigiosa (arts. 1.564, 1.578, 1.694 e 1.704) não foram revogados pela Emenda, devendo ser empregados no divórcio litigioso; e protesta pela apreciação da culpa na própria ação de divórcio, uma vez que não admite que as causas que levaram à ruptura do vínculo conjugal sejam irrelevantes, especialmente para a reparação civil. Por fim, a própria autora reconhece que seria mais apropriada a regulamentação da legislação infraconstitucional para evitar controvérsias ${ }^{424}$.

\footnotetext{
${ }^{420}$ Cf. LÔBO, Paulo Luiz Netto. Dissolução da sociedade conjugal: separação judicial e suas modalidades. In: Chinellato, Silmara Juny de Abreu, SiMÃo, José Fernando, FuJiTA, Jorge Shiguemitsu et ZUCCHI, Maria Cristina (Orgs.). Direito de família no novo milênio. São Paulo: Atlas, 2010, p. 288.

${ }^{421}$ Cf. LÔBO, Paulo Luiz Netto. Op. cit. (nota 403), p. 127.

${ }^{422}$ Cf. MADAlEno, Rolf. Curso de direito de família. $4^{\mathrm{a}}$ ed. Rio de Janeiro: Forense, 2011, p. 292.

${ }^{423}$ Cf. DiAs, Maria Berenice. Divórcio Já! $2^{\mathrm{a}}$ ed. São Paulo: Revista dos Tribunais, 2012, passim.

${ }^{424}$ Cf. CARDIn, Valéria Silva Galdino. Op. cit. (nota 245), pp. 147-151. De forma similar, era a opinião de GLADYS CHAMMA AMARAL SALLES, antes da aprovação da Emenda: “(...) reputamos prematura a interpretação de alguns renomados juristas que afirmam que com a PEC do divórcio nunca mais se poderá discutir a culpa na ruptura da vida em comum. No nosso entender, a vedação da discussão da culpa do
} 
Contudo, opiniões dissonantes acreditam na importância da manutenção da própria separação judicial em nosso ordenamento. Desta forma, parcela da doutrina defende que o instituto da separação judicial não foi extinto, tendo sido eliminados apenas os requisitos objetivos da prévia separação judicial por um ano e da separação de fato por dois anos, ficando à escolha dos cônjuges ingressarem com a separação ou com o divórcio. Logo, não haveria a revogação do modelo dual e, tampouco, a impossibilidade de se arrazoar a culpa pela separação.

Para INACIO DE CARVALHO Neto, a separação judicial ainda conserva grande importância, dada a impossibilidade de se discutir culpa dos cônjuges na ação direta de divórcio ${ }^{425}$. Ele assevera: “parece-nos viável a alteração legal pretendida, mas isto demandará uma adaptação de todo o sistema de dissolução do casamento, não bastando simplesmente revogar as normas relativas à separação judicial ${ }^{, 426}$.

A principal expoente desta corrente doutrinária é REGINA BEATRIZ TAVARES DA SILVA, para quem a Emenda Constitucional n. 66/2010 estabelece que o casamento pode ser dissolvido pelo divórcio, não impondo que deva ser desfeito somente por essa espécie dissolutória, mantendo-se, portanto, as demais espécies previstas no ordenamento jurídico infraconstitucional $^{427}$.

A autora certifica que o objetivo da Emenda era o de facilitar o divórcio, retirando-se o prazo como requisito: “a EC n. 66/2010 entrou em vigor com eficácia imediata ou plena exclusivamente para suprimir os requisitos temporais do divórcio, de modo a eliminar sua natureza conversiva",428. E prossegue: “isso significa que desaparecerá, em consequência, a separação prévia como requisito do divórcio. Afinal, deve ser interpretada a finalidade da norma, que é a facilitação do divórcio ${ }^{, 429}$.

Para esta jurista, a facilitação do divórcio, sem dúvida, é uma iniciativa de mérito. Contudo, alguns autores têm celebrado sua desburocratização sem atentar para a

divórcio no divórcio se aplica apenas aos casos de conversão de separação, judicial ou não, em divórcio. Nos casos de divórcio direto defendemos ser possível, sim, examinar a culpa e todos os demais temas próprios da separação, tais como alimentos, guarda de filhos, partilhas, etc”. SALLES, Gladys Maluf Chamma Amaral. A PEC do divórcio e a discussão da culpa. Artigo IBDFAM, apud CARDIN, Valéria Silva Galdino. Op. cit. (nota 245), p. 150 (sic).

${ }^{425}$ Cf. Carvalho Neto, Inacio de. Op. cit. (nota 86), p. 132.

${ }^{426}$ Idem, p. 134.

${ }^{427}$ Cf. SILVA, Regina Beatriz Tavares da. Op. cit. (nota 198), p. 16.

${ }^{428}$ Idem, p. 81.

${ }^{429}$ Ibidem 
importância dos efeitos da dissolução culposa do casamento ${ }^{430}$. Isto porque a regra da dissolução fundamenta-se no descumprimento de dever por um dos cônjuges, que acarreta em um ato ilícito, nos termos do art. 186 do Código Civil ${ }^{431}$.

A autora pondera cada um dos argumentos contrários à manutenção da separação judicial e da culpa, e avisa que já eram lançados antes da aprovação da Emenda, sendo alegações efetivamente atraentes, embora infundadas ${ }^{432}$.

O primeiro argumento é o de que a eliminação da separação judicial e da espécie de dissolução culposa de nosso ordenamento jurídico seria antiga reinvindicação da sociedade brasileira. Para ela, nenhum membro de nossa sociedade, em sã consciência, pode considerar justa e adequada a eliminação da espécie dissolutória culposa, que se baseia no grave descumprimento de dever conjugal ${ }^{433}$. Ela avaliza que "a verdadeira reinvindicação da sociedade brasileira sempre se voltou, isto sim, à eliminação de prazos, ou seja, à supressão de requisitos temporais ${ }^{, 434}$.

Quanto à segunda alegação, de que a duplicidade da separação judicial e do divórcio equivaleria a mero acréscimo de despesas e sofrimentos para o casal, assevera que, realmente, obrigar a pessoa a passar pela separação judicial para obter o divórcio, ou a esperar dois anos de separação de fato para consegui-lo, não fazia sentido. No entanto, para corrigir esse sistema não é necessário eliminar a dissolução culposa, pois as espécies dissolutórias - separação e divórcio, sem e com culpa - podem e devem coexistir de maneira independente ${ }^{435}$.

Em relação ao terceiro argumento, de que a separação judicial litigiosa equivaleria à mera investigação da causa do desaparecimento do afeto ou desamor, sem qualquer interesse relevante, afirma que também é sedutor, mas não se mantém diante da análise jurídica ${ }^{436}$, pois:

"na dissolução culposa não se investiga a causa da falta do amor, mas sim o descumprimento de deveres conjugais. Ter afeto ou amar não é um dever. Portanto, a

\footnotetext{
${ }^{430}$ Cf. idem, p. 106.

${ }^{431}$ Cf. idem, p. 73.

${ }^{432}$ Cf. idem, p. 62.

${ }^{433}$ Cf. idem, p. 63.

${ }^{434}$ Ibidem.

${ }^{435}$ Cf. idem, p. 64.

${ }^{436}$ Cf. idem, pp. 64-65.
} 
análise da falta de afeto ou de amor e de suas causas descabe nessa espécie de separação judicial. Somente cabe a investigação na dissolução culposa para apurar o descumprimento dos deveres conjugais regulados expressamente em lei (...) ${ }^{\text {,437. }}$

Além disto, observa que "chegava-se ao cúmulo de afirmar que a eliminação da culpa diminuiria o sofrimento dos filhos, como se fosse possível evitar as demandas sobre guarda e visitas (...)"438. Em sua visão, o sofrimento é inevitável na dissolução de um casamento, e dizer que a demonstração da culpa é motivo do seu aumento é ledo engano, pois é inerente ao desfazimento dos laços conjugais e antecede o próprio processo judicial $^{439}$.

A jurista também recorre à psicanálise para justificar a importância da manutenção da culpa na separação conjugal. Neste sentido, afirma que a errônea interpretação que por vezes é feita do conceito de culpa na psicanálise leva à ideia da necessidade de sua abolição pelo Direito, ou seja, combate-se a culpa no direito como se ela fosse abominada pela psicanálise. No entanto, segundo a autora, a eliminação da culpa do Direito de família não tem apoio nesta ciência, para a qual é havida como essencial, pois é um sentimento indispensável para estabelecer limites e possibilitar o convívio em sociedade $\mathrm{e}^{440}$. Esse sentimento propicia a aceitação da ética e das regras morais impostas pela cultura de cada povo, limitando os impulsos instintivos ${ }^{441}$.

Nestes termos, Regina Beatriz TAVARES Da Silva adverte que “(...) devemos ter presente que pensamentos turvos, como o de que cabe eliminar a culpa e as consequências do descumprimento dos deveres conjugais do ordenamento jurídico, não decorrem de desconhecimento ou ignorância, mas sim da vontade de destruir a familia $^{, 442}$.

Assim sendo, propõe uma reflexão responsável sobre a Emenda Constitucional do divórcio, vez que "a depender da interpretação que seja feita, a EC n. 66/2010 poderá

\footnotetext{
${ }^{437}$ Idem, p. 65.

${ }^{438}$ Idem, p. 64.

${ }^{439}$ Cf. ibidem

${ }^{440}$ Cf. SILVA, Regina Beatriz Tavares da. Afetividade e responsabilidade nas relações de família. Revista do Advogado, n. 91, 2007, pp. 114-115.

${ }^{441}$ Cf. KLEIn, Melanie et RIVIERE, Joan. Amor, ódio e reparação: as emoções básicas do homem do ponto de vista psicanalítico. $2^{\mathrm{a}}$ ed. Rio de Janeiro: Imago, 1975, p. 91, apud SiLVA, Regina Beatriz Tavares da. Op. cit. (nota 198), p. 25.

${ }^{442}$ SILVA, Regina Beatriz Tavares da. Op. cit. (nota 198), p. 14.
} 
ser havida como inconstitucional, já que não se pode admitir que seu texto acarrete a violação de outros dispositivos constitucionais e protetivos da dignidade da pessoa humana”,443. Ou seja, para esta jurista, negar à família a proteção determinada pelo art. 226, caput, da Constituição, por meio da eliminação das espécies dissolutórias do casamento e seus respectivos efeitos, acarretaria a inconstitucionalidade da Emenda ${ }^{444}$.

Conforme seu raciocínio, mantidas as espécies dissolutórias, cumprida estará a finalidade do dispositivo constitucional ${ }^{445}$. Ela conclui que a legislação infraconstitucional há de ser interpretada de forma a eliminar a separação de direito e de fato, exclusivamente, como requisito prévio do divórcio, desonerando aqueles que podem optar pelo divórcio diretamente. Por óbvio, o lapso temporal como requisito essencial do divórcio desaparece, por ser ônus desnecessário e porque já era incoerente com a possibilidade de constituição da união estável na separação de fato ${ }^{446}$.

Para a autora, todas "essas dificuldades poderiam ter sido evitadas se a emenda constitucional do divórcio sem prazo tivesse recebido outra redação, embora com o mesmo objetivo, levando em consideração a legislação vigente ou o direito posto ${ }^{\text {447 }}$.

Ademais, também apreende que não se poderia aceitar o vazio legislativo decorrente da falta de recriação do Direito. Seria preciso entender como recepcionadas as normas da legislação ordinária, no que se refere às espécies dissolutórias e aos seus efeitos, e também recriá-las, com a migração dessas espécies para o divórcio ${ }^{448}$. Nestes termos, propõe três novas formas de dissolução conjugal: o divórcio ruptura, sem causa e sem prazo para sua obtenção; o divórcio culposo, fundado nas mesmas causas da separação judicial culposa e com as mesmas consequências previstas no Código Civil para essa espécie dissolutória; e o divórcio remédio, com fulcro na mesma causa e consequências da separação judicial remédio. Desta forma, ela assegura que restarão satisfeitas as finalidades de facilitação da quebra do vínculo conjugal e de proteção aos direitos fundamentais e à personalidade dos divorciandos, em um só instituto ${ }^{449}$.

\footnotetext{
${ }^{443}$ Idem, p. 18.

${ }^{444}$ Cf. idem, p. 73.

${ }^{445}$ Cf. idem, p. 82.

${ }^{446}$ Cf. idem, pp. 108-109.

${ }^{447}$ Idem, p. 16.

${ }^{448}$ Cf. idem, p. 21.

${ }^{449}$ Cf. idem, p. 82
} 
Derradeiramente, a jurista observa que mesmo os doutrinadores que defendem a desnecessidade de verificação de culpa admitem a existência de fatos oriundos dessa análise que, até hoje, não foram dispensados pelos Tribunais brasileiros, pois a culpa, equivalente ao descumprimento de dever jurídico, demandaria sanção ${ }^{450}$.

Ela finaliza dizendo que: "além de afeto, sentimento que se almeja nas relações familiares, a família, ainda mais aquela que se encontra em conflitos e necessita da tutela do Direito, demanda deveres e responsabilidade. É aí que se baseia uma visão crítica da EC n. 66/2010 e dos efeitos que podem ser atribuídos ao emendado $\$ 6^{\circ}$ do art. 226 da Constituição Federal",451.

Perante tal quadro, o grande temor é o de que a retirada por completo da análise da culpa, e da possibilidade de propositura da separação judicial culposa, importará no esvaziamento do exame da responsabilidade civil entre cônjuges.

\subsubsection{CONSAGRAÇÃO DO AFETO}

As transformações anunciadas foram fundamentais para a maior mudança de todas, que se operou na própria concepção do núcleo familiar: a passagem da família como instituição, para a família como instrumento de realização de seus membros, calcada na afetividade. Nas palavras de ANDERSON SCHREIBER: “de fato, toda a evolução recente do direito de família conduz à valorização do aspecto existencial - vez por outra, dito 'afetivo' - das relações constituídas no seu âmbito ${ }^{\text {,452. }}$.

Neste sentido, Gustavo TEPEDINO afiança que a família deixa de possuir valor intrínseco, como uma instituição merecedora de tutela pelo simples fato de existir. Diferentemente, ela passa a ser valorizada de maneira instrumental, tutelada como um núcleo intermediário de desenvolvimento da personalidade e de promoção da dignidade de seus integrantes ${ }^{453}$.

\footnotetext{
${ }^{450}$ Cf. idem, p. 29.

${ }^{451}$ Idem, p. 109.

${ }^{452}$ SCHREIBER, Anderson. O princípio da boa-fé objetiva no direito de família. In: Pereira, Rodrigo da Cunha (Coord.). Família e Dignidade Humana - Anais do V Congresso Brasileiro de Direito de Família. Belo Horizonte: IBDFAM, 2006, p. 139.

${ }^{453}$ TEPEDINO, Gustavo. A disciplina civil-constitucional das relações familiares. In: Temas de direito civil. Tomo 1. $4^{\mathrm{a}}$ ed. Rio de Janeiro: Renovar, 2008, pp. 421-422. MARIA BERENICE DIAS assevera que a famíliainstituição foi substituída pela família-instrumento, ou seja, ela existe e contribui tanto para o
} 
VALÉRIA Silva GALDINO CARDIN ressalta que o afeto está relacionado com a dignidade porque promove a formação do indivíduo e, por isso, é importante nas relações familiares ${ }^{454}$. Para WASHINGTON DE BARRos MONTEIRO: “o ideal a ser alcançado em todas as relações familiares é a harmonia, por meio do afeto" ${ }^{\text {,455. }}$.

$\mathrm{O}$ afeto pode ser conceituado como um sentimento, existente entre duas ou mais pessoas que se amoldam pelo convívio duradouro - seja em virtude de uma origem comum, seja um destino comum que conjuga suas vidas ${ }^{456}$ - cujo relacionamento deve estar inarredavelmente pautado no respeito recíproco. Esse sentimento, não obstante tenha origem psicológica, traz consequências jurídicas.

\section{Na visão de CláUdia MARIA DA SILVA:}

"os vínculos jurídicos e os laços de sangue eram mais importantes e prevaleciam sobre os vínculos de amor. $O$ afeto, na concepção da família patriarcal, era presumido, tanto na formação do vínculo matrimonial e na sua manutenção como nas relações entre pais e filhos. Quando presente, não era exteriorizado, o que levava a uma convivência formal, distante, solene, substanciada quase que unicamente numa coexistência diária ${ }^{, 457}$.

De acordo com este pensamento, o eixo do Direito de família se deslocou do autoritarismo para a valorização do afeto como elemento agregador da própria família, que passou a não ser mais percebida como uma relação de poder e dominação, mas como uma relação afetiva e de respeito ${ }^{458}$. O afeto se ergue ao patamar de valor e princípio do Direito de família, nas palavras de RodRIGO DA CUNHA PEREIRA ${ }^{459}$.

desenvolvimento da personalidade de seus integrantes, como para o crescimento e formação da própria sociedade, o que justifica a sua proteção pelo Estado. Cf. DIAS, Maria Berenice. Manual de direito das famílias. $4^{\text {a }}$ ed. São Paulo: Revista dos Tribunais, 2007, p. 41.

${ }^{454}$ Cf. CARDIn, Valéria Silva Galdino. Op. cit. (nota 245), p. 234. Segundo PaUlo Luiz NetTo LôBO, o princípio da afetividade especializa, no âmbito familiar, os princípios constitucionais fundamentais da dignidade da pessoa humana e da solidariedade. Cf. LôBO, Paulo Luiz Netto. Op. cit. (nota 403), p. 48.

${ }_{455}$ MonTEIRO, Washington de Barros. Op. cit. (nota 348), p. 8.

${ }^{456}$ Cf. Pereira, Caio Mário da Silva. Op. cit. (nota 185), p. 33.

${ }^{457}$ SILVA, Cláudia Maria da. Op. cit. (nota 368), p. 129.

458 "A noção atual de família nas civilizações ocidentais afasta-se cada vez mais da ideia de poder e coloca em supremacia a vontade de seus membros, igualando-se os direitos familiares”. VENOSA, Sílvio de Salvo. Op. cit. (nota 340), p. 2.

${ }^{459}$ PEREIRA, Rodrigo da Cunha. Princípios fundamentais norteadores do direito de família. Belo Horizonte: Del Rey, 2006, p. 190. 
Note-se que o ordenamento civil-familiar, ao absorver esses elementos, consolidou os princípios fixados pela Carta de 1988. Materializa-se, assim, a família socioafetiva, cunhada na dignidade humana, vez que o princípio da afetividade especializa, no campo das relações familiares, a dignidade ${ }^{460}$ e a solidariedade social ${ }^{461}$. Estes dois princípios, por sua vez, refletem-se nas normas que atualmente compõem o Direito de família. Assim, o núcleo familiar, unido por relações de afeto, comunhão de interesses e solidariedade, é regulamentado com vistas a garantir a felicidade de seus membros, ideal a ser alcançado primordialmente através do respeito aos seus direitos personalíssimos.

Portanto, consubstanciada na afetividade, a família busca preservar a personalidade de cada um de seus integrantes, através do companheirismo e do respeito, que devem permear essas relações. Ademais, observa CAIO MÁrIO DA SILVA PEREIRA que o afeto, o diálogo e a solidariedade podem ajudar nos conflitos que se apresentam diversificados em cada configuração familiar ${ }^{462}$.

Igualmente, é salientado que "as trocas afetivas na família imprimem marcas que as pessoas carregam a vida toda, definindo direções no modo de ser com os outros afetivamente, e no modo de agir com as pessoas" ${ }^{\text {"463 }}$. Portanto, é preciso que fique claro que todo ser humano, desde sua infância, precisa receber e dar afeto para se tornar integral. A pessoa tratada com afeto responderá afetuosamente ${ }^{464}$.

Nestes termos, o afeto tem sido especialmente reconhecido como um atributo das relações paterno-filiais. O vínculo entre pai e filho não é mais de posse e domínio, e

\footnotetext{
460 'Mesmo não constando a expressão 'afeto'do Texto Maior como sendo um direito fundamental, pode-se afirmar que ele decorre da valorização constante da dignidade humana”. TARTUCE, Flávio et SIMÃO, José Fernando. Op. cit. (nota 380), p. 41. Também: “(...) o afeto representa importante elemento para a realização da dignidade humana, pois o ser humano necessita dele para estruturar sua vida, sendo primariamente obtido no seio familiar". ANGELUCI, Cleber Affonso. O valor do afeto para a dignidade humana nas relações de família. Revista Jurídica, n. 331, 2005, p. 81.

${ }^{461}$ Segundo Flávio Tartuce e José Fernando Simão, o princípio da solidariedade, por razões óbvias, acaba repercutindo nas relações familiares, no entanto, essa solidariedade não é somente a patrimonial, mas a afetiva e psicológica, que implicam no respeito e consideração mútuos em relação aos membros da entidade familiar. Cf. TARTUCE, Flávio et SiMÃo, José Fernando. Op. cit. (nota 380), pp. 31-32.

${ }^{462}$ Cf. PereIRA, Caio Mário da Silva. Op. cit. (nota 185), p. 33.

${ }^{463}$ Cf. SZYMANSKI, Heloisa. Viver em família como experiência de cuidado mútuo: desafios de um mundo em mudança. Revista Serviço Social e Sociedade, n. 71, pp. 10-11 apud PereIRA, Caio Mário da Silva. Op. cit. (nota 185), p. 42.

${ }^{464}$ Cf. Pereira, Tânia da Silva. O cuidado como valor jurídico. In: Pereira, Tânia da Silva et Pereira, Rodrigo da Cunha (coords.). A ética da convivência: sua efetividade no cotiano dos tribunais. Rio de Janeiro: Forense, 2006, p. 234 apud PEREIRA, Caio Mário da Silva. Op. cit. (nota 185), p. 56.
} 
sim de amor, de ternura, na busca da felicidade mútua, baseada na convivência diuturna e no respeito recíproco ${ }^{465}$.

Fala-se, também, como decorrência da afetividade, em uma nova forma de parentesco civil, a parentalidade socioafetiva, em que os laços de afeto e de solidariedade derivam da convivência e não dos laços sanguíneos. Logo, o vínculo familiar passa a constituir mais um vínculo de afeto do que um vínculo biológico ${ }^{466}$.

Portanto, resta claro que a afetividade é um dos princípios basilares do Direito de família na atualidade, constituindo sua diferença específica ${ }^{467}$.

Para ARNALDo RIZZARDO, o afeto é um valor inerente à vida humana. A sua essencialidade é dimensionada pelas repercussões negativas na personalidade caso não satisfatoriamente realizada, e a própria felicidade depende desse elemento ${ }^{468}$. Por isso, há um anseio social à formação de relações familiares afetuosas, pois, ao se enfatizar o afeto, a família passa a ser o local, por excelência, de promoção da dignidade humana e da felicidade.

Ante o exposto, pode-se afirmar que, segundo esta orientação doutrinária, a afetividade é uma das maiores conquistas advindas da família contemporânea, receptáculo de sentimentos e responsabilidades ${ }^{469}$. Nas palavras de SÉRGIO RESENDE DE BARROS: "ninguém nega a responsabilidade social da família para com os que nela vivem e convivem. Seria negar a própria essência do afeto ${ }^{, 470}$. Em suma: a realização da

465 “A partir da nova modelagem da família - fundada no afeto, na entreajuda e na valorização dos seus membros -, houve maior possibilidade de convívio entre pais e filhos, acentuando-se os sentimentos, alargando a preocupação e colaboração de uns com os outros”. SILVA, Cláudia Maria da. Op. cit. (nota 368), p. 130.

466 Neste sentido, CAIO MÁRIO DA SILVA PEREIRA entende que a primazia dos laços sanguíneos e patrimoniais foi rompida em prol do vínculo afetivo, delineando-se novos paradigmas e novos modelos de família. Cf. PEREIRA, Caio Mário da Silva. Op. cit. (nota 185), p. 50. Alguns autores chegam ao extremo de afirmar que a consagração de diferentes arranjos familiares indica que, na ordem jurídica brasileira vigente, a família encontra respaldo somente no afeto, e não mais em estruturas formais pré-definidas. Ou seja, no atual estágio, o direito de família seria baseado mais na afetividade do que na estrita legalidade. Cf. GISELDA Maria Fernandes novaes HironaKa, mencionada por José Fernando Simão e Flávio TartuCE. Cf. TARTUCE, Flávio et SimÃo, José Fernando. Op. cit. (nota 380), p. 24.

${ }^{467}$ Cf. PereIRA, Caio Mário da Silva. Op. cit. (nota 185), p. 33.

${ }^{468}$ Cf. RizZARDO, Arnaldo. Responsabilidade civil. $3^{\mathrm{a}}$ ed. Rio de Janeiro: Forense, 2007, p. 686.

${ }^{469}$ Cf. PEREIRA, Caio Mário da Silva. Op. cit. (nota 185), pp. 55-56.

${ }^{470}$ BARros, Sérgio Resende de. A tutela constitucional do afeto. In: PEREIRA, Rodrigo da Cunha (Coord.). Família e dignidade humana - anais do V Congresso Brasileiro de Direito de Família. Belo Horizonte: IBDFAM, 2006, p. 888. 
personalidade humana, segundo os padrões de dignidade já alcançados na atualidade histórica da civilização, é o princípio e o fim da tutela constitucional do afeto ${ }^{471}$.

\subsubsection{CRISE DA FAMÍLIA?}

Em razão das mudanças que se operaram no Direito de família, e no próprio núcleo familiar, cabe uma reflexão a respeito da anunciada crise que, para muitos estudiosos, acomete esta instituição.

Alguns doutrinadores afirmam que basta que se lance um rápido olhar sobre a sociedade contemporânea para que se tenha imediatamente a nítida impressão da crise que assoberba a família, e a debacle das forças morais seria a causa desse fato evidente ${ }^{472}$.

Assim se manifesta INÁCIO DE CARVAlHO NetO: "é certo, porém, que a família está em crise, posto que alguns o queiram negar. E a crise da família reflete diretamente na sociedade, já que aquela é a base estrutural desta „473.

Neste compasso, proclamam e lamentam a desagregação da família, ponderando que "nesse momento difícil, a missão do jurista é defender a instituição da família, onde quer que periclitem seus interesses, a fim de evitar-lhe a completa desagregação. Fortalecê-la, ampará-la, procurando neutralizar os elementos dissolventes, como o abandono das idéias religiosas e o temor das responsabilidades (...) ’474.

No entanto, segundo CAio Mário da Silva Pereira, esta crise é mais aparente do que real, “(...) pois o que se observa é a mutação dos conceitos básicos, estruturando o organismo familiar à moda do tempo, que forçosamente há de diferir da conceptualistica das idades passadas ${ }^{, 475}$.

Para o autor, o direito de nosso tempo manifesta cuidados especiais com a família, e nisto já revela uma grande diferença com o passado ${ }^{476}$. Em suas palavras: "não se pode esquecer, que a família, nas últimas décadas e neste início de milênio, busca mecanismos jurídicos diversos de proteção para seus membros, o respeito às diferenças,

${ }^{471}$ Cf. Idem, p. 889.

${ }^{472}$ Cf. MonTEIRO, Washington de Barros. Op. cit. (nota 348), p. 2.

${ }^{473}$ CARVALHO NETO, Inacio de. Op. cit. (nota 86), p. 88.

${ }^{474}$ MONTEIRO, Washington de Barros. Op. cit. (nota 348), p. 2.

${ }^{475}$ Pereira, Caio Mário da Silva. Op. cit. (nota 185), p. 7.

${ }^{476}$ Cf. ibidem. 
necessidades e possibilidades ${ }^{, 477}$. Ele concluiu que houve sensível mudança nos conceitos básicos, que a família modificou-se profundamente, e ainda está se transformando, porém não se podem definir linhas de contorno precisas, dentro do conflito de aspirações. Assim, não se deve falar em desagregação, nem proclamar-se verdadeiramente uma crise ${ }^{478}$.

Também Maria Helena Diniz assevera que a tão falada crise é ilusória: “o que realmente ocorre é uma mudança nos conceitos básicos, imprimindo uma feição moderna à família, mudança esta que atende às exigências da época atual, indubitavelmente diferente das de outrora ${ }^{, 479}$.

Neste sentido, BERNARDO CASTELO BRANCO observa que:

"no século XX foram intensas e profundas as mudanças experimentadas pela família, preparando as bases que alicerçaram a sua nova concepção, que, para alguns, impropriamente, evidenciava o início de seu declínio e de seu vaticinado desaparecimento. No entanto, as transformações apenas revelaram sua nova conformação alinhada com os valores sociais dos nossos dias, cumprindo ao Direito a tarefa de compreendê-los e sistematizá-los segundo essa nova realidade ${ }^{„ 480}$.

Assim, segundo o autor, ao direito de família tem sido continuamente imposta a necessidade de adaptar-se à realidade surgida no novo modelo de família, a partir do qual os antigos princípios, até então considerados inabaláveis, acabaram sendo modificados pela força do fato social ${ }^{481}$.

Já para MARIA CELINA BODIn DE MORAES “não se fala mais em crise ou em morte da família, expressões relativamente comuns até trinta anos atrás. (...) Crise houve, mas não investiu contra a família em si; seu alvo era o modelo familiar único, absoluto e totalizante representado pelo casamento ${ }^{\mathrm{A}} 482$.

Diante destas colocações, é certo afirmar que as relações familiares foram essencialmente atingidas pelas transformações da sociedade: entre pais e filhos, entre

\footnotetext{
${ }^{477}$ Idem, p. 8.

${ }^{478}$ Cf. idem, p. 32.

${ }^{479}$ DINIZ, Maria Helena. Curso de direito civil brasileiro: direito de família. v. 5. $24^{\mathrm{a}}$ ed. São Paulo: Sariava, 2009, p. 25.

${ }^{480}$ BRANCO, Bernardo Castelo. Op. cit. (nota 94), p. 27.

${ }^{481}$ Cf. idem, p. 31.

${ }^{482}$ MorAES, Maria Celina Bodin de. Op. cit. (nota 63), p. 183.
} 
cônjuges e entre os diversos membros do grupo familiar. Por isso se operaram as mudanças no ordenamento. Todavia, a nova concepção de família, que se constrói em nossos dias, não denota a sua crise ou desagregação ${ }^{483}$. A família ainda possui grande prestígio social e por isso mesmo recebe inequívoca proteção do Estado.

Contudo, devemos nos preocupar com as pressões externas, que clamam por modificações por vezes não acompanhadas e internalizadas pelos núcleos familiares, e que podem acabar por desestruturar toda a instituição em razão do conflito de valores. É importante ter sempre em mente que no seio da família originam-se e desenvolvem-se os hábitos, valores, inclinações e sentimentos que decidirão um dia a sorte do indivíduo.

Assim, fazemos nossas as palavras de CAIO MÁRIo DA Silva Pereira: “como organismo natural, a família não acaba. Como organismo jurídico, elabora-se sua nova organização ${ }^{, 484}$.

Influenciando e sendo influenciada pelas intensas mudanças ocorridas na sociedade, a família assumiu, sem dúvida, uma nova conformação que, longe de representar a sua extinção, constitui a manutenção de sua existência, nos lançando o desafio de compreendê-la sob uma nova ótica ${ }^{485}$.

\footnotetext{
483 A discussão sobre a existência de uma crise da família é também encontrada em outros países. Na Inglaterra, JONATHAN HERRING faz afirmação semelhante à que aqui defendemos: "Marriage may be in crisis, that does not mean families are”. HERRRING, Jonathan. Op. cit. (nota 402), p. 30.

${ }^{484}$ PEREIRA, Caio Mário da Silva. Op. cit. (nota 185), p. 32.

${ }^{485}$ Cf. BRANCO, Bernardo Castelo. Op. cit. (nota 94), p. 16.
} 


\subsection{Atual Tratamento do Dano Moral no Direito de Família}

Apresentadas as premissas básicas que envolvem a conceituação do dano moral, seu tratamento pela doutrina civilista, bem como os contornos atuais da família e sua regulamentação, podemos passar à análise da inclusão da responsabilidade civil na pauta do Direito de família.

Nas páginas que seguem vamos explorar o entendimento doutrinário e jurisprudencial a respeito da indenização do dano moral no âmbito familiar, descrevendo o status quaestiones, ou seja, como são analisados esses casos de agravo moral e como é aplicada tal responsabilização na prática.

Conforme demonstramos, é unívoco o entendimento, entre os juristas brasileiros, de que o afeto deve ser apontado como o principal fundamento das relações familiares. Não sendo mais novidade essa assunção do afeto como o alicerce do núcleo familiar, passa-se a dar maior importância aos aspectos afetivos da convivência, valorizando-se cada um dos membros da família.

Em contrapartida, esse enaltecimento do vínculo de afetividade passou a exigir a responsabilidade por atos cometidos no âmbito familiar. Pois, conforme assevera REGINA BEATRIZ TAVARES DA SiLVA, “a família tem como fonte de inspiração e base o amor, mas nem sempre esse sentimento, que não pode ser imposto a seus membros, entre eles perdura ${ }^{, 486}$.

Desta maneira, surge uma nova ordem de perguntas: os agravos decorrentes da falta de afeto entre os familiares, em situações extremas, como no término de um relacionamento ou no abandono de um filho, podem traduzir-se em indenização por danos morais ${ }^{487}$ ?

\footnotetext{
${ }^{486}$ SANTOS, Regina Beatriz Tavares da Silva Papa dos. Op. cit. (nota 95), p. 39.

${ }^{487}$ Esta questão pode ser desdobrada em outras: "o Estado Judiciário deve interferir nas relações familiares, nas relações de afeto? Caso positivo, com que intensidade? Até que ponto o Poder Público pode avançar na vida íntima das pessoas? Dano moral na relação conjugal é possível? É correto buscar um culpado na separação para efeito de indenização patrimonial quando acabou o amor? E o amor, a afetividade, pode-se impor às pessoas?". CASABONA, Marcial Barreto. Op. cit. (nota 189), p. 350. MARCIAL BARRETO CASABONA afiança que "a resposta a essas perguntas tem consequências jurídicas relevantes, e a má ou parcial angulação pode provocar um retrocesso jurídico diante da evolução trazida na vida nos últimos anos". Idem, p. 353.
} 
RUY RoSAdO DE AgUIAR JÚNIOR adverte que o tema da responsabilidade civil na família apresenta pontos de vista antagônicos ${ }^{488}$. Para o autor, são dois os valores constitucionais em confronto. De um lado, o princípio da dignidade da pessoa humana, que deve ficar protegida de qualquer agressão, ideia que se expande também para o Direito privado e tem vigência no Direito de família. De outro, a necessidade de proteção da entidade familiar, atribuída ao Estado. Ou seja, a dignidade do membro da família, como pessoa, pode entrar em conflito com o interesse da entidade familiar. Ele assevera que este fim de preservação da família - base da sociedade - pelo Estado, por certo fica dificultado ou pelo menos abalado com a possibilidade de pleitos reparatórios dos danos morais entre os cônjuges, ou entre pais e filhos ${ }^{489}$.

O jurista nota, ainda, uma segunda ordem de fatores divergentes. O Direito de família mostra uma tendência à sociabilidade, no entanto, o ordenamento acabou deixando a critério das pessoas a decisão sobre o casamento e a sua dissolução, e ampliou os direitos dos filhos, reforçando, nestes pontos, o individualismo e a autonomia da vontade. Deste modo, o interesse predominante passa a ser o da pessoa, não o da entidade familiar ${ }^{490}$. Portanto, no que se refere ao direito de família, cada vez mais a defesa da instituição família cede lugar à realização daqueles que a compõem ${ }^{491}$.

Por sua vez, Maria Celina Bodin De Moraes, partindo da premissa de que a família baseia-se na força do afeto, afirma: “(...) 'dano moral' $e$ 'direito de família' são expressões que em princípio se excluiriam e cuja combinação esboça um oximoro, quase um paradoxo (... $)^{, 492}$. No entanto, ela adverte que este entendimento deixa de ser tão claro quando se têm em consideração as profundas transformações por que passaram esses dois ramos do direito civil - o direito de família e a responsabilidade civil - nas últimas décadas ${ }^{493}$.

Assim, a passagem da família como instituição à família instrumento, capaz de propiciar um ambiente adequado à realização e ao desenvolvimento da personalidade de seus membros, suscitou uma maior autonomia dos mesmos. Esta tendência individualista

\footnotetext{
${ }^{488}$ Cf. AgUIAR JúnIOR, Ruy Rosado de. Op. cit. (nota 15), p. 1.

${ }^{489}$ Cf. ibidem.

${ }^{490}$ Cf. idem, pp. 1-2.

491 Cf. ReSEnde, Nara Rubia Alves de. Da possibilidade de ressarcimento dos danos decorrentes da dissolução da sociedade conjugal. Revista Brasileira de Direito de Família, n. 21, 2004, p. 6.

${ }^{492}$ MoRAES, Maria Celina Bodin de. Op. cit. (nota 63), p. 184.

${ }^{493}$ Idem, p. 186.
} 
nas relações familiares facilitou que se viesse a reavaliar a manutenção dos vínculos de convivência, bem como a qualidade do relacionamento desenvolvido entre os membros da família. Como consequência disto, surge a discussão acerca da possibilidade de indenização de danos exsurgidos das relações familiares ${ }^{494}$.

Por seu turno, o desenvolvimento teórico da responsabilidade civil, a que já fizemos referência, provocou a sistemática expansão da tutela da vítima. Ou seja, aquele instituto passou a se preocupar com o dano injusto, em contraposição à atenção exclusiva que era atribuída ao ato ilícito, transformando-se, aos poucos, em verdadeira fonte de proteção aos direitos fundamentais e se aproximando da noção de justiça ${ }^{495}$.

Essa preocupação crescente com a reparação dos danos injustos no âmbito da responsabilidade civil e a potencialização da autonomia no âmbito familiar acabaram por reduzir os fatores que tradicionalmente serviam como inibidores da responsabilidade civil no Direito de família ${ }^{496}$.

Some-se a isto o entendimento outrora prevalente de que as relações surgidas no interior da família não guardavam qualquer vínculo com as normas jurídicas reguladoras das demais expressões do comportamento humano. Havia um 'escudo' em torno das relações familiares, como se não convergissem com as demais normas do Direito.

Neste sentido, as condutas praticadas dentro dos limites familiares - lesivas ou não a quaisquer de seus membros - não se mostravam permeáveis à incidência das regras da responsabilidade civil, como se houvesse uma espécie de imunização desses acontecimentos às normas que tutelavam, nas demais esferas jurídicas, os direitos patrimoniais e extrapatrimoniais eventualmente violados ${ }^{497}$.

De acordo com BERnARdo CASTElo BRANCO, o caráter extrapatrimonial das relações familiares levaria a esta inaplicabilidade da responsabilidade civil, cabendo a institutos daquele ramo mesmo, como os alimentos, fazer as vezes da reparação ${ }^{498}$.

\footnotetext{
${ }^{494}$ Cf. ReSENDE, Nara Rubia Alves de. Op. cit. (nota 491), p. 6.

${ }^{495}$ Cf. MorAES, Maria Celina Bodin de. Op. cit. (nota 63), p. 186.

${ }^{496}$ Cf. idem, pp. 185-186.

${ }^{497}$ Cf. BRANCO, Bernardo Castelo. Op. cit. (nota 94), p. 17.

${ }^{498}$ Cf. idem, p. 18.
} 
Hodiernamente, esta afirmação de que as relações familiares são insensíveis às regras da responsabilidade civil já não encontra sentido, na medida em que os membros deste núcleo gozam de ampla proteção, especialmente no que toca aos direitos da personalidade, sendo inadmissível que os responsáveis por eventual violação permaneçam imunes, mesmo quando a infração se dê nos limites de uma relação jurídica de caráter especial, como é a relação de Direito de família ${ }^{499}$.

Ademais, conquanto alguns juristas ainda questionem a ausência de dispositivo específico em nosso ordenamento que trate da responsabilidade civil no Direito de família, o ressarcimento dos danos morais neste âmbito vem sendo admitido através da aplicação da regra geral da responsabilidade civil, instituída nos arts. 186 e 927 do Código Civil.

Quanto a este ponto, REgina BEATRIZ TAVARES DA SILVA pondera que sempre existirão princípios e normas de conduta a pautar a atuação do indivíduo, seja no núcleo menor - a família -, seja no grupamento maior, eis que a vida em sociedade necessita de uma organização, que é realizada pelo Direito ${ }^{500}$. É inegável, portanto, que “as normas de conduta têm em vista cumprir a finalidade do Direito, que é a mesma, como não poderia deixar de ser, do Direito de Família: restabelecer o equilíbrio das relações jurídicas, organizando a vida em sociedade ${ }^{, 501}$.

De se cogitar, por esta razão, se os instrumentos próprios do Direito de família são suficientes para atender aos desafios que se impõem ou se, opostamente, a concretização do princípio da dignidade humana reclama outra resposta, mais eficaz às violações aos direitos da personalidade ocorridas no seio familiar.

Todas essas transformações geraram um cenário em que se entrevê a possibilidade de convivência entre o dano moral e o direito de família, conquanto as consequências deste novo quadro não sejam pacíficas. Isto porque o processo de mudança impingido tanto na responsabilidade civil, quanto no direito de família, ainda não

\footnotetext{
${ }^{499}$ Cf. idem, pp. 18-19. Mencione-se, neste ponto, o Projeto de Lei 699/2011 (antigo PL 6.960/2002) objetiva incluir o $\$ 2^{\circ}$ no art. 927, prescrevendo que "os princípios da responsabilidade civil aplicam-se também às relações de família". O Parecer Vicente Arruda rejeitou tal proposta alegando que: "visa a explicitar o óbvio, ou seja, que nas relações de família são aplicados os princípios de responsabilidade civil. Tal regra já nos parece vigente, especialmente em se tratando da interpretação da norma geral do art. 186 do novo CC". DINIZ, Maria Helena. Op. cit. (nota 55), p. 217.

${ }_{500}$ Cf. SANTOS, Regina Beatriz Tavares da Silva Papa dos. Op. cit. (nota 95), p. 34.

${ }^{501}$ SILVA, Regina Beatriz Tavares da. Op. cit. (nota 198), p. 13.
} 
encontrou sua estabilização. No entanto, opiniões favoráveis ressaltam a importância desta confluência.

Na visão de MARIA CELINA BODIN DE MORAES: “a responsabilidade civil entra no seio familiar, reconhecendo danos a serem ressarcidos por maridos às esposas e viceversa, por pais aos filhos, excepcionalmente até por avós aos netos, pessoas habituadas a querer-se bem ou a relacionar-se com afeto" ${ }^{502}$. Desta maneira, "como em todas as demais relações jurídicas, também nas relações familiares, onde ocorrer lesão à igualdade, à integridade psicofísica, à liberdade e à solidariedade familiar terá ensejo o dano moral indenizável ${ }^{, 503}$.

Segundo VAlÉRIA Silva GALdino CARDin, a lesão entre membros da família é mais grave do que aquela provocada por terceiro, em virtude da situação privilegiada do familiar, justificando a responsabilização civil ${ }^{504}$.

Igualmente, é o raciocínio apresentado por FERNANDA OLTRAMARI e VITOR Hugo OltRAMARI: “(...) mais do que em qualquer outro ambiente, no familiar os direitos da personalidade precisam ser reconhecidos e valorizados. Afinal de contas, se entre as pessoas comuns o respeito e a consideração se impõem, ainda mais, no seio da família $^{, 505}$. Para os autores, dentro dessa realidade que valoriza a dignidade humana e garante à pessoa o centro de toda a tutela jurídica civil, é impossível não reconhecer a responsabilidade civil nas relações familiares ${ }^{506}$.

A possibilidade de indenização de valores imateriais é assinalada também por ARNALDO MARMITT, que chama a atenção para a ocorrência frequente da violência e de lesões aos direitos da personalidade neste âmbito ${ }^{507}$. Para JONES FIGUEIRÊDO ALVES, além

\footnotetext{
${ }^{502}$ MoRAES, Maria Celina Bodin de. Op. cit. (nota 63), p. 184.

${ }^{503}$ Idem, pp. 190-191.

${ }^{504}$ Cf. CARDIN, Valéria Silva Galdino. Op. cit. (nota 245), p. 69.

505 Oltramari, Fernanda et OlTRAMARI, Vitor Hugo. Op. cit. (nota 102), p. 54.

506 Segundo eles, não se pode mais conceber o desconhecimento e o silêncio das vítimas de afronta a tais direitos: "a acomodação, tanto das vítimas, como dos advogados e do Judiciário, em geral, à proposta inovadora do reconhecimento e responsabilização pelos danos causados em qualquer das hipóteses analisadas, beneficia e estimula o desrespeito à dignidade humana”. Idem, pp. 73-74.

${ }^{507}$ Cf. MARMiTT, Arnaldo. Dano moral. Rio de Janeiro: Aide, 1999, p. 113.
} 
de preservar a dignidade humana, a responsabilização auxilia na estabilidade institucional do núcleo familiar ${ }^{508}$.

No mesmo sentido, ARNALdo RIZZARDo postula que o Direito não pode ficar alheio à necessidade de proteção e de restabelecimento da ordem abalada, demandando o exame da responsabilidade em casos de afetação aos valores da afetividade ${ }^{509}$.

Para Rolf MAdAlEno, a lesão aos direitos e deveres de ordem familiar é ato sempre suscetível de originar reparação moral. Ele assegura que a indenização, nesses casos, estimula os demais integrantes da sociedade a cumprirem com os deveres éticos impostos nessas relações ${ }^{510}$.

Segundo VAléria Silva Galdino CARdin: “(...) calcada no entendimento de que nada destrói mais em uma família do que o dano causado pelos seus próprios membros, a reparabilidade do dano moral funciona como uma forma de fortalecer os valores atinentes à dignidade e ao respeito humano para aquele que jamais recebeu afeto $^{, 511}$.

Esses juristas defendem, portanto, que na família as garantias individuais igualmente precisam ser aplicadas, devendo-se utilizar as normas da responsabilidade civil quando um familiar, através de ato ilícito, atinge legítimo interesse extrapatrimonial de outro. Percebe-se a preocupação de que a negativa de reparação dos danos morais causados entre os membros da família significaria estímulo à sua reiteração. $\mathrm{O}$ raciocínio parte do pressuposto de que quando se produz um dano no âmbito familiar, a harmonia já não existe mais, havendo um processo de desintegração, sendo necessária a intervenção do Direito para garantir a integridade das pessoas e a sua dignidade.

Conforme sinalizamos nas primeiras passagens deste estudo, a discussão a respeito da responsabilidade civil emana, sobretudo, da preocupação com o tema da dignidade.

\footnotetext{
508 ALVES, Jones Figueirêdo. Algumas questões controvertidas no novo direito de família. In: Questões controvertidas no novo Código Civil. v. 1. São Paulo: Método, 2006, pp. 314-315.

${ }^{509}$ Cf. RizZARDO, Arnaldo. Op. cit. (nota 468), p. 686.

${ }^{510}$ Cf. MAdALENO, Rolf. Op. cit. (nota 49), pp. 272- 274.

${ }^{511}$ CARDIN, Valéria Silva Galdino. Op. cit. (nota 245), p. 71.
} 
JESUALDO EDUARDO DE ALMEIDA JÚNIOR assevera que “(...) é exatamente nas relações familiares em que se acentua a necessidade de proteção dessa dignidade, já que a família é o centro da preservação da pessoa" ${ }^{\text {512 }}$. Sendo a família a primeira destinatária dos direitos fundamentais, fica à mercê de todo o sistema de direitos e garantias previstos constitucionalmente, inclusive a reparação dos danos morais. Para o autor, não se pode falar em direitos de liberdade, de igualdade, de personalidade, à honra etc se tais não forem protegidos já no âmbito familiar ${ }^{513}$.

De modo semelhante, BERNARDO CASTElO BRANCO entende que a responsabilização, neste campo, não serviria como elemento desagregador, mas de salvaguarda da dignidade ${ }^{514}$. Ele garante que não há fundamento lógico-jurídico que justifique a impossibilidade de aplicação das regras da responsabilidade civil às relações de família, porquanto seus membros não escapam da proteção conferida aos direitos da personalidade pela circunstância de a violação ter sido praticada nos limites do núcleo familiar. E conclui que a indenização seria uma resposta enérgica do Direito privado, de sentido educativo, funcionando como um elemento de dignificação dos vínculos familiares $^{515}$.

Em suma, este pensamento afirma que a dignidade é um valor a ser privilegiado em todas as relações jurídicas, mas especialmente nas relações de família, com vistas à proteção da personalidade dos membros que a integram.

Nada obstante, alguns doutrinadores se preocupam em apontar os exageros em matéria de pedidos de indenização por dano moral, principalmente quando os excessos ingressam na seara do direito de família.

É o que destaca SÉRgIO GISCHKOW PEREIRA: “dificilmente o valor da solidariedade convive bem com os excessos monetarizantes (entendida esta expressão não em seu significado técnico econômico-financeiro, mas sim como indevida invasão do plano moral pelo elemento monetário)" amor como ponto central e alicerce do novo Direito de Família, buscando afastar a

\footnotetext{
${ }^{512}$ ALMEIDA JúNIOR, Jesualdo Eduardo de. Op. cit. (nota 141), p. 131.

${ }^{513}$ Cf. idem, pp. 131-132.

${ }^{514}$ Cf. BRANCO, Bernardo Castelo. Op. cit. (nota 94), p. 116.

${ }^{515}$ Cf. idem, pp. 208-209.

${ }^{516}$ PEREIRA, Sérgio Gischkow. Op. cit. (nota 142), p. 354.
} 
prevalência do aspecto patrimonial, seria incoerente admitir a mensuração de sentimentos e impulsos eróticos através do dinheiro" ${ }^{\text {517 }}$. Segundo afirma, o Direito de família moderno oferece argumentos de sobra para enfrentar a invasão monetária, pois está radicado na revalorização dos vínculos afetivos ${ }^{518}$.

Os juristas advertem que o uso indiscriminado dos instrumentos da responsabilidade civil em matéria familiar pode produzir um efeito deletério, patrimonializando essas relações. Contudo, pontuam que este temor não pode suplantar a necessidade de aplicação das regras da responsabilidade civil nos casos em que o Direito de família não fornece resposta suficiente.

Percebemos, assim, que a doutrina gradativamente vem acolhendo os princípios da responsabilidade civil, abandonando a ideia de que as regras do direito de família bastam para responder a todos os conflitos surgidos nessas relações. Apesar de algumas resistências, a reparação dos danos morais nas relações familiares é de aceitação crescente, denotando a convergência entre estes dois institutos.

É natural a apreensão dos operadores do Direito, desafiados a promover a compatibilização dos princípios da responsabilidade civil com as peculiaridades que cercam as famílias. Eis aí o grande desafio: encontrar o necessário equilíbrio entre a especificidade da relação familiar e a generalidade dos instrumentos de responsabilização ${ }^{519}$.

Nas páginas que seguem, apontaremos as hipóteses mais frequentes nas quais se ventila a indenização do dano moral nas relações familiares. Advertimos não ser possível exauri-las, meta inalcançável. Tal desiderato não se mostra factível diante da própria dinâmica das relações humanas e, em especial, das relações familiares, que

\footnotetext{
${ }^{517}$ Ibidem.

${ }^{518}$ Cf. idem, p. 362. O jurista ainda cita alguns exemplos, em sua opinião "tragicômicos", desta aplicação desmedida dos danos morais no âmbito familiar: “(...) a) impor ao cônjuge infiel a 'obrigação ' de comunicar a o parceiro ato eventual de adultério, destruindo o casamento que poderia se manter. b) O pai que visitaria o filho, e vice-versa, apenas por medo de ser réu em ação indenizatória por dano moral. Não seria pior para o filho, ou para o pai, ter uma atenção paterna ou filial falsa e forçada?! c) O cônjuge fazendo amor sob ameaça de indenização... E assim por diante”. Idem, p. 357.

${ }_{519}$ Cf. BRANCO, Bernardo Castelo. Op. cit. (nota 94), p. 207. MARCIAL BARRETO CASABONA assevera que a responsabilidade civil no Direito de família é questão polêmica e controvertida, devendo ser abordada e analisada com prudência, sendo que ao Direito é dada a missão de construir, deontologicamente, uma resposta a tais situações. Cf. CASABONA, Marcial Barreto. Op. cit. (nota 189), p. 350.
} 
impedem o estabelecimento de um rol exaustivo e definitivo das diferentes situações em que se poderia vislumbrar a incidência das regras de responsabilidade civil.

\subsubsection{ESPONSAIS OU NOIVADO}

Derivada do latim sponsio, a palavra esponsais significa promessa solene, compromisso ou garantia. Etimologicamente, portanto, indica o compromisso de casamento assumido pelos nubentes. EDUARDO ESPÍNOLA a define como "uma promessa que recìrocamente se fazem um homem e uma mulher, de futuramente se casarem",520.

No Brasil, a figura recebeu o nome de noivado, que passou a ser o termo mais utilizado para caracterizar o compromisso de contrair futuro casamento. Trata-se de um ato preparatório para o matrimônio, que possibilita aos noivos se conhecer melhor, aquilatarem suas afinidades e suas diferenças.

São requisitos indispensáveis para a configuração do noivado: a capacidade do agente, a manifestação do consentimento e a reciprocidade. A manifestação da vontade dos nubentes deve ser livre e espontânea, bastando a palavra recíproca, sem necessidade de se realizar uma festa de noivado. No entanto, esse compromisso deve transcender as relações personalíssimas dos noivos, não bastando as vãs promessas de casamento.

Assim, a questão não se prende à formalidade do noivado, mas à efetiva promessa de casamento futuro. Sempre haverá uma promessa antecedente ao casamento, mesmo que sem formalização. Nas palavras de EdUARDO DE OliveIRA LEITE, “(...) $a$ promessa de casamento existe e existirá sempre, porque, antes de o casamento ser celebrado, é preciso que o noivo conheça a noiva, que concordem em casar, que dirija aquele, à família da futura esposa, toda uma série de conversações preliminares que identificam a promessa como deliberação de vontade ${ }^{\text {,521. }}$.

A matéria, portanto, continua vigente e é de absoluta atualidade, a partir da simples consideração de que todo casamento é necessariamente precedido de uma promessa que reciprocamente se fazem um homem e uma mulher. Logo, o noivado é ato

\footnotetext{
${ }^{520}$ EsPínOlA, Eduardo. A família no direito civil brasileiro. Rio de Janeiro: Conquista, 1957, p. 33.

${ }^{521}$ LEITE, Eduardo de Oliveira. Rompimento da promessa de casamento: reparação dos danos material e moral. Revista da AJURIS, n. 51, 1991, pp. 67-68.
} 
que continua a ser praticado. O compromisso sempre existe, a formalização ou a oficialização é que podem não ocorrer.

Note-se que nosso Direito não regula os esponsais ou noivado. Efetivamente, não existe nenhum dispositivo no Código Civil, ou em qualquer legislação extravagante, que a ele faça referência. Nestes termos, já assinalava PONTES DE MIRANDA: "os esponsais são ato na dimensão ética; não entram para o mundo jurídico: para o Direito, permanecem no mundo fático "522. Na opinião de INACIO DE CARVALHO NETO: “trata-se, em verdade, de um vínculo de consciência e nada mais ",523.

Para o último autor, a omissão do nosso Direito não deve ser atribuída à falha do legislador, pois este não regulou os esponsais deliberadamente, porque não lhe quis emprestar validade, não pretendeu dar à promessa de casamento força suficiente para obrigar o promitente a se $\operatorname{casar}^{524}$. Deste modo, entende-se que a ideia subjacente à ausência de regulamentação foi garantir maior valor à liberdade de consentir no ato de celebração do casamento $^{525}$.

Não obstante essa ausência de enquadramento nas regras legais, muitos juristas afirmam que o Brasil apresenta um perfil sui generis, uma vez que persistem efeitos jurídicos relacionados aos esponsais ${ }^{526}$.

Várias teorias surgiram com o intuito de estabelecer a natureza jurídica da promessa de matrimônio, o que constitui, para alguns doutrinadores, um dos pontos mais interessantes e difíceis de todo o direito de família ${ }^{527}$. Já se afirmou tratar-se de uma simples relação de fato, de um verdadeiro contrato ou ainda de um pré-contrato. Não vamos analisar os pormenores destas teorias, mas apenas seus desdobramentos para uma possível responsabilização.

\footnotetext{
${ }^{522}$ MIRANDA, Pontes de. Tratado de direito privado: parte especial. v. 53. $3^{\text {a }}$ ed. São Paulo: Revista dos Tribunais, 1984, p. 233.

${ }^{523}$ Carvalho NeTO, Inacio de. Op. cit. (nota 86), p. 426.

${ }^{524}$ Cf. idem, p. 423.

${ }^{525}$ Idem, pp. 423-424.

${ }^{526}$ Cf. LEITE, Eduardo de Oliveira. Op. cit. (nota 521), p. 71.

${ }^{527}$ Cf. Carvalho Neto, Inacio de. Op. cit. (nota 86), p. 425.
} 
Afirmava JOSÉ DE AGUIAR DiAS que a promessa de casamento seria um verdadeiro contrato preliminar ${ }^{528}$.

Na visão de YUSSEF SAID CAHALI, ainda que se aceite o casamento como contrato em sua concepção naturalista (um 'contrato de direito de família'), a especificidade de suas características é inconteste: não comporta execução compulsória específica, nem se sujeita a preceito cominatório para declaração de vontade prometida. Desta maneira, segundo o jurista, em atenção ao primado da liberdade em matéria matrimonial, o vínculo só pode ser estabelecido mediante a livre prestação do consentimento no ato da celebração ${ }^{529}$.

Por esta razão, alguns juristas concluem que o instituto tem natureza de uma obrigação natural, desprovida de tutela jurisdicional ${ }^{530}$.

$\mathrm{Na}$ opinião de EDUARDO DE OLIVEIRA LEITE, juridicamente falando, compromisso não existe, uma vez que a posição unânime da doutrina e da jurisprudência brasileira é a de que os esponsais não têm qualquer sentido de obrigatoriedade, podendo a promessa ser rompida a qualquer momento, bilateral ou unilateralmente. Ou seja, é princípio de ordem pública que qualquer dos noivos tem a liberdade de se casar ou de se arrepender, mesmo no instante da celebração ${ }^{531}$.

MARIA Celina Bodin DE Moraes assegura que, entre todos os atos previstos no ordenamento, o casamento é o que se reputa mais dependente da vontade, consagrando a liberdade dos nubentes, bastando para fundamentar esta assertiva a consulta aos arts. 1.514 e 1.535 do Código Civil de 2002, que enaltecem a volição do ato ${ }^{532}$. Ela também invoca a ausência de regulamentação do contrato esponsalício para afirmar a liberdade subjacente ao matrimônio ${ }^{533}$.

Assim sendo, InAcio De Carvalho Neto conclui que "a promessa de casamento é de natureza toda especial, por faltar-lhe qualquer coercibilidade, a fim de

\footnotetext{
${ }^{528}$ Cf. DiAS, José de Aguiar. Da responsabilidade civil. v. 1. 10ª ed. Rio de Janeiro: Forense, 1995, p. 135 apud CARDIN, Valéria Silva Galdino. Op. cit. (nota 245), p. 76.

${ }_{529}$ Cf. CAHALI, Yussef Said. Op. cit. (nota 39), p. 573.

${ }^{530}$ Cf. CARDIN, Valéria Silva Galdino. Op. cit. (nota 245), p. 77.

${ }^{531}$ Cf. LeITE, Eduardo de Oliveira. Op. cit. (nota 521), p. 68.

${ }^{532}$ Cf. MORAES, Maria Celina Bodin de. Op. cit. (nota 63), p. 190

${ }^{533}$ Cf. ibidem.
} 
que, até o último momento, seja garantida aos noivos inteira liberdade de se arrependerem ${ }^{, 534}$.

Por conseguinte, os autores são unânimes em afirmar que o casamento deve ser celebrado dentro da mais absoluta liberdade, e nenhuma teoria tem o condão de obrigar o nubente arrependido a se casar. Ou seja, até a celebração do matrimônio, os nubentes poderão arrepender-se, desdizer-se, subtrair-se ao compromisso anteriormente assumido, sem receio de serem judicialmente compelidos a contrair núpcias ${ }^{535}$.

Examinando a questão, MARIA CElina Bodin DE MoraEs observa que no rompimento do noivado os interesses contrapostos são, de um lado, a liberdade de casar ou não casar e, de outro, a integridade psicofísica da pessoa abandonada. A contraposição demanda a ponderação dos interesses e, para ela, o princípio da integridade psíquica deve ceder diante do princípio da liberdade, mais condizente com a dignidade humana das pessoas envolvidas. Isto porque na concretização da cláusula de tutela da pessoa humana o ordenamento jurídico protege com maior rigor a liberdade (interesse considerado superior e garantido expressamente por numerosas normas do sistema), em razão da importância da autonomia da vontade no ato do casamento ${ }^{536}$.

Diante desta constatação, podemos concluir: a ruptura em si não é fonte de responsabilidade ${ }^{537}$. Este é o ponto nodal de qualquer estudo a respeito da indenização dos danos morais no noivado.

A conduta formal de descumprimento da promessa não apresenta natureza jurídica, contudo, o modo do exercício desta faculdade, as condições em que foi praticada, enfim, as circunstâncias deste ato podem transmutá-lo em fenômeno do Direito, alterando sua qualidade neutra, impingindo-lhe um valor negativo suficiente para ensejar a responsabilização. Vejamos como a doutrina examina a questão.

De acordo com o ensinamento de YUSSEF SAID CAHALI: “(...) a simples ruptura do noivado não legitima só por isso a pretensão indenizatória, se não vislumbrada

\footnotetext{
${ }^{534}$ CARVAlho NeTO, Inacio de. Op. cit. (nota 86), p. 425.

${ }^{535}$ Cf. OTERO, Marcelo Truzzi. A quebra dos esponsais e o dever de indenizar. Dano material e o dano moral. Revista dos Tribunais, n. 766, 1999, p. 101.

${ }^{536}$ Cf. MoraEs, Maria Celina Bodin de. Op. cit. (nota 63), p. 191.

${ }^{537}$ Cf. LEITE, Eduardo de Oliveira. Op. cit. (nota 521), p. 69.
} 
a ilicitude no rompimento ${ }^{\text {,538. }}$. O autor garante que o término de um relacionamento amoroso, com as angústias e frustrações que lhe são inerentes, por si só, não caracteriza dano moral indenizável. É preciso que se entreveja a prática de um ato ilícito, capaz de dar ensejo à responsabilização civil, pois, em muitos casos, a conduta do nubente situa-se somente no âmbito da reprovação moral, a qual, há tempos, não se confunde com os preceitos jurídicos aplicáveis ${ }^{539}$.

No mesmo sentido é a obtemperação de INACIO DE CARVAlHo NeTO: “(...) se não é possivel obrigar aquele que prometeu casamento a cumprir sua promessa, nem por isso seu ato ficará completamente impune. É possível que o promitente faltoso seja obrigado a indenizar danos causados em função do descumprimento " ${ }^{\text {"40 }}$. Para o jurista, não obstante nosso Direito efetivamente não tenha regulado os esponsais, não lhe atribuindo qualquer eficácia, não impediu que se falasse em obrigação de indenizar, com base na regra geral da responsabilidade civil $^{541}$.

Somente situações especiais permitem a indenização. ARNALDO RIZZARDO exemplifica: “(...) se, durando vários anos, simplesmente some o parceiro, sem qualquer justificação, em total desconsideração à pessoa; ou se procede escandalosamente, com a divulgação acintosa, e desprestigiando o namorado ou namorada, ${ }^{, 542}$.

Também para RUI STOCO, em casos excepcionais, nos quais o rompimento é injustificado e ocorra de forma anormal, através da mentira, do engodo e da indução em erro e, principalmente, da ofensa, do vilipêndio, da humilhação infamante e ignóbil é que se justifica a reparação civil do dano moral ${ }^{543}$. Assim, entende que “(...) esse rompimento, quando normal e civilizado, não tem o condão de ofender a moral ou a honra da pessoa, apta a configurar ato ilícito, posto que tal ruptura prende-se aos riscos e à fragilidade de

\footnotetext{
${ }^{538}$ CAHALI, Yussef Said. Op. cit. (nota 39), p. 569.

${ }^{539}$ Cf. ibidem.

${ }^{540}$ Carvalho Neto, Inacio de. Op. cit. (nota 86), p. 425.

${ }^{541}$ Cf. idem, p. 427-428. Quanto ao alheamento do Direito brasileiro à questão do noivado, VALÉRIA SILVA GALDINO CARDIN assegura: "mesmo havendo uma lacuna em nosso ordenamento jurídico, é evidente que a quebra unilateral da promessa de casamento irá gerar, além da obrigação de devolução dos presentes, das cartas e dos retratos, o direito a indenização, desde que o rompimento ocorra de forma dolosa ou culposa". CARDIN, Valéria Silva Galdino. Op. cit. (nota 245), p. 88.

${ }^{542}$ RIZZARDO, Arnaldo. Op. cit. (nota 468), p. 690. Nada impede que a recusa seja tácita: contrair um novo noivado, manter um comportamento impróprio ao de um noivo, conforme o costume social, ou partir para uma longa viagem sem dar notícias. Cf. CHAVES, Antonio. Esponsais. In: Enciclopédia Saraiva de Direito, v. 33. São Paulo: Saraiva, 1977, p. 325, apud CARVALHO NeTO, Inacio de. Op. cit. (nota 86), p. 437.

${ }^{543}$ Cf. STOCO, Rui. Op. cit. (nota 233), p. 899.
} 
tais relacionamentos ${ }^{, 544}$. Nestes termos, ele conclui que a indenização somente será aceita quando o rompimento do noivado for ofensivo à imagem ou à própria honra da parte repudiada $^{545}$.

Não há previsão legal do noivado, nem por isso, segundo EUCLIDES DE OLIVEIRA, cala-se o Direito, uma vez que nesta fase maior de compromisso de casar, a seriedade leva a outras consequências que são naturalmente aplicáveis no caso, especialmente no campo indenizatório, quando ocorre a quebra injustificada do dever assumido $^{546}$.

De acordo com MARia Celina Bodin De Moraes, na normalidade dos casos a integridade psíquica de um dos nubentes cede diante da liberdade do outro, valor que mais atende à dignidade humana. Porém, reconhece que a liberdade de romper o noivado tem limites, e o abuso é o principal deles ${ }^{547}$.

Calcada no sopesamento de princípios, ela admite que o exercício abusivo da liberdade, como na hipótese em que a noiva é deixada no altar, poderá fazer com que a tutela da integridade psíquica assuma maior peso, possibilitando, nessas situações extremas, a indenização por danos morais ${ }^{548}$. Ou seja, "o exercício da liberdade não pode chegar até este momento porque se torna abusivo e, na ponderação dos interesses concretos, mais peso assumirá a tutela da integridade psíquica, atingindo-se, neste caso e desta forma, a dignidade da pessoa assim abandonada" ${ }^{, 549}$. Logo, para a jurista, o momento a partir do qual o exercício desta faculdade se torna abusivo assume interesse particular.

Assim, a doutrina preleciona que a absoluta liberdade pretendida pelo legislador no ato de celebração do casamento - que impede a executividade da promessa não chega a infirmar a possibilidade de indenização em razão da ruptura qualificada do noivado, que não é indiferente ao Direito.

\footnotetext{
${ }^{544}$ Ibidem.

${ }^{545}$ Cf. idem, pp. 899-900.

${ }^{546}$ Cf. OliveIRA, Euclides de. A escalada do afeto no direito de família: ficar, namorar, conviver, casar. In: PEREIRA, Rodrigo da Cunha (Coord.). Família e Dignidade Humana - Anais do V Congresso Brasileiro de Direito de Família. Belo Horizonte: IBDFAM, 2006, p. 329.

${ }^{547}$ Cf. Moraes, Maria Celina Bodin de. Op. cit. (nota 63), p. 192.

${ }^{548}$ Cf. ibidem.

${ }^{549}$ Ibidem.
} 
EDUARDo DE OlIVEIRA LEITE assegura que, se não houver justo motivo legitimador da quebra do compromisso, o prejudicado terá o direito de obter judicialmente a reparação dos danos materiais e morais que sofreu, ou seja, em não ocorrendo o motivo justo, caracteriza-se a ruptura de promessa de casamento passível de indenização ${ }^{550}$. Assim, para o autor, quando a ruptura é decorrente de mero capricho, sem fundamento razoável, prejudicando a parte que, sem razão, viu sua expectativa frustrada, estamos adentrando no terreno dos elementos constitutivos, ou requisitos indispensáveis à caracterização da figura jurídica da ruptura de promessa de casamento ${ }^{551}$.

INACIO DE CARVALHO NeTO assevera que a indenização dos danos morais é, hoje, praticamente pacífica, e que a recusa do consentimento prometido poderá representar gravame aos legítimos interesses de afeição, estima e consideração do parceiro preterido $^{552}$, no entanto, ressalta a necessidade de que o nubente não tenha justo motivo para que se possa admitir a indenização, pois havendo justificativa, não se pode falar em ato culposo 553 .

Não é outro o entendimento de VALÉRIA SiLVA GALDINO CARDin, para quem, a despeito da liberdade de desfazer a promessa, o abandono sem justo motivo poderá resultar em danos materiais e morais ${ }^{554}$. Da mesma maneira, YUSSEF SAID CAHALI é absolutamente favorável a indenização quando rompido o compromisso esponsalício sem justa causa ${ }^{555}$.

Assim, concluem que o arrependimento não só é possível, como previsível pela ordem pública, com aval da ordem jurídica. Entretanto, se acarretar prejuízos àquele que tomou providências com vistas ao futuro casamento, e não houver justo motivo legitimador de tal atitude, o prejudicado terá o direito de obter judicialmente a reparação do dano, material e moral ${ }^{556}$. Ou seja, caso não haja justo motivo, estes juristas entendem ser

\footnotetext{
${ }^{550}$ Cf. LEITE, Eduardo de Oliveira. Op. cit. (nota 521), p. 74.

${ }^{551}$ Cf. idem, p. 73. Em suas palavras: "ruptura injustificada em face da moral e dos costumes sociais, como o será quando devida a uma leviandade, e um capricho, quando constituir uma deslealdade ou perfídia, um ato de ambição ou egoísmo". Idem, p. 75.

${ }^{552}$ Cf. CARVAlho Neto, Inacio de. Op. cit. (nota 86), p. 445.

${ }_{553}^{55}$ Cf. idem, p. 438.

${ }^{554}$ Cf. CARDIN, Valéria Silva Galdino. Op. cit. (nota 245), p. 86.

${ }^{555}$ Cf. CAHALI, Yussef Said. Op. cit. (nota 39), p. 569.

${ }^{556}$ Cf. LEITE, Eduardo de Oliveira. Op. cit. (nota 521), p. 69.
} 
possível a responsabilização do nubente pelos danos ocasionados com o rompimento do noivado 557 .

Consequentemente, de acordo com esta ideia, toda a questão se desdobra na análise do justo motivo. Porém, da mesma forma em que o ordenamento jurídico não faz referência aos esponsais, também não oferece critérios para estabelecer quais as causas de rompimento que podem ser consideradas justas, nem enumera as situações que ensejam a indenização por danos morais, outorgando ao magistrado, diante do caso concreto, avaliar se houve ou não justo motivo, para então determinar a indenização. Alguns autores procuram estabelecer parâmetros para auxiliar nessa tarefa, mas a doutrina tem se mostrado vacilante quanto à caracterização do que seja motivo justificado ${ }^{558}$.

Para Francisco José Viveiros De CASTRo, justo é o motivo que, uma vez conhecido por uma das partes, a impediria de contrair a promessa de casamento ${ }^{559}$.

Neste sentido, VALÉRIa SiLVA GALDINO CARDIN elenca o que considera justa causa para a recusa: a enfermidade contagiosa ou não, que impossibilite a vida em comum; a infidelidade; a utilização de entorpecentes; a prática de crimes; a mudança de religião; a desonestidade; a insolvência civil, dentre outros, são hipótese aceitas para a ruptura legítima ${ }^{560}$

Por sua vez, MARIA HELENA DINIZ estabelece gradações para aclarar o justo motivo: pode ser grave (erro essencial, sevícia, injúria grave ou infidelidade); leve (prodigalidade, condenação civil por crime desonroso, aversão ao trabalho ou falta de honestidade); ou levíssimo (mudança de religião, grave enfermidade ou constatação de impedimentos ignorados pelo noivo) ${ }^{561}$.

Percebemos, neste ponto, um paralelo entre alguns dos citados justos motivos e aquelas situações, contidas no Código Civil, que autorizam a anulação do casamento em

\footnotetext{
${ }^{557}$ Para o autor argentino RICARDO J. DUTTO, a ausência de explicações não caracteriza quer o dolo, quer a culpa, de maneira que, em razão da absoluta liberdade garantida pela lei, nega a possibilidade de indenização no rompimento do noivado. Cf. DUTTO, Ricardo J. Op. cit. (nota 169), p. 127.

${ }^{558}$ Cf. LeITE, Eduardo de Oliveira. Op. cit. (nota 521), p. 75.

${ }^{559}$ Cf. CASTRO, Francisco José Viveiros de. Os delitos contra a honra da mulher. $3^{\text {a }}$ ed. Rio de Janeiro: Freitas Bastos, 1936, p. 218, apud CARDIN, Valéria Silva Galdino. Op. cit. (nota 245), p. 86.

${ }^{560}$ Cf. CARDIN, Valéria Silva Galdino. Op. cit. (nota 245), p. 87.

${ }^{561}$ Cf. DINIZ, Maria Helena. Op. cit. (nota 55), p. 214.
} 
razão de erro sobre a pessoa do cônjuge, como teremos a oportunidade de explorar mais adiante.

De seu turno, EdUARDo DOS SANTOS aponta que as justas causas seriam aquelas que, segundo as concepções que dominam o ambiente social dos nubentes, obstariam a exigência razoável de continuação do noivado ou a celebração do casamento $^{562}$. A diferença, aqui, assenta-se na consideração da esfera específica dos noivos para encontrar o termo de valoração.

Nesta análise, MARCO AURÉLIO S. ViAnA afirma que têm papel importante o nível social dos envolvidos e as circunstâncias que o caso apresenta. Assim, o magistrado deverá examinar cada caso em função das suas particularidades ${ }^{563}$.

Para EduARDo DE Oliveira Leite, a delimitação entre o que é resultado de uma séria reflexão ou o que é fruto de mero capricho é matéria essencialmente casuística $^{564}$. JosÉ DE AGUIAR DIAS já advertia que em sede de promessa de casamento têm grande influência as circunstâncias do caso concreto ${ }^{565}$, e RUI STOCO acrescenta que não há como estabelecer, a priori, todas as hipóteses que ensejam compensação por dano moral pela ruptura do noivado, pois a casuística fática subsumível ao preceito garantidor é vasta e dinâmica, modificando-se ao longo do tempo, segundo os novos costumes, as alterações sociais e o comportamento das pessoas ${ }^{566}$.

Não obstante, InACiO DE CARVALHO Neto ressalva que “(...) não se pode considerar causa justa para o arrependimento o simples fato de ter o nubente verificado a futura inviabilidade do casamento, seja por desamor, seja por qualquer outra causa dessa natureza ${ }^{, 567}$. Na sua visão, a antijuridicidade do arrependimento estará evidenciada pela promessa de casamento precipitada, sem que o nubente tenha antes averiguado a sua viabilidade $^{568}$.

\footnotetext{
${ }^{562}$ Cf. SANTOS, Eduardo dos. Direito de família. Coimbra: Almedina, 1999, p. 154, apud CARDIN, Valéria Silva Galdino. Op. cit. (nota 245), p. 86.

${ }^{563}$ Cf. Viana, Marco Aurélio S. Esponsais ou promessa de casamento. Ajuris, n. 29, 1983, p. 171.

${ }^{564}$ Cf. LeITE, Eduardo de Oliveira. Op. cit. (nota 521), p. 76.

${ }^{565}$ Cf. DIAS, José de Aguiar. Op. cit. (nota 44), p. 572.

${ }^{566}$ Cf. STOCO, Rui. Op. cit. (nota 233), pp. 900-901.

${ }^{567}$ CARVAlHo Neto, Inacio de. Op. cit. (nota 86), p. 439.

${ }^{568}$ Cf. idem, p. 440.
} 
Ante o exposto, apreende-se que a doutrina majoritária embasa o pleito do ressarcimento de danos no noivado na ausência de justo motivo - a caracterizar o arrependimento como um ato ilícito. Em razão da própria ruptura, não cogitam da reparação.

Para EdUARDo DE Oliveira LeITE, o fato de o legislador não ter disciplinado os esponsais como instituto autônomo demonstra que preferiu deixar a responsabilidade civil pelo rompimento injustificado de promessa sujeita à regra geral do ato ilícito ${ }^{569}$. Também Yussef SAID CAHALI assim apreende: “dai concluir-se que o silêncio do Código Civil (tanto do anterior quanto do atual) não obsta, em tese, a que os esponsais possam dar causa a uma indenização de danos, se verificados os pressupostos do ato ilícito ou abusivo (...), ${ }^{, 570}$.

Neste sentido, a hipótese tem inteira subsunção no art. 186 do Código Civil, dispositivo suficientemente genérico para abranger o rompimento da promessa de casamento $^{571}$. Este seria o fundamento para o pleito da indenização, além do art. 927 do mesmo diploma, que lhe é complementar ${ }^{572}$.

Por conseguinte, devem estar presentes os pressupostos da responsabilidade civil, competindo ao magistrado verificar a existência de prejuízo ou dano, o nexo de causalidade, além de, é claro, constatar se houve justo motivo para a ruptura.

Esta corrente doutrinária alega ainda que resistir à tese da reparação, sob o argumento de que se estaria indiretamente compelindo o promitente à execução da promessa, fica negada pela legislação civil em vigor, pois a regra geral da responsabilidade legitima tal indenização ${ }^{573}$.

No entanto, alguns autores ressalvam que não se pode falar propriamente em ato ilícito, já que aquele que promete casamento não é juridicamente obrigado a cumprir tal promessa, caracterizando-se o rompimento do noivado, na realidade, um exercício abusivo

\footnotetext{
${ }^{569}$ Cf. LEITE, Eduardo de Oliveira. Op. cit. (nota 521), p. 69.

${ }^{570}$ CAHALI, Yussef Said. Op. cit. (nota 39), p. 568.

${ }^{571}$ Cf. Carvalho Neto, Inacio de. Op. cit. (nota 86), p. 431.

572 Michel MASCARENHAS Silva aponta que o inciso III do art. $5^{\circ}$ da Lei Maria da Penha também indicaria a possibilidade de responsabilização no rompimento do noivado, pois estabelece a violência doméstica englobando o dano moral nas relações íntimas de afeto, quando tenha havido convivência, ainda que sem coabitação. SILVA, Michel Mascarenhas. Op. cit. (nota 84), pp. 131-132.

${ }^{573}$ Cf. LeITE, Eduardo de Oliveira. Op. cit. (nota 521), pp. 69-70.
} 
do direito ${ }^{574}$. Esta é a opinião de INACIO DE CARVALHO NETO, que aponta o art. 187 do Código Civil como fundamento legal da reparação ${ }^{575}$. O autor esclarece que a abusividade se caracteriza pela forma como se dá o rompimento, não pelo arrependimento da promessa em si, que é um direito do nubente. Portanto, a indenização não é um efeito da retratação, mas do abuso que ela pode representar ${ }^{576}$.

Já na visão de YUSSEF SAID CAHALI, independentemente de o arrependimento injusto caracterizar-se como ato ilícito ou abuso de direito, é certo que a recusa do consentimento prometido poderá representar gravame aos legítimos interesses de afeição, estima e consideração do parceiro preterido, ou seja, injusta agressão à sua dignidade ${ }^{577}$. Ele assegura que ao vincular o dano moral à conduta injuriosa que envolve o arrependimento, não se deixa o agravo sem a reparação devida; negar a indenização, neste caso, significaria levar o primado da plena vontade matrimonial ao extremo, sacrificando nobres e legítimos sentimentos do nubente repudiado ${ }^{578}$.

Uma última alternativa seria conceber esta responsabilidade como contratual. Mas sobre ela já advertiu INÁCIO DE CARVALHO NETO: "para considerar que a responsabilidade seja contratual seria preciso admitir (como já se sustentou) que a obrigação tem por conteúdo primário o ressarcimento dos prejuízos, não o dever da prestação. Mas o caráter paradoxal desta teoria dispensa explicações "579.

Descartada esta hipótese, portanto, a doutrina trabalha com as ideias de ato ilícito e abuso de direito para sustentar juridicamente a possibilidade de responsabilização.

Na jurisprudência, encontramos manifestações antigas de nossos pretórios a este respeito. Muitos magistrados acolhem os pedidos de indenização por danos morais decorrentes da quebra do noivado, invocando, no mais das vezes, a dor e o sofrimento que advêm do rompimento desmotivado. Frise-se que este tema continua ocupando espaço em nossos tribunais, não sendo inexpressiva, ao contrário do que se pretende, a quantidade de julgados a respeito.

\footnotetext{
${ }^{574}$ Cf. CARVAlho NeTO, Inacio de. Op. cit. (nota 86), p. 428.

${ }^{575}$ Em suas palavras: "a tese do exercício de um direito não se compadece com a teoria do abuso do direito. O rompimento injusto da promessa configura exercício abusivo do direito, o que obriga à indenização”. Idem, p. 431.

${ }^{576}$ Cf. idem, pp. 428-429.

577 Cf. CAHALI, Yussef Said. Op. cit. (nota 39), pp. 573-574.

${ }^{578}$ Cf. idem, p. 574.

${ }^{579}$ Carvalho NeTO, Inacio de. Op. cit. (nota 86), p. 427.
} 
No caso mais antigo de que se tem notícia, o Tribunal de Justiça de Minas Gerais não acolheu o pedido de indenização por danos morais, considerando não provado o traumatismo nervoso alegado pela autora. Cuidava-se de pedido de indenização de noiva abandonada no altar pelo noivo, que não aparecera na igreja. Importante mencionar que o voto do relator esclarece que a indenização não seria concedida pelo simples rompimento do noivado, pois não se ignora que o réu era livre para se casar ou não ${ }^{580}$.

Também em sentido contrário: "noivado é compromisso de natureza puramente moral e, por isso mesmo, ao desamparo de qualquer norma jurídica. Assim, o seu rompimento, em tese, não admitirá nenhuma sanção de ordem econômicofinanceira" ${ }^{, 581}$.

Já o Tribunal de Justiça de São Paulo acolheu pedido de indenização dessa natureza: "a ruptura do noivado, quando este ocorre após sinais de sua exteriorização, alcançando familiares e amigos, gera a indenização por dano moral, uma vez abalados os sentimentos da pessoa atingida, não só em relação a si própria como também perante os grupos sociais com os quais se relaciona ${ }^{\text {,582. }}$.

Neste mesmo sentido foi o entendimento do Tribunal de Alçada Cível do Paraná:

"Responsabilidade civil - Indenização - Dano moral - Artigo $5^{\circ}$ inciso V da Carta Magna - Rompimento de relacionamento amoroso - Possibilidade - Ligação afetuosa e com vias a um futuro casamento - Ruptura desmotivada - Fato que gera a responsabilidade civil. 1. Produzindo-se dano que afeta a parte social da ofendida, seu patrimônio moral, como a honra, reputação, causando-lhe dor, tristeza, com privação da paz, da tranqüilidade de espírito, impõe-se reparação do dano moral. 2. Evidenciadas circunstâncias gravemente injuriosas a envolver a ruptura de relacionamento amoroso, a mulher agravada em sua honra, pela promessa de casamento, tem direito a reparação do dano sofrido, ${ }^{\text {,583. }}$.

Note-se que os Tribunais de Justiça têm confirmado, com relativa frequência, sentenças que estipulam indenização por danos morais em decorrência do rompimento

\footnotetext{
580 TJMG, Ap. Cível n. 38.627, Rel. Des. Assis SANTIAGO, 1974.

${ }^{581}$ TJGuanabara, Ap. Cível n. 90.057, Rel. Des. IVAN LOPES RIBEIRO.

582 TJSP, $2^{\text {a }}$ Câm., Ag. de Inst. n. 36.868-4/3, Rel. Des. Osvaldo CARON, 1997.

${ }^{583}$ TAC do Paraná, Ap. Cível n. 141.321-2, j. em 05-10-99.
} 
imotivado do noivado, como conduta infringente do princípio da boa-fé ou, mais comumente, como ato ilícito ${ }^{584}$.

Assim, acompanhando a doutrina, os magistrados exigem que a ruptura tenha sido injustificada para deferir a indenização, dando atenção, neste exame, ao momento e à forma do rompimento.

Na experiência estrangeira, as soluções são diversas.

EDUARDO DE OLIVEIRA LEITE divide as legislações estrangeiras quanto à regulamentação das promessas de casamento, em quatro classes diferentes: à primeira pertencem os códigos que veem nos esponsais um verdadeiro contrato, e o seu inadimplemento gera a plena obrigação de indenizar - são exemplos típicos os códigos suíço e anglo-americano; à segunda classe filiam-se os códigos que não vislumbram nos esponsais qualquer manifestação contratual, deles não resultando a obrigação de casar, tampouco de satisfazer penas estipuladas, reconhecendo, porém, a possibilidade de indenização à parte repudiada - são representantes desta categoria os códigos austríaco, espanhol, italiano, mexicano, peruano e venezuelano; já a terceira classe, a qual o Brasil se filia, omite qualquer disposição concernente aos esponsais, é igualmente a situação dos códigos francês e romeno; por fim, há uma quarta categoria, que não silencia sobre os esponsais, mas declara expressamente que a lei não os reconhece, nem admite qualquer ação de indenização por prejuízo deles resultantes, pois, como ato privado, encontra seus ditames e limites na honra e consciência pessoais - a esta classe pertencem os códigos uruguaio, chileno e colombiano ${ }^{585}$.

Em complemento, InACIO DE CARVALHo NeTO, destaca que o Direito alemão (BGB, $§ 1.298$ e §1.299) e do Direito português (art. 1.594) regulam os esponsais não para obrigar o cumprimento da promessa, mas justamente para negar tal efeito ${ }^{586}$.

$\mathrm{Na}$ Argentina, a Lei de Matrimônio Civil proibia a indenização por danos causados pelo noivado em seu art. $8^{\circ}$. A Lei 23.515 , contudo, suprimiu esta proibição, abrindo espaço para a reparação neste seara ${ }^{587}$.

\footnotetext{
${ }^{584}$ Cf. MORAES, Maria Celina Bodin de. Op. cit. (nota 63), p. 189.

${ }^{585}$ Cf. LEITE, Eduardo de Oliveira. Op. cit. (nota 521), p.70.

${ }^{586}$ Cf. CARVAlHO NeTO, Inacio de. Op. cit. (nota 86), pp. 422-423.
} 
Graciela Medina cita um caso julgado por magistrado de Córdoba, onde se admitiu a indenização no rompimento do noivado, com fundamento em dois atos que indicavam a culpa do noivo: a) manteve relação com terceira pessoa ao longo dos preparativos para o casamento, inclusive quando se tornou público o futuro casamento (com exposição de lista de presentes, curso de noivos, eleição de padrinhos, reserva de viagem de lua de mel etc); e $b$ ) o noivado foi rompido intempestivamente, quando as causas da ruptura já eram conhecidas com muita anterioridade ${ }^{588}$.

Cumpre assinalar, entretanto, que a sentença foi reformada pela Câmara de Apelações, sob o argumento de que a ruptura intempestiva deveu-se não à má-fé, mas sim à imaturidade do noivo, e que não havia prova da aludida relação sentimental com terceiro $^{589}$.

\subsubsection{CASAMENTO}

O debate sobre o dano moral no Direito de família encontrou seu ápice na análise de sua admissão entre cônjuges.

Em razão da recente discussão sobre a permanência da separação em nosso ordenamento, tornou-se impróprio o termo dano moral na separação, que era comumente utilizado para designar esta hipótese. Daí optarmos por intitular este capítulo simplesmente por casamento, pois esta é a origem do relacionamento em que o dano é cometido.

Muitos juristas reconhecem os efeitos devastadores da ruptura da sociedade conjugal, que podem ser potencializados por atitudes que afrontam os direitos da personalidade dos cônjuges.

BeRnaRdo CASTElo BRANCO chama a atenção para o fato de que, conquanto fosse ideal que os antagonismos próprios da convivência familiar encontrassem solução na compreensão, no respeito e no afeto mútuos, a conduta humana nem sempre se pauta por esses valores. Para o jurista, o notório aumento das separações e divórcios evidencia o crescimento da intolerância, do egoísmo e da violência. Por isso, adverte que não se pode

\footnotetext{
${ }^{587}$ Cf. MEDINA, Graciela. Daños en el derecho de familia. $2^{\text {a }}$ ed. Santa Fé: Rubinzal-Culzoni, 2008, pp. 199203.

${ }^{588}$ Cf. idem, pp. 205-211.

${ }^{589}$ Cf. idem, p. 211.
} 
adotar como dogma a ideia de que a pessoa no seio de sua família estaria imune a eventuais ataques aos seus direitos, por parte daqueles que com ela convivem ${ }^{590}$.

Já na década de 90, CARlos AlBerto BitTAR vislumbrava a possibilidade do surgimento de danos morais entre os cônjuges: "na verdade, há, na ruptura de casamento, situações em que se atingem os direitos da personalidade do outro cônjuge, suscitando então a discussão mais atenta da responsabilidade civil" ${ }^{, 591}$. Ele considerava que essa ruptura, sendo injusta, poderia gerar reparação por danos morais e patrimoniais ${ }^{592}$.

No entanto, notava que o assunto não era estudado com profundidade pela doutrina, pois a maior parte das questões se resolvia dentro das regras do Direito de família, os envolvidos costumavam contentar-se com o instrumental próprio desta área, como a dissolução do vínculo. Ademais, para o jurista, outra razão dessa carência de estudos era a recente estruturação da teoria dos direitos da personalidade e, consequentemente, de toda a temática da reparação de danos que atingem esses direitos. Assim, para o enfrentamento do tema, informava que seria necessário, inicialmente, estabelecer algumas noções sobre o dano, passando-se então à análise do dano na relação conjugal $^{593}$.

Também JosÉ DE CASTRo BIGI mencionava o assunto, fazendo importantes alusões aos direitos da personalidade. Ele reconhecia a intenção do legislador em garantir o socorro da justiça civil para aquele que, no casamento, sofresse violação da sua intimidade, da sua vida privada, da sua honra e imagem ${ }^{594}$.

No entanto, essa responsabilidade civil entre os consortes desavindos, por muito tempo, soou como algo estranho e inusitado para a doutrina.

A admissão dos danos morais entre cônjuges somente obteve respaldo teórico no final do século XX. Invocando a Constituição, especialmente os direitos da personalidade nela consagrados, vários autores encontraram viabilidade na tese sob o

\footnotetext{
${ }^{590}$ Cf. BRANCO, Bernardo Castelo. Op. cit. (nota 94), p. 19.

${ }^{591}$ BITTAR, Carlos Alberto. Op. cit. (nota 11), p. 277.

${ }^{592}$ Cf. idem, p. 284.

${ }^{593}$ Cf. idem, p. 277-278.

${ }^{594}$ Cf. BIGI, José de Castro. Op. cit. (nota 272), p. 48.
} 
argumento de que "a ofensa à dignidade constitui um dano moral, um dano injusto e caberá ao cônjuge culpado o dever de indenizar,"595.

Portanto, pode-se afirmar que o Direito brasileiro só recentemente passou a admitir a aplicação dos princípios da responsabilidade civil nas relações familiares, em especial no âmbito do matrimônio. Todavia, ainda hoje, não há em nosso ordenamento dispositivo específico que trate dessa reparação dos danos entre cônjuges, ao contrário de alguns países, nos quais esta hipótese alcançou a categoria de norma positiva.

Não obstante, muitos avaliam que um importante passo foi dado, na medida em que o casamento deixou de ser considerado circunstância excepcional, a restringir a proteção conferida pela ordem jurídica aos direitos da personalidade. Ou seja, o relacionamento conjugal não se coloca mais como obstáculo à indenização por danos que normalmente se concedem às pessoas que não possuem esse vínculo ${ }^{596}$.

Na visão de ARNALDo RizZARDO, dado o enaltecimento de valores pessoais, morais, próprios da alma, da estima, dos sentimentos - todos relacionados à valorização da personalidade - o cônjuge passou a prezar-se como ser humano sujeito de direitos e deveres, em especial no que envolve a afetividade, o respeito, a liberdade, a honra, a integridade moral e a absoluta igualdade no casamento ${ }^{597}$.

Ante essas considerações, MARCIAL BARRETO CASABONA ressalta que não há como tratar a questão da indenização por dano moral na ruptura da relação conjugal sem passar pela análise do princípio da dignidade humana ${ }^{598}$, porém adverte que é necessária cautela, uma vez que, frequentemente, as separações ocorrem em um clima de ódio e vingança ${ }^{599}$. Assim, ele indaga: "mas será que as dores de cada um justificam judicialização? Será que todo o comportamento decorrente do término da relação de afeto dá ensejo ao aparecimento do dano moral e sua respectiva reparação? É certo que não ${ }^{, 600}$.

\footnotetext{
${ }^{595}$ BIGI, José de Castro. Op. cit. (nota 272), p. 49.

${ }^{596}$ Cf. RIZZARDO, Arnaldo. Op. cit. (nota 468), p. 694.

597 Cf. idem, p. 693.

${ }^{598}$ Cf. CASABONA, Marcial Barreto. Op. cit. (nota 189), p. 354.

599 Idem, p. 360.

${ }^{600}$ Ibidem.
} 
Ruy Rosado DE AgUIAR JÚNIOR assevera que o tema situa-se no vértice de duas tendências modernas: de um lado, a ampliação do instituto da responsabilidade civil, cujo eixo se desloca do fato ilícito, para se preocupar cada vez mais com a reparação do dano injusto, o que facilita o deferimento do pedido de indenização; e, de outro, a abstração do elemento culpa para a separação e o divórcio, o que elimina a possibilidade de incidência do instituto da responsabilidade subjetiva nessas situações ${ }^{601}$. Logo, “(...) $a$ dissolução da relação conjugal é momento propício para aflorar pedidos indenizatórios, cujo deferimento está hoje facilitado com a importância que se atribui à demonstração do dano injusto, mas o modo pelo qual se resolve a separação ou o divórcio inibe qualquer exame de elemento subjetivo, a afastar eventual pedido de reparação "602.

Para o jurista, o posicionamento da pessoa como centro da ordem jurídica também não se harmoniza com a regra do Código Civil que prescreve a comunhão de vida no casamento (art. 1.511). Ou seja, o princípio da supremacia da pessoa, sobre o qual se fundamenta o pedido indenizatório, se mostra incompatível com a concepção original do casamento $^{603}$. Nestes termos, ele pondera: "ou há uma unidade plena de vida, com supressão ou limitação de demandas entre os conviventes, ou bem se resguarda a integridade da pessoa, inclusive com o incentivo a demandas judiciais indenizatórias "604.

Para JESUALDO EdUARDo DE AlMEIDA JÚNIOR, a problemática resume-se em definir se o pleito de reparação de danos morais perante o cônjuge é abusivo ou legítimo $^{605}$.

Vejamos, então, em pormenores esta questão.

\subsubsection{Natureza jurídica}

Há tempos a doutrina trava intenso debate acerca da natureza jurídica do matrimônio. As intercorrências desta discussão são importantes para o estudo da responsabilidade civil entre cônjuges, pois se faz necessário apurar se a eventual

\footnotetext{
${ }^{601}$ Cf. AgUiar Júnior, Ruy Rosado de. Op. cit. (nota 15), pp. 2-3.

${ }^{602}$ Idem, p. 3.

${ }^{603}$ Cf. idem, p. 2.

${ }^{604}$ Ibidem.

${ }^{605}$ Cf. AlmeIDA JÚNIOR, Jesualdo Eduardo de. Op. cit. (nota 141), p. 123.
} 
responsabilização estaria assentada em um descumprimento contratual ou em uma responsabilidade aquiliana ou delitual ${ }^{606}$.

Distinguem-se três correntes doutrinárias: a dos juristas que entendem que o casamento tem natureza contratual; daqueles que propugnam por sua feição institucional; e dos que afirmam que o matrimônio possui uma natureza híbrida, com aspectos contratuais e institucionais, resultando em um contrato sui generis ou um contrato especial de Direito de família ${ }^{607}$.

A primeira corrente preconiza que o casamento é um contrato, conquanto um contrato diverso daquele de direito patrimonial. Ao se casarem, as partes, de livre e espontânea vontade, submetem-se às cláusulas pré-condicionadas pela lei. Logo, é típica instituição de Direito privado ${ }^{608}$.

De outra banda, a segunda corrente apregoa que o casamento não é um negócio jurídico. Suas condições são impostas pela lei e não há possibilidade de se alterálas pela livre vontade das partes. Portanto, sua natureza jurídica é publicista, pois é o Estado que legaliza e lhe impõe condições e consequências ${ }^{609}$.

Segundo InACiO DE CARvalho Neto, como nenhuma destas teorias foi suficiente, chegou-se à teoria do contrato de Direito de família (especial ou sui generis), que apreende o casamento como um ato complexo, ao reunir o elemento volitivo (contratual) e o elemento institucional. Temos, portanto, um misto de contrato e instituição $^{610}$.

Regina BEATRIZ TAVARES DA Silva, expoente teoria contratualista, assevera que os deveres estipulados no art. 1.566 do Código Civil são cláusulas contratuais que, se infringidas, dão azo à responsabilidade contratual ${ }^{611}$.

Também Elizabeth Ana Maria Meisels PaCCA adota este entendimento, ao afirmar que, tendo em vista a natureza contratual do casamento, não há necessidade de se

\footnotetext{
${ }^{606}$ Cf. idem, p. 124.

${ }^{607}$ Cf. Madaleno, Rolf. Divórcio e dano moral. Revista Brasileira de Direito de Família, n. 2, 1999, p. 63.

${ }^{608}$ Cf. AlmEIDA JÚNIOR, Jesualdo Eduardo de. Op. cit. (nota 141), p. 125.

${ }^{609}$ Cf. idem, pp. 124-125.

${ }^{610}$ Cf. CARVAlHo Neto, Inacio de. Op. cit. (nota 86), pp. 94-95.

${ }^{611}$ Cf. SANTOS, Regina Beatriz Tavares da Silva Papa dos. Reparação civil na separação e no divórcio. São Paulo: Saraiva, 1999, pp. 166-169.
} 
perquirir culpa, pois esta é presumida, aplicando-se as regras da responsabilidade civil contratual à sua dissolução ${ }^{612}$.

Para Jesualdo EduARdo de Almeida JúNIOR o casamento é, efetivamente, um contrato, pois há um concurso de vontades para um determinado fim, explicitamente previsto em lei. Portanto, segundo o autor, como o art. 1.571 do Código Civil pontifica que o casamento é uma sociedade conjugal, e a sociedade advém de um pacto, o casamento é um contrato. Ele também entende ser possível o distrato, levado a cabo pelo divórcio. Assim, conclui que a teoria contratualista é a que melhor se encaixa para definir o casamento e, sob este enfoque, a tese da responsabilidade civil 'ganha ainda mais fôlego ${ }^{, 613}$.

Desta forma, o jurista preconiza a aplicação da teoria geral da obrigação contratual ao casamento, naquilo que for compatível, devendo-se analisar o art. 247 do Código Civil. Assim, se o parceiro descumpre um dever a ele imposto, incorre na obrigação de indenizar perdas e danos. Porém, ressalva que, para os casos não contemplados expressamente, aplica-se a regra geral do art. 186 do Código Civil, afora o art. 187, que alberga a regra do exercício abusivo do direito ${ }^{614}$.

JoSÉ DE CASTRO BIGI, por sua vez, inclinava-se mais a apreender o casamento enquanto instituição, deixando claro que as ações de ressarcimento por dano moral ou material originavam-se da culpa extracontratual, culpa aquiliana, e não da culpa contratual. Ele ainda considerava que, mesmo que se admitisse a natureza de contrato de direito de família, sui generis, a culpa decorreria da prática de um ato antijurídico, produzindo consequências não decorrentes do contrato ${ }^{615}$.

CARlos Alberto BitTAR, adepto da terceira corrente, afirmava que quando um homem e uma mulher se uniam pelo matrimônio estavam celebrando um contrato especial, regido pelo Direito de família ${ }^{616}$. O jurista observava que esse contrato era entrecortado por normas de ordem pública, dada a sua natureza solene. Desta maneira, na sua formação, execução e desfazimento imperavam essas normas, para que as partes

${ }^{612}$ Cf. PACCA, Elizabeth Ana Maria Meisels. A nova família e a responsabilidade civil dos cônjuges. Revista Jurídica da Universidade de Franca, n. 9, 2002, p. 97.

${ }^{613}$ Cf. ALMEIDA JÚNIOR, Jesualdo Eduardo de. Op. cit. (nota 141), pp. 125-126.

${ }^{614}$ Cf. idem, p. 134.

${ }^{615}$ Cf. BIGI, José de Castro. Op. cit. (nota 272), pp. 50-51.

${ }^{616}$ Cf. BITTAR, Carlos Alberto. Op. cit. (nota 11), p. 280. 
pudessem se direcionar em consonância com os valores fundamentais do ordenamento jurídico, dentre eles a dignidade da família, da pessoa humana e da prole, podendo surgir danos capazes de gerar indenização ${ }^{617}$.

Para NARA Rubia Alves DE RESENDE, atual e majoritariamente, entende-se que o casamento tem natureza de um contrato especial. Assim, considerando que os deveres do casamento têm sua origem na própria lei, e não no acordo de vontade, a autora afirma que incide a regra da responsabilidade civil extracontratual sobre os danos advindos dessa relação ${ }^{618}$.

Na opinião de INACIO DE CARVALHO NetO, a principal consequência da tese da natureza contratual da responsabilidade civil dos cônjuges seria admitir a inversão do ônus da prova em favor do autor da ação de reparação. Ou seja, incumbiria ao réu demonstrar que não violou um dever do casamento ${ }^{619}$.

Entretanto, o jurista não concorda com tal entendimento e afirma que o casamento é um contrato especial, um misto de contrato e instituição, regido pelas regras cogentes do Direito de família (não pelo Direito das obrigações) ${ }^{620}$. Isto porque não se pode incluir o neminem laedere como cláusula contratual, ou seja, não se pode aceitar a ideia de que o marido que causa lesões corporais em sua mulher está infringindo uma previsão contratual do casamento. Nestes termos, avalia restar claro que a responsabilidade de que se está tratando só pode ser aquiliana ${ }^{621}$.

Ante o exposto, em relação à responsabilidade civil dos cônjuges, os autores que entendem que o casamento é uma instituição aplicam a regra do art. 186 do Código Civil. Aqueles que compreendem o casamento enquanto contrato afirmam que o art. 247 do mesmo Código tem maior pertinência. Já a terceira corrente, do contrato sui generis, tem adotado a mesma solução da teoria institucionalista, aplicando a regra geral da responsabilidade civil extracontratual.

${ }^{617}$ Cf. idem, p. 281.

${ }^{618}$ Cf. ReSENDE, Nara Rubia Alves de. Op. cit. (nota 491), p. 15.

${ }^{619}$ Cf. CARVALHO NeTO, Inacio de. Reparação civil na separação litigiosa culposa. Revista EPD - Direito Civil, n. 1, 2005, p. 325.

${ }^{620}$ Cf. Carvalho Neto, Inacio de. Op. cit. (nota 86), p. 96.

${ }^{621}$ Cf. Carvalho Neto, Inacio de. Op. cit. (nota 619), p. 325. 
NARA Rubia Alves DE RESENDE resume a questão: "então, a forma de responsabilização a ser adotada nos danos decorrentes da dissolução da sociedade conjugal dependerá diretamente da natureza jurídica que se dá ao casamento, e da forma como se entendem aplicáveis as regras dispostas em lei para sua regulamentação "622.

Por conseguinte, como atualmente a maioria dos juristas considera o casamento um contrato especial de Direito de família, tem-se admitido com maior frequência a responsabilidade civil nestas relações como decorrência da prática de um ato antijurídico, sendo constatada pela análise do dano, da culpa e do nexo de causalidade, e não pela inobservância de cláusulas contratuais.

De sua parte, o jurista argentino RICARDo J. DutTo sustenta que a distinção entre a responsabilidade contratual e extracontratual não está na fonte da obrigação, dependendo antes do caráter dela. Neste sentido: "si el deber de no dañar es específico en relación con el objeto de la obligación y con el sujeto obligado, la responsabilidad es contractual; si el deber de no dañar es genérico y no está especificado el sujeto pasivo, la responsabilidad es extracontractual"623.

O autor defende que a responsabilidade por danos nas relações familiares é extracontratual, como de resto também atestam a jurisprudência argentina e a doutrina majoritária deste país, pois a lesão provém da violação de um dever legal e não do descumprimento de um contrato ${ }^{624}$.

\subsubsection{Deveres matrimoniais e consequências do descumprimento}

Com o casamento, o homem e a mulher formulam uma promessa de adesão aos deveres que a lei estabelece como necessários à consecução dos seus fins essenciais. Portanto, a celebração do matrimônio cria deveres recíprocos que se impõem aos cônjuges como condição inafastável de sobrevivência da união conjugal.

Esses deveres foram dispostos no art. 1.566 do Código Civil, a saber: fidelidade recíproca; vida em comum, no domicílio conjugal; mútua assistência; sustento, guarda e educação dos filhos; e respeito e consideração mútuos. O art. 1.573, por sua vez,

\footnotetext{
${ }^{622}$ RESENDE, Nara Rubia Alves de. Op. cit. (nota 491), pp. 13-14.

${ }^{623}$ DuTTO, Ricardo J. Op. cit. (nota 169), p. 46.

${ }^{624}$ Cf. idem, p. 52.
} 
expõe os motivos que podem caracterizar a impossibilidade da comunhão de vida: o adultério; a tentativa de morte; a sevícia ou a injúria grave; o abandono voluntário do lar conjugal, durante um ano contínuo; a condenação por crime infamante; e a conduta desonrosa.

Para ZENO VELOSO, esta enumeração legal não é taxativa, havendo, portanto, deveres implícitos ${ }^{625}$, tais como os deveres de sinceridade, de respeito pela honra e dignidade própria e da família, de não expor o outro cônjuge a companhias degradantes, de não o conduzir a ambientes de baixa moral etc ${ }^{626}$.

Na visão de YUSSEF SAID CAHALI, esses deveres fundam-se não só nas leis como nos princípios do bem agir; sendo que em nenhum outro campo do Direito, mais do que neste, influem a religião, o costume e a moral ${ }^{627}$.

O primeiro dever matrimonial disposto no Código Civil refere-se à fidelidade, cuja forma de violação mais comum se perfaz no adultério. Em linhas gerais, a fidelidade é a abstenção da satisfação do instinto sexual com pessoa estranha ao vínculo conjugal. $\mathrm{O}$ adultério, por sua vez, pode ser conceituado como a conjunção carnal do cônjuge com terceira pessoa ${ }^{628}$.

Já observava PONTES DE MIRANDA:

“a monogamia é o estado mais adequado e, quiçá, o único compatível, no plano jurídico, com a solidariedade social $e$ as demais condições necessárias do aperfeiçoamento e do progresso humano. Consulta os mais elementares imperativos de fisiologia e de psicologia o princípio de que o ser humano feliz procura a permanência da felicidade. O homem ou a mulher que se sente bem na convivência sexual, e não só sexual, com sua companheira ou o seu companheiro, busca

${ }^{625}$ Cf. Veloso, Zeno. Op. cit. (nota 387), p. 179.

${ }^{626}$ Cf. CARVALHO NeTO, Inacio de. Op. cit. (nota 86), p. 101.

${ }^{627}$ Cf. CAHALI, Yussef Said. Divórcio e separação. 10ª ed. São Paulo: Revita dos Tribunais, 2002, p. 58. Vale salientar a observação de INACIO DE CARVALHO NETO: "os deveres conjugais não podem ser tratados por convenções particulares, ao arrepio da lei”. CARVALHO NETO, Inacio de. Op. cit. (nota 86), p. 121.

${ }^{628}$ Muitos autores também admitem que o quase-adultério - prática de atos que, embora não cheguem à cópula carnal, demonstram o propósito de satisfação do instinto sexual com pessoa diversa do cônjuge constitui infração do dever de fidelidade. Cf. SILVA, Regina Beatriz Tavares da. Op. cit. (nota 198), p. 37. 
conservar as circunstâncias que lhe permitam essa convivência. Só a monogamia atende a esse dado ${ }^{, 629}$.

Assevera Regina Beatriz TAvares da SiLva que a fidelidade representa a natural expressão da monogamia, e não constitui, tão somente, dever moral, pois o Direito a exige em nome dos superiores interesses da família e da sociedade ${ }^{630}$.

Por conseguinte, apontam que a fidelidade é o cerne de todo o relacionamento matrimonial, de maneira que seu descumprimento é a mais grave das faltas, ferindo a constituição da família e o regime monogâmico ${ }^{631}$. Nas palavras de LUIZ MURILLO FÁBREGAS, o adultério "é um ultraje à honra e uma traição ao amor do outro cônjuge"632.

Note-se que, até recentemente, o adultério era considerado crime no âmbito penal $^{633}$. Todavia, na visão de ZENO VELOSO: “deixou de ser um crime, o adultério, mas continua sendo ilícito civil; aliás, o mais grave, doloroso e infamante motivo para que o cônjuge requeira a separação, pondo fim à falida sociedade matrimonial "634.

A doutrina entende que o adultério não é a única forma de se infringir o dever de fidelidade. Atos diversos da conjunção carnal também caracterizam infração àquele dever, configurando, genericamente, injúria grave ${ }^{635}$.

Nestes termos, atualmente discute-se a infidelidade por meios eletrônicos, o chamado adultério virtual, no qual os atos libidinosos são 'transmitidos pela internet' ${ }^{636}$.

\footnotetext{
${ }^{629}$ Miranda, Pontes de. Tratado de direito de família. $3^{\text {a }}$ ed. São Paulo: Max Limonad, 1947, p. 60.

${ }^{630}$ SILVA, Regina Beatriz Tavares da. Op. cit. (nota 198), p. 37. Em suas palavras: "pode-se imaginar o que significaria liberar a poligamia, ou seja, permitir que uma mulher conviva com vários homens, ou um homem com várias mulheres: a destruição dos padrões morais da familia e da sociedade como um todo". Ibidem. Também ZENO VELOSO já se manifestou a respeito: "nossa sociedade, ética e juridicamente, é monogâmica, e a fidelidade, que tem de ser guardada pelos cônjuges, é a consequência lógica desse princípio”. VELOSO, Zeno. Op. cit. (nota 387), p. 175.

${ }^{631}$ Cf. PACCA, Elizabeth Ana Maria Meisels. Op. cit. (nota 612), p. 93.

${ }^{632}$ FÁBREGAS, Luiz Murillo. Op. cit. (nota 131), p. 111.

633 Somente em 2005, com a Lei n. 11.106, foi revogado o art. 240 do Código Penal, não obstante sua inaplicabilidade prática.

${ }^{634}$ Veloso, Zeno. Op. cit. (nota 387), p. 175. Também Antônio CARlos MATHIAS Coltro afirma que a exclusão da feição penal de sua prática, não implica em haver-se desconsiderado sua importância para o casamento e para a família. Cf. Coltro, Antônio Carlos Mathias. A descriminalização do adultério, sua repercussão no direito de família e a culpa na responsabilidade pelo fim da conjugalidade. In: PEREIRA, Rodrigo da Cunha (Coord.). Família e dignidade humana - anais do V Congresso Brasileiro de Direito de Família. Belo Horizonte: IBDFAM, 2006, p. 147.

${ }^{635}$ Cf. CARVAlHO NeTO, Inacio de. Op. cit. (nota 619), p. 329-330.
} 
Na opinião de ZENO VELOSO, o adultério virtual, sem dúvida, representa um ato de infidelidade, que não é física, mas é imoral, "e se infidelidade não fosse considerada essa ação, num excessivo rigor terminológico, sem dúvida, é desleal, desrespeitosa, uma falta de consideração ${ }^{\text {"637. }}$.

\section{Não é outro o entendimento de REGINA BEATRIZ TAVARES DA SILVA:}

"é evidente o retrocesso daqueles que concluem que a infidelidade virtual não seria descumprimento desse dever, pelo fato de inexistir relação sexual no plano virtual. Há muito o direito evoluiu para concluir que na infidelidade importa a busca de satisfação sexual fora do par conjugal e não a relação sexual propriamente dita, que pode ou não existir ${ }^{, 638}$.

Portanto, ainda que praticada de forma virtual, ou que não reste comprovada a conjunção carnal, os juristas são unívocos em afirmar que a infidelidade representa a mais nítida manifestação da falência da moral conjugal, pois fere e perturba de modo profundo a vida familiar ${ }^{639}$.

Quanto ao dever de vida em comum, no domicílio conjugal, que muitos designam dever de coabitação, além de significar a convivência diuturna dos cônjuges em seu lar, na visão de alguns juristas implica, em condições normais, o dever de manter relações sexuais. INACIO DE CARVALHO NETO entende que a infração ao débito conjugal pela recursa ao ato sexual pode ocasionar sérios problemas psicológicos e distúrbios ao cônjuge, pois se trata de uma necessidade fisiológica ${ }^{640}$.

Por sua vez, Regina Beatriz Tavares da Silva, entende que a recusa reiterada, injustificada e injuriosa à manutenção de relacionamento sexual acarreta o

636 Para uma maior explanação sobre o assunto, ver: PONZONI, Laura de Toledo. Infidelidade virtual realidade com efeitos jurídicos. Revista da Faculdade de Direito da Universidade de São Paulo, v. 102, 2007.

${ }^{637}$ VeLOSO, Zeno. Op. cit. (nota 387), p. 175.

${ }^{638}$ SILVA, Regina Beatriz Tavares da. Op. cit. (nota 198), pp. 37-38.

639 "De qualquer modo os relacionamentos internéticos pretendem permitir uma quebra, ainda que discreta, da monogamia (...)”. LAGRASTA NeTO, Caetano. Infidelidade virtual. In: LAGRASTA Neto, Caetano, TARTUCE, Flávio et SiMÃo, José Fernando (Coords.). Direito de família: novas tendências e julgamentos emblemáticos. São Paulo: Atlas, 2011, p. 166.

${ }^{640}$ Cf. Carvalho Neto, Inacio de. Op. cit. (nota 619), p. 330. Zeno Veloso assevera: “negar-se, imotivadamente, reiterada e continuadamente, à prática sexual é um abuso, e frustra desejos pertinentes, justificados, abate legítimas expectativas do outro cônjuge, causando-lhe males físicos e psicológicos profundos. A privação sexual, sem dúvida, não está nos planos de quem se uniu a uma pessoa pelo matrimônio, nos casos comuns”. VELOSO, Zeno. Op. cit. (nota 387), p. 177. 
descumprimento do dever de respeito à integridade psicofísica e à autoestima do consorte $^{641}$.

No inciso III do art. 1.566 do Código Civil estabelece-se o dever de mútua assistência. Os doutrinadores advertem que essa expressão precisa ser apreendida em seu significado material e imaterial. Esse dever não se concretiza com a simples prestação alimentar, mas envolve toda a assistência moral, o socorro nas desventuras, nas enfermidades, enfim, o apoio em todas as situações da vida ${ }^{642}$.

Regina Beatriz TAvares Da Silva afiança que o dever de assistência imaterial consubstancia-se na proteção aos direitos da personalidade do cônjuge ${ }^{643}$.

Em relação ao dever de sustento, guarda e educação dos filhos, embora tenha como destinatária a prole, a doutrina afirma tratar-se de um dever para com o cônjuge, dever do casamento, diverso daquele decorrente do poder familiar. Nas palavras de INÁCIO DE CARVAlho Neto: “ou seja, é direito do 'cônjuge' que seus filhos sejam bem tratados por seu consorte,

Também é imposto aos cônjuges o respeito e a consideração mútuos, cujo objeto, para muitos juristas, reside nos direitos da personalidade. Lembre-se que este dever não era previsto no Código Civil de 1916.

Na visão de INACIO DE CARVALHo NETO, este dever nada mais é do que uma especificação da mútua assistência ${ }^{645}$. Já na opinião de ZENO VELOSO, acaba funcionando como cláusula aberta e, de certa forma, abrange os demais deveres recíprocos, antes mencionados $^{646}$.

${ }^{641}$ Cf. SILVA, Regina Beatriz Tavares da. Op. cit. (nota 198), p. 44.

${ }^{642}$ Cf. PACCA, Elizabeth Ana Maria Meisels. Op. cit. (nota 612), p. 94. Neste sentido, observa ZENO VELOSO que ele possui um forte elemento ético, envolvendo a ajuda, o apoio, a solidariedade, o socorro espiritual e moral. Para o autor, "a mútua assistência é a expressão exuberante e indestemível da comunhão de vida, da 'affectio maritalis"”. Veloso, Zeno. Op. cit. (nota 387), p. 177.

${ }^{643}$ Cf. SILVA, Regina Beatriz Tavares da. Op. cit. (nota 198), p. 35.

${ }^{644}$ CARVAlho NeTO, Inacio de. Op. cit. (nota 619), p. 340. Segundo ZENo Veloso, "esse dever de guardar, sustentar e educar os filhos menores, que tem um lado econômico e um aspecto imaterial, deve ser observado - e quantificado -, no caso concreto, conforme a educação, possibilidades financeiras, meio social em que vivem e a cultura dos pais". Veloso, Zeno. Op. cit. (nota 387), p. 178.

${ }^{645}$ Cf. Carvalho NeTO, Inacio de. Op. cit. (nota 86), p. 125.

${ }^{646}$ Cf. Veloso, Zeno. Op. cit. (nota 387), p. 179. 
Deste modo, os juristas apregoam que estão assegurados os direitos da personalidade dos cônjuges, que se devem, mutuamente, assistência e respeito à integridade física e psíquica, à honra, à liberdade, e à privacidade. Chega-se a afirmar que: "desde o descumprimento do dever de fidelidade ou de assistência, material e imaterial, são imposições do respeito aos direitos da personalidade" ${ }^{\text {"647 }}$. Para YUSSEF SAID CAHALI, "esse dever geral de respeito à pessoa do seu semelhante subsiste até mesmo depois de dissolvida a sociedade conjugal ${ }^{, 648}$.

$\mathrm{O}$ art. 1.573 do Código Civil especifica algumas das condutas que denotam a impossibilidade de vida em comum, em razão, justamente, da infração aos deveres matrimoniais. Já analisamos o adultério, em conjunto com o dever de fidelidade, resta ponderarmos as demais hipóteses ali previstas.

A tentativa de morte é o homicídio não consumado do cônjuge, por circunstâncias alheias à vontade do agente, seu consorte. Trata-se de crime tipificado no Código Penal ${ }^{649}$. Mais do que qualquer outra, tal conduta caracteriza a impossibilidade da comunhão de vida dos cônjuges, por razões óbvias.

As sevícias são maus-tratos corporais, atos de crueldade ou torturas físicas, cometidos por um cônjuge contra o outro. Afirma-se que não é imprescindível a agressão física, podendo caracterizar-se como a simples dor moral. Ademais, na lição de INÁCIO DE CARVAlho Neto, basta a prática de uma única sevícia para a configuração da infração do dever de mútuo respeito e assistência moral, não se fazendo mister a sua repetição. Ele também considera desnecessário que tal conduta tenha sido praticada em público, de forma a causar vexame ao cônjuge lesionado ${ }^{650}$.

Já a injúria grave é a violação da honra, da reputação ou da integridade moral do cônjuge. É um dos motivos mais invocados nas rupturas matrimoniais, consistindo na ofensa à dignidade ou ao decoro do consorte ${ }^{651}$.

\footnotetext{
${ }^{647}$ Oltramari, Fernanda et Oltramari, Vitor Hugo. Op. cit. (nota 102), p. 71.

${ }^{648}$ CAHALI, Yussef Said. Op. cit. (nota 39), p. 585.

${ }^{649}$ Art. $121 \mathrm{c} / \mathrm{c}$ art. 14, II, do Código Penal.

${ }^{650}$ Cf. CARVAlHo NeTO, Inacio de. Op. cit. (nota 86), pp. 122-123.

${ }^{651} \mathrm{Na}$ visão de REGINA BEATRIZ TAVARES DA SILVA, “a injúria grave, ofensa direta à honra, tanto pode atingir esse direito da personalidade em seu sentido subjetivo (autoestima) como no objetivo (reputação social), podendo ser praticada por meio de atos ou palavras. Assim, são injúrias graves que ofendem a
} 
Para VAlÉRIa Silva Galdino CARDin, a injúria e a sevícia configuram o descumprimento do dever de mútua assistência. Contudo, considera fundamental que se avalie a gravidade e a intensidade destes atos, bem como a condição social das pessoas envolvidas, o grau de educação e o ambiente em que vivem ${ }^{652}$.

O abandono voluntário do lar conjugal é o afastamento do cônjuge da unidade familiar, sem motivo justificável, e por mais de um ano, a caracterizar a impossibilidade de comunhão de vida entre os consortes.

A condenação por crime infamante repercute negativamente no âmbito pessoal e familiar do cônjuge, por ser considerado comportamento baixo, vil ou vergonhoso, prejudicando a boa fama da família.

E, por fim, a conduta desonrosa é aquela que recebe desaprovação social, por afrontar os bons costumes da comunidade em que vivem os cônjuges. Não se trata de comportamento necessariamente ilícito, mas moralmente reprovável, que importa em desrespeito à honra do consorte ${ }^{653}$.

Descritos os deveres conjugais e os comportamentos que constituem infração a esses deveres, passemos à análise das consequências de seu descumprimento.

O ordenamento previa sanções para quem violasse os deveres matrimoniais, dentre as quais: a perda da guarda dos filhos, do direito à pensão alimentícia e a utilizar o sobrenome conjugal ${ }^{654}$. No entanto, estes preceitos foram mitigados ou eliminados e atualmente considera-se que a transgressão a um dos deveres conjugais é motivo suficiente para decretar-se o término do relacionamento conjugal, sendo esta, possivelmente, a principal consequência para o cônjuge infrator.

honra subjetiva as falsas acusações em demanda judicial e as palavras injuriosas proferidas no recesso do lar”. SILVA, Regina Beatriz Tavares da. Op. cit. (nota 198), p. 32.

${ }^{652}$ Cf. CARDIN, Valéria Silva Galdino. Op. cit. (nota 245), p. 153.

${ }^{653} \mathrm{Na}$ opinião de REGINA BEATRIZ TAVARES DA SILVA, "a conduta desonrosa ofende indiretamente a honra do cônjuge, em razão da solidariedade de honras presente no casamento, exemplificando-se com a prática de crime, a toxicomania, a embriaguez habitual e o vício do jogo". Segundo a autora, na configuração desta conduta é dispensado o animus injuriandi, o elemento intencional da ofensa, bastando que tenha sido praticada em estado de consciência. SILVA, Regina Beatriz Tavares da. Op. cit. (nota 198), p. 32.

${ }^{654}$ Nestes termos, observa ROLF MADALENO que para a culpa pela ruptura do casamento eram previstas as seguintes sanções: primeiro, a sentença que marcava moralmente o esposo faltoso com o sinete da culpabilidade; depois, a culpa separatória influenciava sobre a guarda da prole; ademais, a mulher culpada era condenada à perda do sobrenome de casada; afora os efeitos materiais que ordenavam ou exoneravam os créditos alimentares. Cf. MADALENO, Rolf. Op. cit. (nota 607), p. 63. 
Assim, a guarda dos filhos deixou de ser utilizada como 'trunfo' pelo cônjuge inocente, e passou a ser atribuída ao pai ou à mãe que realizasse o princípio do melhor interesse da criança. Ou seja, o Código Civil de 2002 estabeleceu a fixação da guarda com base no princípio da prevalência dos interesses dos menores, tendo em vista a aptidão, refletida nas condições morais, educacionais e afetivas do genitor. Logo, o marido ou a esposa que tenha agido em contrariedade aos deveres impostos pelo casamento não necessariamente serão assumidos como um 'mau genitor' 655 .

Na questão dos alimentos, o Código Civil de 2002 inovou, passando a assegurá-los também ao cônjuge que infringisse deveres matrimoniais, mas somente os indispensáveis à sua sobrevivência, conforme disposto no parágrafo único do art. 1.704. Entretanto, ele deve comprovar que não possui aptidão para o trabalho e que não existe qualquer parente em condições de prover a sua subsistência. Assim, conquanto de forma abrandada, permanece essa consequência da violação aos deveres do casamento ${ }^{656}$.

Quanto ao nome, igualmente conservam-se resquícios da infração aos deveres conjugais, contudo, de forma atenuada. Isto porque o Código Civil de 2002 vinculou o direito de manter o sobrenome à ocorrência ou não de culpa por parte do portador, entretanto, o artigo 1.578 estabeleceu exceções que acabam se sobrepondo à regra. Assim, o cônjuge declarado culpado na ação de separação judicial perde o direito de usar o

\footnotetext{
${ }^{655} \mathrm{Na}$ opinião de REgina BeATRIZ TAVARES DA SilVA: "o anacrônico regime da perda da guarda pela culpa e da preferência feminina na fixação da guarda em caso de culpas recíprocas violava o art. 227, 'caput', da Constituição Federal, que assegura ao menor a preservação de seus direitos da personalidade, assim como conflitava com o disposto nos arts. $5^{\circ}$, I, e 226, $\$ 5^{\circ}$, da Lei Maior, que estabelecem igualdade entre homens e mulheres, inclusive no casamento". Nestes termos, a autora preconiza que a culpa na separação judicial não deve ser razão determinante da perda da guarda, que será estabelecida sob o princípio da proteção ao bem-estar das crianças e dos adolescentes. Cf. SILVA, Regina Beatriz Tavares da. Op. cit. (nota 198), pp. 45-46. Mesmo sob a égide do Código Civil de 1916, afirmou ANTONIO CeZAR PELuso: "o que decide a guarda jurídica dos filhos são os seus interesses morais e materiais. Esta foi e é a regra geral". PELUSo, Antonio Cezar. A culpa na separação e no divórcio: contribuição para uma revisão legislativa. In: MotTA, Maria Antonieta Pisano (coord.). Caderno de estudos n. 2: direito de família e ciências humanas. São Paulo: Jurídica Brasileira, 1998, p. 43.

${ }^{656} \mathrm{Na}$ visão de INACIO DE CARVALHO NETO, "trata-se de disposição que atende ao 'favor pietatis', para evitar que o cônjuge, embora culpado, morra de fome". Ele ressalta que neste caso o juiz deverá fixar valor que atenda apenas às necessidades básicas do cônjuge culpado, não havendo que se falar em manutenção do status quo. Cf. Carvalho Neto, Inacio de. Op. cit. (nota 86), p. 204. Também Regina Beatriz Tavares DA SILVA afirma que o Código Civil atribui ao cônjuge culpado somente o direito a uma pensão mínima, sem apego ao status social do casal e às possibilidades do prestador dos alimentos, ou, ainda, sem baliza em outras necessidades cuja cobertura não tenha em vista a sobrevivência. No entanto, ela afiança que a falta de aptidão para o trabalho não equivale à ausência de condição real e concreta de prover o próprio sustento, mas sim à inexistência de condição hipotética ou curricular para tal. Assim, a jurista conclui que, em cumprimento dos princípios de solidariedade e dignidade, a legislação garantiu os alimentos indispensáveis ao cônjuge culpado, que deles necessitar por falta de aptidão e de parentes em condições de prestar-lhes. Cf. SILVA, Regina Beatriz Tavares da. Op. cit. (nota 198), pp. 51-52.
} 
sobrenome do outro, desde que a alteração não lhe acarrete: evidente prejuízo para a sua identificação, manifesta distinção entre o seu nome de família e o dos filhos havidos da união dissolvida, ou dano grave reconhecido na decisão judicial. Nesse sentido, prevalece a razoabilidade, pois as repercussões sociais se sobrepõem ao interesse individual do cônjuge ofendido $^{657}$.

Por fim, importa enfatizar que a partilha dos bens independe da culpa de qualquer dos cônjuges, sendo realizada segundo o regime adotado.

Conforme se analisará adiante, todo este panorama dos deveres matrimoniais, e as consequências do descumprimento, fomentam uma discussão maior na doutrina a respeito da possibilidade de responsabilização civil do cônjuge infrator.

\subsubsection{Doutrina contrária à indenização}

Inicialmente, conforme dissemos, a ideia de reparação de danos entre cônjuges, especialmente os de natureza moral, encontrou forte resistência em nosso país.

JosÉ DE CASTRO BIGI arrolava, sinteticamente, três argumentos desfavoráveis à indenização: o primeiro deles desenvolveu-se no sentido de que o ressarcimento seria contrário à moral e aos bons costumes; o segundo de que não havia na lei um dispositivo que especificamente regulasse a espécie; e o terceiro argumento de que se estaria violando o princípio do non bis in idem, pois o cônjuge culpado já seria apenado com a prestação de alimentos, honorários e custas ${ }^{658}$.

\footnotetext{
657 Segundo WAShington DE BARros Monteiro, a perda do nome familiar em razão da culpa pela separação não encontra fundamento na Constituição, já que o nome integra a identidade da pessoa, que é direito da personalidade. Em suas palavras: "a Constituição Federal, em seu art. 5', caput, incisos e parágrafos, prevê a inviolabilidade dos direitos da personalidade, dentre os quais está o direito ao nome, conforme estabelece o art. 16 do novo Código Civil, com a devida proteção ao prenome e sobrenome. O sobrenome do marido passa a integrar a personalidade da mulher que o adota no casamento, e vice-versa, não cabendo à lei determinar a sua perda como regra geral, sob pena de ser inconstitucional”. MONTEIRO, Washington de Barros. Op. cit. (nota 348), p. 282. Também CARLOS DiAs MOTTA assim entende: "ora, uma vez que o nome integra a personalidade do ser humano, a sua perda compulsória afetará o princípio da dignidade da pessoa humana, que deverá prevalecer diante do interesse do cônjuge inocente”. MOTTA, Carlos Dias. Princípios fundamentais de direito matrimonial. In: COLTRO, Antônio Carlos Mathias (Coord.). Estudos jurídicos em homenagem ao centenário de Edgard de Moura Bittencourt: a revisão do direito de família. Rio de Janeiro: GZ, 2009, p. 148. No entanto, para REGINA BEATRIZ TAVARES DA SILVA, essa consequência sancionatória deve permanecer, já que haverá violação ao princípio constitucional da proteção da dignidade da pessoa humana se um homem desrespeitado por sua esposa tiver o seu sobrenome atrelado ao dela para o resto da vida, e a mesma observação serve para a mulher. Cf. SILVA, Regina Beatriz Tavares da. Op. cit. (nota 198), p. 57.

${ }^{658}$ Cf. BIGI, José de Castro. Op. cit. (nota 272), p. 47.
} 
Na opinião de InACio De CARvalho Neto, nenhum deles procede. Se o primeiro argumento fosse válido, a indenização de qualquer dano moral seria contrária à moral e aos bons costumes e não somente a indenização entre cônjuges ${ }^{659}$. Assim, tal argumento seria mais corretamente dirigido contra a reparação do dano moral, não especificamente contra o dano provocado pelo ato culposo do cônjuge ${ }^{660}$.

NARA Rubia Alves DE RESENDE afiança: “e, na verdade, contrário à moral e aos bons costumes é continuar permitindo que as agressões que se dão na sociedade conjugal não sejam reparadas, que recebam tratamento diverso da que se lhe daria se ocorressem nas relações humanas de outra natureza",661.

Quanto ao segundo argumento, observa HUMBERTO THEODORO JÚNIOR que sempre prevaleceu a tese de que inexistindo no Direito de família previsão de responsabilidade civil, o cônjuge inocente não teria base para pleitear, após a separação ou divórcio, qualquer ressarcimento por dano moral pelas infrações aos deveres conjugais ${ }^{662}$.

No entanto, JosÉ DE CASTRO BIGI protesta que não interessa para o deslinde da controvérsia o argumento 'formal e frio' de que não há texto específico ${ }^{663}$. E RoLF MADALENO rebate que também não existe norma que desautorize ou vede esta reparação ${ }^{664}$. Segundo JESUALDo EDUARDo DE ALMEIDA JúNIOR, tanto o texto constitucional como o infraconstitucional não restringem a incidência desses danos e de sua reparação em nenhuma órbita, inclusive na familiar ${ }^{665}$.

Para Inacio de CARvalho Neto, o ato culposo, configurado pela grave violação dos deveres conjugais ou pela conduta desonrosa, é perfeitamente enquadrável como fato gerador de responsabilidade, nos termos do art. 186 do Código Civil. Deste modo, ele assevera que 'cai por terra' o segundo argumento, já que não há necessidade de lei expressa prevendo a indenização para cada caso específico ${ }^{666}$. Ademais, o Direito de família não é um ramo isolado e, portanto, não se ilide a aplicação da regra geral da responsabilidade civil.

\footnotetext{
${ }^{659}$ Cf. Carvalho NeTO, Inacio de. Op. cit. (nota 86), p. 275.

${ }^{660}$ Cf. CARVALHO NeTO, Inacio de. Op. cit. (nota 619), p. 305.

${ }^{661}$ RESENDE, Nara Rubia Alves de. Op. cit. (nota 491), p. 7.

${ }^{662}$ Cf. THEODORO JÚNIOR, Humberto. Op. cit. (nota 35), pp. 87-90.

${ }^{663}$ Cf. Bigi, José de Castro. Op. cit. (nota 272), p. 49.

${ }^{664}$ Cf. MADALENO, Rolf. Op. cit. (nota 607), p. 65.

${ }^{665}$ Cf. AlmEIDA JúnIOR, Jesualdo Eduardo de. Op. cit. (nota 141), p. 132.

${ }^{666}$ Cf. CARVAlHo Neto, Inacio de. Op. cit. (nota 86), pp. 276-277.
} 
Em relação ao terceiro argumento, os autores avaliam que a prestação alimentar não tem caráter indenizatório, não havendo que se falar em infração do princípio do non bis in idem ${ }^{667}$. As intercorrências desta questão serão exploradas separadamente.

Uma variante deste último argumento é a arguição de que o casamento está sujeito a regras próprias, não lhe sendo aplicáveis as normais gerais da responsabilidade civil, ou seja, a violação aos deveres conjugais gera sanções específicas, previstas no âmbito do direito de família. Assim, as consequências para o descumprimento dos deveres do casamento seriam somente aquelas previamente mencionadas: a perda dos alimentos, do sobrenome, da guarda dos filhos e a questão da partilha dos bens.

Para SÉRGIO GISCHKOW PEREIRA, o ordenamento já sanciona o infrator com a pecha de cônjuge culpado, além da perda do direito à guarda e aos alimentos, não se podendo acrescentar mais uma sanção - a indenização por dano moral - sem lei explícita $^{668}$.

Também LUIz FELIPE HADDAD considera que, por mais que cause reprovação, no terreno ético-religioso, a traição de um cônjuge ao compromisso assumido, mormente quando ostensiva e eivada de 'arrogância e deboche', não alcança perante o Direito outros efeitos que não a dissolução da sociedade conjugal culposa, com as sanções e consequências próprias do Direito civil-familiar ${ }^{669}$.

Este pensamento, contudo, já era refutado por PONTES DE MIRANDA, o qual postulava que poderia haver causa suficiente para a reparação com fundamento em outra regra de Direito civil, independente das sanções de ordem familiar, seja na parte geral, seja no Direito das obrigações ${ }^{670}$.

Assim, segundo ÂNGEla CRISTINA DA SILVA CERDEIRA, as consequências previstas no ordenamento familista para o ato culposo não atendem à responsabilização dos danos causados ao consorte pelo cônjuge infrator. Mesmo que se considere o próprio

\footnotetext{
${ }^{667}$ Cf. Carvalho Neto, Inacio de. Op. cit. (nota 619), p. 307. E Cf. Resende, Nara Rubia Alves de. Op. cit. (nota 491), p. 7.

${ }^{668}$ Cf. PEREIRA, Sérgio Gischkow. Op. cit. (nota 142), p. 361.

${ }^{669}$ Cf. HADDAD, Luiz Felipe. Reparação do dano moral no direito brasileiro. Revista de Estudos Jurídicos 2/128, apud CAHALI, Yussef Said. Op. cit. (nota 39), p. 589.

${ }^{670}$ Cf. MIRANDA, Pontes de. Tratado de direito de família. v.1. Campinas: Bookseller, 2001, p. 76, apud CARVAlHo Neto, Inacio de. Op. cit. (nota 86), p. 289.
} 
divórcio como uma sanção, a garantia dos direitos da personalidade continuará fragilizada se, no caso de sua violação, não foram aplicados os princípios da responsabilidade civil ${ }^{671}$.

Na opinião de RolF MADALENO, a indenização moral tem origem diversa das consequências jurídicas implícitas pela separação culposa ${ }^{672}$. Antes, a indenização por dano moral na separação judicial tinha por fito a compensação do sofrimento do cônjugevítima, ressarcindo a honra conjugal afetada, resgatando a integridade moral do ofendido, "reparava os danos morais causados pela violação de dever conjugal, ou por conduta considerada desonrosa que tornasse insuportável a vida em comum"673. Mas, após a EC n. $66 / 10$, não é mais possível a indenização por dano moral em virtude de descumprimento de dever conjugal, que seriam doravante meros 'deveres morais', restritos à 'consciência dos cônjuges'. Isto, todavia, não impediria o dano moral por ofensa a valores constitucionais, de maneira que a indenização deixa de ser remédio do Direito de família, permitindo ao lesado demandá-la de forma independente ${ }^{674}$. (p. 341)

NARA Rubia Alves de RESEnde afiança que não se pode elidir a reparação tão-somente em virtude da natureza específica dessas relações, pois se há um dano culpável, deve ser indenizado ${ }^{675}$.

Outro fundamento contrário, alega que a partilha é suficiente ao cônjuge inocente. Para Jesualdo EdUARdo DE ALMEIDA JÚNIOR, esta ideia leva à premiação do culpado. Ele afirma que a partilha não está atrelada ao comportamento pessoal dos consortes: "quer tenham sido devassos, quer pudicos, o partilhamento do patrimônio em nada será alterado. Portanto, esse argumento, de todos, é o mais absurdo "676.

Portanto, muitos juristas concordam que não há como repudiar a indenização civil no campo do Direito de família apenas porque a legislação já prevê outros meios de punição do cônjuge culpado pela separação.

${ }^{671}$ Cf. CerdeIRA, Ângela Cristina da Silva. Da responsabilidade civil dos cônjuges entre si. Coimbra: Coimbra, 2000, p. 83.

${ }^{672}$ Cf. MADALENO, Rolf. Op. cit. (nota 607), p. 66.

${ }^{673}$ MADALENO, Rolf. Op. cit. (nota 422), p. 340.

${ }^{674}$ Cf. idem, p. 341. "Por força de lei são impostos deveres aos cônjuges e aos conviventes estáveis e uma vez violados esses deveres, ocasionando danos, surge o direito à reparação pelo nexo causal verificado entre $o$ ato ilícito e a responsabilidade civil subjetiva imposta pelo dano subjetivo sofrido pelo parceiro inocente, sem mais nenhum reflexo ou qualquer vinculação ou restrição ao decreto direto e objetivo do divórcio". Idem, p. 347.

${ }^{675}$ Cf. Resende, Nara Rubia Alves de. Op. cit. (nota 491), p. 23.

${ }^{676}$ ALMEIDA JÚNIOR, Jesualdo Eduardo de. Op. cit. (nota 141), p. 136. 
De outra parte, recorde-se que essas consequências sancionatórias foram mitigadas ou excluídas do ordenamento, conforme noticiamos. Nestes termos, manifestase Belmiro Pedro Welter: a partilha é efetuada de acordo com o regime de bens, escolhido antes do casamento, há muito tempo a culpa não interfere na guarda dos filhos e também não tem qualquer ingerência no nome dos cônjuges. Em relação à obrigação de prestar alimentos, afirma ser controvertida no Direito brasileiro, na medida em que, segundo a chamada teoria objetiva da obrigação alimentar, não mais se inquire culpa, mas apenas a necessidade da pensão alimentícia ${ }^{677}$.

Outrossim, atualmente colocam-se contra o propósito indenizatório as seguintes preleções: $a$ ) a tendência do Direito de família é a de reservar a dissolução do casamento à livre disposição das partes, o que é contrariado com a condenação de um dos cônjuges pelos danos causados ao outro; $b$ ) a negociação entre os envolvidos com as questões de família fica comprometida com o incentivo à ação indenizatória; $c$ ) a tese afirmativa em nada contribui para a melhoria das relações familiares, não elimina nem diminui o número de separações, não beneficia os filhos; $d$ ) ao contrário, a sua aceitação é motivo de discórdia entre casados, contribuindo para o esfacelamento da harmonia familiar; e) há preceito ético que afasta a possibilidade de o cônjuge atingido pelo adultério procurar ressarcimento para cobrar o preço de sua honra; $f$ ) não cabe indenização pela dissolução do casamento porque no sistema que o admite amplamente, a hipótese é sempre uma alternativa a considerar por quem pretende casar-se, por isso, não pode pretender pleitear indenização por aquilo que o ordenamento prevê e admite como solução adequada para vencer a crise conjugal; $g$ ) o casamento existe em razão de uma relação afetiva, cujo rompimento não pode ser objeto de uma indenização pecuniária; e $h$ ) e a infração do cônjuge às regras do casamento pode decorrer de causas de ordem afetiva e psicológica postas pelo outro, sendo inconveniente que o Direito ingresse nessa seara para avaliar danos e ressarci-los com pecúnia ${ }^{678}$.

Nesta ordem de ideias, alguns juristas alegam que no Direito de família não existe a figura da indenização, pois amor não se paga, convivência não se indeniza. Essa

\footnotetext{
${ }^{677}$ Cf. Welter, Belmiro Pedro. Dano moral na separação, divórcio e união estável. Revista Jurídica, n. 267, 2000, pp. 29-30.

${ }^{678}$ Cf. AgUiAR JÚNIOR, Ruy Rosado de. Op. cit. (nota 15), pp. 10-11.
} 
tem sido a retórica dos atuais defensores da tese da não ressarcibilidade dos danos morais havidos entre os cônjuges ${ }^{679}$.

Assim, para Lizete PeiXoto XAVIER SchuH, a compensação pecuniária, ou 'pena' imposta ao cônjuge culpado pela infração aos deveres conjugais, pode agravar ainda mais as relações. Ele considera que a ideia de tirar proveito em dinheiro da situação não parece a medida mais eficaz, além do que, inegavelmente, a animosidade estabelecida instiga a cobiça do lucro, de se 'sair bem' diante do litígio. Nestes termos, propõe que a solução mais viável, na impossibilidade de reconciliação, é a própria separação do casal ${ }^{680}$.

Observa, porém, JesuAldo EdUARdo DE AlmeIdA JúnIOR, que os danos morais não são questões patrimoniais, mas a mera reparação de infração a um dever pessoal. Todo cidadão, afirma ele, tem o dever de ressarcir qualquer conduta consciente que tenha imposto um dano a outro ${ }^{681}$.

Portanto, na opinião do autor, não está se impondo reparação pela falta de amor, pois, de fato, o amor não é exigível juridicamente. Sucede que a lei impõe certos deveres, como o de não atacar a honra alheia, e seu descumprimento gera uma sanção, partindo de falsa premissa a opinião de que somente obrigações com caráter econômico se revertem em perdas e danos ${ }^{682}$.

Para BELMIRO PEDRO WELTER, não se está reclamando pecúnia do amor, e sim pagamento contra aquele que se aproveitou da relação jurídica que envolvia o amor para causar graves ofensas delituosas ${ }^{683}$.

Neste compasso, a jurista argentina GRACIELA MEDINA aponta a distinção entre a falta de amor e o dano moral: “(...) la indemnización de los daños y perjuicios

${ }^{679}$ Cf. ALMEIDA JÚNIOR, Jesualdo Eduardo de. Op. cit. (nota 141), p. 126.

${ }^{680}$ Cf. SCHUH, Lizete Peixoto Xavier. Responsabilidade civil por abandono afetivo: a valorização do elo perdido ou não consentido. Revista Brasileira de Direito de Família. Porto Alegre: Síntese-IBDFAM, n. 35, 2006, p. 73. MARIA ANTONIETA PISANO MOTTA adverte que "no momento da separação, cada um quer resgatar o que acha que lhe pertence e foi tomado pelo outro num momento de distração, de relaxamento, de engano. Cada um quer ser indenizado pelo 'prejuizo' sofrido em nome do amor que acabou, e assim o dinheiro torna-se pleno de significações simbólicas. Transforma-se em prêmio e castigo que as pessoas feridas não hesitam em usar para dar vazão às suas mais inconfessáveis emoções”. MOTTA, Maria Antonieta Pisano. Além dos fatos e dos relatos: uma visão psicanalítica do direito de família. In: PEREIRA, Rodrigo da Cunha. A família na travessia do milênio - anais do II Congresso Brasileiro de Direito de Família. Belo Horizonte: Del Rey, 2000, p. 40.

${ }^{681}$ Cf. ALMEIDA JÚNIOR, Jesualdo Eduardo de. Op. cit. (nota 141), p. 119.

${ }^{682}$ Cf. idem, pp. 132-133.

${ }^{683}$ Cf. WelTER, Belmiro Pedro. Op. cit. (nota 677), p. 31. 
derivados del divorcio no procede frente a actos y modos de conducta que son expresiones de desamor, de pérdida del vínculo afectivo, debiendo quedar reservada sólo a las conductas que implican auténticos agravios al otro cónyuge "684.

A última crítica veiculada versa sobre a monetarização do Direito de família, em razão de supostos excessos.

SÉRGIO GISCHKOW PEREIRA é veemente a respeito: “a prosperar este exagero, praticamente TODA a ação de separação judicial ensejaria pedido cumulado de perdas e danos morais, em deplorável e perniciosa monetarização das relações eróticoafetivas ${ }^{, 685}$.

Nesse compasso, INACIO DE CARVALHO NETO teme a banalização do instituto com caprichos pessoais ${ }^{686}$.

\subsubsection{Alimentos e indenização - 'bis in idem'?}

Argumento que se destaca, analisaremos a questão do bis in idem, que merece estudo à parte. Conforme expusemos, a arguição de que a condenação do cônjuge culpado à indenização do dano moral e aos alimentos implicaria bis in idem foi das mais veementes contra a indenização nas relações conjugais.

Conforme Yussef SaId Cahali, omissos os textos legais, nosso Direito, discretamente, partilhava do entendimento de que bastaria a imposição do encargo alimentar em favor do inocente, como forma bastante para ressarcir o prejuízo sofrido pela dissolução da sociedade conjugal de que foi responsável o cônjuge culpado ${ }^{687}$. REGINA BEATRIZ TAVARES DA SILVA, por sua vez, nota que os Tribunais sempre aplicaram a perda

\footnotetext{
${ }^{684}$ MedinA, Graciela. Op. cit. (nota 587), p. 91.

${ }^{685}$ PEREIRA, Sérgio Gischkow. Op. cit. (nota 142), p. 352.

${ }^{686}$ Cf. CARVAlHo NeTO, Inacio de. Op. cit. (nota 619), p. 306. Em tal contexto, não se descure da forte crítica de SÉRGIO COUTO: "colocar no varal das Varas de Família situações graves, chocantes, porque intimistas, para emporcalhar a vida um do outro a pretexto de indenização por dano moral, é alimentar o sadomasoquismo de quem, na desavença judicial, não pretende que feneça as antigas idiossincrasias, parecendo que o assunto se insere nos domínios da psicanálise. Quem pagará por esse dano moral, repristinado à sombra da Justiça? E não venha com o argumento de correrem os feitos em 'segredo de justiça', pois isso não é verdade. As vísceras do amor perdido são lançadas aos olhares dos curiosos, e quando as partes em litígio tem notoriedade, cresce ainda mais o estrepito judicial". COUTO, Sérgio. Afronta à família. Porto Alegre: Síntese Publicações, 2002, apud AlMEIDA JúNIOR, Jesualdo Eduardo de. Op. cit. (nota 141), p. 127.

${ }^{687}$ Cf. CAHALI, Yussef Said. Op. cit. (nota 39), p. 586.
} 
do direito à pensão alimentícia como decorrência do grave descumprimento do dever conjugal $^{688}$.

Nestes termos, muito se discutiu a respeito da natureza jurídica da obrigação alimentar a que era condenado o cônjuge culpado pela separação, podendo-se verificar duas vertentes principais: os que entendiam que tinha caráter indenizatório e os que propugnavam pela sua natureza alimentar.

Segundo MÁrio MoAcyr Porto, a dívida de alimentos era, na verdade, uma indenização por ato ilícito, que se cumpria sob a forma de pensão alimentícia, uma reparação pecuniária pela dissolução prematura e reprovável da sociedade conjugal por culpa de um dos cônjuges. Ele assegurava que não era raro o emprego da expressão alimentos para designar a forma como deveria ser cumprida uma dívida indenizatória, não se podendo utilizar o mero nome jurídico para definir sua natureza. Assim, entendia que a expressão usada pela lei significava apenas que, no pagamento da indenização, dever-se-ia seguir o critério, a forma e o processo empregados para implementar uma obrigação alimentar. Ou seja, era uma referência que servia de base para o cálculo da indenização ${ }^{689}$.

Os partidários deste entendimento argumentavam que a condenação em alimentos do cônjuge culpado tinha justamente por fim a reparação do dano ocasionado pelo ato culposo e que o recebimento dos alimentos pela vítima já a colocava em posição equivalente ao seu status anterior, o que equivalia à indenização in natura.

Atualmente, no entanto, a maioria dos doutrinadores se inclina para admitir a indenização dos danos morais separadamente da verba alimentar.

Para JosÉ DE CASTRo BIGI, a dissolução da sociedade conjugal por si só gera consequências para o culpado, como o débito alimentar em prol do ex-cônjuge. Se aquele, além disto, causou dano injusto ao inocente, tal fato não se apaga com a separação e a pensão $^{690}$.

\footnotetext{
${ }^{688}$ Cf. SILVA, Regina Beatriz Tavares da. Op. cit. (nota 198), p. 52.

${ }^{689}$ Cf. PORTO, Mário Moacyr. Ação de responsabilidade civil entre marido e mulher. Revista Forense, n. 285, 1984, pp. 104-105.

${ }^{690}$ Cf. BIGI, José de Castro. Op. cit. (nota 272), p. 49.
} 
Para Bernardo CAStelo Branco, o dever de prestar alimentos não é sucedâneo da reparação dos danos morais produzidos pelo cônjuge infrator, e tampouco constitui indenização, sendo cumulável com aquela, através da aplicação da regra da responsabilidade civil $^{691}$. E JESUALDO EDUARDO DE ALMEIDA JÚNIOR assevera que a verba alimentar não guarda relação com a reparação pelo descumprimento dos deveres conjugais, posto tratarem-se de institutos diversos ${ }^{692}$.

Na opinião de CAio MÁrio da Silva Pereira, a pensão alimentícia devida pelo cônjuge culpado ao inocente (que substitui o dever de assistência) e a indenização por danos morais sofridos pelo cônjuge inocente possuem origem diferente ${ }^{693}$.

De acordo com ARNALDO RIZZARDO, o encargo alimentar não abrange o prejuízo sofrido nem apaga as ofensas feitas. Nestes termos, ele assevera que para compensar as ofensas morais concede-se uma indenização de natureza diversa, embasada nos arts. 186 e 927 do Código Civil ${ }^{694}$.

Na visão de Rolf MADALENO, os alimentos sempre tiveram a destinação específica de subsistência do parceiro desprovido de recursos próprios para sua manutenção, não se confundindo jamais com a paga indenizatória decorrente do rompimento culposo do casamento, muito embora, sem razão, alguns negassem a indenização dos danos derivados da separação culposa, por considerá-los cobertos com a pensão alimentícia em favor do inocente ${ }^{695}$.

Segundo o jurista afirma, basta ver que a indenização possui como objetivo a punição pecuniária daquele que violou os deveres do casamento, enquanto os alimentos, embora também satisfaçam à vítima, têm como fundamento assegurar-lhe a sobrevivência física, cessando quando desaparecem as necessidades do beneficiário, ou quando surjam outras razões de exoneração ${ }^{696}$.

Em tal contexto, Regina BEATRIZ TAVARES DA Silva afirma ser perfeitamente possível a cumulação do pedido indenizatório com o de pensão alimentícia, já que

\footnotetext{
${ }^{691}$ Cf. BRANCO, Bernardo Castelo. Op. cit. (nota 94), p. 63.

${ }^{692}$ Cf. AlMEIDA JÚNIOR, Jesualdo Eduardo de. Op. cit. (nota 141), p. 135.

${ }^{693}$ Cf. PereIRA, Caio Mário da Silva. Op. cit. (nota 185), p. 554.

${ }^{694}$ Cf. RizZARDO, Arnaldo. Op. cit. (nota 468), pp. 693-694.

${ }^{695}$ Cf. MADALENO, Rolf. Op. cit. (nota 49), pp. 273-274.

${ }^{696}$ Cf. ibidem.
} 
possuem diferentes fundamentos: o direito a alimentos do cônjuge tem um fim assistencial, enquanto a indenização visa à reparação dos efeitos do ato ilícito ${ }^{697}$.

Igualmente, INACIO DE CARVALHO NETO nega que a finalidade da condenação do culpado em alimentos seja a reparação do dano ${ }^{698}$, pois, se os alimentos fossem indenização, seriam eles devidos sempre, e não apenas quando houvesse necessidade por parte do cônjuge ${ }^{699}$. Consequentemente, assevera que não há como confundir a pensão alimentícia com o ressarcimento do ato ilícito conjugal, porquanto os alimentos têm um fim específico, que não abrange todas as finalidades da indenização ${ }^{700}$.

Outro argumento utilizado para se negar a natureza indenizatória dos alimentos é que a responsabilidade civil, em regra, é fundada na culpa. Ao passo que os alimentos não se limitam a esta hipótese; ao contrário, são devidos inclusive na separação litigiosa não culposa, sendo que o art. 1.704, parágrafo único, do Código Civil, reforça este entendimento, pois dispõe que mesmo o cônjuge culpado conserva o direito, em caráter excepcional e de forma restrita, aos chamados alimentos indispensáveis à sobrevivência.

Ademais, INÁCIO DE CARVALHO NETO aponta que se o cônjuge credor casar-se novamente, extingue-se a obrigação alimentar, o que não ocorre com a reparação civil; há possibilidade de renúncia aos alimentos, o que não afeta a indenização; e a pensão alimentícia está sujeita à revisão a qualquer tempo; diferentemente da indenização por ato ilícito $^{701}$.

Assim, o jurista propugna pela natureza puramente alimentar da obrigação instituída pelo art. 1.702 do Código Civil. Ou seja, entende que a pensão alimentícia apenas ressarce os prejuízos causados ao cônjuge inocente pela cessação do dever de assistência material do seu consorte ${ }^{702}$, e, "ainda que possa ela ter eventual caráter

\footnotetext{
${ }^{697}$ Cf. Silva, Regina Beatriz Tavares da. Op. cit. (nota 440), p. 120.

${ }^{698}$ Cf. CARVAlho Neto, Inacio de. Op. cit. (nota 619), p. 313.

${ }^{699}$ Cf. CARVAlHo Neto, Inacio de. Op. cit. (nota 86), p. 283.

700 Cf. CARVAlHo Neto, Inacio de. Op. cit. (nota 619), pp. 313-314. Em suas palavras: “o que se está a afirmar é que, embora possam os alimentos ser computados como indenização de parte dos danos sofridos pela vítima, não configuram eles uma verdadeira indenização, por não atenderem ao requisito da completude, ou seja, por não repararem integralmente o dano”. CARVALHO NETO, Inacio de. Op. cit. (nota 86), p. 286.

${ }^{701}$ Cf. Carvalho Neto, Inacio de. Op. cit. (nota 619), p. 315.

${ }^{702}$ Cf. ibidem.
} 
indenizatório, nada impede a sua cumulação com a indenização dos danos materiais ou morais não cobertos pela condenação em alimentos ",703.

Nestes termos, conclui-se que a diferença está em que os alimentos só podem ser exigidos se comprovada a necessidade, sendo isto irrelevante para a reparação civil e que a indenização, uma vez definida, não poder ser alterada, ao passo que a prestação alimentar é variável conforme as condições econômicas das partes.

Por fim, InACIO DE CARVALHO NeTO observa que, se nem os alimentos podem ser considerados verdadeira indenização, muito menos o serão as verbas de sucumbência, pois têm natureza puramente processual, ressarcindo o vencedor pelas despesas da demanda $^{704}$.

Na opinião de LuIZ Murillo FÁBREGAS, a doutrina majoritária rebateu as críticas que haviam sido formuladas, não deixando dúvidas sobre a possibilidade da indenização, que não depende da pensão alimentícia, a qual nem sempre é devida e cumpre a função de substituir o dever de mútua assistência ${ }^{705}$.

Vimos, deste modo, que são muitos os motivos que a doutrina levanta para afirmar a indenização neste caso: a) a origem da pensão e do dano moral é diversa; $b$ ) a prestação alimentar não tem a mesma dimensão da indenização pelos danos sofridos, havendo diferença de abrangência; c) os alimentos têm a finalidade de manutenção da subsistência (natural ou qualificada), ao passo que a indenização tem função reparatória; d) a necessidade é essencial para a pensão alimentícia, sendo irrelevante para a indenização; e) a reparação depende da culpa, enquanto os alimentos não, apenas variando, de acordo com outros requisitos, sua característica civil ou meramente natural; $f$ ) a prestação alimentar pode cessar por razões totalmente estranhas ao dever de indenizar; $g$ ) a indenização, uma vez firmada, não varia, os alimentos, por sua vez, seguem a equação econômica entre as partes.

Destarte, hodiernamente, a quase totalidade dos juristas assevera que há nítida distinção entre a obrigação de prestar alimentos, fundada na necessidade, e a reparação civil, exigida em razão do cometimento do ato ilícito. Na esteira deste pensamento, os

\footnotetext{
${ }^{703}$ CarValho Neto, Inacio de. Op. cit. (nota 86), p. 287.

${ }^{704}$ Cf. CARVAlHo Neto, Inacio de. Op. cit. (nota 619), p. 318.

${ }^{705}$ Cf. FÁBREGAS, Luiz Murillo. Op. cit. (nota 131), p. 102.
} 
alimentos têm o caráter de substituição do dever de socorro e se mostram insuficientes para compensar ou ressarcir os prejuízos decorrentes do ato ilícito do cônjuge culpado. Já a indenização tem o fim de reparar ou compensar o dano causado.

\subsubsection{Correntes doutrinárias favoráveis à indenização}

Os juristas favoráveis à indenização do dano moral entre cônjuges distinguem duas situações: o dano moral que pode ser padecido por qualquer pessoa e o que somente na condição de cônjuge alguém pode sofrer.

Nestes termos, é possível assinalar duas correntes doutrinárias: a primeira admite a responsabilização tão-somente nas hipóteses que possam ser subsumidas à cláusula geral de responsabilidade civil; e a segunda sustenta o dever de indenizar tanto em casos gerais, como em casos específicos, quando restar caracterizada a infração a um dever conjugal.

MARia Celina Bodin de Moraes esclarece que, para os defensores da primeira corrente, a agressão física do marido à mulher evidentemente gerará dano moral a ser ressarcido, mas a quebra do dever de fidelidade não. Já para a segunda, a indenização dos danos morais poderá ocorrer nas duas situações, tanto pelo ilícito absoluto como pela violação do dever conjugal. Conforme observa, enquanto a jurisprudência parece mais inclinada a adotar a primeira posição, a doutrina nacional vem sustentando a segunda ${ }^{706}$.

Entre os partidários da segunda corrente há que se distinguir, ainda, os doutrinadores que admitem a indenização apenas em razão das causas que determinaram o término do relacionamento conjugal e causaram danos - como a infração dos deveres matrimoniais -, daqueles que também consideram possível reparar os danos ocasionados pelo próprio divórcio.

Desta forma, RUY ROSADO DE AGUIAR JÚNIOR distribui o tratamento da questão entre os que negam peremptoriamente a possibilidade da ação de reparação de danos entre cônjuges; os que admitem amplamente a responsabilização por danos materiais e morais causados pelo consorte contra o outro, seja por ofensas anteriores à separação, seja pelo dano que decorre da separação ou do divórcio; e, em posição

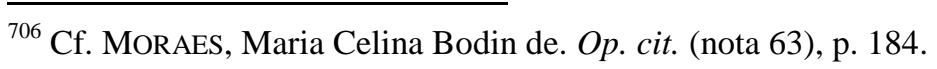


intermediária, os que admitem a responsabilidade por ato do cônjuge, com restrições quanto à natureza, ao fato gerador e à gravidade do prejuízo ${ }^{707}$.

Maria Celina Bodin de Moraes é partidária da tese de que, para a indenização, não basta a violação aos deveres conjugais, que gera somente a possibilidade de propor a separação judicial ${ }^{708}$, uma vez que nenhum preceito prevê o ressarcimento dos danos causados pela própria separação, não obstante gere sofrimentos relevantes ${ }^{709}$.

Assim, balizada pela teoria da ponderação dos interesses contrapostos, a jurista propõe que no relacionamento conjugal se considere, de um lado, a solidariedade familiar (da qual decorrem os deveres conjugais) e, de outro, a autonomia individual (as escolhas individuais de cada cônjuge). Entre estes, afiança que os direitos do indivíduo e as suas próprias opções de vida assumem maior peso, não admitindo que o desrespeito a algum dever conjugal dê causa à ação de responsabilidade civil ${ }^{710}$.

Portanto, assevera que "o relacionamento extraconjugal, em si e por si, não

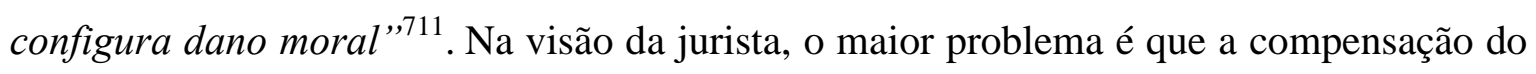
dano moral se faria, essencialmente, em dinheiro, o que acirraria ainda mais a situação gravemente conflituosa, que normalmente acompanha os juízos de separação e divórcio ${ }^{712}$. Em suas palavras: "a ideia de se poder obter dinheiro com a triste circunstância ('rectius', tornar concreta a ameaça de tantos: 'você vai me pagar') faz surgir o que há de pior em nós: a cobiça",713.

Nestes termos, conclui que nos casos de infidelidade, abandono do lar etc, a indenização não emprestaria proteção alguma aos familiares, em particular aos filhos, remanescendo sem utilidade. O raciocínio está equivocado, pois parte de uma visão

\footnotetext{
${ }^{707}$ Cf. AgUIAR JÚNIOR, Ruy Rosado de. Op. cit. (nota 15), p. 7.

708 "se, por circunstâncias que não cabe ao Direito investigar, o que se espera de uma relação conjugal como previsto nos deveres conjugais - não está ocorrendo, solução há e é a sua dissolução. De fato, o único remédio razoável, e que serve como meio apaziguador do conflito, é a separação do casal em virtude da ruptura da vida em comum”. MoRAES, Maria Celina Bodin de. Op. cit. (nota 63), p. 195.

${ }^{709}$ Cf. MoraEs, Maria Celina Bodin de. Op. cit. (nota 63), p. 193.

${ }^{710}$ Cf. idem, p. 194-196.

711 Idem, p. 198.

${ }^{712}$ Cf. idem, p. 196.

${ }^{713}$ Ibidem.
} 
estreita, que encampa a lógica pura de causa e consequência, numa interpretação literal e errônea de que quem sofre o prejuízo moral sempre tem direito a prestação pecuniária ${ }^{714}$.

Entretanto, condizente com a corrente doutrinária a que se filia, a jurista reconhece que se a ruptura da vida em comum vier acompanhada de violência, de humilhação contínua diante de terceiros ou dos próprios filhos, entrar-se-á na seara do ato ilícito, podendo haver a responsabilização pelo dano moral infligido ${ }^{715}$. Nestes casos, em que as relações entre cônjuges atingem os 'lindes da responsabilidade aquiliana', assegura que a cláusula geral prevista nos art. 186 e 927 do Código Civil é suficiente ${ }^{716}$.

MARIA BERENICE Dias também perfilha este entendimento, destacando o dano decorrente de ato ilícito, que em toda e qualquer hipótese geraria obrigação de indenizar, mas que igualmente acarreta grave infração aos deveres do casamento. Em sua opinião, a inclinação da doutrina em sustentar que a mera violação dos deveres do casamento acarreta imposição de sanções é uma tentativa de aplicar penalidade a quem deu causa à dissolução da sociedade conjugal. Assim, endossa o coro dos que afirmam que ninguém pode ser culpado por deixar de amar, que a desilusão sofrida leva à vontade de culpar o outro, mas que o desamor, a solidão e a frustração não seriam indenizáveis, e que a responsabilidade civil apenas ocorrerá quando presentes seus elementos essenciais (dano, ilicitude e nexo (causal) $)^{717}$.

Afirmam Cristiano Chaves Farias e Nelson Rosenvald que "a violação pura e simples de algum dever jurídico familiar 'não é suficiente para caracterizar o dever de indenizar', dependendo da incidência das regras de responsabilidade civil no âmbito do Direito de Família da efetiva prática de um ato ilícito, nos moldes do art. 186 e 187 do Código Civil" 718 .

Na visão de CESAR PELUSO: "a sanção de indole patrimonial é absolutamente ineficaz para o cumprimento dos chamados deveres imateriais, porque ninguém ama, ou

\footnotetext{
${ }^{714}$ Ibidem.

${ }^{715}$ Cf. idem, p. 195. "Evidentemente, qualquer ilícito praticado - como o cárcere privado, a violência física ou moral (o chamado 'mobbing') - por uma pessoa em relação à outra, sendo ou não sendo cônjuges, acarretará dano moral a ser indenizado. Se forem cônjuges, a parte prejudicada poderá obter também a separação judicial”. Idem, p. 196.

${ }^{716}$ Cf. ibidem.

${ }^{717}$ Cf. DiAs, Maria Berenice. Op. cit. (nota 453), pp. 114-115.

${ }^{718}$ FARIAS, Cristiano Chaves de et RosenvaLD, Nelson. Op. cit. (nota 382), p. 88.
} 
respeita, só para não perder dinheiro. E, no fundo, reflete apenas o caráter repressivopenal da teoria clássica: pune-se, porque se quer punir ${ }^{, 719}$.

Nestes termos, segundo Gustavo TEPEDINO, o comportamento contrário à vida conjugal, capaz de levar ao desenlace, não é suscetível de identificação objetiva como ato ilícito. Ele se mostra contrário à indenização pelo mero descumprimento de dever, entendendo que a situação não poderia ser reconduzida ao regime da responsabilidade contratual $^{720}$.

Já para MARCIAL BARRETO CASABONA, unicamente o dever de respeito mútuo, violado por comportamento delituoso do cônjuge agressor, autoriza o pleito de indenização. Afirma que não cabe responsabilização por ausência de assistência moral, por infidelidade de uma das partes, por abandono do lar conjugal, ou por falta de consideração mútua, pois não há como exigir isso de um casamento onde não há mais amor e comunhão de vida. $\mathrm{O}$ autor entende que toda relação amorosa pode causar decepções e frustrações para ambas as partes advindas de seu término, pois 'amar sempre envolve riscos ${ }^{, 721}$.

Para ele, não é a ruptura em si ou violação de deveres que justifica a indenização, mas somente os atos que extravasam os limites naturais da dissolução da relação ${ }^{722}$. Ou seja, somente admite a responsabilidade civil se a conduta do cônjuge ofensor for tipificada como crime, produzindo dano material ou moral comprovado ${ }^{723}$.

Também Bernardo CASTELO BRANCO é cauteloso no exame da matéria. Ele entende que a infração aos deveres do casamento, vista como fenômeno isolado, não é capaz de gerar dano moral indenizável, que somente se perfaz quando o comportamento adotado, além de autorizar a dissolução do casamento, trouxer ao cônjuge inocente inegável sensação de dor, aflição, humilhação, sentimentos de desamor que de forma nítida o influenciaram negativamente, capazes de caracterizar a efetiva ofensa aos direitos inerentes à personalidade ${ }^{724}$.

\footnotetext{
${ }^{719}$ Peluso, Antonio Cezar. Op. cit. (nota 655), p. 53.

${ }^{720}$ TePedINO, Gustavo. O papel da culpa na separação e no divórcio. In: PEREIRA, Rodrigo da Cunha (coord.). Repensando o direito de família: anais do I congresso brasileiro de direito de família. Belo Horizonte: IBDFAM, 1999, p. 200.

${ }^{721}$ Cf. CASABONA, Marcial Barreto. Op. cit. (nota 189), p. 362.

${ }^{722}$ Cf. idem, pp. 361-362.

${ }^{723}$ Cf. idem, p. 366.

${ }^{724}$ Cf. BRANCO, Bernardo Castelo. Op. cit. (nota 94), pp. 66-68.
} 
Nestes termos, se o comportamento pode ser subsumido a uma infração penal, não há dúvida que enseja reparação por danos, sendo implausível afastar esta consequência legal pela qualidade de cônjuge do ofendido. Pelo contrário, esta circunstância constituiria um agravante. No entanto, admitir o dever de indenizar em tais condições não significa a adoção da responsabilidade civil entre cônjuges somente quando decorrente de ilícitos penais. Além disto, sujeitar a possibilidade de reparação do dano moral à configuração do ilícito penal demandaria a prévia condenação do ofensor no juízo criminal, o que, diante dos rigores probatórios e dos princípios próprios daquele ramo do direito, significaria um sério obstáculo à devida resposta à violação sofrida ${ }^{725}$.

De outra parte, ele afiança que a reparação, embora expressa em pecúnia, não busca qualquer vantagem patrimonial em benefício da vítima, revelando-se na verdade como forma de compensação diante da ofensa recebida, que em sua essência é irreparável, atuando ao mesmo tempo em seu sentido educativo-preventivo, na medida em que representa uma sanção aplicada ao ofensor ${ }^{726}$.

SÉRGIO GISCHKOW PEREIRA tem se mostrado assiduamente contrário à tese do ressarcimento de danos morais entre cônjuges em razão da violação dos deveres do casamento, ou seja, naquelas hipóteses em que o dano somente pode ser sofrido pelo cônjuge e na condição de cônjuge. Para o autor, essa inclinação é perigosa e merece reparos, pois amplia demais a possibilidade de ressarcimento do dano moral nas relações familiares ao deferir a indenização indiscriminadamente ${ }^{727}$. Ele assegura que o dano moral nestes casos não encontra ressonância nos valores nacionais, sendo uma postulação não embasada pela moralidade, uma forma de buscar indevido ganho financeiro ${ }^{728}$.

No entanto, o autor ressalva que um cônjuge não pode infligir agressões físicas e morais no outro e ficar isento de indenizar, da mesma forma que qualquer pessoa ${ }^{729}$.

FÁBIO SIEBENEICHLER de ANDRADE é contrário ao dano moral entre cônjuges pelo mero fim do vínculo, o que, em sua visão, acarretaria uma desarmonia sistêmica, por

\footnotetext{
${ }^{725}$ Cf. idem, p. 58.

${ }^{726}$ Cf. idem, p. 116.

${ }^{727}$ Cf. PEREIRA, Sérgio Gischkow. Op. cit. (nota 142), pp. 350-352.

728 Cf. idem, p. 360. Em suas palavras: "uma certa modalidade de moralismo hipócrita ou retrógrado puritanismo vitoriano está, a par dos interesses puramente financeiros, bastante feliz com o desfraldar da cruzada pela conduta exemplar (sob que ótica?...), não pecaminosa e de angelical pureza nas relações erótico-afetivas... ". Idem, p. 355.

${ }^{729}$ Cf. idem, pp. 351.
} 
não haver a previsão legal, bem como porque isto consistiria em constrangimento para impedir o fim do vínculo ${ }^{730}$. Ele nega a possibilidade de dano moral por descumprimento de dever conjugal, postulando a manutenção da especificidade do Direito de família em relação ao Direito das obrigações. Há, em sua visão, um interesse não apenas institucional, da família, mas igualmente do indivíduo, para resguardar o caráter ético dos deveres entre cônjuges $^{731}$.

Entretanto, o autor não admite uma imunidade. Ele diz que é possível o dano moral, mas desde que haja violação a direito da personalidade. Ou seja, “(...) a razão para o reconhecimento do dever de indenizar não repousa na ocorrência de violação de um dever pessoal de família. Reside, isto sim, na infração a um dever absoluto, que surge independentemente da existência ou não de vínculo familiar" ${ }^{732}$. É preciso, ainda assim, uma especial gravidade para caracterizar o dano moral ${ }^{733}$.

O ponto nevrálgico da orientação deste autor reside em sua concepção dos direitos da personalidade, mais restritiva, talvez devido à sua formação germânica. Para ele, o dano moral somente surgiria de violações mais graves, como no caso de injúria grave e sevícias ${ }^{734}$.

CAETANO LAgRASTA pondera que a mera possibilidade de ressarcimento pode perpetuar uma relação falida, impedindo eventual processo de reconstrução da vida e o desenvolvimento dos filhos ${ }^{735}$.

O jurista também considera que o cônjuge-vítima muitas vezes avoca parcela expressiva de responsabilidade pelos danos, ao não recorrer aos mecanismos legais - ou àqueles da esfera policial -, na esperança de manter, a qualquer custo, o relacionamento, não podendo, depois, pretender que sejam indenizados ${ }^{736}$.

Dessa circunstância surge a dúvida na valoração do grau de culpa para caracterizar eventual nexo de causalidade, com necessidade de instauração de verdadeiro

\footnotetext{
${ }^{730}$ Cf. ANDRADE, Fábio Siebeneichler de. A reparação de danos morais por dissolução do vínculo conjugal e por violação de deveres pessoais entre cônjuges. Revista dos Tribunais, v. 802, 2002, p. 23.

${ }^{731}$ Cf. idem, p. 25.

${ }^{732}$ Ibidem.

${ }^{733}$ Cf. idem, p. 23.

${ }^{734}$ Cf. idem, pp. $25-26$.

${ }^{735}$ Cf. LAGRASTA, Caetano. Dano moral no direito de família. Revista do Advogado, n. 91, 2007, p. 32.

${ }^{736}$ Cf. idem, pp. 27-28.
} 
inquérito probatório, o que agrava desnecessariamente o conflito, já que não há qualquer possibilidade de reconciliação ${ }^{737}$. Nestes termos, afiança que não há como definir um único prejudicado ou causador exclusivo pelo fim do casamento ${ }^{738}$.

Não obstante, o autor cogita da indenização entre os cônjuges em razão da gravidade da ofensa, ante a prática de atos atentatórios à liberdade psíquica, quando ultrapassam a esfera individual de proteção ao casamento ${ }^{739}$.

Assim, conclui que não basta acenar aos arts. 186 e 927 do Código Civil ou art. $5^{\circ}$, inciso V, da Constituição Federal para afirmar que o Direito brasileiro admite a indenização por danos morais na dissolução do vínculo conjugal e assevera que o trabalho jurisprudencial deve ser realizado com isenção, visto que a admissão pura e simples poderá induzir à 'banalização do amor e da família' ${ }^{740}$.

Por sua vez, YUSSEF SAID CAHALI explica que a questão não é saber se um ato ilícito, como a agressão, pode ser indenizado se praticado pelo cônjuge, mas sim investigar se é igualmente reparável o dano específico da relação conjugal, aquele que somente pode ser sofrido pelo cônjuge inocente, a ofensa que caracteriza uma grave infração aos deveres do casamento, tornando insuportável a vida em comum ${ }^{741}$.

Para o jurista, a infração dos deveres conjugais, quando apta a produzir danos de natureza moral, já se mostra suficiente para fundamentar o pedido de indenização por parte do cônjuge ofendido. Considera, portanto, que o ato ilícito preserva a sua autonomia, projetando-se duplamente, seja como fundamento para a dissolução do casamento, autorizando os efeitos que lhe são próprios, como também fazendo incidir a regra geral da responsabilidade civil $^{742}$.

JosÉ DE AGUIAR DiAs abriu esta trilha da ampla admissão dos danos morais entre cônjuges, sustentando que o adultério poderia originar reparação civil, entre outras infrações aos deveres do casamento: "a violação das obrigações derivadas do casamento é, indubitavelmente, falta contra a honestidade. É o que se verifica por parte de quem dá,

\footnotetext{
${ }^{737}$ Cf. ibidem.

${ }^{738}$ Cf. idem, p. 25.

${ }^{739}$ Cf. idem, p. 28.

${ }^{740}$ Cf. idem, pp. 25-26.

${ }^{741}$ Cf. CAHALI, Yussef Said. Op. cit. (nota 39), p. 590.

${ }^{742}$ Cf. idem, p. 589.
} 
por seu procedimento, causa à separação de corpos, desquite ou divórcio, acarretando prejuizo moral e material ao outro cônjuge (...), ${ }^{\text {,743 }}$.

Com o acréscimo de argumentos deduzidos da Constituição de 1988, JOSÉ DE CASTRo Bigi retomou esta linha da reparação do dano moral resultante da dissolução da sociedade conjugal, ao certificar que a intenção do constituinte foi considerar indenizáveis os danos morais resultantes da violação da intimidade, da vida privada, da honra e da imagem das pessoas ${ }^{744}$. No entanto, à época, o autor observava que o cônjuge culpado quedava-se livre de indenizar o inocente pelos danos ocasionados com a prática do ato ilícito quando da ruptura do matrimônio, como o adultério ou as agressões físicas continuadas $^{745}$.

YUSSEF SAID CAHALI observa que, atualmente, nos termos em que a questão vem sendo colocada, não há dúvida de que o cônjuge agredido em sua integridade física ou moral pode mover ação de indenização, com fundamento no art. 927 do Código Civil, sem embargo de aquela ofensa representar uma causa que legitima a separação judicial contenciosa $^{746}$.

Também RUI STOCO assevera que o Código Civil de 2002, ao não disciplinar a responsabilidade entre cônjuges, demonstrou a total falta de sensibilidade do legislador, que, “(...) pretendendo ser 'moderno', olvidou e fez 'tábula rasa' de direitos fundamentais como a honra e a imagem das pessoas, expressamente asseguradas na Constituição Federal ${ }^{, 747}$.

Já REgina BEATRIZ TAVARES DA SiLVA denota preocupação com a hipótese de inexistirem consequências para a violação dos deveres matrimoniais. Para ela, esta inocuidade dos deveres levaria ao caos, pois os cônjuges receberiam meras recomendações da lei - a fidelidade, o respeito recíproco -, mas sem estarem obrigados a observá-las, pois seu descumprimento não acarretaria sanção ${ }^{748}$. Assumindo o papel de aconselhamentos, as normas jurídicas do Direito de família seriam transformadas em

\footnotetext{
${ }^{743}$ DiAs José de Aguiar. Da responsabilidade civil. v. II. $8^{\mathrm{a}}$ ed. Rio de Janeiro: Forense, 1987, apud PACCA, Elizabeth Ana Maria Meisels. Op. cit. (nota 612), p. 97.

${ }^{744}$ Cf. CAHALI, Yussef Said. Op. cit. (nota 39), p. 588.

${ }^{745}$ Cf. BIGI, José de Castro. Op. cit. (nota 272), p. 46.

${ }^{746}$ Cf. CaHALI, Yussef Said. Op. cit. (nota 39), p. 589.

${ }^{747}$ STOCO, Rui. Op. cit. (nota 233), p. 809.

${ }^{748}$ Cf. Silva, Regina Beatriz Tavares da. Op. cit. (nota 198), p. 13.
} 
regras de cunho puramente moral, cujas violações não gerariam qualquer implicação a seus infratores, a favorecer o inadimplemento desses preceitos, em contraposto à necessária preservação da dignidade da pessoa nas relações familiares ${ }^{749}$.

Por essa razão, a jurista defende a invocação dos princípios da responsabilidade civil nas relações entre cônjuges, mesmo porque, eles estão inseridos na Parte Geral do Código, aplicando-se a todas as relações de natureza civil, entre as quais estão as relações de família ${ }^{750}$. Nestes termos, ela afiança que, violados os deveres, resultando em danos, nasce o direito à reparação, estando preenchidos os pressupostos da responsabilidade civil $^{751}$.

A doutrinadora ainda observa que em muitos casos não há apenas desamor, pois se apenas falta de amor houvesse não configuraria ação ilícita, como a decorrente da prática de agressões físicas ou morais, que violam gravemente o dever de respeito e consideração mútuos $^{752}$. Por isso, assegura que não se trata de uma tentativa de substituir o afeto pela pecúnia, já que amar não é dever ou direito na órbita jurídica, e sim de criar mecanismos para assegurar a vivência responsável da afetividade ${ }^{753}$. Assim, adverte: “(...) se nos perdermos na seara dos afetos e amores como sentimentos, e não com o devido respeito à dignidade da pessoa humana, ficaremos sem prumo e não encontraremos a solução jurídica, almejada por quem recorre ao Poder Judiciário „754.

Quando ambos os cônjuges violam os deveres conjugais, afirma ela, a culpa é recíproca, de modo que o adultério de um dos consortes não justifica a prática do mesmo ato pelo outro ou de diferentes infrações, como sevícias ou injúrias graves, pois vigora o princípio da inadmissibilidade da compensação de culpas ${ }^{755}$.

Destarte, afiança que os cônjuges que passam por tais situações de desrespeito não vivem mais uma relação de afeto e precisam da proteção do Direito ${ }^{756}$.

\footnotetext{
${ }^{749}$ Cf. idem, pp. 14 e 27

${ }^{750}$ Cf. idem, p. 58.

${ }^{751}$ Cf. Silva, Regina Beatriz Tavares da. Op. cit. (nota 440), p. 116.

${ }^{752}$ Cf. idem, p. 115

${ }^{753}$ Cf. SILVA, Regina Beatriz Tavares da. Op. cit. (nota 198), p. 109.

${ }^{754}$ Idem, p. 58.

${ }^{755}$ Cf. idem, p. 28.

${ }^{756}$ Cf. idem, p. 13. Nestes termos, REgINA BEATRIZ TAVARES DA SILVA conclui que “não será o reino apregoado do afeto que evitará a discórdia e o descumprimento dos deveres conjugais. $O$ descumprimento
} 
Da mesma forma, segundo Elizabeth AnA Maria Meisels PaCcA, os princípios da responsabilidade civil são perfeitamente aplicáveis às relações conjugais. Uma vez impostos deveres, seu desrespeito causa dano, legando direito ao devido ressarcimento. A autora afirma que as sanções impostas pelo legislador ao cônjuge infrator não indenizam o inocente pelos danos sofridos ${ }^{757}$. Assim, pondera que o atual conceito da família, aliado à maior efetividade das normas que implementam os direitos humanos e, ainda, aos novos conceitos de responsabilidade civil, em especial do ressarcimento dos danos morais, trouxe um alento para estes $\operatorname{casos}^{758}$.

FERNANDA OltRAMARI e Vitor Hugo OltRAMARI asseguram que, decorrendo dano da infração a dever matrimonial, resta, como sanção, a responsabilidade civil, tanto material como moral. Conforme observam, mesmo que as partes fossem simplesmente sócios, vizinhos ou conhecidos, haveria o dever de indenizar os danos, consubstanciado na regra geral do Código Civil e, com mais razão, na relação conjugal, onde o compromisso de respeito e consideração é muito maior ${ }^{759}$. E concluem: "havendo culpa, danos e liame causal entre um e outro, é fundamental que haja responsabilização indenizatória ${ }^{, 760}$.

Na visão de VAlÉRIA Silva Galdino CARdin, as infrações dos deveres conjugais podem ensejar reparação por danos morais quando provocarem lesão aos direitos personalíssimos do outro, causando-lhe dor, sofrimento, humilhação, vexame, afronta, ultraje etc, configurando ato ilícito. Contudo, também afirma ser necessário que os requisitos da responsabilidade civil estejam presentes ${ }^{761}$.

De tal modo, observa que os casos de separação judicial litigiosa podem dar origem à indenização por perdas e danos, em face dos prejuízos morais ou patrimoniais sofridos pelo cônjuge que não deu causa à separação ${ }^{762}$. Ou seja, pode responder por danos morais aquele que comete adultério, assim como o que descumpre injustificadamente o

desses deveres, que gera o desequilíbrio antes exposto, continuará a receber sanções legais, sob pena de transformação da família numa fantasia jurídica”. Idem, p. 14.

${ }_{757}^{757}$ Cf. PACCA, Elizabeth Ana Maria Meisels. Op. cit. (nota 612), p. 96.

${ }_{758}^{758}$ Cf. idem, p. 98.

${ }_{759}^{75}$ Cf. OltramARI, Fernanda et Oltramari, Vitor Hugo. Op. cit. (nota 102), p. 72.

${ }^{760}$ Idem, p. 74.

${ }^{761}$ Cf. CARDIN, Valéria Silva Galdino. Op. cit. (nota 245), p. 158.

${ }^{762}$ Cf. idem, p. 138. 
dever de mútua assistência ${ }^{763}$. Ela ressalva que a indenização não restitui, nem assegura o afeto, mas por meio dela os danos podem ser minorados ${ }^{764}$.

Belmiro Pedro Welter entende necessária a presença dos seguintes requisitos para a reparação dos danos morais em tais casos: as ações de separação judicial e indenização devem ser ajuizadas logo após a ocorrência da conduta culposa, sob pena de incidir o perdão do cônjuge ofendido; o direito ao dano moral é exclusivo do cônjuge inocente (não admite o pedido indenizatório quando houver culpa recíproca); o pedido somente é possível na ação de separação judicial litigiosa e com culpa; a conduta do cônjuge culpado deve ser tipificada como crime; e o comportamento delituoso deve ser ofensivo à integridade moral do cônjuge ofendido, produzindo dor martirizante e profundo mal-estar e angústia ${ }^{765}$.

Por sua vez, CAROLINA VALENÇA FERRAZ assevera que o ato ilícito praticado por um dos cônjuges não desconfigura a ocorrência de dano, ao contrário, por ser tão próximo, aquele pode incorrer em danos ainda maiores ${ }^{766}$.

Para Rolf MADALENO, a violação dos direitos e deveres de ordem familiar é sempre suscetível de reparação patrimonial ou moral. Deste modo, entende que todas as causas culposas da separação judicial podem redundar em um ato ilícito, capaz de ocasionar lesão factível de reparação ${ }^{767}$. Em seu ponto de vista, não há que se falar em especialização, pois o conteúdo do Direito de família não está fora do alcance do Direito privado, não se podendo impedir a aplicação do princípio do neminem laedere, que tem hierarquia constitucional $^{768}$.

Segundo o autor, a indenização moral busca compensar o real sofrimento do cônjuge judicialmente declarado vítima da separação litigiosa, sua função é a de ressarcir a

\footnotetext{
${ }^{763}$ Cf. idem, pp. 133-135.

${ }^{764}$ Cf. idem, p. 71.

${ }^{765}$ Cf. Welter, Belmiro Pedro. Op. cit. (nota 677), pp. 28-29.

766 Cf. FERrAZ, Carolina Valença. Responsabilidade civil por dano moral e patrimonial na separação judicial. Dissertação de mestrado apresentada à Pontifícia Universidade Católica de São Paulo - PUC, São Paulo, 2001.

${ }^{767}$ Cf. MADALENO, Rolf. Op. cit. (nota 49), pp. 271-272.

${ }^{768}$ Cf. Madaleno, Rolf. O dano moral no direito de família. In: Delgado, Mário Luiz et Alves, Jones Figueirêdo. Novo código civil: questões controvertidas. v. 5. São Paulo: Método, 2006, p. 537.
} 
honra conjugal afetada ou, como prescreve o Direito constitucional, reparar a transgressão de seus direitos de personalidade ${ }^{769}$.

No entanto, adverte que o tempo conta substancialmente na configuração jurídica deste dano, devendo o acionamento judicial ser imediato ${ }^{770}$, pois: “a inércia temporal conspira contra a invocação da causa da separação e faz com que os resíduos conflituosos não mais transpirem em processos nos quais a fática e já enfadonha ruptura transformou-se em silenciosa resignação" ${ }^{\text {,771 }}$. De tal forma, entende que o longo silêncio dos cônjuges desavindos demonstra que já perdoaram eventuais desinteligências e possíveis excessos de condutas, apagando os ressentimentos nascidos do descumprimento de dever conjugal ${ }^{772}$.

Para Luiz Murillo FÁBREgAS, a falta dos deveres impostos no casamento, independentemente de sua intensidade, gravidade e consequências, autoriza a reparação do dano. Informa ainda que há disposição expressa a este respeito na legislação de outros países, o que não nos impede invocar, na ausência da regra particular, a previsão geral de reparação civil ${ }^{773}$.

JESUALDO EDUARDo DE ALMEIDA JÚNIOR considera que, descumpridos os deveres do casamento, impõe-se a reparação pela ofensa, pois a infração não é obrigacional ou contratual, mas sim uma transgressão a dever jurídico. O jurista infere que, não obstante a consagração constitucional, a indenização dos danos morais fundamenta-se na regra geral da responsabilidade civil e do abuso de direito ${ }^{774}$.

$\mathrm{O}$ autor ressalta que se deve perquirir a culpa, pois nem toda separação ou divórcio gera o dever de indenizar, mas apenas se houver o descumprimento de um dos deveres impostos pela lei, tendo sido demonstrada a culpa ou dolo do ofensor. Em sua visão, retomar a discussão da culpa não caracteriza um retrocesso, pois o caso da

\footnotetext{
${ }^{769}$ Cf. MADALENO, Rolf. Op. cit. (nota 607), p. 66.

${ }^{770}$ Cf. ibidem.

${ }^{771}$ Idem, p. 65.

${ }^{772}$ Cf. ibidem. De forma análoga, a notícia de que: "a demora no ingresso em juízo, de modo exagerado em proporção ao dano sofrido, se apresenta na jurisprudência como fato capaz de impor redução ao valor da condenação". CIANCI, Mirna. Op. cit. (nota 227), p. 103,

${ }^{773}$ Cf. FÁBREGAS, Luiz Murillo. Op. cit. (nota 131), p. 111.

${ }^{774}$ Cf. ALMEIDA JÚNIOR, Jesualdo Eduardo de. Op. cit. (nota 141), pp. 131-133.
} 
indenização seria outro, diferente da sua investigação para fins de divórcio, onde a medida é inócua e contraproducente ${ }^{775}$.

No entanto, em seu ponto de vista, a simples ruptura da sociedade conjugal 'pela cessação do amor' não gera danos morais, pois ninguém é obrigado a amar: a lei não impõe esse dever, e se não há dever, não há sanção. Assim, conclui que o amor é uma obrigação moral, destituída de sanção jurídica. O dano, desta maneira, deve ser plausível, razoável, evitando-se embates fúteis, de menor importância ${ }^{776}$.

Ele rejeita, contudo, a tese de alguns, que exigem a publicidade dos fatos (traição conhecida por terceiros, desrespeito presenciado por outros etc) para a configuração do dano, pois o dano moral visa a reparar o embaraço, o desagrado a diminuição da autoestima e, sobretudo, a defender a dignidade humana, indagando: "como negar-se que um esposo que se viu traído não se sinta humilhado, enxovalhado?",777. Se os fatos se tornam públicos, temos uma agravante para a mensuração da condenação ${ }^{778}$.

No que diz respeito à quantificação do dano, adota os seguintes parâmetros: $a$ ) a natureza específica da ofensa sofrida; $b$ ) a intensidade efetiva do sofrimento da vítima; c) a repercussão da ofensa no meio social; $d$ ) a existência de dolo por parte do ofensor e/ou o grau de culpa; e) o comportamento da vítima; e f) as práticas atenuantes realizadas pelo ofensor visando a diminuir a dor do ofendido ${ }^{779}$.

Para Zeno Veloso, o argumento de que não se deve indenizar o desamor é falacioso, lembrando o mesmo raciocínio utilizado para se refutar a própria indenização do dano moral, quando se questionava qual seria o preço da tristeza, como quantificar uma decepção, como pagar uma lágrima ou quanto vale a dor. Entretanto, ele assegura que não se trata de admitir pagamento pela carência ou falta de amor, mas de indenizar o ato ilícito praticado, que violou direito e causou dano à vítima ${ }^{780}$.

Ele reconhece, porém, que há um risco de se monetarizar as relações conjugais nos momentos de crise. Logo, se a atitude de um cônjuge é apenas reflexo do

\footnotetext{
${ }^{775}$ Cf. idem, pp. 136-137.

${ }^{776}$ Cf. idem, pp. 137-138.

${ }^{777}$ Idem, p. 137.

${ }^{778}$ Cf. ibidem.

${ }^{779}$ Cf. idem, p. 140.

${ }^{780}$ Cf. Veloso, Zeno. Op. cit. (nota 387), p. 180.
} 
afrouxamento ou do fim do vínculo afetivo, sem significar um agravo moral, não se pode falar em indenização. Todavia, se a quebra do dever matrimonial equivale a um ato ilícito e causa danos ao cônjuge inocente, a indenização é pertinente ${ }^{781}$. Em suas palavras, “ $a$ distinção é fina, delicada, o limite é tênue, mas os bons juízes saberão separar uma situação da outra, e decidir com Justiça" ${ }^{\text {,782. }}$.

Também CARlos AlBERTo BITTAR assevera que a deterioração das relações familiares, ditada pelos problemas que a convivência inadequada pode trazer, é fonte de danos morais, ou seja, a desinteligência grave entre o casal pode levar a agressões, injúrias e situações vexatórias, suscetíveis de reparação ${ }^{783}$. O autor distingue os danos morais, reparáveis como compensação e sanção, e os danos materiais, cuja indenização serve para recompor patrimônio atingido ${ }^{784}$.

InACIO DE CARVAlHo NeTO aborda o tema sob outro ângulo. Embora alguns entendam que o simples fato da ruptura não implica reparação, na ausência de fundamento legal para tal pedido, não lhe parece que tenham razão: "tendo-se em conta que toda a espécie de danos deve ser indenizada, não podemos desprezar essa profícua fonte de danos, que é a ruptura do casamento em si considerada,"785.

Desta forma, o jurista passa a distinguir os danos acarretados pelo descumprimento do dever conjugal e os prejuízos oriundos da ruptura do casamento. Em sua visão, os primeiros podem ser de natureza moral ou material e derivam de fatos que são, ao mesmo tempo, causas legais do rompimento matrimonial. Estes danos são denominados imediatos, pois mantêm conexão direta com os deveres matrimoniais ${ }^{786}$.

\footnotetext{
${ }^{781}$ Cf. idem, p. 182.

${ }^{782}$ Ibidem.

783 Cf. BitTaR, Carlos Alberto. Op. cit. (nota 14), p. 189. Assim, protesta: "ora, essas situações todas mostram que existem reflexos outros das relações conjugais que devem ser amparados na Teoria da Responsabilidade Civil, por meio dos danos morais e patrimoniais. Isso significa, portanto que em todas essas hipóteses de ruptura em que se atinjam os direitos da personalidade, podem então as partes obter a necessária reparação. Basta para isso, portanto, que a parte invoque a Teoria da Responsabilidade Civil e obterá então, em juízo, a necessária reparação”. BITTAR, Carlos Alberto. Op. cit. (nota 11), p. 282.

${ }^{784}$ Cf. idem, p. 284.

${ }^{785}$ CARVAlHO NeTO, Inacio de. Op. cit. (nota 619), p. 321, nota 52.

${ }^{786}$ Cf. CARVAlHo Neto, Inacio de. Op. cit. (nota 86), p. 291. "Apresentam-se como danos morais imediatos aqueles que atingem a esfera da personalidade do cônjuge lesado, causando-lhe sofrimento, dentre os quais estão os oriundos do descumprimento do dever de fidelidade, por adultério ou pela prática de ato que demonstre a intensão de satisfação do instinto sexual fora do tálamo; do dever de coabitação, pelo abandono voluntário e injustificado do lar e pela recusa de satisfação do débito conjugal; do dever de mútua
} 
Já os danos decorrentes do rompimento do matrimônio são chamados mediatos, pois se vinculam ao descumprimento do dever conjugal apenas indiretamente. Segundo afirma, tais danos têm caráter quase sempre patrimonial, por embasarem-se nas disparidades que a ruptura do matrimônio pode originar entre os consortes, mas também podem ser de ordem moral, se referentes ao sofrimento ocasionado pelo rompimento do casamento $^{787}$. Em ambos os casos, estão preenchidos os pressupostos da obrigação de indenizar $^{788}$.

Note-se que o autor também admite a possibilidade de obrigação de indenizar na separação litigiosa não culposa fundada em doença mental grave de cura improvável (prevista no art. $1.572, \S 2^{\circ}$, do Código Civil), pois, ainda que legalmente permitida, afirma que essa hipótese não deixa de configurar uma infração do cônjuge ao dever de mútua assistência, ou seja, um ato ilícito, obrigando à indenização ${ }^{789}$.

Além disso, o jurista recorda ser imaginável que ambos os cônjuges cometam condutas desonrosas ou atos que importem em grave violação dos deveres do casamento, reciprocamente $^{790}$. No entanto, em sua opinião, não é possível a compensação de culpas, é dizer, a culpa de um pelo abandono do lar não ilide a do outro pelo adultério, do mesmo modo, o adultério de um dos cônjuges não é causa para que o outro o cometa.

Desta forma, se ambos os cônjuges praticarem adultério, a separação poderá ser decretada por culpa recíproca, não ficando imune da condenação o que cometeu por último $^{791}$. Já quanto à possibilidade de indenização, o jurista afiança que nada impede a demanda por qualquer um deles ou até mesmo por ambos ${ }^{792}$. Não obstante, ele ressalva que se os atos culposos forem excludentes entre si, a configurar causa de não responsabilização, não se poderá falar em indenização pela infração do dever conjugal,

assistência, pela prática de tentativa de homicídio, de sevícias e de injúrias graves; e do dever de sustento, guarda e educação dos filhos, pela prática de maus-tratos contra os infantes, por exemplo”. Idem, p. 292.

${ }^{787}$ Cf. SANTOS, Regina Beatriz Tavares da Silva Papa dos. Op. cit. (nota 611), pp. 153-154.

${ }^{788}$ CARVAlHo NeTO, Inacio de. Op. cit. (nota 86), p. 289.

${ }^{789}$ Cf. idem, pp. 345-346.

${ }^{790}$ Cf. idem, p. 252.

${ }^{791}$ Cf. idem, pp. 259-260.

${ }^{792}$ Ele exemplifica: se a mulher comete adultério e o marido a agride fisicamente, ambos cometeram atos culposos, sendo possível a decretação da separação por culpa recíproca. Assim, o marido pode pedir indenização pelos danos morais sofridos em função do adultério, bem como a mulher, em virtude das sevícias. Não caberia, nesta última hipótese, falar em culpa exclusiva da vítima para afastar a indenização, já que o adultério da mulher não pode ser considerado a 'causa' das sevícias praticadas pelo marido Cf. idem, pp. 293-294 e 324. 
como no caso de ambos os cônjuges cometerem adultério, em condições semelhantes de agravamento à honra do consorte ${ }^{793}$.

O autor avalia que na hipótese de culpa recíproca só há possibilidade de indenização pelo dano decorrente dos atos culposos em si, não pelo rompimento da relação. Logo, não se poderá falar em indenização dos danos derivados do rompimento da relação conjugal, já que a culpa pelo término do casamento foi de ambos ${ }^{794}$.

Ele também considera que se o cônjuge ofendido perdoar a causa culposa não poderá requerer indenização do ofensor, pois as demandas entre cônjuges, na constância do casamento, devem ser evitadas, para não desestabilizarem a família e, dependendo do regime de bens vigente entre eles, seria incongruente falar em obrigação de um indenizar o outro. Assim, o perdão configura hipótese de renúncia, não ensejando a responsabilidade ${ }^{795}$.

Em suma, as conclusões de INACIO DE CARVALHO NETO são:

"o ato de grave violação dos deveres do casamento e a conduta desonrosa são enquadráveis no art. 186 do Código Civil. (...) Há danos derivados do descumprimento dos deveres conjugais e danos derivados do rompimento da relação matrimonial, ambos indenizáveis. (...) Mesmo havendo culpa recíproca, pode se dar a obrigação de um cônjuge indenizar o outro pelos atos culposos que cometeu. A responsabilidade, nestes casos, não é contratual, mas aquiliana, baseada no 'neminem laedere'. Havendo perdão, a causa perdoada não poderá servir de fundamento para pedir indenização, por caracterizar o perdão hipótese de renúncia ${ }^{, 796}$.

Também para NARA Rubia Alves DE RESEnde a indenização por danos decorrentes da separação judicial é possível; entretanto, adverte que é preciso tomar cuidado, a fim de não reduzir a dinheiro todas as dores advindas do término de uma relação conjugal ${ }^{797}$.

\footnotetext{
${ }^{793}$ Cf. idem, pp. 294-295.

${ }^{794}$ Cf. idem, p. 294.

${ }^{795}$ Cf. idem, p. 297.

${ }^{796}$ Idem, p. 498.

${ }^{797}$ Cf. RESENDE, Nara Rubia Alves de. Op. cit. (nota 491), p. 7.
} 
Se, por um lado, o Direito brasileiro não dispõe especificamente sobre a possibilidade de indenização em decorrência da ruptura da vida em comum, em contrapartida, também não a proíbe. Assim, a princípio a indenização seria possível com fundamento na regra geral da responsabilidade civil ${ }^{798}$.

Desta maneira, no caso de ruptura litigiosa, que culmina em lesões à integridade física e moral, à própria personalidade do indivíduo, impossível não se falar em responsabilidade, pois a proteção das pessoas que integram a família é mais importante $^{799}$. O indivíduo se sobrepõe à instituição, proteger e garantir a sua felicidade, sua realização, tornam-se objetivos de maior grandeza ${ }^{800}$.

Além desses danos, decorrentes da ruptura em si mesma, a autora admite a existência de lesões ocasionadas pelas causas que motivaram a separação, como, por exemplo, a difamação, a injúria grave, as sevícias, a lesão corporal e outros que emanem do descumprimento do dever conjugal ${ }^{801}$. Na opinião da jurista, nestes casos temos responsabilidade civil subjetiva ${ }^{802}$, requerendo a constatação do dano, do nexo de causalidade e da culpa ${ }^{803}$.

Na avaliação desses requisitos, adverte a autora, deve-se contextualizar o fato. Isto porque hipóteses que, fora da família, são indubitavelmente danosas, quando ocorridas neste âmbito, podem perder o caráter ilícito, tendo em vista a intimidade que cerca tais relacionamentos. As relações desenvolvidas na família são peculiares, caracterizadas pela cumplicidade e liberdade que se estabelece entre seus membros, onde se verifica a prática de atos que não seriam considerados naturais se ocorressem fora de seu domínio ${ }^{804}$.

Deste modo, mesmo discussões e brigas que à primeira vista são insolúveis, acabam se resolvendo na família e, por isso, os danos decorrentes da dissolução da sociedade conjugal não podem ser mensurados na mesma medida daqueles oriundos de relações sociais de outra natureza: "é preciso que o aplicador do direito haja com

\footnotetext{
${ }^{798}$ Cf. idem, p. 16.

${ }^{799}$ Cf. RESENDE, Nara Rubia Alves de. Op. cit. (nota 491), p. 6.

${ }^{800}$ Cf. idem, p. 29.

${ }^{801}$ Cf. idem, p. 17.

${ }^{802}$ Cf. idem, p. 30.

${ }^{803}$ Cf. idem, p. 24

${ }^{804}$ Cf. idem, p. 30.
} 
sabedoria ao verificar a ocorrência da responsabilidade civil e que não se esqueça de adequar a norma à especialidade dos fatos ${ }^{, 805}$.

Destarte, neste contexto em que se busca a proteção integral do indivíduo, a jurista pondera que não se pode descuidar das peculiaridades que envolvem as relações conjugais $^{806}$. Nestes termos, ela acredita ser possível a indenização, mas alerta que o cuidado e a diligência na sua concessão são imprescindíveis, a fim de também se garantir a aplicação dos princípios da igualdade e da dignidade do ser humano, que é o que afinal se pretende proteger $^{807}$.

Não obstante, ela também chama a atenção para o perigo de se tabelar financeiramente todos os fatos ocorridos na dissolução da sociedade conjugal, o que poderia coagir as pessoas a continuarem casadas para evitar uma indenização, ferindo a dignidade dos envolvidos ${ }^{808}$.

Derradeiramente, a autora relembra que mesmo aqueles que se levantam contra a indenização por danos morais nas relações familiares, pelo perigo de se transformar qualquer relacionamento em um valor pecuniário, a admitem nos casos que extrapolam a normalidade da ruptura, em que a honra, a dignidade e até mesmo a integridade física do consorte são afetadas ${ }^{809}$.

RUY ROSADO DE AGUIAR JÚNIOR propõe algumas conclusões sobre o tema. Para o jurista, a colisão entre os princípios de proteção da dignidade da pessoa humana, da conservação da família e da preservação da intimidade deve ser resolvida de modo a que prevaleça a regra geral da responsabilização civil do autor do dano, ainda que o ato tenha sido praticado contra o cônjuge. O casamento não é causa eximente da responsabilidade civil, nem causa privilegiadora de isenção, diz ele ${ }^{810}$.

Não obstante, ressalva que a existência desse conflito de princípios exige que a regra geral de responsabilidade seja aplicada com temperamento no âmbito do Direito de família, de modo a não destruir outros valores em voga. Por isso, a ação somente será

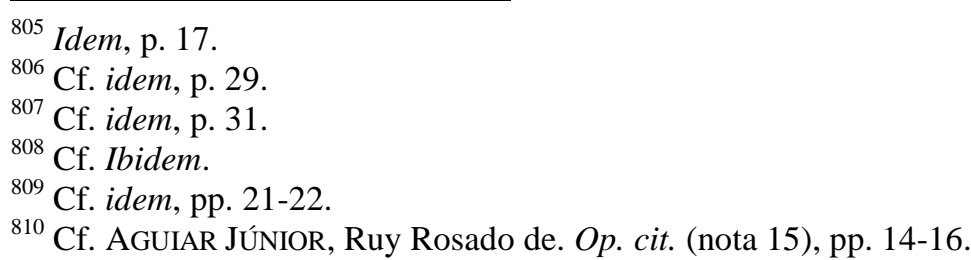


cabível quando demonstrada a gravidade da ofensa, a justificar o afastamento dessas restrições para permitir a justa indenização do ofendido, que deverá reparar o dano material e o extrapatrimonial experimentados ${ }^{811}$.

Nestes termos, ele toma a análise das infrações aos deveres dos cônjuges tipificadas na lei como critério para admissão da indenização, desde que verificadas a existência do dano material ou moral e a gravidade do resultado ${ }^{812}$.

Assim, considerando a peculiaridade de ser o casamento uma relação afetiva, o juiz deverá evitar reconhecer a responsabilidade do cônjuge apenas porque se retirou da relação pelo desaparecimento do afeto, salvo quando a consequência dessa conduta for altamente lesiva $^{813}$.

Portanto, para o jurista a responsabilização poderá decorrer de ato ilícito absoluto, nos termos dos arts. 186 e 187 do Código Civil, ou de fato tipificado no Direito de família, e informa que as regras do Código Penal são úteis para orientar essa responsabilização ${ }^{814}$. Ademais, pondera que o cônjuge considerado o único culpado pela separação ou divórcio não tem o direito de pedir indenização por violação a deveres do casamento; mas isso não ocorre no caso de culpas concorrentes ${ }^{815}$.

Destarte, admite a responsabilidade civil pelo dano causado ao cônjuge em razão de ilícito absoluto ou de infração a regra do Direito de família. Neste último caso, em virtude de fato ocorrido na convivência do casal, como a infração aos deveres do casamento, ou do dano decorrente da separação ou do divórcio, aceitas as restrições que a peculiaridade da relação impõe. Adverte que caberá ao juiz ponderar os valores éticos em conflito, atender à finalidade social da norma e reconhecer que o fato de existir a família por si só não pode ser causa de imunidade civil, embora possa inibir a ação quando dela surgir dano social maior do que o pretendido reparar ${ }^{816}$. Em todas estas hipóteses a

\footnotetext{
${ }^{811}$ Cf. ibidem.

${ }^{812}$ Cf. idem, pp. $15-16$.

${ }^{813}$ Cf. ibidem.

${ }^{814}$ Nos casos em que a lei criminal agrava ou aumenta a pena, ou ainda quando inclui como elementar do crime a qualidade de cônjuge, isto deverá influir na aceitação do processo civil de reparação do dano. Cf. ibidem. ${ }^{815}$ Cf. ibidem.

${ }^{816}$ Cf. idem, pp. 16-17.
} 
indenização deverá contemplar a finalidade sancionadora, ao lado do propósito reparatório $^{817}$.

\subsubsection{Hipóteses de danos em razão da infração aos deveres conjugais}

Em razão de sua importância, examinaremos, em separado, as hipóteses de danos morais pela quebra dos deveres conjugais.

O adultério é o tema sobre o qual mais se debruçaram os autores no desenvolvimento da teoria da responsabilidade civil entre os cônjuges, ensejando entendimentos conflitantes. Muitos apontam que, indubitavelmente, é devida a reparação civil dos danos causados em razão da quebra do dever de fidelidade, isto porque o ultraje à honra é indiscutível; entretanto, alguns juristas procuram relativizar a possibilidade de indenização neste caso.

Segundo Antonio JeOVÁ SANTOS, a hipótese de separação originada por infidelidade conjugal de um dos cônjuges dá azo à reparação por danos morais ${ }^{818}$. No mesmo sentido, é a opinião de José DE AGUIAR DiAs ${ }^{819}$.

INACIO DE CARVALHO NETO afiança que não é necessário fixar um 'padrão ideal de fidelidade' para se falar em ato ilícito no caso de infração a esse dever ${ }^{820}$. Assim, o adultério gera dano moral, sobretudo quando vem a conhecimento público ${ }^{821}$.

No entanto, alguns juristas prelecionam que somente quando o adultério se torna público é que se perfaz em dano moral reparável.

Cristiano Chaves Farias e Nelson Rosenvald negam que a prática de adultério, isoladamente, pudesse gerar dano moral indenizável, admitindo, contudo, no caso de publicidade do ato ${ }^{822}$.

Na visão de NARA Rubia Alves DE RESENDE, essa possibilidade dependerá da análise do caso concreto e do contexto social em que se desenvolveu, devendo-se

\footnotetext{
${ }^{817}$ Cf. idem, pp. 11-12.

${ }^{818}$ Cf. SANTOS, Antonio Jeová. Op. cit. (nota 13), p. 195.

${ }^{819}$ Cf. DiAs, José de Aguiar. Op. cit. (nota 44), p. 572.

${ }^{820}$ Cf. CARVAlHo NeTO, Inacio de. Op. cit. (nota 619), p. 307, nota 9.

${ }^{821}$ Cf. CARVAlho Neto, Inacio de. Op. cit. (nota 86), p. 299.

${ }^{822}$ Cf. FARIAS, Cristiano Chaves de et RosenvalD, Nelson. Op. cit. (nota 382), p. 89.
} 
averiguar a presença efetiva do dano, da culpa e do nexo de causalidade, pois, hipoteticamente, pode se falar em adultério sem dano ${ }^{823}$.

Para Michel Mascarenhas Silva, "o adultério que não tenha levado injúria nem difamação ou vergonha ao cônjuge ou companheiro traído, não tendo sido de conhecimento público, não pode ser usado como motivo para a reparação civil" ${ }^{824}$.

Por sua vez, Rui STOco discorda deste entendimento que condiciona a responsabilidade à despudorada exibição pública do amante, a causar constrangimento ao cônjuge traído ${ }^{825}$. Para o jurista, a ofensa moral é ínsita - in re ipsa - mostrando-se exagerado e desarrazoado impor que essa infidelidade ganhe publicidade para se reconhecer a obrigação de o cônjuge infiel reparar o dano ${ }^{826}$.

Ele pondera que o adultério consiste em uma traição a toda a família cônjuge, filhos, parentes e até amigos -, uma ofensa às instituições e a valores religiosos, ferindo a dignidade, o amor próprio da pessoa, chegando a ser, para alguns, uma situação insuportável ${ }^{827}$. De tal modo, conclui que, embora o adultério tenha sido descriminalizado, no âmbito civil se amolda ao conceito de ato ilícito do art. 186 do Código Civil, fazendo incidir a regra geral do art. 927, que estabelece a obrigação de reparar o dano, podendo ser de ordem material e moral ${ }^{828}$.

Regina Beatriz Tavares da Silva comunga do mesmo entendimento, destacando que, uma vez comprovado o dano decorrente de violação ao dever de fidelidade, incidem os princípios da responsabilidade civil ${ }^{829}$. Não obstante, a autora considera mais grave a infidelidade que tem como consequência a contaminação do cônjuge por doença sexualmente transmissível, adquirida em relacionamentos

\footnotetext{
${ }^{823}$ Cf. ReSEnde, Nara Rubia Alves de. Op. cit. (nota 491), p. 24.

${ }^{824}$ SILVA, Michel Mascarenhas. Op. cit. (nota 84), p. 101.

${ }^{825}$ Ele é contundente a respeito: "não há como prestigiar e aderir a esse entendimento. $O$ ato ilícito é um só. Se estiver tipificado na lei penal, será considerado crime. Caso não esteja, ainda assim poderá ingressar no campo genérico do 'neminen laedere' e configurar o ato ilícito a que se refere o art. 186 do CC, quando violar direito. E, se além de violar direito, causar dano, enseja reparação”. STOCO, Rui. Op. cit. (nota 233), p. 809.

${ }^{826}$ Cf. ibidem.

${ }^{827}$ Cf. ibidem.

${ }^{828}$ Cf. ibidem. "Não obstante, embora atualmente os cônjuges estejam livres de eventual pena privativa de liberdade, e ainda que não se possa mais falar em condenação criminal, que criaria o título executivo no âmbito civil, não há como afastar o adultério da condição de ilícito civil e, portanto, sujeita a pessoa ao dever de reparar o dano causado". Idem, p. 808.

${ }^{829}$ Cf. SILVA, Regina Beatriz Tavares da. Op. cit. (nota 198), p. 39.
} 
extraconjugais. Neste caso, assegura que haverá direito à reparação dos danos causados pela ofensa à integridade psíquica e física do cônjuge vítima ${ }^{830}$.

Também InACIO DE CARVAlHo Neto pontua que a transmissão de doenças entre os cônjuges em virtude do adultério justifica a indenização, citando como exemplo o caso da $\operatorname{AIDS}^{831}$. Para o jurista, não se exige o conhecimento prévio da doença pelo cônjuge que a transmite, uma vez que a conduta culposa pode ser anterior à própria aquisição da enfermidade ${ }^{832}$.

O autor entrevê que, como o adultério, outros atos podem, igualmente, causar danos ao cônjuge e gerar a obrigação de indenizar, por exemplo: o relacionamento homossexual com terceiros ${ }^{833}$; a prática de atos diversos extraconjugais e íntimos (abraços, beijos, etc), que violam a reputação do outro cônjuge; e a infidelidade virtual, a qual, apesar de não constituir verdadeiro adultério, infringe o dever de fidelidade ${ }^{834}$.

O adultério, por sua gravidade, é a violação que mais chamou a atenção dos juristas $^{835}$. Não obstante, JoSÉ DE AGUIAR DiAs afiança que no mesmo plano devem ser

${ }^{830}$ Cf. idem, p. 61.
${ }^{831}$ Cf. CARVAlHO Neto, Inacio de. Op. cit. (nota 86), p. 304.
${ }^{832}$ Cf. CARVAlHO Neto, Inacio de. Op. cit. (nota 619), p. 332.
${ }^{833}$ Cf. Regina BeAtriZ TAVARES DA Silva também vislumbrou essa hipótese. Cf. Silva, Regina Beatriz Tavares da. Op. cit. (nota 198), p. 61.

${ }^{834}$ Cf. CARVAlHO NeTO, Inacio de. Op. cit. (nota 86), p. 302. A este respeito, RUI BERFORD DiAS, atualizador da obra de JOSÉ DE AGUIAR DIAS, assim se manifestou: "a internet trouxe uma nova forma de traição, impensável há pouco tempo atrás, consistente no relacionamento 'virtual' de pessoas casadas, com parceiros acessados também por esse meio eletrônico. Da curiosidade inicial em conhecer 'sites' de batepapo ou do desejo sub-reptício de procurar uma aventura extraconjugal, não é raro passar-se à prática 'real' do adultério. Quando o próprio casal resolve as crises de ciúmes, de baixa estima e de insegurança quanto ao seu futuro, nenhuma consequência se dá relativamente à questão da responsabilidade civil. Quando, entretanto, o cônjuge 'traído' não aceita o comportamento do outro, diante dos valores que cultua, então é perfeitamente invocável a responsabilidade civil, à busca de reparação por danos morais”. DIAS, José de Aguiar. Op. cit. (nota 44), p. 573, nota do atualizador RUI BERFORD DIAS (nota 727). Também tivemos a oportunidade de nos manifestar: "neste contexto, acreditamos que a infidelidade virtual pode gerar responsabilização e indenização, em determinadas circunstâncias excepcionais, quando atinge a integridade psíquica de um dos cônjuges, já que nos aproximamos do princípio da dignidade humana”. PONZONI, Laura de Toledo. Op. cit. (nota 636), p. 1039.

${ }^{835}$ OTÁVIO LUIZ RODRIGUES JUNIOR chega a analisar inclusive a hipótese de se pleitear danos morais contra o terceiro cúmplice do adultério, fazendo a distinção entre diversas situações desta interferência: $a$ ) desconhecida; $b$ ) conhecida e tolerada; $c$ ) conhecida e não tolerada; $d$ ) exclusivamente por iniciativa própria; $e$ ) por iniciativa de um dos cônjuges; $f$ ) por iniciativa de ambos os cônjuges; $g$ ) por iniciativa própria e de um dos cônjuges; $h$ ) do terceiro que desconhece o casamento. Nos casos $b$ e $f$ entende haver supressio/surrectio. Quanto aos demais, entende não se poder falar em ilicitude, pois não existiria o dever de respeitar casamento alheio. Igualmente, segundo ele, não se poderia falar de ato contrário aos bons costumes, pois o ato perdeu muito de seu grau de repugnância, o que se poderia denotar da descriminalização do adultério. Cf. RODRIGUES JUNIOR, Otávio Luiz. A doutrina do terceiro cúmplice nas relações matrimoniais. In: SILVA, Regina Beatriz Tavares da et CAMARGo NeTO, Theodureto de Almeida (Coords.). Grandes temas de direito de família e das sucessões. São Paulo: Saraiva, 2011, pp. 40-45. 
observadas as demais infrações aos deveres conjugais, máxime quando em si mesmas constituam violação de um dever geral para com outrem ${ }^{836}$.

Já se vislumbrou o abandono do lar como gerador de danos e da possibilidade de indenização, quando não houver justo motivo, e especialmente se for o cônjuge mantenedor da família, que deixa seu consorte ao desamparo moral e material ${ }^{837}$.

Na opinião de Regina BeAtriz TAVARES DA SiLVA, desde que ocasionado dano, conforme as condições em que se deu o abandono do lar, o lesionado terá direito à indenização ${ }^{838}$. De seu turno, na visão de INACIO DE CARVALHO NETO, independentemente de se tratar do cônjuge que mantém a família materialmente, o abandono provocará danos morais indenizáveis ${ }^{839}$.

Segundo aquela jurista, muito embora não exista meio coercitivo para o cumprimento do dever de assistência imaterial, sua violação, se acarretar danos morais ou materiais ao cônjuge, dará causa à aplicação dos princípios da responsabilidade civil ${ }^{840}$.

Alguns autores também fazem referência à recusa injustificada à satisfação do débito conjugal como passível de indenização. Na visão de INÁCIO DE CARVALHO NETO, esta conduta, que igualmente fundamenta a separação culposa (infração ao dever de vida em comum no domicílio conjugal), configura ato ilícito, podendo ensejar reparação ${ }^{841}$. No entanto, ele adverte que não se trata de recusa única, mas de uma recusa constante, ou seja, a ausência do ato sexual prolongada por um período razoável ${ }^{842}$.

Todavia, MARia Celina Bodin DE Moraes se mostra veementemente contrária a esta hipótese ${ }^{843}$.

${ }^{836}$ Cf. DIAS, José de Aguiar. Op. cit. (nota 44), p. 573.

${ }^{837}$ Cf. RESENDE, Nara Rubia Alves de. Op. cit. (nota 491), pp. 25-26.

${ }^{838}$ Cf. Silva, Regina Beatriz Tavares da. Op. cit. (nota 198), p. 43.

${ }^{839}$ Cf. CARVAlHO Neto, Inacio de. Op. cit. (nota 86), p. 302.

${ }^{840}$ Cf. Silva, Regina Beatriz Tavares da. Op. cit. (nota 198), p. 35.

${ }^{841}$ Cf. Carvalho Neto, Inacio de. Op. cit. (nota 86), p. 303.

${ }^{842}$ Cf. CARVAlHO NeTO, Inacio de. Op. cit. (nota 619), p. 331, nota 78.

843 "Somente uma ótica que ignora a funcionalização dos institutos jurídicos, preocupando-se unicamente com esquemas estruturais ultrapassados, poderia entrever dano moral na recusa em manter relações sexuais. (...) põe-se erroneamente em funcionamento o mecanismo, já criticado, segundo o qual, sendo o débito conjugal um dever decorrente do casamento, seu descumprimento gera 'sofrimento' que deve, assim, ser reparado”. MORAES, Maria Celina Bodin de. Op. cit. (nota 63), p. 195. 
Em relação à exigência de práticas sexuais anormais, YUSSEF SAID CAHALI assevera que existem limites na prestação do débito conjugal, corolários do respeito mútuo entre os cônjuges, vislumbrando-se um verdadeiro ato ilícito o assédio para a consumação destes atos sexuais anômalos ${ }^{844}$.

Sobre o assunto, CARlos Alberto BitTar, exemplificando a ruptura do casamento pela quebra do dever conjugal de coabitação, cita a submissão da esposa a práticas vexatórias, a 'práticas animalescas', que considera passível de ensejar dano moral pelo vexame indevidamente suportado ${ }^{845}$.

Por sua vez, InACIO DE CARVALHO NeTO, após observar que "tem-se afirmado que a prática de coito anal e demais práticas sexuais ditas anormais (sodomia, sadomasoquismo etc) podem dar margem à obrigação de indenizar" "846, obtempera que somente darão lugar ao dano moral e, eventualmente, até material, se houver lesão e quando forem praticados contra a vontade expressa da mulher. Portanto, segundo o autor, havendo consentimento nessa prática, ainda que tácito, ou até mesmo a pura tolerância, não se poderá falar em obrigação de indenizar ${ }^{847}$.

Com relação ao atentado contra a vida pelo cônjuge, os juristas entendem ser evidente que possa gerar danos morais e, inclusive, materiais.

Na opinião de INACIO DE CARVALHO NETO, esses danos são indiscutivelmente ressarcíveis, mesmo quando se trate de tentativa branca, isto é, ainda que não acarrete lesão corporal. Para o autor, não há necessidade de participação direta do cônjuge, bastando que tenha se envolvido dolosamente no crime ${ }^{848}$.

Outra causa frequentemente divisada pelos autores como geradora de danos indenizáveis é a prática de sevícias pelo cônjuge.

JosÉ DE CASTRO BIGI, preocupado com a configuração desses danos, fazia a seguinte comparação:

\footnotetext{
${ }^{844}$ Cf. CAHALI, Yussef Said. Op. cit. (nota 39), p. 584.

${ }^{845}$ Cf. BITTAR, Carlos Alberto. Op. cit. (nota 11), p. 281-282.

${ }^{846}$ CARVAlHo Neto, Inacio de. Op. cit. (nota 619), p. 331.

${ }^{847}$ Cf. ibidem.

${ }^{848}$ Cf. idem, p. 333.
} 
"suponhamos que o marido pela agressão fisica causou à mulher problemas de saúde, p. ex.: a perda parcial da audição, com diminuição, também, da capacidade laborativa. O cônjuge delinquente, o ofensor, deixará de indenizar pelo simples fato de ser casado com a ofendida. Bastará tão-só a pensão alimentar, que é um dos deveres inerentes ao matrimônio? (....). Mas se essa mulher gravemente seviciada fosse apenas a namorada do ofensor, este não escaparia da obrigação de indenizar. É claro que essa solução em nada contribuiria para o fortalecimento da instituição do casamento ${ }^{, 849}$.

INACIO DE CARVALHO NETO afiança que além de justificar a separação litigiosa por culpa, e a possível ação penal pelo crime de lesões corporais, a prática de sevícias pode configurar obrigação de indenizar os danos sofridos pelo cônjuge vítima. Ele ainda assegura que o dano moral persiste mesmo que não tenham sido provocadas lesões corporais $^{850}$.

$\mathrm{Na}$ esteira deste raciocínio, ARNALDO RIZZARDO garante que o tapa, a bofetada, o pontapé e outras modalidades de agressões ofendem mais pelo que representam ao cônjuge: a humilhação, o vexame, o escândalo, o ridículo ${ }^{851}$.

Note-se que a Lei Maria da Penha, de combate à violência doméstica (Lei n. 11.340/06), foi a primeira a estabelecer explicitamente a aplicação dos princípios da responsabilidade civil nas relações de família, estatuindo que a prática de ato ilícito pelo marido contra a esposa sujeita o ofensor à condenação em indenização por perdas e danos materiais.

A este respeito, Regina Beatriz TAVARES Da Silva observa que, embora em seu art. 24 a Lei mencione apenas os danos materiais, a indenização dos danos morais é assegurada pela regra geral de responsabilidade civil $^{852}$.

Também já se aventou o dano moral sofrido pelo cônjuge que vê o consorte maltratar sua prole, diverso dos danos provocados aos próprios filhos.

\footnotetext{
${ }^{849}$ BIGI, José de Castro. Op. cit. (nota 272), p. 50.

${ }^{850}$ Cf. Carvalho Neto, Inacio de. Op. cit. (nota 86), p. 306.

851 Cf. RizzARDo, Arnaldo. Separação e divórcio. In: PEREIRA, Rodrigo da Cunha (coord.). Direito de família contemporâneo. Belo Horizonte: Del Rey, 1997, pp. 447-448, apud CARVALHO NeTO, Inacio de. Op. cit. (nota 86), p. 306.

${ }^{852}$ Cf. SILVA, Regina Beatriz Tavares da. Op. cit. (nota 198), p. 51.
} 
Neste sentido, InACIO DE CARvalho Neto afirma que o testemunho dos maus-tratos dos filhos comuns ou exclusivos pode causar profunda dor ao cônjuge, que sofre pelo mal praticado contra os filhos. Portanto, segundo o jurista, é direito do cônjuge que seus filhos sejam bem tratados por seu consorte. Se a infração a esse dever pode ensejar a separação judicial culposa, nada impede também a reparação do dano moral, sem prejuízo da indenização ao filho vítima ${ }^{853}$.

$\mathrm{Na}$ literatura jurídica argentina, cita-se hipótese análoga, a duplicidade de danos decorrentes da violência contra a esposa, mas em virtude das agressões sofridas por ela mesma, com uma repercussão em duas frentes diversas: "en primer lugar por la persona de la mujer en sí misma y en segundo lugar por el espectáculo de desaprensión que los hijos absorben y que pueden proyeactar en sus relaciones futuras (de padres golpeadores a hijos golpeadores) ${ }^{, 854}$.

Alguns juristas simplesmente enumeram as situações em que entendem cabível a indenização pelos danos morais entre cônjuges, geralmente ressaltando a necessidade de gravidade desses atos.

Na visão de MARCiAL BARREto CASABOnA, é possível a indenização decorrente da ruptura da sociedade conjugal se violado o dever de respeito e consideração mútuos, nos casos de: lesão corporal grave; violência sexual; injúria grave; transmissão dolosa de moléstia sexual contagiosa; e tentativa de homicídio, ou ele próprio ${ }^{855}$.

FERNANDA OLTRAMARI e ViTOR Hugo OltRAMARI entendem que são atos que ensejam a indenização entre os consortes: a transmissão de uma doença venérea, como a AIDS; a difamação profissional, com manifestos prejuízos materiais e morais; a violência física; a injúria grave; os maus-tratos e o adultério escandaloso ${ }^{856}$.

MARIA Helena Diniz enumera uma série de condutas que considera ensejadoras de danos morais na dissolução da sociedade conjugal: dissabor por

\footnotetext{
853 Cf. Carvalho Neto, Inacio de. Op. cit. (nota 619), p. 340. Para a doutrina argentina, a situação de pertencer a uma dada família confere ao membro uma dignidade e honra especiais, de maneira que a ofensa a um de seus integrantes pode gerar dano indireto aos demais. É possível pleitear, portanto, a reparação de dano indireto, por ofensa a integrante do mesmo grupo, com fulcro no art. 1079 do Código Civil argentino. Cf. GHersi, Carlos, Weingarten, Celia et GHERsi, Sebastián. Op. cit. (nota 52), pp. 144-145.

${ }^{854}$ Idem, p. 133.

${ }^{855}$ Cf. CASABOnA, Marcial Barreto. Op. cit. (nota 189), p. 364.

${ }^{856}$ Cf. Oltramari, Fernanda et Oltramari, Vitor Hugo. Op. cit. (nota 102), p. 72.
} 
incompetência coeundi, sadismo erótico, prática sexual anormal ou vexatória, vigilância mortificante, gestos ultrajantes, comparações desprimorosas, recusa infundada ao débito cnjugal, difamação, calúnia, injúria, transmissão de moléstia venérea, sevícias e maustratos, tentativa de homicídio, não cumprimento dos deveres conjugais lesivo ao direito da personalidade do cônjuge ${ }^{857}$.

Também Nara Rubia Alves DE RESENDE conclui que são indenizáveis os danos nas seguintes hipóteses: lesão corporal; difamação e situação vexatória que se expõe àquele que foi traído; violência sexual; prática forçada de atos sexuais anormais; e injúria $\operatorname{grave}^{858}$.

Na opinião de Elizabeth ANA MARia MeISEls PACCA, o adultério, a transmissão de moléstia contagiosa, a injúria ou a calúnia, a agressão física ou verbal, são exemplos de atos ensejadores de responsabilidade civil por parte do cônjuge infrator ${ }^{859}$.

Ademais, outras situações menos comuns de danos entre cônjuges já foram acenadas pela doutrina: a mulher que espalha perante a sociedade que o marido é impotente ou que não é o verdadeiro pai de seus filhos; a simulação de gravidez; e o fato de um dos cônjuges demandar, maliciosamente, a interdição do outro, sabendo ser falsa a doença imputada ${ }^{860}$.

Belmiro Pedro Welter, por sua vez, menciona condutas tipificadas como crime $^{861}$.

Por outro lado, observe-se que essas hipóteses de reparação de danos que configuram crimes praticados por um cônjuge contra o outro não estão diretamente relacionadas ao problema da ruptura do relacionamento, mas equivalem ao ato danoso praticado por qualquer indivíduo.

\footnotetext{
${ }^{857}$ Cf. DINIZ, Maria Helena. Op. cit. (nota 55), p. 216.

${ }^{858}$ Cf. RESENDE, Nara Rubia Alves de. Op. cit. (nota 491), p. 30.

${ }^{859}$ Cf. PACCA, Elizabeth Ana Maria Meisels. Op. cit. (nota 612), p. 97.

${ }^{860}$ Cf. CARVAlHo NeTO, Inacio de. Op. cit. (nota 619), pp. 339-340.

${ }^{861}$ Tais como: estupro praticado pelo marido contra a mulher; extorsão mediante sequestro contra o cônjuge; roubo e extorsão contra o consorte; reduzir o cônjuge à condição análoga à de escravo; sequestro e cárcere privado ou lesão corporal dolosa contra o consorte; e calúnia, difamação e injúria, de tal envergadura, que reflitam na reputação do cônjuge, em sua atividade profissional e social. Cf. WELTER, Belmiro Pedro. Op. cit. (nota 677), p. 30.
} 
Derradeiramente, INACIO DE CARVALHO NETO menciona que a imputação de fatos ofensivos em juízo pode, da mesma forma, gerar danos morais, sendo uma especificação da ofensa à honra. Esta conduta, em sua opinião, caracteriza abuso de direito $^{862}$. Segundo o autor, é indispensável a ciência pelo cônjuge da falsidade da causa imputada, não bastando a improcedência da demanda. Contudo, ele pondera que esta hipótese deverá ser tratada autonomamente, em razão de sua frequente incidência, de sua relação com a teoria do abuso do direito e de sua maior gravidade ${ }^{863}$.

Ante o exposto, a doutrina distingue inúmeras situações de infração aos deveres conjugais que podem dar ensejo à reparação de danos ${ }^{864}$.

\subsubsection{Jurisprudência}

Há vinte anos, José de CASTRo Bigi afirmava que, se as ações de responsabilidade civil entre ex-cônjuges não 'chegavam à barra dos nossos tribunais', era porque os advogados não se 'abalançavam' a propô-las. Na época, o autor encontrou apenas um acórdão do Tribunal de Justiça do Rio Grande do Sul que, embora tenha julgado improcedente a ação, para ele constituiu-se em verdadeiro marco do direito pretoriano brasileiro pelos caminhos que abriu o voto vencido do Desembargador ATHOS GUSMÃO CARNEIRO ${ }^{865}$.

Recentemente, YUSSEF SAID CAHALI observou que a jurisprudência vem ensaiando a indenização do dano moral sofrido pelo cônjuge inocente em razão da causa que provocou a dissolução do matrimônio ${ }^{866}$. Porém, RUY ROSADO DE AGUIAR JÚNIOR assinala que, não obstante os julgados demonstrem forte orientação no sentido favorável, de sua leitura se percebe a grande divergência que lavra entre os tribunais ${ }^{867}$.

Portanto, na jurisprudência pátria se verifica a presença dos mesmos posicionamentos conflitantes da doutrina no tratamento do tema.

\footnotetext{
${ }^{862}$ CARVAlHo NeTO, Inacio de. Op. cit. (nota 619), pp. 337-338.

863 Cf. CARVAlHO Neto, Inacio de. Op. cit. (nota 86), pp. 310-311.

${ }^{864}$ Vale dizer que REGINA BEATRIZ TAVARES DA SILVA assegura que os exemplos mencionados são apenas alguns, de tantas outras práticas ofensivas aos direitos da personalidade entre cônjuges Cf. SILVA, Regina Beatriz Tavares da. Op. cit. (nota 198), p. 70.

${ }^{865}$ TJRS, Ap. Cível n. 36.016, j. em 17-03-91. Cf. Bigi, José de Castro. Op. cit. (nota 272), pp. 46-48.

${ }^{866}$ Cf. CaHali, Yussef Said. Op. cit. (nota 39), p. 586.

${ }^{867}$ Cf. Aguiar Júnior, Ruy Rosado de. Op. cit. (nota 15), pp. 13-14.
} 
Em decisões mais antigas, permeava o entendimento de que seria indevida a indenização por danos morais entre cônjuges, pois as sanções aplicáveis no término do casamento eram somente aquelas previstas no direito de família.

Este foi o argumento denegatório do seguinte acórdão do Tribunal de Justiça do Rio de Janeiro:

"O eventual descumprimento dos deveres do casamento não se resolve em perdas e danos, como nas obrigações, porque dá ensejo à separação judicial e posterior divórcio, figuras do Direito de Família, que já trazem em si sanções outras, específicas, em detrimento do cônjuge declarado culpado, tais como: a mesma declaração de culpa, a obrigação ou exoneração de prestar alimentos, a obrigação de partilhar os bens, conforme o regime de casamento, a perda da guarda dos filhos, a perda do direito de usar o nome do cônjuge varão. Sanções estas que, a não ser para os espíritos essencialmente materialistas, são mais eficazes para reparar os danos imaterias do cônjuge inocente do que a compensação do dano moral, que se pretende fazer com uma certa soma em dinheiro, em outras situações, convenhamos, 868 .

O Superior Tribunal de Justiça se manifestou a respeito somente em 2001. Trata-se de um acórdão muito citado pela doutrina e pelos próprios magistrados, pois, pela primeira vez, aquela Corte expressamente admitiu a possibilidade jurídica da indenização por danos morais entre cônjuges. A propósito, transcrevemos a ementa do referido acórdão:

"Separação judicial. (...). Danos morais (reparação). Cabimento. (...) O sistema jurídico brasileiro admite, na separação e no divórcio, a indenização por dano moral. Juridicamente, portanto, tal pedido é possível: responde pela indenização o cônjuge responsável exclusivo pela separação. 3. Caso em que, diante do comportamento injurioso do cônjuge varão, a Turma conheceu do especial e deu provimento ao recurso, por ofensa ao art. 159 do Cód. Civil, para admitir a obrigação de se ressarcirem danos morais ${ }^{\prime \prime 669}$.

${ }_{868}^{86}$ TJRJ, Ap. Cível n. 14.156/98, Rel. Des. MARLAN DE MORAES MARINHO, j. em 13-05-99.

869 STJ, REsp n. 37.051-SP, Rel. Min. NILSON NAVES, j, em 17-04-01. 
No caso, a recorrente ajuizara ação ordinária de separação alegando que o réu sempre a tratou como escrava, praticando violências físicas e fazendo ameaças de morte. Diante de tais fatos, também pediu a indenização civil.

Em primeira instância, o juiz considerou induvidosa a prática de maus tratos do marido contra a mulher e julgou procedentes os pedidos, decretando a separação por culpa exclusiva do cônjuge e impondo a indenização por dano moral. No entanto, o Tribunal de Justiça de São Paulo reformou a sentença, ponderando que havia, de fato, tensão na vida matrimonial, porém que a instabilidade tinha origem e fulcro nas atitudes dominadoras do marido, porventura 'desvestidas de maior sensibilidade, desvelo e carinho' em razão de sua origem oriental. Assim, entendeu correta a separação por culpa do varão, afastando, contudo, a ilicitude geradora da indenização.

Por sua vez, o relator do Recurso Especial, Ministro NILSON NAVES, afirmou ser juridicamente possível o pedido de danos morais entre cônjuges e concluiu que, em face da realidade descrita nos autos, não se justificava o fundamento denegatório empregado pelo Tribunal de Justiça de São Paulo, pois houve efetivamente um comportamento injurioso. No mesmo sentido votaram os Ministros WALDEMAR ZVEITER e MENEZES DiREITo, tendo o Ministro EDUARDo RIBEIRO acompanhado o acórdão recorrido $^{870}$.

Assim, expõe-se o entendimento conflituoso dos magistrados.

Todavia, MARIA CElinA Bodin DE MORAES, ao comentar o decisum, ressalta que se baseou na cláusula geral de responsabilidade subjetiva, eis que o caso dizia respeito à violência física e moral praticada pelo marido. Assim, na visão da jurista, não se tratou propriamente de descumprimento de dever conjugal e sim de lesão à integridade física da mulher, situação a ser devidamente protegida e reparada, independentemente do âmbito matrimonial $^{871}$.

\footnotetext{
${ }^{870}$ Nas palavras deste último: "o relacionamento conjugal sempre foi tenso, sendo que as testemunhas enfatizam a atitude dominadora do varão que intervinha e censurava o relacionamento social da mulher, imiscuía-se no trato desta com os filhos comuns e de modo geral tratava-a com brusquidão e aspereza, alçando-lhe a voz, etc. Até aí não me parece que apontadas razões são capazes de justificar a pretendida indenização. Descreve-se alguém com personalidade difícil, podendo ser classificado como grosseiro e dominador. Não mais que isso. Não se apontou, nos autos, fato que justificasse a conclusão de que seu comportamento representasse ofensa grave, de maneira a ensejar reparação por dano moral".

${ }^{871}$ Cf. MoraEs, Maria Celina Bodin de. Op. cit. (nota 63), p. 193.
} 
Dois acórdãos relativamente recentes - julgados na mesma época, o primeiro do Tribunal de Justiça de São Paulo, o segundo do Tribunal de Justiça do Rio Grande do Sul, relacionados diretamente ao descumprimento de dever conjugal em razão do adultério, evidenciam a contenda existente. Vejamos as ementas correspondentes:

"Separação judicial - Pretensão à reforma parcial da sentença, para que o autor reconvindo seja condenado no pagamento de indenização por danos morais, (...) Fidelidade recíproca que é um dos deveres de ambos os cônjuges, podendo o adultério caracterizar a impossibilidade de comunhão de vida - Inteligência dos arts. 1566, I, e 1573, I, do Código Civil - Adultério que configura a mais grave das faltas, por ofender a moral do cônjuge, bem como o regime monogâmico, colocando em risco a legitimidade dos filhos - Adultério demonstrado, inclusive com o nascimento de uma filha de relacionamento extraconjugal - Conduta desonrosa e insuportabilidade do convívio que restaram patentes - Separação do casal por culpa do autor-reconvindo corretamente decretada - Caracterização de dano moral indenizável - Comportamento do autor-reconvindo que se revelou reprovável, ocasionando à ré-reconvinte sofrimento e humilhação, com repercussão na esfera moral - Indenização fixada em RS 45.000,00 (...),872.

"Ação de separação litigiosa. Prática de adultério. Reconhecimento da culpa afastada. Irrelevância para o deslinde da demanda (...) Dano moral (...) A orientação da jurisprudência gaúcha é no sentido da irrelevância da aferição da culpa quando da separação judicial, uma vez que a eventual infração cometida por um dos cônjuges decorre da natural deteriorização da relação conjugal. (...) A prática de adultério por qualquer dos cônjuges gera tão somente a dissolução da sociedade conjugal, com os seus reflexos, não gerando dano moral indenizável à parte ofendida (...) Apelações parcialmente providas ${ }^{, 873}$.

Conforme se verifica, o Tribunal de Justiça de São Paulo decidiu pela indenização irrestrita, em razão do 'sofrimento e da humilhação' produzidos na esfera moral do cônjuge. Já o Tribunal de Justiça do Rio Grande do Sul negou esse mesmo

${ }^{872}$ TJSP, Ap. Cível n. 539.390.4/9, Rel. Des. LuIZ ANTONIO DE Godoy, j. em 10-06-08.

${ }^{873}$ TJRS, Ap. Cível n. 70021640743, Rel. Des. Claudir FidÉlis FACCENDA, j. em 13-03-08. 
pedido, afirmando categoricamente a impossibilidade de indenização apenas em razão da quebra de algum dos deveres conjugais ${ }^{874}$.

Deste cotejo, percebe-se que o último pretório está mais inclinado à mitigação do elemento culpa na separação e, consequentemente, à impossibilidade de ressarcimento dos danos morais entre cônjuges. O mesmo, no entanto, não se pode dizer a respeito da jurisprudência paulista.

O Tribunal de Justiça de São Paulo também já considerou devida a indenização por dano moral decorrente da simulação do estado de gravidez para fins escusos, que causou perturbação nas relações psíquicas do ex-marido ${ }^{875}$. Na opinião de INACIO DE CARVALHO NETO, assiste razão àquela Corte, pois esta simulação pode realmente gerar dano moral indenizável ${ }^{876}$.

Da análise da jurisprudência, MARCIAL BARRETO CASABONA infere que nas decisões que acolheram o pedido de indenização, o dano, em verdade, não estava relacionado à desobediência aos deveres dos cônjuges, mas sim ao caráter de grave ilícito ou até mesmo delituoso da conduta ${ }^{877}$.

Para BernaRdo CASTElo BRANCO, o atual posicionamento da nossa jurisprudência demonstra cautela, pois não fecha as portas para as demandas reparatórias fundadas na ofensa moral praticada no casamento, porém, na maioria dos casos, exige a demonstração de condutas extraordinárias, não condizentes com a simples violação dos deveres conjugais ${ }^{878}$.

\footnotetext{
${ }^{874}$ Nas palavras do Relator: "a decepção amorosa no âmbito das relações é uma possibilidade perfeitamente previsível e que pode ocorrer a qualquer tempo no curso do relacionamento conjugal. Da mesma forma, a prática do adultério é um comportamento que permeia toda e qualquer sociedade conjugal, não estando quaisquer dos cônjuges livre de experimentar a infidelidade do parceiro. Todavia, as desilusões no restrito campo dos sentimentos, que pode gerar, inclusive, depressão, perda de peso, como parece ter sido o caso da autora, não me parece ter a gravidade suficiente para gerar indenização por abalo moral".

${ }^{875}$ TJSP, Ap. Cível n. 272.221-1/2, Rel. Des. TESTA MARCHI, j. em 10-10-96.

${ }^{876}$ Cf. CARVAlHo Neto, Inacio de. Op. cit. (nota 86), p. 312.

877 Cf. CASABONa, Marcial Barreto. Op. cit. (nota 189), p. 361

${ }^{878}$ Cf. BRANCO, Bernardo Castelo. Op. cit. (nota 94), p. 64.
} 


\subsubsection{Culpa e Emenda Constitucional n. 66/2010}

A remissão à culpa sempre foi importante no Direito de família. Da análise da doutrina, verifica-se que muitos juristas atrelam a admissão da indenização à culpa de um dos cônjuges, quando restar evidenciado o descumprimento de dever matrimonial.

No entanto, a tendência em se desprezar a investigação da culpa pela ruptura do casamento vem se tornando cada vez mais pronunciada. As consequências da aprovação da Emenda Constitucional n. 66/2010 ainda não são pacíficas, conforme já vimos em item anterior. Atualmente, perquire-se também a permanência da culpa enquanto pressuposto para a responsabilidade civil por danos entre cônjuges.

Portanto, como no assunto ora abordado volta e meia se faz referência ao elemento culpa, somos impelidos a expor as possíveis decorrências desta modificação, embora poucos autores tenham feito comentários a este respeito.

Talvez por esta razão, Regina BeAtriz TAVARES DA Silva, uma das vozes doutrinárias críticas à abolição da culpa nas dissoluções matrimonias, é também árdua defensora da indenização por danos morais em decorrência da violação dos deveres conjugais. Na opinião da jurista, a culpa no Direito de família nada mais é do que o descumprimento consciente de dever conjugal e não pode deixar de ser averiguada no rompimento de uma relação ${ }^{879}$.

Daí a obtemperação da autora: conquanto a afetividade ou amor venham sendo proclamados como impeditivos da decretação da culpa na dissolução da sociedade conjugal e da responsabilização pelo término do casamento, no Direito esses sentimentos equivalem à dignidade da pessoa humana, cláusula geral de tutela da personalidade ${ }^{880}$ Manifestando sua oposição, ela alerta que a dignidade será violada se, numa relação conjugal desfeita pelo comportamento culposo e danoso de um dos cônjuges, for recusada a decretação da culpa e a cominação de suas consequências legais ${ }^{881}$.

\footnotetext{
${ }^{879}$ Cf. Silva, Regina Beatriz Tavares da. Op. cit. (nota 198), p. 25.

${ }^{880}$ Cf. SILVA, Regina Beatriz Tavares da. Op. cit. (nota 440), pp. 113-115.

${ }^{881}$ Cf. Silva, Regina Beatriz Tavares da. Op. cit. (nota 198), pp. 69-70.
} 
A doutrinadora questiona qual seria a proteção jurídica que o membro da família receberia se tão-somente nas relações familiares o descumprimento de um dever jurídico não resultasse em sanção ao seu violador ${ }^{882}$. Na sua visão:

“o pensamento de que a família não poderia ser alcançada pelos princípios da culpa, a imaginar que a colocaria num pedestal ou plano superior, na verdade deixaria de oferecer proteção aos membros de uma família, transformando os deveres conjugais em meras recomendações, permitindo a violação desses deveres sem qualquer sanção e impedindo-lhes a utilização de relevante instrumento jurídico, que assegura condições existenciais da vida em sociedade: a reparação civil de danos" ${ }^{\text {} 883}$.

Desta feita, ela conclui que, ainda que prospere qualquer outra interpretação para a Emenda Constitucional n. 66/2010, sempre subsistirá a responsabilidade civil nas relações familiares, uma vez que a reparação de danos é princípio norteador de todo o Direito civil, e se aplica ao Direito de família. Ou seja, mesmo desaparecendo a separação culposa do Direito brasileiro e também não se aceitando o divórcio baseado no grave descumprimento dos deveres conjugais, ficará mantida a possibilidade de ajuizamento de ação de reparação de danos entre ex-cônjuges, na presença dos pressupostos da responsabilidade civil, com fundamento no art. 186 do Código ${ }^{884}$.

Quanto às demais consequências previstas no ordenamento para a culpa no desenlace conjugal, a jurista alerta: caso a Emenda não seja devidamente interpretada, favorecerá aquele que descumpre gravemente os deveres matrimoniais, a ponto de facultarlhe a exigência de pensão alimentícia plena, a ser paga pela vítima do ato ilícito ${ }^{885}$, além de se permitir que o culpado continue a utilizar o sobrenome do consorte, situações em que considera evidente a violação à dignidade humana ${ }^{886}$.

Desse modo, a despeito da previsão legal do dever de fidelidade, se eliminada a culpa das relações familiares o cônjuge poderá ser um infiel contumaz e nenhuma consequência sofrerá, da mesma forma que não haverá sanção civil para aquele que tenha

\footnotetext{
${ }^{882}$ Cf. idem, p. 73.

${ }^{883}$ Ibidem.

${ }^{884}$ Cf. idem, p. 109.

${ }^{885}$ Cf. idem, p. 18. Ela assegura que a eliminação desse efeito acarretaria situações esdrúxulas, como a de uma mulher violentada pelo marido continuar a sustentá-lo, ou de um homem ter de alimentar plenamente a mulher que o traiu, em benefício até mesmo de seu amante. Cf. idem, p. 56.

${ }^{886}$ Cf. idem, p. 71 .
} 
violentado física e moralmente o seu consorte, descumprindo o dever de respeito aos direitos da personalidade ${ }^{887}$.

Nesta ordem de ideias, a autora percebe uma contradição, pois, se os mais diversos setores da sociedade estão preocupados com a violência doméstica, inclusive com a promulgação da Lei Maria da Penha, estabelecendo normas para combatê-la, na busca de sanção penal eficaz contra o agressor, maior preocupação deveria existir entre aqueles que se dedicam ao Direito de família ${ }^{888}$.

Ante o exposto, REgina BEATRIZ TAVARES DA SiLVA conclui não fazer sentido eliminar a culpa das relações familiares ${ }^{889}$, e clama não restarem dúvidas de que permanece o interesse jurídico e moral na verificação da causa culposa da dissolução do casamento ${ }^{890}$.

Outra solução é sugerida por VALÉRIA SiLVA GALDINO CARDIN, a qual, sendo favorável à responsabilização do cônjuge em razão do descumprimento dos deveres conjugais, propõe, todavia, que os danos morais decorrentes da culpa passem a ser discutidos na própria ação de divórcio.

A jurista pondera que quando a vida conjugal se tornar martirizante para um dos consortes, em decorrência da conduta desairosa do outro, e dessa conduta advier angústia e mal-estar, o cônjuge lesado poderá ingressar com o divórcio cumulado com o pedido de reparação por danos morais ${ }^{891}$. Portanto, segundo apreende, a infração do dever de fidelidade, que constitui injúria grave, poderá ser alegada no próprio processo de divórcio e fundamentar o pleito de danos, quando expuser o cônjuge ofendido a uma situação vexatória ${ }^{892}$.

Logo, na sua opinião, a Emenda n. 66/2010 não suprimiu os deveres oriundos do casamento, admitindo a discussão da culpa na ruptura do vínculo matrimonial com fundamento na própria teoria da responsabilidade civil. Em seu modo de ver, excluir a

\footnotetext{
${ }^{887}$ Cf. idem, pp. 27-28.

${ }^{888}$ Em suas palavras: "de que adiantaria punir o cônjuge que ofende a integridade física ou moral de seu consorte na esfera penal, ou mesmo oferecer-lhe medidas protetivas de urgência, como faz a Lei $n$. 11.340/2006, se, ao mesmo tempo, fosse possibilitado ao ofensor exigir do ofendido a prestação de pensão alimentícia plena?". Idem, p. 74.

${ }^{889}$ Cf. idem, pp. $27-28$.

${ }^{890}$ Cf. idem, p. 65.

${ }^{891}$ Cf. CARDIN, Valéria Silva Galdino. Op. cit. (nota 245), p. 156.

${ }^{892}$ Cf. idem, pp. 151-152.
} 
discussão sobre a culpa do processo de divórcio significaria a institucionalização da irresponsabilidade pessoal dos cônjuges. Nestes termos, ela alerta que os tribunais não podem mitigar a fixação da culpa nas causas do divórcio, caso contrário, os deveres conjugais previstos no Código Civil não serão observados, ante a inexistência de sanção pelo descumprimento ${ }^{893}$.

Ante o exposto, na visão da jurista, a vantagem da mudança foi uma só: o divórcio passou a ser o único instrumento para a ruptura do matrimônio, com a supressão de qualquer lapso temporal, diminuindo as despesas processuais. Porém, assevera que ainda é possível discutir a violação dos deveres conjugais, a má-fé, a lesão, o abuso do direito, dentre outros atos desonrosos, podendo haver a cumulação da ação de divórcio com a de responsabilidade civil ${ }^{894}$. Ela conclui que, "nesse particular, a responsabilidade será fundamental ponto de equilíbrio para divórcios conscientes e maduros ${ }^{\text {,895. }}$.

Conquanto tenhamos consultado a última edição da obra de INACIO DE CARVALHO NETO, não verificamos nenhuma alusão específica à Emenda Constitucional n. 66/2010. Não obstante, é possível deduzir algumas conclusões deste jurista.

Segundo afiança, em hipótese alguma se admite a perquirição de culpa no divórcio direto, nem mesmo em razão de seus efeitos ${ }^{896}$. Portanto, assevera que para falarmos em obrigação reparatória pelo rompimento da relação, é necessário caracterizá-lo como ato ilícito, de modo a fazer incidir o art. 186 do Código Civil ${ }^{897}$. Como o litígio, na ação de divórcio, é mitigado, eis que a contestação só poderá versar sobre o decurso do prazo, afirma que não terá cabimento a perquirição de culpa de qualquer dos cônjuges nesta hipótese ${ }^{898}$. Desta feita, o autor preleciona que se um dos cônjuges pretende provar a culpa do outro para se beneficiar de seus efeitos, deve utilizar-se da ação de separação culposa $^{899}$.

Todavia, ele mesmo ressalva que nada impede a existência de danos derivados de causas culposas que não foram discutidas no processo de separação, mas que

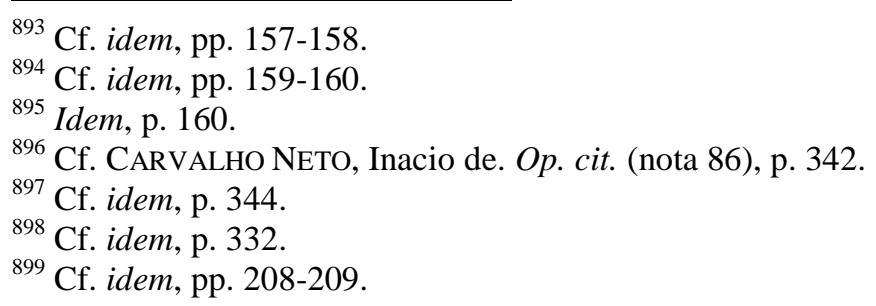


futuramente poderão ser objeto de um pedido específico de reparação no juízo cível ${ }^{900}$, isto é, o fato de não se discutir a ocorrência de culpa não significa, necessariamente, que ela não tenha existido ${ }^{901}$.

O jurista desenvolve este mesmo raciocínio para o divórcio direto. Também considera difícil a caracterização de atos culposos no rompimento da relação matrimonial, entretanto, vislumbra a possibilidade de reparação dos danos causados por atos que não puderam ser discutidos na ação direta de divórcio, nos mesmos moldes da separação litigiosa não culposa ${ }^{902}$.

Destarte, InAcio de CARvalho Neto acaba por admitir a possibilidade de haver danos indenizáveis, derivados de atos culposos não discutidos no divórcio, os quais, entretanto, deverão ser objeto de um pedido autônomo no juízo cível ${ }^{903}$.

Por fim, note-se que alguns autores, como SÉRgio GischKow PEREIRA, têm aproveitado esta indefinição para alardear que, se a ideia mais avançada é elidir a consideração da culpa, menos base haverá para se cogitar do ressarcimento dos danos morais entre cônjuges ${ }^{904}$.

\subsubsection{Questões processuais}

O tema envolve relevantes questões processuais. A doutrina majoritária tem se mostrado favorável à cumulação dos pedidos de ressarcimento por danos morais e separação judicial, pois consideram que não há nenhum óbice à competência das varas de família para apreciação da indenização. Assim, afiançam que os três requisitos para essa cumulação, previstos no art. 292, $§ 1^{\circ}$, incisos I, II e III do Código de Processo Civil, estão preenchidos: há compatibilidade dos pedidos, competência jurisdicional das varas de família e adequação do procedimento, que é o ordinário.

Este é o posicionamento de Regina BeAtriz TAVAREs DA SiLva, para quem a cumulação das demandas é plenamente possível. Segundo a jurista, mais do que

\footnotetext{
${ }^{900}$ Cf. idem, p. 346.

${ }^{901}$ Cf. idem, p. 348.

902 "Ou seja: não é possível se falar em culpa no rompimento da relação conjugal, mas é possível se discutir a reparabilidade de eventuais causas culposas ocorridas antes do divórcio, que não puderam ser tratadas no processo de divórcio direto, mas que nem por isso são excluídas de eventual caracterização como causa culposa". Idem, p. 349.

${ }^{903}$ Cf. idem, p. 499.

${ }^{904}$ Cf. PereIRA, Sérgio Gischkow. Op. cit. (nota 142), p. 361.
} 
compatibilidade, há conexão no que se refere às causas de pedir, nos termos do art. 103 do Diploma Processual, pois tanto o pedido de separação judicial, quanto o de reparação de danos, referem-se às graves violações dos deveres conjugais ${ }^{905}$. Nestes termos, ela assevera que “(...) a 'causa petendi' dos danos morais, no caso em espécie, não é decorrente de relações meramente civis, mas de relações de família, que têm especificidades e natureza próprias ${ }^{\text {,906. }}$

Quanto à competência jurisdicional, como a norma de organização judiciária do Estado de São Paulo atribui às varas de família e sucessões as ações relativas a estado e seus acessórios ${ }^{907}$, a doutrinadora afirma que ambos os pedidos podem ser avaliados pelo mesmo juízo, pois a ação de reparação de danos decorre da violação de dever que advém do casamento, e é questão acessória à ação de separação judicial, que é relativa ao estado da pessoa $^{908}$.

Nestes termos, a jurista argumenta que a cumulação se faz necessária a fim de que, proferida a sentença, seja considerado o valor da indenização na fase de execução da partilha, uma vez que o patrimônio do lesante irá por ele responder. Se não houver cumulação dos pedidos, entende que a ação reparatória deverá ser distribuída, por prevenção, à mesma vara em que tramita a ação de separação judicial, sob pena de serem proferidas decisões conflitantes a respeito da violação a dever conjugal. Ela ressalva que a ação de reparação de danos poderá ser eventualmente promovida após o trânsito em julgado da sentença de separação judicial, porém, desde que distribuída ao mesmo juízo ${ }^{909}$.

Para MÁrio MoAcyr Porto, é possível formular os dois pedidos em uma mesma demanda. No entanto, nada impede que a indenização seja pleiteada antes ou depois da instauração do processo para obtenção da dissolução contenciosa da sociedade conjugal $^{910}$.

Já segundo JESUALDO EDUARDO DE ALMEIDA JÚNIOR, o pedido de reparação de danos morais pode ser lançado na própria petição inicial de separação ou divórcio

\footnotetext{
${ }^{905}$ Cf. SILVA, Regina Beatriz Tavares da. Op. cit. (nota 440), p. 118.

${ }^{906}$ Idem, pp. 118-119.

${ }^{907}$ Cf. SILVA, Regina Beatriz Tavares da. Op. cit. (nota 198), pp. 82-83.

${ }^{908}$ Cf. Silva, Regina Beatriz Tavares da. Op. cit. (nota 440), p. 118.

${ }^{909}$ Cf. idem, pp. 120-121.

${ }^{910}$ Cf. PoRTO, Mário Moacyr. Op. cit. (nota 689), p. 106.
} 
litigioso, ou em sede de reconvenção ${ }^{911}$. YUSSEF SAID CAHALI considera razoável afirmar que, tratando-se de pedido de danos morais veiculado por meio de reconvenção em ação de separação judicial litigiosa, prevalece a competência das varas de família ${ }^{912}$.

Note-se que, não obstante a jurisprudência paulista venha admitindo a competência das varas de família e a cumulação dos pedidos ${ }^{913}$, há entendimento no sentido oposto ${ }^{914}$.

Também na doutrina, encontramos manifestações contrárias a essa cumulação.

Para InACIO DE CARVAlho Neto, é questionável tal entendimento, especialmente em função do disposto no art. 292, $§ 1^{\circ}$, II, do Código de Processo Civil ${ }^{915}$. Isto porque o julgamento de pedido indenizatório compete à vara cível e o processo de separação, à vara de família, não havendo norma específica que admita tal cumulação ${ }^{916}$.

Na opinião de CAETANO LAGRASTA, a indenização é possível desde que desvinculada do processo de dissolução do casamento, pois considera que " $a$ mercantilização do sentimento produz reflexos duradouros e sensíveis entre os adultos $e$, com especial ênfase, à prole, com certeza, parte menos protegida da família, nesse momento ${ }^{, 917}$. Assim, ele entende que a ação indenizatória deve ser resolvida na esfera cível, distanciada do Direito de família ${ }^{918}$.

Mesmo após a aprovação da Emenda Constitucional n. 66/2010, alguns juristas permanecem sustentando a cumulação dos pedidos, agora com relação ao divórcio.

Regina Beatriz TAVARES DA Silva, conquanto defenda a conservação da separação judicial em nosso ordenamento, prevê que, em face da compatibilidade entre o pedido culposo de divórcio e o de reparação de danos, da adequação do mesmo tipo de procedimento para ambos, e da competência das varas de família, podem ser

\footnotetext{
${ }^{911}$ Cf. AlmeIDA JÚNIOR, Jesualdo Eduardo de. Op. cit. (nota 141), p. 141.

912 Cf. CAHALI, Yussef Said. Op. cit. (nota 39), p. 593.

913 TJSP, Ag. de Inst. n. 574.036-4/0-00, Rel. Des. MAthias COltro, j. em 04-02-09; TJSP, Ag. de Inst. n. 475.358-4/8-00, Rel. Des. LuIZ AnTONio Costa, j. em 28-03-07; e TJSP, Ag. de Inst. n. 435.183-4, Rel. Des. José LuIZ GAVIÃo DE ALMEIDA, j. em 14-02-06.

914 TJSP, Ag. de Inst. n. 313.831-4/4, Rel. Des. ANTONIO VILENILSON, j. em 13-04-04.

${ }^{915}$ Cf. CARVAlHo Neto, Inacio de. Op. cit. (nota 619), p. 323.

${ }^{916}$ Cf. CARVAlHo Neto, Inacio de. Op. cit. (nota 86), p. 293.

${ }^{917}$ LAGRASTA, Caetano. Op. cit. (nota 735), p. 32.

${ }^{918}$ Cf. idem, 31.
} 
cumulados $^{919}$. Ela reitera que, para o deslinde dessas questões, o melhor caminho não é apurar o descumprimento do dever conjugal em ação própria, após a dissolução do casamento pelo divórcio, afinal, nesta hipótese, o vínculo já foi extinto ${ }^{920}$.

Michel MASCARENHAS SiLVA opina que, onde há divisão funcional e material de competência, é melhor atribuir ao juiz da vara de família o julgamento de dano moral. Todavia, aponta que em alguns Estados a norma de organização judiciária veda o julgamento de reparação civil pelo juízo de família ${ }^{921}$.

Ele aduz que não se poderia, nos casos da proibição mencionada, se utilizar da modificação da competência por conexão, haja vista que, dentro os requisitos desta, está a da competência do juízo para conhecer todos os pedidos (art. 292, I, do Código de Processo Civil) ${ }^{922}$. Defende, ainda, que o julgamento das demandas se faça no mesmo processo de dissolução da sociedade conjugal ou vínculo matrimonial, ressaltando o perigo de prescrição da pretensão de reparação civil ${ }^{923}$.

Por fim, também VALÉRIA Silva GALDINO CARDin defende a possibilidade de cumulação da ação de divórcio e de reparação de danos, bem como de alimentos e de guarda. Ela entende que a vítima do dano terá assegurado seu direito à indenização perante as varas de família e não as varas cíveis quando se discutir a culpa durante a tramitação do divórcio litigioso, que segue o rito ordinário ${ }^{924}$.

\subsubsection{Direito estrangeiro}

Após esmiuçarmos o tratamento do dano moral entre cônjuges no Direito de família brasileiro, faremos breve exposição dos entendimentos adotados por alguns países, mormente os de origem romano-germânica.

\footnotetext{
919 Cf. SILVA, Regina Beatriz Tavares da. Op. cit. (nota 198), p. 85.

${ }^{920}$ Cf. idem, p. 56. A jurista ainda demonstra que não haveria vantagem para as partes, para a sociedade, e para a tão almejada celeridade processual, caso não se admitisse a cumulação dos pedidos de divórcio, alimentos, reparação de danos, e quanto à utilização do sobrenome conjugal, pois ocorreria a duplicação, triplicação, ou até mesmo quadriplicação dos processos judiciais. Assim, afiança que a competência para todos esses feitos é das varas especializadas de família, e que devem ser distribuídos ao mesmo juízo por prevenção, em razão do risco de decisões conflitantes. Cf. idem, p. 110.

${ }_{921}$ Cf. SILVA, Michel Mascarenhas. Op. cit. (nota 84), pp. 148-149.

${ }^{922}$ Cf. idem, p. 151.

${ }^{923}$ Cf. idem, p. 153.

${ }^{924}$ Cf. CARDIN, Valéria Silva Galdino. Op. cit. (nota 245), pp. 154-156.
} 
No Direito francês, a questão é disciplinada pelo art. 266 do Código Civil ${ }^{925}$, com a redação que lhe foi dada pela Lei de 11 de julho de 1975, que dispõe: no caso de divórcio decretado por culpa exclusiva de um dos cônjuges, este estará sujeito à reparação ao seu consorte dos danos materiais e morais decorrentes da dissolução do casamento. No entanto, também se admite que a reparação seja requerida em razão dos fatos determinantes da dissolução do matrimônio, por força do disposto no art. 1.382 do mesmo diploma $^{926}$.

Assim, distinguem-se dois fundamentos legais para a reparação de danos no divórcio: os prejuízos provocados diretamente pela dissolução do casamento; e os danos acarretados por grave violação de dever conjugal ${ }^{927}$.

$\mathrm{O}$ art. 266 fundamenta a reparação de danos oriundos da própria ruptura do vínculo conjugal, impondo, como requisito para sua obtenção, que o divórcio tenha sido decretado por culpa exclusiva do cônjuge que causou os prejuízos e que essa reparação seja pleiteada por ocasião da ação de divórcio. Tal indenização destina-se a reparar o sofrimento resultante do fim do casamento. Assim, os efeitos deletérios da própria separação do casal, quando aptos à produção de dano moral, podem fundamentar o pedido de reparação ${ }^{928}$.

Já o art. 1.382 embasa a reparação dos prejuízos advindos da própria causa do divórcio, não se confundindo com os danos acarretados pelo divórcio em si. Ou seja, no Direito francês, se o cônjuge pretende ser indenizado por violação dos deveres conjugais,

925 “Article 266 - Sans préjudice de l'application de l'article 270, des dommages et intérêts peuvent être accordés à un époux en réparation des conséquences d'une particulière gravité qu'il subit du fait de la dissolution du mariage soit lorsqu'il était défendeur à un divorce prononcé pour altération définitive du lien conjugal et qu'il n'avait lui-même formé aucune demande en divorce, soit lorsque le divorce est prononcé aux torts exclusifs de son conjoint. Cette demande ne peut être formée qu'à l'occasion de l'action en divorce”. Tradução livre: “Artigo 266 - Sem prejuízo da aplicação do artigo 270, se poderá conceder uma indenização por perdas e danos a um dos cônjuges para reparar as consequências de especial gravidade que sofrer em razão da dissolução do matrimônio, bem quando for a parte demandada em um divórcio pronunciado por alteração definitiva do vinculo matrimonial e sem que o mesmo haja interposto nenhuma demanda de divórcio, ou bem quando o divórcio for pronunciado atribuindo exclusivamente as causas de culpabilidade a seu cônjuge. Este pedido somente poderá ser formulado durante o processo de divórcio".

926 "Article 1.382 - Tout fait quelconque de l'homme, qui cause à autrui un dommage, oblige celui par la faute duquel il est arrivé à le réparer”. Tradução livre: “Artigo 1.382 - Qualquer ação de uma pessoa que cause dano a outra, obrigará o causador do dano, culpado, a repará-lo”.

${ }^{927} \mathrm{Na}$ visão de INÁCIO DE CARVALHO NETO, a doutrina francesa faz claramente a distinção entre os danos mediatos, do art. 266, e imediatos, previstos no art. 1.382. Cf. CARVALHO NeTO, Inacio de. Op. cit. (nota 86), p. 292.

${ }_{928}$ Para LuIZ MURILlo FÁBREGAS, por força deste dispositivo é indiscutível a reparação do dano moral, não obstante a dificuldade na fixação do valor da indenização. Cf. FÁBREGAS, Luiz Murillo. Op. cit. (nota 131), p. 105. 
deve fazê-lo com base no preceito geral de responsabilidade civil. Nesta hipótese, cumpre ao cônjuge apontar o prejuízo sofrido, sem vinculação com o resultante do divórcio ${ }^{929}$. Os danos fundamentados nesse dispositivo são os ocasionados pelo descumprimento de dever conjugal, como aqueles provocados por violência física, atentado à dignidade, recusa à coabitação e adultério ${ }^{930}$. Tais danos podem ser de ordem moral ou material ${ }^{931}$, e sua reparação tem cabimento no divórcio decretado por culpa exclusiva de um dos cônjuges e também naquele por culpas recíprocas ${ }^{932}$.

Nestes termos, para sancionar a violação dos deveres conjugais, é utilizado na França o regime da responsabilidade civil ${ }^{933}$.

A doutrina francesa esclarece que, tanto na ruptura do casamento, como no inadimplemento de dever conjugal, o cálculo das perdas e danos não é realizado conforme os recursos ou possibilidades das partes, mas buscando a reparação dos prejuízos acarretados ao cônjuge. Para isto, pode ser utilizado o pagamento em moeda ou sob a forma de pensão vitalícia, somando-se ainda a prestação compensatória ${ }^{934}$. Ademais, a indenização não visa à punição do divórcio, mas sim, das faltas conjugais graves ou renovadas ${ }^{935}$.

Destarte, a França é um dos poucos países que expressamente prevê a possibilidade de condenação do cônjuge culpado em perdas e danos em razão do término do casamento, sendo certo que também admite a aplicação do regime de responsabilidade civil ao Direito de família, em razão da infração dos deveres conjugais.

\footnotetext{
${ }^{929}$ Cf. ANDRADE, Fábio Siebeneichler de. Op. cit. (nota 730), pp. 15-16.

${ }^{930}$ Cf. SILVA, Regina Beatriz Tavares da. Op. cit. (nota 198), pp. 95-96.

931 Cf. FERRANDO, Gilda. Rapporti familiari e responsabilità civile. In: CENDON, Paolo (Coord.). Persona e danno III: le persone deboli, i minori, i danni in famiglia. Milano: Giuffrè, 2004, p. 2790.

932 Cf. WeILl, Alex et Terré, François. Droit civil: les personnes - la famille - les incapacités. $5^{\mathrm{a}}$ ed. Paris: Dalloz, 1983, p. 420, apud CARVALHO NeTO, Inacio de. Op. cit. (nota 86), p. 271.

${ }_{933}$ Cf. AlMEIDA JúNIOR, Jesualdo Eduardo de. Op. cit. (nota 141), p. 124.

934 Cf. Voulet, Jacques. Toutes les questions pratiques sur le divorce et la separation de corps. $7^{\mathrm{a}}$ ed. Paris: J. Delmas, 1976, p. 17, apud CARVALHO NeTO, Inacio de. Op. cit. (nota 86), p. 272.

935 Cf. Carbonnier, Jean. Droit civil: la famille. 20a ed. Paris: Puf, 1999, p. 577, apud Carvalho Neto, Inacio de. Op. cit. (nota 86), p. 272.
} 
Na visão de LuIZ MuRILlo FÁBREGAS, modernamente o Direito francês deu os primeiros passos para a aplicação da reparação do dano moral decorrente do divórcio, sendo inspiração para os países que vieram a acolher tal entendimento ${ }^{936}$.

O Código Civil português, da mesma forma, expressamente autoriza a reparação dos danos causados em consequência da separação ou do divórcio. Quanto àqueles produzidos durante a vida em comum e que foram determinantes para a dissolução do casamento, igualmente se aplica o princípio geral da responsabilidade civil.

Também no Direito português o pleito de indenização por danos não patrimoniais, provocados pela dissolução do casamento, pode ser examinado na ação de divórcio, sendo excluída nesta fase a análise dos eventuais prejuízos causados pelo fundamento do divórcio. Entretanto, neste último caso não há restrição para que o interessado trilhe a via comum da responsabilidade civil a fim de obter a reparação ${ }^{937}$.

A primeira hipótese, disposta no art. $1.792^{0938}$, com a redação dada pelo Decreto-Lei 496/77, estabelece que o pedido deve necessariamente ser deduzido na própria ação de divórcio; enquanto a reparação dos danos derivados das causas que determinaram a dissolução do matrimônio, embasada no art. $483^{\circ 939}$ - que trata do princípio geral da responsabilidade por fatos ilícitos -, deve ser reclamada sempre em ação autônoma, pois são considerados atos de natureza ilícita, equiparados aos demais, independentemente do vínculo entre ofensor e ofendido.

Nestes termos, percebe-se certa similitude entre a solução adotada por este ordenamento e aquela do Direito francês, sendo que em ambos é dominante a concepção de que a responsabilidade civil abrange as relações conjugais ${ }^{940}$.

\footnotetext{
${ }_{936}$ Cf. FÁBREGAS, Luiz Murillo. Op. cit. (nota 131), p. 103.

${ }_{937}$ Cf. ANDRADE, Fábio Siebeneichler de. Op. cit. (nota 730), pp. 16-17.

938 “Artigo $1792^{\circ}$ (Reparação de danos não patrimoniais) - 1. O cônjuge declarado único ou principal culpado e, bem assim, o cônjuge que pediu o divórcio com o fundamento da alínea c) do artigo $1781^{\circ}$, devem reparar os danos não patrimoniais causados ao outro cônjuge pela dissolução do casamento. 2. O pedido de indemnização deve ser deduzido na própria acção de divórcio”.

939 “Artigo $483^{\circ}$ (Princípio geral) - 1. Aquele que, com dolo ou mera culpa, violar ilicitamente o direito de outrem ou qualquer disposição legal destinada a proteger interesses alheios fica obrigado a indemnizar o lesado pelos danos resultantes da violação. 2. Só existe obrigação de indemnizar independentemente de culpa nos casos especificados na lei".

${ }^{940}$ Cf. ANDRADE, Fábio Siebeneichler de. Op. cit. (nota 730), p. 17. Contudo, para FÁBIO SIEBENEICHLER DE ANDRADE, a separação entre os danos decorrentes do divórcio e os danos decorrentes da violação dos deveres conjugais é mais rigorosa em Portugal. Cf. idem, p. 15.
} 
O Código Civil Peruano de 1984, por sua vez, previu a indenização dos danos morais entre cônjuges no art. $351^{941}$. Esta norma regula a reparação moral pelos fatos determinantes do divórcio, não chegando, porém, a acolher idêntico direito para prejuízos derivados do próprio rompimento da relação matrimonial. Portanto, a solução adotada neste país é diversa, sendo a única que encontramos desta estirpe.

No Direito italiano não há uma solução pacífica para a questão, que não foi regulamentada pelo Código Civil.

A doutrina italiana se indaga se o cônjuge vítima de ato ilícito praticado pelo consorte somente teria à disposição as regras de Direito de família ou se poderia se valer do ressarcimento civil do dano ${ }^{942}$.

Em princípio, a doutrina tradicional teria negado esta possibilidade ${ }^{943}$. Segundo YUSSEF SAID CAHALI, embora MiNOZZI mostrasse favorável à reparação do dano moral consequente do adultério, GABBA qualificava como chocante a concessão de uma indenização ao marido traído pela esposa, criticando os arestos que a concediam ${ }^{944}$.

A Corte de Cassação também se recusava a este reconhecimento, sob o argumento de que:

"costituendo la separazione personale un diritto inquadrabile tra quelli che garantiscono la libertà della personna (cioè un bene di altissima rilevanza costituzionale) ed avendone il legislatore specificato analitcamente le conseguenze nella disciplina del diritto di famiglia (cioè nella sede sua propria), deve escludersi proprio in omaggio al principio secondo cui 'inclusio unius, exclusio alterius' - che a tale conseguenze si possano aggiungere anche quelle proprie della responsabilità aquiliana" ${ }^{945}$.

\footnotetext{
941 "Artículo $351^{\circ}$ - Reparación del cónyuge inocente - Si los hechos que han determinado el divorcio comprometen gravemente el legítimo interés personal del cónyuge inocente, el juez podrá concederle una suma de dinero por concepto de reparación del daño moral”. Tradução livre: "Artigo 351 (Reparação do cônjuge inocente) - Se os fatos que determinaram o divórcio comprometem seriamente o legítimo interesse pessoal do cônjuge inocente, o juiz poderá conceder-lhe uma quantia em dinheiro a título de reparação do dano moral".

${ }_{942}$ Cf. FERRANDO, Gilda. Op. cit. (nota 931), p. 2780.

${ }^{943}$ Cf. FÁBREGAS, Luiz Murillo. Op. cit. (nota 131), p. 107.

${ }^{944}$ Cf. CaHAli, Yussef Said. Op. cit. (nota 39), p. 591.

${ }^{945}$ Corte di Cassazione, 6.4.1993, n. 4108, apud FERRANDO, Gilda. Op. cit. (nota 931), p. 2781.
} 
De acordo com GILDA FERRANDO, foram dois os principais argumentos utilizados: a separação seria um direito de liberdade pessoal e o Direito de família é uma ilha com regras próprias, impermeável às regras do direito comum, especialmente da responsabilidade civil ${ }^{946}$.

No mesmo sentido, observa Jesualdo EduARdo de Almeida JÚnior que algumas decisões acolhiam, quando muito, a reparação dos danos materiais ${ }^{947}$.

Todavia, BernARdo CASTElo BRANCO informa que também na Itália o princípio da igualdade entre cônjuges vem acarretando mudanças no sentido da admissibilidade da reparação dos danos na dissolução do casamento ${ }^{948}$.

Para a jurista italiana GILDA FERRANDO, a evolução da responsabilidade civil como instrumento eficaz de proteção das situações jurídicas de natureza pessoal permite seu avanço sobre o Direito de família. Deste desenvolvimento, a autora destaca dois aspectos: a) a mutação da noção de dano injusto para a de lesão a interesse merecedor de tutela, por meio da ponderação dos interesses contrapostos, conduzida pelos princípios fundamentais do ordenamento; e $b$ ) a transformação do conceito de dano, não mais estreitado em contornos patrimoniais, passando a abranger os prejuízos causados à atividade de realização da pessoa ${ }^{949}$.

Ela cita que a jurisprudência mais recente da Corte de Cassação rejeita a leitura tradicional do dano moral subjetivo, propondo a noção de dano não patrimonial como uma categoria abrangente, que compreenda 'toda hipótese em que se lesa um valor inerente da pessoa' ${ }^{950}$. E comenta o caso em que, pela primeira vez, se admitiu que a violação dos deveres familiares determina, além dos efeitos do Direito de família, o remédio ressarcitório, quando presentes os pressupostos para tanto ${ }^{951}$.

Quanto aos chamados ilícitos absolutos, a solução da doutrina italiana é a mesma da brasileira:

\footnotetext{
${ }^{946}$ Cf. FERRANDO, Gilda. Op. cit. (nota 931), p. 2781.

${ }^{947}$ Cf. AlmEIDA JúnIOR, Jesualdo Eduardo de. Op. cit. (nota 141), p. 124.

${ }^{948}$ Cf. BRANCO, Bernardo Castelo. Op. cit. (nota 94), p. 74.

${ }^{949}$ Cf. FERRANDO, Gilda. Op. cit. (nota 931), pp. 2784-2785.

${ }^{950}$ Cf. idem, p. 2785.

951 Trata-se da Corte di Cassazione, 7.6.2000, n. 7713, apud FERRANDO, Gilda. Op. cit. (nota 931), p. 2785.
} 
"Ad esempio, il comportamento violento del coniuge che provoca lesioni all'integrità fisica o alla salute dell'altro, costituisce nello stesso tempo violazione dei doveri di assistenza e di rispetto e lesione del diritto alla salute. Ed il coniuge dovrebbe essere tenuto a risponderne non diversamente da quanto sarebbe tenuto l'estraneo che si fosse macchiato delle medesine colpe" ${ }^{952}$.

Daí a afirmação de GILDA FERRANDO: "la famiglia non è più l'isola, il microcosmo governato da regole proprie, impenetrabili a logiche di altra natura; è invece rimessa nel circuito dei principi e delle regole generali che anche ad essa si applicano, quando non siano espressamente derogati" ${ }^{953}$.

Já quanto aos ilícitos que somente pode ser cometidos pelo cônjuge, como o descumprimento do dever de fidelidade, a controvérsia ainda é acentuada.

O argumento contrário à aceitação de dano moral nestas situações próprias das relações familiares diz que a previsão de um remédio específico pela violação de dever conjugal faz precluir a possibilidade de se recorrer à regra geral da responsabilidade civil $^{954}$.

GILDA FERRANDO, de sua parte, faz o contraposto: "il fatto è che la violazione deglie obblighi familiari mette in gioco diritti fondamentali della persona, la dignità, l'eguaglianza, la libertà, l'autonomia, diritti di rango costituzionale, la cui lesione merita piena tutela" 955 .

Ao longo do debate teórico e jurisprudencial na Itália, chegou-se à criação da figura do mobbing. GRACIELA MEDINA comenta que a Corte de Turim consagrou a expressão mobbing para designar o dano sofrido por um cônjuge durante o casamento ${ }^{956}$. Em suas palavras, o mobbing se caracteriza "por la repetición de comportamientos hostiles, técnicas de desestabilización, que desarrolla como reacción graves problemas

\footnotetext{
${ }^{952}$ FERRANDO, Gilda. Op. cit. (nota 931), p. 2786.

${ }^{953}$ Idem, p. 2787.

${ }^{954}$ Cf. idem, p. 2790.

${ }^{955}$ Ibidem.

${ }^{956}$ Cf. MedinA, Graciela. Op. cit. (nota 587), p. 96.
} 
psicológicos duraderos, es decir que se trata de un proceso destructivo sutil que puede llevar a la discapacidad permanente" 957.

Igualmente, para GILDA FERRANDO o mobbing familiar consiste na “(...) sistematica denigrazione delle qualità morali dell'altro nei rapporti sociali, condotta che è stata riguardata come violazione dell'eguaglianza morale del coniuge e come lesione della sua dignità’958.

Neste contexto, a jurista italiana comenta um caso julgado pelo Tribunal de Milão, onde a indenização se deu não por violação de deveres comuns a todos, mas específicos da relação familiar. A decisão considerou a 'particular gravidade' do fato, vista não apenas sob o aspecto subjetivo (o dolo do marido), mas também objetivamente, pois a conduta concreta, em seu complexo, era lesiva a direitos invioláveis, tutelados de modo pleno e absoluto pelo ordenamento. Na visão da autora, o argumento mais forte do decisum residia na referência a princípios constitucionais, pois nem toda violação, mesmo grave, daria lugar ao dano injusto, mas apenas aquelas que infringem direitos e princípios tutelados de forma particular e proeminente pela Constituição ${ }^{959}$.

Ela acaba reconhecendo que, após superar a tese de imunidade endofamiliar, o 'coração do problema' está em estabelecer os parâmetros para identificar quando é admissível a responsabilidade nestas hipóteses. Ao lado da ponderação de interesses no caso concreto, ela assinala a utilização da figura do abuso de direito, que já era aproveitada pela doutrina francesa ${ }^{960}$.

$\mathrm{Na}$ Espanha, somente foram previstos os danos morais entre cônjuges nas hipóteses de anulação do casamento (art. 98 do Código Civil espanhol) ${ }^{961}$.

Neste sentido, há decisões favoráveis ao dano moral nas relações familiares em casos de nulidade de matrimônio: por vício da vontade do tipo coação (a título de

\footnotetext{
${ }^{957}$ Idem, p. 97.

${ }^{958}$ FERRANDO, Gilda. Op. cit. (nota 931), p. 2791.

${ }^{959}$ Cf. idem, pp. 2792-2793.

${ }^{960}$ Cf. idem, p. 2794.

961 “Artículo 98 - El cónyuge de buena fe cuyo matrimonio haya sido declarado nulo tendrá derecho a una indemnización si ha existido convivencia conyugal, atendidas las circunstancias previstas en el artículo 97”. Tradução livre: "Artigo 98 - O cônjuge de boa fé, cujo casamento tenha sido declarado inválido, terá direito a indenização se existiu vida conjugal, atendidas as circunstâncias previstas no artigo 97”.
} 
responsabilidade aquiliana) e em virtude de erro essencial sobre a pessoa do cônjuge (a título de responsabilidade contratual) ${ }^{962}$.

Já quanto à indenização por quebra dos deveres familiares, a situação do Direito espanhol é peculiar.

Tanto o Código Civil espanhol quanto o Código de Família catalão contêm normas isoladas que estabelecem a obrigação de indenizar pela violação de deveres relacionadas à administração ou disposição de bens (respectivamente, os arts. 1390 e 1391 do Código Civil e arts. 145.1 e 147.1 do Código de Família), mas nada dizem quanto às infrações aos demais deveres ${ }^{963}$.

O Supremo Tribunal espanhol pronunciou-se a respeito do descumprimento do dever de fidelidade, afirmando que, na falta de previsão específica, "la infracción del deber de fidelidad origina un reproche ético-social, pero no un resarcimiento del daño moral irrogado" 964 .

O jurista JOSEP FERRER RIBA entende que os deveres matrimoniais não admitem coerção, em razão de ser o matrimônio uma comunidade de vida assumida e mantida voluntariamente. A isto se soma, na sua visão, a dificuldade de calcular os danos e o escasso poder dissuasório da responsabilidade civil para prevenir abusos e outras violações na família. Por isto, sua violação comporta, em regra, apenas as consequências previstas no Direito de família, vale dizer, a possibilidade de se pleitear a separação e o divórcio 965 . Para ele, neste caso "el silencio del legislador debe interpretarse como una negativa al resarcimiento de daños"966.

Por outro lado, o autor distingue a violação dos deveres conjugais dos danos decorrentes de condutas que violam direitos ou deveres conceitualmente separáveis do interesse na manutenção do matrimônio. Ou seja, admite a indenização de danos referentes

\footnotetext{
${ }^{962}$ Cf. PÉREZ MAYOR, Adrián. Op. cit. (nota 52), pp. 168-169.

${ }^{963}$ Cf. Ferrer RIBA, Josep. Relaciones familiares y límites del derecho de daños. InDret. Barcelona, 2001, p. 5.

${ }^{964}$ Cf. PÉreZ MAYOR, Adrián. Op. cit. (nota 52), p. 166.

${ }^{965}$ Cf. FERRER RIBA, Josep. Op. cit. (nota 963), p. 14.

${ }^{966}$ Cf. idem, p. 15.
} 
à integridade física e psíquica, à saúde, à liberdade, à honra e à liberdade sexual, por exemplo $^{967}$.

Considerando, contudo, que é muito difícil separar um e outro dano, ele faz referência à utilização da tipicidade penal como parâmetro, de modo que a eleição das violações mais graves operada pelo legislador no Direito Criminal serviria para tanto ${ }^{968}$.

Por outro lado, com a reforma introduzida pela Lei 15/05, alterou-se o sistema de dissolução do vínculo conjugal na Espanha, permitindo-se o divórcio direto sem necessidade de prévia separação judicial. Assim, deixou-se de exigir a apresentação de motivos para a separação, por se entender que a manutenção do vínculo matrimonial está adstrita à liberdade dos cônjuges.

Não é possível afirmar se esta modificação alterará a orientação da doutrina e jurisprudência quanto à indenização nestes casos. Por ora, GRACIELA MEDINA noticia que a jurisprudência espanhola continua a negar a indenização do dano moral nas relações conjugais $^{969}$.

A literatura argentina é bastante comentada pelos juristas brasileiros, pois, por não contar com norma expressa, a controvérsia doutrinária e jurisprudencial é semelhante à de nosso país ${ }^{970}$.

Observa BERNARDO CASTELO BRANCO que coube à doutrina e à jurisprudência estabelecer os limites da admissibilidade daquela reparação e, muito embora não haja um consenso a respeito, tem predominado a tese afirmativa ${ }^{971}$. Também LUIZ MuRILLO FÁBREGAS afiança que a doutrina majoritária tem se mostrado favorável à reparação de danos morais pelos fatos que deram causa ao divórcio ou à separação, entendendo cabível a aplicação do princípio geral de responsabilidade civil ${ }^{972}$.

Assim, segundo YUSSEF SAID CAHALI, muitos juristas argentinos aceitam que os fatos que podem dar lugar ao divórcio são condutas antijurídicas, pelo que suas

\footnotetext{
${ }^{967}$ Cf. ibidem.

${ }^{968}$ Cf. idem, pp. $15-16$.

${ }^{969}$ Cf. MEDINA, Graciela. Op. cit. (nota 587), pp. 116-120.

970 Cf. Oltramari, Fernanda et Oltramari, Vitor Hugo. Op. cit. (nota 102), p. 59. Cf. FÁBregas, Luiz Murillo. Op. cit. (nota 131), p. 108.

${ }^{971}$ Cf. BRANCO, Bernardo Castelo. Op. cit. (nota 94), p. 76.

972 Cf. FÁBregAs, Luiz Murillo. Op. cit. (nota 131), p. 109.
} 
consequências devem ser reparadas; não se cuida de beneficiar o cônjuge inocente senão de ressarci-lhe os danos efetivamente sofridos. Ademais, entendem que sendo a matéria relativa ao matrimônio de ordem pública, é interesse da sociedade que o culpado pela quebra do casamento repare o dano causado ${ }^{973}$.

Embora a legislação argentina não contenha disposição específica sobre a reparabilidade dos danos derivados da infração aos deveres conjugais, a doutrina majoritária considera tais prejuízos indenizáveis com apoio na regra geral sobre responsabilidade civil por atos ilícitos, ditada pelo art. 1.109 do Código Civil ${ }^{974}$.

Assim, os juristas defendem que esta reparação é fruto da regra geral, apenas direcionada a uma relação social diferente:

"Es obvio - por lo supuesto - que sostenemos que la reparación de daños en el derecho de familia integra - en este aspecto - la teoría general de la reparación de daños o derecho de daños, como 'marco contenedor' precisamente de los daños y en su reparación, es decir que no se trata de un 'subsistema especial', sino que es un 'subsistema integrativo', con la particularidad de que el 'sustrato' es la familia",975.

GRACIELA MEDINA elencou os argumentos da doutrina contrários à indenização de danos no divórcio, combatendo um a um. Em síntese e com as adaptações necessárias, teríamos o seguinte quadro, com os fundamentos para a negação e as réplicas que afirmam a possibilidade da reparação ${ }^{976}$ :

a) O Direito de família apresenta especialidade: mas não se basta a si mesmo, nem impede a aplicação dos princípios gerais da responsabilidade, sendo parte integrante do direito civil.

b) Falta de previsão específica: é possível aplicar as regras gerais, sendo que a exigência de norma expressa é contrária à conformação do sistema jurídico.

\footnotetext{
${ }^{973}$ Cf. CAHALI, Yussef Said. Op. cit. (nota 39), p. 591.

974 “Art. 1.109. Todo el que ejecuta un hecho, que por su culpa o negligencia ocasiona un daño a otro, está obligado a la reparación del perjuicio. Esta obligación es regida por las mismas disposiciones relativas a los delitos del derecho civil". Tradução livre: "Art. 1.109 do Código Civil: Todo aquele que executa um ato, que por culpa sua ou negligência, ocasiona um dano a outrem, fica obrigado a repará-lo. Esta obrigação é regida pelas mesmas disposições relativas aos delitos do direito civil”.

${ }^{975}$ GHERsi, Carlos, WeINGarten, Celia et GHERsi, Sebastián. Op. cit. (nota 52), p. 20.

${ }^{976}$ Cf. MEDINA, Graciela. Op. cit. (nota 587), pp. 47-65.
} 
c) O erro de eleição do cônjuge não é indenizável: não se repara a eleição do cônjuge, mas sim os danos sofridos.

d) Alguns danos devem permanecer sem reparação: desde que não observados os pressupostos da responsabilidade civil.

e) Os danos são compensados pela obrigação de pagar alimentos: esta prestação é assistencial, e não reparadora; os alimentos somente são atribuídos ao inocente, ao passo que a indenização não; legislações que admitem expressamente a indenização, como na França, mantêm os alimentos concomitantemente.

f) A divisão de bens independe de culpa: não se trata de dividir os bens, mas de reparar dano.

g) A impossibilidade de distinguir entre os deveres matrimoniais e as obrigações naturais: o dever de indenizar está previsto em lei e tem conteúdo patrimonial.

h) Os países que admitem a reparação têm legislação expressa: na França a aceitação jurisprudencial ocorreu antes da previsão legal.

i) A admissão pode redundar na diminuição dos casamentos: a possibilidade de outras pessoas não se casarem não é eximente de responsabilidade e os precedentes de indenização são raros, não configurando uma força social relevante para criar este efeito negativo.

De qualquer maneira, a indenização de tais danos passou a ser acolhida pela jurisprudência argentina ${ }^{977}$. Vê-se que os pleitos reparatórios têm sido aceitos a partir da aplicação das normas gerias de responsabilidade civil, embora sem corporificar uma unanimidade entre os magistrados.

Há que se mencionar o posicionamento adotado pelo Direito alemão, que não acompanha a tendência observada em outras nações. Trata-se da maior referência de modelo restritivo de indenização por danos entre cônjuges.

Na Alemanha, o princípio da culpa foi totalmente substituído pelo princípio da ruptura no casamento. A violação culposa dos deveres conjugais não encontra mais guarida no direito alemão, havendo a previsão genérica de que o vínculo termina com o fracasso do

977 Cf. SILVA, Regina Beatriz Tavares da. Op. cit. (nota 198), pp. 98-99. 
casamento. Ou seja, o BGB (Bürgerliches Gesetzbuch - o Código Civil alemão de 1900) prevê como único pressuposto para o divórcio a constatação de fracasso da relação conjugal, o que se evidencia pela leitura do $§ 1.565^{978}$.

Assim, como naquele país não se examina a culpa para a concessão do divórcio, seria incoerente que se previsse no âmbito do Direito de família o dever de indenizar o cônjuge culpado pela dissolução ${ }^{979}$.

Segundo FÁBIo SIEBENEICHLER DE ANDRADE, a Alemanha mostra-se refratária a qualquer interferência externa no âmbito das relações matrimoniais, a indenização por ofensas praticadas no casamento redundaria em pressão externa para que houvesse o cumprimento dos deveres inerentes àquele vínculo, o que seria inadmissível. Permitir a reparação civil entre os cônjuges, ademais, reintroduziria no Direito de família alemão o princípio da culpa, que foi substituído pela noção da livre dissolução do vínculo conjugal $^{980}$.

Não há, portanto, a possibilidade de indenização pela ocorrência do divórcio, tampouco no campo da responsabilidade civil. Entende-se que nestas situações deve vigorar entre os cônjuges as regras do Direito da família ${ }^{981}$.

Jesualdo EduARDo De AlMEIDA JÚNIOR nota que os Tribunais Superiores na Alemanha têm rejeitado as ações reparatórias deste jaez sob o argumento de que a regulamentação especial do direito de família exclui qualquer pretensão de natureza aquiliana $^{982}$. Também ANGELA CRISTINA DA SILVA CERDEIRA observa que a jurisprudência alemã informa que as regras da responsabilidade civil não são aplicáveis aos cônjuges

\footnotetext{
978 "\$ 1565 Scheitern der Ehe - (1) Eine Ehe kann geschieden werden, wenn sie gescheitert ist. Die Ehe ist gescheitert, wenn die Lebensgemeinschaft der Ehegatten nicht mehr besteht und nicht erwartet warden kann, dass die Ehegatten sie wiederherstellen.(2) Leben die Ehegatten noch nicht ein Jahr getrennt, so kann die Ehe nur geschieden werden, wenn die Fortsetzung der Ehe für den Antragsteller aus Gründen, die in der Person des anderen Ehegatten liegen, eine unzumutbare Härte darstellen würde". Tradução livre: "\$1565 Fracasso do casamento - (1) Um matrimônio pode ser dissolvido pelo divórcio em decorrência de seu fracasso. Entende-se que o matrimônio fracassou quando a comunhão de vida entre os cônjuges não existe mais e não se puder esperar a sua restauração. (2) Se a separação dos cônjuges ainda não tiver um ano, o casamento somente poderá ser dissolvido pelo divórcio se a sua continuação representar uma dificuldade excessiva para o requerente, por razões que se encontram na pessoa do outro cônjuge".

${ }^{979}$ Cf. AGUIAR JÚNIOR, Ruy Rosado de. Op. cit. (nota 15), pp. 7-9.

${ }^{980}$ Cf. ANDRADE, Fábio Siebeneichler de. Op. cit. (nota 730), pp. 19-20.

${ }^{981}$ Cf. idem, p. 20.

982 Cf. AlMEIDA JÚNIOR, Jesualdo Eduardo de. Op. cit. (nota 141), p. 124.
} 
entre si, em conformidade com a ideia de que a comunidade familiar deve ser mantida em um contexto de liberdade e não graças à ameaça de sanções ressarcitórias ${ }^{983}$.

A Alemanha, portanto, apresenta característica peculiar no tratamento da responsabilidade por danos causados no âmbito da relação matrimonial: a repele de forma veemente.

No que diz respeito à Common Law, ensina JOSEP FERRER RIBA: "Los ordenamientos de 'Common Law', a su vez, forjaron históricamente reglas generales de inmunidad a favor de ciertas personas en atención a su relación familiar con la víctima del daño, que dieron lugar a excepciones denominadas de relaciones familiares o de 'Domestic Relations" "984.

A imunidade era de dois tipos. A primeira era a interpousal immunity, estabelecida entre os cônjuges, derivada da doutrina da marital unity ou unity of spouses, de inspiração bíblica, a qual prelecionava que a mulher se fundia ao marido, formando uma só pessoa ${ }^{985}$.

Esta doutrina teria sido renegada em meados do séc. XIX, com os Married Women's Property Acts (datados de 1844 nos Estados Unidos e de 1870 e 1882 na Inglaterra), os quais outorgavam à mulher casada capacidade patrimonial e de litigância por danos patrimoniais ${ }^{986}$.

Quanto aos danos pessoais, por um tempo os Tribunais mantiveram a imunidade, sob o argumento de preservação da privacidade e harmonia familiar ${ }^{987}$.

$\mathrm{Na}$ Inglaterra, a imunidade caiu por vez em 1962, com o Law Reform (Husband and Wife) Act, permitindo todos os tipos de ações de responsabilidade entre os cônjuges, embora deferindo ao magistrado o poder de suspender o exercício da ação se

\footnotetext{
983 Cf. CerdeIRA, Ângela Cristina da Silva. Op. cit. (nota 671), p. 107.

${ }^{984}$ FERRER RIBA, Josep. Op. cit. (nota 963), p. 5.

${ }^{985}$ Cf. idem, p. 6.

${ }^{986} \mathrm{Cf}$. ibidem.

${ }^{987}$ Cf. ibidem.
} 
entendesse que a continuação do processo não produziria benefícios substanciais às $\operatorname{partes}^{988}$.

Mesmo em casos mais graves, a jurisprudência inglesa pondera a natureza diferenciada das relações familiares, destacando, por exemplo, as tensões emocionais exacerbadas dentro da família, bem como a necessidade corriqueira de os membros continuarem em contato $^{989}$.

O segundo tipo de imunidade - parental immunity - foi elaborado pelas Cortes norte-americanas, não tendo precedentes no Direito inglês. No período de 1891 a 1905, três sentenças formaram a great trilogy da imunidade paterna ${ }^{990}$.

A jurisprudência também foi atenuando o alcance desta imunidade, esquadrinhando o padrão flexível do reasonable and prudent parent ${ }^{991}$.

Dessa maneira, nos Estados Unidos da América, após o período da imunidade conjugal, que obstava ações entre cônjuges, até mesmo em casos de violência, hoje em dia poucos tribunais negam o direito à indenização à mulher vítima de agressões físicas. A discussão norte-americana persiste, todavia, quanto à admissão dos danos psicológicos e emocionais na ausência de danos físicos ${ }^{992}$.

Ante este breve esboço do status jurídico do tema no estrangeiro, constatamos que as legislações da França, Portugal e Peru contêm disposições expressas quanto à possibilidade de indenização dos danos entre cônjuges. As duas primeiras, em razão da ruptura do vínculo matrimonial; já a legislação peruana, pela infração aos deveres conjugais.

\footnotetext{
${ }^{988}$ Cf. ibidem. Após tais modificações, a possibilidade de divórcio não culposo foi introduzida no Direito inglês em 1969, prevendo as hipóteses de conversão após dois anos ou o divórcio direto após cinco anos de separação de fato. Cf. HARRIS-SHORT, Sonia et MILES, Joanna. Family law: text, cases, and materials. $2^{\mathrm{a}}$ ed. Oxford: Oxford University Press, 2011, p. 308. Daí a indicação de ANTONIO CEZAR PELUso, aludindo que na Grã-Bretanha, com o Divorce Reform Act, de 1969, em vigor a partir de 1971, adotou-se o sistema da ruptura (breakdown of marriage). PELUSO, Antonio Cezar. Op. cit. (nota 655), p. 47.

989 Conforme, por exemplo, o caso Hale vs Tanner (2000), citado por HARRIS-SHORT, Sonia et MILES, Joanna. Op. cit. (nota 988), pp. 276-278.

${ }_{990}$ Cf. FerRER RIBA, Josep. Op. cit. (nota 963), pp. 6-7. São eles: Hewellette v. George (1891), a mãe havia internado ilegalmente sua filha em um estabelecimento psiquiátrico; McKelvey v. McKelvey (1903), a filha processou o pai e a madrasta por maus-tratos cometidos por esta, com a conivência daquele; e Roller $v$. Roller (1905), onde se afastou responsabilidade por danos de um pai que havia sido declarado criminalmente culpado por ter violado a filha. Cf. idem, p. 7.

${ }^{991}$ Cf. ibidem.

${ }^{992}$ Cf. MedinA, Graciela. Op. cit. (nota 587), p. 144.
} 
Logo, há que se diferenciar as soluções adotadas, pois os ordenamentos francês e português admitem a reparação entre cônjuges de maneira mais ampla, considerando a sua viabilidade em razão das consequências danosas da própria dissolução matrimonial, por regra expressa, e pela regra geral da responsabilidade civil, em razão da infração dos deveres conjugais. Por sua vez, o Código Civil peruano apenas admite esta segunda hipótese, porém de forma específica, e não pela aplicação da responsabilidade civil.

Ao que apuramos, o único país que nega peremptoriamente a indenização entre cônjuges é a Alemanha. Nos demais, a discussão permanece no âmbito doutrinário e jurisprudencial.

\subsubsection{UNIÃO ESTÁVEL}

Os efeitos jurídicos das uniões de fato foram objeto de lenta evolução doutrinária e jurisprudencial, que culminou em seu reconhecimento como entidade familiar pela Constituição Federal de 1988, sua regulamentação pelas Leis n. 8.971/94 e n. 9.278/96 e, por fim, sua consolidação no Código Civil de 2002.

REgina BEATRIZ TAVARES DA SiLVA observa que “muito evoluiu a matéria da união estável em nosso Direito, para o fim de reconhecer-se na relação de fato entre um homem e uma mulher, preenchidos certos requisitos, uma entidade familiar e não mais uma união ilícita, realizada à margem do casamento "993.

Consoante dispõe o art. 1.723 do Código Civil, a união estável é caracterizada como a relação entre um homem e uma mulher, com ou sem filhos e com aparência de casamento, desde que inexistente qualquer impedimento. Trata-se de uma comunhão de vida e de interesses, uma convivência com intenção de ser duradoura e com o objetivo de constituir uma família.

São requisitos essenciais para a união estável: a diversidade de $\operatorname{sexos}^{994}$; a ausência de impedimento matrimonial; a notoriedade de afeições recíprocas ${ }^{995}$; e a

\footnotetext{
${ }^{993}$ SANTOS, Regina Beatriz Tavares da Silva Papa dos. Op. cit. (nota 95), p. 24.

${ }^{994}$ Após a decisão proferida pelo Supremo Tribunal Federal na Arguição de Descumprimento de Preceito Fundamental n. 132 e na Ação Direta de Inconstitucionalidade n. 4.277, que equiparou a união homoafetiva à união estável, parcela da doutrina passou a entender que a diversidade de sexos deixou de ser condição sine qua non para a caracterização dessa união. Nas palavras de VALÉRIA SILVA GALDINO CARDIN, “assim, o que importa para o reconhecimento da união homoafetiva é o afeto, agregado ao objetivo de constituir família e
} 
exclusividade. Note-se que o prazo de duração do relacionamento deixou de ser condição para sua configuração, ficando a critério do juiz verificar ante o caso concreto se existiu uma convivência duradoura entre os companheiros, com o intuito de formar uma família $^{996}$. Ademais, vale lembrar que esta união não foi equiparada ao casamento, possuindo requisitos e efeitos próprios.

Embora a união estável seja uma relação de fato, constituída com o passar do tempo (portanto, desprovida de um marco inicial formal), com o objetivo de salvaguardar a família e, principalmente, proteger os conviventes, o ordenamento previu deveres para os companheiros, a exemplo das regras estabelecidas no casamento. Deste modo, foram instituídos no art. 1.724 do Código Civil os deveres a serem observados na constância da união: lealdade, respeito e assistência, guarda, sustento e educação dos filhos.

Na opinião de MARIA BERENICE DIAS: "não se atina o motivo de ter o legislador substituído 'fidelidade’ por 'lealdade'. Como na união estável é imposto tão-só o dever de lealdade, pelo jeito inexiste a obrigação de ser fiel, assim como não há o dever da vida em comum sob o mesmo teto" ${ }^{, 997}$. Nestes termos, chegou-se a afirmar que a ausência da expressão fidelidade proporcionaria uma maior liberalização nas uniões estáveis.

No entanto, para a maioria dos juristas, indubitavelmente este dever está expresso no vocábulo lealdade, que inclusive possui contornos mais amplos. Ou seja, a lealdade corresponde ao dever de fidelidade previsto no casamento, traduzindo-se na abstenção da prática sexual com terceira pessoa e na atitude escorreita e honesta do companheiro.

aos elementos que caracterizam a união estável, como a estabilidade, a continuidade, a notoriedade e a unicidade de vínculo”. CARDIN, Valéria Silva Galdino. Op. cit. (nota 245), p. 183.

${ }^{995}$ A união estável pressupõe a notoriedade, uma vez que os relacionamentos secretos ou clandestinos não podem ter estabilidade e produzir efeitos jurídicos. Cf. SANTOS, Regina Beatriz Tavares da Silva Papa dos. Op. cit. (nota 95), p. 28.

${ }^{996}$ REginA BEATRIZ TAVARES DA SILVA entende que o legislador agiu bem ao não fixar prazo mínimo de duração para a união estável, mas sim que a convivência seja duradoura, deixando ao prudente arbítrio do juiz a avaliação do requisito temporal. Cf. ibidem. Na opinião de JOSÉ CARLOS TEIXEIRA GIORGIS: "esta adjetivação da união como 'estável' traduz a ideia de permanência, tanto que ela não existe em casos de relacionamento fugaz, passageiro, efêmero, eventual, aqui residindo um dos requisitos que a distinguem do casamento". GIORGIS, José Carlos Teixeira. Direito de família contemporâneo. Porto Alegre: Livraria do Advogado, 2010, p. 116.

${ }^{997}$ DIAS, Maria Berenice. Op. cit. (nota 453), p. 165. 
RodRigo DA CUNHA PEREIRA avaliza que a fidelidade é uma espécie do gênero lealdade. Impõe-se como dever dos companheiros em atendimento ao princípio jurídico da monogamia, que, por sua vez, funciona como um ponto chave das conexões morais. Para o autor, a lealdade está intrinsecamente atrelada ao respeito e consideração ao companheiro e, principalmente, ao animus de preservação da relação ${ }^{998}$. Ele conclui: “a razão de se adotar lealdade, ao invés de fidelidade, é o intuito do legislador de acatar uma postura mais ampla e mais aberta, posto que não se restringe à questão sexual, mas abrange a exigência de honestidade mútua dos companheiros "999.

ZENO VELOSO compartilha da mesma opinião: "o dever de lealdade implica franqueza, consideração, sinceridade, informação e, sem dúvida, fidelidade. Numa relação afetiva entre homem e mulher, necessariamente monogâmica, constitutiva de família, além de um dever jurídico, a fidelidade é requisito natural ${ }^{\prime 1000}$.

Também Regina BeAtriz TAVARES DA Silva assevera que a fidelidade é o dever de lealdade, sob o aspecto físico e moral ${ }^{1001}$.

Considerando impensável admitir que pudessem os partícipes da união estável assumir um comportamento sexual livre e irrestrito, ÁlvARO VILLAÇA AZEVEDO afiança que a quebra do dever de lealdade implica injúria apta a motivar a separação de fato dos conviventes $^{1002}$.

Deste modo, as expressões teriam um sentido análogo, ressaltando um comportamento moral dos casados ou conviventes, bem como o dever de preservar a exclusividade nas suas relações. Ou seja, embora haja distinção terminológica, a doutrina assegura que a fidelidade inclui-se entre os deveres inerentes à união estável, vez que se

\footnotetext{
998 Cf. PEREIRA, Rodrigo da Cunha. Concubinato e união estável. $7^{\text {a }}$ ed. Belo Horizonte: Del Rey, 2004. p. 31.

${ }^{1001}$ Cf. SANTOS, Regina Beatriz Tavares da Silva Papa dos. Responsabilidade Civil dos Cônjuges. In: Pereira, Rodrigo da Cunha. A família na travessia do milênio - anais do II Congresso Brasileiro de Direito de Família - IBDFAM. Belo Horizonte: Del Rey, 2000. p. 128. Segundo a jurista: "típico exemplo de violação da honra do companheiro é a infidelidade, o relacionamento do convivente com terceira pessoa, com vistas á satisfação do instinto sexual". SANTOS, Regina Beatriz Tavares da Silva Papa dos. Op. cit. (nota 95), pp. 32-33.

${ }^{1002}$ Cf. AzEVEDo, Álvaro Villaça. Estatuto da família de fato. $2^{\text {a }}$ ed. São Paulo: Atlas, 2002. p. 189.
} 
adota o princípio monogâmico das relações afetivas, e não pode haver respeito e consideração mútuos, no contexto de um projeto de vida em comum, sem exclusividade.

Quanto ao dever de assistência, segundo REgINA BEATRIZ TAVARES DA SILVA, é o verdadeiro alicerce da união estável e acaba por favorecer o cumprimento dos demais deveres pelos conviventes. De acordo com esta jurista, a figura pode ser definida como a obrigação de proteger os direitos da personalidade do companheiro (sendo que a assistência moral tem como conteúdo a observância recíproca da conduta própria de duas pessoas que se amam). Porém, adverte que esse dever não pode conduzir ao controle abusivo de um dos conviventes sobre o outro, razão pela qual é imposto também o dever de respeito. Assim, propõe que os deveres de respeito e de assistência moral sejam analisados em conjunto, em razão da identidade de objetos, pois ambos têm em vista a preservação dos direitos da personalidade ${ }^{1003}$.

No que tange ao dever de guarda, sustento e educação dos filhos, fazemos referência às considerações já elaboradas no item precedente sobre o casamento, pois as mesmas observações são aplicáveis à união estável.

Destarte, os deveres possuem extrema relevância na união estável, eis que neles se manifesta a observância dos direitos da personalidade.

Vale recordar que a formação, duração e dissolução inter vivos da união estável é marcada pelo elemento volitivo. Ou seja, é a vontade dos conviventes que impera em todas as fases dessa união, que, por sua própria natureza, pode se desfazer a qualquer momento.

Não obstante, se na constância desta união houver por parte do companheiro agravo à personalidade do outro, pela infração a um dos deveres previstos em lei, os juristas têm preconizado a responsabilização pelos danos morais ocasionados.

Muitos notam que em uniões sem casamento é comum a ocorrência de danos, pois, desaparecido o interesse, podem aflorar os sentimentos negativos, provocando-se fissuras na moralidade da vítima por força de investidas indevidas do agente.

${ }^{1003}$ Cf. SAnTOS, Regina Beatriz Tavares da Silva Papa dos. Op. cit. (nota 95), pp. 30-32. 
Assim, na visão de Regina Beatriz TAVAREs DA Silva, os deveres foram estabelecidos aos conviventes com a finalidade de fortalecer a família e evitar a sua desagregação. Por essa razão, quando descumpridos, podem ocasionar graves danos, e o companheiro não merece ficar desprovido do direito à reparação ${ }^{1004}$.

Por sua vez, ANTÔNio CARlos MAthias COltro aduz que o mero descumprimento de dever não dá ensejo a dano moral, mas é possível o pedido indenizatório por violação do dever de lealdade, desde que demonstrado o resultado $\operatorname{lesivo}^{1005}$.

Para Bernardo CASTElo Branco, atualmente se desenha um cenário favorável à tese da admissibilidade dos danos morais na ruptura da união estável, especificamente quando precedida de comportamentos ofensivos adotados por um companheiro em relação ao outro ${ }^{1006}$. Segundo o autor, a infidelidade e as agressões físicas ou verbais, comportamento determinantes do rompimento da união estável, são aptos a causar prejuízos de ordem moral, sendo implausível considerar que os conviventes estão imunes à regra da responsabilidade civil $^{1007}$.

Nestes termos, Elizabeth Ana Maria Meisels PaCCA entende que a aplicação da responsabilidade civil na dissolução do casamento deve se estendida às uniões estáveis ${ }^{1008}$. Também BELMIRO PEDRO WELTER admite tal indenização em caso de união estável $^{1009}$.

REgina BEATRIZ TAVARes DA SILVA arremata: "realmente não se pode entender pensamento diverso, que ao pretender colocar as uniões estáveis e conjugais num pedestal, inatingível pelos princípios da responsabilidade civil, acaba por deixar de oferecer-lhes proteção, ao ponto de desconsiderar a possibilidade da reparação civil

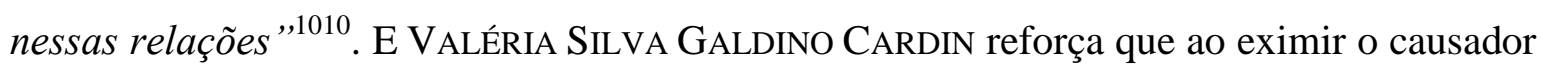
do dano da indenização pelo prejuízo material e/ou moral neste caso, estar-se-ia

\footnotetext{
${ }^{1004}$ Cf. SANTOS, Regina Beatriz Tavares da Silva Papa dos. Op. cit. (nota 95), p. 39.

1005 Coltro, Antônio Carlos Mathias. A união estável e a responsabilidade por dano moral. In: DELGADO, Mário Luiz et ALVES, Jones Figueirêdo. Novo código civil: questões controvertidas. v. 5. São Paulo: Método, 2006, pp. 32-35.

${ }^{1006}$ Cf. BRANCO, Bernardo Castelo. Op. cit. (nota 94), p. 87.

${ }^{1007}$ Cf. idem, p. 90.

${ }^{1008}$ Cf. PACCA, Elizabeth Ana Maria Meisels. Op. cit. (nota 612), p. 97.

${ }^{1009}$ Cf. Welter, Belmiro Pedro. Op. cit. (nota 677), p. 29.

${ }^{1010}$ SAnTos, Regina Beatriz Tavares da Silva Papa dos. Op. cit. (nota 95), p. 38.
} 
amparando a impunidade ${ }^{1011}$. Portanto, segundo as autoras, estando presentes os elementos caracterizadores da responsabilidade civil, o pleito é cabível.

Desta forma, os juristas entendem que a responsabilidade civil dos conviventes encontra amparo nos arts. 186 e 927 do Código Civil, aplicando solução semelhante àquela encontrada para a responsabilização dos cônjuges por infração a dever conjugal.

Neste sentido, REgina BEATRIZ TAVARES DA Silva afirma que os princípios da responsabilidade civil se aplicam às relações entre conviventes: uma vez violados os deveres estabelecidos na união estável com a ocorrência de danos, surge o direito do ofendido à reparação, em razão do preenchimento dos pressupostos da responsabilidade civil, como ocorre diante da prática de ato ilícito em outras relações jurídicas ${ }^{1012}$.

No entanto, entende que se aplicam as regras da responsabilidade civil contratual à união estável quando da sua dissolução, pois os deveres dos conviventes nascem do contrato, verbal ou escrito, de união estável, embora sejam estabelecidos em lei ${ }^{1013}$. Assim, apregoa que:

"esses deveres impõem certos comportamentos aos conviventes, cujo descumprimento consciente do qual resulte dano acarreta a responsabilidade do faltoso, sem que seja necessária a demonstração do dolo - vontade deliberada de causar o prejuízo, e tampouco a negligência ou imprudência do inadimplente, por tratar-se de responsabilidade civil contratual, em que, como antes visto, a culpa, em sentido amplo, é presumida ${ }^{, 1014}$.

Já YUSSEF SAID CAHALI adverte que, a rigor, as circunstâncias postas como causa do dano moral na união estável são de Direito comum, uma vez que a sua dissolução prescinde de decreto judicial de separação litigiosa em razão de uma causa culposa, bastando-se com a cessação da convivência, por iniciativa de qualquer dos companheiros $^{1015}$.

${ }^{1011}$ Cf. CARDIN, Valéria Silva Galdino. Op. cit. (nota 245), p. 177.

1012 Cf. SANTOS, Regina Beatriz Tavares da Silva Papa dos. Op. cit. (nota 95), p. 36.

1013 Cf. idem, p. 37.

1014 Ibidem.

1015 Cf. CaHali, Yussef Said. Op. cit. (nota 39), p. 579. 
No item sobre o casamento, estudamos a hipótese de dano moral pelo término do vínculo conjugal. Em sede de união estável, a questão se repete, com uma peculiaridade, em razão da ausência de formalidade para a ruptura desta sociedade.

Neste contexto, para RUI STOCO a descontinuidade da união estável não enseja direito à reparação, seja no plano material, seja no extrapatrimonial; o que não significa, contudo, que se vede essa possibilidade quando há prática de ato ilícito ou de ofensa moral $^{1016}$.

Compartilha deste mesmo entendimento NiCOLAU ElÁdio BASSALO CRISPINO, para quem o simples fato da ruptura não enseja reparação de danos. Contudo, o autor também ressalva que no momento da dissolução nada impede que um dos companheiros tenha praticado um ato ilícito causador de prejuízo moral ou material ao outro. Se assim ocorrer, mesmo que este ato seja o motivo da ruptura da união, deve o dano ser $\operatorname{ressarcido}^{1017}$.

Também Claudio Luiz BuEno DE Godoy observa que o descumprimento dos deveres na união estável pode ensejar consequências outras, incluindo o dano moral ${ }^{1018}$.

Neste sentido, a doutrina exemplifica situações nas quais a ruptura dos laços de companheirismo se dá de maneira ilícita, gerando a obrigação de reparação.

Para Regina Beatriz TAVARES Da Silva, a sevícia (nome dado em direito de família à lesão corporal) ocorre independentemente de sua gravidade, eis que um único tapa importaria em descumprimento do dever de respeito à integridade física ${ }^{1019}$. Ademais, observa que "ao lado da proteção, tem o convivente o dever de respeitar a vida do companheiro, sendo a tentativa de morte o sinal mais evidente de desamor, ao qual se equipara a falta de cuidados essenciais para impedir a transmissão de doenças contagiosas e letais, como a AIDS ${ }^{, 1020}$. Por fim, ela menciona a toxicomania, a

\footnotetext{
${ }^{1016}$ Cf. STOCO, Rui. Op. cit. (nota 233), p. 833.

${ }^{1017}$ Cf. CRISPINO, Nicolau Eládio Bassalo. Responsabilidade civil dos conviventes. In: PEREIRA, Rodrigo da Cunha. A família na travessia do milênio - anais do II Congresso Brasileiro de Direito de Família IBDFAM. Belo Horizonte: Del Rey, 2000, p. 116.

${ }^{1018}$ GodoY, Claudio Luiz Bueno de. Efeitos pessoais da união estável. In: Chinellato, Silmara Juny de Abreu, Simão, José Fernando, FuJita, Jorge Shiguemitsu et ZucChI, Maria Cristina (Orgs.). Direito de família no novo milênio. São Paulo: Atlas, 2010, p. 333.

${ }^{1019}$ Cf. SANTOS, Regina Beatriz Tavares da Silva Papa dos. Op. cit. (nota 95), p. 32.

${ }^{1020}$ Ibidem.
} 
embriaguez habitual, o vício do jogo, e a prática de crime como atitudes que também ofendem os direitos da personalidade do convivente ${ }^{1021}$.

Também VAlÉRIa Silva Galdino CARdin exemplifica a possibilidade de indenização no caso em que o convivente comete adultério, contrai AIDS e a transmite à sua companheira, provocando um abalo sentimental oriundo da infidelidade, e outro em decorrência da doença contraída ${ }^{1022}$.

Destarte, a maioria dos doutrinadores anuncia que os danos reparáveis em união estável são aqueles decorrentes direta e imediatamente da violação de dever dos conviventes, aplicando-se os princípios da responsabilidade civil. Ou seja, o rompimento da união não assegura ao companheiro preterido o direito à indenização, apenas se esta separação for motivada pela quebra dos deveres que devem ser observados na constância do relacionamento, sendo que caberá ao magistrado examinar, no caso concreto, a existência de um dano a ensejar a reparação.

Na jurisprudência, encontramos algumas manifestações favoráveis a respeito da indenização de danos morais na união estável.

O Tribunal de Justiça de São Paulo já decidiu pela procedência de ação indenizatória promovida pela mulher, em razão das agressões morais e físicas praticadas pelo companheiro $^{1023}$.

Assim sendo, Rui Stoco e Yussef SAID CAHALI compartilham da mesma opinião de que nossos Tribunais têm enfrentado a questão e tendem a reconhecer a inadmissibilidade do dano moral nos casos de rompimento da união estável, ao pressuposto de que o compromisso amoroso traz ínsita a ideia de risco ${ }^{1024}$. No entanto, o último jurista ressalva que nossos magistrados não são totalmente insensíveis à reparação de danos morais consequentes da ruptura de uma união estável prolongada no tempo, a depender das circunstâncias especiais em que se tenha verificado este rompimento da relação $\operatorname{amorosa}^{1025}$.

\footnotetext{
${ }^{1021}$ Cf. idem, pp. 32-33.

1022 Cf. CARDIN, Valéria Silva Galdino. Op. cit. (nota 245), p. 174.

1023 TJSP, Apelação n. 994.05.043430-4, Rel. Des. CAETANO LAGRASTA, j. em 30-06-10.

${ }^{1024}$ Cf. STOCO, Rui. Op. cit. (nota 233), p. 577.

${ }^{1025}$ Cf. CaHali, Yussef Said. Op. cit. (nota 39), pp. 578-579.
} 
Diante deste quadro, para BERNARDO CASTELO BRANCO resta enfraquecido o posicionamento daqueles que simplesmente negam a possibilidade de indenização, sem apresentar fundamentos jurídicos consistentes, por cerrarem os olhos a uma realidade que se mostra cada vez mais presente, constituindo fato social a merecer a necessária valoração do Direito ${ }^{1026}$.

Não obstante, essas mesmas conclusões não se aplicam ao concubinato. $\mathrm{Ou}$ seja, não podem os concubinos pleitear danos morais quando do rompimento deste relacionamento, que não encontra amparo em nosso ordenamento jurídico.

Quanto às uniões homoafetivas, alguns doutrinadores já se pronunciaram a respeito. Entendem que, da mesma forma que a responsabilidade civil dos conviventes, estas relações encontraram amparo no art. 186 do Código Civil. Neste sentido, afiança VAlÉRIA Silva GALDINO CARDIN: "logo, na união homoafetiva, quando um dos companheiros cometer um ato ilícito em relação ao outro, que acarrete transtornos de ordem sentimental, psíquica e física, a vítima poderá ingressar com a ação de reparação de danos morais e materiais" $" 1027$.

Esta breve análise da reparação dos danos morais na união estável permite reconhecer que, paulatinamente, as resistências à ideia de responsabilização civil no âmbito das relações de família estão sendo vencidas, diante da constatação de que a dignidade da pessoa humana e sua personalidade devem ser preservadas nas diferentes esferas dos relacionamentos, inclusive no seio da família, sobrepujando o temor de ingerência externa nessa espécie particular de relação.

\subsubsection{ABANDONO AFETIVO}

Acolhida a possibilidade de incidência das regras da responsabilidade civil no âmbito familiar, os juristas atualmente buscam a admissão deste instrumento nas relações paterno-filiais. Consequentemente, trava-se grande debate no Direito de família a respeito do que se convencionou chamar de abandono afetivo.

Segundo MARIA CelinA Bodin De Moraes, o interesse da criança, na qualidade de pessoa em desenvolvimento, protegida com prioridade pela Constituição da

${ }^{1026}$ Cf. BRANCO, Bernardo Castelo. Op. cit. (nota 94), pp. 98-99.

${ }^{1027}$ CARDIN, Valéria Silva Galdino. Op. cit. (nota 245), p. 188. 
República, deve ser interpretado como um dos aspectos mais fundamentais das relações familiares na sua atual configuração ${ }^{1028}$. Assim, apreende que a família passou a girar em torno dos filhos, sendo que as normas constitucionais e infraconstitucionais determinam, de modo indelével, a mais ampla proteção a eles ${ }^{1029}$.

Em diversas passagens do ordenamento, mostra-se nítido o intuito do legislador em amparar e proteger a criança e o adolescente em seu ambiente familiar. $\mathrm{O}$ art. 227, caput, da Constituição Federal dispõe que é dever da família assegurar-lhes, com absoluta prioridade, o direito à vida, à saúde, à alimentação, à educação, à dignidade, ao respeito, à liberdade e à própria convivência familiar, dentre outros; e o art. 229 estabelece o dever dos pais de assistir, criar e educar os filhos menores. Estas regras aludem ao princípio do melhor interesse da criança e do adolescente, mantendo estreita relação não só com os direitos e garantias fundamentais, mas também com a dignidade da pessoa humana.

Da mesma forma, o Código Civil enumera no art. 1.634 os direitos e deveres que incubem aos pais em relação à prole, e prevê nos arts. 1.637 e 1.638 as hipóteses de suspensão e perda do exercício do poder familiar. Ademais, ao relacionar os deveres dos cônjuges, no art. 1.566, menciona o sustento, a guarda e a educação dos filhos.

O Estatuto da Criança e do Adolescente - ECA (Lei n. 8.069/90), por sua vez, foi elaborado justamente com o escopo de conferir proteção àqueles que ainda não atingiram a idade adulta, consagrando o direito da criança e do adolescente de ser criado e educado no seio de sua família (art. 19), incumbindo deveres aos pais (art. 22) e prevendo sanções pelo descumprimento dos mesmos (art. 249).

Também não se descure que o Código Penal tipifica o abandono material e intelectual dos filhos menores como condutas criminosas (arts. 244 e 246), aptas a ensejar a condenação dos genitores às penas de detenção e de multa.

Neste contexto, ClÁUdia MARIA DA Silva observa que "mais do que nunca a relação paterno-filial assume destaque nas disposições sobre a temática da família"1030. Segundo afirma, atribui-se especial atenção à filiação, pois se trata de seres com

\footnotetext{
${ }^{1028}$ Cf. MoraEs, Maria Celina Bodin de. Op. cit. (nota 63), p. 201.

${ }^{1029}$ Cf. MORAES, Maria Celina Bodin de. Op. cit. (nota 65), p. 55.

${ }^{1030}$ SILVA, Cláudia Maria da. Op. cit. (nota 368), p. 123.
} 
personalidade em desenvolvimento, pelo que se faz imperiosa a convivência familiar plena $^{1031}$.

Portanto, a convivência familiar passa a ser entendida de forma abrangente, garantindo ao menor o direito de receber de seus genitores toda a assistência necessária ao desenvolvimento de sua personalidade e ao resguardo de sua dignidade ${ }^{1032}$. Ademais, os autores preconizam que a família deve ser instituída com fundamento no afeto, que passa a ser uma exigência desta convivência ${ }^{1033}$.

Assim, muitos tomam a afetividade como um dever dos pais, justificando que o relacionamento paterno-filial norteado pelo amor e carinho é fundamental para o crescimento emocional da criança ${ }^{1034}$. O descumprimento deste dever ocasiona sérios prejuízos à personalidade do filho, de maneira que a condenação a indenizar pelo abandono afetivo se dá em razão da lesão à sua dignidade ${ }^{1035}$.

Também a doutrina argentina destaca que o dano moral reparável, referente à falta de assistência paterna, tem seu fundamento na afetação da personalidade do filho, na mácula de sua dignidade, que impede o exercício e o gozo dos direitos inerentes ao estado de família que lhe é correspondente ${ }^{1036}$.

Note-se que por muito tempo o descumprimento da obrigação alimentar - que constitui uma das duas únicas hipóteses de prisão civil por dívida admitidas no nosso direito (art. $5^{\circ}$, inciso LXVII, da Constituição Federal) - foi tema constante na doutrina e na prática forense. Agora, os juristas têm voltado à atenção para o descumprimento da convivência familiar e da afetividade, e suas consequências. Assim, procuram esclarecer como a tutela jurisdicional poderá tornar obrigatória a concretização desses deveres, e identificar os elementos que contribuem para a trajetória do sentimento de abandono afetivo, além de evidenciar os efeitos da condenação do genitor à indenização pecuniária.

\footnotetext{
${ }^{1031}$ Cf. idem, p. 131.

${ }^{1032}$ Cf. idem, p. 138.

1033 Cf. Costa, Maria Isabel Pereira da. Família: do autoritarismo ao afeto; como e a quem indenizá-lo? Revista Magister de Direito Civil e Processual Civil, n. 5, 2005, p. 68.

${ }^{1034}$ Cf. CASABONA, Marcial Barreto. Op. cit. (nota 189), p. 364.

1035 Cf. TARTUCE, Flávio et SiMÃo, José Fernando. Op. cit. (nota 380), p. 28

${ }^{1036}$ Cf. Ghersi, Carlos, Weingarten, Celia et GHERSI, Sebastián. Op. cit. (nota 52), pp.127-128.
} 
Tanto Inacio de Carvalho Neto quanto Bernardo Castelo Branco assinalam que as hipóteses de responsabilidade civil na relação de paternidade são múltiplas $^{1037}$.

Para LIZETE PeiXoto XAVIER SCHUH, pensar no ressarcimento pelo abandono afetivo evidencia que o ser humano passou a exigir mais do que os ordenamentos jurídicos, até então, formalmente estabeleciam ${ }^{1038}$.

A afetividade, na visão desta autora, cuidada inicialmente pelos psicólogos e educadores, ingressou no rol de preocupações dos juristas ${ }^{1039}$. Esta imigração, porém, trouxe consigo uma diversidade de indagações, tornando o abandono afetivo um tema jurídico atual e polêmico ${ }^{1040}$.

\subsubsection{Poder familiar}

O instituto do poder familiar estabelece normas de interesse e proteção dos menores, podendo ser definido como o conjunto de direitos e deveres que o ordenamento jurídico atribui aos pais, responsabilizando-os pela criação dos filhos.

Esta figura jurídica, na observação de INACIO DE CARVALHO NETO, traz consigo mais ônus do que propriamente poderes para seus titulares ${ }^{1041}$. Seguindo tal raciocínio, MARCIAL BARRETO CASABONA aponta que atualmente é elementar conceber o poder familiar enquanto um poder-função, um poder-dever, em suma: um dever ${ }^{1042}$. LUIZ EDSON FACHIN, por sua vez, aponta que a expressão poder-dever denota a necessidade de que seja exercido sempre no interesse alheio, é dizer, no interesse dos filhos ${ }^{1043}$.

${ }^{1037}$ Cf. Carvalho Neto, Inacio de. Op. cit. (nota 86), p. 464 e BRAnCo, Bernardo Castelo. Op. cit. (nota 94), p. 197.

${ }^{1038}$ Cf. SCHUH, Lizete Peixoto Xavier. Op. cit. (nota 680), p. 54.

${ }^{1039}$ Cf. idem, p. $72-73$.

${ }^{1040} \mathrm{Cf}$. idem, p. 53. Mister assinalar que a doutrina argentina traz exemplos de abandono paternal condizentes com os teóricos pátrios: $a$ ) abstenção de visitas ou exercício de forma irregular (fora dos horários, deixando o filho com terceiros); $b$ ) não tomar conhecimento das inquietudes e problemas do filho; mas igualmente traz casos que talvez fossem colocados, em nosso país, no campo da alienação parental: c) imiscuir-se exageradamente nas funções do outro genitor, $d$ ) influir negativamente contra este. Cf. DUTTO, Ricardo J. Op. cit. (nota 169), pp. 241-242.

${ }^{1041}$ Cf. CARVAlHo Neto, Inacio de. Op. cit. (nota 86), p. 463.

${ }^{1042}$ Cf. CASABONA, Marcial Barreto. Op. cit. (nota 189), pp.364-365.

${ }^{1043}$ Cf. FACHIN, Luiz Edson. Comentários ao novo Código Civil: do direito de família, do direito pessoal, das relações de parentesco. v. 18. Rio de Janeiro: Forense, 2003, p. 245. 
A partir dessas ponderações, podemos afirmar que a expressão poder familiar, substituindo a antiga denominação pátrio poder, embora tenha buscado atender à igualdade entre o homem e a mulher, não agradou os juristas, pois manteve a ênfase no aspecto do poder, deslocando-o do pai para a família ${ }^{1044}$. SILVIO RODRIGUES acredita que o legislador pecou ao se preocupar mais em retirar a palavra pátrio do que incluir o seu real conteúdo, o qual, antes de um poder, representa uma obrigação dos pais, não da família, como o nome sugere $^{1045}$.

Daí porque vemos a doutrina simpatizar com a denominação autoridade parental $^{1046}$.

Cláudia MARIA DA Silva propõe a utilização deste termo, assinalando que a expressão poder familiar conserva uma carga de supremacia e comando que não se coaduna com o seu verdadeiro sentido: o complexo e relevante conjunto de deveres, e não propriamente de poderes, que os pais têm com relação aos filhos ${ }^{1047}$.

Assim, em sua perspectiva atual, especialmente sob o influxo do princípio da prioridade absoluta assegurada à criança e ao adolescente, o poder familiar é visto como um conjunto de deveres em relação à prole, que notoriamente necessitam de especial proteção nessa fase de desenvolvimento incompleto ${ }^{1048}$. BERNARDO CASTELO BRANCO observa que o poder familiar se coloca a serviço do desempenho da tarefa maior, que é a de proporcionar aos filhos os meios necessários ao desenvolvimento das potencialidades inerentes à sua personalidade ${ }^{1049}$.

Neste contexto, Maria Celina Bodin de Moraes acentua que o termo responsabilidade é o que melhor caracteriza a paternidade ${ }^{1050}$. Na visão da jurista, o poder familiar é posto no interesse exclusivo dos filhos e com a finalidade de satisfazer as suas

\footnotetext{
1044 Cf. DIAS, Maria Berenice. Op. cit. (nota 453), p. 377.

1045 Cf. RODRIGUES, Silvio. Op. cit. (nota 339), p. 355.

1046 Para LUIZ FELIPE BRASIL SANTOS: "melhor refletiria a concepção hodierna do instituto a noção de 'autoridade parental'. Ocorre que 'poder' carrega um sentido de unilateralidade e prepotência que atualmente não é mais próprio a esse direito-dever que os pais têm em relação aos filhos. Ademais, 'parental' exprime melhor o exercício por parte de pai e mãe do que 'familiar', que é um conceito por demais amplo”. SANTOS. Luiz Felipe Brasil. Guarda de menores e reponsabilidade civil. In: DELGADO, Mário Luiz e Alves, Jones Figueirêdo. Novo Código Civil - Questões Controvertidas - Série Grandes Temas de Direito Privado. v. 5. São Paulo: Método, 2006, p. 371.

1047 Cf. Silva, Cláudia Maria da. Op. cit. (nota 368), pp. 134-135.

1048 Cf. SANTOS. Luiz Felipe Brasil. Op. cit. (nota 1046), p. 372.

1049 Cf. BRANCO, Bernardo Castelo. Op. cit. (nota 94), p. 114.

${ }^{1050}$ Cf. MorAES, Maria Celina Bodin de. Op. cit. (nota 65), p. 56.
} 
necessidades existenciais, em razão da doutrina conhecida como 'da proteção integral'. Com isso, informa que há uma ampliação das intervenções nas relações de filiação, pois o legislador e o juiz tomam a si o encargo de tutelar os menores em face de todos, inclusive dos pais ${ }^{1051}$.

Segundo AnA CAROlina Brochado TeIXEIRA, a função dos deveres parentais é instrumentalizar os direitos fundamentais dos filhos ${ }^{1052}$.

Na doutrina inglesa, também notamos a mudança de clave. Os direitos dos pais são vistos apenas como necessários para o cumprimento dos deveres e responsabilidades inerentes à paternidade: "that is, they are instrumental: they exist only insofar as they are necessary for parents to perform their parental duties and responsibilities. It is therefore parental duties and responsibilities, not parental rights, which 'should' be regarded as standing at the heart of parenthood" 1053.

Este poder-dever familiar desdobra-se em aspectos pessoais e patrimoniais. Os primeiros se manifestam na guarda, educação e correção dos filhos. Já o âmbito patrimonial compreende a administração de seus bens.

A guarda é um dos atributos do poder familiar, mas não se confunde com este. Ela representa apenas um de seus elementos ${ }^{1054}$, porém a falta de convivência sob o mesmo teto não limita e nem exclui esse poder-dever ${ }^{1055}$. Quando os pais estão separados, e a guarda é deferida a um deles, resta ao outro o direito de visita, no entanto, permanece intacto o seu poder familiar. Assim, ela é simultaneamente um direito e um dever dos genitores, que visa, precipuamente, assegurar à criança e ao adolescente a assistência material, moral e educacional, conforme preleciona o art. 33 do ECA.

${ }^{1051}$ Cf. Moraes, Maria Celina Bodin de. Op. cit. (nota 63), p. 197.

1052 TEIXEIRA, Ana Carolina Brochado. A disciplina jurídica da autoridade parental. In: PEREIRA, Rodrigo da Cunha (Coord.). Família e Dignidade Humana - Anais do V Congresso Brasileiro de Direito de Família. Belo Horizonte: IBDFAM, 2006, p. 111.

${ }^{1053}$ HARRIS-SHORT, Sonia et MILES, Joanna. Op. cit. (nota 988), p. 656. A assertiva ganhou acolhimento jurisprudencial no caso Gillick versus W. Norfolk and Wisbech AHA, julgado em 1986, onde LORD SCARMAN argumentou que os direitos dos pais existem apenas a fim de desempenhar seus deveres para com os filhos. Cf. HerrRing, Jonathan. Op. cit. (nota 402), p. 400. Há uma distinção na doutrina inglesa, entretanto, entre direitos dos pais centrados na paternidade e direitos dos pais centrados nos filhos. Como exemplo daqueles, teríamos o direito de criar a prole na religião dos pais, o que se justifica não pelo melhor interesse da criança, mas sim porque não se pode provar que prejudicam estes, enquanto que beneficiam os pais. Cf. idem, p. 401.

${ }^{1054}$ Cf. VenOSA, Sílvio de Salvo. Op. cit. (nota 340), p. 263.

1055 Cf. DiAs, Maria Berenice. Op. cit. (nota 453), p. 381. 
A omissão dos pais, deixando o filho em desamparo, é considerada grave, podendo levar à perda do poder familiar, além das sanções previstas no Código Penal pelos crimes de abandono material e intelectual. Portanto, é indiscutível que os genitores têm o dever de educar os filhos e assistir-lhes material e moralmente ${ }^{1056}$.

Para VALÉRIA SILVA GALDINO CARDIN, quando os pais negligenciam intelectualmente os filhos estão contribuindo para que não tenham condições de serem cidadãos provedores do seu próprio sustento. Também afirma que os valores morais devem ser repassados, para que os indivíduos saibam se relacionar em sociedade ${ }^{1057}$. Nestes termos, a jurista não descura que os pais têm o direito de correção, que deve ser moderado e compatível com a gravidade do fato cometido pelo menor, pois o rigor excessivo extrapola a finalidade educacional, podendo acarretar prejuízos de ordem física e psicológica. Ou seja, ela afiança que o ordenamento não repele esse direito dos pais, contudo, se transpuser o limite da tolerância, sujeitará o genitor à suspensão ou até destituição do poder familiar, podendo responder civil e criminalmente por tais atos ${ }^{1058}$.

Também Flávio TARtuce e José Fernando Simão observam que a obediência aos pais deve ser exigida com moderação, sem que a relação entre eles seja ditatorial, violenta ou explosiva, e afirmam que qualquer abuso cometido pode gerar a suspensão ou destituição do poder familiar, além da incidência das regras da responsabilidade civil relacionadas ao abuso do direito (art. 187 Código Civil) ${ }^{1059}$.

Maria Celina Bodin de Moraes ressalta que, como a relação entre pais e filhos é permanente, o seu término é custoso e excepcional, só ocorrendo em casos de risco elevado ou de abuso ${ }^{1060}$. Para CAIO MÁRIO DA SILVA PEREIRA, a perda do poder familiar é a sanção mais grave imposta ao pai por faltar com seus deveres ou falhar em relação à sua

\footnotetext{
${ }^{1056}$ Neste ponto, conforme a observação de SILVIO RODRIGUES, deve-se entender por abandono não apenas o ato de deixar o filho sem assistência material, mas também o descaso intencional pela sua criação, educação e moralidade. Cf. RodRIGUES, Silvio. Op. cit. (nota 339), p. 371.

${ }^{1057}$ Cf. CARDIN, Valéria Silva Galdino. Op. cit. (nota 245), p. 239.

1058 Cf. idem, p. 210.

${ }^{1059}$ Cf. TARTUCE, Flávio et SIMÃO, José Fernando. Op. cit. (nota 380), p. 37.

1060 Cf. Moraes, Maria Celina Bodin de. Op. cit. (nota 63), p. 198. Segundo Fernando CAMPos SCAFF, "apesar de serem situações que se imaginam excepcionais, concedeu-se ao Estado um enorme alcance de atuação nos casos em que se evidencie ou mesmo se suspeite de negligência quanto à criação dos filhos, não havendo um elenco taxativo que tenha sido determinado pela lei quanto às situações em que pode haver a modificação das situações de poder familiar". SCAFF, Fernando Campos. Considerações sobre o "poder familiar'. In: Chinellato, Silmara Juny de Abreu, Simão, José Fernando, FuJiTA, Jorge Shiguemitsu et ZuCCHI, Maria Cristina (Orgs.). Direito de família no novo milênio. São Paulo: Atlas, 2010, 580.
} 
condição paterna ou materna ${ }^{1061}$. Já SILVIO RoDRIGUES entende que tais sanções têm menos um intuito punitivo aos pais, do que de preservação do interesse dos filhos, ou seja, é mais um ato em prol dos menores, afastando-os da nociva influência daqueles ${ }^{1062}$.

Todos têm a liberdade de conceber filhos - como dispõe a Constituição no tocante ao planejamento familiar -, no entanto, os juristas alertam que os pais devem assumir sua responsabilidade, cumprindo seus deveres, exercendo a paternidade em harmonia com o princípio da dignidade humana.

\subsubsection{Doutrina}

Quanto à admissão da responsabilidade civil nas relações paterno-filiais, as opiniões dividem-se em duas: a dos juristas que sustentam a isenção, imunidade ou 'privilégio' dos pais na relação intrafamiliar; e a dos que se manifestam favoravelmente à reparação dos danos ocasionados aos filhos.

Os autores que repudiam a indenização do abandono afetivo temem a chamada 'monetarização do amor', por isso, procuram ser cautelosos no exame da questão, alegando que não há no ordenamento jurídico previsão de obrigatoriedade dos pais no sentido de dar afeto aos filhos. Ou seja, afirmam que a lei não pode obrigar os genitores a nutrir afeição pelos filhos, sendo também impossível impor a manutenção de um laço sentimental quando já rompido ou inexistente.

Portanto, de acordo com esta corrente, o elo que une pais e filhos é componente que advém do espírito, do psíquico humano, sendo a lei incapaz de determinar a sua criação ou extinção. Assim, entendem que o legislador não poderia invadir o campo humano da sentimentalidade, e menos ainda o Poder Judiciário poderia impor certo comportamento $^{1063}$.

Segundo LEONARDo CASTRO, a indenização do abandono afetivo não alcança a sua função social e tampouco demonstra qualquer finalidade positiva ${ }^{1064}$. Para o autor, "nas relações familiares, cabe ao Judiciário apenas a defesa aos direitos fundamentais do menor. A sua intromissão em questões relacionadas ao sentimento é abusiva, perigosa e

\footnotetext{
${ }^{1061}$ Cf. PereirA, Caio Mário da Silva. Op. cit. (nota 185), p. 464.

1062 Cf. Rodrigues, Silvio. Op. cit. (nota 339), pp. 368-369.

1063 Cf. CASABOna, Marcial Barreto. Op. cit. (nota 189), pp. 364.

${ }^{1064}$ Cf. CASTRO, Leonardo. Precedente perigoso: o preço do abandono afetivo. Site BDJur, p. 8.
} 
põe em risco relações que não são de sua alçada. O amor é resultado de algo alheio ao nosso entendimento, e não da coação "1065.

De tal modo, a relação afetuosa deverá ser fruto da aproximação espontânea, cultivada reciprocamente, e não de força judicial. Por isso, não vê razão para a reparação, exceto em casos extremos, onde haja comprovado nexo causal entre um dano específico e o abandono. E adverte que após a lide uma barreira intransponível afastará mais o pai de seu filho, 'sepultando' qualquer tentativa futura de reconciliação ${ }^{1066}$.

Neste contexto, nota o surgimento de um grave problema: muitos pais, temendo a justiça, passam a postular judicialmente a participação ativa na vida do filho, criando uma condição de 'amor compulsório', pior do que a mera ausência. Inaugura-se o abandono do pai presente, já que não é preciso estar distante fisicamente para demonstrar a falta de interesse afetivo ${ }^{1067}$.

Demais disto, ele receia o surgimento de uma 'enxurrada de ações indenizatórias munidas de interesses mercenários' e afirma que não há como exigir do julgador a 'faculdade sobrenatural' do discernimento entre a 'real angústia do abandono e a ganância inescrupulosa' ${ }^{1068}$.

Na esteira deste pensamento, para ANTONio CARlos MAHTIAS Coltro, se a lei não contém disposições que permitam obrigar a manifestação do afeto, seria difícil pretender impor o dever indenizatório “em função da 'perda' ou o 'não exercício' (?) do afeto" ${ }^{1069}$.

De outra parte, MARCIAL BARRETO CASABONA se mostra favorável à indenização pelo abandono moral, alegando que não se trata de impor o afeto, mas de obrigar uma pessoa à prestação de seu dever paterno de solidariedade. Todavia, entende

\footnotetext{
1065 Idem, p. 9.

${ }^{1066}$ Cf. idem, p. 8. No que diz respeito à necessidade de preservação da unidade familiar, RICARDO J. DUTTO pondera que não se poderia ignorar que a esperança de sua reconstituição estava aniquilada muito antes de se constituir a ameaça de um processo judicial. Cf. DUTTO, Ricardo J. Op. cit. (nota 169), p. 227.

${ }^{1067}$ Cf. CASTRO, Leonardo. Op. cit. (nota 1075), p. 7.

${ }^{1068}$ Cf. idem, pp. 2-3.

${ }^{1069}$ COLTRO, Antonio Carlos Mathias. Responsabilidade civil no direito de família. In: RODRIGUES JUNIOR, Otavio Luiz, MAMEDE, Gladstone et ROCHA, Maria Vital da. Responsabilidade civil contemporânea: em homenagem a Sílvio de Salvo Venosa. São Paulo: Atlas, 2011, p. 489.
} 
que a indenização pecuniária é inadequada nestes casos, e sugere que o pai forneça ao filho tratamento psicológico, que o ajude a superar ou mitigar a dor experimentada ${ }^{1070}$.

Na opinião de VAlÉRIA Silva GALDINo CARDIN, é verdade que o afeto não pode ser monetarizado, contudo, sua falta acarreta inúmeros danos psicológicos a uma criança ou adolescente, que se sente rejeitado e humilhado, e terá dificuldades em se relacionar no futuro ${ }^{1071}$. É justificável, para ela, a utilização da teoria geral da responsabilidade civil $^{1072}$, propondo a indenização, todavia, como uma forma de oferecer auxílio psicológico ${ }^{1073}$.

Para ARNALDo RizZARDo, a privação do filho da convivência com um dos progenitores é extremamente grave, ocasionando carências e frustrações de ordem emotiva, sentimental e afetiva. Esse convívio, afiança, é um direito dos filhos, e não interessa a separação de seus genitores ou a completa incompatibilidade entre eles ${ }^{1074}$.

Nestes termos, o autor conclui que a frustração na realização da afetividade enseja a indenização pelo dano moral que se abate sobre o filho ${ }^{1075}$. Ele faz, ainda, uma comparação, afirmando que se a morte de um dos pais, em face da sensação de ausência, enseja o direito à reparação por dano moral, não será diferente no caso do afastamento voluntário de um deles, o que, segundo afirma, “(...) encontra repulsa pela consciência comum e ofende os mais comezinhos princípios de humanidade

FLÁVIO TARTUCE considera possível a indenização por abandono afetivo, com base no art. 186 do Código Civil, pois há violação do direito à convivência paterna. Ele afirma que a violação do direito alheio fica clara pelo estudo do art. 1.634 do Código Civil, comando legal que prevê os atributos do poder familiar. Ademais, menciona o art. 229 da

\footnotetext{
${ }^{1070}$ Cf. CASABONA, Marcial Barreto. Op. cit. (nota 189), pp. 364-366.

1071 A autora considera que "os danos aos direitos do menor, produzidos por um dos genitores, são de gravame muito maior do que se fossem provocados por terceiro, ante a situação privilegiada que aquele desfruta". CARDIN, Valéria Silva Galdino. Op. cit. (nota 245), p. 236.

1072 Cf. ibidem.

${ }^{1073}$ Cf. idem, p. 239. Registre-se que a doutrina inglesa também aponta que muitos dos problemas familiares advêm de distúrbios da personalidade, que seriam mais bem resolvidos por meio da terapia. HERRRING, Jonathan. Op. cit. (nota 402), p. 32.

${ }_{1074}^{107 .}$ RizZARDO, Arnaldo. Op. cit. (nota 468), p. 692.

1075 Cf. idem, p. 693. "Em relação aos filhos, enquanto menores, há o direito à convivência com os pais. A afetividade resta gravemente ferida na ausência dessa imposição, porquanto a natureza humana demanda a necessidade não apenas da presença, mas da real participação do pai e da mãe na criação e formação dos filhos". Idem, p. 691.

${ }^{1076}$ Idem, p. 693.
} 
Constituição, que também faz menção aos deveres dos pais pelos filhos. Tratando-se de deveres jurídicos, uma vez violados geram o direito subjetivo a indenização ${ }^{1077}$.

Para ele, a anterior convivência ou não do pai em relação ao filho não interfere na existência do dano, mas deve repercutir na fixação da indenização, de acordo com o art. 944 do Código Civil ${ }^{1078}$.

Rui StOco alerta que a privação de convívio e amparo gera dano irreversível. O abandono afetivo decorrente do distanciamento físico, do afastamento, da omissão sentimental, da negação de carinho, de atenção, de amor e de consideração, do desinteresse, do desprezo e da falta de apoio ou, até mesmo, da completa ausência de relacionamento entre o genitor e o filho, desponta como causa de responsabilização por dano moral ${ }^{1079}$.

$\mathrm{O}$ autor informa que o direito à proteção efetiva dos filhos tem fulcro no princípio da dignidade da pessoa humana. Portanto, considera um dever dos pais cuidar e proteger os filhos, seja no plano material, educacional, afetivo ou psíquico, e vislumbra que a ausência de qualquer deles poderá interferir na formação da criança, de seu intelecto e personalidade, principalmente se já existia um vínculo de afetividade ${ }^{1080}$.

Todavia, ele adverte que o reconhecimento de tal responsabilização não poderá dar 'ensancha a abusos', criando verdadeira indústria de ações judiciais de filhos, supostamente ofendidos, contra os pais. Por esta razão, propõe que o dano moral seja reconhecido somente em caráter excepcional, quando os pressupostos da reparação se

\footnotetext{
1077 Cf. TARTUCE, Flávio. Princípios constitucionais e direito de família. In: Chinellato, Silmara Juny de Abreu, Simão, José Fernando, FujITA, Jorge Shiguemitsu et ZucCHI, Maria Cristina (Orgs.). Direito de família no novo milênio. São Paulo: Atlas, 2010, p. 43. Deste modo, ele informa que a discussão sobre o abandono afetivo não deve considerar, como ponto principal, se o pai é ou não obrigado a conviver com o filho, ou se o afeto pode ser imposto ou não, havendo uma mudança de foco, que passa a ser o de que no abandono afetivo há a presença da lesão a um direito alheio, pelo desrespeito a um dever jurídico estabelecido em lei. Cf. Idem, p. 44.

${ }^{1078}$ Cf. TARTUCE, Flávio. Abandono afetivo (indenização) - comentários a julgado do Tribunal de Justiça de São Paulo. Danos morais por abandono moral. In: LAGRASTA NeTO, Caetano, TARTUCE, Flávio et SiMÃo, José Fernando (Coords.). Direito de família: novas tendências e julgamentos emblemáticos. São Paulo: Atlas, 2011, p. 325.

${ }^{1079}$ Cf. STOCO, Rui. Op. cit. (nota 233), pp. 945-946.

${ }^{1080}$ Cf. idem, p. 945.
} 
apresentarem estreme de dúvida, através de estudos sociais e laudos técnicos de equipe interdisciplinar $^{1081}$.

TEResa AnCona Lopez igualmente aborda o tema com prudência, a fim de que os vínculos familiares não sejam transformados em relações 'argentarias'. Em suas palavras: "é preciso avaliar como a pessoa elaborou a indiferença paterna. Acredito que só quando ficar constatado em perícia judicial que o projeto de vida daquele filho foi trocado pelo abandono, configurando o dano psicológico, é que cabe indenização" ${ }^{\text {"1082 }}$. É comum, destaca a jurista, as mães inflamarem os filhos contra os pais, o que demanda cautela, justificando a necessidade de perícia judicial ${ }^{1083}$.

Na visão de Lizete PeIXOTO XAVIER SCHUH, o estado de filiação assenta uma questão de fato, mas nem sempre gera uma relação de afeto. O direito ao uso do apelido de família do genitor, as questões de cunho patrimonial, os direitos sucessórios, a prestação de alimentos, todos estes são consectários lógicos das relações parentais. Ao lado disto, temos o apoio afetivo ${ }^{1084}$. Em situações excepcionais, quando o amor e o afeto não se conjugam com uma relação familiar saudável, paira a dúvida de como torná-los obrigatórios ${ }^{1085}$ : ela questiona se a indenização pecuniária seria o bastante para aquele que busca a afetividade perdida ou não consentida ${ }^{1086}$.

A autora nota que o posicionamento contrário entende que se trata de pedido impossível, em razão da incoerência de ser concedido 'amor' ao postulante ou exigir-se que o genitor, forçosamente, estabeleça um elo de afeto com o abandonado ${ }^{1087}$.

No entanto, ela assevera que, uma vez negados o direito à paternidade, ao amor, ao convívio familiar, estar-se-á negando a própria dignidade ${ }^{1088}$. As relações paterno-filiais requerem uma abordagem diferente, tendo-se como fundamento maior a responsabilidade, em razão da vulnerabilidade dos filhos menores, a quem o ordenamento

\footnotetext{
${ }^{1081}$ Cf. idem, p. 946.

1082 LOPEZ, Teresa Ancona. Jornal do Advogado. São Paulo: OAB, n. 289, 2004, p.14.

1083 Ibidem.

${ }^{1084}$ Cf. SCHUH, Lizete Peixoto Xavier. Op. cit. (nota 680), p. 74.

1085 Cf. idem, p. 62.

${ }^{1086}$ Cf. idem, p. 72.

1087 "É dificultoso cogitar-se a possibilidade de determinada pessoa postular amor em juízo, visto que a capacidade de dar e de receber carinho faz parte do intimo do ser humano (...)”. Idem, p. 67.

${ }^{1088}$ Cf. idem, p. 69.
} 
deve a máxima proteção ${ }^{1089}$. Portanto, na visão da jurista, a prática de atos ilícitos nas relações de família poderá gerar danos, e o abandono moral evidencia um desrespeito aos direitos da personalidade, o que assegura aos lesados a reparação ${ }^{1090}$.

No que concerne a essa indenização, ela acredita ser impossível estabelecer qualquer metodologia precisa ou vinculativa e considera tormentoso o estabelecimento de uma reparação em pecúnia, visto que as obrigações podem ser impostas, mas os laços afetivos devem ser conquistados, sendo o 'preço do amor, desconhecido, 1091 .

A grande dificuldade nos julgamento deste tipo de lide parece estar, conforme a autora, centrada nos fatores probantes, no nexo causal, além da premente necessidade de um conhecimento interdisciplinar por parte dos operadores do Direito, uma vez que a matéria versa sobre sentimentos e relacionamentos humanos ${ }^{1092}$.

Segundo Theodureto de Almeida Camargo Neto, da mesma forma que a ideia da responsabilidade objetiva, hoje aceita sem discussões, assombrou os cultores da culpa, a reparação do dano afetivo é repugnante para alguns, mas, sem dúvida, uma esperança para outros ${ }^{1093}$, assim, "se o interesse da vítima foi, no passado, preponderante para a adoção da responsabilidade sem culpa, por que não pode sê-lo, também, agora, quando se discute acerca da reparabilidade do dano afetivo?",1094.

O jurista define o dano afetivo - enquadrado no gênero dos danos morais, na subespécie dos danos à pessoa - como aquele que atinge a criança ou o adolescente em consequência do descumprimento do direito-dever de visita do pai, ou da mãe, fixado de comum acordo entre os cônjuges ou imposto coercitivamente pelo juiz. Ele assinala que esse dever não consiste apenas na prerrogativa do respectivo titular de se avistar com o

\footnotetext{
${ }^{1089}$ Cf. idem, pp. 73-74.

1090 Cf. idem, p. 62. A autora elenca outras situações de abandono afetivo, como o caso de filhos que convivem com genitores drogados, criminosos, prostitutos, em ambientes degradantes, e que podem se tornar alvo de discriminação no meio escolar, na comunidade em que estão inseridos, acarretando-lhes prejuízos psicológicos das mais diversas espécies. Cf. idem, p. 70-71.

${ }^{1091}$ Cf. idem, p. 72.

1092 Cf. idem, p. 76.

1093 Cf. CAMARGo Neto, Theodureto de Almeida. A responsabilidade civil por dano afetivo. In: SILVA, Regina Beatriz Tavares da e CAMARGo NeTO, Theodureto de Almeida (Coords.). Grandes temas de direito de família e das sucessões. São Paulo: Saraiva, 2011, pp. 17-18.

${ }^{1094}$ Idem, p. 18. Ele compara a indenização do dano moral originada do protesto irregular de título e a admissão dessa possibilidade em razão do abandono afetivo: "afinal, dúvida não pode haver de que as mágoas, os ressentimentos, as tristezas decorrentes da omissão dos pais deixam sequelas muito mais graves no espírito das vítimas do que aquelas que se originam de simples abalo de crédito”. Idem, p. 29.
} 
filho, mas também de com ele se comunicar por outros meios. Logo, considera que o dever de visita pressupõe que haja convivência e comunicação para que o vínculo se estabeleça ou se consolide, e a criança ou o adolescente possam receber o afeto, a atenção, a vigilância e a influência daquele que não detém sua guarda, de modo a alcançar a plena higidez física, emocional e espiritual ${ }^{1095}$.

Nestes termos, descumprido o dever de visita, surgem sequelas psíquicas e emocionais para o filho, podendo ensejar a condenação do pai ao pagamento de indenização desses danos ${ }^{1096}$. Ele considera estreme de dúvidas que a criação no seio da família e o contato com os pais são direitos dos filhos. Destarte, ainda que à primeira vista possa parecer repulsiva a troca do afeto pela reparação pecuniária, a mesma exercerá influência no espírito do genitor recalcitrante no desempenho de seus deveres ${ }^{1097}$.

Também Rolf MADALENO assevera que pela frustração do direito de ser visitado o filho abandonado faz jus à condenação que constranja o pai a pagar-lhe eficaz tratamento psicológico, para restituir-lhe a saúde emocional, além da indenização do dano moral, pela lesão de bem que integra os seus direitos da personalidade ${ }^{1098}$. A reparação serve não apenas para que os deveres parentais deliberadamente omitidos não fiquem impunes, mas, principalmente, para que no futuro qualquer inclinação ao irresponsável abandono possa ser dissuadida ${ }^{1099}$.

Álvaro Villaça dE AzEVEdo obtempera que o descaso paterno merece punição, para preservar, senão o amor (o que seria impossível), a responsabilidade ante o descumprimento do dever de cuidar, que causa trauma moral ${ }^{1100}$.

Na opinião de Cláudia Maria DA Silva, a formação da personalidade dos filhos depende diretamente da participação e modo como os genitores exercem os seus

\footnotetext{
${ }^{1095}$ Cf. Idem, pp. 22-23.

1096 Cf. Idem, p. 23.

${ }^{1097}$ Cf. Idem, pp. 28-29.

1098 Cf. MADALENO, Rolf. O preço do afeto. In: Repensando o direito de família. Porto Alegre: Livraria do Advogado, 2007, pp. 124-127. Para ele, “(...) amor e afeto são direitos natos dos filhos, que não podem ser punidos pelas desinteligências e ressentimentos dos pais, porquanto a falta deste contato influencia negativamente na formação e no desenvolvimento do infante, permitindo este vazio a criação de carências incuráveis, e de resultados devastadores na autoestima da descendência, que cresceu acreditando-se rejeitada e desamada". MADALENO, Rolf. Op. cit. (nota 422), p. 379.

${ }^{1099}$ Cf. MADALENO, Rolf. Op. cit. (nota 1098), p. 169.

${ }^{1100}$ Cf. AzEvedo, Álvaro Villaça. Jornal do Advogado. São Paulo: OAB, n. 289, 2004, p.14.
} 
papéis de pai e de mãe, como estabelecem e mantêm a convivência familiar ${ }^{1101}$. Na assunção de seus papéis, devem cuidar para que seus encargos não se limitem ao aspecto material, ao sustento: “alimentar o corpo sim, mas também cuidar da alma, da moral, do psíquico. Estas são as prerrogativas do poder familiar e, principalmente, da delegação divina de amparo aos filhos, $" 1102$.

Portanto, para a jurista o descumprimento do dever de convivência familiar gera um vazio no desenvolvimento do filho, sendo tal conduta 'condenável e repugnante'. Lembra que o próprio art. 227 da Constituição Federal estabelece a proteção do menor contra toda forma de negligência, discriminação, exploração, violência, crueldade e opressão, e que o art. 98, II, do ECA prevê condutas que conduzem à responsabilidade civil pelo descumprimento do dever de convivência familiar ${ }^{103}$.

Ademais, segundo apreende, o ato do genitor pode ser comissivo, conduta positiva e danosa, ou uma conduta negativa, negligente, uma inexecução de comportamento exigido pelo legislador para o bem-estar do filho ou, ainda, um abuso de direito propriamente dito ${ }^{1104}$.

Em seu ponto de vista, é preciso superar a ideia de convivência familiar enquanto um dever-direito de visita-companhia-fiscalização para difundi-la como garantia de uma efetiva e perpétua participação na formação e no desenvolvimento da personalidade dos filhos ${ }^{1105}$. Se o elo conjugal for rompido, deve-se manter a convivência familiar ou até mesmo intensificar a relação, diante das adversidades causadas pelo

\footnotetext{
${ }^{1101}$ Cf. SILVA, Cláudia Maria da. Op. cit. (nota 368), p. 132.

${ }^{1102}$ Idem, p. 123. Segundo a autora, a partir de um ambiente familiar em que os filhos recebam atenção, afeição, amor e confiança, é que demonstrarão capacidade para formar novas relações humanas, pois, "do nascimento à fase adulta, os filhos crescem e se desenvolvem em trono da auto-estima, do senso de moralidade, responsabilidade, empatia e de outros tantos aspectos ligados à formação da personalidade. $E$ por isso que a cautela em torno da convivência familiar nasce com o indivíduo, uma vez que são determinantes para sua personalidade a forma e o contexto familiar quando de seu ingresso à vida". Idem, p. 132.

${ }_{1103}$ Cf. idem, pp. 139-140.

${ }^{1104} \mathrm{Cf}$. ibidem. Ela assevera que "é induvidoso que a negativa de convivência familiar importa nos ilícitos ora descritos que se tornam mais graves quando o agressor é o genitor que, embora reconhecidamente recebeu a prole, a ela não desfere o amparo afetivo, a assistência moral e psíquica, atingindo, por consequência, sua honra, a dignidade, a moral e a reputação social, enfim, atributos ligados à personalidade deste ofendido". Idem, p. 140.

${ }^{1105}$ Cf. idem, p. 145.
} 
desenlace $^{1106}$. Esta participação não se esgota com a mera presença física, com o hábito único de visitação ${ }^{1107}$.

Neste sentido, a imposição de sanção civil pela prática de ato danoso do genitor em desfavor de sua prole surte importante 'freio' a tal conduta, além de possibilitar a reconstrução dos laços afetivos. Não se trata, conclui ela, de 'dar preço ao amor' ou 'compensar a dor', mas conscientizar o pai do gravame causado ao filho, sinalizando para ele e para outros que este comportamento é reprovável ${ }^{1108}$.

Da mesma forma, no entendimento de AmANDA IdALINA MENEZES CoRdEIRO, a indenização pecuniária não visa reparar tais danos, mas desestimular outros pais a cometer atos ilícitos que possam vir a causar danos a seus filhos ${ }^{1109}$. Ela assinala que o filho desprezado pode ter distúrbios irreversíveis, realçando a importância da convivência para um desenvolvimento normal, em respeito a seus direitos da personalidade, à sua dignidade $^{1110}$.

Segundo Regina Beatriz Tavares da Silva, "amar não é dever, tampouco direito na órbita jurídica" "1111, e mesmo nas relações de família não há o dever jurídico de amar. No entanto, ela entende que o afastamento injustificado do pai viola o dever de ter o filho em sua companhia, caracterizando ação ou omissão jurídica, pressuposto da responsabilidade civil. Se dessa conduta resultar prejuízos ao filho, que podem ser apurados por laudo pericial, estão preenchidos os demais requisitos: nexo causal e dano ${ }^{1112}$.

Nestes termos, na visão da jurista, não é a falta de amor que pode gerar a condenação paterna ao pagamento de indenização, mas, sim, o ato ilícito em razão da violação do dever de companhia. No entanto, ressalva que se o pai deixa de ver o filho por

\footnotetext{
${ }^{1106}$ Cf. idem, p. 124.

${ }^{1107}$ Cf. idem, p. 137.

${ }_{1108}$ Cf. idem, pp. 141-142.

1109 Cf. CORDEIRO, Amanda Idalina Menezes. Indenização por abandono afetivo. Centro de Ensino Superior de Brasília - CESB, p. 12.

${ }^{1110}$ Cf. Idem, p. 8.

${ }^{1111}$ SILVA, Regina Beatriz Tavares da. Responsabilidade civil nas relações entre pais e filhos. In: DELGADO, Mário Luiz e Alves, Jones Figueirêdo. Novo Código Civil - Questões Controvertidas - Série Grandes Temas de Direito Privado, v. 5. São Paulo: Método, 2006, p. 466.

${ }^{1112}$ Cf. idem, pp. 466-468.
} 
motivos de força maior há quebra do nexo causal (art. 393 do Código Civil), e não poderá haver condenação no pagamento de indenização ${ }^{1113}$.

A autora preleciona que a indenização nestes casos busca aliviar o sofrimento da vítima e desestimular o ofensor quanto à prática de novas ofensas, ao passo que a perda do poder familiar cumpre uma única finalidade: a punição. Nesta última hipótese, o afastamento entre pai e filho é inevitável, já que o genitor perde o direito de visitas. Por outro lado, a condenação do pai no pagamento de indenização conserva este direito ${ }^{1114}$.

Na perspectiva desta doutrinadora, a condenação de um pai ou de uma mãe que abandona moralmente o filho não pode ser vista como monetarização do amor, mas como aplicação dos princípios da responsabilidade civil às relações familiares, desde que seja bem analisado o caso concreto e estejam preenchidos os seus requisitos ${ }^{1115}$.

Na opinião de MARIA BERENICE DIAS, o conceito atual de família, centrado no afeto como elemento agregador, exige dos pais o dever de criar e educar os filhos sem lhes omitir o carinho necessário para a formação plena de sua personalidade, lembrando que atualmente se fala em paternidade responsável. O distanciamento dos pais produz sequelas de ordem emocional nos filhos e reflexos no seu sadio desenvolvimento, que podem ser permanentes. Por isso, assevera que a omissão do genitor em cumprir os encargos decorrentes do poder familiar, deixando de atender ao dever de ter o filho em sua companhia, produz danos emocionais merecedores de reparação ${ }^{1116}$.

Nestes termos, a jurista também salienta o caráter pedagógico da condenação, observando que o relacionamento mantido sob pena de recompensa financeira não é a forma mais correta de se estabelecer um vínculo afetivo, porém é melhor do que gerar no filho o sentimento de abandono ${ }^{1117}$.

Reconhecendo o novo perfil que expressa o vínculo de filiação no Direito contemporâneo, no âmbito do qual a proteção aos filhos assume papel de destaque,

\footnotetext{
${ }^{1113}$ Cf. idem, pp. 467-468.

${ }^{1114}$ Cf. idem, p. 469.

1115 Cf. idem, p. 473.

1116 Cf. DIAS, Maria Berenice. Op. cit. (nota 453), p. 407.

${ }^{1117}$ Cf. idem, p. 409.
} 
BERNARDo CASTElo BRANCO aventa algumas hipóteses de reparação moral em razão violação aos direitos da personalidade dos filhos ${ }^{118}$.

O autor adverte, contudo, que o caráter peculiar de que se reveste o vínculo entre pais e filhos não autoriza a admissão indiscriminada de demandas indenizatórias ${ }^{1119}$. Ou seja, "se de um lado, não se pode conceber a existência de uma imunidade conferida aos pais em relação aos atos danosos praticados contra seus filhos, por outro, não se pode deixar de reconhecer que o caráter peculiar desse vínculo não admite uma interpretação ampliativa do direito à demanda reparatória ${ }^{\text {,1120. }}$

Percebe-se que o jurista não aceita a aplicação integral dos princípios que regem a responsabilidade civil neste caso. Em sua visão, é preciso aferir em que medida o comportamento adotado pelo pai foi capaz de romper os eventuais laços de afeto com o filho, uma vez que a reparação não pode servir de 'estopim' a provocar a desagregação da família. Em outras palavras, a indenização dos danos morais nas relações de filiação está circunscrita às situações nas quais, seja por conta do comportamento lesivo, seja pela ausência de vínculo afetivo preexistente, é impossível conceber a subsistência da relação paterno-filial $^{1121}$.

Desta forma, ele recomenda prudência no julgamento da matéria, examinandose o comportamento lesivo de maneira contextualizada, para que se possa aferir, com razoável segurança, quais as repercussões da demanda para a relação de filiação ${ }^{1122}$.

Quanto aos comportamentos de violência e agressividade, certifica que não podem, como no passado, escapar à incidência das regras que disciplinam o Direito de família e a responsabilidade civil. Da análise do ordenamento jurídico, é possível reconhecer danos morais no caso de violência familiar praticada contra o menor, tenha ou não origem no exercício do poder de correção ${ }^{1123}$.

\footnotetext{
1118 Cf. BRANCO, Bernardo Castelo. Op. cit. (nota 94), p. 117.

${ }^{1119}$ Cf. idem, p. 200.

1120 Ibidem.

${ }^{1121}$ Cf. idem, pp. 118-119.

1122 O autor observa: "um pai afetuoso e dedicado ao filho pode, num momento de cólera, agir de forma destemperada, exorbitando do dever de correção. Conquanto o abuso dos meios de correção, especialmente quando cause lesões físicas ou problemas psíquicos a filho, possa, em tese, representar uma conduta apta a produzir o direito à reparação do dano moral, necessário que se avalie tal comportamento de todo o contexto da vida familiar, e não como fato isolado, que muitas vezes jamais poderá se repetir”. Idem, p. 118. ${ }^{1123}$ Cf. idem, pp. 196-197.
} 
Da mesma forma, constitui comportamento ilícito a conduta omissiva dos pais na formação moral de seus filhos, permitindo-lhes o livre acesso a ambientes nocivos ao seu desenvolvimento, o contato com jogos, álcool e drogas, entre outros fatores deturpadores da personalidade, já que consubstancia descumprimento de um dever juridicamente imposto aos titulares do poder familiar ${ }^{1124}$.

Por outro lado, desatender às necessidades materiais do filho, descumprindo a prestação alimentar, acarreta inegáveis prejuízos à saúde física e mental, obstando o acesso à educação e à profissionalização, impedindo, assim, o desenvolvimento de suas potencialidades, de maneira que a inadimplência da obrigação de sustento igualmente pode dar ensejo aos danos morais, não sendo motivo justificável a alegação de dificuldade econômica $^{1125}$.

A priori, todas essas condutas, capazes de provocar a efetiva violação à integridade física, psíquica, moral e intelectual dos menores, podem levar ao dever de indenizar os danos morais. Entretanto, entende o jurista que são imprescindíveis os demais requisitos para a incidência da responsabilidade civil no Direito de família, notadamente a culpa grave e o dolo ${ }^{1126}$.

$\mathrm{Na}$ mesma linha, CAETANo LAgRASta dispõe que o abandono material ou psicológico merece respaldo, porquanto evidencia o dolo consciente do genitor que não paga alimentos ou deixa de acompanhar o desenvolvimento dos filhos, com reflexos negativos duradouros ${ }^{1127}$.

Giselda Maria Fernandes Novaes Hironaka entende que o dever de indenizar decorrente do abandono afetivo encontra seus elementos na funcionalização das entidades familiares, as quais devem tender à realização da personalidade de seus membros, com especial destaque para os filhos. Ela se coloca favoravelmente ao pleito, porém salienta que este intrumento deve ser utilizado com parcimônia e bom sendo, para

${ }^{1124}$ Cf. idem, p. 194.

${ }^{1125}$ Cf. idem, pp. 191-192.

${ }^{1126}$ Cf. idem, p. 199. Neste compasso, ele aduz que os comportamentos que determinam a suspensão ou a perda do poder familiar, previstos no Código Civil, podem atribuir responsabilidade civil por dano moral. Assim, afiança que o abuso no exercício do poder familiar, a imposição de castigos imoderados, as diferentes formas de abandono e a prática de atos contrários à moral e aos bons costumes podem constituir hipóteses nas quais estejam presentes os elementos autorizadores da reparação por danos morais. Cf. idem, pp. 198-199 1127 Assim, sopesa que a prole “(...) acaba corroída pelo desencontro e pela agressividade, servindo de receptáculo ao orgulho ferido ou à vingança que se seguem à falência do sentimento e à instalação definitiva da hipocrisia”. LAGRASTA, Caetano. Op. cit. (nota 735), p. 30. 
que não se converta em 'verdeiro altar de vaidades e vinganças' ou da busca do lucro fácil, e instrumentalize a aproximação do Direito de família com a contemporaneidade, desempenhando, inclusive, um papel pedagógico neste âmbito ${ }^{1128}$.

Já MARIa CElina Bodin DE MoRAES apresenta uma construção particular. Em seu ponto de vista, a Constituição e a lei obrigam os genitores a cuidar dos filhos menores e, na ausência deste cuidado, que ocasiona prejuízos à integridade daqueles a quem o legislador atribui prioridade absoluta, pode haver dano moral a ser reparado ${ }^{1129}$.

Inicialmente, a jurista faz uma comparação entre a relação conjugal e a parental, ressaltando que há duas 'relevantíssimas' diferenças entre elas. A primeira, que a relação conjugal se dá entre pessoas presumidamente iguais, emancipadas, aptas a exercerem autonomamente a liberdade, ao passo que a relação parental se estabelece entre pessoas em situação essencialmente desigual, sendo uma delas dependente e vulnerável. Esta vulnerabilidade é fundamental quando o foco são os filhos menores ${ }^{1130}$.

A esta diferença, ela acrescenta o fato de que a relação conjugal é facilmente dissolúvel, através da separação ou do divórcio, enquanto na relação parental o vínculo é permanente ${ }^{1131}$. Desses apontamentos, a autora constata que a abordagem da responsabilidade civil deve ser diversa nas relações parentais: "primeiramente porque os dois tipos de relação - conjugal e filial - se diferenciam em muito, tanto estrutural quanto funcionalmente. Enquanto um tem fundamentos na liberdade e na igualdade, o outro se baseia justamente na responsabilidade. Ambos remetem-se, por óbvio, à solidariedade familiar, mas de maneiras muito particulares" ${ }^{\text {1132. }}$

Assim, procedendo à ponderação dos interesses contrapostos, a jurista afirma que, de um lado, se teria a tutelar o princípio da liberdade dos genitores (de fazer o que bem entendessem, inclusive abandonar afetivamente os filhos) e, da parte dos filhos, o princípio da solidariedade familiar. Dada a peculiar condição destes e a responsabilidade dos pais pela sua criação, educação e sustento, entende que seria incabível valorizar mais a

\footnotetext{
${ }^{1128}$ Cf. HIRONAKA, Giselda Maria Fernandes Novaes. Pressuposto, elementos e limites do dever de indenizar por abandono afetivo. In: PEREIRA, Tânia da Silva et PEREIRA, Rodrigo da Cunha (coords.). A ética da convivência familiar: sua efetividade no quotidiano dos tribunais. Rio de Janeiro: Forense, 2005, p. 148.

${ }^{1129}$ Cf. MORAES, Maria Celina Bodin de. Op. cit. (nota 63), p. 198.

${ }^{1130}$ Cf. idem, p. 197.

1131 Cf. idem, p. 201.

1132 Idem, p. 197.
} 
liberdade paterna em detrimento da solidariedade familiar e da própria integridade psíquica dos menores. Do cotejo entre os direitos, estes dois últimos se superpõem à autonomia dos genitores $^{1133}$.

Nas duas hipóteses (relação conjugal e relação paternal) tanto o princípio da solidariedade quanto o princípio da liberdade subsistem. No entanto, a especificidade da relação parental acrescenta à avalição o princípio da integridade psicofísica dos menores. Nesta relação, o vínculo de solidariedade familiar, assegura esta jurista, é o mais forte que existe e por isso, juntamente com a integridade psicofísica das crianças e dos adolescentes, poderá ensejar o dano moral quando houver o abandono completo por parte do genitor biológico $^{1134}$.

A responsabilidade dos pais não desaparece em razão de simples ato de vontade ou por 'falta de amor', e no caso de abandono são lesados os direitos fundamentais implícitos na condição jurídica de filho e de menor, cujo respeito, por parte dos genitores, é pressuposto para o sadio e equilibrado crescimento da criança, além de condição para a sua ajustada inserção na sociedade ${ }^{1135}$.

A construção guarda semelhança com a proposta do jurista espanhol JOSEP FERRER RIBA. Ele mostra-se contrário à indenização por danos na quebra dos deveres conjugais. De outra parte, no que tange aos deveres paternos, traz solução diferente. Para ele, opostamente à relação matrimonial, pais e filhos são partes desiguais, o vínculo entre eles não é consensual, havendo uma dependência da prole, sendo que a ruptura desta relação de parentesco somente se faz de forma excepcional e custosa ${ }^{1136}$.

Ele pondera, calcado na experiência da Common Law, que é razoável admitir que os pais tenham amplos poderes, estando na melhor posição para julgar o que é mais benéfico aos filhos (parental judgemente rule), cabendo ao Direito estabelecer padrões mínimos, atuando apenas diante da culpa grave e do dolo ${ }^{1137}$.

\footnotetext{
${ }^{1133}$ Ou seja, "nesta hipótese, a realização do princípio da dignidade humana se dá a partir da integralização do princípio da solidariedade familiar que contém, em si, como característica essencial e definidora, a assistência moral dos pais em relação aos filhos menores". MORAES, Maria Celina Bodin de. Op. cit. (nota 65), p. 58.

${ }^{1134}$ Cf. MoraEs, Maria Celina Bodin de. Op. cit. (nota 63), p. 201.

${ }^{1135}$ Cf. MoraEs, Maria Celina Bodin de. Op. cit. (nota 65), p. 58.

${ }^{1136}$ Cf. FERRER RIBA, Josep. Op. cit. (nota 963), p. 16.

${ }^{1137}$ Cf. idem, p. 17.
} 
De forma análoga, acatando o filtro da excepcionalidade, MARIA CELINA BODIN DE MORAES elucida que para a configuração do dano moral é preciso que tenha havido o completo abandono por parte do pai (ou da mãe) e a ausência de uma figura substituta. Ou seja, entende que se alguém 'faz as vezes' do genitor, desempenhando suas funções, não haverá dano a ser indenizado, independentemente do comportamento moralmente condenável do pai biológico ${ }^{1138}$.

A jurista também não admite qualquer caráter punitivo à indenização do dano moral, pois assevera que não se trata de condenar um pai que abandou seu filho (eventual 'dano causado'), mas de reparar o 'dano sofrido' pelo filho, quando, abandonado pelo genitor, não pôde contar também com uma figura substituta ${ }^{1139}$.

Consequentemente, MARIA CELINA BODIN DE MORAES reconhece que pode não haver qualquer 'prazer' ou 'satisfação' em ter um filho, no entanto, este é um encargo que deve ser assumido tanto pela mãe quanto pelo pai, a quem é atribuída a responsabilidade pela criação e sustento da criança ${ }^{1140}$.

No entanto, se preocupa em evitar dois excessos: o de favorecer a subjetivista e 'atécnica' visão que parte da doutrina e da jurisprudência adotam sobre o dano moral, como mero sofrimento a ser ressarcido; e o de estimular a mercantilização das relações familiares, em razão das demasias e dos problemas que, com frequência, caracterizam a indenização desta espécie de dano ${ }^{1141}$. Logo, considera imprescindível a explicitação dos critérios utilizados pelo magistrado para a determinação dos valores reparatórios, sendo a motivação do quantum debeatur elemento essencial da decisão ${ }^{1142}$.

\footnotetext{
${ }^{1138}$ Cf. MoRAEs, Maria Celina Bodin de. Op. cit. (nota 63), p. 198. Em suas palavras, "quanto aos pais, 'tertius non datur': ou se tem pais ou se tem ausência de pais. Quando este último caso ocorrer, configurado na ausência do exercício da paternidade (ou da maternidade), estará caracterizado o dano moral". MORAES, Maria Celina Bodin de. Op. cit. (nota 65), p. 58. Ao que podemos depreender, a autora entende que a presença de substituto afasta o dano moral em virtude de que houve o cuidado devido, embora realizado por outrem.

${ }_{1139}$ Cf. idem, pp. 58-59.

${ }^{1140}$ Em suas palavras: "portanto, é evidente que a lei não exige que um pai ame seus filhos, mas ela demanda que o pai se comporte como se o amasse, criando-os, educando-os e sustentando-os. Tal responsabilidade não é facultativa. É a lei a impor o dever, além do sustento, de criação e educação dos filhos (...)”. Idem, p. 57.

${ }^{1141}$ Cf. MoraEs, Maria Celina Bodin de. Op. cit. (nota 63), p. 201.

${ }^{1142}$ Cf. MoraEs, Maria Celina Bodin de. Op. cit. (nota 65), p. 61.
} 
Nesta avaliação, ela entende que uma das problemáticas mais complexas é a de saber se houve abandono paterno ou se foi o guardião que impediu a visita e a convivência do outro genitor com os filhos, quando não haveria responsabilidade deste último ${ }^{1143}$.

Por fim, MARIA ISABEl PEREIRA DA COSTA, propõe que se reflita se a indenização em tais casos não se transformará em fonte de abuso, pois adverte que afeto e dinheiro são grandezas diferentes e não podem simplesmente se compensar ${ }^{1144}$.

$\mathrm{Na}$ visão da jurista, a principal função da família é criar as condições de desenvolvimento da personalidade dos filhos para que se tronem 'dignos integrantes da sociedade ${ }^{1145}$.

A falta de convivência e amparo significa uma violação de direito fundamental do filho ${ }^{1146}$. A omissão de afeto a quem está em fase de formação da personalidade, causa danos e desequilíbrio emocional, prejudicando seu pleno desenvolvimento, e este sofrimento deve ser reparado ${ }^{1147}$. Ou seja, se o afeto passa a ser uma exigência da convivência familiar, vivam ou não os genitores e os filhos sob o mesmo teto, será oportuno o dever de indenizar ${ }^{1148}$.

Ela esclarece que não basta a ausência temporária dos pais, devendo ser avaliado o contexto do exercício do poder familiar. Só a ausência contínua e deliberada constitui indício de omissão de afeto. Contudo, ressalva que mesmo os pais que convivem com o filho sob o mesmo teto podem negar-lhe afeto ou impingir-lhe maus tratos ${ }^{1149}$. Portanto, em razão da complexidade desta aferição, considera indispensável a atuação de um psicólogo ou psiquiatra para avaliar o grau do dano sofrido pela criança ou pelo adolescente em razão da omissão do afeto ${ }^{1150}$.

Nesses termos, a autora pugna que devem estar presentes os pressupostos da responsabilidade pelo ilícito civil, sendo crucial avaliar o grau de culpabilidade pela

\footnotetext{
${ }^{1143}$ Cf. idem, p. 63.

${ }^{1144}$ Cf. CosTA, Maria Isabel Pereira da. Op. cit. (nota 1033), p. 59.

1145 Ela afirma que: "esses são valores que primeiramente têm que ser aprendidos dentro de casa. E ensinamentos dessa natureza não se fazem com truculência nem com omissão de carinho ou de afeto". Idem, p. 67.

${ }_{1146}$ Cf. idem, p. 69.

${ }^{1147}$ Cf. idem, pp. 73-74.

${ }^{1148}$ Cf. idem, p. 68.

${ }^{1149}$ Cf. idem, pp. 70-71.

${ }^{1150}$ Cf. idem, p. 73.
} 
omissão do afeto, através da análise do caso concreto, pois, não havendo culpa em sentido lato, não há que se falar em indenização ${ }^{1151}$.

Ao lado disto, a jurista entende que somente os filhos menores de idade, ou incapazes, têm legitimidade para pedir indenização aos pais pela omissão do afeto. Já aos filhos maiores não caberia tal indenização, pois não estão mais em fase de formação da personalidade $^{1152}$.

Ante o exposto, conclui que a indenização deve ser em valor suficiente para cobrir as despesas necessárias para corrigir ou amenizar o dano psicológico, mediante tratamento terapêutico adequado e somente quando isto não for possível é que deve ser fixada a indenização em dinheiro. Com esse parâmetro indenizatório, ela assegura que se reduz, significativamente, a possibilidade de mercancia do afeto nas relações familiares, evitando-se o abuso e a má-fé na propositura das ações indenizatórias ${ }^{153}$.

\subsubsection{Jurisprudência}

Ações requerendo indenização por dano moral aos filhos eram raras em nossos Tribunais. Via-se, com maior frequência, o pedido de alimentos. No entanto, o tema passou a ser enfrentado pelos magistrados nos últimos anos.

As situações mais comumente levadas ao Judiciário são aquelas em que, separado o casal, o cônjuge que se afasta do lar acaba rompendo os laços não apenas com o consorte, mas também com o filho. Muitas vezes esse rompimento concretiza-se pelo abandono material, em razão do não pagamento dos alimentos devidos, porém, em outras, o abandono é afetivo, caracterizado pelo absoluto desinteresse em manter contato com o filho.

A primeira decisão favorável de que se tem notícia é do Rio Grande do Sul, da Comarca de Capão de Canoa ${ }^{1154}$. O juiz MARIo RoMANo MAGGIONI concedeu indenização

\footnotetext{
${ }^{1151}$ Cf. idem, p. 72.

${ }^{1152}$ Cf. idem, p. 68.

${ }^{1153}$ Cf. idem, p. 74. É dizer: "à parte a indenização monetária, o dano moral pode ser compensado também de modo não pecuniário, caso isso atenda ao interesse da vítima”. SCHREIBER, Anderson. Op. cit. (nota 53), p. 17.

${ }^{1154}$ Comarca de Capão Canoa, $2^{\mathrm{a}}$ Vara, Processo n. 141/1030012032-0, j. em 15-09-03.
} 
à filha abandonada afetivamente pelo pai, com fundamento no art. $5^{\circ}$, inciso $\mathrm{X}$, da Constituição Federal e no art. 22 do $\mathrm{ECA}^{1155}$.

Em outro julgado, da $31^{\text {a }}$ Vara Cível de São Paulo ${ }^{1156}$, o juiz LuIS FERNANDO CIRILlo também condenou o pai a indenizar sua filha por danos morais, tendo sido constatado, por meio de perícia, que a jovem apresentava conflitos de identidade deflagrados pela rejeição paterna.

Assim, alguns magistrados de primeira instância passaram a condenar genitores que, independentemente de se desincumbirem do ônus alimentar, faltavam com o dever de assistência moral aos seus filhos, se fazendo ausentes no desenvolvimento deles.

CláUDIA MARIA DA SILVA observa que: “nas reiteradas decisões, o aspecto de extrema relevância é que a configuração do abandono voluntário se deu em resposta a uma intensa busca do filho pela presença paterna, pela convivência familiar em sentido amplo, pelo afeto. Após lançar mão das várias formas de cessar a rejeição paterna, coubelhes, como último recurso, as mencionadas ações "1157.

Todavia, no Tribunal de Justiça do Rio de Janeiro ${ }^{1158}$, entendeu-se que “ninguém está obrigado a conceder amor e afeto a outrem, mesmo que seja filho”. Sendo esta uma pretensão marcadamente mercantilista

Segundo MARIA CElina Bodin DE MoRAES, o referido acórdão coloca-se na junção de duas problemáticas contemporâneas: de um lado, o Direito de família, em plena transformação com a progressiva valorização jurídica dos direitos e interesses dos filhos; e de outro, a responsabilidade civil, com suas significativas mutações, dentre as quais a multiplicação das figuras de danos morais ressarcíveis ${ }^{1159}$.

\footnotetext{
${ }^{1155}$ Ao proferir a sentença afirmou que: "a educação abrange não somente a escolaridade, mas também a convivência familiar, o afeto, amor, carinho, ir ao parque, jogar futebol, brincar, passear, visitar, estabelecer paradigmas, criar condições para que a criança se autoafirme. Desnecessário discorrer acerca da importância da presença do pai no desenvolvimento da criança. A ausência, o descaso e a rejeição do pai em relação ao filho recém-nascido ou em desenvolvimento violam a sua honra e a sua imagem. Basta atentar para os jovens drogados e ver-se-á que grande parte deles derivam de pais que não lhe dedicam amor e carinho; assim também em relação aos criminosos. De outra parte se a inclusão no SPC dá margem à indenização por danos morais pois viola a honra e a imagem, quanto mais a rejeição do pai”.

${ }_{1156}$ Comarca de São Paulo, $31^{\mathrm{a}}$ Vara Cível Central, Processo n. 01.036747-0, j. em 05-06-04.

1157 SILVA, Cláudia Maria da. Op. cit. (nota 368), p. 144.

1158 TJRJ, Ap. Cível n. 2004.001.13664, Rel. Des. MÁrio dOS SANTOS PAUlo, j. 08-09-04.

${ }^{1159}$ Cf. MorAES, Maria Celina Bodin de. Op. cit. (nota 65), p. 45.
} 
Após analisar o caso, a jurista informa que a 'ausência de amor' é que teria sido a causa do afastamento do pai, pois o próprio acórdão menciona a falta de 'prazer' deste com relação à paternidade para concluir que a lei não poderia obrigar ninguém a amar outra pessoa, 'mesmo que seja filho'. Ela resume o raciocínio empregado da seguinte maneira: pelo fato de não amar sua filha, dela o pai afastou-se, e não pode ser obrigado a indenizá-la (aspecto jurídico), devido, unicamente, à falta de amor (aspecto moral). Todavia, a autora assevera que este entendimento não vinga, pois a lógica da responsabilidade civil mudou profundamente nos últimos anos, deixando de significar apenas a sanção por uma falta, por um ato ilícito cometido, ou a consequência de uma conduta antijurídica ${ }^{1160}$.

Nestes termos, assevera que o aludido acórdão adota uma argumentação radical, pois nega peremptoriamente a reparação de dano moral por abandono do pai, utilizando expressões como 'indústria do dano moral', 'lucro fácil' e 'pretensão oportunista', para ultimar que 'não há amparo legal, por mais criativo que possa ser o julgador, que assegure ao filho indenização por falta de afeto e carinho'1161. Ademais, também observa que outra grande preocupação refere-se ao precedente, isto é, ao incentivo a tais ações ${ }^{1162}$.

No entanto, a autora afirma que "se o pai não tem culpa de não amar sua filha, tem a culpa de tê-la negligenciado" ${ }^{\text {1163 }}$. Assim, entende que, no caso concreto, o pai deveria arcar com a responsabilidade por ter abandonado sua filha, por não ter cumprido o seu dever de assistência moral, por não ter convivido com ela, por não lhe ter educado, todos esses deveres impostos por lei ${ }^{1164}$.

O Superior Tribunal de Justiça foi instado a se manifestar sobre o assunto pela primeira vez em 2006, oportunidade em que negou o reconhecimento do dano moral pelo abandono afetivo. $\mathrm{O}$ acórdão se tornou paradigmático e foi inúmeras vezes debatido pela doutrina, ficando conhecido como o caso Alexandre.

A propósito, transcrevemos a ementa do julgado:

\footnotetext{
${ }^{1160}$ Cf. idem, p. 54.

${ }^{1161}$ Cf. idem, p. 44.

${ }^{1162}$ Cf. idem, p. 64.

${ }^{1163}$ Idem, p. 55.

${ }^{1164}$ Cf. ibidem.
} 
"Responsabilidade Civil. Abandono Moral. Reparação. Danos Morais. Impossibilidade. 1. A indenização por dano moral pressupõe a prática de ato ilícito, não rendendo ensejo à aplicabilidade da norma do art. 159 do Código Civil de 1916 o abandono afetivo, incapaz de reparação pecuniária. 2. Recurso especial conhecido e provido",1165.

No caso, o filho havia promovido ação de reparação de danos morais fundamentando o pedido na falta de amor paterno, em virtude do seu afastamento. Durante o processo foi realizada perícia, cujo laudo informou o desenvolvimento de sintomas psicopatológicos no filho, em razão da ausência do pai.

Todavia, em primeira instância o pedido foi julgado improcedente, com fundamento na inexistência de nexo causal entre o afastamento paterno e os danos na psique do filho. Tal decisão foi reformada em segundo grau pelo Tribunal de Alçada de Minas Gerais ${ }^{1166}$, que condenou o pai à indenização dos danos morais, sob os argumentos de que a afetividade deveria presidir as relações paterno-filiais e a falta de amor feriu o princípio da dignidade humana ${ }^{167}$. Derradeiramente, o Superior Tribunal de Justiça, por maioria, acabou afastando a condenação por abandono afetivo.

O Relator do Recurso, Ministro FERnANDo GonÇALVES, registrou que no caso de abandono ou do descumprimento injustificado do dever de sustento, guarda e educação dos filhos, a legislação prevê como punição a perda do poder familiar. Assim, asseverou que tal pena - a mais grave a ser imputada a um pai - já se encarregava da função punitiva e, principalmente, dissuasória, mostrando de forma eficiente aos indivíduos que o Direito e a sociedade não se compadecem com a conduta do abandono. Ademais, considerou que a condenação de um pai a indenizar um filho por não ter atendido às suas necessidades de afeto poderia acarretar o afastamento definitivo entre eles.

\footnotetext{
${ }^{1165}$ STJ, 4 ${ }^{\text {a }}$ Turma, REsp n. 757.411/MG, Rel. Min. FERNANDO GONÇALVES, j. em 29-11-05, publ. em 27-0306.

1166 "Indenização por danos morais. Relação paterno-filial. Princípio da dignidade da pessoa humana. Princípio da afetividade. A dor sofrida pelo filho, em virtude do abandono paterno, que o privou do direito à convivência, ao amparo afetivo, moral e psíquico, deve ser indenizável, com fulcro no princípio da dignidade da pessoa humana”. (TAMG, $7^{\text {a }}$ Câmara Cível, Ap. Cível n. 408.550-5, Rel. Juiz UNIAS SILVA, j. em 01-0404).

${ }^{1167}$ Nas palavras do Relator, juiz UNIAS SILVA, "ser pai não é só dar o dinheiro para as despesas, mas suprir as necessidades dos filhos", pois "a responsabilidade não se pauta tão somente no dever alimentar, mas se insere no dever de possibilitar o desenvolvimento humano dos filhos, baseado no princípio da dignidade da pessoa humana". Assim, afirmou ser "legítimo o direito de se buscar indenização por força de uma conduta imprópria, especialmente quando ao filho é negada a convivência, o amparo afetivo, moral e psíquico, bem como a referência paterna, magoando seus mais sublimes valores".
} 
O único voto divergente foi proferido pelo Ministro BARRos MONTEIRO, que afirmou expressamente que a destituição do poder familiar não interferiria na indenização, somente devendo admitir o afastamento desta quando o genitor comprovasse a ocorrência de um motivo de força maior para o abandono ${ }^{1168}$.

Comentando o aresto, Regina Beatriz Tavares da Silva informa que estavam presentes os pressupostos da responsabilidade civil para a reparação de danos, pois o filho rejeitado pelo pai teve sua auto-estima, consideração e integridade psíquica, enfim, os seus direitos da personalidade atingidos pela conduta omissiva paterna $^{1169}$.

No entanto, ela considera que o fato de o autor ter embasado o pedido na ausência de afeto do pai pode ter ocasionado o seu indeferimento: "parece-nos que uma exagerada fundamentação na falta de amor, matéria que tem sede psicanalítica e não jurídica, com que a ação reparatória em análise foi promovida, causou o receio dos julgadores de criar insegurança jurídica, levando o Superior Tribunal de Justiça ao nãoacolhimento ou deferimento do pedido de indenização ali realizado"1170. Assim, salienta que o resultado poderia ter sido outro, caso o autor tivesse se pautado na regra inscrita no art. 186 do Código Civil, alegando a violação aos deveres parentais previstos nos incisos I e II do art. 1.634 daquele diploma legal, e nos arts. $3^{\circ}, 4^{\circ}$ e $5^{\circ}$ do $\mathrm{ECA}^{1171}$.

Giselda MARIA FERnANDES Novaes HiRONAKA fez acirrada crítica a respeito da decisão, afirmando que é preciso refletir acerca de um novo viés que pode estar nascendo para a sociedade e para as famílias brasileiras, uma vez que a justiça autoriza que os pais abandonem afetivamente seus filhos, caso representarem empecilhos em suas próprias vidas, punido-os, ou favorecendo, apenas com a cessação do poder familiar ${ }^{1172}$.

No ano de 2012, contudo, a justiça brasileira observou a mudança deste entendimento. O Superior Tribunal de Justiça proferiu acórdão admitindo o dano moral por

\footnotetext{
${ }^{1168}$ Em suas palavras: "ao lado do dever de assistência material, tem o dever de dar assistência moral ao filho, de conviver com ele, de acompanhá-lo e de dar-lhe o necessário afeto" ou "ao lado da assistência econômica, o genitor tem o dever de assistir moral e afetivamente o filho".

${ }^{1169}$ Cf. Silva, Regina Beatriz Tavares da. Op. cit. (nota 1111), p. 466.

${ }^{1170}$ Idem, p. 470.

${ }^{1171}$ Cf. idem, pp. 466-467.

1172 Cf. Giselda Maria Fernandes Novaes HironaKa, apud TARtuce, Flávio et Simão, José Fernando. Op. cit. (nota 380), p. 30.
} 
abandono afetivo, o que poderá significar um novo marco jurisprudencial sobre a matéria $^{1173}$. Dada a importância da decisão, vamos analisa-la em pormenores.

Trata-se do recurso especial n. 1.159.242-SP, julgado pela terceira turma do Superior Tribunal de Justiça, Relatado pela Ministra NANCY ANDRIGHI.

Por maioria de votos, os ministros entenderem cabível a indenização no caso $^{1174}$, travando um debate interessante, onde diversos aspectos deste intrincado tema foram tratados, gerando precedente importante para a uniformização da interpretação de lei federal.

A Ministra NANCY ANDRIGUI, fazendo afirmação que viria a se incorporar à ementa do Acórdão, foi enfática ao pronunciar: “não existem restrições legais à aplicação das regras relativas à responsabilidade civil $e$ o consequente dever de indenizar/compensar, no Direito de Família". Alegou que as normas constitucionais e legais que cuidam da matéria o fazem de maneira ampla e irrestrita, albergando as relações familiares. Tendo em vista esta premissa geral, que afastaria a impossibilidade jurídica da questão, a Relatora passou a examinar os elementos necessários para a caracterização do dano moral no caso concreto.

Segundo a Ministra, a responsabilidade estaria calcada no exercício da liberdade humana, de modo que, sendo a filiação (natural ou civil) desdobramento da vontade, também se encontraria naquele campo. Mais do que isto, a posição de genitor traz consigo uma série de deveres, dentre os quais a assistência moral, em todos seus desdobramentos ${ }^{1175}$. Nesse compasso, a julgadora passou a discriminar os quatro aspectos da responsabilidade civil: a ilicitude, a culpa, o dano e o nexo causal.

Os dois primeiros elementos - ilicitude e culpa - foram analisados de acordo com o dever jurídico de cuidado. É dizer, havendo o dever de assistência moral ao filho, o genitor que não o observa incide em negligência (culpa), descumprindo norma jurídica (ilicitude).

\footnotetext{
${ }^{1173}$ STJ, REsp n. 1.159.242/SP, Rel. Min. NANCY ANDRIGHI, julgado em 24-04-12, pub. em 10-05-12.

1174 Votaram a favor, com a Relatora, os Ministros SIDNEI BENETI, PAUlo DE TARSO SANSEVERINO e RICARDO VILlAS BÔAS CUEVA. O Ministro MASSAMI UYEDA emitiu voto contrário.

1175 Nas palavras da Relatora: “(...) tanto pela concepção, quanto pela adoção, os pais assumem obrigações jurídicas em relação à sua prole, que vão além daquelas chamadas necessarium vitae."
} 
É sobremaneira relevante acentuar aqui a distinção realizada pela Ministra - e que fez deste caso verdadeiro leading case, destoando do entendimento anterior, exposto no famigerado caso Alexandre - entre a obrigação de amar e a de cuidar: "não se discute mais a mensuração do intangível - o amor - mas, sim, a verificação do cumprimento, descumprimento, ou parcial cumprimento, de uma obrigação legal: cuidar". Para não haver dúvidas, a Relatora voltou a dizer claramente: "aqui não se fala ou se discute o amar e, sim, a imposição biológica e legal de cuidar, que é dever jurídico, corolário da liberdade das pessoas de gerarem ou adotarem filhos". E mais à frente sintetizou o raciocínio: "Em suma, amar é faculdade, cuidar é dever".

Logo em seguida, demonstrando a extensão do voto, a Ministra já apontou para caracteres específicos que podem levar a outras conclusões, a depender das circunstâncias do caso concreto. Ou seja, já foram delineadas as exceções ao raciocínio jurídico geral que fundamentou o julgado. É assim que foram feitas duas ressalvas. Não haveria ilicitude e culpa nos casos de: a) exercício de um direito (como o divórcio, separações temporárias, alteração de domicílio, constituição de nova família etc); ou $b$ ) impossibilidade prática de realizar o ato devido.

No primeiro caso, a Relatora asseverou que o exercício de um direito não causa dano, afirmação à qual, com a devida vênia, faríamos uma pequena modificação: o exercício de um direito pode causar dano, mas não enseja responsabilidade. Uma coisa é o dano sofrido, e outra é a responsabilidade jurídica a ele relacionada.

Já na segunda hipótese, temos um dado extremamente relevante, que não apenas pode servir como excludente de responsabilidade, mas igualmente é utilizado como parâmetro para medir o grau de culpa, influenciando na quantificação da indenização.

A depender do grau de culpa do genitor, podemos ter desde uma ausência de responsabilização até a obrigação de indenizar, partindo de pequenas quantias até vultosas somas. Aqui, interessa saber a qualidade da conduta, a intensidade com que podemos imputar ao réu o dano causado, sopesando as possibilidades concretas de que dispunha para agir, bem como a ação de terceiros. É a aplicação do conhecido binômio necessidade e possibilidade. 
Feitas essas observações, a Ministra passou a argumentar que o dano moral em tais casos é in re ipsa, presumível a partir dos relatos da autora, sendo desnecessária comprovação particular de um dano sofrido, bastando o quadro geral de negligência do pai, ausência que causaria dano moral inegável. Consta do voto a ponderação de que é possível a comprovação por meio de laudo pericial, atestando o dano concretamente e a relação causal com a ação ou omissão do genitor, mas que tal documento não seria imprescindível, sendo suficiente o relato dos fatos em detalhes que permitam a conclusão pela existência de dano imputável.

Após a apresentação do voto da Relatora, o Ministro MASSAMI UYEDA expôs sua discordância, obtemperando que o precedente teria efeitos deletérios. Em qualquer família, aduziu, poderia um dos filhos argumentar que estaria sendo preterido em relação aos demais, o que levaria, no âmbito do Judiciário, à quantificação das relações familiares e à potencialização das mágoas íntimas, causando uma cizânia dentro da família. Além disto, o Ministro aventou a impropriedade da consequência jurídica, vez que o dever de assistência estaria calcado no pátrio poder, enquanto que a negligência de cumprimento poderia levar à perda deste poder e, eventualmente, à imputação de crime de abandono material. Isto é, se há uma negligência tal, de tamanha gravidade, o ordenamento prescreve a perda do poder familiar, e sem o poder familiar não haveria vínculo jurídico para se cobrar a indenização, restando apenas a responsabilidade penal.

Em seguida, o Ministro SIDNEI BENETI realizou voto-vista, reforçando as razões da Relatora e procurando afastar as objeções apresentadas pelo Ministro MASSAMI UYEDA. A conclusão trazida em seu voto assentou-se na premissa geral já enunciada, segundo a qual não haveria exclusão da indenização em virtude da natureza familiar do vínculo. Demais disto, ressaltou o Ministro, a perda do poder familiar não levaria a esta eximente, "porque de uma sanção, de natureza familiar, por ação ou omissão reprováveis do genitor, a perda do poder familiar, não será congruente extrair o despojamento de direito a outra sanção, de consequências patrimoniais, consistente na indenização por dano moral'. Ou seja, conforme este raciocínio, a existência de um tipo de sanção (familiar) não obsta outra (indenizatória).

O julgador ainda destacou que os efeitos do raciocínio oposto seriam inaceitáveis, pois redundaria em: 
"impor ao lesado a perda de um direito (indenização por dano moral) devido a haver sido vítima de ação ou omissão do mesmo ofensor (abandono), ao mesmo tempo em que isso ensejaria dupla vantagem ao ofensor, com o despojamento de responsabilidades familiares e indenizabilidade de dano moral (tornando-se verdadeiro incentivo ao abandono familiar)".

Depois de encampar a tese geral da Relatora, o Ministro SidNEI BENETI também enfatizou a necessidade de haver proporção entre a ação ou omissão do genitor e o valor da indenização. Neste ponto, o voto-vista torna-se deveras relevante, pois examinou em pormenores as diversas condutas comissivas e omissivas que delinearam o caso concreto. Assim, após elencar os diversos fatos de abandono, o Ministro apresentou o esboço de uma tipologia para averiguar a responsabilidade em tais situações, distinguindo entre itens de responsabilidade exclusiva do genitor, responsabilidade compartilhada, e dosando o grau de responsabilidade, se maior ou menor, em cada circunstância.

Por fim, o Ministro PAUlo DE TARSO SANSEVERINO apresentou seu voto-vista, acompanhando a Relatora, conquanto tenha feito advertências e obtemperações que relativizam a possibilidade da indenização por abandono afetivo. Na visão deste julgador, a natureza delicada dos relacionamentos familiares leva a uma distinção entre a responsabilidade nesta seara em relação à responsabilidade civil extracontratual em geral. As frustrações experimentadas no seio familiar de fato influenciam no desenvolvimento do indivíduo, todavia, são, em parte, próprias da vida e, por isso mesmo, inevitáveis.

Segundo o Ministro, cuidar a responsabilidade na família de maneira indiscriminada significaria exigir, no trato familiar, uma cautela incompatível com as relações que ali se dão, conduzindo à sua patrimonialização. Desta forma, entende que o reconhecimento do dano moral na família é situação excepcionalíssima, admissível somente em casos extremos. Ele ainda argumentou que o dever de cuidado dos genitores, no que diz respeito a este ponto, tem conteúdo subjetivo. Portanto, deve-se assentar em substrato firme o bastante, reservando a responsabilidade civil dos pais apenas em caso de abandono completo e notório, "quando o progenitor descumpre totalmente seu dever de cuidado, infringindo flagrantemente as mais comezinhas obrigações para com seu filho". Por fim, uma vez consignada a ponderação, este julgador endossou a necessidade de se considerar a conduta de terceiros - no caso, da mãe -, que podem dificultar o relacionamento entre pai e filhos. 
Ante o exposto, para que o ordenamento permita a responsabilização por dano moral, o Superior Tribunal de Justiça destaca qualidades especiais à ação do genitor, que devem ter afetado gravemente os direitos da prole, violando - na expressão que figura na ementa do julgado - o "núcleo mínimo de cuidados parentais".

Não há dúvida, então, de que este julgamento retratou a questão de maneira abrangente e inovadora, consubstanciando verdadeiro leading case da matéria. Temos neste decisum os diversos aspectos que marcam a responsabilidade civil nas relações familiares, onde assume importância crucial a ponderação da natureza deste campo da vida, que demanda um rigor ainda maior para a caracterização da responsabilidade.

\subsubsection{DEMAIS SITUAÇÕES}

Outras situações ensejadoras de danos morais no âmbito familiar, menos frequentes na prática, foram ventiladas pela doutrina, chegando, em alguns casos, até o Judiciário.

\subsubsection{Casamento anulado por erro quanto à pessoa do cônjuge e casamento putativo}

$\mathrm{O}$ erro é a falsa percepção acerca de um fato ou de alguma coisa. $\mathrm{O}$ art. 1.556 do Código Civil dispõe que o casamento pode ser anulado se houver vício da vontade por parte de um dos nubentes ao consentir em razão de erro essencial quanto à pessoa do outro, que torne insuportável a continuidade da vida matrimonial.

Assim, o erro quanto à identidade do cônjuge se dá em relação ao conjunto de atributos e qualidades com que a pessoa aparece na sociedade. Neste caso, descobre-se, após o casamento, algum predicado inesperado e inadmitido, alguma característica repulsiva, capaz de transformar a concepção que se tem daquela pessoa.

Na visão de VALÉRIA SILVA GALDINO CARDIN, o intuito do legislador foi tornar inválido o matrimônio contraído pelo cônjuge que jamais teria consentido se tivesse conhecimento de determinado fato ${ }^{1176}$.

${ }^{1176}$ Cf. CARDIN, Valéria Silva Galdino. Op. cit. (nota 245), p. 111. 
Ressalte-se que este instituto da anulação do casamento teve grande importância no passado, pois, não sendo possível o divórcio, era a única forma de se dissolver o matrimônio, permitindo novas núpcias ${ }^{1177}$.

Foram elencados, no art. 1.557 do Código Civil, os principais fatos que levam à anulação do casamento em razão de erro. No entanto, na opinião de SILVIO RoDRIGUES, há grande arbítrio por parte do juiz para verificar essa questão, cabendo a alegação de qualquer espécie de engano sério sobre a qualidade do outro cônjuge ${ }^{1178}$. Desta forma, o magistrado deverá, apenas, se certificar de que o consorte foi realmente ludibriado, e que a vida em comum tornou-se insuportável após o conhecimento dos fatos.

Em relação a esta hipótese de anulação do casamento, alguns juristas já aventaram a possibilidade de indenização dos danos morais ao cônjuge que incidiu em erro. São poucos os doutrinadores que tratam do tema, porém é pacífica entre eles a reparação neste caso.

INACIO DE CARVALHO NETO assevera que “as hipóteses são várias, na mesma proporção em que variam os casos de erro essencial. Em todas elas pode-se facilmente falar de danos morais, em face da ocultação da causa de anulação pelo cônjuge que induz o outro em erro" ${ }^{\prime 179}$.

Não há dispositivo que trate especificamente desta indenização, entretanto, os autores têm apontado que o seu embasamento legal reside na regra geral da reparação de danos, disposta nos arts. 186 e 927 do Código Civil. Na opinião de INACIO DE CARVALHO NETO, também o art. 1.564 daquele diploma fundamenta esta possibilidade ${ }^{1180}$.

Na realidade, em todas as situações de anulação do casamento em razão de erro temos, na origem do ato causador do dano, um comportamento contrário à boa-fé. Por isso, os juristas afirmam que a invalidade do matrimônio realizado sob a égide do erro essencial gera danos morais para o cônjuge enganado, ante as expectativas criadas e o próprio comportamento de má-fé do seu consorte.

${ }^{1177}$ Cf. CARVAlHo NeTO, Inacio de. Op. cit. (nota 86), p. 380.

${ }^{1178}$ Cf. RodRigues, Silvio. Op. cit. (nota 339), p. 100.

${ }^{1179}$ Carvalho NeTO, Inacio de. Op. cit. (nota 86), p. 417.

${ }^{1180}$ Cf. idem, p. 412. 
Este mesmo raciocínio pode ser utilizado em matéria de casamento putativo, observadas as peculiaridades deste instituto.

O termo putativo significa aquilo que aparenta ser verdadeiro, legal e certo, sem o ser. Ocorre o casamento putativo quando ambos os nubentes, ou um deles, o contraem de boa-fé, ou seja, na convicção de que se trata de ato válido.

$\mathrm{O}$ art. 1.561 do Código Civil preceitua que, mesmo nulo ou anulável, o casamento putativo produz todos os efeitos civis em relação ao consorte que estava de boafé. Assim, o principal requisito para a configuração da putatividade é a boa-fé, que resulta da ignorância das causas que se opunham à validade do casamento, por um ou por ambos os cônjuges ${ }^{1181}$. No entanto, a boa-fé não suprime eventual impedimento, pois o intuito do legislador foi barrar a união entre pessoas que afetasse a prole, os bons costumes, a moralidade pública e os interesses de terceiros, conforme rol de impedimentos disposto no art. 1.521 do Código Civil.

Segundo VALÉRIA Silva GALDINo CARDIN, “tais impedimentos foram criados por razões éticas, baseadas no interesse público, com o objetivo de proteger a família enquanto instituição e manter a moralidade e a estabilidade social "1182.

Em sendo o casamento putativo, produzirá efeitos ao cônjuge de boa-fé, porém será anulado. Na visão de INACIO DE CARVALHO NETO, nada impede que os cônjuges, ao invés de postularem sua anulação, peçam o divórcio direto ou a separação judicial, se assim preferirem $^{1183}$.

Também no casamento putativo os juristas entendem que o cônjuge que estiver de má-fé ao contrair o matrimônio poderá responder pelos prejuízos materiais e morais que ocasionar ao outro, aplicando-se neste caso, igualmente, a teoria geral da responsabilidade civil, já que o ordenamento não traz norma expressa acerca de tais danos.

\footnotetext{
${ }^{1181}$ Para INACIO DE CARVALHO NETO, justamente um dos temas mais complicados no tocante à putatividade é o conceito de boa-fé, que pode gerar diversos problemas. Cf. CARVALHO NeTO, Inacio de. Op. cit. (nota 86), p. 398.

${ }_{1182}$ CARDIN, Valéria Silva Galdino. Op. cit. (nota 245), p. 96.

${ }^{1183}$ Cf. CARVAlHo NeTO, Inacio de. Op. cit. (nota 86), p. 401. Ele destaca que "a distinção entre a anulação do casamento e o divórcio está em que, na primeira, trata-se de dissolver um casamento inválido, ao passo que, no último, o casamento é válido”. Idem, p. 380.
} 
Afirma VALÉRIa Silva GALDINO CARDin que o cônjuge que estava de boa-fé tem o direito de pleitear indenização por danos morais em relação ao que estava de má-fé, ou seja, àquele que detinha conhecimento do impedimento, mas, mesmo assim, contraiu núpcias, cometendo um ato antijurídico, causando prejuízos de ordem material e principalmente moral, uma vez que esse tipo de ruptura sempre deixa sequelas no foro íntimo do outro, muitas vezes irreversíveis ${ }^{1184}$.

De sua parte, INÁCIO DE CARVALHO NETO exemplifica a questão na hipótese da bigamia, que pode gerar obrigação de indenizar em duas ordens diferentes. Em uma, a vítima é o primeiro cônjuge do bígamo, desde que não tenha aquiescido com a bigamia, contudo, esta hipótese está relacionada à separação judicial culposa pela infração ao dever de fidelidade. A outra diz respeito ao segundo cônjuge do bígamo, que desconhecia o fato de já ser o seu consorte casado. Segundo o autor, afora tal situação configurar um casamento putativo - dando-lhe os efeitos de um casamento válido até a sentença de anulação (o que minimiza seus danos materiais) - é de se entender possível a hipótese de danos morais, a justificar a condenação do bígamo na obrigação de indenizá-lo ${ }^{1185}$.

Na verdade, a admissão da ação ressarcitória nos dois casos ora tratados não é tão acirradamente discutida na doutrina. VALÉRIA Silva GALDINO CARDIN observa que não chega a ser matéria divergente ${ }^{1186}$.

Ela ressalta, por fim, que também os filhos oriundos de um casamento putativo ou anulado em razão de erro essencial sobre a pessoa do cônjuge têm o direito de pleitear danos morais do cônjuge de má-fé, seu genitor, porquanto sentirão todas as agruras oriundas da ruptura do matrimônio, que certamente os afetarão psicologicamente, uma vez que a desconstituição da família sempre deixa sequelas irreversíveis ${ }^{1187}$.

\subsubsection{Investigação de paternidade}

A determinação de um critério que tornasse certa a filiação sempre preocupou os juristas. Por muito tempo, a presunção pater is est ofereceu uma resposta favorável ao

\footnotetext{
${ }^{1184}$ Cf. CARDIN, Valéria Silva Galdino. Op. cit. (nota 245), p. 109.

1185 Cf. CARVAlho Neto, Inacio de. Op. cit. (nota 86), p. 414. Ele ainda ressalta que o segundo cônjuge, se tinha conhecimento do casamento anterior, pode ser legitimado passivo na ação de indenização movida pelo primeiro cônjuge do bígamo. Cf. idem, p. 415.

${ }^{1186}$ Cf. CARDIN, Valéria Silva Galdino. Op. cit. (nota 245), p. 104.

${ }^{1187}$ Cf. idem, pp. 109 e 127-128.
} 
dilema. No entanto, com o desenvolvimento do exame de DNA, passou-se a atestar, com certeza científica, a paternidade ${ }^{1188}$.

Não obstante, o sistema de presunções estabelecido pelo Código Civil continua em vigor. Preconiza o art. 1.597 daquele diploma legal que sempre haverá presunção de que o filho oriundo do casamento foi gerado por ambos os cônjuges, admitindo-se prova em contrário. Porém, as regras de presunção quanto à paternidade não são absolutas, mas juris tantum, no intuito de proteger o estado de filiação. Isto porque, atualmente, busca-se pautar a filiação pela veracidade científica ${ }^{1189}$.

Quando a concepção se dá fora do âmbito matrimonial, não se aplicam as regras de presunção, sendo necessário o reconhecimento da paternidade pelo genitor. Este reconhecimento pode ser voluntário ou judicial. O reconhecimento voluntário ou espontâneo é considerado uma espécie de confissão, pois quando o genitor expressa a vontade de reconhecer um filho tal ato torna-se irrevogável, só podendo ser posteriormente anulado se comprovado o vício de consentimento. Por sua vez, o reconhecimento judicial ou oficioso possui como principal característica a ausência de qualquer atitude espontânea: “(...) é aquele decorrente de sentença havida em ação de investigação de paternidade e na qual se proclama que o autor é filho do investigado" ${ }^{, 1190}$. Esta sentença que declara a paternidade tem eficácia absoluta, produzindo efeitos ex tunc, porquanto retroage até a data do nascimento do filho, garantindo-lhe todos os direitos pessoais e patrimoniais.

Na visão de VALÉRIA Silva GALdino CARDin, a discussão acerca da ação de investigação de paternidade mostra-se atual e de extrema importância, pois a origem familiar não é uma simples curiosidade do ser humano, ao contrário, faz parte da sua personalidade, justificando o pedido judicial para a declaração do status familiae ${ }^{1191}$.

\footnotetext{
${ }^{1188}$ Por consequência, o instituto da coisa julgada foi relativizado nas ações de investigação de paternidade. Os casos decididos pela negativa em razão da ausência de provas passaram a ter, com a perícia do DNA, a possibilidade de uma certeza científica. Cf. OltRAMARI, Fernanda et OltRAMARI, Vitor Hugo. Op. cit. (nota 102), p. 63.

1189 'Depreende-se que o Código Civil de 2002, ao repetir a mesma fórmula 'pater is est' utilizada pelo Código Civil de 1916, manteve um critério considerado ultrapassado para os dias de hoje, em que nem sempre a verdade jurídica, representada pela presunção relativa dos incisos I e II do art. 1.599, coincide com a verdade biológica". FuJITA, Jorge Shiguemitsu. Filiação na contemporaneidade. In: CHINELLATO, Silmara Juny de Abreu, SIMÃo, José Fernando, FuJiTA, Jorge Shiguemitsu et ZuCCHI, Maria Cristina (Orgs.). Direito de família no novo milênio. São Paulo: Atlas, 2010, p. 472.

${ }^{1190}$ Rodrigues, Silvio. Op. cit. (nota 339), p. 319

${ }^{1191}$ Cf. CARDIn, Valéria Silva Galdino. Op. cit. (nota 245), p. 200.
} 
Por esta razão, ultimamente perquire-se se o repúdio paterno ao reconhecimento do filho, cerceando-lhe direito inerente à sua identidade pessoal, configura dano moral. Observa MARIA CELINA Bodin DE MORAES que vem se tornando cada vez mais comum o filho reconhecido através de ação investigatória pleitear a reparação dos danos ${ }^{1192}$. Para muitos juristas, esta indenização deve ser deferida.

Segundo AntÔNio JeOVÁ SANTOS, o não reconhecimento de filho pode ser causa de alterações psíquicas, já que a criança cresce em sua vida de relação com a 'pecha de quem não tem pai', é vista com o estigma de quem não foi reconhecido pelo pai. Assim, em sua opinião, o dano moral é evidente e perfeitamente indenizável ${ }^{193}$. Sua origem remonta ao:

“(...) menoscabo espiritual 'in re ipsa' da omissão do reconhecimento espontâneo pelo progenitor, e se traduz, entre outros aspectos, no fato de não poder contar com o apelido paterno e de não ser considerado filho do progenitor, além do que deriva das carências afetivas, e da frustração ao projeto de vida familiar que inclui ter uma família e gozar dela" ${ }^{, 1194}$.

Para RolF MADALENO, a falta de reconhecimento espontâneo engendra um ato ilícito, o que outorga ao descendente o direito de obter o ressarcimento pelo dano moral padecido $^{1195}$. Com este ilícito o pai 'se opõe à felicidade do rebento', atinge e lesiona um direito subjetivo do menor ao desconsiderar a criança no âmbito de suas relações, criandolhe inegáveis carências afetivas, traumas e agravos morais ${ }^{1196}$.

O mesmo autor considera que a intensidade do dano cresce na medida em que o pai posterga o registro do filho que sabidamente é seu, criando em juízo, e fora dele, todos os obstáculos possíveis ${ }^{1197}$. Assim, considera que a atitude claramente protelatória do reconhecimento parental, quando o investigado se vale de todos os subterfúgios

${ }^{1192}$ Cf. MORAES, Maria Celina Bodin de. Op. cit. (nota 65), p. 47.

1193 Cf. SANTOS, Antonio Jeová. Op. cit. (nota 13), pp. 196-197.

${ }^{1194}$ Idem, pp. 196-197.

1195 Cf. MADALENO, Rolf. Op. cit. (nota 49), p. 278.

${ }^{1196}$ Cf. idem, p. 280. "Transitar pela vida, em tempo mais curto ou mais longo, sem o apelido paterno, com sua identidade civil incompleta, causa em qualquer pessoa um marcante dano psíquico, máximo na etapa de seu crescimento e de sua formação moral, caracterizada pela extrema sensibilidade, a suscitar insegurança e sobressaltos na personalidade psíquica do descendente (...)”. Idem, pp. 281-282.

${ }^{1197}$ Cf. MADAlEno, Rolf. Direito de família: aspectos polêmicos. Porto Alegre: Livraria do Advogado, 1998, p. 150. Ele exemplifica com o caso do genitor que, depois de apresentado o laudo judicial e científico de incontestável paternidade, prossegue 'negando guarida ao espírito humano de seu filho investigante'. Cf. MADALENO, Rolf. Op. cit. (nota 49), p. 278. 
processuais para dissimular a verdade biológica, esquivando-se do exame pericial genético, origina dano moral passível de reparação ${ }^{1198}$. Ou seja, segundo o jurista, é a relutância infundada por parte do genitor que constitui o agravo ${ }^{1199}$.

Também VALÉRIA SiLva GALDINO CARDIN assevera que a postergação injustificada do reconhecimento da paternidade ocasiona danos à honra do filho, à sua personalidade, ao seu status perante a sociedade ${ }^{1200}$, admitindo a responsabilidade civil por danos morais $^{1201}$.

FERnANDA Oltramari e VitOR Hugo Oltramari comungam desta mesma opinião, aduzindo que a negativa da paternidade de filho havido fora do casamento ofende seu direito ao nome de família e seus consentâneos. Segundo avaliam, surgem danos materiais e morais ao filho, que sofre, ao lado das privações naturalmente dedutíveis, a pecha de 'filho de mãe solteira'. Eles consideram que o comportamento extraprocessual tem relevância, pois, se o investigado sabia ou tinha condições de supor que era o pai e não tomou a iniciativa do reconhecimento, pode ser responsabilizado ${ }^{1202}$.

InACIO DE CARvalho Neto, igualmente, afirma que a recusa do pai ao reconhecimento do filho pode ensejar a ocorrência de danos morais e até mesmo materiais ressarcíveis ${ }^{1203}$. Para o autor, na maioria dos casos, esta recusa tem por fim apenas ganhar tempo, sendo, por isso, indiscutivelmente devida a indenização ${ }^{1204}$.

No entanto, em sua visão, "obviamente, não se falará em indenização quando o pai tenha fundados motivos para suspeitar não ser seu ofilho, como poderia ocorrer em

\footnotetext{
${ }^{1198}$ Cf. ibidem.

${ }^{1199}$ Cf. idem, pp. 280-281. Vale ressaltar que o autor também entende haver responsabilidade na omissão da mãe sobre a identidade paterna quando do registro civil, sem prejuízo do dano moral decorrente da própria conduta omissiva paterna. Cf. MADALENO, Rolf. Op. cit. (nota 422), p. 373.

1200 “A não utilização do patronímico paterno, que denotaria sua origem, concorre para o abandono material, moral e intelectual e certamente acarreta danos por vezes irreversíveis, de ordem sentimental e psíquica, a alguém que poderia sofrer menos percalços da vida se desfrutasse da presença paterna ou materna tanto no âmbito sentimental quanto material”. CARDIN, Valéria Silva Galdino. Op. cit. (nota 245), p. 205.

${ }^{1201}$ Cf. idem, p. 201.

1202 Cf. Oltramari, Fernanda et Oltramari, Vitor Hugo. Op. cit. (nota 102), pp. 66-68.

${ }^{1203}$ Cf. CARVAlHO NeTO, Inacio de. Op. cit. (nota 86), p. 482.

${ }^{1204}$ Cf. idem, p. 484.
} 
caso de ser a mãe mulher de vida fácil. Nestes casos, teria o pai o direito de aguardar a produção da prova adequada, que lhe confira certeza para o reconhecimento" ${ }^{205}$.

Para BERnARdo CASTElo BrAnCO, deve-se necessariamente compreender a declaração do estado de filiação como um direito inerente à personalidade ${ }^{1206}$. Sendo assim, a negativa injustificada ou a resistência ao reconhecimento constitui conduta alcançada pela norma geral de responsabilidade civil ${ }^{1207}$. Conforme aponta, a reparação dos danos também encontra fundamento no art. 227, caput e $\$ 6^{\circ}$ da Constituição Federal e no art. 27 do $\mathrm{ECA}^{1208}$.

O jurista entende que esse dano moral é presumido, fundado em ofensa aos direitos da personalidade, sendo, todavia, imprescindível a presença da culpa como fator de atribuição do dever de indenizar ${ }^{1209}$. Por outro lado, considera possível afastar essa presunção de culpa que recai sobre o pai, desde que comprove que o seu comportamento esteve fundado em dúvida séria sobre a existência do vínculo imputado ${ }^{1210}$.

Ante o exposto, muitos autores admitem a indenização dos danos morais na investigação de paternidade, mesclando as hipóteses de reparação pela recusa ao reconhecimento voluntário ou espontâneo, pela resistência injustificada à realização da perícia - que atesta cientificamente a aludida paternidade - ou ainda pelo protelamento do registro. Em todos esses casos, propugnam pela aplicação da teoria geral da responsabilidade civil, pois, igualmente às demais hipóteses estudadas, não há dispositivo legal expresso que trate do assunto.

Por sua vez, Belmiro Pedro Welter contesta os argumentos favoráveis a essa indenização, alegando que: não existe lei obrigando ao reconhecimento voluntário; o

\footnotetext{
1205 Ibidem.

${ }^{1206}$ Cf. BRANCO, Bernardo Castelo. Op. cit. (nota 94), p. 120. "é inegável que o reconhecimento da filiação tem implicações diretas com a identidade social de cada um de nós, pois é a partir dele que firmamos os nossos vínculos de parentesco, nos consideramos inseridos numa família e dela adotamos o nome, nos tornamos, enfim, uma pessoa reconhecida socialmente, identificada por esses traços particulares". Idem, p. 121.

${ }^{1207}$ Cf. idem, p. 122.

1208 "Da interpretação conjunta dos dispositivos, resulta claro que a criança e o adolescente, privados do reconhecimento da paternidade, encontram-se em situação de evidente violação do direito à convivência familiar e social plena, como também afrontados no respeito à sua dignidade, pois são inevitáveis as repercussões negativas que o não estabelecimento integral do estado de filiação acarreta no filho, o que se agrava principalmente na infância, fase inicial de sua sociabilização e da formação da sua personalidade”. Idem, p. 121.

${ }^{1209}$ Cf. idem, p. 128.

${ }^{1210}$ Cf. idem, pp. 133-134.
} 
investigado tem direito constitucional à ampla defesa, inclusive facultada a repetição do exame de DNA; e há outros meios de penalizar aquele que se opõe injustificadamente ao reconhecimento, tais como a aplicação de pena de multa ou fixação de alimentos provisionais $^{1211}$.

Mas, na opinião de INACIO DE CARVALHo Neto, estas objeções não são suficientes para ilidir a possibilidade de indenização, já que a ausência de lei obrigando ao reconhecimento voluntário não impede que vislumbremos um verdadeiro dever quando não exista justa razão para contestar a paternidade ${ }^{1212}$. Ademais, afirma que a obrigação de reparar o dano e os alimentos provisionais não configuram penalidade e também não se confundem $^{1213}$.

Já CAetano LagRasta manifesta preocupação no sentido de que “(...) definida e aceita a paternidade, seria demasia pretender-se que respondesse o investigado também por indenização, eis que o excesso levaria à impossibilidade de aproximação e ao completo estremecimento entre genitor e filho ${ }^{, 1214}$. Contudo, o próprio jurista admite a indenização quando restar evidente que, após a produção de provas seguras, o genitor se recusou a reconhecer o filho ${ }^{1215}$.

Em que pesem essas manifestações da doutrina, a jurisprudência segue no sentido de afastar a fixação da indenização por danos morais quando do reconhecimento judicial da paternidade. Rolf Madaleno, na companhia de Fernanda Oltramari e VITOR Hugo OLTRAMARI, adverte que não tem sido a prática judicial brasileira a reparação moral da conduta omissiva paterna ao reconhecimento da filiação ${ }^{1216}$.

A propósito:

"A tese das razões apelatórias, defendidas com brilho invulgar, exige indenização do pai ao filho, a título de dano moral, pelas privações sofridas na infância e até o reconhecimento forçado da paternidade, em virtude da negligência do pai do abandono a que este o submeteu, mercê de sua recusa

${ }^{1211}$ Cf. CARVAlho Neto, Inacio de. Op. cit. (nota 86), p. 483.

${ }^{1212}$ Cf. idem, p. 483.

${ }^{1213}$ Cf. idem, p. 484.

${ }^{1214}$ Lagrasta, Caetano. Op. cit. (nota 735), p. 29.

${ }^{1215}$ Cf. idem, p. 30.

${ }^{1216}$ Cf. MAdAleno, Rolf. Op. cit. (nota 49), pp. 280-181. Cf. Oltramari, Fernanda et Oltramari, Vitor Hugo. Op. cit. (nota 102), p. 65. 
obstinada em reconhecer a condição de pai. (...) Ao contrário, portanto, do que se alegou na inicial, a filiação só se constituiu, ou seja, o apelante só passou a ser filho do apelado, a partir do trânsito em julgado da respeitável sentença. Antes disso, não existia filiação reconhecida e conseguintemente, não poderia o paleado descumprir quaisquer deveres inerentes à condição de pai $^{, 1217}$.

Para YUSSEF SAID CAHALI, a fundamentação dessa decisão parece absolutamente equivocada. Isto porque a ação de investigação de paternidade é eminentemente declaratória. Com a sentença de procedência, o juiz limita-se à constatação da existência da relação jurídica concernente à filiação paterna; ou seja, o estado de filiação preexiste à sentença, e não se constitui através desta. Assim, os deveres inerentes à paternidade responsável devem ser cumpridos ainda que o filho não tenha sido reconhecido voluntariamente, não podendo o genitor tirar proveito da sua própria malícia ${ }^{1218}$.

Não obstante, ROLF MADALENO ressalta que a condenação em reparação deste dano não se confunde com a litigância de má-fé, porquanto embora esta figura seja uma punição processual, para reparar a postergação do processo, ela não ampara, por sua gênese, a lesão moral que exsurge desta relutância ${ }^{1219}$.

Em sua visão, a compensação financeira da dor moral tem função punitiva, moralizadora ou, sob a ótica do transgressor, tem a finalidade de desestimular outras agressões ao direito de carregar, desde o nascimento, a integral personalidade civil e social. Assim, conclui que o quantum devido deverá estar em conformidade com as circunstâncias do caso e a situação econômica do responsável pelo dano ${ }^{1220}$.

Quanto à questão processual, o jurista considera possível a cumulação da ação de investigação de paternidade com o pedido de ressarcimento do dano moral, decorrente do ato ilícito de recusa ao reconhecimento ${ }^{1221}$. Já INACIO DE CARVALHO NETO tem opinião contrária, em razão das diferentes competências ${ }^{1222}$. Também BELMIRO PEDRO WELTER posiciona-se de forma contrária à cumulação, ao lembrar que normalmente a conduta do

1217 TJRS, Ap. Cível n. 596.125.757, Rel. Des. ARAKEN DE ASSIS, 1997.

${ }^{1218}$ Cf. CAHALI, Yussef Said. Op. cit. (nota 39), pp. 580-581.

${ }^{1219}$ Cf. MADALENO, Rolf. Op. cit. (nota 49), p. 281.

${ }^{1220}$ Cf. idem, pp. 282-283.

${ }^{1221}$ Cf. MADALENO, Rolf. Op. cit. (nota 1197), p. 149.

1222 Cf. CARVAlHo NeTO, Inacio de. Op. cit. (nota 86), p. 487. 
pai ensejadora do dano ocorrerá no curso da ação de investigação, ou seja, depois dela proposta, impossibilitando, assim, a sua condenação ${ }^{1223}$.

INACIO DE CARVALHO NETO, por sua vez, ventila outra questão: “(...) se a recusa ao reconhecimento se dá logo após o nascimento, tendo a ação investigatória sido julgada rapidamente, antes que o filho chegue à fase de consciência, e não se tendo constatado alterações psíquicas no infante, seria possível ainda assim se falar que sofreu ele dano moral? "'1224. O próprio autor responde, considerando que o dano moral objetivo independe da consciência da parte de quem o sofre, sendo perfeitamente possível admitir o infante como vítima ${ }^{1225}$.

Também MARIA CELINA BODIN DE MORAES concorda que não há que se fazer diferenciação quanto à idade da vítima para fins de reparação. Assim, independentemente da idade do filho quando do reconhecimento, terá direito à indenização ${ }^{1226}$.

Ao lado disto, VALÉRIA SILVA GALDINO CARDIN lembra que a proteção contra o dano moral, mormente nas relações de família, tem como pressuposto a preservação do direito à honra, inclusive a do menor impúbere ${ }^{1227}$.

No mesmo sentido, Rolf MADALENo afiança que o grau de entendimento e percepção da ofensa pelo incapaz não é argumento que lhe retire o direito à honra, garantido pela Constituição Federal e pelo ECA. Ele acrescenta que, certamente, não estariam tutelados valores tão preciosos acaso a Justiça pudesse ignorar a desonra porque o menor não pôde captar e compreender o agravo e a extensão do dano sofrido. Assim, conclui que a ofensa moral é punida para castigar o ânimo e a potencialidade de agressão do ofensor ${ }^{1228}$.

\footnotetext{
${ }^{1223}$ Cf. Welter, Belmiro Pedro. Coisa julgada na investigação de paternidade. Porto Alegre: Síntese, 2000, pp. 135-136, apud CARVALHO NETO, Inacio de. Op. cit. (nota 86), p. 487.

${ }^{1224}$ CARVALHO NeTO, Inacio de. Op. cit. (nota 86), p. 486.

${ }^{1225}$ Cf. ibidem. Em suas palavras: "mesmo o infante em fase de inconsciência pode ser vítima de dano moral por recusa injusta ao reconhecimento voluntário, em face da distinção entre dano moral objetivo e dano moral subjetivo". Idem, p. 500.

${ }^{1226}$ Cf. MORAES, Maria Celina Bodin de. Op. cit. (nota 65), p. 64.

${ }^{1227}$ Cf. CARDIN, Valéria Silva Galdino. Op. cit. (nota 245), p. 201.

${ }^{1228}$ Cf. MADALENO, Rolf. Op. cit. (nota 49), p. 279.
} 
Destarte, segundo esses autores, a aferição do dano não tem como suporte o grau de compreensão da vítima, pois, se assim fosse verificado, grassaria grande injustiça e ficariam desabrigadas exatamente aquelas pessoas que mais precisam de amparo.

Outra situação de dano moral vislumbrada pela doutrina é a propositura de ação de investigação de paternidade contra pessoa sabidamente estranha ao vínculo: o caso da mãe que processa quem sabe não ser o pai.

Esta é a opinião de InACIO DE CARVAlHo Neto, para quem a hipótese configura abuso do direito de ação, possibilitando ao imputado acionar a mãe para ser indenizado pelo dano que eventualmente sofreu ${ }^{1229}$.

Uma última hipótese em que já se aventou a possibilidade de indenização diz respeito à ocultação, pela mãe, do nascimento ou da paternidade de uma criança.

Segundo InACIO DE CARVAlHo NeTO, “a ocultação ao pai, pela genitora da criança, do nascimento, ou mesmo a ocultação do fato de ser ele o pai da criança, gera

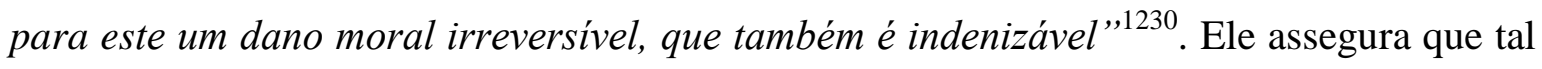
situação não gera prejuízos somente ao pai, pois a criança sofre a privação da companhia paterna, sendo também parte legítima para requerer indenização da mãe que lhe ocultou a paternidade $^{1231}$.

Não é outro o entendimento de Bernardo CASTElo Branco, para quem a omissão da mãe já produz efeitos deletérios durante toda a infância e adolescência do filho, os quais não se apagam com a possibilidade de reconhecimento posterior, em ação movida pelo próprio filho, quando de sua maioridade ${ }^{1232}$.

Vale mencionar que no Direito argentino já existe precedente de indenização por dano moral nas ações de investigação de paternidade. O pai, a quem é atribuída a

\footnotetext{
${ }^{1229}$ Cf. CARVAlHo NeTO, Inacio de. Op. cit. (nota 86), pp. 480-481. Na visão de YusSEF SAID CAHALI, "não se pode negar que toda ação de investigação de paternidade improcedente representa para o demandado uma situação de constrangimento; segundo os preconceitos ainda vigorantes, a simples imputação da existência de filho nascido fora das relações matrimoniais coloca em crise a reputação, a honrabilidade, a correção e o respeito do indigitado pai (...)”. CAHALI, Yussef Said. Op. cit. (nota 39), p. 579.

${ }^{1230}$ CARVAlHo Neto, Inacio de. Op. cit. (nota 86), p. 488.

${ }^{1231}$ Cf. ibidem.

${ }^{1232}$ Cf. BRANCO, Bernardo Castelo. Op. cit. (nota 94), p. 131.
} 
paternidade, pode ser condenado também a indenização por dano moral, uma vez que privou o seu filho dos recursos que teria permitido a ele um melhor desenvolvimento ${ }^{1233}$.

Segundo Rolf MADALENO, interessantes arestos recolhidos dos tribunais argentinos têm acolhido o ressarcimento do dano moral nesses casos, pois negar a paternidade implica a violação dos direitos à personalidade de um sujeito, ao abandoná-lo nos momentos mais difíceis da sua vida, elidindo ao filho a inscrição de seu apelido paterno no registro civil ${ }^{1234}$.

Com esses breves apontamentos, é possível verificar a preocupação crescente entre os juristas em cominar responsabilização aos genitores que se omitem no reconhecimento da filiação, em uma tentativa de afastar os perniciosos efeitos que produzem na personalidade da criança.

\subsubsection{Alienação parental}

Outra hipótese relacionada à filiação diz respeito à alienação parental, cuja particularidade reside na possibilidade de reparação do dano moral não apenas ao filho, mas igualmente ao genitor alijado da convivência.

Segundo VAlÉRIa Silva Galdino CARdin, somente nos últimos anos os juristas passaram a identificá-la, despertando para a sua gravidade e para as consequências nefastas que acarreta: "tais condutas sempre existiram, mas somente agora, com a valorização do afeto nas relações familiares e com a conscientização da paternidade responsável, é que passaram a ter relevância para a sociedade ${ }^{, 1235}$.

A alienação parental consiste na programação mental do filho, por um dos genitores, para que hostilize o outro, que não detém a guarda. O menor passa a ter um vínculo de dependência e estabelece um pacto de lealdade inconsciente com o alienador, desvinculando-se afetivamente do genitor alienado ${ }^{1236}$.

Na visão de JORGE TRINDADE, o genitor alienador transforma a consciência de seu filho, mediante diferentes formas e estratégias de atuação, com o objetivo de impedir,

\footnotetext{
${ }^{1233}$ Cf. CARVAlHo Neto, Inacio de. Op. cit. (nota 86), p. 481.

${ }^{1234}$ Cf. MADALENO, Rolf. Op. cit. (nota 49), p. 281.

1235 CARDIN, Valéria Silva Galdino. Op. cit. (nota 245), p. 227.

${ }^{1236}$ Cf. idem, p. 224.
} 
ou mesmo destruir, seu vínculo com o outro genitor, sem que existam motivos reais que justifiquem essa condição ${ }^{1237}$.

De acordo com a construção de JONES FIGUEIRÊDO ALVES:

“Cometerá abuso de direito, portanto, o detentor da guarda que, à luz do caso concreto, invalide tais premissas, recusando ou inibindo uma maior participação do pai não guardião, ou, em evidência de maior abusividade, dificulte o exercício da visitação, sob o pálio egoístico de afastar afetivamente o filho do seu outro progenitor" ${ }^{1238}$.

O grande desafio, segundo os juristas, é detectar quando a alienação existe ou quando a rejeição do filho é um resultado das próprias atitudes do genitor.

Alguns autores chegam a enumerar uma série de ações que podem denotar a ocorrência de alienação parental, tais como: denegrir a imagem do outro; atrapalhar a realização das visitas ou controlar excessivamente os horários de visitação; não comunicar fatos importantes relacionados à vida do filho; tomar decisões com relação ao filho sem prévia consulta ao outro; apresentar novo companheiro à criança como sendo novo pai ou nova mãe; e emitir falsas imputações ao outro genitor, como abuso sexual, uso de drogas e álcool ${ }^{1239}$.

De tal modo, informam que essas condutas infringem os direitos da personalidade do menor e do genitor alienado, como o direito à convivência familiar, à afetividade, à integridade psíquica e à própria dignidade ${ }^{1240}$.

Nestes termos, Raquel Pacheco Ribeiro DE Souza adverte que os ressentimentos provenientes da ruptura não caracterizam por si só a alienação parental. $\mathrm{Ou}$ seja, o divórcio não ocasiona estes problemas psicológicos no filho, a morbidez é gerada pelo conflito, pelo estado de tensão, pela discórdia familiar, pela instabilidade das relações

${ }^{1237}$ Cf. TRINDADE, Jorge. Síndrome da alienação parental (SAP). In: DIAS, Maria Berenice (coord.). Incesto e alienação parental: realidades que a Justiça insiste em não ver. São Paulo: Revista dos Tribunais, 2007, p. 101, apud CARDIN, Valéria Silva Galdino. Op. cit. (nota 245), p. 227.

${ }^{1238}$ Alves, Jones Figueirêdo. Abuso de direito no direito de família. In: PEREIRA, Rodrigo da Cunha (Coord.). Família e dignidade humana - anais do V Congresso Brasileiro de Direito de Família. Belo Horizonte: IBDFAM, 2006, p. 492.

${ }_{1239}$ Cf. CARDIN, Valéria Silva Galdino. Op. cit. (nota 245), p. 229.

${ }^{1240}$ Segundo VAlÉRIa Silva Galdino CARDIN, a alienação também fere o princípio da solidariedade, que corresponde ao compromisso pelo qual as pessoas se obrigam umas pelas outras, em comunhão de atitudes e sentimentos. Cf. CARDIN, Valéria Silva Galdino. Op. cit. (nota 245), p. 233. 
e pela insegurança que isto tudo acarreta, o que acaba fazendo com que o filho perca os seus referenciais ${ }^{1241}$.

Assim, muitos juristas verificam que a alienação ocorre quando um dos cônjuges não quer a ruptura do relacionamento e alimenta mágoas do outro ${ }^{1242}$.

Aponta a doutrina que própria Constituição Federal estabeleceu, no art. 229, que a paternidade deve ser exercida de forma responsável. No entanto, isto nem sempre ocorre, especialmente após o processo de separação dos genitores. Ademais, o mesmo diploma, em seu art. 227, consagrou o princípio da convivência familiar, condição de desenvolvimento e formação da personalidade da criança, o que, ressaltam os juristas, é dificultado pela alienação.

Essa alienação parental também pode desencadear uma síndrome, conhecida como Síndrome de Alienação Parental - SAP, que se caracteriza por um conjunto de sintomas padecidos pelo filho. São sequelas emocionais e comportamentais sofridas pela criança ou pelo adolescente vítima do alijamento, que fica exposto a uma série de eventos psicológicos. De acordo com Cristiano Chaves Farias e Nelson Rosenvald, a síndrome de alienação parental também é chamada de implantação de falsas memórias ${ }^{1243}$.

Portanto, a síndrome não se confunde com a alienação parental, mas é decorrente desta.

Independentemente de caracterizada a síndrome ou a alienação parental, os doutrinadores entendem que o detentor da guarda, ao interferir na relação do filho com o outro genitor, comete uma forma de abuso. Consignam que o genitor que detém a guarda não desempenha papel mais importante porque está com a criança, ao contrário do que possa parecer, pois a participação de ambos os pais é imprescindível para o seu desenvolvimento, mesmo após a ruptura do relacionamento. Por isso, consideram ilícita e abusiva a atitude daquele que impede esta convivência.

${ }^{1241}$ Cf. SouZA, Raquel Pacheco Ribeiro de. Os filhos da família em litígio. Site IBDFAM, apud CARDIN, Valéria Silva Galdino. Op. cit. (nota 245), p. 229.

${ }^{1242}$ Nas palavras de VALÉRIA SILVA GALDINO CARDIN: "normalmente, a alienação parental ocorre quando um dos pais não consegue elaborar adequadamente o luto da ruptura do vínculo matrimonial, desencadeando um processo de desmoralização e de descréditos do outro que não detém a guarda e a criança se torna instrumento de vingança". CARDIN, Valéria Silva Galdino. Op. cit. (nota 245), p. 226.

${ }^{1243}$ FARIAS, Cristiano Chaves de et ROSENVALD, Nelson. Op. cit. (nota 382), p. 76. 
Desta forma, preconizam pela responsabilização do alienador, que deverá indenizar os danos ocasionados tanto ao filho quanto ao genitor alienado. Esta tem sido a opinião da doutrina majoritária: detectada a alienação parental, é indispensável a responsabilização do genitor alienador, e não há necessidade de norma específica, aplicando-se, neste caso, a teoria geral da responsabilidade civil.

Nestes termos, Bernardo CASTElo Branco percebe a ilicitude da conduta daquele que, sem motivo justificável, obstrui a visita, o contato indispensável entre pai ou mãe e o filho que não se acha sob sua guarda ${ }^{1244}$. Ele assevera estarem presentes todos os elementos necessários à caracterização da responsabilidade civil por dano moral, não restando dúvida de que incorre o responsável na prática de comportamento capaz de estabelecer o dever de reparar o dano experimentado pelo menor, derradeiro beneficiário daquele direito ${ }^{1245}$.

Em seu ponto de vista, a alienação não emerge tão-somente da restrição do contato com o outro titular do poder familiar, pois o direito de visita não é prerrogativa restrita aos pais, sendo também extensiva aos avós e outros parentes que com o menor mantenha laços afetivos ${ }^{1246}$.

Assim, conclui VALÉRIA SILVA GALDINo CARDIN que se não houvesse esta responsabilização do genitor alienador, estar-se-ia estimulando a reiteração desta conduta, acelerando o processo de desintegração familiar, pois nada 'destrói' mais uma família do que os danos causados pelos seus próprios membros ${ }^{1247}$.

A par disto, foi editada a Lei n. 12.318/10, que disciplinou os efeitos jurídicos da alienação parental, estabelecendo em seu art. $3^{\circ}$ que esta prática fere direito fundamental da criança ou do adolescente à convivência familiar saudável, prejudica a realização do afeto e constitui abuso moral por parte do alienador, o que justifica a sua responsabilização civil ou criminal, além de outras medidas, como a modificação da guarda ou a suspensão do poder familiar.

\footnotetext{
${ }^{1244}$ Cf. BRANCO, Bernardo Castelo. Op. cit. (nota 94), p. 180.

${ }^{1245} \mathrm{O}$ autor ainda adverte que a responsabilidade emerge com mais força quando a regulamentação das visitas se deu por decisão judicial ou acordo em juízo, não restando dúvida quanto ao surgimento da obrigação de reparar o dano moral. Cf. idem, p. 184.

1246 Cf. idem, p. 187.

${ }^{1247}$ Cf. CARDIN, Valéria Silva Galdino. Op. cit. (nota 245), pp. 236-237.
} 


\subsection{PROPOSTA DE AFerição DO DANO MORAL NAS RelaÇÕES FAMILIARES}

Após percorrer o exame do dano moral, as transformações no Direito de família e as hipóteses mais recorrentes daquela espécie de dano neste âmbito, notamos uma tendência para se aceitar a aplicação da responsabilidade civil, mas sem a formação de um corpo teórico sólido.

Se, por um lado, as hipóteses de danos morais nas relações familiares se espalham nas mais comezinhas conjecturas, com discussões alongadas, a solução que propomos tem caráter geral e é simples, servindo a todas elas. Assim, é possível dar uma unidade ao problema, que traz questões aparentemente dispersas.

\subsubsection{A DISTINÇão ESSENCIAL}

O ponto crucial deste trabalho é deixar clara a distinção entre aplicação da responsabilidade em um tipo de relação (familiar) e não em um tipo de Direito (de família).

O dano moral é um instituto próprio da responsabilidade civil, nada impedindo sua ocorrência no âmbito familiar. No entanto, é incoerente falar em dano moral no Direito de família, pois não foram previstas normas específicas a este respeito neste ramo jurídico ${ }^{1248}$. Ou seja, nosso ordenamento civil-familiar não prevê consequências para os agravos à personalidade do ofendido e, por isso, a discussão deve cingir-se ao âmbito da responsabilidade civil.

A responsabilidade civil é uma só. Não há responsabilidade civil no Direito de família e responsabilidade civil em outros Direitos. A responsabilidade civil integra o Direito das obrigações, mas é aplicável às mais diversas esferas da realidade, as quais, por seu turno, podem integrar outros ramos do Direito.

Portanto, sendo um instituto próprio da responsabilidade civil, os danos morais apenas podem surgir em uma relação de origem familiar, e não no Direito de família.

Assim, os conflitos aptos a produzirem o agravo moral, que ora analisamos, surgem no seio de uma família, entre indivíduos que se relacionam em razão de um

${ }^{1248}$ Família e Direito de família são coisas diversas. A família é um dado da realidade, o Direito de família é um conjunto de normas que regulam os relacionamentos familiares. 
compromisso de noivado, de um casamento, de uma união estável, de uma relação filial, entre outros.

Consequentemente, toda a discussão a respeito dos danos morais deve ser travada na perspectiva da responsabilidade civil, não havendo efeitos jurídicos do Direito de família, e sim sobre as relações familiares. Ou seja, a análise desses danos não deve ser transposta ao Direito de família, como se fossem diversos de quaisquer outros danos, produzidos nas inúmeras esferas do indivíduo. A questão não é a aplicação da teoria da responsabilidade civil em uma área do Direito, mas sim em um tipo de relação humana.

Daí a nossa opção pelo título desta tese - danos morais nas relações familiares - que contém em si a nossa conclusão.

Esta distinção acabou sendo negligenciada e este lapso causou confusões, impedindo que os juristas tratassem o tema com a clareza necessária e que se produzisse uma teoria consistente a este respeito.

É claro que existem especificidades na análise do dano moral nas relações de família, mas não quanto aos seus pressupostos essenciais, que foram cunhados pela teoria geral da responsabilidade civil.

Na leitura dos arts. 186 e 927 do Código Civil identificamos esses pressupostos para a configuração da responsabilidade subjetiva: a conduta do agente (ação ou omissão), sua culpa, o dano e o nexo de causalidade. Qualquer estudo de responsabilidade civil subjetiva implica o exame destes requisitos, que configuram a regra geral para a reparação dos danos.

Sendo assim, tudo o mais deverá ser reconduzido à teoria geral da responsabilidade civil, todas as peculiaridades devem ser reduzidas a um dos pressupostos: conduta culposa, dano e nexo causal.

É verdade que a grande maioria afirma ser aplicável a teoria geral da responsabilidade civil na esfera familiar, inclusive enumerando os pressupostos e citando aqueles dispositivos legais. Todavia, em um segundo momento, passam à análise do caso sem levar em conta esta premissa. Ou seja, a alegação da aplicabilidade da teoria geral da 
responsabilidade civil acaba se tornando só mais um argumento, sem vincular a forma de exame dos casos concretos.

A doutrina não está equivocada, mas acaba sendo imprecisa, inexata. O olhar parte do Direito de família, com a análise da casuística, de suas idiossincrasias, sem referência àquela teoria geral.

Não se descura totalmente dos pressupostos da responsabilidade civil. Todavia, os requisitos desta teoria acabam ficando subentendidos, sem vir à tona, prestando-se atenção aos critérios tópicos de cada grupo de casos (dano moral no noivado, no casamento, nas relações paterno-filiais etc), de maneira que aquela teoria remanesce implícita, o que redunda em discussões deletérias, por vezes contraditórias com a doutrina da responsabilidade civil, algumas que giram ao redor de pontos periféricos, outras que lidam com conceitos não-técnicos.

Pretendemos demonstrar que a presença consciente da distinção fundamental que oferecemos tornará tudo mais claro e objetivo, aproveitando as contribuições da doutrina ao agregá-las a uma teoria unitária, coerente e precisa.

\subsubsection{O PROBLEMA DA CULPA}

O caráter emocional que permeia a área familiar, bem como as alterações que vêm sucedendo no Direito de família podem ter contribuído para a dificuldade no trato do tema.

A tendência doutrinária e jurisprudencial de relativização ou mitigação da culpa nas ações de separação judicial esteve relacionada à própria aplicação do princípio da dignidade humana em sede familiar. Assim, muitos apregoavam que se era direito da pessoa constituir o núcleo familiar, também era direito seu não manter esta entidade, sob pena de comprometer-lhe a existência digna ao se questionar suas motivações.

Após a aprovação da Emenda Constitucional n. 66/2010, ficou patente a divisão na doutrina: de um lado, os que acolhem a modificação como consagração do princípio da ruptura, de outro, os que propugnam pela importância da manutenção da culpa. 
Em nosso ponto de vista, ainda que permaneça a separação culposa na lei, ela provavelmente cairá em desuso, por um grande motivo: a facilitação do rompimento do vínculo conjugal através do divórcio direto, com redução do tempo e das despesas. Além disto, conforme apontamos, as principais consequências da dissolução culposa já haviam sido excluídas de nosso ordenamento ou mitigadas, o que também subtraiu a utilidade prática desta figura no Direito de família, reduzindo o impacto que proporcionava aos envolvidos.

Daí a preocupação com a existência do dano moral: parcela da doutrina teme que a retirada da culpa por completo das questões familiares inviabilize a aplicação do instituto da responsabilidade civil neste âmbito. Ou seja, a preocupação é que, se levada às últimas consequências essa impossibilidade de discussão de culpa na separação, o resultado será o esvaziamento dos danos morais originados de agravos provocados no âmbito familiar.

\subsubsection{UM MESMO FATO, MAIS DE UMA NORMA}

A preocupação exposta no item anterior pode ser dissipada por uma importante distinção, para a qual não se dá a devida atenção.

O que tem ocorrido é um problema no manejo das categorias jurídicas - dano e descumprimento do dever -, pois o suporte fático de preenchimento do dever, pelo descumprimento, também pode preencher o dano. Ademais, a despeito do substrato fático deste descumprimento do dever, ele não traz mais implícitas outras consequências jurídicas nas relações conjugais, portanto, tornou-se inócuo (não há mais a perda da guarda, dos alimentos e do nome, nem mesmo para a concessão do divórcio é necessário comprovar a quebra de um dos deveres, pois basta a impossibilidade de convivência).

Esta solução é muito simples e resolve a maioria das questões que afligem os juristas neste âmbito. Aliás, esta é a resposta para qualquer área em que se discutem danos morais (ocorre que no Direito de família esta confusão é maior em razão da previsão dos deveres matrimoniais e também entre pais e filhos).

A culpa no Direito de família pode até ser extinta, mas não o será no Direito das obrigações, na responsabilidade civil. Uma coisa é a culpa pela separação, outra é a 
culpa enquanto pressuposto para o dano moral. São situações distintas, são apenas homônimos, uma mesma palavra designando coisas diversas.

Um só fato (a injúria de um cônjuge contra o outro) pode implicar a ocorrência de duas normas: o descumprimento de um dever e a responsabilidade civil. A incidência dúplice não pode embotar nossa análise. Se um dos efeitos desaparece, isto não interfere no outro.

Assim, é infundado o temor dos que vislumbraram na extirpação da culpa do Direito de família o perigo de imunidade por dano moral. Desde que fique claro que a subsunção aos dispositivos da responsabilidade civil não depende da subsunção a outro tipo de norma (do Direito de família, no caso, mas poderia ser de outro ramo), a proteção contra o dano moral resta incólume.

Do mesmo modo, o ato ilícito que gera o dano moral concomitantemente pode gerar descumprimento de dever familiar. Daí porque os juristas se indagam se cabe dano moral pelo descumprimento de dever. A pergunta, todavia, mistura as categorias jurídicas $^{1249}$. O mais correto seria dizer: $o$ fato que gera este descumprimento do dever também gera dano moral?

A relação será sempre entre o fato e a norma, e não entre duas normas. $\mathrm{O}$ problema é saber se aquele fato pode ser subsumido à regra da responsabilidade civil e não se o descumprimento do dever causa a aplicação de outra norma.

Além disto, cabe ressaltar que os deveres familiares consagram valores da sociedade, ao passo que o dano moral versa sobre valores do indivíduo. A afetação da dignidade deverá ser analisada no caso concreto, conforme os valores entronizados pela pessoa, desde que consagrados no ordenamento (direitos da personalidade).

Por isto, no caso de uma relação 'liberal', em que os cônjuges admitem relações íntimas com terceiros, está configurada a quebra do dever de fidelidade, porém, não há afetação da dignidade, pois a pessoa não assume como seu o valor da monogamia,

\footnotetext{
${ }^{1249}$ Por vezes, como alertamos, afirma-se a aplicação da responsabilidade civil, mas se analisa a quebra de dever familiar. Como exemplo: "a responsabilidade civil subjetiva é pressuposto do dano moral no âmbito das relações conjugais. É necessário que se comprove a culpa no comportamento do cônjuge e o efetivo descumprimento do dever conjugal”. PEREIRA, Caio Mário da Silva. Op. cit. (nota 185), p. 306.
} 
de maneira que sua personalidade resta incólume. Não se avalia violação de deveres (centrados nos valores gerais da sociedade), mas a afetação da dignidade (centrada nos valores individuais).

\subsubsection{CASUÍSTICA E PRESSUPOSTOS DA RESPONSABILIDADE CIVIL}

Segundo afirmamos, as soluções propugnadas pela doutrina não estão erradas, apenas são imprecisas, pois não deixam explícita a utilização dos pressupostos gerais da responsabilidade civil.

É neste sentido que entendemos todas as observações feitas a respeito da casuística do dano moral nas relações familiares. Os juristas acertam ao distinguir as peculiaridades de cada grupo de casos, faltando apenas reconduzir os critérios específicos àqueles pressupostos.

De uma perspectiva negativa, a tipificação de condutas que geram danos morais nas relações familiares é, por um lado, desnecessária e, por outro, inconveniente. Desnecessária porque para a avaliação do dano moral são suficientes os requisitos gerais da responsabilidade civil; e inconveniente porque, como a análise daqueles pressupostos se faz sempre diante do caso concreto, onde se examina a presença dos requisitos gerais e a ausência de eximentes de responsabilidade, a tipificação induz à falsa ideia de que este exame é dispensável ${ }^{1250}$.

De fato, poderiam ocorrer situações 'típicas' que, no caso concreto, apresentassem contornos tais que eximissem o imputado de responsabilidade. Ademais, essa enumeração também restringe as hipóteses que, se não são infinitas, são indefinidas.

Ao examinarmos as situações usualmente citadas, podemos concluir que: $a$ ) em todos aqueles casos, a teoria geral da responsabilidade civil manteve-se como o verdadeiro fundamento, estando por trás de toda a argumentação utilizada pelos juristas; $b$ ) por mais particulares que fossem as situações, sempre eram amoldáveis a essa teoria geral; e $c$ ) os

\footnotetext{
${ }^{1250}$ Não há respostas apriorísticas, e o juiz deverá sempre analisar o caso concreto. Por isso, é impossível estabelecer, a priori, quais situações em que haverá danos morais neste âmbito, ou certos estereótipos, por exemplo: traiu, cabem danos morais; abandonou o filho, cabem danos morais etc. O modelo abstrato não contém os dados concretos para o exame dos pressupostos, nem mesmo os valores individuais para verificar a afetação da dignidade.
} 
problemas vislumbrados em cada um dos casos, eram, na realidade, os mesmos verificados na teoria geral da responsabilidade civil.

Portanto, nossa análise dos danos morais na família jamais teve a intenção de ser exaustiva, mas apenas de evidenciar que a teoria geral da responsabilidade civil é a única técnica adequada àqueles casos.

De uma perspectiva positiva, podemos aproveitar todas as análises casuísticas para evidenciar as particularidades dos pressupostos da responsabilidade civil neste tipo de relação.

Com este intuito, procuraremos evidenciar a ligação entre os aspectos específicos trazidos na discussão doutrinária e aqueles requisitos, utilizando para tanto os exemplos paradigmáticos do rompimento de noivado, da infidelidade, do dano pela própria dissolução do casamento e pelo abandono afetivo, já estudados.

A indenização dos danos morais decorrentes da ruptura do noivado provavelmente foi a primeira hipótese a ser aventada na doutrina civil-familiar. Contudo, ainda hoje, gera polêmica.

O critério encontrado pelos juristas para identificar esses danos foi o justo motivo. Ou seja, na presença de uma causa considerada justa para o rompimento, não haveria que se falar em responsabilidade civil do nubente arrependido.

Em quais dos pressupostos gerais (conduta, culpa, dano e nexo causal) se enquadra o justo motivo?

Em qualquer rompimento de noivado, sempre haverá uma ação do nubente que quebra o compromisso (conduta), podendo gerar a violação de um direito da personalidade (dano e nexo causal). O justo motivo, neste caso, vem a ser uma excludente de ilicitude, ao afastar a culpa do nubente.

É este requisito - a culpa - que desaparece com a justificação do agir. Contudo, somente o exame do caso concreto é que poderá determinar a existência ou não do justo motivo. Não é possível classificar, de antemão, quais motivos são justos, apenas podemos utilizar este critério como norte orientador. 
Não obstante, é preciso, ainda, fazer uma última colocação. Quando o nubente recusa-se a declinar os motivos que o levaram a romper o compromisso, pois são de ordem pessoal e poderiam, inclusive, constranger o outro nubente pela exposição de sua esfera íntima, levando ao agravamento de sua personalidade, sua conduta é culposa? Ou seja, o justo motivo, nesta situação, não foi explicitado, já que a publicidade de suas razões levaria a um constrangimento maior. É possível sustentar a culpa ou há justificação? É lícito o rompimento do noivado por motivo de foro íntimo?

Seja qual for a resposta para essas perguntas, a análise será mais proveitosa se for baseada na teoria da responsabilidade civil.

O segundo grupo de casos relaciona-se ao casamento. Trata-se da hipótese mais estudada pela doutrina e que, por conseguinte, deu causa a inúmeras vicissitudes.

A questão colocada com insistência pelos juristas, e que se tornou o cerne da discussão, é a existência de dano moral no caso de infidelidade.

De uma parte, afirma-se que não cabem danos morais pela simples quebra do dever de fidelidade. Outros alegam que somente seria possível quando isso ocorresse de forma vexatória ou pública. Por fim, há os que entendem bastar o descumprimento daquele dever.

Conforme explicamos anteriormente, não se deve analisar esta hipótese sob o prisma do descumprimento do dever, mas sim através do preenchimento dos pressupostos da responsabilidade civil.

No adultério, por exemplo, há uma ação (relacionamento íntimo do cônjuge com terceira pessoa) que pode ocasionar (nexo causal) a afetação de direito à personalidade (dano moral). A conduta seria dolosa, de maneira que a culpa igualmente estaria presente.

A quebra do dever não vem ao caso. Novamente seria preciso explicar que não estamos lidando com uma relação entre normas (descumprimento de dever e responsabilidade civil), mas com a existência ou não, no caso concreto, dos pressupostos da responsabilidade civil. 
O fato adultério é descumprimento do dever e, possivelmente, dano moral. A doutrina por vezes utiliza a categoria jurídica errada, dever e não responsabilidade civil, apesar de o suporte fático ser o mesmo.

O fato de tal ação (adultério) ter sido prevista pelo ordenamento como infração a um dos deveres dos cônjuges não necessariamente resultará em danos morais. Conforme dissemos, a responsabilidade civil é geral e independe de tipificação, de previsão jurídica expressa. A previsão de tal ação como um dever matrimonial apenas reforça o entendimento no sentido de que sua infração provavelmente gerará um dano.

A lista de deveres conjugais pode ser vista como um caminho balizador que fornece indícios ao juiz do que a sociedade entende como necessário para a manutenção de um relacionamento, de sorte que sua infração denota, no mínimo, um desrespeito ao cônjuge ofendido. No entanto, a verificação da responsabilidade civil somente se dá através de seus pressupostos.

Assim, ao se afirmar que a quebra dos deveres conjugais gera danos morais está-se partindo da premissa errada, pois não surgem em razão da quebra dos deveres, mas sim da ação ilícita que agrava a personalidade do ofendido.

Logo, a ação cometida por um dos cônjuges, que é também prevista pelo ordenamento como um dever a ser observado na constância do casamento, e por isso reflete valores de nossa sociedade, pode causar um dano ao outro consorte, um agravo à sua personalidade, e assim deverá ser indenizada.

Desta forma, somente a questão da publicidade permanece. Em qual dos requisitos gerais podemos localizá-la? A resposta é simples: no dano.

O conhecimento por terceiros do fato infiel ou, de maneira mais abrangente, o modo como se deu a infidelidade, diz respeito à existência ou não do pressuposto do dano. Considerando que o dano moral é a afetação de direito da personalidade, devemos saber qual direito está sendo objeto de violação. Não existem dúvidas de que se trata da honra.

O que aparentemente era uma discussão sobre o descumprimento de dever conjugal é na verdade um debate sobre a existência ou não de um direito da personalidade, pois a divisão se dá quanto à aceitação ou não do direito à honra subjetiva. 
É que alguns admitem, dentro do direito da personalidade, somente a honra objetiva e outros também a subjetiva ${ }^{1251}$. Para os primeiros, não haverá dano moral, na falta de direito à personalidade, para os segundos, o dano advém da violação da honra subjetiva.

No mesmo sentido, para a primeira corrente, a publicidade geraria um agravo maior, justamente porque as duas faces do direito à honra seriam atingidas.

A terceira hipótese que merece destaque é a possibilidade de responsabilização em razão da própria separação ou divórcio, distinguindo-se esta hipótese dos fatos que levaram a ela.

Nos ordenamentos de Portugal e França há previsão específica de indenização em razão do próprio fim do relacionamento, independentemente de suas causas. Os motivos que levaram ao término do vínculo são reconduzidos à regra da responsabilidade civil.

A solução para nosso país é diferente ${ }^{1252}$. Mais uma vez, devemos analisar se estão presentes os pressupostos da responsabilidade civil. Ocorre que, no caso, não

\footnotetext{
${ }^{1251}$ É na doutrina criminalista onde mais encontramos manifestações amparando a distinção. Neste sentido: "a honra é um valor que a própria pessoa se atribui ou por outrem a ela é atribuído, e, por tais razões, deve ser examinada sob um dúplice aspecto: 'subjetivo'e 'objetivo'. O aspecto subjetivo é constituído pelo juizo que cada indivíduo faz de seus dotes ou de si mesmo, o 'sentimento' de seu próprio valor social. O aspecto 'objetivo' é representado 'pelo juízo' dos outros, ou, mais precisamente, 'a consideração' que cada indivíduo tem na comunidade", PIERANGELI, José Henrique. Manual de direito penal brasileiro: v. 2, parte especial: arts. 121 a 361. $2^{a}$ ed. São Paulo: Revista dos Tribunais, 2007, pp. 115-116; “(...) a honra, do ponto de vista 'objetivo', seria a reputação que o indivíduo desfruta e, determinado meio social, a estima que lhe é conferida; 'subjetivamente', a honra seria o sentimento da própria dignidade ou decoro”, PRADO, Luiz Regis. Curso de direito penal brasileiro: vol. 2, parte especial: arts. 121 a 183. $5^{\text {a }}$ ed. São Paulo: Revista dos Tribunais, 2006, p. 246; “A subjetiva diz respeito ao sentimento de cada um sobre si próprio, sobre as suas próprias qualidades morais. A honra subjetiva está relacionada a valores pessoais, à dignidade, ao decoro da pessoa. A honra objetiva é representada pela reputação da pessoa no grupo social. Está relacionada à boa fama e à estima que cada um desfruta no seu ambiente social", FRANCO, Alberto Silva et STOCO, Rui (coord.). Código penal e sua interpretação: doutrina e jurisprudência. $8^{\mathrm{a}}$ ed. São Paulo: Revista dos Tribunais, 2007, p. 718; “(...) diferem-se, com propriedade, as noções de honra objetiva e honra subjetiva, pois dizem respeito a diversos aspectos da integridade, reputação e bom conceito da pessoa. Honra objetiva é o julgamento que a sociedade faz do indivíduo, vale dizer, é a imagem que a pessoa possui no seio social. (...) Honra subjetiva é o julgamento que o indivíduo faz de si mesmo, ou seja, é um sentimento de autoestima, de autoimagem. (...) Trata-se de um senso ligado à dignidade (respeitabilidade ou amor-próprio) ou ao decoro (correção moral)", NuCCI, Guilherme de Souza. Código penal comentado. 10a ed. São Paulo: Revista dos Tribunais, 2010, p. 673. ANDERSON SCHREIBER assegura que a distinção de fato surgiu da doutrina penalista. Cf. SCHREIBER, Anderson. Op. cit. (nota 53), p. 70.

${ }^{1252}$ Cada ordenamento reflete os valores da sociedade para os quais foram instituídos. No âmbito do Direito de família, onde os vetores axiológicos são muito particulares, variando de nação para nação, o Direito comparado acaba tendo um intuito mais informativo, sendo praticamente impossível transpor a solução
} 
obstante possa haver agravo a direito da personalidade (dano) em virtude (nexo causal) da separação ou do divórcio (conduta), não há ato ilícito.

A responsabilidade civil, em regra, deriva da ilicitude do ato, por decorrência da previsão do art. 186 do Código Civil. Somente existe responsabilidade por ato lícito como exceção, que deverá ser expressa no ordenamento. Não havendo dispositivo deste jaez em nosso país para as relações familiares, não vislumbramos esta possibilidade.

\section{O último exemplo paradigma é o abandono afetivo.}

Sinteticamente, o problema neste âmbito resumia-se à arguição de que não se poderia obrigar alguém a ter afeto, que isto geraria a monetarização do amor.

O próprio nome da figura - abandono afetivo - induz ao erro. Não é o abandono ou falta de afeto que será indenizado, mas ações concretas que produziram um agravo aos direitos da personalidade do filho.

A recente decisão do Superior Tribunal de Justiça, já analisada, caminhou no sentido de distinguir a obrigação de afeto, realmente inexistente no Direito, e as demais obrigações previstas no ordenamento, como o dever de assistência.

A solução, destarte, reside exatamente nesta diferença: não se responsabiliza pela falta de afeto, mas pelas atitudes que traduzem a falta de assistência. Todavia, isto não basta, pois o risco de erroneamente afirmarmos que a responsabilização se dá pelo descumprimento de dever é aqui muito grande.

Os diversos deveres parentais estão espalhados pelo ordenamento, na Constituição, no Código Civil e no ECA, e muitos deles estão implícitos naqueles deveres gerais de educação, sustento e guarda. Portanto, a lei não concentra esses deveres em um dispositivo, como faz no casamento.

Devemos recordar, entretanto, que não é a violação de uma norma (que prevê o dever) que causa a incidência de outra (da responsabilidade civil), mas sim um mesmo fato, que dá origem a diversos efeitos jurídicos.

adotada em outros países para o nosso. A solução, de qualquer forma, sempre esteve à disposição dos juristas brasileiros, em nosso próprio ordenamento. 
Cada uma das normas gerará seu próprio efeito, desde que preenchido o suporte fático para tanto. Assim, um mesmo fato poderá levar à suspensão do poder familiar, à responsabilidade civil por dano moral e, até mesmo, ao crime de abandono. Para todas estas repercussões será preciso realizar o exame de suas condições individualmente, não se podendo deduzir da incidência de um dispositivo a ocorrência dos demais.

Então, verificando os pressupostos da responsabilidade civil, teremos: uma omissão em prestar assistência (conduta) que causa (nexo causal) a violação de um direito da personalidade (dano moral).

$\mathrm{O}$ aspecto distintivo desta hipótese reside no caráter omissivo da conduta. Tratando-se de omissão, não existe nexo causal natural. O liame entre o não agir e o resultado advém de uma norma geral de cuidado ${ }^{1253}$.

Deste modo, se no rompimento do noivado o problema residia na culpa e na infidelidade estava no dano, aqui a questão é o nexo causal e a conduta.

No abandono afetivo, a ligação entre o dano e o agente, ou seja, entre a violação do direito da personalidade e a conduta omissiva, se dá em virtude da relação familiar existente. É exatamente na relação parental que reside o liame entre conduta e dano.

Os danos psicológicos sofridos pelo filho podem ser imputados ao pai em virtude da relação de paternidade, que torna relevante as omissões do genitor. E esta omissão caracteriza descumprimento de dever paterno. Os deveres servem aqui como norte para caracterizar não situações de dano, mas sim nexos de causalidade, haja vista que neste caso o nexo causal não é natural, mas jurídico.

Da mesma forma que no adultério, os danos não surgem da quebra dos deveres familiares, mas do agravo à personalidade do envolvido.

\footnotetext{
${ }^{1253}$ Conforme ensina PAULO JOSÉ DA COSTA JR., "quando se afirma que um homem não agiu de determinada maneira, implicitamente se reconhece que uma norma delineia a forma pela qual ele deveria pautar sua conduta. Sem este momento normativo - do qual a omissão não prescindirá jamais - o juízo permanece cego", e complementa aduzindo que o juízo de imputação neste caso “(...) completa-se com seu segundo momento: o predicado, que se realiza com base em uma norma (jurídica, moral, social, técnica, higiênica, econômica, gramatical, lógica). Trata-se, então, de averiguar se a conduta é contrária, ou conforme a norma", portanto, “é a norma que confere vida e realidade à omissão". COSTA JúNIOR, Paulo José da. Nexo causal. $4^{\mathrm{a}}$ ed. São Paulo: Revista dos Tribunais, 2007, pp. 36, 40 e 41.
} 
Neste momento, caberia uma palavra sobre a técnica da ponderação de interesses que é adotada por parte da doutrina.

Em nossa visão, a adoção ou não desta teoria é indiferente para o que afirmamos. É possível a utilização deste método, que não substitui nossa proposta, mas deve ser jungido com ela, pois a solução que ofertamos tem caráter preliminar. Ou seja, a ponderação deve partir da premissa de que a análise a ser realizada é a mesma da responsabilidade civil, para examinar cada um dos seus pressupostos, reconduzindo as questões invariavelmente a um dos requisitos gerais ${ }^{1254}$.

Nosso intuito, ao explorar esses exemplos paradigmáticos não foi esgotar seu exame, mas apenas demonstrar como, de fato, as discussões sobre os danos morais travadas no âmbito familiar são, no fundo, questões da responsabilidade civil. Intentamos, desta forma, deixar explícita esta relação e esclarecer que por detrás das múltiplas idiossincrasias arroladas pela doutrina civil-familiar escondiam-se os elementos essenciais da responsabilidade civil.

Abre-se, assim, um caminho para os juristas, que, se não é novo, há tempos não tem sido trilhado.

\subsubsection{O QUANTUM DA INDENIZAÇÃO}

Um erro comum, que acomete muitos dos juristas que se propõe a estudar os danos morais é a confusão entre a dificuldade em se arbitrar tais danos com a sua própria identificação.

Em todas as demandas que envolvem danos morais, o juiz defronta-se com o mesmo problema: a perplexidade ante a inexistência de critérios legais para arbitrar um valor adequado.

A análise do dano moral, contudo, não pode ficar prejudicada por esse obstáculo. Em primeiro lugar, devemos ficar atentos para a diferença que há entre a existência do dano moral e o valor de sua indenização. São momentos diversos.

${ }^{1254}$ Por exemplo, a ponderação poderia ser utilizada para, na análise do pressuposto do dano, balizar dentre os interesses contrapostos aquele que mais realiza a dignidade humana. 
Consoante expusemos, a existência do dano é verificada por meio dos pressupostos gerais da responsabilidade civil, mesmo nas relações familiares. Ou seja, não há uma diferença específica a retirar das relações familiares quer a possibilidade de proteção contra as violações à personalidade, quer a aplicação da teoria geral da responsabilidade civil.

O tipo especial de relação (familiar) não modifica a teoria geral, pelo contrário, são as especificidades das relações familiares que se adaptam a ela, de maneira que cada um dos parâmetros tópicos encontrados pela doutrina será reconduzido a um dos requisitos gerais da responsabilidade civil (conduta, culpa, dano e nexo causal).

Da mesma forma, o arbitramento do quantum indenizatório deve seguir os parâmetros gerais. Sucede que, como vimos, neste âmbito ainda remanesce grande dificuldade, não havendo consenso seja a respeito da necessidade de maior regulamentação legal (por meio de tarifas ou cálculos matemáticos), seja sobre quais aspectos do caso devam ser considerados.

Cumpre-nos recordar que as circunstâncias que irão nortear a atividade de mensuração dependem de quais funções se atribuem à indenização. Se o pagamento serve para compensar, para punir o ofensor, para prevenir novas lesões ou para reestabelecer o equilíbrio social, os fatores que integram o exame do caso vão variar.

Seria preciso responder, então, à pergunta fundamental sobre a função da reparação do dano moral em geral e, depois, se existe alguma diferença especial nas relações familiares que justifique finalidade diversa.

Em nossa visão, a função primordial da indenização é a compensatória, sendo as demais meros efeitos da condenação. Nas relações de família não é diferente. Daí porque, na quantificação, devem ser utilizados os critérios doutrinários que dizem respeito ao dano experimentado pela vítima.

De outra parte, no que se refere ao problema das 'culpas recíprocas' (rectius, agravos recíprocos), parte da doutrina tomava a duplicidade como impedimento para a indenização, em virtude de compensação. 
No entanto, de acordo com nosso entendimento, é preciso analisar cada ação individualmente, a partir dos pressupostos da responsabilidade civil. Cada uma delas gera um dever de indenizar próprio, porém, o valor corresponde poderá ser influenciado, seja para atenuação ou mesmo anulação ${ }^{1255}$.

É importante salientar a necessidade de fundamentação clara e exaustiva por parte do magistrado, quer para afirmar a existência do dano, quer para sua quantificação. Um bom desempenho no dever de motivação é essencial para que se saiba de que modo o juiz chegou às suas conclusões, permitindo o controle da decisão, evitando, assim, os famigerados exageros.

Não é de todo correto, neste aspecto, falar em arbítrio judicial na determinação do quantum indenizatório. O juiz é essencial não para exercer a discricionariedade, mas porque é ele a inteligência agente que 'descobre' o dano por meio da análise concretamente situada dos valores individuais afetados.

No que toca às formas alternativas de reparação do dano, como vislumbrada por alguns, acreditamos ser interessante a hipótese de que os danos morais sejam reparados pelo custeio de um tratamento psicológico, quando adequado ao caso.

A premissa, de seu turno, vale igualmente para o ofensor. Isto é, a ofensa também surge de questões psicológicas de quem ofende. Neste ponto, poderíamos cogitar se um tratamento conjunto, uma terapia familiar, não seria um caminho mais adequado. Contudo, qual seria a eficácia desta medida se vier como imposição compulsória? Quiçá esta solução seja viável por meio da conciliação e mediação dos conflitos.

\footnotetext{
${ }^{1255}$ Não são as 'culpas' que são compensadas (ambas as ações continuam aptas a originar a reparação), mas sim o valor das respectivas indenizações. Neste sentido, a notícia de que: "a culpa concorrente tem sido reiteradamente reconhecida como causa de diminuição do valor indenizatório". CiANCI, Mirna. Op. cit. (nota 227), p. 100. No mesmo sentido: "se houver concorrência de culpas, do autor do dano e da vítima, a indenização deverá ser reduzida”. MONTEIRO, Washington de Barros. Curso de direito civil: direito das obrigações. v. 5. 36a ed. São Paulo: Saraiva, 2009, p. 546; “também 'não' se justifica a denominação 'compensação de culpas', pois a conduta de uma das partes envolvidas não é anulada ou absorvida pela outra, mas cada uma terá direito à reparação dos danos sofridos, segundo a participação 'causal' verificada". CALIXTO, Marcelo Junqueira. A culpa na responsabilidade civil: estrutura e função. Rio de Janeiro: Renovar, 2008, pp. 332-333.
} 


\subsubsection{QUESTÃO PROCESSUAL}

Como consequência de toda essa construção, entendemos possível a análise dos casos de danos morais advindos de relações familiares no juízo cível, pois não geram efeitos no Direito de família, mas sim nas relações familiares.

Partindo do pressuposto de que o dano moral é originado no agravo à personalidade, sendo este o real motivo da sua indenização, perde sentido falar em julgamento na vara de família.

Ademais, a proximidade com outros casos de indenização por danos morais, bem como a distância do drama familiar podem proporcionar um julgamento mais isento e técnico da responsabilidade civil, sem a influência dos aspectos do Direito de família que vêm sendo erroneamente sobrepostos neste exame, muitos dos quais são combatidos por parcela da doutrina e estão perdendo seu espaço no ordenamento (por exemplo, a culpa na separação).

Note-se que havia um grande esforço por parte dos juristas para admitir esta análise nas varas de família. Todavia, esta situação não se mostra a melhor, visto que acaba deturpando o que realmente está em exame: a averiguação de agravos à personalidade oriundos de relações familiares.

A conclusão é reforçada pela aprovação da Emenda Constitucional n. 66/10. Sem prejuízo de nossas críticas à interpretação que postula a revogação dos dispositivos legais, fica patente que o acolhimento deste entendimento majoritário e o consequente desuso da figura da separação transporão o debate sobre a indenização para um segundo momento, afastado do divórcio e do Direito de família.

Também desaparece o risco de decisões conflitantes, que fundamentava posicionamentos pela cumulação das demandas ou distribuição ao mesmo juízo, uma vez que a análise da conduta culposa do cônjuge tornou-se irrelevante para o término do casamento.

Nossa proposta tem ainda outra vantagem, uma vez que a discussão a respeito de eventuais agravos entre cônjuges somente será levada adiante caso realmente se mostre necessária, ou seja, somente se houver, de fato, uma situação que ofendeu direito da 
personalidade de um dos envolvidos. Muitas vezes, a proximidade com o conflito familiar leva a pedidos despropositados de danos morais, unicamente com o intuito de vingança. Desta forma, acreditamos que reduzirão as demandas neste âmbito, afastando-se a chamada 'indústria do dano moral' da seara familiar, que tanto preocupa os juristas.

Igualmente, nos demais casos de danos morais nas relações familiares, a competência deve recair sobre o juízo cível, não havendo motivo para subtrair de sua análise um julgamento sobre responsabilidade civil, já que não estamos no campo do Direito de família. 


\section{CONCLUSÃo}

Em temas intrincados, é sempre recomendada prudência. As mudanças na família, as mudanças no Direito de família, as mudanças no Direito em geral, tudo isso torna a precaução mais necessária.

Após um tempo de incerteza, o dano moral alcançou amparo unânime, na doutrina, na jurisprudência e na legislação. Alguns pontos persistem em discussão - seu conceito, seus fundamentos, suas funções, seu modo de aferição e quantificação -, embora seja possível afirmar que a teoria jurídica já é bastante avançada, tendo se aproximado muito da solidez científica.

De sua parte, o turbilhão por que vem passando o Direito de família, com alterações em diversos aspectos, ainda não permitiu a chegada do consenso. Pelo contrário, os desencontros entre teóricos, julgadores e até legisladores é acentuado, por vezes dividindo os grupos de maneira radical.

A tutela da pessoa humana, que no campo mais geral é motivo de união, acaba sendo arena de disputas quando associada aos relacionamentos de família.

Vêm sendo criados critérios na dogmática e na jurisprudência, que se acumulam ao redor de casos paradigmáticos, trazendo alguma unificação ao menos sobre o que é importante analisar em cada grupo de casos: os justos motivos do rompimento do noivado, o descumprimento dos deveres conjugais e da união estável, o interesse jurídico que perpassa o abandono afetivo, o erro imputável no casamento nulo, os efeito da negação da paternidade conhecida ou provável, a dificuldade da prova na alienação parental.

A cautela devida em tais assuntos polêmicos, todavia, nos leva a exigir uma coerência geral que unifique as mais comezinhas situações em uma só teoria. Foi justamente esta a intenção deste trabalho.

Para desempenharmos esta missão, foi preciso distinguir que a responsabilidade civil incide sobre as relações familiares, e não no Direito de família. $\mathrm{O}$ descumprimento de dever entre cônjuges, companheiros ou pais e filhos, neste sentido, não é a figura apropriada para o exame, que deve partir dos requisitos gerais da responsabilidade civil. 
Todos os critérios encontrados pela doutrina devem ser reconduzidos aos pressupostos da responsabilidade civil, permitindo um julgamento mais rigoroso e translúcido.

Da mesma maneira, a quantificação do dano moral nas relações familiares deve se orientar pela dogmática geral, e vai depender, como sucede sempre, das funções que se atribuem à indenização. Sendo um assunto do Direito das obrigações, o dano moral entre familiares compete às varas cíveis, local mais adequado para julgar os casos de responsabilidade civil.

Tornar mais claro o modo de se perquirir o dano moral nas relações familiares poderá contribuir para que a doutrina se desenvolva de maneira eficiente, bem como abre espaço para uma motivação mais segura e transparente das decisões judiciais. 


\section{Bibliografia}

Acquaviva, Marcus Cláudio. Dicionário Acadêmico de Direito. São Paulo: Jurídica Brasileira, 1999.

AgUiar JÚNIOR, Ruy Rosado de. Responsabilidade civil no direito de família. $A D V$ Advocacia Dinâmica: seleções jurídicas, n. 2, 2005.

AguIRRE, João Ricardo Brandão. O regime patrimonial da união estável à luz do código civil de 2002. Dissertação de mestrado apresentada à Pontifícia Universidade Católica de São Paulo - PUC, São Paulo, 2004.

ALMEIDA JÚNIOR, Jesualdo Eduardo de. Os danos morais pelo descumprimento dos deveres pessoais do casamento. Revista IOB de Direito de Família, n. 59, 2010.

Alves, Jones Figueirêdo. Abuso de direito no direito de família. In: PEREIRA, Rodrigo da Cunha (Coord.). Família e dignidade humana - anais do V Congresso Brasileiro de Direito de Família. Belo Horizonte: IBDFAM, 2006.

Algumas questões controvertidas no novo direito de família. In: Questões controvertidas no novo Código Civil. v. 1. São Paulo: Método, 2006.

ALves, Leonardo Barreto Moreira. O fim da culpa na separação judicial: uma perspectiva histórico-jurídica. Belo Horizonte: Del Rey, 2007.

AmAro, Elisabete Aloia. Responsabilidade civil por ofensa aos direitos da personalidade. In: NeRY, Rosa Maria de Andrade et DonNINI, Rogério (Coords.). Responsabilidade civil: estudos em homenagem ao professor Rui Geraldo Camargo Viana. São Paulo: Revista dos Tribunais: 2009.

ANDRADE, André Gustavo Corrêa de. Indenização punitiva. Revista da EMERJ, n. 36, 2006.

ANDRADE, Fábio Siebeneichler de. A reparação de danos morais por dissolução do vínculo conjugal e por violação de deveres pessoais entre cônjuges. Revista dos Tribunais, v. 802, 2002.

ANGELUCI, Cleber Affonso. O valor do afeto para a dignidade humana nas relações de família. Revista Jurídica, n. 331, 2005.

Azevedo, Álvaro Villaça. Estatuto da família de fato. $2^{\text {a }}$ ed. São Paulo: Atlas, 2002. Jornal do Advogado. São Paulo: OAB, n. 289, 2004.

Azevedo, Antonio Junqueira de. Por uma nova categoria de dano na responsabilidade civil: o dano social. Revista Trimestral de Direito Civil, v. 19, 2004. 
BArros, Sérgio Resende de. A tutela constitucional do afeto. In: PereIRA, Rodrigo da Cunha (Coord.). Família e dignidade humana - anais do V Congresso Brasileiro de Direito de Família. Belo Horizonte: IBDFAM, 2006.

Beviláqua, Clóvis. Código Civil dos Estados Unidos do Brasil comentado. Rio de Janeiro: Paulo de Azevedo, 1953.

Bigi, José de Castro. Dano moral em separação e divórcio. Revista dos Tribunais, v. 679, 1992.

BITTAR, Carlos Alberto. O direito civil na Constituição de 1988. $2^{\mathrm{a}}$ ed. São Paulo: Revista dos Tribunais, 1991.

. Reparação civil por danos morais. $3^{\text {a }}$ ed. São Paulo: Revista dos Tribunais, 1999.

- Danos morais e materiais decorrentes da ruptura do casamento. Revista da Faculdade de Direito da Fundação Armando Alvares Penteado, n. 1, São Paulo, 2002.

Branco, Bernardo Castelo. Dano moral no direito de família. São Paulo: Método, 2006.

Cahali, Yussef Said. Divórcio e separação. 10a ed. São Paulo: Revista dos Tribunais, 2002.

. Dano moral. $4^{\mathrm{a}}$ ed. São Paulo: Revista dos Tribunais, 2011.

Caldas Aulete. Dicionário Contemporâneo da Língua Portuguesa. $3^{\mathrm{a}}$ ed. Rio de Janeiro: Delta, 1979.

CALIXTO, Marcelo Junqueira. A culpa na responsabilidade civil: estrutura e função. Rio de Janeiro: Renovar, 2008.

CAmargo Neto, Theodureto de Almeida. A responsabilidade civil por dano afetivo. In: Silva, Regina Beatriz Tavares da e CAMARgo Neto, Theodureto de Almeida (Coords.). Grandes temas de direito de família e das sucessões. São Paulo: Saraiva, 2011.

Canotilho, J.J. Gomes. Direito constitucional e teoria da constituição. $7^{\mathrm{a}}$ ed. Coimbra: Almedina, 2000.

CARdin, Valéria Silva Galdino. Dano moral no direito de família. São Paulo: Saraiva, 2012.

CARVAlHo Neto, Inacio de. Reparação civil na separação litigiosa culposa. Revista EPD Direito Civil, n. 1, 2005.

. Responsabilidade civil no direito de família. $4^{\text {a }}$ ed. Curitiba: Juruá, 2011. 
CASABOna, Marcial Barreto. Responsabilidade civil no direito de família. In: NERY, Rosa Maria de Andrade e DonNINI, Rogério (Coords.). Responsabilidade civil: estudos em homenagem ao professor Rui Geraldo Camargo Viana. São Paulo: Revista dos Tribunais: 2009.

Cavalieri Filho, Sergio. Programa de responsabilidade civil. $9^{\text {a }}$ ed. São Paulo: Atlas, 2010.

Cendon, Paolo et Sebastio, Giovanna. La responsabilità civile fra marito e moglie. In: CEndon, Paolo (Coord.). Persona e danno III: le persone deboli, i minori, i danni in famiglia. Milano: Giuffrè, 2004.

CERDEIRA, Ângela Cristina da Silva. Da responsabilidade civil dos cônjuges entre si. Coimbra: Coimbra, 2000.

Chaves, Antônio. Tratado de direito civil. v. 3. São Paulo: Revista dos Tribunais, 1985.

CiAncI, Mirna. O valor da reparação moral. $3^{\text {a }}$ ed. São Paulo: Saraiva, 2009.

ColetTI, Sabatini. Il Sabatini Coletti Dizionario della Lingua Italiana. Milano: RCS Libri, 2007.

Coltro, Antônio Carlos Mathias. A descriminalização do adultério, sua repercussão no direito de família e a culpa na responsabilidade pelo fim da conjugalidade. In: PEREIRA, Rodrigo da Cunha (Coord.). Família e dignidade humana - anais do $\mathrm{V}$ Congresso Brasileiro de Direito de Família. Belo Horizonte: IBDFAM, 2006.

. A união estável e a responsabilidade por dano moral. In: DELGADO, Mário Luiz et Alves, Jones Figueirêdo. Novo código civil: questões controvertidas. v. 5. São Paulo: Método, 2006.

. Dissolução da sociedade conjugal: separação extrajudicial. In: CHINELlato, Silmara Juny de Abreu, SimÃo, José Fernando, FuJiTA, Jorge Shiguemitsu et ZuCCHI, Maria Cristina (Orgs.). Direito de família no novo milênio. São Paulo: Atlas, 2010.

CORDEIRO, Amanda Idalina Menezes. Indenização por abandono afetivo. Centro de Ensino Superior de Brasília-CESB.

Costa, Maria Isabel Pereira da. Família: do autoritarismo ao afeto; como e a quem indenizá-lo? Revista Magister de Direito Civil e Processual Civil, n. 5, 2005.

Costa JÚnior, Paulo José da. Nexo causal. $4^{\text {a }}$ ed. São Paulo: Revista dos Tribunais, 2007.

CRISPINO, Nicolau Eládio Bassalo. Responsabilidade civil dos conviventes. In: PEREIRA, Rodrigo da Cunha. A família na travessia do milênio - anais do II Congresso Brasileiro de Direito de Família - IBDFAM. Belo Horizonte: Del Rey, 2000. 
Delgado, Mário Luiz. Direitos da personalidade nas relações de família. In: Pereira, Rodrigo da Cunha (Coord.). Família e dignidade humana - anais do V Congresso Brasileiro de Direito de Família. Belo Horizonte: IBDFAM, 2006.

Delgado, Rodrigo Mendes. $O$ valor do dano moral: como chegar até ele. $3^{\text {a }}$ ed. Leme: $\mathrm{J}$. H. Mizuno, 2011.

De Plácido e Silva. Vocabulário Jurídico. Rio de Janeiro: Forense, 1975.

DiAs, Cristina Manuela Araújo. Responsabilidade civil e direitos familiares conjugais (pessoais e patrimoniais): possibilidade de indemnização ou fragilidade da garantia? Scientia Ivridica - Revista de Direito Comparado Português e Brasileiro, n. 286/288, 2000 .

DiAs, José de Aguiar. Da responsabilidade civil. 11 a ed. Rio de Janeiro: Renovar, 2006.

DiAs, Maria Berenice. Manual de direito das famílias. $4^{\mathrm{a}}$ ed. São Paulo: Revista dos Tribunais, 2007.

. Divórcio Já! 2a ed. São Paulo: Revista dos Tribunais, 2012.

DinIz, Maria Helena. Curso de direito civil brasileiro: direito de família. v. 5. 24a ed. São Paulo: Sariava, 2009.

Curso de direito civil brasileiro: responsabilidade civil. v. 7. $26^{\mathrm{a}}$ ed. São Paulo: Saraiva, 2012.

DutTo, Ricardo J. Daños ocasionados en las relaciones de família. $1^{\mathrm{a}}$ ed. Buenos Aires: Hammurabi, 2006.

EsPíNOLA, Eduardo. A família no direito civil brasileiro. Rio de Janeiro: Conquista, 1957.

FÁBREGAS, Luiz Murillo. O dano moral resultante do divórcio ou da separação injusta e o seu ressarcimento. Revista da EMERJ, n. 6, 1999.

FACHIN, Luiz Edson. Elementos críticos do direito de família. Rio de Janeiro: Renovar, 1999.

. Comentários ao novo Código Civil: do direito de família, do direito pessoal, das relações de parentesco. v. 18. Rio de Janeiro: Forense, 2003.

FARIAS, Cristiano Chaves de. A proclamação da liberdade de permanecer casado (ou um réquiem para a culpa na dissolução das relações afetivas). Revista brasileira de direito de família, n. 18, 2003.

O novo procedimento para a separação e o divórcio consensuais e a sistemática da Lei n. 11.441/2007: o bem vencendo o mal. Revista Brasileira de Direito de Família. Belo Horizonte, n. 40, 2007. 
Farias, Cristiano Chaves de et Rosenvald, Nelson. Direito das famílias. $2^{\text {a }}$ ed. Rio de Janeiro: Lumen Juris, 2010.

FENSTERSEIFER, Nelson Dirceu. Dano extrapatrimonial e direitos fundamentais. Porto Alegre: Sergio Antonio Fabris, 2008.

FERRANDO, Gilda. Rapporti familiari e responsabilità civile. In: CENDON, Paolo (Coord.). Persona e danno III: le persone deboli, i minori, i danni in famiglia. Milano: Giuffrè, 2004.

Ferrater Mora, José. Dicionário de Filosofia. Tomo III. São Paulo: Loyola, 2001.

FERRAZ, Carolina Valença. Responsabilidade civil por dano moral e patrimonial na separação judicial. Dissertação de mestrado apresentada à Pontifícia Universidade Católica de São Paulo - PUC, São Paulo, 2001.

Ferreira, Aurélio Buarque de Holanda. Novo Dicionário Aurélio da Língua Portuguesa. $4^{a}$ ed. Curitiba: Positivo, 2009.

FERRER RIBA, Josep. Relaciones familiares y límites del derecho de daños. InDret. Barcelona, 2001.

FigueIREDO, Isabela Ribeiro de. A valoração do dano moral. Revista Síntese de Direito Civil e Processual Civil, n. 10, 2001.

FRANCO, Alberto Silva et STOCO, Rui (coord.). Código penal e sua interpretação: doutrina e jurisprudência. $8^{\text {a }}$ ed. São Paulo: Revista dos Tribunais, 2007.

FujITA, Jorge Shiguemitsu. Filiação na contemporaneidade. In: CHINELlato, Silmara Juny de Abreu, Simão, José Fernando, FuJITA, Jorge Shiguemitsu et ZUCCHI, Maria Cristina (Orgs.). Direito de família no novo milênio. São Paulo: Atlas, 2010.

GAMA, Guilherme Calmon Nogueira da. O companheirismo: uma espécie de família. $2^{\mathrm{a}}$ ed. São Paulo: Revista dos Tribunais, 2001.

Garcez Neto, Martinho. Prática de responsabilidade civil. $4^{\mathrm{a}}$ ed. São Paulo: Saraiva, 1989.

Ghersi, Carlos Alberto, Weingarten, Celia et Ghersi, Sebastián R. Daños y delitos en las relaciones de familia. $1^{\text {a }}$ ed. Rosario: Nova Tesis Editorial Juridica, 2010.

Giorgis, José Carlos Teixeira. Direito de família contemporâneo. Porto Alegre: Livraria do Advogado, 2010.

Godoy, Claudio Luiz Bueno de. Efeitos pessoais da união estável. In: ChInEllato, Silmara Juny de Abreu, SiMÃo, José Fernando, FuJITA, Jorge Shiguemitsu et ZuCCHI, Maria Cristina (Orgs.). Direito de família no novo milênio. São Paulo: Atlas, 2010. 
GOMES, Orlando. Tendências modernas na teoria da responsabilidade civil. In: FRANCESCO, José Roberto Pacheco di. Estudos em homenagem ao professor Silvio Rodrigues. São Paulo: Saraiva,1989.

GonÇALVES, Carlos Roberto. Responsabilidade civil. 11ª ed. São Paulo: Saraiva, 2009.

GouvÊA, José Roberto Ferreira et SILVA, Vanderlei Arcanjo da. Dano moral: quantificação pelo STJ. Revista Síntese de Direito Civil e Processual Civil, n. 37, 2005.

HARris-ShORT, Sonia et MiLes, Joanna. Family law: text, cases, and materials. $2^{\mathrm{a}}$ ed. Oxford: Oxford University Press, 2011.

Herrring, Jonathan. Family law. $5^{\mathrm{a}}$ ed. Essex: Logman Law Series, Pearson Education Limited, 2011.

HironaKa, Giselda Maria Fernandes Novaes. Pressuposto, elementos e limites do dever de indenizar por abandono afetivo. In: PEREIRA, Tânia da Silva et PEREIRA, Rodrigo da Cunha (coords.). A ética da convivência familiar: sua efetividade no quotidiano dos tribunais. Rio de Janeiro: Forense, 2005.

HouAISs, Antônio. Dicionário Houaiss: Sinônimos e Antônimos. 2a ed. São Paulo: Publifolha, 2008.

. Dicionário Houaiss da Língua Portuguesa. Rio de Janeiro: Objetiva, 2009.

Lagrasta, Caetano. Dano moral no direito de família. Revista do Advogado, n. 91, 2007.

Infidelidade virtual. In: Lagrasta Neto, Caetano, TARTuce, Flávio et Simão, José Fernando (Coords.). Direito de família: novas tendências e julgamentos emblemáticos. São Paulo: Atlas, 2011.

LaUdelino Freire. Grande e Novíssimo Dicionário da Língua Portuguesa. v. 2. $3^{\mathrm{a}}$ ed. Rio de Janeiro: José Olympio, 1957.

LEITE, Eduardo de Oliveira. Rompimento da promessa de casamento: reparação dos danos material e moral. Revista da AJURIS, n. 51, 1991.

A família monoparental como entidade familiar. In: WAMBIERT, Teresa Arruda Alvim et LEITE, Eduardo de Oliveia (coords.). Repertório de doutrina sobre direito de família - aspectos constitucionais, civis e processuais. v. 2. São Paulo: Revista dos Tribunais, 1995.

LisboA, Roberto Senise. Responsabilidade civil nas relações de consumo. São Paulo: Revista dos Tribunais, 2001.

LôBo, Paulo Luiz Netto. Direito civil: famílias. São Paulo: Saraiva, 2008. 
Dissolução da sociedade conjugal: separação judicial e suas modalidades. In: Chinellato, Silmara Juny de Abreu, Simão, José Fernando, FujiTA, Jorge Shiguemitsu et ZuCCHI, Maria Cristina (Orgs.). Direito de família no novo milênio. São Paulo: Atlas, 2010.

LoPEZ, Teresa Ancona. O dano estético: responsabilidade civil. $2^{\mathrm{a}}$ ed. São Paulo: Revista dos Tribunais, 1999.

. Jornal do Advogado. São Paulo: OAB, n. 289, 2004.

. Princípio da precaução e evolução da responsabilidade civil. São Paulo: Quartier Latin, 2010.

MADALENO, Rolf. O dano moral na investigação da paternidade. Revista da Ajuris, n. 71, 1997. 1998.

Direito de família: aspectos polêmicos. Porto Alegre: Livraria do Advogado, Divórcio e dano moral. Revista Brasileira de Direito de Família, n. 2, 1999.

. O dano moral no direito de família. In: Delgado, Mário Luiz et Alves, Jones Figueirêdo. Novo código civil: questões controvertidas. v. 5. São Paulo: Método, 2006.

. O preço do afeto. In: Repensando o direito de família. Porto Alegre: Livraria do Advogado, 2007.

Responsabilidade civil na conjugalidade e alimentos compensatórios. Revista brasileira de direito de família e sucessões, v. 13, 2010.

. Curso de direito de família. $4^{\mathrm{a}}$ ed. Rio de Janeiro: Forense, 2011.

MARMitT, Arnaldo. Dano Moral. Rio de Janeiro: Aide, 1999.

MedinA, Graciela. Daños en el derecho de familia. $2^{a}$ ed. Santa Fe: Rubinzal-Culzoni, 2008.

Melo, Diogo Leonardo Machado de. Ainda sobre a função punitiva da reparação dos danos morais (e a destinação de parte da indenização para entidades de fins sociais art. 883, parágrafo único, do Código Civil). Revista de Direito Privado, n. 26, 2006.

Melo, Nehemias Domingos de. Dano moral - problemática: do cabimento à fixação do quantum. $2^{\mathrm{a}}$ ed. São Paulo: Atlas, 2011.

Miranda, Pontes de. Manual do código civil. v. 16. Rio de Janeiro: Jacinto Ribeiro dos Santos, 1927.

. Tratado de direito de família. $3^{\text {a }}$ ed. São Paulo: Max Limonad, 1947. 
Tratado de direito privado: parte especial. v. 53. $3^{\text {a }}$ ed. São Paulo: Revista dos Tribunais, 1984.

Tratado de direito privado: parte geral. Tomo XXVI: direito das obrigações. São Paulo: Revista dos Tribunais, 2012.

Monteiro, Washington de Barros. Curso de direito civil: direito de família. v. 2. $39^{\mathrm{a}}$ ed. São Paulo: Saraiva, 2009. 2009.

Moraes, Maria Celina Bodin de. Deveres parentais e responsabilidade civil. Revista Brasileira de Direito de Família, n. 31, 2005.

. Danos morais em família? Conjugalidade, parentalidade e responsabilidade civil. Revista Forense, v. 386, 2006.

Danos à pessoa humana: uma leitura civil-constitucional dos danos morais. Rio de Janeiro: Renovar, 2009.

A constitucionalização do direito civil e seus efeitos sobre a responsabilidade civil. In: Na medida da pessoa humana: estudos de direito civil-constitucional. Rio de Janeiro: Renovar, 2010.

- Ampliando os direitos da personalidade. In: Na medida da pessoa humana: estudos de direito civil-constitucional. Rio de Janeiro: Renovar, 2010.

O princípio da dignidade da pessoa humana. In: Na medida da pessoa humana: estudos de direito civil-constitucional. Rio de Janeiro: Renovar, 2010.

MotTA, Carlos Dias. Princípios fundamentais de direito matrimonial. In: Coltro, Antônio Carlos Mathias (Coord.). Estudos jurídicos em homenagem ao centenário de Edgard de Moura Bittencourt: a revisão do direito de família. Rio de Janeiro: GZ, 2009.

MotTA, Maria Antonieta Pisano. Além dos fatos e dos relatos: uma visão psicanalítica do direito de família. In: PEREIRA, Rodrigo da Cunha. A família na travessia do milênio anais do II Congresso Brasileiro de Direito de Família. Belo Horizonte: Del Rey, 2000.

NERY, Rosa Maria de Andrade. Entidades familiares - comunidades emocionais responsabilidade da dutrina. In: NERY, Rosa Maria de Andrade et DONNINI, Rogério (Coords.). Responsabilidade civil: estudos em homenagem ao professor Rui Geraldo Camargo Viana. São Paulo: Revista dos Tribunais, 2009.

NuCCI, Guilherme de Souza. Código penal comentado. 10a ed. São Paulo: Revista dos Tribunais, 2010. 
Oltramari, Fernanda et Oltramari, Vitor Hugo. As tutelas da personalidade e a responsabilidade civil na jurisprudência do direito de família. Revista Brasileira de Direito de Família, n. 13, 2002.

Otero, Marcelo Truzzi. A quebra dos esponsais e o dever de indenizar. Dano material e o dano moral. Revista dos Tribunais, n. 766, 1999.

OXFORD. The Oxford English Dicitionary. v. III. Oxford, 1933.

PACCA, Elizabeth Ana Maria Meisels. A nova família e a responsabilidade civil dos cônjuges. Revista Jurídica da Universidade de Franca, n. 9, 2002.

Peluso, Antonio Cezar. A culpa na separação e no divórcio: contribuição para uma revisão legislativa. In: MotTA, Maria Antonieta Pisano (coord.). Caderno de estudos n. 2: direito de família e ciências humanas. São Paulo: Jurídica Brasileira, 1998.

PereIRA, Caio Mário da Silva. Responsabilidade civil. $6^{\mathrm{a}}$ ed. Rio de Janeiro: Forense, 1995.

Instituições de direito civil: direito de família. vol. V. $18^{\mathrm{a}}$ ed. Rio de Janeiro: Forense, 2010.

PEREIRA, Rodrigo da Cunha. A culpa no desenlace conjugal. In: MotTA, Maria Antonieta Pisano (coord.). Caderno de estudos n. 3: direito de família e ciências humanas. São Paulo: Jurídica Brasileira, 2000.

. Concubinato e união estável. $7^{\mathrm{a}}$ ed. Belo Horizonte: Del Rey, 2004.

. Código civil anotado. Porto Alegre: Síntese, 2004.

. Princípios fundamentais norteadores do direito de família. Belo Horizonte: Del Rey, 2006.

PEREIRA, Sérgio Gischkow. Dano moral e direito de família: o perigo de monetizar as relações familiares. Revista da AJURIS, n. 85, 2002.

Pereira, Virgílio de Sá. Direito de família. 3ª ed. Rio de Janeiro: Forense, 2008.

PÉREZ MAYOR, Adrián. Crisis matrimoniales e indemnización por daño moral. Revista Jurídica de Catalunya, n. 1. Barcelona, 2004.

PIERANGeli, José Henrique. Manual de direito penal brasileiro: v. 2, parte especial: arts. 121 a 361. $2^{\mathrm{a}}$ ed. São Paulo: Revista dos Tribunais, 2007.

Piovesan, Flávia. Direitos humanos e o direito constitucional internacional. São Paulo: Max Limonad, 2000.

PonzOnI, Laura de Toledo. Infidelidade virtual - realidade com efeitos jurídicos. Revista da Faculdade de Direito da Universidade de São Paulo, v. 102, 2007. 
PoRTo, Mário Moacyr. Ação de responsabilidade civil entre marido e mulher. Revista Forense, n. 285, 1984.

PRADO, Luiz Regis. Curso de direito penal brasileiro: vol. 2, parte especial: arts. 121 a 183. $5^{\mathrm{a}}$ ed. São Paulo: Revista dos Tribunais, 2006.

PÜSCHEL, Flavia Portella. A função punitiva da responsabilidade civil no direito brasileiro: uma proposta de investigação empírica. Revista Direito GV, n. 2, 2007.

REAle, Miguel. Política e direito: ensaios. São Paulo: Saraiva, 2006.

REIS, Clayton. A avaliação do dano moral. Rio de Janeiro: Forense, 1998.

Dano moral. Rio de Janeiro: Forense, 2010.

RESEDÁ, Salomão. A função social do dano moral. Florianópolis: Conceito Editorial, 2009.

RESENDE, Nara Rubia Alves de. Da possibilidade de ressarcimento dos danos decorrentes da dissolução da sociedade conjugal. Revista Brasileira de Direito de Família, n. 21, 2004.

RIBEIRO, Paulo Hermano Soares et FonseCA, Edson Pires da. Casamento e divórcio na perspectiva civil constitucional. Leme: J. H. Mizuno, 2012.

RizZARDo, Arnaldo. Responsabilidade Civil. $3^{\mathrm{a}}$ ed. Rio de Janeiro: Forense, 2007.

RoDRIGUES, Silvio. Direito civil: responsabilidade civil. vol. 4. 20ª ed. São Paulo: Saraiva, 2003.

. Direito civil: direito de família. vol. 6. 28ª ed. São Paulo: Saraiva, 2004.

RODRIGUES JUNIOR, Otávio Luiz. A doutrina do terceiro cúmplice nas relações matrimoniais. In: Silva, Regina Beatriz Tavares da et CAMARgo Neto, Theodureto de Almeida (Coords.). Grandes temas de direito de família e das sucessões. São Paulo: Saraiva, 2011.

SAnTos, Antonio Jeová. Dano moral indenizável. $4^{\mathrm{a}}$ ed. São Paulo: Revista dos Tribunais, 2003.

SAntos. Luiz Felipe Brasil. Guarda de menores e reponsabilidade civil. In: DELGADO, Mário Luiz e Alves, Jones Figueirêdo. Novo Código Civil - Questões Controvertidas - Série Grandes Temas de Direito Privado. v. 5. São Paulo: Método, 2006.

SAntos, Regina Beatriz Tavares da Silva Papa dos. Reparação Civil na Separação e no Divórcio. São Paulo: Saraiva, 1999.

Responsabilidade civil dos conviventes. Revista Brasileira de Direito de Família, n. 3, 1999. 
Responsabilidade Civil dos Cônjuges. In: PEREIRA, Rodrigo da Cunha. A família na travessia do milênio - anais do II Congresso Brasileiro de Direito de Família IBDFAM. Belo Horizonte: Del Rey, 2000.

SARLet, Ingo Wolfgang. Dignidade da pessoa humana e direitos fundamentais na Constituição Federal de 1988. Porto Alegre: Livraria do Advogado, 2001.

SCAFF, Fernando Campos. Considerações sobre o 'poder familiar'. In: ChINELlato, Silmara Juny de Abreu, SIMÃo, José Fernando, FuJITA, Jorge Shiguemitsu et ZUCCHI, Maria Cristina (Orgs.). Direito de família no novo milênio. São Paulo: Atlas, 2010.

SCHREIBER, Anderson. O princípio da boa-fé objetiva no direito de família. In: Pereira, Rodrigo da Cunha (Coord.). Família e Dignidade Humana - Anais do V Congresso Brasileiro de Direito de Família. Belo Horizonte: IBDFAM, 2006.

- Novos paradigmas da responsabilidade civil: da erosão dos filtros da reparação à diluição dos danos. $2^{\text {a }}$ ed. São Paulo: Atlas, 2009.

Direitos da personalidade. São Paulo: Atlas, 2011.

SCHUH, Lizete Peixoto Xavier. Responsabilidade civil por abandono afetivo: a valorização do elo perdido ou não consentido. Revista Brasileira de Direito de Família, n. 35, 2006.

SEREJO, Lourival. Direito constitucional de família. Belo Horizonte: Del Rey, 1999.

SILVA, Cláudia Maria da. Descumprimento do dever de convivência familiar e indenização por danos à personalidade do filho. Revista Brasileira de Direito de Família, n. 25, 2004.

SiLva, José Afonso. Curso de direito constitucional positivo. 32a ed. São Paulo: Malheiros, 2009.

SILVA, Michel Mascarenhas. A responsabilidade civil no rompimento do casamento e da união estável. Florianópolis: Conceito Editorial, 2009.

SILVA, Regina Beatriz Tavares da. Responsabilidade civil nas relações entre pais e filhos. In: Delgado, Mário Luiz e Alves, Jones Figueirêdo. Novo Código Civil - Questões Controvertidas - Série Grandes Temas de Direito Privado, v. 5. São Paulo: Método, 2006.

. Afetividade e responsabilidade nas relações de família. Revista do Advogado, n. 91, 2007.

A emenda constitucional do divórcio. São Paulo: Saraiva, 2011.

Stoco, Rui. Tratado de responsabilidade civil: doutrina e jurisprudência. $7^{\mathrm{a}}$ ed. São Paulo: Revista dos Tribunais, 2007. 
Tartuce, Flávio et Simão, José Fernando. Direito civil: direito de família. vol. 5. $3^{\text {a }}$ ed. São Paulo: Método, 2008.

Tartuce, Flávio. Princípios constitucionais e direito de família. In: ChInEllato, Silmara Juny de Abreu, SIMÃO, José Fernando, FuJITA, Jorge Shiguemitsu et ZUCCHI, Maria Cristina (Orgs.). Direito de família no novo milênio. São Paulo: Atlas, 2010.

Abandono afetivo (indenização) - comentários a julgado do Tribunal de Justiça de São Paulo. Danos morais por abandono moral. In: LAGRASTA NeTO, Caetano, TARTUCE, Flávio et Simão, José Fernando (Coords.). Direito de família: novas tendências e julgamentos emblemáticos. São Paulo: Atlas, 2011.

TEIXEIRA, Ana Carolina Brochado. A disciplina jurídica da autoridade parental. In: PEREIRA, Rodrigo da Cunha (Coord.). Família e Dignidade Humana - Anais do V Congresso Brasileiro de Direito de Família. Belo Horizonte: IBDFAM, 2006.

Telles Junior, Goffredo. Palavras do amigo aos estudantes de direito. $2^{\mathrm{a}}$ ed. São Paulo: Juarez de Oliveira, 2005.

TEPEDINO, Gustavo. O papel da culpa na separação e no divórcio. In: PEREIRA, Rodrigo da Cunha (coord.). Repensando o direito de família: anais do I congresso brasileiro de direito de família. Belo Horizonte: IBDFAM, 1999.

A tutela da personalidade no ordenamento civil-constitucional brasileiro. In: Temas de direito civil. Tomo 1. $4^{\mathrm{a}}$ ed. Rio de Janeiro: Renovar, 2008.

A disciplina civil-constitucional das relações familiares. In: Temas de direito civil. Tomo 1. $4^{\text {a }}$ ed. Rio de Janeiro: Renovar, 2008.

TheOdORo JÚNIOR, Humberto. Dano moral. $7^{\mathrm{a}}$ ed. Belo Horizonte: Del Rey, 2010.

Veloso, Zeno. Código civil comentado. Vol. XVII. AzEVedo, Álvaro Villaça (coord.). São Paulo: Atlas, 2003

Deveres dos cônjuges - responsabilidade civil. In: ChINELlato, Silmara Juny de Abreu, Simão, José Fernando, FuJITA, Jorge Shiguemitsu et ZuCCHI, Maria Cristina (Orgs.). Direito de família no novo milênio: estudos em homenagem ao professor Álvaro Villaça Azevedo. São Paulo: Atlas, 2010.

Venosa, Sílvio de Salvo. Direito civil: responsabilidade civil. vol. 4. $7^{\mathrm{a}}$ ed. São Paulo: Atlas, 2007.

Direito civil: direito de família. vol. 6. $7^{\text {a }}$ ed. São Paulo: Atlas, 2007.

VianA, Marco Aurélio S. Esponsais ou promessa de casamento. Ajuris, n. 29, 1983.

Welter, Belmiro Pedro. Dano moral na separação, divórcio e união estável. Revista Jurídica, n. 267, 2000. 
Yoshikawa, Eduardo Henrique de Oliveira. A incompatibilidade do caráter punitivo da indenização do dano moral com o direito positivo brasileiro (à luz do art. 5. ${ }^{\circ}$, XXXIX, da CF/88 e do art. 944, caput, do CC/02). Revista de Direito Privado, n. 35, 2008.

ZANEllato, Ezequiel Paulo. O afeto como fator preponderante para a manutenção da sociedade conjugal. Revista Brasileira de Direito de Família, n. 28, 2005.

ZINGARELLI, Nicola. Il Nuovo Zingarelli. 10 a ed. Zanichelli.

ZuLIANI, Ênio Santarelli. Dano moral: a era da jurisprudência. Revista Síntese de Direito Civil e Processual Civil, n. 13, 2001. 